\section{0) Wiadomości Lekarskie \\ Czasopismo Polskiego Towarzystwa Lekarskiego}

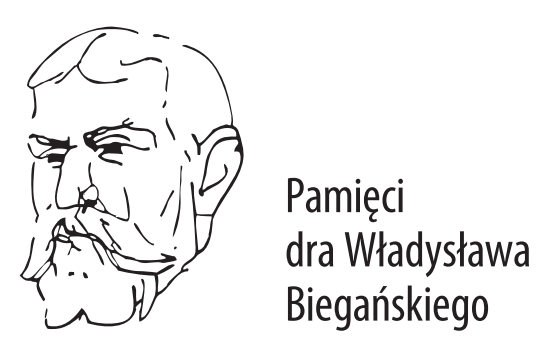

Rok założenia 1928 


\section{Ministry of Science and Higher Education \\ Republic of Poland}

The journal Wiadomości Lekarskie is financed under Contract No. 888/P-DUN/2019 by the funds of the Minister of Science and Higher Education.

The Journal has been included in the register of journals published by The Polish Ministry of Science and Higher Education on July 31st, 2019 with 20 points awarded.

Wiadomości Lekarskie is abstracted and indexed in: PubMed/Medline, EBSCO, SCOPUS, Index Copernicus, Polish Medical Library (GBL), Polish Ministry of Science and Higher Education.

Copyright: $\odot$ ALUNA Publishing.

Articles published on-line and available in open access are published under Creative Common Attribution-Non Commercial-No Derivatives 4.0 International (CC BY-NC-ND 4.0) allowing to download articles and share them with others as long as they credit the authors and the publisher, but without permission to change them in any way or use them commercially.

\section{Zasady prenumeraty miesięcznika Wiadomości Lekarskie na rok 2020}

Zamówienia na prenumeratę przyjmuje Wydawnictwo Aluna:

- e-mailem: prenumerata@wydawnictwo-aluna.pl

- listownie na adres:

Wydawnictwo Aluna

ul. Z.M. Przesmyckiego 29, 05-510 Konstancin-Jeziorna

Prosimy o dokonywanie wpłat na numer rachunku Wydawnictwa: Credit Agricole Bank Polska S. A.: 82194010763010740700000000

Cena prenumeraty dwunastu kolejnych numerów: 240 zł/rok (w tym VAT)

Cena prenumeraty zagranicznej: 120 euro/rok.

Cena pojedynczego numeru - $30 \mathrm{zł}$ (w tym VAT) + koszt przesyłki. Przed dokonaniem wpłaty prosimy o złożenie zamówienia. 


\section{2) Wiadomości Lekarskie}

\section{Editor in-Chief:}

Prof. Władysław Pierzchała

\section{Deputy Editor in-Chief:}

Prof. Aleksander Sieroń

\section{Statistical Editor:}

Dr Lesia Rudenko
Polskie Towarzystwo Lekarskie:

Prof. Waldemar Kostewicz - President PTL

Prof. Jerzy Woy-Wojciechowski - Honorary President PTL

Prof. Tadeusz Petelenz

\section{International Editorial Board - in-Chief:}

Marek Rudnicki

Chicago, USA

\section{International Editorial Board - Members:}

Kris Bankiewicz

Christopher Bara

Krzysztof Bielecki

Zana Bumbuliene

Ryszarda Chazan

Stanislav Czudek

Jacek Dubiel

Zbigniew Gasior

Andrzej Gładysz

Nataliya Gutorova

Marek Hartleb

Roman Jaeschke

Andrzej Jakubowiak

Oleksandr Katrushov

Peter Konturek

Jerzy Korewicki

Jan Kotarski
San Francisco, USA

Hannover, Germany

Warsaw, Poland

Vilnius, Lithuania

Warsaw, Poland

Ostrava, Czech Republic

Cracow, Poland

Katowice, Poland

Wroclaw, Poland

Kharkiv, Ukraine

Katowice, Poland

Hamilton, Canada

Chicago, USA

Poltava, Ukraine

Saalfeld, Germany

Warsaw, Poland

Lublin, Poland
George Krol

Krzysztof Łabuzek

Henryk Majchrzak

Ewa Małecka-Tendera

Stella Nowicki

Alfred Patyk

Palmira Petrova

Krystyna Pierzchała

Tadeusz Płusa

Waldemar Priebe

Maria Siemionow

Vladyslav Smiianov

Tomasz Szczepański

Andrzej Witek

Zbigniew Wszolek

Vyacheslav Zhdan

Jan Zejda
New York, USA

Katowice, Poland

Katowice, Poland

Katowice, Poland

Memphis, USA

Gottingen, Germany

Yakutsk, Russia

Katowice, Poland

Warsaw, Poland

Houston, USA

Chicago, USA

Sumy, Ukraine

Katowice, Poland

Katowice, Poland

Jacksonville, USA

Poltava, Ukraine

Katowice, Poland

\section{Managing Editor:}

Agnieszka Rosa

International Editor:

Lesia Rudenko

I.rudenko@wydawnictwo-aluna.pl

Distribution and Subscriptions:

Bartosz Guterman prenumerata@wydawnictwo-aluna.pl

\section{Graphic design / production:}

Grzegorz Sztank

www.red-studio.eu

\section{Publisher:}

ALUNA Publishing

ul. Przesmyckiego 29, 05-510 Konstancin - Jeziorna www.aluna.waw.pl www.wiadomoscilekarskie.pl www.medlist.org 


\section{REGULAMIN PRZYJMOWANIA I OGŁASZANIA PRAC} W WIADOMOŚCIACH LEKARSKICH

1. Miesięcznik Wiadomości Lekarskie jest czasopismem Polskiego Towarzystwa Lekarskiego, ma charakter naukowo-edukacyjny. Zamieszczane są w nim prace oryginalne, kliniczne i doświadczalne oraz poglądowe w języku polskim lub angielskim oraz innych językach (za zgodą redakcji).

2. Publikacja pracy w Wiadomościach Lekarskich jest płatna. Od stycznia 2017 roku koszt opublikowania artykułu wynosi 1000 zł plus 23\%VAT. Jeżeli pierwszym autorem pracy jest członek Rady Naukowej czasopisma lub zespołu recenzentów - za druk nie pracy nie pobieramy opłaty, jeśli zaś jest kolejnym współautorem - opłata wynosi 500 zł plus 23\%VAT. Wydawca wystawia faktury. Opłatę należy uiścić po otrzymaniu pozytywnej recenzji, przed opublikowaniem pracy. Z opłaty za publikację zwolnieni są członkowie Polskiego Towarzystwa Lekarskiego z udokumentowaną opłatą za składki członkowskie za ostatnie 3 lata.

3. Prace zapisane w formacie DOC (z wyłączeniem rycin, które powinny stanowić osobne pliki) należy przesłać pocztą elektroniczną na adres redakcji: Agnieszka Rosa-amarosa@wp.pl.

4. Objętość prac oryginalnych - łącznie z rycinami i piśmiennictwem - nie może przekraczać 21600 znaków (12 stron maszynopisu), prac poglądowych - do 36000 znaków (20 stron).

5. Strona tytułowa powinna zawierać:

- tytuł w języku angielskim i polskim,

- pełne imiona i nazwiska autorów,

- afiliację autorów,

6. Praca oryginalna powinna mieć następującą strukturę: wstęp, cel pracy, materiał i metody, wyniki, dyskusja i wnioski, które nie mogą być streszczeniem pracy. Przy zastosowaniu skrótów konieczne jest podanie pełnego brzmienia terminu przy pierwszym użyciu. W pracach doświadczalnych, w których wykonano badania na ludziach lub zwierzętach, a także w badaniach klinicznych, należy umieścić informację o uzyskaniu zgody komisji etyki badań naukowych.

7. Streszczenia zarówno w języku polskim, jak i angielskim powinny zawierać 200250 słów. Streszczenia prac oryginalnych, klinicznych i doświadczalnych powinny posiadać następującą strukturę: cel, materiał i metody, wyniki wnioski. Nie należy używać skrótów w tytule ani w streszczeniu.

8. Słowa kluczowe (3-6) należy podawać w języku angielskim i polskim, zgodnie z katalogami MeSH (Medical Subject Headings Index Medicus http://www.nim. nih.gov.mesh/MBrower.html). Słowa kluczowe nie mogą być powtórzeniem tytułu pracy.

9. Materiał ilustracyjny - ryciny, wykresy, rysunki, fotografie, slajdy - powinien być opisany cyframi arabskimi i zapisany jako pliki JPG, TIFF lub EPS o rozdzielczości 300 DPI (nie w plikach tekstowych). Ich opisy należy przesłać w osobnym pliku. W tekście muszą znajdować się odniesienia do wszystkich rycin (w nawisach okrągłych).

10. Tabele - ich tytuły (nad tabelą) i treść - powinny być zapisane w programie Microsoft Word, ponumerowane cyframi rzymskimi. Wszystkie stopki dotyczące tabeli powinny znajdować się poniżej tekstu tabeli. W tekście pracy należy umieścić odniesienia do wszystkich tabel (w nawiasach okrągłych).

11. W wykazie piśmiennictwa ułożonym według kolejności cytowania należy uwzględnić wyłącznie te prace, na które autor powołuje się w tekście. W pracach oryginalnych nie powinno być więcej niż 30 pozycji, a w poglądowych nie więcej niż 40 pozycji. Każda pozycja powinna zawierać: nazwiska wszystkich autorów, pierwsze litery imion, tytuł pracy, skrót tytułu czasopisma (wg Index Medicus), rok, numer, stronę początkową i końcową. Przy pozycjach książkowych należy podać: nazwisko autora (autorów), pierwszą literę imienia, tytuł rozdziału, tytuł książki, wydawnictwo, miejsce i rok wydania. Dopuszcza się cytowanie stron internetowych z podaniem adresu URL i daty użycia artykułu oraz o ile to możliwe nazwisk autorów. Każda pozycja piśmiennictwa powinna mieć odwołanie w tekście pracy umieszczone w nawiasie kwadratowym, np. [1], [3-6]. Pozycje zapisuje się w sposób zaprezentowany w Załączniku nr 1 do niniejszego regulaminu umieszczonym na stronie internetowej czasopisma.

12. Po piśmiennictwie należy podać adres do korespondencji, nazwisko i imię pierwszego autora, adres, numer telefonu oraz adres e-mail.

13. Do pracy należy dołączyć oświadczenie podpisane przez wszystkich autorów określające udział poszczególnych autorów w przygotowaniu pracy (np. koncepcja i projekt pracy, zbieranie danych i ich analiza, odpowiedzialność za analizę statystyczną, napisanie artykułu, krytyczna recenzja itd.), a także oświadczenie, że biorą oni odpowiedzialność za treść. Ponadto należy zaznaczyć, że praca nie była publikowana ani zgłaszana do druku w innym czasopiśmie.

14. Jednocześnie autorzy powinni podać do wiadomości wszelkie inne informacje mogące wskazywać na istnienie konfliktu interesów, takie jak:

- zależności finansowe (zatrudnienie, płatna ekspertyza, doradztwo, posiadanie akcji, honoraria),

- zależności osobiste,

- współzawodnictwo akademickie i inne mogące mieć wpływ na stronę merytoryczną pracy,

- sponsorowanie całości lub części badań na etapie projektowania, zbierania, analizy i interpretacji danych lub pisanie raportu.

Konflikt interesów ma miejsce wtedy, gdy przynajmniej jeden z autorów ma powiązania lub zależności finansowe z przemysłem bezpośrednie lub za pośrednictwem najbliżzzej rodziny. Jeśli praca dotyczy badań nad produktami częściowo lub całkowicie sponsorowanymi przez firmy, autorzy mają obowiązek ujawnić ten fakt w załączonym oświadczeniu.

15. Każda praca podlega weryfikacji w systemie antyplagiatowym (zapora ghostwriting).

16. Redakcja przestrzega zasad zawartych w Deklaracji Helsińskiej, a także w Interdisciplinary and Guidlines for the Use of Animals In Research, Testing and Education, wydanych przez New York Academy nof Sciencees' Adhoc Resarch. Wszystkie prace odnoszące się do zwierząt lub ludzi muszą być zgodne z zasadami etyki określanymi przez Komisję Etyczną.

17. Czasopismo recenzowane jest w trybie podwójnej, ślepej recenzji. Nadesłane prace są oceniane przez dwóch niezależnych recenzentów, a następnie kwalifikowane do druku przez Redaktora Naczelnego. Recenzje mają charakter anonimowy. Krytyczne recenzje autorzy otrzymują wraz z prośbą o poprawienie pracy lub z decyzją o niezakwalifikowaniu jej do druku. Procedura recenzowania artykułów jest zgodna z zaleceniami Ministerstwa Nauki i Szkolnictwa Wyższego zawartymi w opracowaniu „Dobre praktyki w procedurach recenzyjnych w nauce" (Warszawa 2011).

18. Redakcja zastrzega sobie prawo redagowania nadesłanych tekstów (dokonywania skrótów i poprawek). Prace są wysyłane do akceptacji autorów. Poprawki autorskie należy przesłać w terminie 3 dni od daty wysłania wiadomości e-mail (pocztą elektroniczną). Brak odpowiedzi w podanym terminie jest równoznaczny z akceptacją przez autora nadesłanego materiału.

19. Przyjęcie pracy do druku oznacza przejęcie praw autorskich przez Redakcję Wiadomości Lekarskich.

20. Autorzy otrzymują nieodpłatnie plik PDF wydania, w którym znajduje się ich praca, a na życzenie - egzemplarz drukowany. Plik elektroniczny przeznaczony jest do indywidualnego użytku autora, bez prawa do rozpowszechniania bez zgody redakcji.

21. Prace przygotowane niezgodnie z regulaminem zostaną zwrócone autorom do poprawienia.

22. Redakcja nie odpowiada za treść zamieszczanych reklam. 


\section{CONTENS / SPIS TREŚCI}

\section{ORIGINAL ARTICLES / PRACE ORYGINALNE}

Artem Z. Aikian, Viktoriya I. Shynkevych, Igor P. Kaidashev

QUANTITATIVE ASSESSMENT OF CD68+ AND CD163+ MACROPHAGES IN THE PRIMARY FOCUS AND METASTATIC LESIONS OF REGIONAL LYMPH NODES

IN NON-LUMINAL HER2-POSITIVE INVASIVE BREAST CARCINOMA

Andrzej Kulach, Paweł Stachowiak, Marek Prasal, Katarzyna Sawicka, Wojciech Kosmala, Dariusz Kosior, Jarosław D Kasprzak, Mariusz Skowerski, Bozena Sobkowicz, Władysław Sinkiewicz, Edyta Plonska-Gościniak, Milosz Stepien, Katarzyna Mizia-Stec A QUESTIONNAIRE-BASED, MULTICENTER REGISTRY OF RESISTANT AND PSEUDO-RESISTANT ARTERIAL HYPERTENSION IN POLAND - A PILOT STUDY

Anatoliy Svintsitskyy, Galyna Solovyova, Sergiy Maliarov, Tetiana Alianova

PECULIARITIES OF PSYCHOLOGICAL STATUS IN PATIENTS WITH FUNCTIONAL DYSPEPSIA: POSTPRANDIAL DISTRESS SYNDROME

Oksana S. Khukhlina, Olha Ye. Hryniuk, Inna V. Dudka, Svitlana V. Kovalenko, Tetiana V. Dudka, Olha Ye. Mandry

THE ROLE OF HYDROGEN SULFIDE IN THE PROGRESSION OF CHRONIC OBSTRUCTIVE PULMONARY DISEASE IN PATIENTS WITH NON-ALCOHOLIC STEATOHEPATITIS

Oleg V. Rybalov, Pavel I. Yatsenko, Oleg I. Yatsenko, Maksim V. Khorosh, Dmitry M. Korol, Dmitry D. Kindiy, Victor D. Kindiy

HYPERMOBILITY OF THE ARTICULAR HEADS OF THE TEMPOROMANDIBULAR JOINT: PATHOLOGY OR VARIANT OF THE NORM?

Angelika Kędzior, Beata Łabuz-Roszak, Sylwia Jezierska

ENTERAL NUTRITION IN CYSTIC FIBROSIS

Oleh Kobyletskyi, Andrii Netliukh, Nataliya Matolinets, Andrii Kulmatytskyi, Oksana Kovalska, Dzvenislava Moskviak-Lesniak, Taras Gutor

THE SIGNIFICANCE OF NO GAS TRANSMITTER AND NUCLEASES IN SHAPING THE SEQUELAE OF TRAUMATIC BRAIN INJURY

Aleksey V. Bida, Serhii M. Hermanchuk, Volodymyr I. Struk, Vitaliy I. Bida, Yuliya I. Zabuha, Alexander V. Bida

REHABILITATION OF PATIENTS WITH BOUNDED EDENTULOUS SPACES BY NON-REMOVABLE DENTURE STRUCTURES SUPPORTED BY DENTAL IMPLANTS

IN CONDITIONS OF INSUFFICIENT BONE MINERAL DENSITY

Vasyl V. Kishchuk, Oleksandr D. Bondarchuk, Andriy V. Kostyuchenko, Nataliya V. Tytarenko, Ihor V. Dmitrenko, Andriy I. Bartsihovskyiy, Kateryna A. Lobko

LOCAL IMMUNITY STATUS OF OROPHARYNX IN PATIENTS WITH SCLEROMA

Anatoly A. Avramenko

THE EFFECT OF INTRACELLULAR"DEPOT"HELICOBACTER PYLORI INFECTION ON THE QUALITY OF ERADICATION WITH MONOTHERAPHY OF PATIENTS

WITH CHRONIC NON-ATROPHIC GASTRITIS BY THE BISMUTH COLLOIDAL SUBCITRATE

Vera D. Kuroiedova, Yuliya K. Sokolohorska-Nykina, Oleksandr S. Proskurin, Yuriy V. Yukrovskyi

THE CONDITION OF SKELETAL SYSTEM IN PUPILSWITH HEARING IMPAIRMENT

Natalia S. Mykhailovska, Tamila 0. Kulynych, Hanna V. Grytsai, Oksana 0. Lisova, Olga I. Riznyk

THE POSSIBILITIES OF PREDICTION THE CORONARY HEART DISEASE COURSE AFTER COMMUNITY ACQUIRED PNEUMONIA

Maryna A. Trishchynska, Maryna V. Globa, Vasyl V. Orzheshkovskyi, Yuriy V. Voronenko, Yurij I. Holovchenko, Olena V. Tkachenko, Vasyl M. Mykhalchuk

ASSESSMENT OF ENDOTHELIAL FUNCTION IN PATIENTS WITH INITIAL MANIFESTATIONS OF CHRONIC CEREBRAL ISCHEMIA

Larysa Katrushova, Svitlana Yalanska, Lesia Rudenko, Oleksandr Katrushov

PECULIARITIES OF THE PROCESS OF PSYCHOLOGICAL ADAPTATION OF FOREIGN STUDENTS OF UKRAINIAN HIGHER EDUCATION INSTITUTIONS

OF MEDICAL PROFILE, ROLE OF EMOTIONAL INTELLIGENCE INTHE SOCIALIZATION PROCESS

Anatoliy M. Potapchuk, Volodymyr S. Melnyk, Liudmyla F. Horzov, Vasyl'M. Almashi

PREVENTION OF MAIN DENTAL DISEASES IN CHILDREN USING HERBAL TEA «DENTESVITA»

Anzhelika V. Payenok, Olga G. Morozova, Oleksandr S. Payenok, Irina M. Mitelman, Oleg Yu. Bilianskyi

FEATURES OF ESTIMATION OF MUSCLE TONE AND FUNCTIONAL STATE OF SPINAL MOTOR NEURONS IN PATIENTS WITH POST-STROKE SPASTICITY

ON A BACKGROUND OF A PHARMACOLOGICAL CORRECTION

Vasyl D. Moskaliuk, Tetiana R. Kolotylo, Khrystyna I. Pudiak, Ivanna V. Rudan, Oksana I. Goliar, Iryna V. Balanyk

THE PECULIARITIES OF IMMUNOLOGICAL INDICATORS IN HIV-INFECTED PERSONS WITH TUBERCULOSIS 
Halyna 0. Vaskivska, Svitlana P. Palamar, Olha M. Vlasenko

HEALTH IN THE CIVIC STUDENTS' VALUE SYSTEM: EMPIRICAL ANALYSIS

Nataliia 0. Marchenkova, Svitlana S. Riabokon, Mariia 0. Riabokon

THE MAIN MISTAKES IN SONOGRAPHIC EXAMINATION OF HIP JOINTS IN INFANTS UNDER ONE YEAR OF AGE

Vira M. Helei, Natalia I. Zhero, Nazariy I. Helei, VladimirV. Kryvanich

CHOICE OF THE TREATMENT METHOD OF THE INFLAMMATORY PROCESS IN THE ALVEOLAR TOOTH SOCKET

Palmira G. Petrova, Eya E. Egorova, Victoriya E. Egorova, Semen E. Grigor'ev, Lena R. Turkebaeva

THE RESULTS OF THE MICROSCOPIC AND HEMATOLOGICAL STUDIES OF LIQUID BODY MALOLYAKHOVSKY MAMMOTH

\section{REVIEW ARTICLES / PRACE POGLĄDOWE}

Igor P. Vakaliuk, Roksolana V. Nesterak, Denys A. Volynskyi, Volodymyr I. Sovtus, Viktor M. Yakimchuk, Andrij I. Volynskyi PATTERNS OF CARDIOVASCULAR DISEASE IN THE CARPATHIAN REGION

Oleksandr P. Volosovets, Sergii P. Kryvopustov, Tetiana M. Volosovets, Oleksandr E. Abaturov, Tetyana 0. Kryuchko

CHANGES IN HEALTH STATUS OF CHILD POPULATION OF UKRAINE AFTER CHERNOBYL CATASTROPHE

Andriy M. Galushka, Olesya M. Ivanko, Irina V. Ogorodniyshyk, Mikolay Yu. Olym, Borys I. Palamar, Vyacheslav P. Pechyborshch

EPIDEMIOLOGICAL SUPPORT FOR HIV / AIDS IN THE ARMED FORCES OF UKRAINE: PROBLEM QUESTIONS AND WAYS FOR DECISION-MAKING

1977

Alicja Piontek, Jakub Szeja, Michał Błachut, Karina Badura-Brzoza

SEXUAL PROBLEMS IN THE PATIENTS WITH PSYCHIATRIC DISORDERS

1984

Vitalii Pashkov, Marianna Liubchenko, Oleksii Liubchenko

PROVIDING THE RIGTH TO HEALTH OF INVOLUNTARILY DISPLACED PERSONS

1989

Wojciech Maciej Ciepierski, Monika Adamczyk-Sowa, Tomasz Męcik Kronenberg, KrzysztofWierzbicki

DIAGNOSTICS OF SPORADIC CREUTZFELDT-JAKOB DISEASE - LITERATURE REVIEW

1995

Liudmyla Sokurenko, Sergiy Omelchuk, Serhii Herashchenko, Olena Deltsova, Yuri Chaikovsky

PERIPHERAL NERVE GAP MANAGEMENT: ROCK-PAPER-SCISSORS

Dorota Suszek, Maria Majdan, Karolina Widłak, Joanna Radulska, Klaudia Sowa, Ewa Stryjecka, Aleksandra Szuster, Justyna Tyburek, Daria Zalewska

MONITORING THE ACTIVITY OF ANCA-ASSOCIATED VASCULITIS: SOME QUESTIONNAIRES AND LABORATORY PARAMETERS

Sergiy 0. Chertov, Olena M. Batyhina, Andrii 0. Harkusha

THE IMPACT OF AGRICULTURAL PRODUCTION FACTORS ON CHILDREN'S HEALTH

Ewelina Użarowska, Michał Kościółek, Anna Wójcicka

GENETIC BACKGROUND OF ATYPICAL HEMOLYTIC-UREMIC SYNDROME AND ITS INFLUENCE ON THE COURSE OF DISEASE AND THERAPEUTIC EFFECTS

Tetiana S. Gruzieva, Mykhailo D. Diachuk, Hanna V. Inshakova, Viktoria B. Zamkevych

MODERN DEMOGRAPHIC TRENDS IN UKRAINE AS A GROUND FOR REALIZATION OF PREVENTION STRATEGIES

Marianna V. Markova, Artur R. Markov, Maya V. Savina, Tsira B. Abdriakhimova, Inna R. Muharovska, Kostiantyn D. Gaponov

MEDICAL AND PSYCHOLOGICAL CONSEQUENCES OF USING ON-SCREEN TECHNOLOGIES OF INFORMATIONAL AND PSYCHOLOGICAL INFLUENCE:

ANALYSIS OF THE PROBLEM

\section{CASE REPORTS / OPISY PRZYPADKÓW}

Martyna Maciejewska, Inga Janik-Fuks, Patrycja Zielińska, Agata Mularczyk, Olimpia Sipak

SELECTED PSYCHOLOGICAL ASPECTS OF FUNCTIONING OF A PATIENT AFTER REPEATED MISCARRIAGES - CASE STUDY

Victor D. Urzhumov, Nana M. Pasiyeshvili, Nataliia V. Kapustnyk, Mykhailo S. Myroshnychenko, Iryna V. Borzenkova, Dmytro V. Molodan, Victor N. Grinevich

CLINICAL-MORPHOLOGICAL FEATURES OF WILMS'TUMOUR: ANALYSIS OF LITERATURE DATA AND A CASE FROM PRACTICE

Mateusz Jeziorny

HARD PALATE ABSCESS AND NASOPALATINE FISTULA AS A RESULT OF IMPACTED TOOTH IN JAW - CASE REPORT 
PRACA ORYGINALNA

ORIGINAL ARTICLE

\title{
QUANTITATIVE ASSESSMENT OF CD68+ AND CD163+ MACROPHAGES IN THE PRIMARY FOCUS AND METASTATIC LESIONS OF REGIONAL LYMPH NODES IN NON-LUMINAL HER2-POSITIVE INVASIVE BREAST CARCINOMA
}

\author{
Artem Z. Aikian, Viktoriya I. Shynkevych, Igor P. Kaidashev \\ UKRAINIAN MEDICAL STOMATOLOGICAL ACADEMY, POLTAVA, UKRAINE
}

\begin{abstract}
Introduction: Tumor-associated macrophages are an important prognostic factor and have been shown to be associated with invasion and migration of various types of cancer. Unlike M1-macrophages, which have pro-inflammatory and anti-cancer activity, M2-macrophages are immunosuppressive, promoting the restoration of the intracellular matrix, and therefore they contribute to the tumor growth.

The aim: To study the quantitative characteristic and localization of CD68+ and CD163+ M2-like TAM that infiltrate non-luminal HER2-enriched carcinomas of BC in the primary focus without metastases and in paired specimens with metastases in the lymph nodes, as well as the pathomorphological characteristics of this type of $B C$.

Materials and methods: The material of the study were intraoperative tissues of tumors and ipsilateral lymph nodes at radical removal of mammary glands. Immunohistochemical characteristics of the removed tumors (ER, PR, HER2, Ki67) were used to organize two groups of patients with primary BC according to the N1 / 0 status.

Results: The statistical processing of the entire set of digital data confirmed a significant increase in CD68+TAM, but not CD163+M2 under metastatic conditions ( $p<0.0001$ ), which may suggest an increase in M1-type TAM and their promotion of metastases in non-luminal HER2-enriched BC. Analysis of peculiarities of TAM localization showed that CD68+TAM was localized by clusters within the tumor nests and adjacent stroma, necrotized nests, whereas the typical localization of CD163+TAM M2-like macrophages predominated in the stroma and near the necrotic sites (where their quantitative characteristics coincide with those of (D68+TAM). This may indicate a relative predominance of M1 macrophages precisely in tumor nests. Along with the results on increased CD68+TAM (but not CD163+TAM) in metastases, it is possible to assume the contribution of M1 macrophages to the development / metastasis of $B C$, as prognosticated for other tumors.

Conclusions: A significant decrease in the number of CD68+TAM in metastases of the lymph node as compared with the primary clusters of $B C$, along with the absence of correlations, may reflect other functions of TAM in the affected lymph nodes or change of the tumor type in the metastasis.
\end{abstract}

KEY WORDS: tumor-associated macrophages, immunohistochemical studies, CD68+ and CD163+, non-luminal HER2-enriched carcinoma, breast cancer

Wiad Lek 2019, 72, 10, 1861-1865

\section{INTRODUCTION}

The immune system plays an important role in the progression of cancer. In solid tumors, $5-40 \%$ of tumor mass is represented by tumor-associated macrophages (TAM), and this ratio correlates with a negative prognosis depending on the type of tumor. It is considered that TAM are usually similar to M2-macrophages [1]. In contrast to M1-macrophages with proinflammatory and anticancer activity, M2-macrophages are immunosuppressive, they promote restoration of the intercellular matrix, and therefore contribute to tumor growth. However, the role of TAM in the progression of breast cancer (BC) is not fully understood.

\section{THE AIM}

The study of the relationship between the pathogistological characteristics of $\mathrm{BC}$ and the representation of TAM therein is important for understanding the local functions of these cells and their consequences, such as metastasis. Therefore, we studied the quantitative characteristics of localization of CD68+ and CD163+M2-like TAM that infiltrate non-luminal HER2-enriched carcinomas of BC in the primary focus without metastases and in paired specimens with metastases in the lymph nodes, as well as the pathomorphological characteristics of this type of BC.

\section{MATERIALS AND METHODS}

Biopsy material and clinical data were obtained from patients undergoing treatment at Poltava Regional Clinical Dispensary. The study was approved by the Ethics Commission of Ukrainian Medical Stomatological Academy.

Materials of the research were intraoperative tissues of tumors and ipsilateral lymph nodes in radical mastectomy.

Immunohistochemical (IHC) characteristics of removed tumors (HER2, ER, PR, Ki67) were used to select a group 
of non-luminal HER2-positive specimens. Morphological and IHC findings were obtained according to the criteria for determining the molecular and biological subtype.

According to the data of meta-analysis [2], the use of CD68 as a biomarker of TAM for IHC evaluation has priorities as compared with individual definition of CD163 or CD206.

We analyzed 2 sub-groups of non-luminal BC balanced by N1/0 status, 3 specimens in each, and 3 specimens of lymph node metastases, respectively. The average age of patients was 60 years, from 29 to 76 .

IHC studies on determining TAM and M2-like macrophages were performed using the streptavidin-peroxidase method. Paraffin sections $5 \mu \mathrm{m}$ in thickness, obtained by the standard technique of the automated cycle of the pathologic-anatomical laboratory, were deparaffinized, dehydrated, antigens were restored in citrate buffer $\mathrm{pH}$ 6.0 ) in a microwave oven, cooled for $20 \mathrm{~min}$, washed in distilled water and phosphate-saline buffer (PSB, pH 7.27.4) for $2 \mathrm{~min}$, the endogenous peroxidase was blocked with a PolyVue HRP/DAB Detection System (For Mouse \& Rabbit Primary Antibodies, Diagnostic BioSystems, USA) reagent, and then washed in PSB for 3 min. Further, the sections were incubated at the temperature of $4^{\circ} \mathrm{C}$ overnight with murine anti-CD68 monoclonal antibodies (clone PG-M1, REF PD M065-S, Diagnostic BioSystems, USA) and anti-CD163 (clone 10D6, REF Mob460-01, diluted 1:100 in Antibody Diluent Buffer for DTP (Antibody Diluent, Dako, USA). Subsequently, the sections were processed in two steps by Mouse / Rabbit PolyVueTM HRP / DAB Detection System (Diagnostic BioSystems, USA), the detector system for visualizing the response of $\mathrm{DAB}$ chromogenic substrates; the nuclei were counterstained with Meyer's hematoxylin and enclosed under a cover glass in cedar balm. Antibody Diluent buffer instead of primary antibodies was used as a negative control value, lymph node tissue - as a positive one.

Evaluation of immunohistochemical staining was performed by calculation of CD68+TAM and CD163+M2-like TAM under the light microscope (Biolam, LOMO, Russia: lens $\times 40$, eyepiece $\times 7$ ) in at least five fields of vision of the intensive IHC-reaction of each section, calculating the arithmetic mean, within the tumor nests and tumor stroma. The count included immunopositive cells with macrophage morphology. Microphotographs were obtained using the Leica DM500, Leica, Germany (lens $\times 40$ ) microscope.

Statistical analysis was performed using the GraphPad Prism software using nonparametric and parametric methods.

\section{RESULTS}

The study is organized as a descriptive pathomorphological comparison between two subgroups: N0 and N1, non-luminal HER2+ breast cancer (BC), comparison of quantitative characteristics of CD68+TAM and CD163+M2-like fraction of TAM, as well as for verification of possible correlation relations between quantitative characteristics of macrophages in the primary tumor and in the corresponding metastasis to the ipsilateral axillary lymph nodes (the second subgroup).

CD68 is the best marker protein of TAM and is common to all macrophage markers, which is widely used as a prognostic value in many tumors [3]. In the research, the marker was used to identify general population of TAM in the microenvironment of BC. CD163 is considered a "marker of pre-tumor macrophages" [4]. In the study, it was used to identify the M2-like macrophages in the microenvironment of $\mathrm{BC}$.

The first group included three specimens of non-luminal N0 BC: invasive ductal carcinoma of the mammary gland (MG) of solid structure and two specimens of Paget's carcinoma, which were characterized as HER2+. All specimens were also clinically characterized as positive for Ki67.

The first specimen of invasive ductal carcinoma was represented by atypical nuclei of high-degree polymorphism; massive fibrotic stroma in the central parts of the specimen; marked lymphoplasmic infiltrates and the presence of necrotic foci. CD68+TAM were placed evenly and in clusters (Fig. 1). In places of intense IHC-response, the average number of CD68+ cells was 10.7 in the field of vision, they were of elongated and rounded shape with branches of cytoplasm, localized predominantly in the stroma and separate in the tumor nests. The specimen also represented fields of vision which were completely free of immunopositive cells, and in particular such areas were densely arranged clusters of tumor cells and stroma units with a high representation of fibrous structures and intercellular substances.

CD163+ M2-like TAM were characterized by a high degree of coincidence of their placement with CD68+TAM on serial sections, that is, they were colocalized, but their number was considerably smaller. The shape of cells was both round and spindle-like (Fig. 2), immunoreactivity was relatively lighter as compared to CD68. Single CD163+ Mph were also found in the clusters of tumor cells. However, their predominant majority was located along with other infiltrating cells of lymphocytic morphology in the stroma. The average number was 3.1 cells per field of vision.

The other two specimens of the subgroup were represented by Paget's carcinoma. In the stroma, the signs of desmoplastic reaction were revealed, and larger or smaller signs of inflammation in the form of expressive lymphoid infiltration. The foci of necrotic changes were observed in 2 out of 3 specimens.

Immunosuppressive cells were located mainly in the stroma, around the tumor clusters. The number of CD68+TAM in most fields of vision prevailed over the number of CD163+M2-like. In general, TAM and M2 infiltration was rated as low, except for the first specimen.

The quantitative characteristics of TAM are summarized in Table I.

Examples of non-luminal HER2+BC N1 are presented by specimens from three patients. The first specimen is pathohistologically described as invasive $\mathrm{BC}$ with signs of pleomorphic lobular carcinoma with metastasis in one 


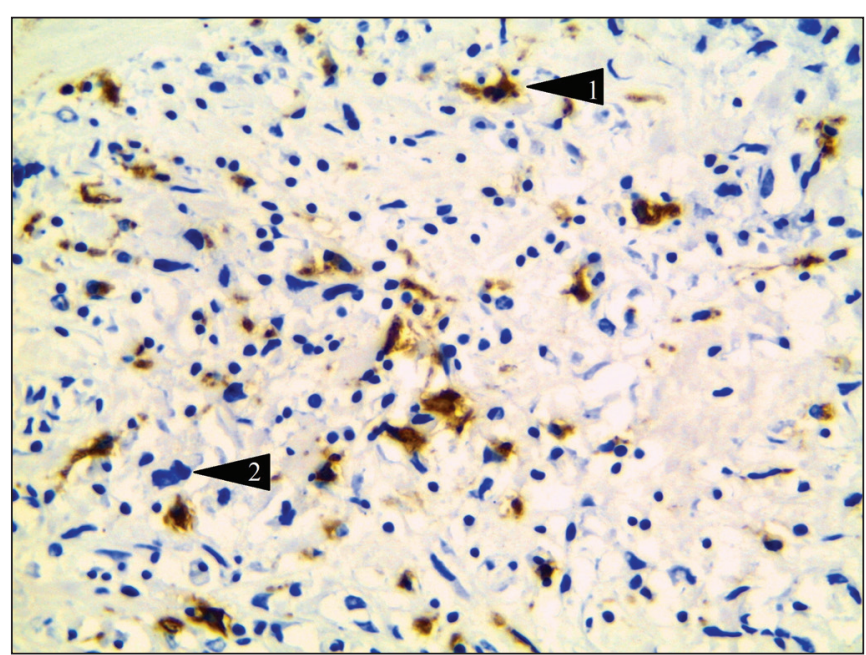

Fig. 1. Immunohistochemical detection of TAM $(C D 68+)$ in the biopsy material of BC. The site with a moderate representation of TAM: 1 - TAM; 2-atypical nucleus. Contrasting: Meyer's hematoxylin, lens $\times 40$.

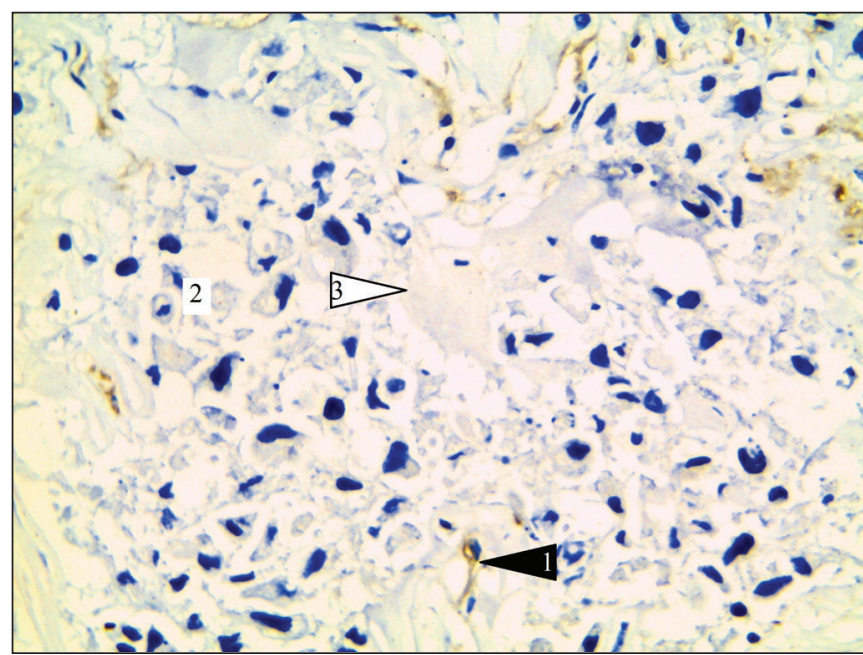

Fig. 2. Immunohistochemical detection of M2 (CD163+) in the biopsy material of BC: 1- M2; 2- clusters of tumor cells with hyperchromatic nuclei of high degree atypia; 3 - a fragment of fibrous stroma. Contrasting: Meyer's hematoxylin, lens $\times 40$.

Table I. Quantitative characteristics of TAM

\begin{tabular}{cc} 
The first group, N0 & The second group, N1 \\
\hline TAM $-10.7-$ moderate; & Primary tumor \\
M2 $-3.1-$ mild & TAM $-21.6-$ dense, \\
\cline { 2 - 2 } TAM $-3.6-$ mild; & mild \\
\hline$M 2-1.9-$ mild & TAM $-32.1-$ dense, \\
TAM $-5.8-$ mild; & M $-0-1-$ mild \\
M2 $-4.8-$ mild & TAM $-16.2-$ dense, \\
\hline
\end{tabular}

Note. The average number of cells in the field of vision and the density of infiltration are conventionally divided into: up to 10 cells - mild, 10-15 - moderate, $>15$ - dense.

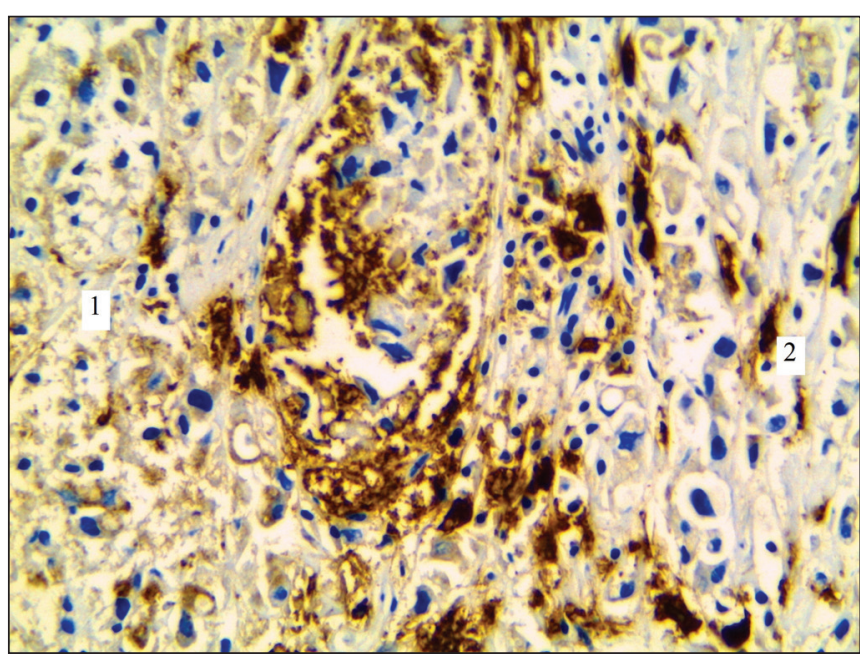

Fig. 3. Immunohistochemical detection of TAM $(C D 68+)$ in the BC biopsy material of the second group. Accumulation of CD68+TAM at the border with the tumor necrotic area: 1- necrotic area; 2- tumor cells that have lost junction between themselves. Contrasting: Mayer's hematoxylin, lens $\times 40$

of the lymph nodes (characteristic feature is that the cells do not have a junction with each other). Numerous areas with necrotic changes (including rather extensive ones)

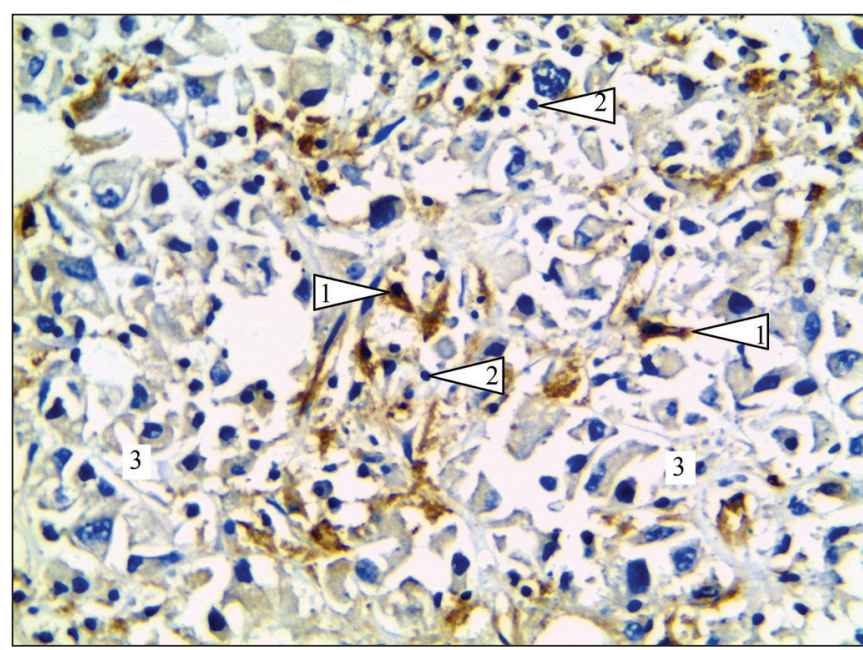

Fig. 4. Immunohistochemical detection of $\mathrm{M} 2$ (CD163+) in the BC biopsy material of the second group. Immunosuppressive (1) and lymphoid cells (2) among the tumor cells (3). Contrasting: Meyer's Hematoxylin, lens $\times 40$

were observed. Stroma of the tumor was with desmoplastic reaction and fibroadipose. A marked lymphoid infiltration was observed. 


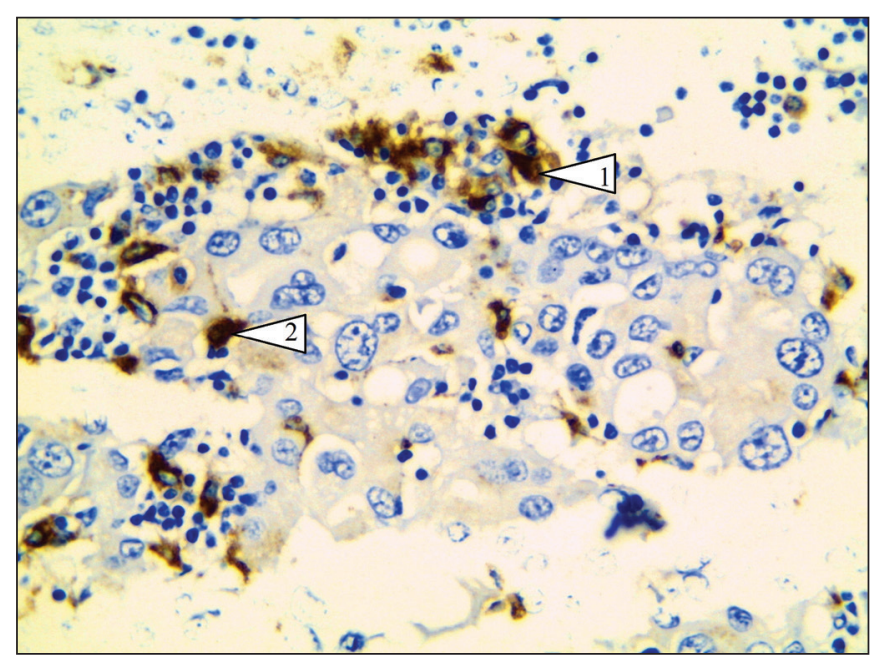

Fig. 5. Immunohistochemical detection of TAM (CD68 +) in the biopsy material of a lymph node with metastasis. Localization of TAM around (1) and within the tumor nest (2). Contrasting: Mayer's hematoxylin, lens $\times 40$.

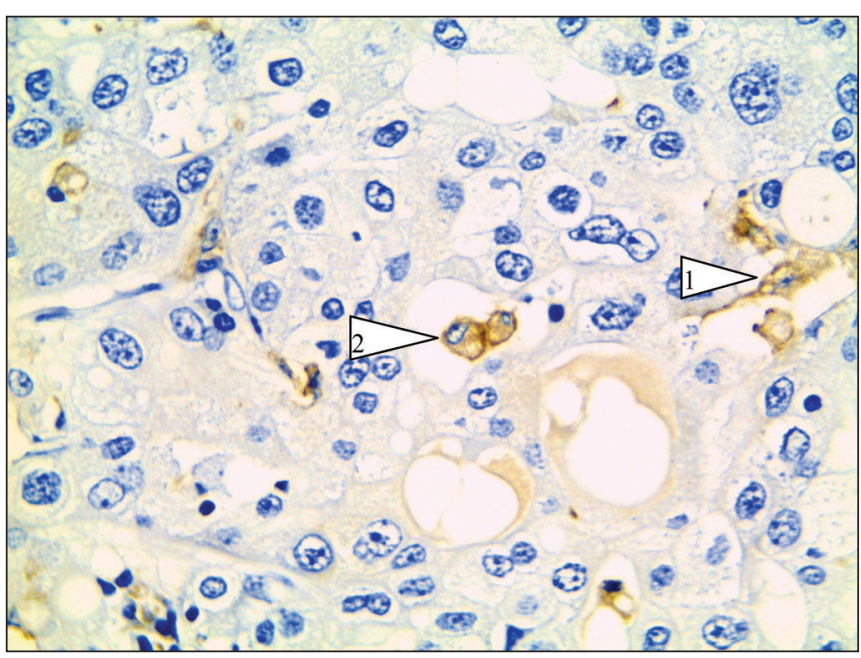

Fig. 6. Immunohistochemical detection of $M 2(C D 163+)$ in the biopsy material of a lymph node with metastasis. 1- M2 localized in the stroma; 2 M2 localized in the tumor nest. Contrasting: Mayer's hematoxylin, lens $\times 40$.
The other two specimens were represented by invasive carcinoma of BC of solid or trabecular structure. Common features of all specimens were desmoplastic reaction of the stroma, necrosis focus, the presence of microcalcifications and a pronounced inflammatory reaction in the form of lymphoplasmacytic infiltration. These features are not remarkable and may be inherent in other IHC-types of BC.

CD68+TAM infiltrated the tumor tissue at a high level, and were placed around and within the nests evenly and in clusters (Fig. 3), as well as in the necrosis foci. We observed their regular presence in the areas of lymphoid infiltration.

CD163+M2-like cells were found less frequently than TAM, but clearly repeated their localization: around and within the tumor nests and among lymphoid cells (Fig. 4). These cells were also regularly located in the fibrous central stroma, at the same quantitative level as CD68+.

The corresponding specimens of metastases in the lymph nodes histologically showed that atypical cells differ from the primary foci to a greater or lesser extent (which is well observed on the photos from the first patient of the second group: Figures 3-6).

CD68+TAM infiltrated the metastasis uniformly and in clusters, and were present both in the stroma (Figure 5: 1) and in the nests (Figure 5:2). The grouping was observed more often on the periphery of the tumor. On average, infiltration is assessed as low (Table 1), but in clusters, the immunopositive cells counted up to 40 cells in the field of vision in specific biopsy specimens.

$\mathrm{CD} 163+\mathrm{M} 2$ rather accurately repeated the localization and shape of CD68 + TAM: in the stroma (Figure 6: 1) and in the nests of the tumor (Figure 6: 2), but were represented by a smaller amount or even singly (they were almost absent among the densely located tumor nests). However, within the visually preserved lymphoid tissue of the lymph nodes they formed clusters of 6-10 cells in the field of vision.

\section{DISCUSSION}

The analysis of individual patient's data and its pathogenetic or prognostic value is the task of personalized medicine, which requires increasingly more attention of scientists and doctors around the world, thus replacing evidence-based medicine.

The statistical processing of the entire set of digital data confirmed a significant increase in CD68+TAM, but not CD163+M2 under metastatic conditions ( $p<0.0001$ ), which may suggest an increase in M1-type TAM and their promotion of metastases in non-luminal HER2-enriched $\mathrm{BC}$. This data is contrary to mass clinical studies showing that it is $\mathrm{CD} 163+\mathrm{M} 2$ that promotes metastases in $\mathrm{BC}$, although they do not distinguish narrow IHC subgroups of $\mathrm{BC}$ [5]. In addition, the authors observed that the presence of high levels of CD163+TAM is more commonly observed in HER2-positive, basal-like and triple-negative BC, and is associated with signs of aggressive tumors, in particular vascular invasion. However, other studies suggest that tumor invasion can be an independent prognostic factor [6] .

Analysis of peculiarities of TAM localization showed that CD68+TAM was localized by clusters within the tumor nests and adjacent stroma, necrotized nests, whereas the typical localization of CD163+TAM M2-like macrophages predominated in the stroma and near the necrotic sites (where their quantitative characteristics coincide with those of CD68+TAM). This may indicate a relative predominance of M1 macrophages precisely in tumor nests. Along with the results on increased CD68+TAM (but not CD163+TAM) in metastases, it is possible to assume the contribution of M1 macrophages to the development / metastasis of BC, as prognosticated for other tumors [7]. Other researchers confirm the prognostic value of CD68+TAM after studying larger groups of patients with $\mathrm{BC}$ [8]. High density infiltration of CD68+TAM negatively correlates with the 5-year survival rates of patients with BC [9].

The results of the research showed a significant decrease in the number of CD68+TAM in metastases of the lymph 
node as compared with the primary BC. However, within the visually preserved lymphoid tissue of the lymph nodes, around the metastases, TAM formed remarkable clusters. Other authors report that in the affected lymph nodes, the density of TAM infiltration is significantly lower than in the intact paired ones, which suggests an association between quantitative characteristics of TAM with metastasis [9]. We observed the morphological diversity of $\mathrm{BC}$ within the IHC types, as well as the differences between the primary source and metastases in the lymph nodes. It is known that non-luminal tumors, common in myoepithelial origin, develop in lobular and ductal histological forms [10].

Despite the common features of $\mathrm{BC}$, for example, with respect to the desmoplastic stromal response, the extracellular matrix varies widely among different $\mathrm{BC}$ patients [11]. Thus, the chosen design further emphasizes the importance of an individual approach to interpretation of research results.

\section{CONCLUSIONS}

- Analysis of the results of quantitative changes in TAM showed a marked increase in CD68+TAM, but not $\mathrm{CD} 163+\mathrm{M} 2$ in metastatic conditions $(\mathrm{p}<0.0001)$, which may suggest an increase in the M1-type TAM and their promotion of metastases in non-luminal HER2-enriched BC.

- A significant decrease in the number of CD68+TAM in metastases of the lymph node as compared with the primary clusters of $\mathrm{BC}$, along with the absence of correlations, may reflect other functions of TAM in the affected lymph nodes or change of the tumor type in the metastasis.

- The morphological diversity of BC within the IHC types along with typical pathomorphological findings is incorporated into the current understanding of interand intratumoral heterogeneity, which is traditionally considered the greatest barrier in treatment.

- The selected design of the research in small, highly specialized groups of patients further emphasizes the importance of interpreting the individual findings, which is consistent with the principles of personalized medicine.

\section{REFERENCES}

1. Sousa S, Brion R, Lintunen $M$ et al. Human breast cancer cells educate macrophages toward the M2 activation status. Breast Cancer Res. 2015;17:101. doi: 10.1186/s13058-015-0621-0.

2. Zhao X, Qu J, Sun Yet al. Prognostic significance of tumor-associated macrophages in breast cancer: a meta-analysis of the literature. Oncotarget. 2017;8(18):30576-30586. doi: 10.18632/oncotarget.15736.

3. Ruffell B, Au A, Rugo HS et al. Leukocyte composition of human breast cancer. Proc Natl Acad Sci USA. 2012;109:2796-801.
4. Komohara Y, Ohnishi K, Takeya M Possible functions of CD169-positive sinus macrophages in lymph nodes in anti-tumor immune response. Cancer Sci. 2017 Mar; 108(3): 290-295. doi: 10.1111/cas.13137

5. Klingen TA, Chen Y, Aas $\mathrm{H}$ et al. Tumor-associated macrophages are strongly related to vascular invasion, non-luminal subtypes, and interval breast cancer. Hum Pathol. 2017 Nov;69:72-80. doi: 10.1016/j. humpath.2017.09.001. Epub 2017 Sep 18.

6. Klingen TA, Chen Y, Stefansson IM et al. Tumour cell invasion into blood vessels is significantly related to breast cancer subtypes and decreased survival. J Clin Pathol. 2017 Apr;70(4):313-319. doi: 10.1136/ jclinpath-2016-203861. Epub 2016 Sep 9.

7. Hedbrant A, Wijkander J, Seidal T et al. Macrophages of M1 phenotype have properties that influence lung cancer cell progression. Tumour Biol. 2015 Nov;36(11):8715-25. doi: 10.1007/s13277-015-3630-9. Epub 2015 Jun 7.

8. Mahmoud SM, Lee AH, Paish EC et al. Tumour-infiltrating macrophages and clinical outcome in breast cancer. J Clin Pathol. 2012;65:159-63.

9. Ju Yang, Xiaojing Li, Xiuping Liu et al. The role of tumor-associated macrophages in breast carcinoma invasion and metastasis. Int J Clin Exp Pathol. 2015; 8(6): 6656-6664.

10. http://www.webpathology.com/image.asp?n $=8 \&$ Case $=289$.

11. Rachael N, Heba S, Faraz K et al. Microenvironmental Heterogeneity Parallels Breast Cancer Progression: A Histology-Genomic Integration Analysis. PLoS Med. 2016 Feb; 13(2): e1001961. Published online 2016 Feb 16. doi: 10.1371/journal.pmed.1001961

\section{Acknowledgement}

We thank T.V. Mamontova, Ph.D. for technical assistance in immunohistochemical research.

\section{Authors' contributions:}

According to the order of the Authorship.

\section{ORCID numbers:}

Viktoriya I. Shynkevych - 0000-0002-2436-9449

Igor P. Kaidashev - 0000-0002-4708-0859

\section{Conflict of interest:}

The Authors declare no conflict of interest.

\author{
CORRESPONDING AUTHOR \\ Artem Z. Aikian \\ Ukrainian Medical Stomatological Academy \\ 23 Shevchenko Str., Poltava 36011 Ukraine \\ tel: +380997808494 \\ e-mail:docaikart@gmail.com
}

Received: 11.02 .2019

Accepted: 27.09.2019 


\title{
A QUESTIONNAIRE-BASED, MULTICENTER REGISTRY OF RESISTANT AND PSEUDO-RESISTANT ARTERIAL HYPERTENSION IN POLAND - A PILOT STUDY
}

\author{
Andrzej Kulach', Paweł Stachowiak ${ }^{2}$, Marek Prasal ${ }^{3}$, Katarzyna Sawicka ${ }^{4}$, Wojciech Kosmala ${ }^{5}$, Dariusz Kosior ${ }^{6}$, \\ Jarosław D Kasprzak ${ }^{7}$, Mariusz Skowerski ${ }^{1}$, Bozena Sobkowicz $^{8}$, Władysław Sinkiewicz ${ }^{9}$, Edyta Plonska-Gościniak², \\ Milosz Stepien ${ }^{2}$, Katarzyna Mizia-Stec ${ }^{10}$ \\ 'DEPARTMENT OF CARDIOLOGY, SCHOOL OF HEART SCIENCES, MEDICAL UNIVERSITY OF SILESIA, KATOWICE, POLAND \\ 2DEPARTMENT OF CARDIOLOGY, POMERANIAN MEDICAL UNIVERSITY, SZCZECIN, POLAND \\ ${ }^{3}$ DEPARTMENT OF CARDIOLOGY, MEDICAL UNIVERSITY OF LUBLIN, POLAND \\ ${ }^{4}$ DEPARTMENT OF INTERNAL MEDICINE, MEDICAL UNIVERSITY OF LUBLIN, POLAND \\ ${ }^{5}$ DEPARTMENT OF CARDIOLOGY, WROCLAW MEDICAL UNIVERSITY, WROCLAW, POLAND \\ ${ }^{6}$ DEPARTMENT OF ARTERIAL HYPERTENSION, CENTRAL CLINICAL HOSPITAL OF THE MSWIA, WARSAW, POLAND \\ 'DEPARTMENT OF CARDIOLOGY, MEDICAL UNIVERSITY OF LODZ, LODZ, POLAND \\ ${ }^{8}$ DEPARTMENT OF CARDIOLOGY, MEDICAL UNIVERSITY OF BIALYSTOK, BIALYSTOK, POLAND \\ 'DEPARTMENT OF CARDIOLOGY, COLLEGIUM MEDICUM IN BYDGOSZCZ, NICOLAUS COPERNICUS UNIVERSITY IN TORUN, POLAND \\ ${ }^{10}$ FIRST DEPARTMENT OF CARDIOLOGY, SCHOOL OF MEDICINE, MEDICAL UNIVERSITY OF SILESIA, KATOWICE, POLAND
}

\begin{abstract}
Introduction: Hypertensive patients with poor blood pressure (BP) control are commonly referred to tertiary centers with a diagnosis of resistant hypertension (RH).

The aim of the study was to identify the causes of insufficient BP control and to assess the incidence of true resistant hypertension.

Material and Methods:We ran a questionnaire-based, multicenter study ( 10 high volume tertiary centers in Poland) of patients referred with an initial diagnosis of RH. Only patients with ABPM-confirmed uncontrolled hypertension (systolic $\geq 140 \mathrm{mmHg}$ and/or diastolic $\geq 90 \mathrm{mmHg}$ despite maximal doses of $\geq 3$ medications, including a diuretic) were included. We assessed the causes of non-optimal BP control, a proportion of patients with excluded secondary hypertension, and the burden of hypertension-related complications. Results: We analyzed 124 patients aged 41-88, with a history of hypertension of $17.5 \pm 9$ years. $90 \%$ of them had developed systemic complications, the most common being LV hypertrophy (73.4\%) and LV diastolic dysfunction (63.4\%). In only $47 \%$ all major causes of secondary hypertension were excluded. In $90.3 \%$ of subjects, at least one factor affecting BP control was identified. The most frequent factors were medication noncompliance (52.4\%), metabolic syndrome (43.6\%) excessive sodium intake (66.1\%) and chronic administration of non-steroid anti-inflammatory drugs (40\%). The incidence of real resistant hypertension was only $4.8 \%$.

Conclusions: Among patients referred with uncontrolled hypertension, the incidence of real resistant hypertension is small. A majority of these patients have multiple factors potentially responsible for poor BP control, the most common being medication non-adherence, use of drugs increasing BP, excessive salt intake and metabolic syndrome
\end{abstract}

KEY WORDS: resistant hypertension, pseudo-resistant hypertension, non-compliance

Wiad Lek 2019, 72, 10, 1866-1871

\section{INTRODUCTION}

Resistant hypertension is defined as in-office blood pressure (BP) of at least $140 \mathrm{mmHg}$ systolic and/or $90 \mathrm{mmHg}$ diastolic in patients on maximal doses of three or more antihypertensive medications, including a diuretic. The definition excludes secondary hypertension, white-coat hypertension and other causes of uncontrolled BP, such as poor adherence or non-optimal medication regimen and dosing [1]. The latter situation is referred to as pseudo-resistant hypertension.

According to American and European registries and observational studies, true resistant hypertension occurs in $15 \%$ of patients treated for essential hypertension and about $12.5 \%$ of all hypertensive subjects $[2,3]$. The real incidence of resistant hypertension confirmed in $24 \mathrm{~h}$ ambulatory blood pressure monitoring (ABPM), is difficult to assess [4] and ranges from about $50 \%$ to as low as $7.9-10.1 \%$ of patients referred with resistant hypertension [5].

We ran a questionnaire-based, multicenter study of patients referred to tertiary high-volume cardiology centers with an initial diagnosis of resistant hypertension.

The aim of the study was to identify causes of insufficient BP control in subjects with uncontrolled blood pressure (systolic BP of at least $140 \mathrm{mmHg}$ and/or diastolic 90 $\mathrm{mmHg}$ despite maximal doses of three or more medications, including a diuretic) and to assess the incidence of the true resistant hypertension among them.

Additionally, we assessed the most common causes of non-optimal BP control, the incidence of non-compliance to medica- 
tion, the burden of hypertension-related complications and the prevalence of non-pharmacological therapeutic interventions

\section{MATERIAL AND METHODS}

Data were collected in two months in 2017 in ten high volume tertiary hospitals in Poland, both in cardiology wards and in cardiology outpatient units.

We conducted a questionnaire-based study among patients referred with the diagnosis of resistant hypertension. The key inclusion criterion was the presence of uncontrolled blood pressure (systolic BP of at least $140 \mathrm{mmHg}$ and/or diastolic $90 \mathrm{mmHg}$ ), confirmed in ambulatory blood pressure monitoring (ABPM), despite maximal doses of three or more medications, including a diuretic.

Within the study period in all centers, eligible patients were screened and included (unless refused to give consent). The data was gathered by a trained physician based on subjects' answers and available medical history.

Statistical analysis was performed Statistical analysis was performed with Statistica 13.1. All values were expressed as means \pm standard deviation (average \pm SD). Differences were considered to be significant at $\mathrm{p}<0.05$.

\section{RESULTS}

We analyzed 124 patients aged 41-88, (mean $68.2 \pm 10$ years old) with a history of hypertension of $17.5 \pm 9$ years.
The baseline characteristics and medication are shown in table 1.

Mean Home BP measurement (HBPM) values were similar to ABPM values (SBP $145 \pm 18$ vs. $140 \pm 17 \mathrm{mmHg}$, $\mathrm{p}=0.17$; DBP $88 \pm 10 \mathrm{mmHg} v s .86 \pm 13 \mathrm{mmHg}, \mathrm{p}=0.744$ )

$40 \%$ of patients were treated with three anti-hypertensive medications, while $60 \%$ received four or more drugs. The most common therapy modifications were CCB adding or up-titration and adding MRAs.

There were no differences in pharmacological treatment between males and females, except alpha-blockers, which were more commonly used in men.

\section{SYSTEMIC COMPLICATIONS}

Almost all patients (97\%) presented with at least one systemic complication of hypertension. LV hypertrophy and LV diastolic dysfunction were the most common $(73.4 \%$ and $63.4 \%$ respectively). LV systolic dysfunction occurred in $34.2 \%$ and was more frequent in men than in women ( $48.0 \%$ vs. $25.4 \%, \mathrm{p}=0.01)$. Other acknowledged complications of hypertension were less common.

MODIFIABLE FACTORS AFFECTING BP CONTROL IN THE TREATMENT OF HYPERTENSION

The most frequent factors to affect the effectiveness of anti-hypertension treatment were medication noncompli-

Table 1. Baseline characteristics

\begin{tabular}{|c|c|}
\hline Parameter & Result (mean \pm SD or $n \%$ ) \\
\hline Age (years) & $68.2 \pm 10.6$ years \\
\hline Sex (male \%) & $40.3 \%$ \\
\hline History of hypertension & $17.5 \pm 9.2$ years \\
\hline History of anti-hypertensive treatment & $14.5 \pm 7.4$ years \\
\hline Heart failure & $33.9 \%$ \\
\hline Coronary artery disease & $61.0 \%$ \\
\hline Peripheral artery disease & $26.0 \%$ \\
\hline Diabetes & $46.3 \%$ \\
\hline LVEF & $52.8 \% \pm 11 \%$ \\
\hline \multicolumn{2}{|l|}{ Medication } \\
\hline Diuretic & $100 \%$ \\
\hline Beta-blocker & $69.1 \%$ \\
\hline $\mathrm{CCB}$ & $69.9 \%$ \\
\hline Alpha-blocker & $22.3 \%$ \\
\hline ACE-I & $65.0 \%$ \\
\hline ARB & $27.6 \%$ \\
\hline MRA & $23.6 \%$ \\
\hline Other & $10.6 \%$ \\
\hline
\end{tabular}

CCB - calcium channel blockers,

$A C E-I$ - angiotensin converting enzyme inhibitors,

ARB - angiotensin receptor blockers, MRA - mineralocorticoid receptor antagonist;

LVEF - left ventricle ejection fraction 
Table 2. Differences between patients with good and poor drug compliance (data with significant differences presented)

\begin{tabular}{cccc}
\hline & Good adherence & Poor adherence & $\mathbf{p}$ \\
\hline Age & $66.5 \pm 10$ years & $69.7 \pm 11$ years & 0.02 \\
\hline Excessive salt intake & $55.9 \%(33)$ & $75.4 \%(49)$ & 0.02 \\
\hline Excessive alcohol drinking & $1.7 \%(1)$ & $10.8 \%(7)$ & 0.04 \\
\hline LV systolic dysfunction & $24.1 \%(14)$ & $43.1 \%(28)$ & 0.02 \\
\hline Coronary artery disease & $45.8 \%(27)$ & $75.0 \%(0)$ & $<0.01$ \\
\hline
\end{tabular}

LV - left ventricle

ance (52.4\%), metabolic syndrome (43.6\%) and excessive sodium intake $(66.1 \%)$. They were similar in men and women. Sleep apnea syndrome and alcohol intake were more common in males vs. females $(20.0 \%$ vs. $12.7 \%$, $\mathrm{p}=0.010$ and $14.0 \%$ vs. $1.4 \%, \mathrm{p}<0.01$, respectively). Of note, in $90.3 \%$ of subjects, at least one factor affecting BP control was identified.

We also recorded the use of medications that are thought to affect BP control. Chronic administration of non-steroid anti-inflammatory drugs (NSAIDs; almost $39.5 \%$ of cases) and steroids (11.3\%) was the most common.

\section{SECONDARY HYPERTENSION EXCLUSION}

The approach to exclude secondary hypertension was divergent among centers. For analysis purposes exclusion of following conditions were taken into account: renal artery stenosis, Cushing disease, pheochromocytoma, primary hyperaldosteronism, hyperthyroidism, hyperparathyroidism, and coarctation of the aorta. Out of these factors, none was excluded in $19 \%$ of cases, $1-2$ were excluded in $23 \%$ of patients and all 7 were excluded in $47 \%$ of patients.

Considering the burden of factors affecting blood pressure control (mostly including non-compliance, excessive salt intake and metabolic syndrome and the use of NSAIDs and steroids), the incidence of real resistant hypertension in subjects with properly excluded secondary hypertension was only $4.8 \%$.

\section{ADHERENCE TO MEDICATION}

$47.6 \%$ of patients declared regular drugs taking, whereas the remaining $52.4 \%$ admitted not to comply fully with treatment recommendations. We compared the subgroups with good and poor compliance, and revealed, that among patients with better adherence to a therapy other factors related to lifestyle risk factors were less common (excessive salt intake, alcohol drinking). Moreover, there were fewer patients with CAD and HF in this group. Also, in patients with good adherence, the causes of secondary hypertension were more commonly excluded (Tab. 2).

In multivariate regression analysis, we identified following factors to increase the risk of poor compliance: age (HR 1.03/year; CI 0,996-1,067, $\mathrm{p}=0,087$ ), excessive salt intake (HR 2,413 95\%CI 1,125-5,176, $\mathrm{p}=0,0237$ ), excessive alcohol drinking (HR 7,00, 95\% CI 0,835-58,71, $\mathrm{p}=0,073$ ), systolic LV dysfunction (HR 2,38, 95\%CI 1,094-5,17 p=0,0287) and
CAD (HR 3,551 95\%CI 1,67-7,63, p=0,0011)

The subjects were also asked about the lifestyle changes they made to improve BP control. Physical activity (at least 30 minutes three times a week) and weight reduction (by at least $5 \mathrm{~kg}$ ) was declared by $59.5 \%$ and $58.1 \%$ respectively. $36.6 \%$ of participants were on DASH diet.

\section{DISCUSSION}

Uncontrolled hypertension remains an important healthcare problem. Despite the availability of effective treatment, growing awareness of possible complications among patients and efforts of public health organizations, the satisfactory blood pressure control is reached in approximately half of the patients treated for hypertension. In some of these patients, therapeutic goals are difficult to achieve, even if the therapy is well-tailored for a patient. The problem of real resistant hypertension, however, is not as common as diagnosed $[7,8]$.

Our study was conducted among patients referred with an initial diagnosis of resistant hypertension to cardiology departments. The population was relatively small, but the data was collected in 10 tertiary cardiology centers, in consecutive patients over a well-defined period. Women were dominating in a studied group (60\%), which is consistent with the literature [6]. Comorbidities of subjects enrolled in the analysis were typical for cardiology patients, and such conditions as coronary artery disease, peripheral artery disease and heart failure were more common than in many registries, there are, however, reports, in which the prevalence of cardiovascular diseased, including CAD and PAD, was also high (40-45\%) [9]. In our cohort, there was a high frequency of hypertension-related complications, including LV hypertrophy, LV systolic and diastolic dysfunction. We believe that this was due to routine cardiac diagnostic performed in our patients (echocardiography), possibly more detailed than in other registries where such thorough cardiac assessment might have not been conducted. Severe macroangiopathic complications, like stroke and aortic aneurysm, were uncommon, but they occur on later stages of the disease when treatment is ineffective for a long time. Data from the literature is consistent with this finding [14].

In our registry, $60 \%$ of patients received four or more antihypertensive agents. The most common combination to reach therapeutic goals was diuretic, ACE-I, calcium channel blockers (CCB) and beta-blocker, which is similar to other reports [10]. Among drug most commonly added 
to improve BP control were CCB and MRAs. In our study, clonidine was surprisingly frequently used as an additional drug in resistant (and pseudo-resistant) hypertension.

The most interesting finding was, that in over $95 \%$ there were identifiable factors that have or could have affected the effectiveness of hypertension treatment. Similarly, in the meta-analysis by Noubiap et al, in some studies, up to $94 \%$ of patients were eventually diagnosed with pseudo-resistant hypertension, and poor BP control was related mostly to pood adherence to medication [11]. In our group, only $50 \%$ of patients declared taking drugs as prescribed. In the INSPiRED trial [REF 38], nonadherence was observed in 44-50\% [REF $38 \mathrm{R}, 35]$. In the studies, where objective methods were used to assess compliance (blood/urine test for drug metabolites) the prevalence of non-compliance reached $80 \%$ [REF 37].

Age is a common factor to affect therapy compliance. This is also one of the factors related to nonadherence in our study. Besides, we identified CAD and HF as factors related to nonadherence. The most likely causation is that the nonadherence leads to CV complications.

In our study, the use of NSAIDs was another modifiable factor potentially affecting BP control. The use of NSAIDs was 3-4 times more common than reported in the literature [12], and may be related to the high availability of this group as OTC drugs in Poland, along with intensive advertising campaigns in public and commercial media. Any efforts should be made to educate patients with the emphasis being put on complications and drug interactions when these drugs are taken without control [13].

Exclusion of secondary hypertension is an important part of the diagnostic approach in uncontrolled hypertension and a crucial step do diagnose resistant hypertension. Thyroid function tests and renal artery ultrasound are performed most often - the tests are easy to perform, inexpensive and cover two most common causes of secondary hypertension. In our study $80 \%$ and $60 \%$ respectively had these tests done. However, only half of the patients had all 7 major causes of secondary hypertension excluded, while $23 \%$ had only one or 2 conditions ruled out, and every 5th patient did not have any test.

The results of our study clearly state, that the group of patients with uncontrolled hypertension, which is referred to tertiary units to treat resistant hypertension is very heterogeneous and the initial diagnosis of therapy resistance is confirmed in very few cases. This calls for unified strategy at the level of primary care and a step-by-step approach, where the key elements are: confirming uncontrolled $\mathrm{BP}$ in ABPM, assessment of medication adherence, modification and up-titration of antihypertensive therapy, eliminating NSAIDs and other drugs affecting BP whenever possible, and finally a proper excluding secondary hypertension.

\section{LIMITATIONS}

The study population is relatively small and recruited in cardiology centers thus selecting a group with more cardiovascular conditions. The study was a questionnaire-based analysis, thus some data are not verifiable. Moreover, some conditions listed questionnaire should have been defined more precisely and analyzed more thoroughly (e.g. metabolic syndrome, sleep apnea syndrome).

\section{CONCLUSIONS}

- Among patients referred with uncontrolled hypertension, the incidence of real resistant hypertension is small.

- A majority of patients referred with resistant hypertension have multiple factors potentially responsible for poor BP control

- The most common causes of pseudo-resistance to therapy are: non-compliance to medication, use of drugs increasing BP, excessive salt intake and metabolic syndrome

\section{REFERENCES}

1. Williams B, Mancia G, Spiering W et al. 2018 ESC/ESH Guidelines for the management of arterial hypertension. Eur Heart J. 2018.

2. Falaschetti E, Chaudhury M, Mindell J, Poulter N. Continued improvement in hypertension management in England: results from the Health Survey for England 2006. Hypertension. 2009;53(3):480-6.

3. Egan BM, Zhao Y, Axon RN. US trends in prevalence, awareness, treatment, and control of hypertension, 1988-2008. JAMA. 2010;303(20):2043-50.

4. Sarafidis PA. Epidemiology of resistant hypertension. J Clin Hypertens (Greenwich). 2011;13(7):523-8.

5. Judd E, Calhoun DA. Apparent and true resistant hypertension: definition, prevalence and outcomes. J Hum Hypertens. 2014;28(8):463-8.

6. Gijon-Conde T, Graciani A, Banegas JR. Resistant hypertension: demography and clinical characteristics in 6,292 patients in a primary health care setting. Rev Esp Cardiol (Engl Ed). 2014;67:270-6, doi: 10.1016/j.rec.2013.09.027.

7. Rossignol P, Massy ZA, Azizi M et al. The double challenge of resistant hypertension and chronic kidney disease. Lancet. 2015;386:1588-98, doi: 10.1016/S0140-6736(15)00418-3.

8. Vongpatanasin W. Resistant hypertension: a review of diagnosis and management.JAMA. 2014;311:2216-24, doi: 10.1001/jama.2014.5180.

9. Romano S, Idolazzi C, Fava C et al. Prevalence and Comorbidities of Resistant Hypertension: A Collaborative Population-Based Observational Study. High Blood Press Cardiovasc Prev. 2018;25(3):295-301. doi: 10.1007/s40292-018-0268-x.

10. de la Sierra A, Armario P, Oliveras A et al. Antihypertensive drug use in resistant and nonresistant hypertension and in controlled and uncontrolled resistant hypertension. J Hypertens. 2018;36(7):15631570, doi: 10.1097/HJH.0000000000001729.

11. Noubiap JJ, Nansseu JR, Nyaga UF, et al. Global prevalence of resistant hypertension: a meta-analysis of data from 3.2 million patients. Heart. 2018 Aug 7. pii: heartjnl-2018-313599. doi: 10.1136/ heartinl-2018-313599.

12. Hwang AY, Dave CV, Smith SM. Use of Prescription Medications that Potentially Interfere with Blood Pressure Control in New-Onset Hypertension and Treatment-Resistant Hypertension. Am J Hypertens. 2018 Jul 25. doi: 10.1093/ajh/hpy118.

13. Zheng L, Du X. Non-steroidal anti-inflammatory drugs and hypertension. Cell Biochem Biophys. 2014 Jun;69(2):209-11, doi: 10.1007/s12013013-9791-5.

14. Blanch $P$, Armario $P$, Oliveras A et al. Association of Either Left Ventricular Hypertrophy or Diastolic Dysfunction With 24-Hour Central and Peripheral Blood Pressure. Am J Hypertens. 2018 Aug 1. doi: 10.1093/ ajh/hpy123. 


\section{ORCID:}

Andrzej Kułach - 0000-0002-3140-1806

Jarosław D Kasprzak - 0000-0002-5850-8187

Mariusz Skowerski - 0000-0002-9598-1862

Edyta Płońska-Gościniak - 0000-0003-1632-3261

Katarzyna Mizia-Stec - 0000-0001-6907-2799

\section{Conflict of interest}

Authors declare no conflict of interest.

\section{CORRESPONDING AUTHOR}

Andrzej Kułach

Department of Cardiology

School of Heart Sciences, Medical University of Silesia,

ul. Ziołowa 47, 40-635 Katowice, Poland;

tel/fax +48322527407 ;

e-mail: andrzejkulach@gmail.com

Nadesłano: 15.07.2019

Zaakceptowano: 13.09.2019

Appendix

\section{A QUESTIONNAIRE FOR THE REGISTRY OF RESISTANT HYPERTENSION}

1 Center (name)

Center No

Date

Center type: university hospital, county hospital., outpatient dept; cardiology, hypertension;

pts/year total ....... HT ......... resistant HT......./year

2 Patient's age .... Sex F/M Family history of HT yes/no

$3 \mathrm{HT}$ - diagnosis

- Yeas from HT diagnosis ......

- Years of treatment .....

- Years of non-optimal treatment ........

- Was the resistant HT diagnosed while patient on 3 medications incl. diuretic? YES/NO

- recent medication:

\begin{tabular}{|c|c|}
\hline \multicolumn{2}{|r|}{ Diuretic yes/no, drug: } \\
\hline \multicolumn{2}{|r|}{$\beta$-Blocker yes/no, drug: } \\
\hline \multicolumn{2}{|c|}{ Ca-Blocker yes/no, drug: : ................................., dose .............. } \\
\hline \multicolumn{2}{|r|}{ a-Blocker yes/no, drug: } \\
\hline ACEl yes/no, & drug: : ................................., dose ............. \\
\hline ARB yes/no, & drug: .................................., dose ............. \\
\hline MRA yes/no, & .........., dose .............. \\
\hline others yes/no, & 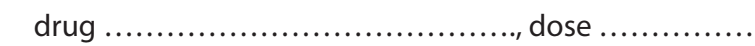 \\
\hline
\end{tabular}

ACEI-angiotensin-converting-enzyme inhibitors; ARB-Angiotensin II receptor antagonists; MRA-mineralocorticoid receptor antagonist;

- Is the BP controlled based on the regimen of at least 3 antihypertensives? yes/:

\begin{tabular}{|c|c|}
\hline \multicolumn{2}{|r|}{ Diuretic yes/no, drug: } \\
\hline \multicolumn{2}{|r|}{$\beta$-Blocker yes/no, drug: } \\
\hline \multicolumn{2}{|c|}{ Ca-Blocker yes/no, drug: : ................................. dose $\ldots \ldots \ldots \ldots \ldots$} \\
\hline \multicolumn{2}{|r|}{ a-Blocker yes/no, drug: } \\
\hline ACEl yes/no, & 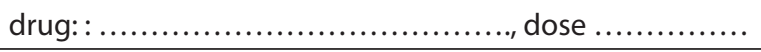 \\
\hline ARB yes/no, & drug: ................................., dose ............. \\
\hline MRA yes/no, & 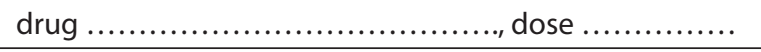 \\
\hline others yes/no, & 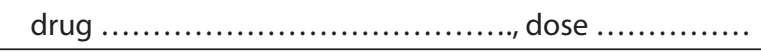 \\
\hline
\end{tabular}

ACEI-angiotensin-converting-enzyme inhibitors; ARB-Angiotensin II receptor antagonists; MRA-mineralocorticoid receptor antagonist; 
Mean BP values :

- ambulatory patients' self control (measurement taken over 7 days, averaged extremes excluded)

- ABPM

Family history of HT: yes/no

4 Factors responsible for HT resistance

- Non-adherence

YES/NO

- Metabolic syndrome

YES/NO

- Excessive sodium intake

YES/NO

- Sleep apnea syndrome

YES/NO

- Kidney failure

YES/NO

- Excessive alcohol intake

YES/NO

- cocaine, amphetamine, psycho stimulants

YES/NO

Drugs inducing HT and affecting BP control

- NSAIDs

YES/NO

- Glycocorticosteroids

YES/NO

- Anabolic steroids

YES/NO

- Oral contraceptives

YES/NO

- Psychotropic drugs.

YES/NO

- Appetite suppressants

YES/NO

- Sympathomimetics

YES/NO

- Cyclosporine

YES/NO

- Erythropoietin

YES/NO

5 Was the secondary HT excluded?

- Renal artery stenosis

YES/NO

- Cushing disease

YES/NO

- Pheochromocytoma

YES/NO

- Primary hyperaldosteronism

YES/NO

- hyperparathyroidism

YES/NO

- Hyperthyroidism TAK/NIE

- Coarctation of Aorta

YES/NO

- Intracranial tumor

YES/NO

6 Were the therapeutic lifestyle changes introduced?

- Weight reduction

YES/NO

- Sodium intake reduction

YES/NO

- Alcohol intake reduction

YES/NO

- Physical activity increase

YES/NO

- DASH diet

YES/NO

7 Complications

- LV systolic dysfunction

YES/NO, EF

- LV diastolic dysfunction

YES/NO,

- LV hypertrophy

YES/NO

- Retinopathy

YES/NO

- Nephropathy

YES/NO

- Stroke

YES/NO

- Aortic aneurysm

YES/NO

- Heart failure

YES/NO

8 Comorbidities

- CAD

YES/NO

- PAD

YES/NO

- Diabetes

YES/NO

- Others

Signature of a qualified medical staff 


\title{
PECULIARITIES OF PSYCHOLOGICAL STATUS IN PATIENTS WITH FUNCTIONAL DYSPEPSIA: POSTPRANDIAL DISTRESS SYNDROME
}

\author{
Anatoliy Svintsitskyy ${ }^{1}$, Galyna Solovyova ${ }^{1,2}$, Sergiy Maliarov ${ }^{2}$, Tetiana Alianova' \\ ${ }^{1}$ BOGOMOLETS NATIONAL MEDICAL UNIVERSITY, KYIV, UKRAINE \\ 2"OBERIG" CLINIC, KYIV, UKRAINE
}

\begin{abstract}
Introduction: Among all causes of epigastric pain or burning, early satiety, bothersome fullness, the most common one is functional dyspepsia (FD). Analysis of psychological peculiarities of patients with FD becomes one of the key problems.

The aim: To compare the level of anxiety, depression, and social functioning of patients with postprandial distress syndrome (PDS), patients with epigastric pain syndrome (EBS), and healthy volunteers.

Materials and methods: This cross-sectional study was conducted in adult patients with FD (58 patients with PDS and 37 patients with EPS) and healthy volunteers ( 30 persons). Patients'social functioning was assessed with the 36-Item Short Form Health Survey (SF-36). Anxiety and depression levels were measured with the Hospital Anxiety and Depression Scale (HADS).

Results: Patients with PDS showed significantly lower rates of physical functioning $(p=0.0002)$, role physical $(p=0.003)$, bodily pain $(p=0.0001)$, general health ( $p=0.0001)$, vitality $(p=0.0001)$, and social functioning ( $p=0.0003$ ), in comparison with healthy volunteers. This group also showed significantly lower rates of general health ( $p=0.041)$, and social functioning $(\mathrm{p}=0.048)$, as compared to patients with EPS. FD led to an increase in anxiety levels regardless of the type of disease as compared with healthy volunteers $(p=0.024)$. Patients with PDS had elevated depression levels compared to patients with EPS $(p=0.023)$ and healthy volunteers $(p=0.001)$.

Conclusions: Each type of FD has a certain impact on the social functioning, anxiety and depression levels. Patients with PDS manifested significant differences in the psychological state as compared to patients with EPS, and healthy volunteers.
\end{abstract}

KEY WORDS: functional dyspepsia, postprandial distress syndrome, social functioning, anxiety, depression

Wiad Lek 2019, 72, 10, 1872-1877

\section{INTRODUCTION}

Epigastric pain or burning, early satiety, bothersome fullness are the most common causes of gastroenterological consultations [1]. Among all causes of dyspepsia, the most common one is functional dyspepsia (FD) [2,3]. A lot of studies demonstrated that FD affects nearly $10-30 \%$ of the population in the countries with advanced living standards. Most of those patients are from working age group [4]. Ford A. et al. analyzed results of esophagogastroduodenoscopy in 5389 patients with dyspepsia and showed that in $82.0 \%$ of cases there were no organic pathology of gastroduodenal area and the symptoms were caused by FD [2].

Functional dyspepsia is not associated with increased mortality, therefore psychological assessment is an important indicator of what impact the disease has on patients $[5,6]$. Patients with FD have reduced quality of life. The reasons include constant emotional distress because of chronic symptoms of FD, financial aspects, and reduced serviceability. FD has two recognized subtypes, which are not mutually exclusive: postprandial distress syndrome (PDS) and epigastric pain syndrome (EPS). PDS is defined by bothersome postprandial fullness or bothersome early satiation. EPS is defined by bothersome epigastric pain or bothersome epigastric burning [7]. PDS is the most common subtype of FD: nearly $50 \%$ of patients with FD have a PDS type of the disease. EPS is diagnosed in $25 \%$ of all other cases, and there is an overlap of these two conditions in $25 \%$ of the total number of patients with FD [8].

The symptoms of postprandial distress syndrome (PDS) include bothersome postprandial fullness or early satiety severe enough to affect daily life or ability to finish a regular-size meal for three or more days per week in the past 3 months, with at least a 6-month history. The symptoms of epigastric pain syndrome (EPS) include bothersome epigastric pain or epigastric burning one or more days per week in the past 3 months, with at least a 6-month history. Both types of FD were discovered to have multiple pathophysiological factors, as was reflected in Rome IV definition. They are gastric emptying, impaired gastric accommodation, gastric and duodenal hypersensitivity to distention, acidity, and the other intraluminal stimuli, duodenal low-grade inflammation, mucosal permeability, food antigens, environmental exposures, Helicobacter pylori infection, and psychological factors (disorders of gut-brain interaction) $[9,10]$.

Therefore, further analysis of psychological peculiarities of patients with FD becomes one of the key problems. 


\section{THE AIM}

To compare the level of anxiety, depression, and social functioning of patients with PDS, patients with EBS, and healthy volunteers.

\section{MATERIALS AND METHODS}

This study was conducted as a cross-sectional study in adult patients with FD and healthy volunteers. The 3 study groups were formed:

- Group 1 included 58 patients with PDS.

- Group 2 included 37 patients with EBS.

- Group 3 included 30 healthy volunteers.

The study was conducted from 01 January 2018 till 01 June 2019 at the Gastroenterological Center of the "Oberig" Clinic in Kyiv, Ukraine. The study was performed in accordance with the Helsinki Declaration.

To be eligible for this study, subjects had to meet all the inclusion criteria and none of the exclusion criteria.

\section{INCLUSION CRITERIA}

1. Men or women $\geq 18$ years of age with a clinical diagnosis of FD, based on Rome IV criteria either for PDS to be included into Group 1, or for EPS to be included into Group 2. Participants had to be free of any diseases or complaints to be included in Group 3.

2. Participant can understand the nature of the study and has provided written informed consent to participate in the study.

Exclusion criteria:

1. Evidence of organic, systemic, or metabolic disease that is likely to explain the symptoms on routine checkups (including an upper endoscopy).

2. Any of the following red flag symptoms: age of onset $>45$ years, persistent vomiting, signs of bleeding, iron deficiency anemia, family history of upper gastrointestinal cancer, progressive dysphagia and/or odynophagia.

3. Known or possible drug and/or alcohol addiction.

4. Relevant abnormalities on physical examination.

There were no differences in age, sex, body mass index, comorbidities among all study groups, and the duration of symptoms was equal in Group 1 and Group 2. The details are provided in Table 1.

The investigators collected the medical history data for all the participants of the study, diagnosis of FD was set according to Rome IV criteria. All the participants underwent a complete blood count, glucose level test, thyroid-stimulating hormone test, stool test, and abdominal ultrasound. Helicobacter pylori infection was diagnosed via rapid one-step immunochromatographic assay for detection of monoclonal Helicobacter pylori antigen in stool samples or in PCR for Helicobacter pylori DNA or using histological methods. Biopsies from the duodenum and stomach were obtained from subjects older than 45 , and additionally they had esophagogastroduodenoscopy with proximal jejunoscopy and chromoscopy. Magnetic resonance imaging and/or computed tomography scan of abdominal cavity were also performed when necessary to exclude any organic pathology.

Patients' social functioning was assessed with the 36-Item Short Form Health Survey (SF-36). The SF-36 consists of eight scaled scores, which are the weighted sum of the questions in their section. Each scale is directly transformed into a $0-100$ scale on the assumption that each question carries equal weight. The lower the score, the more disabled subjects are, and the higher the score, the less disabled they are, i.e., a score of zero is equivalent to maximum disability and a score of 100 is equivalent to no disability. The SF-36 measures eight domains: physical functioning (PF), role physical (RP), bodily pain (BP), general health $(\mathrm{GH})$, vitality $(\mathrm{VT})$, social functioning $(\mathrm{SF})$, role emotional (RE), and mental health (MH).

Anxiety and depression levels were measured with the Hospital Anxiety and Depression Scale (HADS). The questionnaire comprises seven questions for anxiety and seven questions for depression. Scores equal to or greater than 11 on either scale indicate a definitive case, the results of 8-10 are qualified as a masked condition, lower than 7 mean that symptom is absent.

Both questionnaires were filled by the participants themselves. Group 1 and Group 2 completed the questionnaires before any treatment started.

Table 1. Clinical characteristics of study participants

\begin{tabular}{|c|c|c|c|c|c|}
\hline \multirow[b]{2}{*}{ Characteristics } & \multicolumn{3}{|c|}{ Study groups } & \multicolumn{2}{|c|}{$\mathbf{p}$} \\
\hline & $\begin{array}{c}\text { Group } 1 \\
(n=58)\end{array}$ & $\begin{array}{c}\text { Group } 2 \\
(n=37)\end{array}$ & $\begin{array}{c}\text { Group } 3 \\
(n=30)\end{array}$ & $P_{1-2}$ & $\mathbf{p}_{1-3}$ \\
\hline Age, years $(\mathrm{M} \pm \mathrm{SD})$ & $35.5 \pm 6.7$ & $33.2 \pm 5.1$ & $32.0 \pm 4.1$ & $0.061^{*}$ & $0.006^{*}$ \\
\hline Women/men, $\mathrm{n}$ & $38 / 20$ & $24 / 13$ & $18 / 12$ & $0.948^{\#}$ & $0.682^{\#}$ \\
\hline Body mass index, $\mathrm{kg} / \mathrm{m}^{2}(\mathrm{M} \pm \mathrm{SD})$ & $21.1 \pm 1.8$ & $20.8 \pm 1.7$ & $21.0 \pm 1.7$ & $0.506^{*}$ & $0.669^{*}$ \\
\hline Duration of symptoms, months $(\mathrm{M} \pm \mathrm{SD})$ & $92.5 \pm 11.7$ & $91.6 \pm 10.9$ & - & $0.704^{*}$ & - \\
\hline Gastroesophageal reflux disease, n (\%) & $12(20.7 \%)$ & $10(27.0 \%)$ & $11(29.7 \%)$ & $0.475^{\#}$ & $0.316^{\#}$ \\
\hline Irritable bowel syndrome, n (\%) & $6(10.3 \%)$ & $5(13.5 \%)$ & $4(10.8 \%)$ & $0.638^{\#}$ & $0.942^{\#}$ \\
\hline Hypertension, n (\%) & $2(3.4 \%)$ & $1(2.7 \%)$ & $1(2.7 \%)$ & $0.839^{\#}$ & $0.839^{\#}$ \\
\hline Non-alcoholic fatty liver disease, n (\%) & $3(5.2 \%)$ & $2(5.4 \%)$ & $2(5.4 \%)$ & $0.960^{\#}$ & $0.960^{\#}$ \\
\hline
\end{tabular}


Table 2. Analysis of separate SF-36 domains in the study groups

\begin{tabular}{|c|c|c|c|c|c|c|c|c|}
\hline \multirow{2}{*}{ Study groups } & \multicolumn{8}{|c|}{ Results (M, 95\% Cl) } \\
\hline & PF & $\mathbf{R P}$ & BP & GH & VT & SF & RE & MH \\
\hline Group $1(n=58)$ & $\begin{array}{c}74.7 \\
(70.1-79.3)\end{array}$ & $\begin{array}{c}67.1 \\
(60.0-74.1)\end{array}$ & $\begin{array}{c}58.8 \\
(54.3-63.4)\end{array}$ & $\begin{array}{c}53.4 \\
(49.2-55.6)\end{array}$ & $\begin{array}{c}56.8 \\
(52.6-61.0)\end{array}$ & $\begin{array}{c}78.1 \\
(72.8-80.2)\end{array}$ & $\begin{array}{c}74.7 \\
(68.5-77.2)\end{array}$ & $\begin{array}{c}76.2 \\
(74.9-79.4)\end{array}$ \\
\hline Group $2(n=37)$ & $\begin{array}{c}77.4 \\
(69.6-85.3)\end{array}$ & $\begin{array}{c}72.0 \\
(60.9-83.1)\end{array}$ & $\begin{array}{c}58.5 \\
(51.0-66.0)\end{array}$ & $\begin{array}{c}63.2 \\
(56.4-69.9)\end{array}$ & $\begin{array}{c}59.7 \\
(52.6-66.5)\end{array}$ & $\begin{array}{c}86.5 \\
(80.3-92.7)\end{array}$ & $\begin{array}{c}84.3 \\
(77.3-92.3)\end{array}$ & $\begin{array}{c}80.6 \\
(75.9-85.3)\end{array}$ \\
\hline Group $3(n=30)$ & $\begin{array}{c}84.1 \\
(82.7-85.5)\end{array}$ & $\begin{array}{c}78.3 \\
(75.8-80.8)\end{array}$ & $\begin{array}{c}73.9 \\
(72.1-75.7)\end{array}$ & $\begin{array}{c}69.7 \\
(68.3-71.2)\end{array}$ & $\begin{array}{c}70.4 \\
(68.9-71.9)\end{array}$ & $\begin{array}{c}89.3 \\
(88.0-90.6)\end{array}$ & $\begin{array}{c}81.9 \\
(79.7-84.2)\end{array}$ & $\begin{array}{c}82.8 \\
(80.8-84.9)\end{array}$ \\
\hline $\mathrm{p}_{1-2}{ }^{*}$ & 0.556 & 0.457 & 0.946 & 0.041 & 0.470 & 0.048 & 0.370 & 0.125 \\
\hline $\mathrm{p}_{1-3} *$ & 0.0002 & 0.003 & 0.0001 & 0.0001 & 0.0001 & 0.0003 & 0.119 & 0.236 \\
\hline
\end{tabular}

\section{STATISTICAL ANALYSIS}

In this study we used descriptive statistics of the endpoints and comparisons among groups were applied. We used Fisher's exact test and $\chi^{2}$ test for categorical variables, and t-tests for continuous variables for comparative analysis between groups of patients with FD (Group 1 and Group 2 ) and in comparison with the Group 3. Statistical significance was considered at $\mathrm{p}<0.05$.

\section{RESULTS AND DISCUSSION}

Detailed results of SF-36 domains are provided in Table 2.

$\mathrm{PF}$ is a subscale which indicates the impact of the physical condition on the physical activity. According to the analysis, PF score in Group 1 was the lowest (74.7 vs 77.4 and 84.1). There were no statistically significant differences in PF score in comparison with Group 2. However the score was significantly lower, as compared with Group 3 $(\mathrm{p}=0.0002)$. Consequently, FD leads to the decrease of PF score regardless of its type.

The subscale RP allows to evaluate the influence of physical condition on daily role activity. The results in Group 1 were the lowest, although there was no statistically significant difference as compared to Group 2 (67.1 vs 72.0). RP score was significantly lower in Group 1 as opposed to Group 3 (67.1 vs 78.3; $p=0.003$ ). According to the results, FD causes the decrease of RP score regardless of its type.

$\mathrm{BP}$ is an indicator of the impact of pain on the ability to perform normal daily work, including household duties. There were no differences in BP rate shown for Group 1 and Group 2 ( 58.8 vs 58.5 ). BP score was significantly lower in Group 1 in comparison with Group 3 (58.8 vs 73.9; $\mathrm{p}=0.0001$ ). Consequently, FD leads to the decrease of BP score regardless of the disease type.

The subscale GH is self-assessment of a person's current state of health and the prospects for treatment if/when necessary. The statistical analysis demonstrated that the lowest GH score was in the Group 1. The difference was significant in comparison with Group 2 score ( 53.4 vs 63.2; $\mathrm{p}=0.041$ ) and with Group 3 score (53.4 vs $69.7 ; \mathrm{p}=0.0001$ ). Consequently, patients with PDS have a significantly lower GH score in comparison to patients with another type of FD - EBS, and with healthy people.
VT is an indicator of a degree of strength and energy, or vice versa, of weakness. The VT score was lower in Group 1 as compared with Group 2 (56.8 vs 59.7), although there was no evidence of any statistically significant differences $(\mathrm{p}=0.470)$. The VT score was significantly lower in the Group 1 than in Group 3 (56.8 vs 70.4; $\mathrm{p}=0.0001$ ). These results demonstrate that FD leads to the decrease of VT score regardless of the disease type.

The subscale SF determines the extent to which the physical or emotional state limits social activity (communication). Group 1 score was significantly lower in contrast to Group 2 (78.1 vs $86.5 ; \mathrm{p}=0.048$ ), and Group 3 (78.1 vs 89.3; $\mathrm{p}=0.0003$ ). Consequently, patients with PDS have a significantly lower SF score in relation to patients with EBS, and healthy people.

$\mathrm{RE}$ is an indicator of influence of the emotional condition on the ability to perform the work, including everyday activities. No statistically significant differences in RE scores were detected for all study groups.

$\mathrm{MH}$ subscale characterizes mood, the presence of depression, anxiety. There was no evidence of statistically significant differences in $\mathrm{MH}$ scores for the study groups.

Consequently, the presence of FD leads to decrease in social functioning according to SF-36. The significantly lower rates for Groups 1 and 3 were shown for PF, RP, BP, GH, VT, and SF. Patients with PDS were demonstrated to have lower scores in GH and SF subscales in comparison with patients with EPS (Fig. 1).

Detailed results of anxiety and depression scores for each group are provided in Table 3 .

The highest mean value of the anxiety was in Group 1 (7.9). $28.8 \%$ of the patients from this group did not have anxiety, $71.2 \%$ did $(28.8 \%$ - masked anxiety, $42.4 \%$ definite anxiety). Although the anxiety score was lower for Group 2 (7.5), no statistically significant differences for Group 1 and Group 2 were revealed $(p=0.637)$. The comparison of Group 1 and Group 3 demonstrated a significant increase of anxiety level in patients from Group $1(\mathrm{p}=0.024)$. Consequently, FD leads to the increase of anxiety level regardless of the type of disease (Fig. 2).

The highest mean value of depression was discovered in Group 1 (8.2). 39.6\% of the subjects from this group did not have depression, $60.4 \%$ of them showed signs of depression 


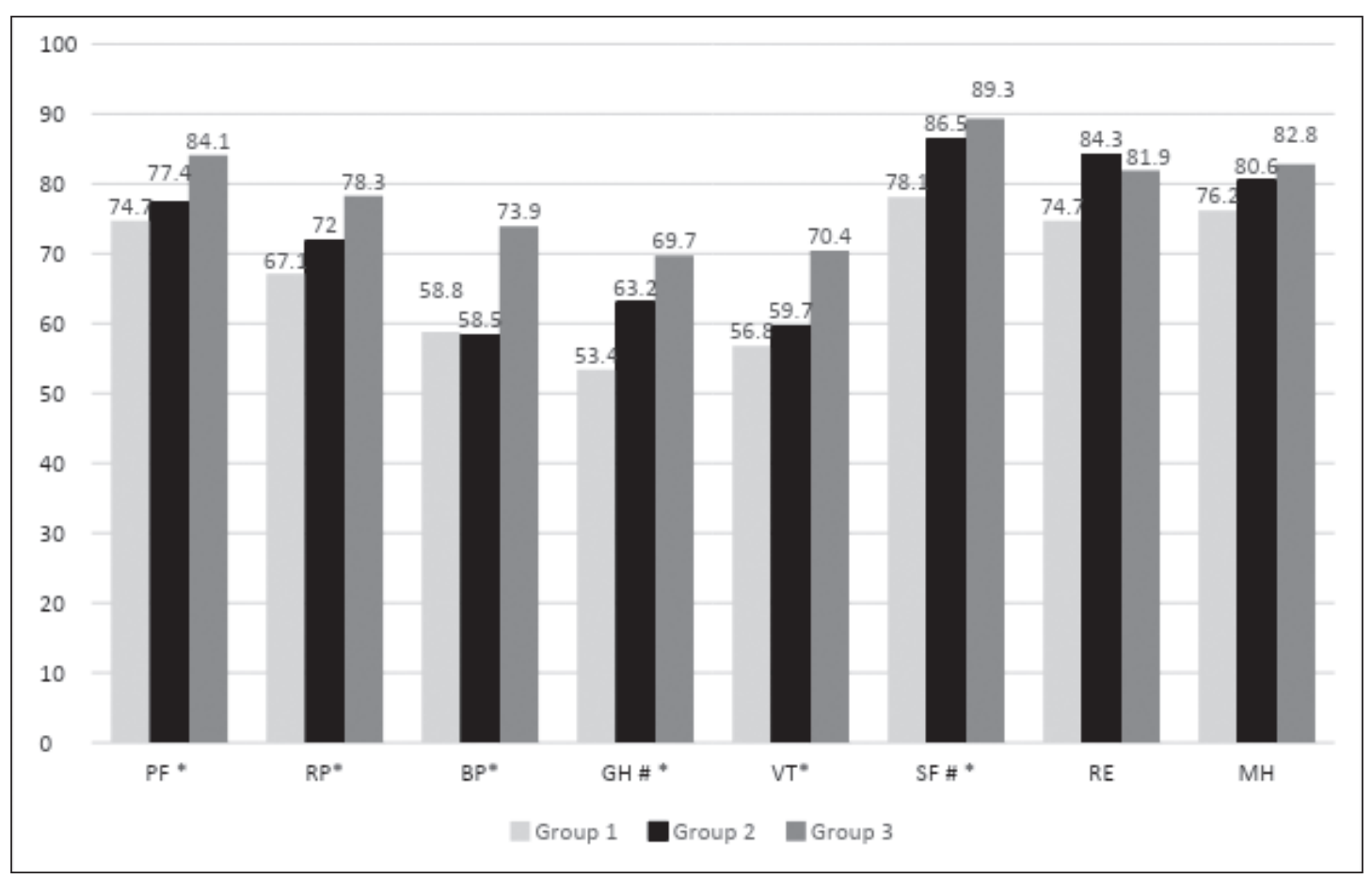

Fig. 1. Results of SF-36 questionnaire analysis for the study groups

\# - statistical significance of differences for Group 1 and Group 2

* - statistical significance of differences for Group 1 and Group 3

Table 3. The results of HADS subscales for the study groups

\begin{tabular}{|c|c|c|c|c|c|c|}
\hline & \multirow[b]{2}{*}{ Characteristics } & \multicolumn{3}{|c|}{ Study groups } & \multicolumn{2}{|c|}{$\mathbf{p}^{*}$} \\
\hline & & $\begin{array}{c}\text { Group } 1 \\
(n=58)\end{array}$ & $\begin{array}{c}\text { Group 2 } \\
(n=37)\end{array}$ & $\begin{array}{c}\text { Group } 3 \\
(n=30)\end{array}$ & $\mathbf{p}_{1-2}$ & $\mathbf{p}_{1-3}$ \\
\hline \multirow{4}{*}{ 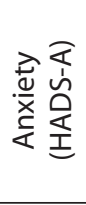 } & No anxiety (for the score $0-7$ ), \% & 28.8 & 32.4 & 90 & & \\
\hline & Masked anxiety $(8-10), \%$ & 28.8 & 32.4 & 10 & & \\
\hline & Definite anxiety (11-21), \% & 42.4 & 35.2 & 0 & & \\
\hline & Total score $(\mathrm{M} \pm \mathrm{SD})$ & $7.9 \pm 4.7$ & $7.5 \pm 3.5$ & $3.9 \pm 2.3$ & 0.637 & 0.024 \\
\hline \multirow{4}{*}{ 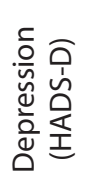 } & No depression (for the score $0-7$ ), \% & 39.6 & 67.5 & 96.6 & & \\
\hline & Masked depression (8-10), \% & 22.4 & 21 & 3.4 & & \\
\hline & Definite depression (11-21), \% & 38 & 11.5 & 0 & & \\
\hline & Total score $(M \pm S D)$ & $8.2 \pm 5.3$ & $5.0 \pm 3.9$ & $4.0 \pm 3.0$ & 0.023 & 0.001 \\
\hline
\end{tabular}

(22.4\% - masked depression, $38 \%$ - definite depression). Further analysis demonstrated statistically significant differences for Group 1 compared with Group 2 ( $\mathrm{p}=0.023$ ), and for Group 1 compared with Group $3(\mathrm{p}=0.001)$. Consequently, patients with PDS have an elevated level of depression as compared to patients with EBS and to healthy volunteers (Fig. 3).

We also compared received data with results of another studies. P. Aro et al. published the results that demonstrated the SF-36 domain scores in the Kalixanda endoscopic study population differ from Swedish mean values only for $\mathrm{RP}$ and $\mathrm{GH}$, and their mean values were very near the respective values found in the Finnish general population. All SF-36 domain scores in PDS, except for RE, were both clinically and statistically significantly lower compared with nondyspeptic individuals. The authors also compered the received data with previous trials that took place in the Western European countries and concluded there were only minor differences in the results [11]. O.I. Sergiienko and O.V. Bezsonova also received the data that confirmed the decreased social functioning levels in patients with FD in Ukrainian population [12].

B.F. Filipović et al. concluded that depression and anxiety level is the highest in patients with FD, if to compare with patients with chronic gastritis and healthy volunteers [13]. Similar results were received by P. Aro et al. They performed a prospective cohort study in Sweden, in which 1000 persons participated for 10 years. They demonstrated that in Swedish population anxiety at baseline, but not depression, increased the risk for development of FD [14]. Similar opinion demonstrated F. De Giorgi et al. who con- 


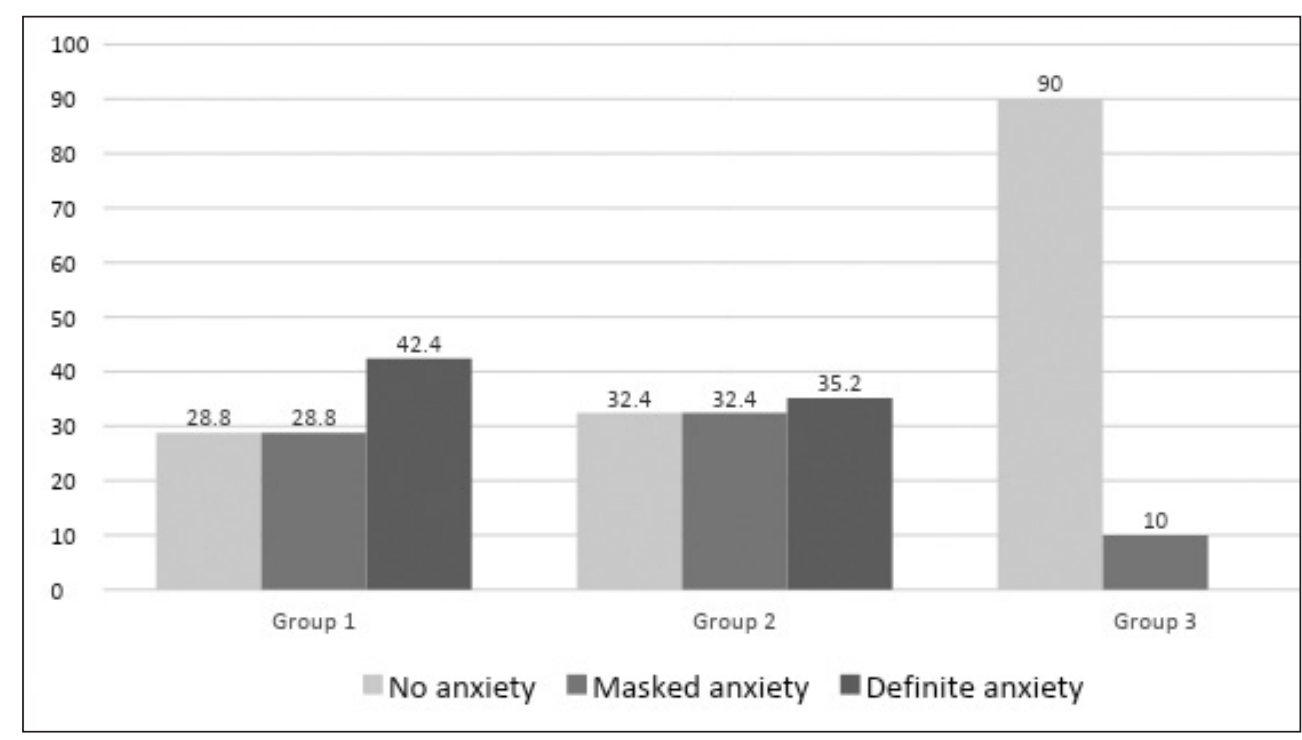

Fig. 2. Anxiety levels according to HADS-A analysis in the study groups

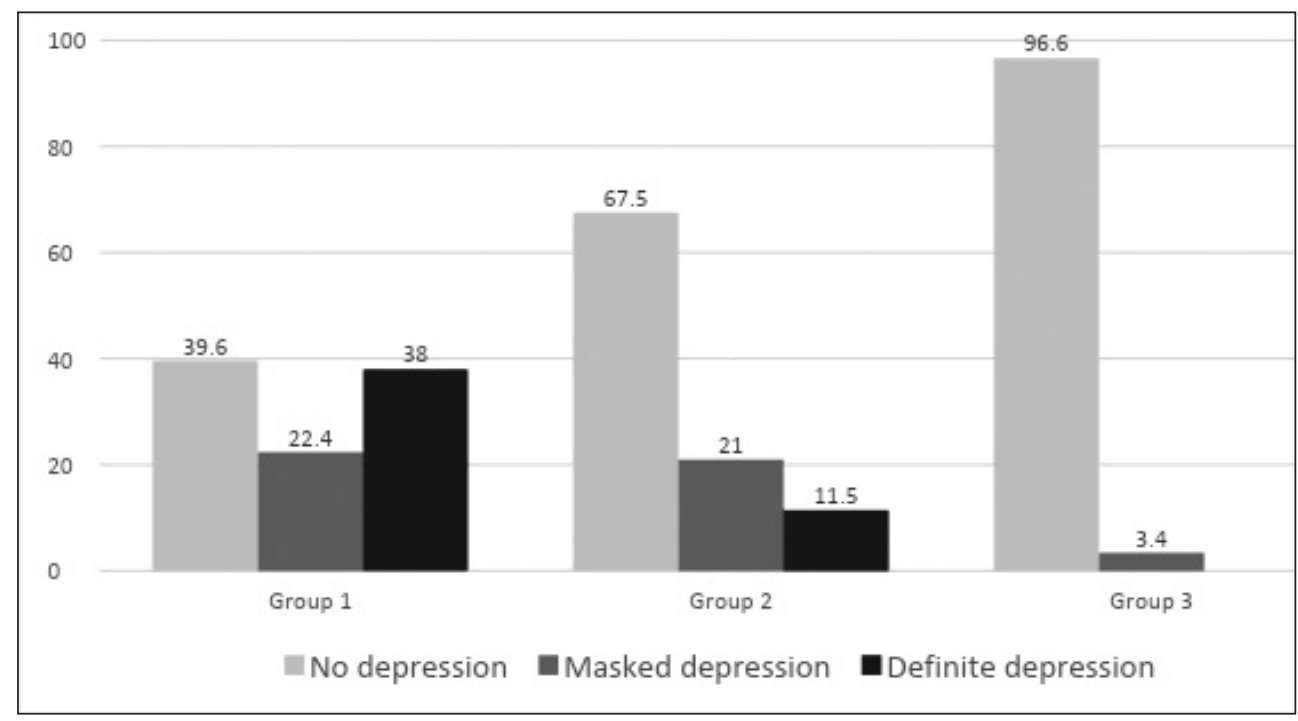

Fig. 3. Depression levels according to HADS-D analysis in the study groups

cluded that FD is related to increased anxiety level [15]. In Ukraine D. Janelidze discovered the relation between depression level and FD symptoms severity [16].

Our findings are consistent with the published literature. However in previous researches no differential statistical analysis was performed for different types of FD - PDS and EBS. The data that was collected in those studies also was based on Rome III criteria to set the diagnosis of FD. As a result currently the lack of updated data is present.

\section{CONCLUSIONS}

Each type of functional dyspepsia - postprandial distress syndrome and epigastric pain syndrome - has a certain impact on the social functioning, anxiety and depression levels. Patients with postprandial distress syndrome manifested significant differences in the psychological state as compared to patients with epigastric pain syndrome, and healthy volunteers:
- Patients with postprandial distress syndrome showed significantly lower rates of physical functioning, role physical, bodily pain, general health, vitality, and social functioning, in comparison with healthy volunteers.

- Patients with postprandial distress syndrome showed significantly lower rates of general health, and social functioning, as compared to patients with epigastric pain syndrome.

- Functional dyspepsia led to an increase in anxiety levels regardless of the type of disease as compared with healthy volunteers.

- Patients with postprandial distress syndrome had elevated depression levels compared to patients with epigastric pain syndrome and healthy volunteers.

\section{REFERENCES}

1. Moayyedi P, Lacy BE, Andrews CN et al. ACG and CAG clinical guideline: Management of dyspepsia. Am J Gastroenterol. 2017;112(7):988-1013. doi: 10.1038/ajg.2017.154. 
2. Ford AC, Marwaha A, Lim A, Moayyedi P. What is the prevalence of clinically significant endoscopic findings in subjects with dyspepsia? Systematic review and meta-analysis. Clin Gastroenterol Hepatol. 2010;8(10):830-837. doi: 10.1016/j.cgh.2010.05.031.

3. Stanghellini V, Chan FK, Hasler WL et al. Gastroduodenal disorders. Gastroenterology. 2016;150(6):1380-1392. doi: 10.1053/j. gastro.2016.02.011.

4. Palsson OS, Whitehead WE, van Tilburg MA et al. Rome IV diagnostic questionnaires and tables for investigators and clinicians. Gastroenterology. 2016;150(6):1481-1491. doi: 10.1053/j. gastro.2016.02.014.

5. Hantoro IF, Syam AF, Mudjaddid E et al. Factors associated with healthrelated quality of life in patients with functional dyspepsia. Health Qual Life Outcomes. 2018;16(1):83. doi: 10.1186/s12955-018-0913-z.

6. Marrie RA, Leung $S$, Tyry T et al. Functional gastrointestinal disorders negatively affect health-related quality of life in MS. Neurology: Neurol Clin Pract. Published online 2019 May 24. doi: 10.1212/ CPJ.0000000000000668.

7. Futagami S, Yamawaki H, Agawa S et al. New classification Rome IV functional dyspepsia and subtypes. Transl Gastroenterol Hepatol. 2018;3:70. doi: 10.21037/tgh.2018.09.12.

8. Friesen CA, Schurman JV. The challenges of evolving Rome criteria for functional dyspepsia. Transl Gastroenterol Hepatol. 2018;3:63. doi: 10.21037/tgh.2018.09.08.

9. Drossman DA, Hasler WL. Rome IV - functional GI disorders: disorders of gut-brain interaction. Gastroenterology. 2016;150(6):1257-1261. doi: 10.1053/j.gastro.2016.03.035.

10. Drossman DA, Tack J, Ford AC et al. Neuromodulators for functional gastrointestinal disorders (disorders of gut-brain interaction): a Rome Foundation working team report. Gastroenterology. 2018;154(4):1140 1171. doi: 10.1053/j.gastro.2017.11.279.

11. Aro P, Talley NJ, Agréus L et al. Functional dyspepsia impairs quality of life in the adult population. Aliment Pharmacol Ther. 2011;33(11):12151224. doi: 10.1111/j.1365-2036.2011.04640.x.

12. Sergiienko 0I, Bezsonova OV. Peculiarities of clinical manifestations of functional dyspepsia and chronic gastritis depending on patients' psychological state and gender. Zaporozhye Medical Journal. 2011;13(5):50-53.

13. Filipović BF, Randjelovic T, Ille T et al. Anxiety, personality traits and quality of life in functional dyspepsia-suffering patients. Eur J Intern Med. 2013;24(1):83-86. doi: 10.1016/j.ejim.2012.06.017.
14. Aro P, Talley NJ, Johansson SE et al. Anxiety is linked to newonset dyspepsia in the Swedish population: a 10-year follow-up study. Gastroenterology. 2015;148(5):928-937. doi: 10.1053/j. gastro.2015.01.039.

15. De Giorgi F, Sarnelli G, Cirillo C et al. Increased severity of dyspeptic symptoms related to mental stress is associated with sympathetic hyperactivity and enhanced endocrine response in patients with postprandial distress syndrome. Neurogastroenterol Motil. 2013;25(1):31-38. doi: 10.1111/nmo.12004.

16. Janelidze D. Helicobacter pylori infection and depression level correlation in patients with overlap syndrome, functional dyspepsia and nonerosive reflux disease. Collection of Scientific Works of StaffMembers of Shupyk NMAPE. 2013;22(2):21-26.

\section{Authors' contributions:}

According to the order of the Authorship.

\section{ORCID numbers:}

Anatoliy Svintsitskyy - 0000-0002-0689-5365

Galyna Solovyova - 0000-0001-8245-3051

Sergiy Maliarov - 0000-0002-3318-3830

Tetiana Alianova - 0000-0001-5790-8480

\section{Conflict of interest:}

The authors declare no conflict of interest.

\author{
CORRESPONDING AUTHOR \\ Anatoliy Svintsitskyy \\ Department of Internal Medicine \\ Bogomolets National Medical University \\ 13 T. Shevchenko Blvd., Kyiv, 01601, Ukraine \\ e-mail:sasnmu@gmail.com
}

Received: 08.07.2019

Accepted: 30.09 .2019 


\title{
THE ROLE OF HYDROGEN SULFIDE IN THE PROGRESSION OF CHRONIC OBSTRUCTIVE PULMONARY DISEASE IN PATIENTS WITH NON-ALCOHOLIC STEATOHEPATITIS
}

\author{
Oksana S. Khukhlina, Olha Ye. Hryniuk, Inna V. Dudka, Svitlana V. Kovalenko, Tetiana V. Dudka, Olha Ye. Mandryk \\ HIGHER STATE EDUCATIONAL ESTABLISHMENT OF UKRAINE «BUKOVINIAN STATE MEDICAL UNIVERSITY», CHERNIVTSI, UKRAINE
}

\begin{abstract}
Introduction: The steady increase in the incidence of comorbidity of chronic obstructive pulmonary disease and non-alcoholic steatohepatitis against the background of obesity in people of working age in Ukraine and in the world stipulates the need of investigation of the mechanisms of interconnection and the search for new factors of the pathogenesis of progression of this comorbid pathology. Attention to the role of hydrogen sulfide in the development of fibrosis has only been recently paid.

The aim: To establish the role of hydrogen sulfide in the mechanisms of progression of chronic obstructive pulmonary disease and non-alcoholic steatohepatitis against the background of obesity.

Materials and methods: 100 patients with chronic obstructive pulmonary disease have been examined, including 49 with non-alcoholic steatohepatitis and obesity of the $1^{\text {st }}$ stage: group $1-28$ patients with chronic obstructive pulmonary disease (2B GOLD); group $2-23$ patients with chronic obstructive pulmonary disease (3C, D); group $3-25$ patients with chronic obstructive pulmonary disease (2B) with non-alcoholic steatohepatitis; group $4-24$ patients with chronic obstructive pulmonary disease (3C, D) and non-alcoholic steatohepatitis. The average age of patients was (47.3 3.1 ) years. There were 20 apparently healthy persons of the corresponding age and sex in the control group. Results: The received data confirm that patients with chronic obstructive pulmonary disease secondary to non-alcoholic steatohepatitis, which developed against the background of obesity, suffer from a significant increase in the synthesis of collagen and glycoproteins, accompanied by an ineffective resorption of newly formed collagen due to insufficient activation of collagenolysis and proteolysis, a significant imbalance in the connective tissue metabolism system, which leads to progressive fibrosis of the lungs and liver and disturbances of their functions. This was caused by the disorder of $\mathrm{H}_{2} \mathrm{~S}$ homeostasis, confirmed by the data of correlation analysis.

Conclusions: Patients with chronic obstructive pulmonary disease and non-alcoholic steatohepatitis, which developed against the background of obesity, are characterized by a significant increase in the synthesis of collagen and glycoproteins, which was accompanied by an ineffective resorption of newly formed collagen against the background of substantial activation of proteinase inhibitors ( $\left.a_{2}-M G\right)$, accompanied by the hyperproduction of nitrogen monoxide, endothelin-1, hyperlipidemia, deficiency of hydrogen sulfide liberation.
\end{abstract}

KEY WORDS: chronic obstructive pulmonary disease, non-alcoholic steatohepatitis, hydrogen sulfide

Wiad Lek 2019, 72, 10, 1878-1882

\section{INTRODUCTION}

The steady increase in the incidence of comorbidity of chronic obstructive pulmonary disease (COPD) and non-alcoholic steatohepatitis (NASH) against the background of obesity in people of working age in Ukraine and in the world $[1,2,3,4]$ stipulates the need of investigation of the mechanisms of interconnection and the search for new factors of the pathogenesis of progression of this comorbid pathology. Attention to the role of hydrogen sulfide $\left(\mathrm{H}_{2} \mathrm{~S}\right)$ in the development of fibrosis has only been recently paid $[5,6,7]$. Studies have revealed that $\mathrm{H}_{2} \mathrm{~S}$ plays a dose-dependent role in the development of fibrosis in the lungs, liver, kidneys and myocardium $[8,9]$. Research results show that the processes of fibrosis formation in the organs correlate in strong interdependence with the disorder of endogenous $\mathrm{H}_{2} \mathrm{~S}$ synthesis, decrease in the activity of $\mathrm{H}_{2} \mathrm{~S}$-generating enzymes in blood plasma and directly in tissues $[9,10]$. Stimulation and renewal of exogenous $\mathrm{H}_{2} \mathrm{~S}$ synthesis reduces the severity of fibrosis in various experimental animal models [7]. Enzymes that provide the endogenous synthesis of $\mathrm{H}_{2} \mathrm{~S}$ (cystathionine- $\beta$-synthase (CBS), cystathionine $\gamma$-lyase (CSE)) are present in the liver and lungs [11]. $\mathrm{H}_{2} \mathrm{~S}$ is generated by transsulfuration from L-cysteine and homocysteine [12]. In addition, 3-mercaptopyruvatesulfurtransferase (MST) can also catalyze $\mathrm{H}_{2} \mathrm{~S}$ formation together with cysteine aminotransferase [13].

Liver fibrosis is a dynamic process occurring in response to various stimuli, which leads to the destruction of the architectonics of the liver parenchyma, with subsequent excessive deposition of the extracellular matrix (ECM) components, formation of fibrous tissue, and pathological regeneration with the development of cirrhosis (the final pathological stage of liver fibrosis) $[14,15,16]$. Significant inhibition of CBS and CSE expression/activity and decreased levels of $\mathrm{H}_{2} \mathrm{~S}$ in plasma have been detected in patients with liver cirrhosis [17]. The investigation based on animal models of fibrosis of different organs has demonstrated a significant reduction in endogenous $\mathrm{H}_{2} \mathrm{~S}$ levels in plasma and tissues and inhibition of $\mathrm{H}_{2} \mathrm{~S}$-producing 
enzymes, while the introduction of exogenous $\mathrm{H}_{2} \mathrm{~S}$ may inhibit fibrosis development [18]. The development of lung fibrosis is a consequence of COPD caused by various factors, such as organic and inorganic particles, chemicals, ionizing radiation and infections $[19,20]$. Its final stage is the formation of a cellular lung - a rough deformation of the pulmonary pattern, with the replacement of pulmonary parenchyma by an excessively synthesized connective tissue [21]. $\mathrm{H}_{2} \mathrm{~S}$-producing enzymes, (CSE, CBS and/or MST) are expressed in human and animal lungs [22], and the amount of physiological $\mathrm{H}_{2} \mathrm{~S}$ concentration in healthy people is from 10 to $300 \mu \mathrm{mol} / 1$ [ 23 ]. The change in the activity of the enzymes producing $\mathrm{H}_{2} \mathrm{~S}$ and endogenous $\mathrm{H}_{2} \mathrm{~S}$ levels is associated with the development of pulmonary fibrosis. This has been proven in the studies on pathological models of Bleomycinum (BLM) - induced pulmonary fibrosis, which showed that $\mathrm{H}_{2} \mathrm{~S}$ content in plasma and the rate of $\mathrm{H}_{2} \mathrm{~S}$ production in pulmonary tissues in the experimental groups decreased by $44 \%$ and $27 \%$ respectively on the $7^{\text {th }}$ day. These results may be related to the compensatory mechanism of reducing $\mathrm{H}_{2} \mathrm{~S}$ in the body. The content of hydroxyproline in the lungs, as a collagen deposition marker, increased by $43 \%$ in the BLM treatment group on the $7^{\text {th }}$ day and by $100 \%$ on the $28^{\text {th }}$ day with histological changes in infiltration of inflammatory cells, proliferation of fibroblasts and collagen precipitation, whereas intraperitoneal administration of sodium hydrosulfide $-\mathrm{H}_{2} \mathrm{~S}$ donator ( $\mathrm{NaHS}, 1.4$ and $7 \mu \mathrm{mol} / \mathrm{kg}$ of body weight, respectively) reduced the hydroxyproline content twice a day and neutralized the severity of lung fibrosis [25]. According to BLM-induced pulmonary fibrosis, a decrease in the endogenous level of $\mathrm{H}_{2} \mathrm{~S}$ in plasma and pulmonary tissue was observed in another model of lung fibrosis caused by tobacco smoking, accompanied by an increase in the expression of type I collagen and the emergence of typical histopathological changes of pulmonary fibrosis, whereas when using NaHS at $8 \mu \mathrm{mol} / \mathrm{kg}$ once a day $\mathrm{H}_{2} \mathrm{~S}$ level significantly increases and passive pulmonary fibrosis, caused by smoking, is inhibited [26]. According to the above-mentioned studies, exogenous $\mathrm{H}_{2} \mathrm{~S}(\mathrm{NaHS})$ is considered to be a protective factor against the development of lung fibrosis at a comparatively low dose from $1.4 \mu \mathrm{mol} / \mathrm{kg}$ of body weight 2 times a day to $28 \mu \mathrm{mol} / \mathrm{kg}$ once a day. However, high concentrations of $\mathrm{H}_{2} \mathrm{~S}$ ( $>500 \mathrm{ppm}$ ) can cause pulmonary edema and ultimately lead to chronic inflammation and pulmonary fibrosis $[7,27]$. In addition to the clear protective role of $\mathrm{H}_{2} \mathrm{~S}$, proved in many studies, including animal models and in vitro experiments [28,29], disorders of the expression of endogenous $\mathrm{H}_{2} \mathrm{~S}$-producing enzymes and levels of endogenous $\mathrm{H}_{2} \mathrm{~S}$ in patients with COPD and pulmonary fibrosis against the background of NASH are still unknown. Comprehensive studies of $\mathrm{H}_{2} \mathrm{~S}$ homeostasis may reveal new mechanisms for COPD and NASH intercomplication. Based on the established data, it will be possible to justify the ways of correction of the established disorders.

\section{THE AIM}

To establish the role of $\mathrm{H}_{2} \mathrm{~S}$ in the mechanisms of progression of chronic obstructive pulmonary disease and non-alcoholic steatohepatitis against the background of obesity.

\section{MATERIALS AND METHODS}

100 patients with COPD have been examined, including 49 with NASH and obesity of the $1^{\text {st }}$ stage: group $1-28$ patients with COPD (2B GOLD); group $2-23$ patients with COPD (3C, D); group 3 - 25 patients with COPD (2B) with NASH; group $4-24$ patients with COPD (3C, D) and NASH. The average age of patients was $(47.3 \pm 3.1)$ years. There were 20 apparently healthy persons (AHP) of the corresponding age and sex in the control group. The study did not contradict ethical standards and was checked by the ethics committee of the HSEE of Ukraine «Bukovinian State Medical University».

The content of $\mathrm{H}_{2} \mathrm{~S}$ in the blood was determined by the spectrophotometric method [21]. Changes in the metabolism of the components of the extracellular matrix were determined by the content of oxyproline in the blood: free oxyproline (FOP) - by S.S. Tetianets (1985) and protein-bound oxyproline (PBOP) by M.S. Osadchuk (1979), hexosamines (HA) by O.H. Arkhipova (1988), seromucoids (SM), sialic acids (SA) with the help of sets of «Danysh Ltd» (Lviv), ceruloplasmin (CP) by M.R. Revin method (1976). The state of proteolytic activities of blood plasma was studied by the total activity of blood serum proteinases - according to M. Kunitz (1975), lysis intensity of lowmolecular weight proteins (azoalbumin), macromolecular proteins (azocasein) and collagen (azocol lysis) with the help of the «Danysh Ltd» (Lviv) reagents. The state of the proteinase-inhibitor system was studied by the content of $\alpha_{2}$-MGin blood serum, the content of $\alpha_{1}$-IP in blood plasma («Danysh Ltd», Lviv). The lipid profile of the blood was studied based on the content of common lipids, total cholesterol (TCh), triacylglycerols (TG), low density lipoprotein (LDL) cholesterol, high density lipoprotein (HDL) cholesterol, and atherogenic index (AI). The functional state of the endothelium was studied according to the content of nitrogen monoxide (NO) (nitrites/nitrates) metabolites, endothelin-1in the blood, by means of ELISA method.

Statistical processing of the results of the research was carried out using parametric and nonparametric methods of variation statistics. The normal distribution was checked using the Shapiro-Wilk test and the method of direct visual evaluation of eigenvalues distribution histograms. Quantitative indices having a normal distribution are represented as mean $(\mathrm{M}) \pm$ standard deviation (S).In case of a nonparametric distribution, the data are presented as median $(\mathrm{Me})$ as a position measure, upper $\left(\mathrm{Q}_{75}\right)$ and lower quartile $\left(\mathrm{Q}_{25}\right)$ as a measure of scattering. Parametric tests for the evaluation of Student's t-criterion, Fisher's F-criterion were used to compare the data having a normal distribution pattern. Pearson correlation analysis at the parametric distribution and Spearman's rank correlation coefficient were used to estimate the degree of dependence between variables. $\chi^{2}$ criterion of maximum likelihood (log-likelihood) (ML $\chi^{2}$ ) was applied to compare discrete variables in independent groups, calculation of the precise Fisher criterion (mid-p) modification was used to compare pairs of discrete values. Software packages Statistica for Windows version 8.0 (Stat Soft Inc., USA), Microsoft Excel 2007 (Microsoft, USA) were used for statistical and graphical analysis of the obtained results. 


\section{RESULTS AND DISCUSSION}

The analysis of the stage of bronchial obstructive syndrome in the comparison groups has revealed that the degree of FEV1reduction is lower in patients with COPD accompanied by NASH, than that in patients undergoing the isolated course (Table I): the reduction in group 1 of patients was 1.4 times compared with the AHP $(\mathrm{p}<0.05)$, in group $3-1.7$ times $(\mathrm{p}<0.05)$ respectively. In patients of groups 2 and 4 it was 2.4 and 2.8 times $(\mathrm{p}<0.05)$ respectively. Thus, comorbidity with NASH in patients with COPD contributes to increased obstruction of the bronchi. It should also be noted that the activity of NASH increases with the increase in the stage of COPD: the activity of ALAT exceeded the data in the AHP by 2.2 and 2.8 times $(\mathrm{p}<0.05)$ in patients of groups 3 and 4 respectively, indicating the unfavorable effect of COPD on the course of NASH.

The content of $\mathrm{H}_{2} \mathrm{~S}$ in the blood of patients of groups 1-4 was reduced: in $1.3,1.5,1.7$ and 2.6 times $(p<0.05)$ respectively in comparison with this index in AHP. The analysis of the intensity of fibrous reactions in patients with COPD, depending on the presence of comorbid NASH, indicates a probable increase in the content of PBOP in the blood of patients of all groups: in the $1^{\text {st }}$ group - 1.5 times in comparison with the AHP $(\mathrm{p}<0.05)$, in patients of group $2-1.8$ times $(\mathrm{p}<0.05)$, group $3-2.0$ times $(\mathrm{p}<0.05)$, in patients of group $4-2.4$ times $(\mathrm{p}<0.05)$. At the same time, the index of FOP content in the blood (Table I), which is the biochemical marker of collagen catabolism, in patients with COPD of group 1 was 1.2 times higher $(p<0.05)$ than that in AHP, in patients of group $2-1.4$ times $(\mathrm{p}<0.05)$, indicating a parallel increase in collagen degradation against the background of its high synthesis. The activity of collagen degradation was even more intense in comorbidity with NASH: in patients of groups 3 and $4-1.5$ and 1.7 times $(\mathrm{p}<0.05)$ respectively (Table I). A reliable increase in blood collagenolytic activity indices was detected in patients of all groups, its intensity exceeded the index in AHP in group 1 - by $10.7 \%(\mathrm{p}<0.05)$, in patients group 2 - by $16.7 \%(\mathrm{p}<0.05)$, in patients of groups 3 and 4 - more intensively: $34.5 \%$ and $61.9 \%$ with a reliable intergroup difference $(\mathrm{p}<0.05)$.

Lysis intensity of low molecular weight proteins in patients of all groups was higher than the index in AHP, 1.51.9 times $(\mathrm{p}<0.05)$ respectively and increased depending on the stage of COPD and with the occurrence of NASH. A reliable increase of $\alpha_{2}-\mathrm{MG}$ in blood (Table I) depending on the stage of COPD has been detected: in patients of group 2 (1.7 times versus 1.5 times in patients of group 1, $\mathrm{p}<0.05$ ), but these indices did not change at comorbidity with NASH $(p>0.05)$. Indices of ceruloplasmin content indicate its reliable increase in patients of all groups of observation $(\mathrm{p}<0.05)$ with the reliable prevalence in $\mathrm{pa}-$ tients of group 4 (2.3 times versus 1.9 times in group 3, 1.3 times - in group $1, \mathrm{p}<0.05)$ (Table I). The indices of the functional state of the endothelium indicate its dysfunction: NO rate in the blood was significantly increased in patients of groups 1 and $2-11.3 \%$ and $31.7 \%(p<0.05)$ respectively, whereas in patients of groups 3 and 4 it has increased by $37.6 \%$ and $41.7 \%(\mathrm{p}<0.05)$. At the same time ET- 1 content in the blood exceeded this index in AHP by 1.4-2.4 times $(\mathrm{p}<0.05)$ respectively, indicating a significant predominance of vasoconstrictors that promote hypoxia, liver and lung parenchyma ischemia, and are optional factors of damage due to oxygen and energy starvation $[14,21,24]$. In our opinion, hyper- and dyslipidemia (see Table I) became the reason for the imbalance of markers of the functional state of the endothelium. Thus, a probable increase in the content of total cholesterol in the blood - by $11.3 \%$ and $16.8 \%(\mathrm{p}<0.05)$ in groups 1 and 2 respectively has been diagnosed in patients with COPD. When accompanied by NASH, the content of cholesterol in the blood increased more significantly: in patients of groups 3 and 4 - by $41.5 \%$ and $44.5 \%(\mathrm{p}<0.05)$.TG content in the blood of patients with COPD was significantly increased: by 1.4 and 1.7 times $(\mathrm{p}<0.05)$, and with the comorbidity of NASH - even higher: by 2.1-2.2 times $(\mathrm{p}<0.05)$.

There have been established the correlation relationships between the $\mathrm{H}_{2} \mathrm{~S}$ content and the hepatocyte cytolysis activity (ALAT: $\mathrm{r}=-0.63-0.66, \mathrm{p}<0.05$ ), bronchial obstruction (FEV1: $\mathrm{r}=0.69, \mathrm{p}<0.05)$, hyperlipidemia $(\mathrm{r}=-0.52-0.61$, $\mathrm{p}<0.05$ ), hyperproduction of connective tissue components (protein-bound oxyproline, glycosaminoglycans, sialic acids), indicating organ fibrosis $(\mathrm{r}=-0.65-0.71, \mathrm{p}<0.05)$, proteolysis $(r=-0.48-0.56, p<0.05)$, endothelial dysfunction (nitrogen monoxide, ET-1 ( $\mathrm{r}=-0.55-0.69, \mathrm{p}<0.05)$, Chl and TG content in the blood $(r=-0.61-0.65, p<0.05)$ indicate the role of $\mathrm{H}_{2} \mathrm{~S}$ deficiency in the mechanisms of intercomplication of the comorbidity. The received data confirm that patients with COPD secondary to NASH, which developed against the background of obesity, suffer from a significant increase in the synthesis of collagen and glycoproteins, accompanied by an ineffective resorption of newly formed collagen due to insufficient activation of collagenolysis and proteolysis, a significant imbalance in the connective tissue metabolism system, which leads to progressive fibrosis of the lungs and liver and disturbances of their functions. This was caused by the disorder of $\mathrm{H}_{2} \mathrm{~S}$ homeostasis, confirmed by the data of correlation analysis. Under the conditions of $\mathrm{H}_{2} \mathrm{~S}$ deficiency, COPD and NASH comorbidity, both synthesis and resorption of collagen are activated but the anabolic processes predominate resulting from the activation of the fibroblasts system, with a more significant hyperproduction of acute-phase proteins, fibronectin, $\mathrm{HA}$, a higher stage of hyper- and dyslipidemia $(\mathrm{p}<0.05)$, a higher degree of endothelial dysfunction (hyperproduction of NO and ET-1) $(\mathrm{p}<0.05))$. The protective role of $\mathrm{H}_{2} \mathrm{~S}$ under conditions of COPD and fatty liver disease progression is explained by its antioxidant, antiapoptotic, anti-inflammatory, vasodilating and antihypoxant effects, the ability to stimulate angiogenesis, reduce the content of proatherogenic lipoproteins in the bloodstream and inhibit the fibroblasts activity $[9,10,11,14,17,19,22]$. All of these factors are likely risk factors and direct links of pathogenesis for the progression of COPD and NASH $[1,2,3,4,5,6,7,8,24]$, which should be influenced by adequate medication support [3]. 


\section{CONCLUSIONS}

1. Patients with chronic obstructive pulmonary disease and non-alcoholic steatohepatitis, which developed against the background of obesity, are characterized by a significant increase in the synthesis of collagen and glycoproteins, which was accompanied by an ineffective resorption of newly formed collagen against the background of substantial activation of proteinase inhibitors $\left(\alpha_{2}-M G\right)$, accompanied by the hyperproduction of nitrogen monoxide, endothelin-1, hyperlipidemia, deficiency of hydrogen sulfide liberation. Both synthesis and resorption of collagen are activated, but the anabolic processes prevail, despite the compensatory activation of collagenolysis with substantial hyperproduction of acute-phase proteins, glycosaminoglycans, leading to progressive lung and liver fibrosis and disorders of their functions.

2. Hydrogen sulfide deficiency in the blood significantly affects the mechanisms of chronic obstructive pulmonary disease and non-alcoholic steatohepatitis progression against the background of obesity based on the research of content of protein and carbohydrate-protein components of the extracellular matrix and proteinase-inhibitory system, lipid profile, endothelial functional status.

\section{REFERENCES}

1. Khukhlina OS, Antoniv AA, Mandryk OYe, Hryniuk OYe. Nealkoholna zhyrova khvoroba pechinky ta komorbidni stany: osoblyvosti patohenezu, kliniky, diahnostyky, likuvannia: kol. monoh. Chernivtsi. 2018:58-61. ISBN 978-966-697-546-4

2. Viglino D, Jullian-Desayes I, Minoves $M$, et al. Nonalcoholic fatty liver disease in chronic obstructive pulmonary disease. Eur Respir J. 2017 Jun 8;49(6): 1601923. doi: 10.1183/13993003.01923-2016.

3. European Association for the Study of the Liver (EASL), European Association for the Study of Diabetes (EASD), European Association for the Study of Obesity (EASO). EASL-EASD-EASO Clinical Practice Guidelines for the management of non-alcoholic fatty liver disease. J Hepatol 2016; 64: 1388-1402.

4. Aron-Wisnewsky J, ClementK, Pépin J-L. Nonalcoholic fatty liver disease and obstructive sleep apnea. Metabolism 2016; 65: 1124-1135.

5. Viglino D, Jullian-Desayes I, Minoves M. et al.: Nonalcoholic fatty liver disease in chronic obstructive pulmonary disease. Eur.Respir. J. 2017; 49(6): 1601923.

6. Ballestri S, Nascimbeni F, Romagnoli D, et al. The independent predictors of non-alcoholic steatohepatitis and its individual histological features: insulin resistance, serum uric acid, metabolic syndrome, alanine aminotransferase and serum total cholesterol are a clue to pathogenesis and candidate targets for treatment. Hepatol Res 2016; 46: 1074-1087.

7. Koike $S, 0$ gasawara Y. Sulfur atom in its bound state is a unique element involved in physiological functions in mammals. Molecules. 2016; 21(12): 17-53.

8. Fan HN, Chen NW, Shen WL. et al. Endogenous hydrogen sulfide is associated with angiotensin II type 1 receptor in a rat model of carbon tetrachloride-induced hepatic fibrosis. Mol. Med. Rep. 2015;12 (3): 3351-3358. doi: 10.3892/mmr.2015.3873

9. Nekrut D0, Zaichko NV, Strutynska 0.B. Riven insulinopodibnogo faktoru rostu-1 ta gidrogensulfidu u shhuriv iz nealkogolnoyu zhyrovoyu xvoroboyu pechinky, asocijovanoyu iz gipergomocysteyinemiyeyu. Medychna ta klinichna ximiya. 2017; 19(1): 40-46.
10. Vanfleteren LE. Does COPD stand for "Comorbidity with Pulmonary Disease"? Eur Respir J 2015; 45: 14-17.

11. Nekrut DO, Zaichko NV, Strutynska O.B. Riven insulinopodibnogo faktoru rostu-1 ta gidrogensulfidu u shhuriv iz nealkogolnoyu zhyrovoyu xvoroboyu pechinky, asocijovanoyu iz gipergomocysteyinemiyeyu. Medychna ta klinichna ximiya. 2017; 19(1): 40-46.

12. Gerush IV, Ferenchuk OYe. Hydrogen sulfide and mitochondria. Biopolymers and Cell. 2019; 35(1):3-15.

13. Kabil 0, Motl N, Banerjee R. H2S and its role in redox signaling. Biochimica et Biophysica Acta. 2014; 1844 (8): 1355-1366.

14. Italian Association for the Study of the Liver. AISF position paper on nonalcoholic fatty liver disease (NAFLD): updates and future directions. Dig. Liver. Dis. 2017; 49: 471-483.

15. Rinella ME. Nonalcoholic fatty liver disease: a systematic review. JAMA 2015; 313: 2263-2273.

16. Ahmed A, Wong RJ, Harrison SA. Nonalcoholic Fatty Liver Disease Review: Diagnosis, Treatment, and Outcomes. Clin Gastroenterol Hepatol. 2015; 13(12):2062-70.

17. Lonardo A, Ballestri S, Marchesini G, Angulo P, Loria P. Nonalcoholic fatty liver disease: a precursor of the metabolic syndrome. Dig Liver Dis. 2015; 47(3):181-90.

18. Yuan S, Pardue S, Shen $X$ et al. Hydrogen sulfide metabolism regulates endothelial solute barrier function. Redox Biol. 2016; 9: 157-66.

19. Tanni SE, Zamuner ATS, Coelho LS, Vale SA, Godoy I, Paiva SAR. Are metabolic syndrome and its components associated with 5 -year mortality in chronic obstructive pupmonary disease patients? Metab Syndr Relat Disord 2015; 13(1):52-4.

20. Qin L, Yang Z, Zhang W, Gu H, Lu S, Shi Q, et al. Association between metabolic syndrome and lung function in middle-aged and elderly Chinese individuals. Diabetes Res Clin Pract. 2015;108: 46-8. Huang Y, Yu F, Wang J, Chen L. Near-infrared fluorescence probe for in situ detection of superoxide anion and hydrogen polysulfides in mitochondrial oxidative stress. Anal Chem. 2016; 88(7): 4122-9.

21. Vogelmeier, C. F. et al. Global Strategy for the Diagnosis, Management, and Prevention of Chronic Obstructive Lung Disease 2017 Report. GOLD Executive Summary. Am. J. Respir. Crit. Care Med. 2017; 195:557-582.

22. Sukmanskyj 0.I. Sirkovmisni gazovi sygnalni molekuly. Fiziol. zhurn. 2017; 63(6): 106-117.

23. Guo C., Liang F., Shah Masood W., Yan X. Hydrogen sulfide protected gastric epithelial cell from ischemia/reperfusion injury by Keap1 s-sulfhydration, MAPK dependent anti-apoptosis and NF-KB dependent anti-inflammation pathway. European Journal of Pharmacology. 2014;725 (1): 70-78.

24. Olson K. Hydrogen sulfide as an oxygen sensor. Antioxid Redox Signal. 2015; 22:377-97.

25. Liu T, De Los Santos FG, and Phan SH, "The bleomycin model of pulmonary fibrosis," Methods in Molecular Biology. 2017; 1627:27-42.

26. Jingyao Zhang, Ruixia Cui, Yang Feng, et al. Serotonin Exhibits Accelerated Bleomycin-Induced Pulmonary Fibrosis through TPH1 Knockout Mouse Experiments. Hindawi Mediators of Inflammation. 2018; 1-10. ID7967868. https://doi.org/10.1155/2018/7967868

27. Vanfeteren, LEGW, Spruit, MA, Wouters EFM. \& Franssen, FME. Management of chronic obstructive pulmonary disease beyond the lungs. Lancet Respir. Med. 2016; 4: 911-924.

28. Bazhanov N, Ansar M, Ivanciuc T, Garofalo R, Casola A. Hydrogen sulfide: a novel player in airway development, pathophysiology of respiratory diseases, and antiviral defenses. Am J Respir Cell Mol Biol. 2017; 57:403- 10. 
29. Olson K. Hydrogen sulfide as an oxygen sensor. Antioxid Redox Signal. 2015; 22:377-97.

This work is a fragment of the research work "Pathogenetic mechanisms of mutual burden and clinical features of non-alcoholic fatty liver disease and chronic kidney disease, justification of differentiated treatment», registration number 0117 U002351 (2017-2019).

\section{Authors' contributions:}

According to the order of the Authorship.

\section{Conflict of interest:}

The Authors declare no conflict of interest.

\section{CORRESPONDING AUTHOR}

\section{Inna V. Dudka}

Department of Internal Medicine, Clinical Pharmacology

and Occupational Diseases of the

Higher State Educational Establishment of Ukraine

«Bukovinian State Medical University»

Heroiv Krut Boulevard, 9/151, 58032, Chernivtsi, Ukraine

tel: +380509200719

e-mail:dudkainnav@gmail.com

\section{INFORMACJA PRASOWA \\ ALLERGOFF ${ }^{\circledR}$ - SKUTECZNY NEUTRALIZATOR ALERGENÓW KURZU DOMOWEGO}

Kurz domowy jest najczęstszym czynnikiem wywołującym reakcje alergiczne. Zawiera niemal wszystkie znajdujące się w domu alergeny, m. in. alergeny zwierząt domowych, grzybów pleśniowych i pyłków roślin. Całkiem się go z domu i ze swojego otoczenia nie pozbędziemy, choćbyśmy zaprzęgli do pracy najlepszą ekipę sprzątającą. Ale możemy zneutralizować działanie kryjących się nim alergenów, stosując preparaty z linii Allergoff.

ALLERGOFF' spray to innowacyjny preparat, który służy do ochrony przed chorobotwórczym działaniem alergenów obecnych w kurzu domowym, takich jak alergeny roztoczy kurzu domowego, zwierząt domowych, grzybów pleśniowych i pyłków roślin. Obniża ryzyko rozwoju uczulenia lub zaostrzenia przebiegu choroby alergicznej. Wspomaga leczenie objawów choroby alergicznej i astmy oskrzelowej.

Preparat ma dwukierunkowe działanie, bo:

- neutralizuje działanie alergenów,

- obniża ryzyko wdychania alergenów.

ALLERGOFF spray zawiera wodną zawiesinę polimerowych mikrokapsułek silnie oddziałujących na alergeny. Zawarta w nich mieszanina składników aktywnych modyfikuje strukturę cząstek alergizujących, dzięki czemu tracą one swoje chorobotwórcze działanie. Skleja drobiny kurzu w większe agregaty, co zmniejsza ich lotność i pozwala na łatwe usunięcie ze środowiska (na przykład odkurzaczem).

ALLERGOFF spray jest przeznaczony dla:

- dzieci mogących dziedziczyć skłonność do alergii, w celu ochrony przed wystąpieniem pierwszych objawów uczulenia,

- osób uczulonych, u których wystąpily pierwsze objawy alergii - w celu ograniczenia rozwoju choroby alergicznej,

- osób z rozwinietymi objawami alergii - w celu poprawy jakości życia i ochrony przed zaostrzeniem (dotyczy to chorych cierpiących na atopowe zapalenie skóry - AZS, astmę alergiczną, katar alergiczny, alergiczne zapalenie spojówek),

- osób dbających o czystość w swoich domach.

Zaleca się opryskiwanie takich miejsc w mieszkaniu, gdzie stężenie alergenów kurzu domowego jest najwyższe - w szczególności materace, łóźka i inne miejsca do spania (legowiska zwierząt), kołdry i poduszki, meble tapicerowane, dywany, wykładziny, zasłony oraz pluszowe zabawki i tapicerka samochodowa.

ALLERGOF' spray jest:

- bezpieczny dla dzieci i zwierząt,

- przebadany w testach toksykologicznych, dermatologicznych i klinicznych,

- posiada atest Narodowego Instytutu Zdrowia Publicznego - Państwowego Zakładu Higieny nr PZH/HT-3362/2017,

- opakowanie nie zawiera gazów pędnych.

Preparat jest bardzo wydajny, bo opakowanie $400 \mathrm{ml}$ wystarcza do spryskania powierzchni do ok. $40 \mathrm{~m}^{2}$. Działa skutecznie przez około 6 miesięcy po jednorazowym zastosowaniu. Długi czas działania wynika z zastosowania w preparacie technologii SLOW RELEASE Technology, która powoduje stopniowe uwalnianie substancji przezścianki polimerowych mikrokapsułek. Dzieki temu skuteczność preparatu utrzymuje się przez pół roku, a ilości uwalnianych składników są bezpieczne dla ludzi (także dzieci) oraz zwierząt.

ALLERGOF” spray ma neutralny zapach. Wygodny i łatwy w użyciu spryskiwacz pozwala równomiernie pokryć duże powierzchnie.

Opakowanie $-400 \mathrm{ml}$

Cena-ok. $50 \mathrm{zl}$

Producent: ICB Pharma

www.allergoff.pl

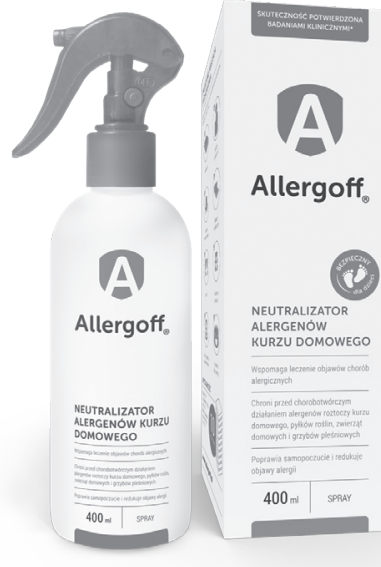

Alergia lub uczulenie jest to nadwrażliwa reakcja układu immunologicznego pojawiająca się wskutek kontaktu organizmu z alergenem. Nadwrażliwość może przyczyniać się do rozwoju poważnych chorób, takich jak: alergiczny nieżyt nosa (ANN), astma alergiczna, atopowe zapalenie skóry (AZS) i alergiczne zapalenie spojówek. Alergia wziewna jest najczęściej występującym rodzajem alergii na świecie. Otaczające nas środowisko pełne jest substancji alergizujących. Kontakt z nimi może powodować uciążliwe dla dróg oddechowych objawy. Do grupy alergenów najczęściej powodujących alergię wziewną należą: alergeny roztoczy kurzu domowego, pyłki roślin, alergeny zwierząt domowych, alergeny grzybów pleśniowych

Skuteczność preparatu ALLERGOF spray została potwierdzona badaniami klinicznymi. Badania były przeprowadzone przez Kliniczny Oddział Chorób Wewnętrznych, Dermatologii i Alergologii w Zabrzu.

Wnioski ogólne z badań:

Zastosowanie preparatu Allergoff w mieszkaniach pacjentów przyczyniło się do:

- istotnej redukcji alergenów roztoczy kurzu domowego,

- poprawy samopoczucia osób uczulonych na roztocze kurzu domowego,

- zmniejszenia objawów alergii,

- ograniczenia ilości przyjmowanych leków przeciwalergicznych

Wnioski szczegółowe:

Zastosowanie preparatu Allergoff w środowisku domowym pacjentów spowodowało obniżenie poziomu alergenu głównego roztocza Dermatophagoides pteronyssinus (Der p 1). W wyniku zastosowania działań profilaktycznych z użyciem preparatu ALLERGOFF" u badanych pacjentów zaobserwowano istotną redukcję objawów klinicznych alergicznego nieżytu nosa i spojówek oraz objawów astmy, w tym objawów nocnych. U badanych chorych zaobserwowano zmniejszenie o $42 \%$ konieczności stosowania leków przeciwalergicznych w stosunku do oceny wyjściowej. Stosowanie preparatu ALLERGOFF nie wyzwoliło żadnych objawów niepożądanych u badanych chorych

Wykazano, że jednorazowe zastosowanie preparatu ALLERGOFF spray w mieszkaniach osób uczulonych powoduje istotne obniżenie stężenia alergenu Der p 1, poprawę stanu zdrowia oraz zmniejszenie ilości przyjmowanych leków przeciwalergicznych.

Po zastosowaniu:

U 89,9\% pacjentów odnotowano istotny spadek stężenia alergenu roztoczowego Der p 1, będącego główną przyczyną alergii.

U 89,1\% pacjentów z podejrzeniem alergii na roztocze kurzu domowego nastapiła istotna poprawa samopoczucia.

U 60,9\% pacjentów zmniejszyły się objawy alergicznego nieżytu nosa.

U 64,1\% pacjentów stwierdzono złagodzenie objawów alergii oraz zmniejszenie ilości przyjmowanych leków przeciwalergicznych. 
PRACA ORYGINALNA

ORIGINAL ARTICLE

\title{
HYPERMOBILITY OF THE ARTICULAR HEADS OF THE TEMPOROMANDIBULAR JOINT: PATHOLOGY OR VARIANT OF THE NORM?
}

\author{
Oleg V. Rybalov', Pavel I. Yatsenko', Oleg I. Yatsenko², Maksim V. Khorosh', Dmitry M. Korol', Dmitry D. Kindiy', \\ Victor D. Kindiy ${ }^{1}$ \\ 'UKRAINIAN MEDICAL STOMATOLOGICAL ACADEMY, POLTAVA, UKRAINE \\ 2KYIV INTERNATIONAL UNIVERSITY, KYIV, UKRAINE
}

\begin{abstract}
Introduction: Among the large contingent of patients with TMJ dysfunctions, there are persons with hypermobility of the joint heads of the lower jaw. Moreover, at present, the question of the frequency of occurrence of hypermobility of articular heads of the TMJ is not reflected.

The aim of the work is to find out the frequency of occurrence of hypermobility of articular head among a healthy population and to evaluate the clinical, radiological, and electromyographic characteristics of the muscular-articular complex in these individuals.

Materials and methods: Surveys were conducted for 476 students aged 19 to 25 years. For people with revealed articular hypermobility of the articular heads, chewing and temporal muscle electromyography, TMJ aiming zonography in a lateral projection with open and closed mouth were performed with an assessment of the correspondence of the articular fossa of the temporal bone to the size of the articular head, the location of the articular heads relative to the apex of the articular tubercle.

Results: 0 the examined 476 students, 95 people (20\%) revealed hypermobility of the articular heads of TMJ. According to the results of clinical, functional and radiological studies of TMJ, we identified three degrees of hypermobility: light, moderately expressed, significant. With light to moderate degree of hypermobility, electromyography of the temporal and chewing muscles and TMJ zonography did not reveal a difference in performance compared to healthy ones. Most of the examined did not note functional discomfort from the joints. With a significant degree of hypermobility of the articular heads, electromyography of the temporal and chewing muscles revealed a lack of synergism in their work. On TMJ zonograms with an open mouth, the articular heads extended anteriorly beyond the tops of the articular tubercles almost under their outer base.

Conclusions: It has been established that hypermobility of the joint heads of the TMJ, which does not cause signs of pathology in the form of masticatory function disorders, discoordination of the masticatory muscles and uncontrolled displacements of the lower jaw, the presence of a pain symptom should be considered as a variant of norm.
\end{abstract}

KEY WORDS: TMJ, hypermobility articular heads, electromyography, zonography

Wiad Lek 2019, 72, 10, 1883-1889

\section{INTRODUCTION}

The results of population studies, which relate to the prevalence of dysfunctional diseases of the temporomandibular joint (TMJ), state that they are $89 \%[1,2,3,4]$. In individuals with intact dentition and orthognathic type of bite, this pathology occurs in $57.3 \%-80.9 \%$ of cases $[5,6]$.

The recognition of common TMJ dysfunction in the form of instability of its components: hypermobility of the articular heads, compression and dislocation phenomena in the joints, inadequate displacements of the articular disc, muscle-capsular elements, however, there are few detailed scientific developments regarding these pathological processes $[7,8,9]$.

American Dental Association refers to hypermobility of the articular head of the lower jaw as a functional disorder of the TMJ [10].

Hypermobility of the articular heads in a number of sources is indicated differently: subluxation of the lower jaw, unstable joint, dislocation syndrome, articular looseness $[11,12,13,14]$. Speaking of hypermobility of the articular heads, it should be noted that in some cases it is considered as reactive, and in others as a pathological condition that has peculiar clinical manifestations [15, $16,17,18]$.

Thus, the problem of a reliable understanding of the essence of hypermobility of TMJ articular heads remains unresolved to date, which raises the problem of adequate pathogenetic treatment and explains the relevance of this issue.

\section{THE AIM}

The aim of our study was to determine the frequency of occurrence of hypermobility of the articular heads of the temporomandibular joint and to compare its clinical, radiological, and electromyographic manifestations. 


\section{MATERIALS AND METHODS}

The results of the work are based on a survey of 476 students of the Ukrainian Medical Stomatological Academy, whose age is from 19 to 25 years. The study involved 285 women and 191 men. The examination included the study of violations of the face configuration, the nature of the bite, the presence of anomalies in the position and shape of individual teeth, dentitions, the presence of abnormal tooth wear.We found out the presence of discomfort in the area of one or both TMJs at rest, when opening and closing the mouth, the nature of the movements of the lower jaw (strictly vertical, progressive forward, Z-shaped, step-like).Separately, the size of the maximum mouth opening was measured by the distance between the cutting surfaces of the central upper and lower incisors (in $\mathrm{mm}$ ); a comparative assessment of the mass of the right and left temporal and chewing muscles, the position of the articular heads of the lower jaw was carried out by palpation. Pain was detected with light pressure on the articular heads with a closed mouth and when the lower jaw was shifted down and to the sides. Separately, attention was fixed on the position of the articular heads with the maximum opening of the mouth, the appearance of extraneous sounds (crunching, clicking) in the joints.

During the study, the statute of limitations of the identified symptoms, the availability of therapeutic measures for dysfunctional conditions of the TMJ were clarified.In the anamnestic data, the presence of a similar pathology in close relatives, transferred and concomitant somatic diseases, injuries of the maxillofacial region was found out.

Hypermobility of the articular heads of the lower jaw was evaluated by clinical manifestations, the results of electromyography of the masticatory and temporal muscles, and targeted zonography of TMJ in the lateral projection with open and closed mouth. At the same time, attention was paid to the size and shape of the articular heads of the lower jaw, their correspondence to the articular fossa of the temporal bone, the location of the articular heads in relation to the articular tubercle, the width of the joint spaces.

\section{RESULTS AND DISCUSSION}

Of the 476 students who took part in our study, 105 people $(22 \%)$ did not have any abnormalities in the dentoalveolar apparatus (healthy group).

Various deviations from the dentition occurred in 371 people (78\%): 148 students (31\%) experienced changes in the form of anomalies in the shape and position of teeth, malocclusions, malformations and sizes of dental arches, and jaw deformities; 223 people (47\%) had muscular-articular disorders: 56 people had TMJ compression and dislocation dysfunctions, 39 people had TMJ articulation and occlusal dysfunctions, 33 people had myalgia of chewing muscle, 95 people had hypermobility of TMJ head, which was $19,98 \%$ of the total number of examined people.

Among the individuals in whom the phenomena of hypermobility of the heads of the lower jaw were found, there were 64 women and 31 men. All examined patients had a physiological bite, intact dentitions.
According to the results of clinical, functional and radiological studies of TMJ, we identified three degrees of hypermobility: light (37 people), moderately expressed (39 people), significant (19 people).

All 37 students with a light degree of hypermobility of the articular heads of the lower jaw did not observe any functional disorders of the dentoalveolar apparatus.

During the examination of external violations from the maxillofacial region was not determined.The face of the majority of the examined was symmetrical, eight of them had a slight physiological asymmetry. The mass of the right and left temporal and masticatory muscles were the same and corresponded to the constitution of the subject in each of the examined patients of this group. The joint heads of the lower jaw occupied the correct anatomical position, were painless on palpation both at rest and during movements of the lower jaw. When opening the mouth, the movements of the lower jaw were strictly vertical without deviation, the articular heads slightly extended under the base of the zygomatic arches. There were no extraneous sounds in the joints during auscultation.With maximum opening of the mouth, the distance between the cutting edges of the incisors of the upper and lower jaws was $53.24 \pm 0.42 \mathrm{~mm}$ (in healthy people $-40.92 \pm 1.33 \mathrm{~mm}$ ).

The results of electromyography of the temporal and masticatory muscles did not reveal a difference in performance compared to healthy ones (Fig. 1).

On targeted radiographs of the TMJ, which were performed on 7 volunteers, it was noted that with an open mouth, the articular heads slightly extend anteriorly beyond the tops of the articular tubercles. With a closed mouth, the articular heads were usually located on the posterior slopes of the articular tubercles, the joint spaces in the back were widened (Fig. 2).

Of the 39 people in whom a moderate degree of hypermobility of the articular heads of the lower jaw was revealed, 31 patients had no complaints of functional discomfort from the musculo-articular complex. Eight students had periodically occurring clicking sounds in one (in 3 people) or both (5 people) TMJ.

During the examination, insignificant physiological asymmetry of the face was determined in 11 examined, in the rest the face was symmetrical.During palpation, the mass of the right and left temporal and chewing muscles were the same and corresponded to the constitution of the subject. Externally, the articular heads of the lower jaw occupied the correct anatomical position, were painless on palpation both at rest, and with movements of the lower jaw.During the opening of the mouth, the displacement of the lower jaw was strictly vertical without deviation, the articular heads were clearly emerging under the bases of the zygomatic arches equally on both sides.During auscultation, in 26 people, during the opening of the mouth, no extraneous sounds were detected in the joints, in 7 people the sounds were not very pronounced, rustling, in 6 people loud, popping sounds were detected.At the maximum opening of the mouth, the distance between the cutting edges of the incisors of the upper and lower jaws was $56.65 \pm 0.62 \mathrm{~mm}$. 


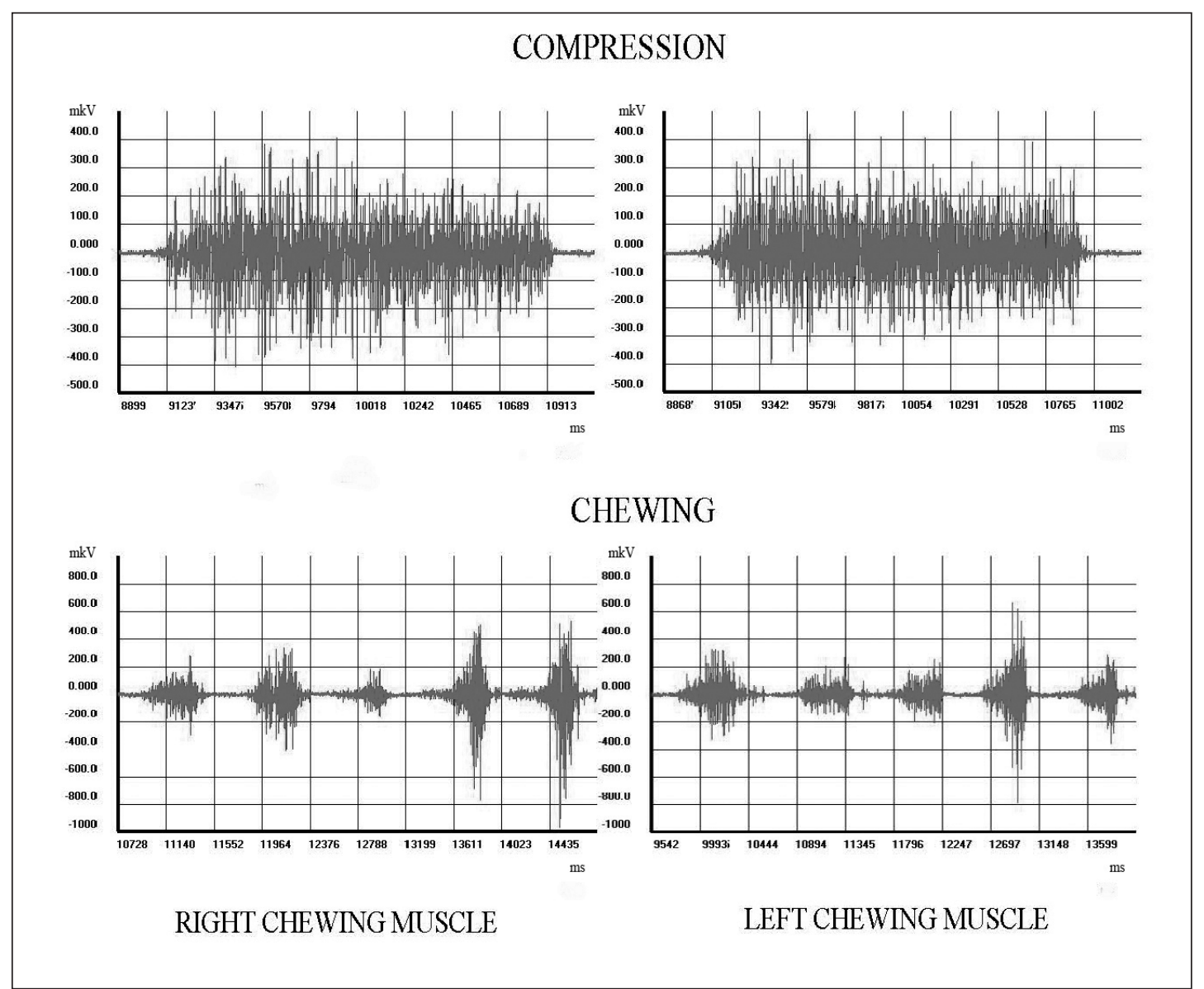

Fig. 1. Electromyograms of the actual masticatory muscles of student K., 23 years old, with light hypermobility of the joint heads of the TMJ. The physiological asymmetry of the bioelectrical activity of the right and left muscles is noted both in the periods of chewing and compression of the teeth. Myograms correspond to the characteristics of a healthy person.
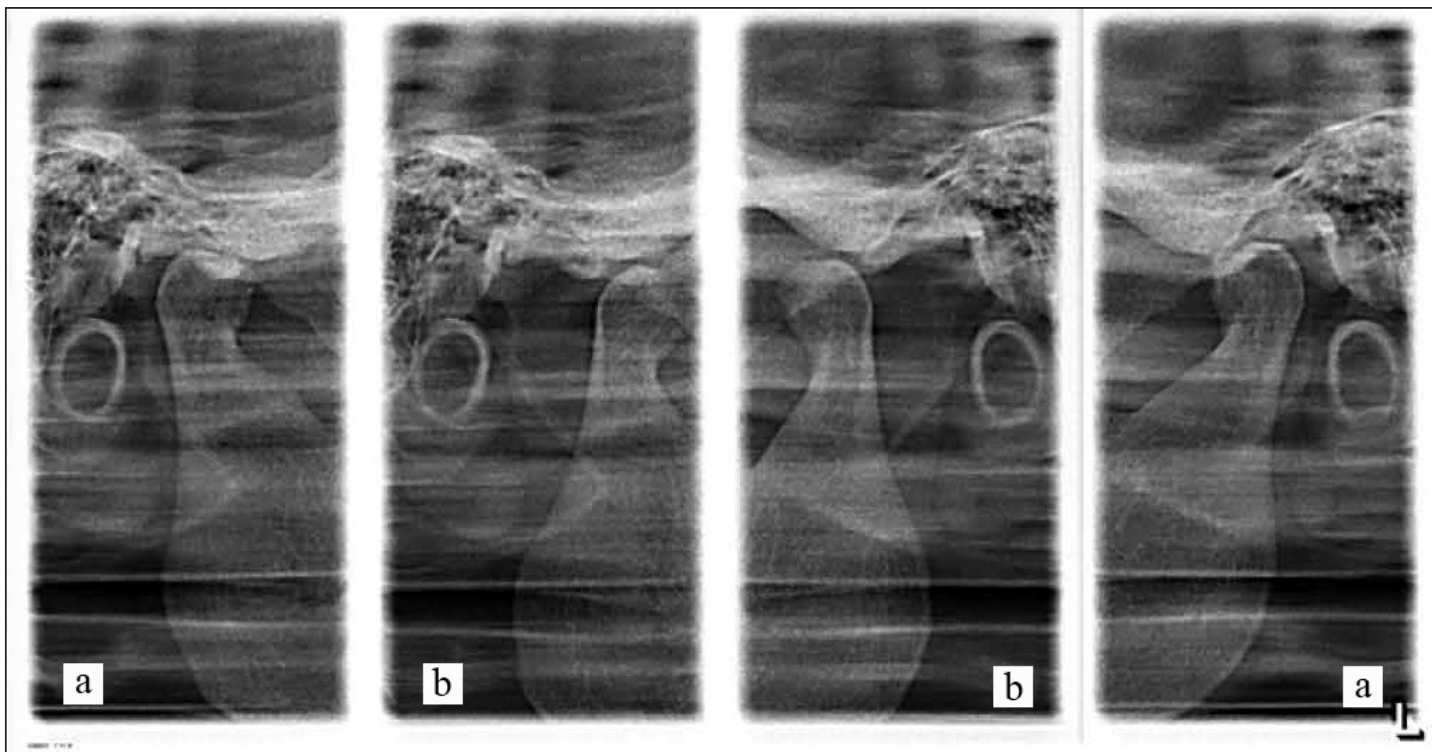

Fig. 2. Zonograms of TMJ of student K., 23 years old with clinical manifestations of mild hypermobility of the articular heads of the lower jaw. Short articular processes, small articular fossae, flat articular tubercles are determined. With a closed mouth (a), the joint spaces above and behind are widened; with an open mouth (b), the joint heads are located slightly anterior to the apices of the tubercles.

The results of electromyography of the temporal and masticatory muscles did not reveal a difference to the values in healthy people.
On targeted X-ray images of the TMJ made by 6 volunteers, it was noted that with an open mouth, the articular heads more than those with a light degree went anteriorly beyond the tops of the articular 


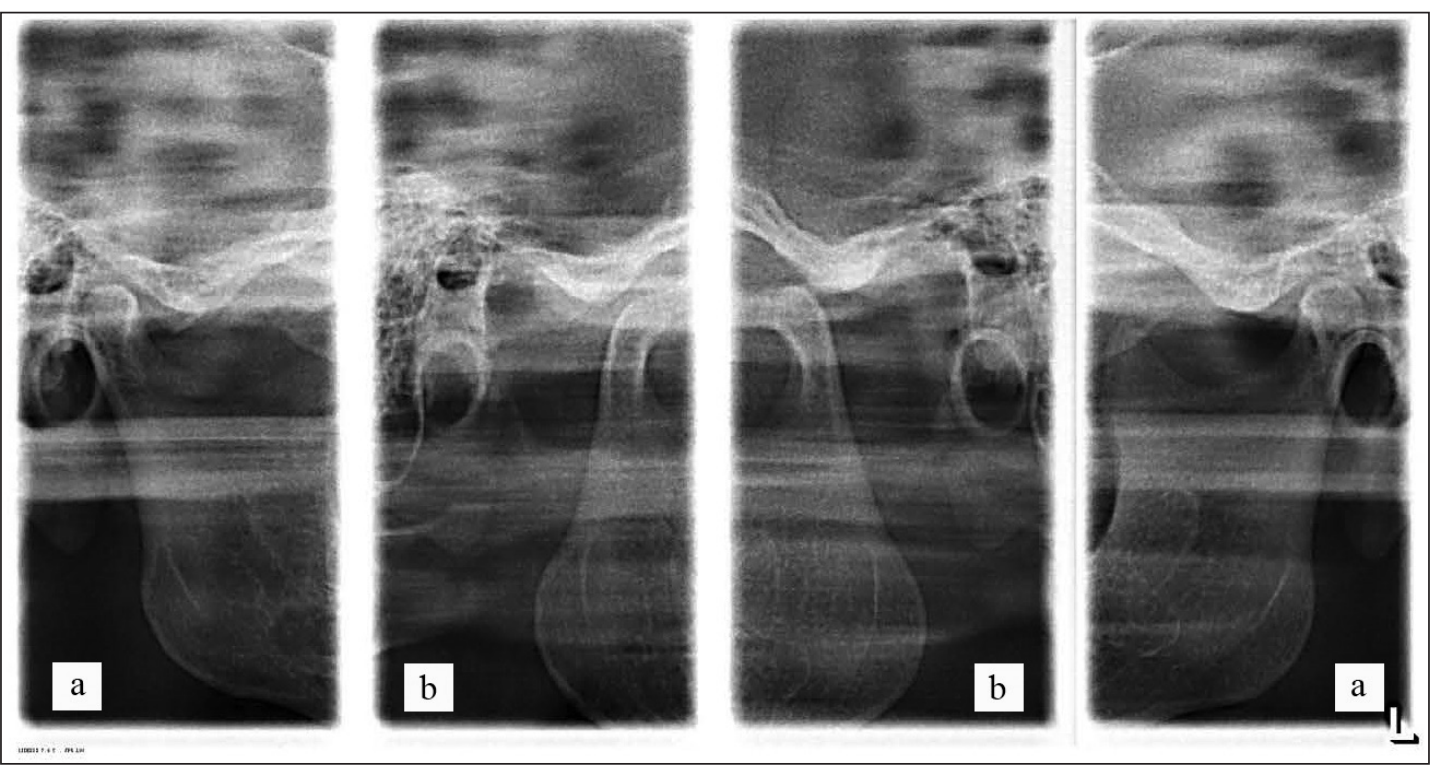

Fig. 3. Zonograms of TMJs of student A., 24 years old, with moderate manifestations of hypermobility of articular heads. The exit of articular heads beyond the tops of the articular tubercles is determined by $1 / 3$ of their height with an open mouth (b). With a closed mouth, a slight expansion of the joint spaces in the anterior fossa (a).

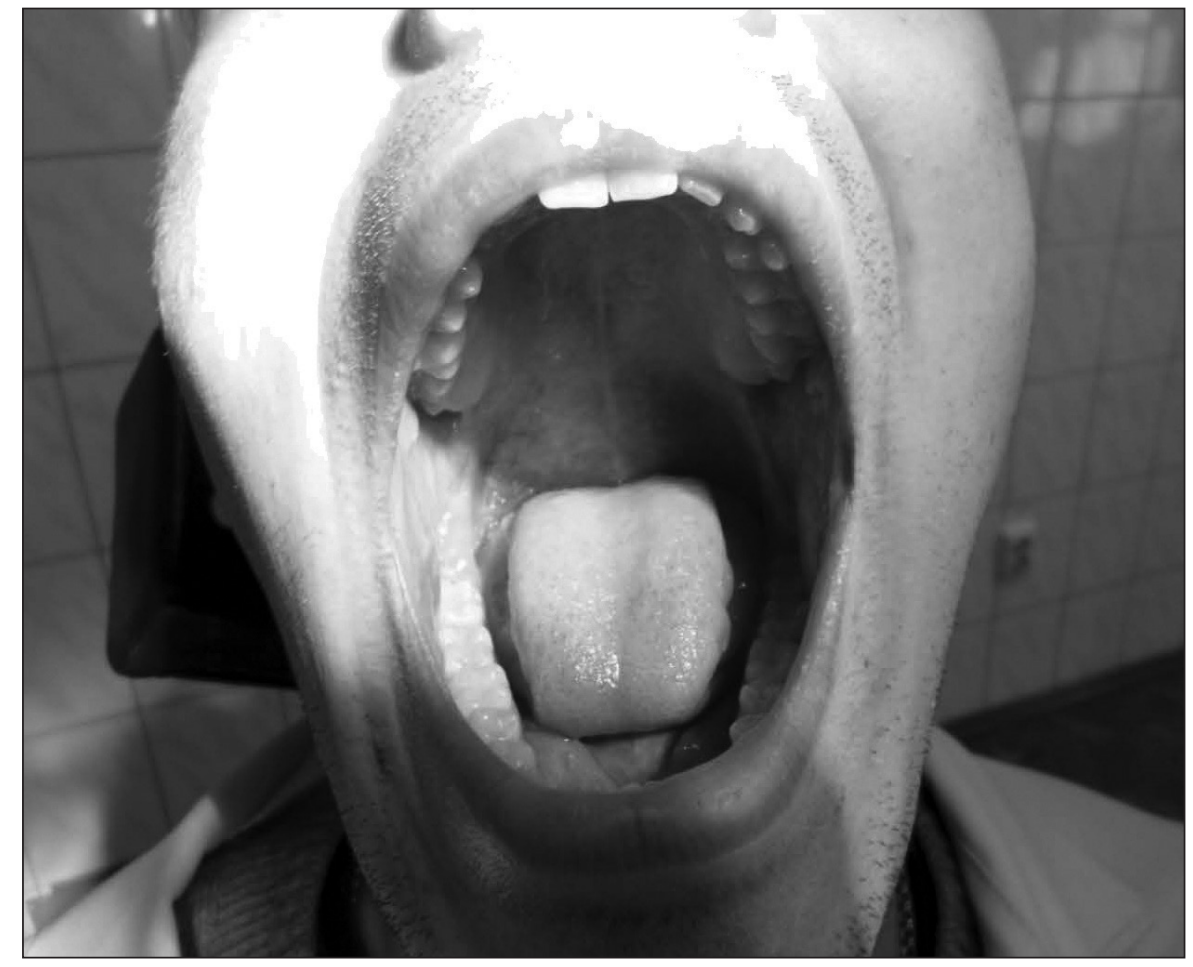

Fig. 4. Photo of the student's maximum mouth opening with a significant degree of hypermobility of the articular heads of the lower jaw. tubercles. With a closed mouth, the articularheads usuallyoccupied the correct anatomical location in the articular fossa (Fig. 3).

With a pronounced (significant) degree of hypermobility of the articular heads of the lower jaw (Fig. 4), which was established in 19 students, 15 of them did not express the presence of masticatory apparatus disorders.

Five students had periodically occurring clicking sounds in one (in 2 people) or both (3 people) joints with wide opening of the mouth.

Physiological asymmetry of the face was observed in 6 patients; in the rest, the face was symmetrical.On palpation, the mass of the right and left temporal and chewing muscles were the same on both sides.Externally, the articular heads of the lower jaw occupied the correct anatomical position, were painless on palpation both at rest and with movements of the lower jaw.During the opening of the mouth, in 16 people the displacement of the lower jaw was strictly vertical without deviation, in 3 students the lower jaw made z-like movements. The joint heads with maximum opening of the mouth expressed out under the bases of the zygomatic arches equally on both sides of all examined.During auscultation, in 11 people, when opening the mouth, no 


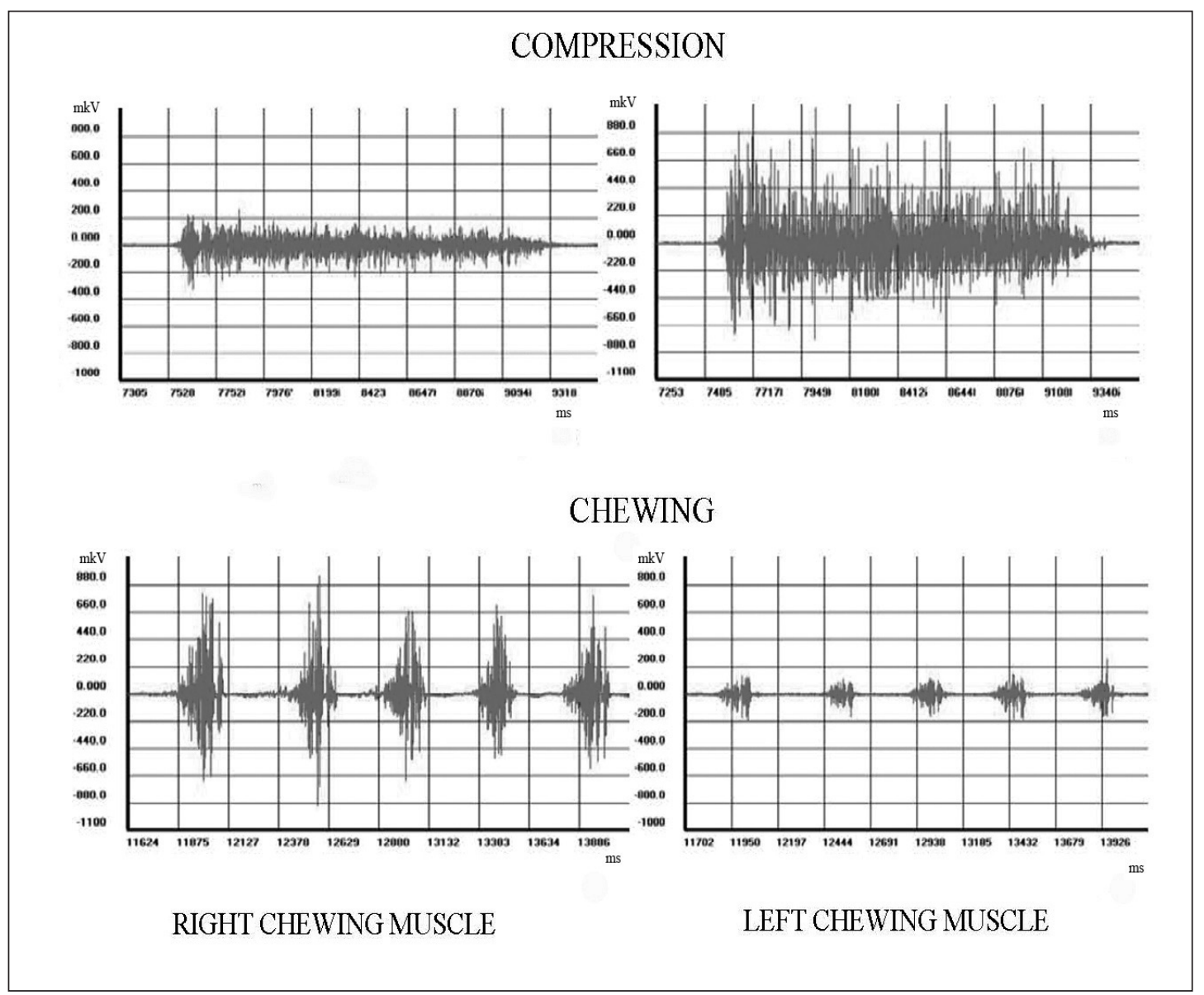

Fig. 5. Electromyograms of the temporal muscles of a student $V ., 25$ years old, with significant manifestations of hypermobility of TMJ articular head. There is a dissonance in the bioelectric activity of the right and left muscles during chewing and compression of the teeth.
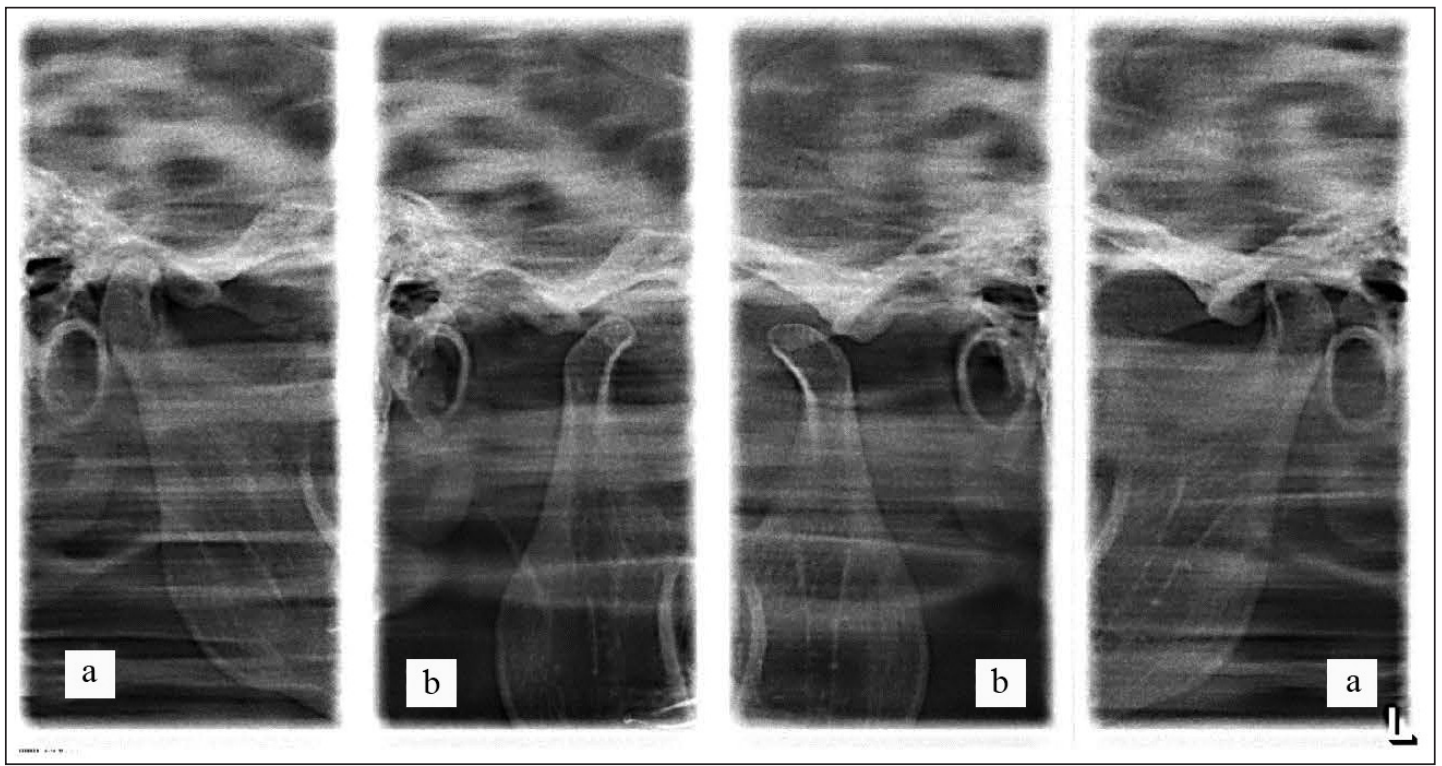

Fig. 6. Zonograms of TMJ of a student Sch., 21 years old, with the phenomena of hypermobility of the articular heads of a significant degree. There is a departure of the articular heads beyond the tops of the articular tubercles by almost 2/3 of their height, with an open mouth (b). With a closed mouth, the expansion of the joint spaces in the anterior and posterior fossa (a).

extraneous sounds were detected in the joints, in 5 people they were not very pronounced, rustling, in 3 people - the sounds were sonorous, like crackling, crunching. At the maximum opening of the mouth, the distance between the cutting edges of the incisors of the upper and lower jaws in this group of students was equal to $62.51 \pm 0.72 \mathrm{~mm}$. 
The results of electromyography of the temporal and masticatory muscles, made by 4 students with a crunch in the joints and deviation of the lower jaw, revealed paradoxical phenomena in the form of discoordination of the temporal and masticatory muscles (lack of synergism) (Fig. 5).

On targeted X-ray images of the TMJ made by 7 volunteers, it was noted that with an open mouth, the articular heads went anteriorly beyond the tops of the articular tubercles almost under their outer base. With a closed mouth, the articular heads were usually located in the upper poles of the articular fossa, the articular fissures were usually widened posteriorly and anteriorly, in 2 people the articular tubercles were smoothed (Fig. 6).

First of all, when discussing this topic, it is worth observing that according to published data hypermobility of TMJs is considered an inadequate dislocation of one articular head of the lower jaw, forgetting to give a description of the state of the symmetrical joint $[19,20,21]$. However, with the hypermobility of one joint head in the opposite joint, compression phenomena occur, that is, compression-dislocation dysfunction of the TMJ develops $[22,23]$.Thus, with true hypermobility ща TMJ, both joint heads of the lower jaw are in a state of dislocation.

In our opinion, hypermobility of the joint head of the TMJ, which does not cause signs of pathology in the form of violations of the chewing function, support function of the articular surfaces, discoordination of the masticatory muscles and uncontrolled displacements of the lower jaw, the presence of a pain symptom should be considered as type of the norm, as well as for individuals, low blood pressure or different height of a person.In those cases when the above symptoms appear, it can be argued about the development of joint dysfunction on the background of hypermobility of the heads of the lower jaw, the same as in individuals without hypermobility, and carry out appropriate treatment.

\section{CONCLUSIONS}

According to the results of our studies regarding the incidence of hypermobility of TMJ articular heads in persons aged $18-25$ years, this indicator was $19.98 \%$. A systematic analysis of clinical, electromyographic and radiological studies of the muscular-articular complex made it possible to establish three degrees of hypermobility of the articular heads: light, moderate and significant.In the predominant number of examined patients, the presence of clinically determined hypermobility of the articular heads had no complaints about inadequate opening of the mouth. Radiologically determined displacement of the articular heads beyond the tops of the articular tubercles anteriorly to various degrees did not cause functional disturbances in the activity of the masticatory and temporal muscles, with the exception of isolated cases with significant degree of hypermobility.In this case, probably, the leading role played by the violation of the structural and functional structures of the right and left joints due to changes in the mechan- ical qualities of their capsule and ligamentous apparatus without its injury.Thus, hypermobility of the joint head of the TMJ, which does not cause signs of pathology in this category of subjects, should be considered as variant of the norm.

\section{REFERENCES}

1. Manfredini D, Guarda-Nardini L, Winocur E et al. Research diagnostic criteria for temporomandibular disorders: a systematic review of axis I epidemiologic findings. Oral Surgery, Oral Medicine, Oral Pathology, Oral Radiology, and Endodontology. 2011; 112(4):453-462.

2. Renata Nogueira Barbosa, Fabio Robles, Andréa VideiraAssaf et al. Temporomandibular disorders and relationship with socio-demographic and clinical variables in a University of the state of Rio de Janeiro. Rev Dor. São Paul02017;18(1):59 - 64.

3. Rodríguez D, Rey T, Ramírez M, Cabrera D. Clinical and sociodemographic characterization of patients with temporomandibular dysfunction at the University Hospital of Maracaibo. Int J Med SurgSci 2018;5(2):75 - 79.

4. JatsenkoP, NovikovV, Ivanickaja 0, etal.Mediko-statistichna harakteristika chastoti ta vidiv disfunkcionalnih staniv skronevo-nizhnoshelepnogo sugloba. [Medical-statistical characteristic of frequency and types of dysfunctional conditions of the temporomandibular joint]. Journal of Clinical and Experimental Dentistry. 2018;2 (3):43 - 44.

5. Celic R, Kraljevic K, Krajevic $S$. et al. The correlation between temporomandibular disorders and occlusion. Acta Stomatologica Croatica 2000; 1 (34): 780-785.

6. Murphy M, Mac Barb R, Wong M et al. Temporomandibular Joint Disorders: A Review of Etiology, Clinical Management, and Tissue Engineering Strategies Int. J. Oral Maxillofac. Implants 2013, Nov-Dec;28 (6):393-414.

7. Ribalov 0, Jatsenko I. Anatomo-funkcionalna nestabilnist skronevonizhnoshelepnogo sugloba. [Anatomic and functional instability of the temporomandibular joint]. J. Galician Medical Bulletin 2005;1:27-30.

8. Haghigaht A, Davoudi A, Rybalov 0 et al. Condylar distances in hypermobile temporomandibular joints of patients with excessive mouth openings by using computed tomography. J ClinExpDent. 2014; 6(5): 509-513.

9. Ribalov 0, Jatsenko 0, Moskalenko P. Klinika i diagnostika gipermobilnosti sustavnoj golovki visochno-nizhnechelyustnogo sustava. [Clinic and diagnosis of hypermobility of the articular head of the temporomandibular joint]. J. Dentist 2010;12(150): 16-17.

10. Bell W.E. Clinical management of temporomandibular disonders. Chicago; London1982; $231 \mathrm{p}$.

11. Stegenga B. Nomenclature and classification of temporomandibular joint disorders. J. Oral Rehabil 2010;10(37): 760-765.

12. Eric L. Schiffman. Diagnostic Criteria for Temporomandibular Disorders (DC/TMD) for Clinical and Research 1. Application: Recommendations of International RDC/TMD Consortium Network and Orofacial Pain Special Interest Group . J. of Oral\&Facial Painand Headache 2014; 1:6-27.

13. International Classification of Diseases ICD-10. Electronic version. Electronic resource. http://www.mkbl0.com

14. Cooper B. Diseases of the temporomandibular joint.Dental Market 2012;1:39-46.

15. Girish K, Syed S, Shashi S, Khan M et al. Management oftemporomandibular joint dislocation: review of literature. Int J Sci Res.- 2016. - № 5(1). - P. $574-577$. 
16. Peck C, Goulet J, Lobbezoo F et al. Expanding the taxonomy of the diagnostic criteria for temporomandibular disorders. Journal of Oral Rehabilitation. 2014; 41(1):2-23.

17. Liddell A, Perez DE. Temporomandibular joint dislocation. Oral MaxillofacSurgClin North Am 2015; 27: 125 - 136.

18. Ribalov 0, Moskalenko P, Semenenko U. Rezultati vivchennya biopotencialiv vlasno-zhuvalnih m'yaziv u hvorih z riznim stupenem gipermobilnosti golovki skronevo-nizhnoshelepnogo sustava. [The results of the study of the biopotentials of self-chewing muscles in patients with varying degrees of hypermobility of the head of the temporomandibular joint]. World of Medicine and Biology. 2011;1:9194. (In Ukrainian).

19. Gross M, Mathews J. Occlusion in Restorative Dentistry. Churchill Livingstone, Edinburgh, London, Melbourne and New York, 1982. 288 p.

20. Petres R, Gross Sh. Temporomandibular Disorders and Orofacial Pain. II Quintessence. Chicago.1995.368 p.

21. Sofie Bui. The Effectiveness OfExercise Therapy For Temporomandibular Disorders The University of Adelaide: Australia 2013. 163 p.

22. Moskalenko P, Yu V, Lakhtin N. Klepach Modelling the tension of articular tubercle bone tissue in the treatment of habitual dislocation of the mandibular bone in patients with anatomical instability of the temporomandibular joint. GISAP: Medical Science, Pharmacology. 2016:18-20

23. Ribalov 0, Ivanickaja 0, Jatsenko 0. Kriteriï ocinki stupenja funkcional'noy nestabil'nosti suglobovoy golivki nizhn'oy shhelepi na osnovi klinichnih harakteristik ta artrofonografiy skronevo-nizhn'oshhelepnogo suglobu [Criteria for assessing the degree of functional instability of the joint head of the mandible based on clinical characteristics and arthrophonography of the temporomandibular joint], Svit medicini ta biologii [The World of Medicine and Biology] 2013; 4 (41): 57 - 60
Authors' contributions:

According to the order of the Authorship.

\section{ORCID numbers:}

Oleg V. Rybalov - 0000-0001-9467-2913

Pavel I. Yatsenko - 0000-0002-8440-8905

Oleg I. Yatsenko - 0000-0003-0061-8508

Maksim V. Khorosh - 0000-0002-2083-1333

Dmitry M. Korol - 0000-0002-8331-0500

Dmitry D. Kindiy - 0000-0002-1113-478X

Victor D. Kindiy - 0000-0003-0665-0269

\section{Conflict of interest:}

The Authors declare no conflict of interest.

\section{CORRESPONDING AUTHOR} Oleg V. Rybalov

Ukrainian Medical Stomatological Academy

23 Shevchenko Str., Poltava 36011 Ukraine

e-mail address: enever@ukr.net

Received: 18.07.2019

Accepted: 30.09 .2019 
PRACA ORYGINALNA

ORIGINAL ARTICLE

\title{
ŻYWIENIE DOJELITOWE W MUKOWISCYDOZIE
}

\section{ENTERAL NUTRITION IN CYSTIC FIBROSIS}

\author{
Angelika Kędzior', Beata Łabuz-Roszak ${ }^{1,2}$, Sylwia Jezierska ${ }^{3}$ \\ 'KATEDRA I ZAKŁAD PODSTAWOWYCH NAUK MEDYCZNYCH, WYDZIAŁ ZDROWIA PUBLICZNEGO W BYTOMIU, ŚLĄSI UNIWERSYTET MEDYCZNY \\ W KATOWICACH, BYTOM, POLSKA \\ ${ }^{2}$ ODDZIAŁ NEUROLOGIII I UDAROWY, WSS IM. ŚW. JADWIGI, OPOLE, POLSKA \\ ${ }^{3}$ CENTRUM ONKOLOGII - INSTYTUT IM. MARII SKŁODOWSKIEJ-CURIE, ODDZIAŁ W GLIWICACH, GLIWICE, POLSKA
}

\begin{abstract}
STRESZCZENIE
Wstęp: Mukowiscydoza jest chorobą uwarunkowaną genetycznie. Obecnie jest wykrywana zaraz po urodzeniu, dzięki programowi badań przesiewowych. Tak wczesne wykrycie pozwala na szybkie włączenie leczenia. Terapia mukowiscydozy ma kompleksowy charakter. Niezwykle istotny jest też sposób żywienia. Celem niniejszego badania była ocena korzyści i ryzyka stosowania żywienia dojelitowego u chorych z mukowiscydozą.

Materiały i metody: W badaniu wzięły udział 53 osoby (15 mężczyzn, 38 kobiet) z rozpoznaną mukowiscydozą. Kwalifikacja do badania wymagała spełnienia trzech warunków: żywienie dojelitowe stosowane od co najmniej miesiąca, brak przyrostu masy ciała przy stosowaniu diety wysokoenergetycznej oraz stwierdzona niedowaga. Badania przeprowadzono przy pomocy autorskiej ankiety.

Wyniki: Średni wiek badanych wynosił 19,9 44 lata. Mediana przyrostu masy ciała po zastosowaniu żywienia dojelitowego wynosiła $7 \mathrm{~kg}(1 ; 20)$. Większość ankietowanych ( $n=42 ; 79,2 \%)$ nie zgłaszała żadnych skutków ubocznych. Nieliczni zgłaszali infekcje miejscowe ( $n=9 ; 17 \%)$ lub wypadnięcie balonika $(n=2 ; 3,8 \%)$. Wszyscy natomiast zgłaszali korzyści - były to głównie przyrost masy ciała i poprawa samopoczucia. W części przypadków ( $n=22 ; 41,5 \%$ ) przy stosowaniu żywienia dojelitowego zaobserwowano zmniejszenie częstości infekcji układu oddechowego.

Wnioski: Żywienie dojelitowe jest korzystną metodą żywienia u tych chorych z mukowiscydozą, u których doustne żywienie wysokoenergetyczne jest niewydajne.
\end{abstract}

SŁOWA KLUCZE: mukowiscydoza, niedożywienie, żywienie dojelitowe

\begin{abstract}
Introduction: Cystic fibrosis is a genetically determined disease. It is currently detected right after birth thanks to a screening program. This early detection allows for quick treatment inclusion. Cystic fibrosis therapy has a comprehensive character. The way of nutrition is also very important.

The aim of this study was to evaluate the benefits and risks of enteral nutrition in patients with cystic fibrosis.

Materials and methods: 53 people with cystic fibrosis participated in the study (15 men, 38 women). Qualification for the study required the fulfillment of three conditions: enteral nutrition used for at least one month, no increase in body weight when using a high energy diet, underweight. The research was carried with use of self-constructed questionnaire.

Results: The mean age of the respondents was $19.9 \pm 4$ years. The median weight gain after enteral nutrition was $7 \mathrm{~kg}$. Most $(\mathrm{n}=42,79.2 \%)$ did not report any side effects. Few reported local infections $(n=9 ; 17 \%)$ or prolapse of the balloon $(n=2,3.8 \%)$. On the other hand, everyone reported benefits - it was mainly weight gain and improved quality of life. In some cases $(n=22,41.5 \%)$ with the use of enteral nutrition, a decrease in the frequency of respiratory infections was observed. Conclusions: Enteral nutrition is a beneficial method in those patients with cystic fibrosis, in whom high-energy oral nutrition is inefficient.
\end{abstract}

KEY WORDS: cystic fibrosis, malnutrition, enteral nutrition

Wiad Lek 2019, 72, 10, 1890-1893

\section{WSTĘP}

Mukowiscydoza (CF - cystic fibrosis), inaczej zwłóknienie wielotorbielowate, jest chorobą uwarunkowaną genetycznie, dziedziczoną się w sposób autosomalny recesywny. Należy do ogólnoustrojowych chorób przewlekłych. Objawia się głównie niewydolnością oddechową, a także enzymatyczną trzustki. O jej przebiegu decyduje szybkość dysfunkcji różnych narządów wewnętrznych. Organizm chorego produkuje bardzo gęsty śluz, co powoduje zaburzenia w każdym narządzie, który posiada gruczoły śluzowe. Częstość występowania mukowiscydozy wynosi 1:2500 żywo urodzonych dzieci. Od drugiej połowy 2006r. $\mathrm{w}$ Polsce prowadzony jest program badań przesiewowych noworodków w kierunku mukowiscydozy $[1,2]$

Za wystąpienie mukowiscydozy odpowiedzialne są mutacje genu, zlokalizowanego na długim ramieniu chro- 
mosomu VII (locus 7q31.2), który odpowiedzialny jest za kodowanie białka błonowego CFTR (Cystic Fibrosis Transmembrane Regulator). Mutacje tego genu są odpowiedzialne za wadliwą syntezę białka, co powoduje upośledzenie transportu chlorków z komórki, a nasila ich absorbcję do komórki. W wyniku tego następuje zmniejszenie zawartości wody, co powoduje zagęszczenie śluzu w przewodach wyprowadzających gruczołów zewnątrzwydzielniczych. Wiele chorych wykazuje zmiany wielonarządowe, jednakże o jakości i długości życia decydują głównie zmiany powstałe w układzie oddechowym [3].

Mukowiscydoza najczęściej ujawnia się w wieku wczesnodziecięcym. W przypadku postaci o łagodnym przebiegu jej rozpoznanie może nawet nastąpić w wieku 20-30 lat. Do objawów mukowiscydozy zaliczamy: gęsty i lepki śluz zalegający w oskrzelach, uciążliwy kaszel, duszność, nawracające zapalenia oskrzeli i płuc, trudno poddające się typowemu leczeniu, prowadzące do rozstrzeni oskrzeli i zwłóknienia płuc; przewlekłe zapalenie zatok, polipy nosa, krwioplucia, nawracające lub przewlekłe zakażenia Pseudomonas aeruginosa lub Staphylococcus aureus, przewlekłe obturacyjne zapalenie oskrzeli. Ponadto u chorych występuje niedobór masy ciała i szybka męczliwość przy wysiłku fizycznym. Badaniem fizykalnym można stwierdzić zmiany osłuchowe (furczenia, rzężenia, świsty), palce pałeczkowate, objawy marskości wątroby $[1,3]$.

Leczenie mukowiscydozy jest wyłącznie objawowe, może jedynie spowolnić przebieg choroby i zmniejszyć jej objawy. Stosowane jest leczenie na wielu płaszczyznach w postaci: farmakoterapii, rehabilitacji oraz dietoterapii $[4,5]$.

W leczeniu zaostrzeń oskrzelowo - płucnych stosuje się antybiotykoterapię. W celu rozrzedzenia i usunięcia wydzieliny z płuc stosuje się leki rozszerzające oskrzela, mukolityki oraz leki upłynniające wydzielinę. $\mathrm{Z}$ kolei w zaburzeniach trawienia i wchłaniania, które są objawami ze strony układu pokarmowego zaleca się stosowanie enzymów trzustkowych. Ich dawkowanie uzależnione jest od stopnia zewnątrzwydzielniczej niewydolności trzustki. Preparaty enzymów trzustkowych należy podawać do posiłku.

W zaawansowanej niewydolności płuc wykonuje się przeszczep obu płuc. Jak podają statystyki, na dzień dzisiejszy odsetek przeżyć 5-letnich wynosi powyżej 50\%. W niektórych krajach, jak np. Kanada, wyniki są jeszcze bardziej imponujące i wynoszą dla 5 lat blisko 67\%, a dla 10 lat 50\% [6,7]. Natomiast w zaawansowanej marskości wątroby wykonuje się jej przeszczep, gdzie odsetek przeżyć 5-letnich zbliża się według badań do $86 \%$ dla dorosłych pacjentów i 73\% dla dzieci [8].

Fizjoterapia jest istotnym elementem terapii mukowiscydozy. Powinna być stosowana codziennie nawet u osób, które nie wykazują zmian w układzie oddechowym. Planowanie fizjoterapii powinno uwzględniać wiek, zaawansowanie choroby, a także możliwości chorego. Powinna ona zawierać techniki, które ułatwiają rozluźnienie, przesunięcie, a także usunięcie zalegającej wydzieliny z drzewa oskrzelowego. Wraz z rozwojem fizjoterapii, oprócz standardowego drenażu ułożeniowego, wprowadzono techniki wspomagające drenaż, takie jak: wstrząsanie, uciskanie czy też oklepywanie klatki piersiowej. Fizjoterapia nie ogranicza się obecnie tylko do wyżej wymienionych, a tradycyjnych już technik. Wprowadza się do niej także terapie komplementarne, jak np.: akupunktura, haloterapia (oddychanie powietrzem wzbogaconym w sól), pilates, techniki relaksacyjne (np. aromaterapia), a nawet tai chi czy joga [9].

Leczenie dietetyczne $\mathrm{w}$ mukowiscydozie jest podstawą postępowania terapeutycznego w tej chorobie. Dieta powinna być bardzo dobrze zbilansowana, a przede wszystkim wysokoenergetyczna, ze względu na znaczny wysiłek oddechowy. Podaż energii dla pacjenta należy ustalić indywidualnie. Należy jednak pamiętać, że zapotrzebowanie energetyczne wynosi $130-150 \%$ podstawowego zapotrzebowania [10-12]. Według niektórych źródeł zapotrzebowanie na energię u chorych na mukowiscydozę wynosi 110-200\% zapotrzebowania, które jest wymagane dla zdrowych osobników tej samej płci i w tym samym wieku [13]. Stosowanie diety wysokoenergetycznej ma na celu zapobieganie niedożywieniu lub jego leczenie [10-12].

W diecie osoby chorej na mukowiscydozę podaż tłuszczu powinna wynosić 35-45\% dziennego zapotrzebowania. Źródła tłuszczu w diecie powinny stanowić różnego rodzaju oleje, masło, sosy, śmietana, pełnotłuste mleko. Tłuszcze należy dodawać do ryżu, ziemniaków, surówek. Spożycie węglowodanów powinno wynosić około $40-45 \%$ całodziennego zapotrzebowania energetycznego. Wyjątek stanowi sytuacja, kiedy u osoby chorej na mukowiscydozę występuje cukrzyca. Wtedy należy zmodyfikować podaż węglowodanów [10-12].

Zaburzenia wchłaniania u osób z mukowiscydozą wiążą się z niedoborami witamin, zwłaszcza tych, które są rozpuszczalne w tłuszczach. Również stężenie sodu jest niższe, ze względu na jego dużą utratę, szczególnie z potem. Prócz samej diety można stosować wysokokaloryczne odżywki.

W sytuacji, kiedy zastosowanie diety wysokoenergetycznej nie przynosi oczekiwanych rezultatów, należy wziąć pod uwagę zastosowanie żywienia dojelitowego.

Żywienie dojelitowe polega na podaży białka, węglowodanów, tłuszczy, elektrolitów, witamin i wody pod postacią specjalnie przygotowanej diety przemysłowej, podawanej przez zgłębnik lub sondę (gastrostomię) do przewodu pokarmowego. Żywienie dojelitowe jest inwazyjną metodą leczenia niedożywienia. Wyróżniamy kilka metod odżywiania dojelitowego. Przy krótkotrwałym stosowaniu zalecane jest żywienie przez zgłębnik nosowo-żołądkowy lub nosowo-jelitowy. Przy konieczności długotrwałego stosowania żywienia dojelitowego, wytwarza się przetokę pod postacią: przezskórnej gastrostomii endoskopowej (PEG - percutaneous endoscopic gastrostomy) lub jejunostomii (cewnik wprowadzony do jelita cienkiego). Wyróżniamy następujące techniki żywienia dojelitowego: żywienie przerywane (podaż żywności odbywa się w następujący sposób: 3 godziny - wlew specjalnej diety, przerwa na minimum 2 godziny, ponowny wlew) oraz żywienie nocne (podaż specjalnej diety odbywa się metodą wlewu ciągłego przez noc - około 10-12 godzin) [10-12].

Przy prawidłowo wykonanej gastrostomii ryzyko powikłań jest bardzo niewielkie i łączny odsetek pacjentów 
cierpiących $\mathrm{z}$ tego powodu wynosi niewiele ponad 5\% [14]. Z Możliwe powikłania to najczęściej krwawienia i/ lub lekkie zakażenia bakteryjne. Późniejsze komplikacje, które mogą wystąpić, to zakażenie rany wokół cewnika PEG-a i pęknięcie balonika, a co za tym idzie wypadnięcie PEG-a [10-12,14].

\section{CEL PRACY}

Celem niniejszego badania była ocena korzyści i ryzyka stosowania żywienia dojelitowego u chorych z mukowiscydozą.

\section{MATERIA I METODY}

$\mathrm{W}$ badaniu wzięły udział 53 osoby z rozpoznaną mukowiscydozą zgodnie z obowiązującymi kryteriami [1]. Wszyscy badani byli członkami Polskiego Towarzystwa Walki z Mukowiscydozą. Dobór grupy badanej opierał się na następujących kryteriach:

- osoby biorące udział w badaniu miały włączone żywienie dojelitowe od co najmniej miesiąca,

- przed włączeniem żywienia została stwierdzona niedowaga,

- brak przyrostu masy ciała przy stosowaniu doustnej diety wysokoenergetycznej.

Badania zostały przeprowadzone w 2017 roku, na podstawie autorskiej ankiety. Udział w badaniu był dobrowolny i anonimowy.

Analizę statystyczną przeprowadzono przy pomocy programów Microsoft Excel i Statistica.

\section{WYNIKI}

Badaniem objęto 38 kobiet (72\% respondentów) oraz 15 mężczyzn (28\% respondentów). Średni wiek badanych wynosił 19,9 \pm 4 lata (najniższy wiek ${ }^{\circ} 12$ lat, najwyższy wiek - 36 lat). W badaniu uczestniczyło 25 osób (47\%) w wieku $\leq 18$ lat oraz 28 osób (53\%) w wieku $>18$ lat.

Średni wzrost ankietowanych wynosił $165,2 \mathrm{~cm} \pm 9,2 \mathrm{~cm}$, zaś aktualna średnia masa ciała $-57 \pm 10 \mathrm{~kg}$. Natomiast średnia masa ciała przed włączeniem żywienia dojelitowego wynosiła $49 \pm 11 \mathrm{~kg}$. Mediana przyrostu masy ciała w czasie stosowania żywienia dojelitowego wynosiła $7 \mathrm{~kg}$ (min $1 \mathrm{~kg}$; $\max 20 \mathrm{~kg}$ ).

U wszystkich badanych osób $(\mathrm{n}=53 ; 100 \%)$ stosowane było żywienie dojelitowe przez cewnik wprowadzany do żołądka - PEG. Najwięcej osób stosowało tryb żywienia nocny ( $\mathrm{n}=41 ; 77 \%), 11$ osób - tryb żywienia dzienny (21\%) oraz 1 osoba tryb żywienia przerywany.

Czas stosowania żywienia dojelitowego wynosił od 6 miesięcy do 7 lat. 11 respondentów stosowało żywienie dojelitowe poniżej roku (21\%), 30 osób - od roku do 2 lat (56\%), 12 osób - powyżej 2 lat (23\%).

Badani wymieniali następujące subiektywne korzyści z zastosowania żywienia dojelitowego:

- przyrost masy ciała $(n=53 ; 100 \%)$,

- poprawa odporności i zmniejszenie częstości infekcji $(\mathrm{n}=22 ; 41,5 \%)$
- poprawa jakości życia $(\mathrm{n}=6 ; 11,3 \%)$,

- lepsza przyswajalność preparatów witaminowych $(\mathrm{n}=13 ; 24,5 \%)$.

42 osoby nie zauważyły żadnych skutków ubocznych żywienia dojelitowego (79,2\%).

Pozostali badani zgłaszali infekcje wokół cewnika $(n=9$; $17 \%)$; pęknięcie balonika i wypadnięcie cewnika $(\mathrm{n}=2$; $3,8 \%$ ). Większość powikłań występowała w okresie do 6 miesięcy od założenia cewnika.

Pacjenci zauważali korzyści po zastosowaniu żywienia dojelitowego już po 2 tygodniach do 6 miesięcy, średnio po 2-3 miesiącach.

\section{DYSKUSJA}

W niniejszym badaniu wszystkie osoby były żywione dojelitowo wyłącznie przez PEG. Jak wskazują badania, jejunostomię wykorzystuje się tylko wtedy, kiedy nie jest możliwe żywienie dożołądkowe. Gastrostomia jest więc metodą dojelitowego leczenia żywieniowego z wyboru w mukowiscydozie [15].

Przed założeniem przetoki odżywczej u pacjenta wykonuje się badanie kontrastowe przewodu pokarmowego, scyntygrafię żołądka, 24-godzinną pH-metrię przełyku, a także wlew doodbytniczy cieniujący. Ma to na celu wykluczenie zaburzeń motoryki przewodu pokarmowego, a także wykrycie refluksu żołądkowo-przełykowego. Jeżeli stwierdzi się masywny refluks żołądkowo-jelitowy, to równocześnie z zakładaniem gastrostomii wykonuje się zabieg przeciwrefluksowy [16].

Wszyscy ankietowani pacjenci w niniejszym badaniu zgłosili poprawę po zastosowaniu żywienia dojelitowego. Był to najczęściej przyrost masy ciała. Ponadto chorzy zgłaszali poprawę odporności, mniejszą częstość infekcji i lepszą przyswajalność preparatów witaminowych. Analiza czynników, które motywują osobę chorą do odżywiania dojelitowego, pokazuje, iż główną przyczyną jest zmniejszenie częstotliwości infekcji układu oddechowego, co jest spowodowane lepszym odżywieniem organizmu, a co za tym idzie, mobilizacją układu immunologicznego [1,3-5].

U osób chorych na mukowiscydozę najlepsze rezultaty daje dojelitowa podaż diety przemysłowej, której kaloryczność wynosi $1,5 \mathrm{kcal} / 1 \mathrm{ml}$, podawana podczas nocnego żywienia w połączeniu z wysokoenergetyczną dietą podawaną doustnie. Większość osób badanych deklarowała chęć stosowania żywienia nocnego. Tak było też $\mathrm{w}$ analizowanych badaniach - zdecydowana większość stosowała tryb nocny.

Jak pokazują wyniki prac, zastosowanie żywienia dojelitowego w pewnej grupie pacjentów chorych na mukowiscydoze daje niezaprzeczalne korzyści - przy bardzo rzadko występujących skutkach ubocznych - tylko nieliczni zgłaszali miejscowe infekcje i wypadnięcie balonika.

Od wielu lat wiodące światowe ośrodki zajmujące się badanym zagadnieniem pracują wspólnie nad wypracowaniem konsensusu i ogólnych wytycznych czy też rekomendacji, które mogłyby być wprowadzone jako standardy w leczeniu niedożywienia u chorych na mukowiscydozę 
[17]. Obecnie najbardziej rozpowszechnionym i uznanym wydaje się zestaw 33 rekomendacji opracowany przez kilkudziesięciu ekspertów z kilkunastu wiodących instytucji medycznych, zaproszonych do współpracy przez Cystic Fibrosis Foundation [18].

Po przeprowadzeniu opisanych w niniejszym artykule badań, spośród wszystkich rekomendacji CF Foundation, za najbardziej uniwersalne autorzy uważają dziesięć, które dotyczą najważniejszych aspektów stosowania alternatywnych form żywienia w przebiegu mukowiscydozy. Rekomendacje nr 3 i 4 sugerują, aby decyzja o wdrożeniu żywienia dojelitowego była poprzedzona analizą przeciwskazań, a pacjent wraz z rodziną powinien brać czynny udział w tym procesie z pełną świadomością potencjalnych korzyści, ale i możliwych powikłań. W rekomendacji nr 7 eksperci wskazują, że w krótkim okresie (do 3 miesięcy) wymaganego dożywiania, najlepszym rozwiązaniem jest sonda wprowadzana nosowo. Jeśli planowane jest dożywianie metodą PEG, konieczna jest uprzednia bardzo staranna analiza historii choroby oraz aktualnego stanu zdrowia pacjenta (rekomendacja nr 9), ponieważ jak wskazują liczne wyniki badań, pozwala to ustrzec się większości poważnych wczesnych i późniejszych powikłań. Jako że wiele badań wskazuje, że istotny negatywny wpływ na proces dożywiania dojelitowego ma występowanie u pacjenta refluksu żołądkowo-przełykowego, CF Foundation rekomenduje w punkcie nr 10, aby przeprowadzić badanie w tym kierunku. Dla zmniejszenia ryzyka poważnych powikłań proponowane jest także, aby nie wprowadzać dożywiania dojelitowego w ciężkim przebiegu choroby (rekomendacja nr 14). Wiele wyników badań i analiz wskazuje, że stosowanie dożywiania w warunkach domowych jest możliwe i nie prowadzi do częstszych czy poważniejszych powikłań niż w warunkach ambulatoryjnych. Warunkiem jest jednak, aby pacjent i rodzina zostali odpowiednio przeszkoleni, oraz aby w całym procesie mogli korzystać ze wsparcia specjalistycznej pomocy, co zawarte zostało w rekomendacji nr 28. Dwie kolejne, niezmiernie ważne rekomendacje nr 29 i 30 wskazują na istotną rolę specjalistów od spraw żywienia dla właściwego wyliczenia zapotrzebowania energetycznego oraz ewaluacji wyników dożywiania przy użyciu obiektywnych wskaźników. Wreszcie ostatnia rekomendacja mówi, że pacjenci, którzy korzystali z dożywiania, byli następnie monitorowani przez gastroenterologa co najmniej raz do roku [18].

\section{PIŚMIENNICTWO}

1. Zasady rozpoznawania i leczenia mukowiscydozy. Stanowisko Polskiej Grupy Roboczej Mukowiscydozy. Stand Med 2002;2:16-27.

2. Walkowiak J, Pogorzelski A, Sands D et al. Zasady rozpoznawania i leczenia mukowiscydozy. Zalecenia Polskiego Towarzystwa Mukowiscydozy 2009 Poznań - Warszawa - Rzeszów. Standardy Medyczne / Pediatria 2009;6:352-378.

3. Thomson AH. Mukowiscydoza. 1st edn. Warszawa: PZWL., 2013.

4. Milanowski A. Zasady rozpoznania i leczenia mukowiscydozy. Stand Med 2002;4(supl.):138-146.

5. Sands D. Mukowiscydoza: Choroba wieloukładowa. Poznań: Termedia, 2018.
6. Stephenson AL Sykes J, Berthiaume Y, Singer LG, Aaron SD, Whitmore GA, Stanojevic S. Clinical and demographic factors associated with post-lung transplantation survival in individuals with cystic fibrosis. J Heart Lung Transplant 2015;34(9):1139-1145.

7. Snell G, Reed A, Stern M, Hadjiliadis D. The evolution of lung transplantation for cystic fibrosis: A 2017 update. J Cyst Fibros 2017;16(5):553-564.

8. Mendizabal M, Reddy KR, Cassuto J et al. Liver transplantation in patients with cystic fibrosis: analysis of united network for organ sharing data. Liver Transpl 2011;17:243-250.

9. Cystic Fibrosis - our focus. Standards of care and good clinical practice for the physiotherapy management of cystic fibrosis. 3rd edition. Cystic Fibrosis Trust. London April 2017.

10. Szajewska H. Żywienie i leczenie żywieniowe dzieci i młodzieży. 1st edn. Kraków: Medycyna Praktyczna, 2017.

11. Książyk J. Postępy w żywieniu dzieci. Pediatria Współczesna Gastroenterologia, Hepatologia i Żywienie Dziecka 2000;2:69-75.

12. Kozłowska-WojciechowskaM,Makarewicz-Wujec M. Terapiażywieniowa chorych na mukowiscydozę. Poznań: Termedia Wydawnictwa Medyczne, 2009.

13. Collins $S$. Nutritional management of cystic fibrosis - an update for the 21st century. Paediatr Respir Rev 2018;26:4-6.

14. Szlagatys-Sidorkiewicz A, Borkowska A, Popińska Ket al.Complications of $P E G$ are not related to age - the result of 10 -year multicenter survey. Adv Med Sci 2016;16:1-5.

15. Hollander FM, de Roos NM, Belle van Meerkerk G, Teding van Berkhout $F$, Heijerman HGM, van de Graaf EA. Body weight and body mass index in patients with end-stage cystic fibrosis stabilize after the start of enteral tube feeding. J Acad Nutr Diet 2017;117(11):1808-1815.

16. Laskowska J, Sibilska M, Książyk J. Leczenie żywieniowe przez przewód pokarmowy. Med Prakt. - Pediatria 2008.

17. Rozga M, Handu G. Nutrition care for patients with cystic fibrosis: an evidence scoping review. J Acad Nutr Diet 2019;119(1):137-151.

18. Schwarzenberg SJ, Hempstead SE, MCDonald CM et al. Enteral tube feeding for individuals with cystic fibrosis: Cystic Fibrosis Foundation evidence-informed guidelines. J Cyst Fibros 2016;15:724-735.

\section{ORCID:}

Beata Łabuz-Roszak - 0000-0002-9835-8240

Konflikt interesów

Autorzy deklaruja brak konfliktu interesów

\author{
AUTOR KORESPONDUJĄCY \\ Beata Łabuz-Roszak \\ Katedra i Zakład Podstawowych Nauk Medycznych, \\ Wydział Zdrowia Publicznego SUM; \\ ul. Piekarska 18, Bytom \\ tel. 605097110; \\ e-mail:broszak@sum.edu.pl
}

Nadesłano: 03.03.2019

Zaakceptowano: 10.09.2019 


\title{
THE SIGNIFICANCE OF NO GAS TRANSMITTER AND NUCLEASES IN SHAPING THE SEQUELAE OF TRAUMATIC BRAIN INJURY
}

\author{
Oleh Kobyletskyi', Andrii Netliukh', Nataliya Matolinets' ${ }^{2}$, Andrii Kulmatytskyi', Oksana Kovalska ${ }^{3}$, \\ Dzvenislava Moskviak-Lesniak ${ }^{3}$, Taras Gutor ${ }^{3}$ \\ 'DEPARTMENT OF NEUROPATHOLOGY AND NEUROSURGERY, DANYLO HALYTSKY LVIV NATIONAL MEDICAL UNIVERSITY, LVIV, UKRAINE \\ 2DEPARTMENT OF ANESTHESIOLOGY AND INTENSIVE CARE, DANYLO HALYTSKY LVIV NATIONAL MEDICAL UNIVERSITY, LVIV, UKRAINE \\ ${ }^{3}$ DEPARTMENT OF SOCIAL MEDICINE, ECONOMICS AND ORGANIZATION OF HEALTH CARE, DANYLO HALYTSKY LVIV NATIONAL MEDICAL UNIVERSITY, LVIV, UKRAINE
}

\begin{abstract}
Introduction: Traumatic brain injuries are at present remaining an important worldwide medical problem due to substantial percentages of incapacitation and lethality, especially among people of working age. All therapeutic interventions in TBI and their timeliness and efficacy depend on timely and quality diagnosis of patient's condition, including laboratory parameters of blood and urine.

The aim: To assess for peculiar patterns in changes of NO gas transmitter levels in patients with severe traumatic brain injury during the treatment period and to investigate into its relationship with nuclease enzymes in the context of various treatment outcomes.

Materials and methods: This research work has used clinical data, history and diagnostic tests obtained in 72 patients with severe traumatic brain injury, age 18 to 76 years (mean age 42.26 \pm 15.02 years), who six months later have been divided into the following four groups according to Glasgow outcome scale: "Death", "Severe disability", "Moderate disability" and "Recovery".

Results: Biochemical assessments in patients with severe traumatic brain injury have shown supranormal levels of urinary nitric oxide and serum DNAses. Going forward, nitric oxide levels significantly decreased over the time of treatment in subjects with favorable outcomes ("Moderate disability" and "Recovery" groups) and increased with treatment time in subjects with unfavorable outcomes ("Severe disability" and "Death" groups). The diagnostic markers of further unfavorable survival outcomes may be present at the onset of treatment (Day 1) and may include urinary levels of nitric oxide below $1.1 \mu \mathrm{mol} / \mathrm{L}$ and DNAse levels below $26 \mu \mathrm{U} / \mathrm{mL}$. A positive diagnostic sign of favorable survival and health outcomes may include DNAse I levels over $30.0 \mu \mathrm{U} / \mathrm{mL}$ from Day 7 of treatment.

Conclusions: The findings of this work can be used when making a diagnosis/selecting an optimal treatment schedule and predicting the sequelae of traumatic brain injury in a patient, which may cumulatively minimize the impact of the injury.
\end{abstract}

KEY WORDS: traumatic brain injury, nitric oxide, deoxyribonuclease, death, disability

Wiad Lek 2019, 72, 10, 1884-1899

\section{INTRODUCTION}

Traumatic brain injuries (TBI) are at present remaining an important worldwide medical problem due to substantial percentages of incapacitation and lethality, especially among people of working age. All therapeutic interventions in TBI and their timeliness and efficacy depend on timely and quality diagnosis of patient's condition, including laboratory parameters of blood and urine [1].

One of such laboratory parameters is nitric oxide (NO), a gas transmitter taking part in regulation of blood circulation and immunological and neurotransmitter functions; this substance is one of the most important biological mediators, which is involved in many pathophysiological processes $[2,3]$.

Traumatic brain injuries are associated with destruction of nerve cells. This activates deoxyribonucleases (DNAse I and DNAse II), the latter being specific enzymes for disintegration and synthesis of nucleic acids, leading to further increase in their levels in neurocytes and, respectively, in the blood of the patients [4]. In the light of the above, the activity of nucleases in the remote post-TBI period is probable to be higher than in the control groups. This increase in nuclease activity in venous serum of subjects with post-injury syndromes may suggest continuous reparative processes of neuronal regeneration of the brain as a response to increased neuronal death caused by damaging factors $[5,6]$.

\section{THE AIM}

To assess for peculiar patterns in changes of $\mathrm{NO}$ gas transmitter levels in patients with severe TBIs during the treatment period and to investigate into their relationship with nuclease enzymes in the context of various treatment outcomes.

\section{MATERIALS AND METHODS}

The research is in line with the ethical standards of Declaration of Helsinki. The research work has used clinical data, 
history and diagnostic tests from 72 subjects with severe traumatic brain injuries of various origin, age from 18 to 76 years (mean age $42.26 \pm 15.02$ years), treated as in-patients at the Department of Neurosurgery, Communal Municipal Teaching Hospital of Emergency Medical Services of the City of Lviv. In order to compare the biochemical parameters in the patients, a group of 22 virtually healthy volunteer subjects was assessed (mean age $46.6 \pm 0.9$ years).

Depending on treatment outcomes and health sequelae, in six months (180 days) all patients were divided into four groups according to Glasgow outcome scale (GOS): Group I ("Death" or 1 point on GOS) included 36 patients where life-saving interventions have failed and who succumbed to their injuries; Group II ("Severe disability" or 3 points on GOS) included eight patients with severe residual neurological damage; Group III ("Moderate disability" or 4 points on GOS) included 18 patients who have not regained their full pre-accident working capacity and Group IV ("Recovery" or 5 points on GOS) included 10 patients who regained their full pre-accident working capacity as a result of treatment and went back to normal life.

All patients admitted with severe TBIs had biochemical blood tests, which could be indicators of severity of condition in patients with head injuries. These tests included nitric oxide gas transmitter and such enzymes as deoxyribonuclease I and II (DNAse I and DNAse II). Biological material (blood and urine) was sampled from the patients on the day of admission and on Days 3, 5, 7, 9, 14 and 30 of hospitalization.

Medical statistical analysis was used to evaluate and to summarize the data obtained. Mean values with respective errors were calculated $(\mathrm{M} \pm \mathrm{m})$; a Gaussian-type distribution was found. Unpaired Student's t-test was used to compare the 2 populations; paired Student>s t-test was

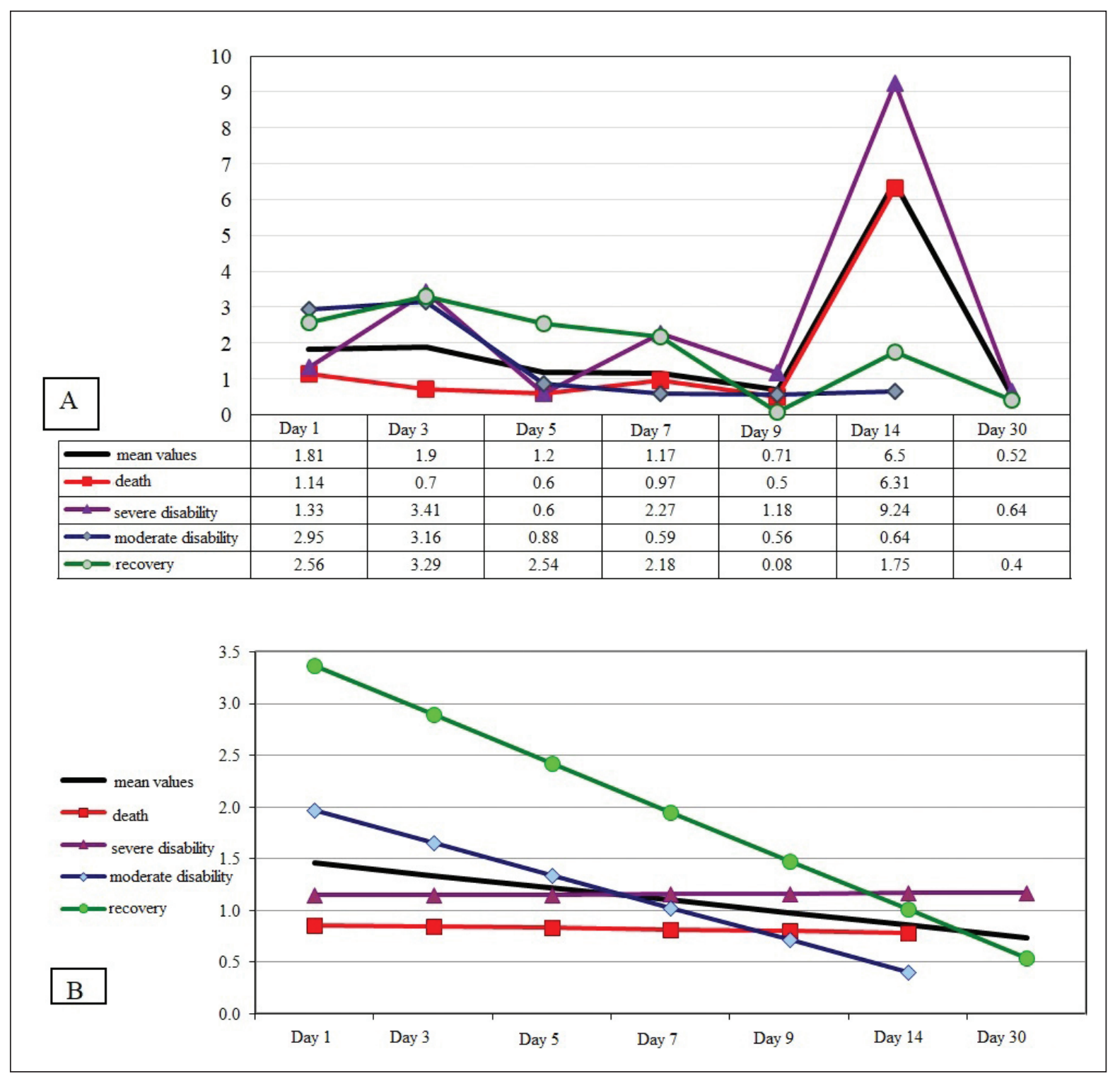

Fig. 1 Changes in nitric oxide levels with time ( $\mu \mathrm{mol} / \mathrm{L})$ : actual average data $(A)$ and aligned conditional data $(B)$ in patients with TBl of various outcome groups during the 30 days of treatment 


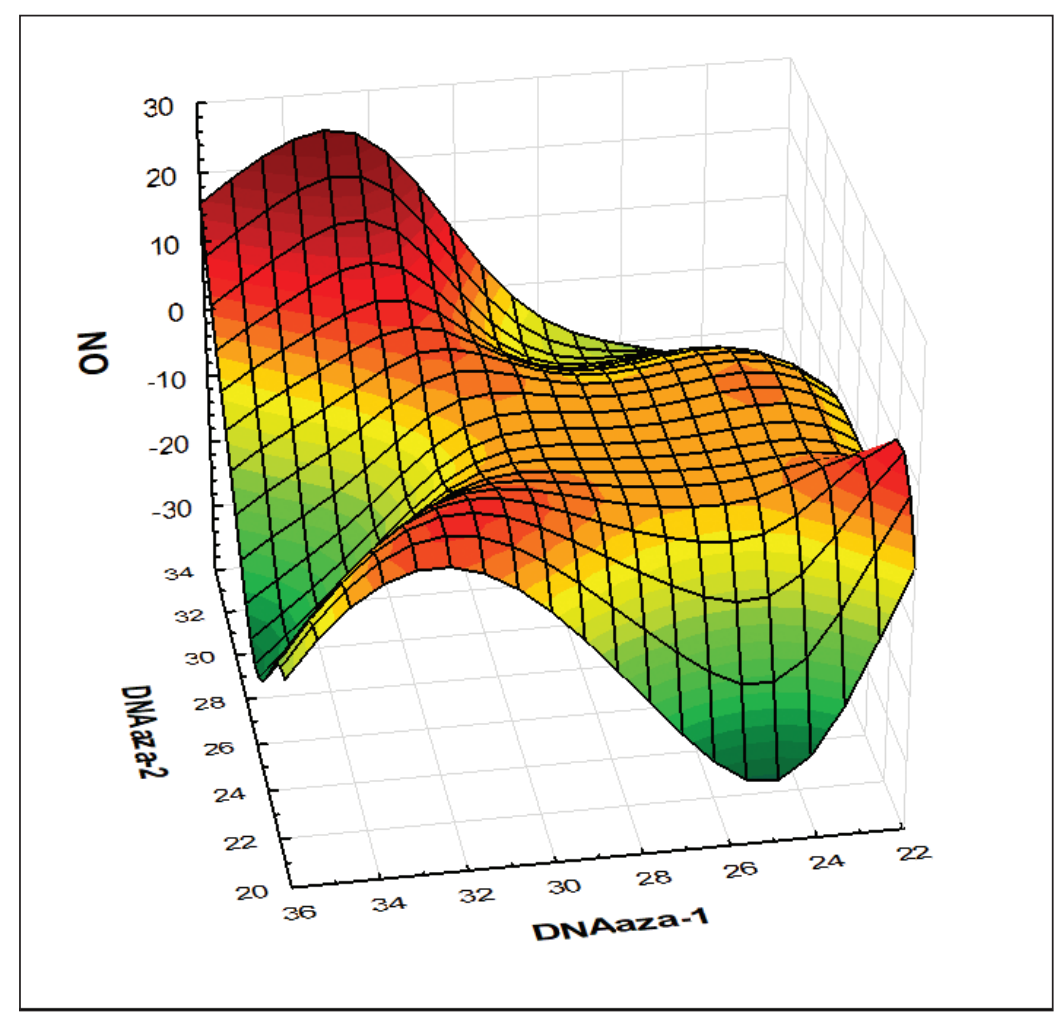

Fig. 2. The $3 D$ image of a relationship between the values of N0, DNAse I and DNAse II in patients with used to evaluate the probability of changes in parameters with time in each group. The least squares method was used for alignment of time series. The correlation relationship between the parameters was evaluated using Pearson's linear correlation (r) [7]. Statistical hypotheses were tested at a significance level of $\mathrm{p}<0.05$.

\section{RESULTS}

As reported by assessment of urinary levels of NO gas transmitter, its average level in the injured subjects of the main group was $1.34 \pm 0.16 \mu \mathrm{mol} / \mathrm{L}$, which was significantly $(\mathrm{p}<0.01)$ higher than the respective value in control group subjects $(0.595 \pm 0.049 \mu \mathrm{mol} / \mathrm{L})$. In the majority $(69.44 \%)$ patients of the main group with severe TBIs, NO levels on Day 1 of assessment were above normal and only in approximately one third of patients $(30.56 \% ; n=22)$ this parameter was within normal. Moreover, most of these included the subjects who subsequently died $(n=16)$; the remaining patients with initially normal NO levels included five subjects with subsequent disability and one patient from the "Recovery" group.

Generally speaking, all study patients with severe TBIs were observed to have a clear trend to reduction in nitric oxide levels, i.e. from $1.81 \pm 0.36 \mu \mathrm{mol} / \mathrm{L}$ on Day 1 to $0.52 \pm 0.12 \mu \mathrm{mol} / \mathrm{L}$ on Day 30 at $\mathrm{p}<0.01$ (the rate of increase/ decrease [increase rate, IR] was $28.73 \%$ ) (see Fig. 1).

The patients from the "Death" group were observed to have insignificant undulating reductions in the parameter until Day 9 and a sharp increase in NO starting from Day 14, which has demonstrated an overall trend of increasing nitric oxide levels among the patients who subsequently died.
Thus, overall NO levels across the "Death" group have increased 4.53-fold ( $\mathrm{IR}=553.51 \%$ ), i.e. from $1.14 \pm 0.26 \mu \mathrm{mol} / \mathrm{L}$ to $6.31 \pm 5.42 \mu \mathrm{mol} / \mathrm{L}(\mathrm{p}>0.05)$. Significantly higher NO values in this group (compared to control group) were obtained only during the first day of observations $(\mathrm{p}<0.05)$.

Compared to other groups of study patients, the levels of nitric oxide in the "Death" group were observed to be lower than the respective values in all other groups on virtually all days of observations (except for Day 14); a significant difference in the values was confirmed for the groups "Severe disability" (Day 7, $\mathrm{p}<0.01$ ) and "Recovery" (Days 1 and $5, \mathrm{p}<0.05)$. Therefore, urinary levels of nitric oxide below $1.1 \mu \mathrm{mol} / \mathrm{L}$ at the beginning of treatment (Day 1) may be a diagnostic marker of further unfavorable vital outcomes.

The levels of nitric oxide in patients of the "Severe disability" group also had a downward trend, a 2.08fold reduction ( $\mathrm{IR}=48.12 \%$ ) (from $1.33 \pm 0.29 \mu \mathrm{mol} / \mathrm{L}$ to $0.64 \pm 0.00 \mu \mathrm{mol} / \mathrm{L}, \mathrm{p}<0.05)$ with a surge on Day 14 , which was also true for the "Death" group. Compared with the control group, significantly higher values were documented on Day $1(\mathrm{p}<0.01)$ and on Day $7(\mathrm{p}<0.05)$. Compared to other groups, NO levels on Day 1 and Day 5 were the lowest from all groups, while on Day 3 and on Days 7 to 14 the NO levels were higher than in all groups $(\mathrm{p}<0.05)$, with a significant difference from the "Death" and "Moderate disability" groups on Day $7(\mathrm{p}<0.01)$ and from the "Recovery" group on Day $5(\mathrm{p}<0.05)$.

The NO levels in patients of the "Moderate disability" group have decreased significantly, a 4.61-fold reduction, $\mathrm{IR}=21.69 \%$, i.e. from $2.95 \pm 1.26 \mu \mathrm{mol} / \mathrm{L}$ to $0.64 \pm 0.00 \mu \mathrm{mol} / \mathrm{L}(\mathrm{p}<0.01)$. Compared to other groups, special findings for the NO parameter were present on 
Table 1. The values of the correlation coefficient between NO and DNAse I/DNAse II in patients of the study groups in course of treatment

\begin{tabular}{|c|c|c|c|c|c|c|c|c|c|c|c|}
\hline \multirow[t]{2}{*}{ Days } & \multirow[t]{2}{*}{ DNAses } & \multicolumn{2}{|c|}{ Total } & \multicolumn{2}{|c|}{ Death } & \multicolumn{2}{|c|}{ Severe disability } & \multicolumn{2}{|c|}{$\begin{array}{l}\text { Moderate } \\
\text { disability }\end{array}$} & \multicolumn{2}{|c|}{ Recovery } \\
\hline & & $r$ & $\mathbf{p}$ & $r$ & $\mathbf{p}$ & $\mathbf{r}$ & $\mathbf{p}$ & $r$ & $\mathbf{p}$ & $\mathbf{r}$ & $\mathbf{p}$ \\
\hline \multirow{2}{*}{ Day 1} & DNAse I & 0.17 & 0.14 & 0.39 & 0.01 & 0.63 & 0.04 & 0.19 & 0.41 & -0.16 & 0.62 \\
\hline & DNAse II & 0.14 & 0.22 & 0.31 & 0.05 & 0.60 & 0.05 & 0.15 & 0.54 & -0.12 & 0.70 \\
\hline \multirow{2}{*}{ Day 3} & DNAse I & 0.44 & 0.01 & 0.29 & 0.26 & 0.95 & 0.001 & 0.13 & 0.77 & 0.99997 & 0.000 \\
\hline & DNAse II & 0.43 & 0.01 & 0.15 & 0.57 & 0.998 & 0.000 & 0.06 & 0.90 & 0.99 & 0.000 \\
\hline \multirow{2}{*}{ Day 5} & DNAse I & 0.18 & 0.55 & - & & 0.9999 & 0.000 & 0.92 & 0.01 & 0.40 & 0.49 \\
\hline & DNAse II & 0.47 & 0.09 & - & & 0.90 & 0.02 & 0.87 & 0.04 & 0.50 & 0.38 \\
\hline \multirow{2}{*}{ Day 7} & DNAse I & 0.70 & 0.002 & 0.61 & 0.07 & - & & 0.998 & 0.000 & - & \\
\hline & DNAse II & 0.66 & 0.004 & 0.56 & 0.10 & - & & 0.999 & 0.000 & - & \\
\hline \multirow{2}{*}{ Day 9} & DNAse I & 0.70 & 0.02 & 0.90 & 0.02 & 0.99 & 0.001 & - & & - & \\
\hline & DNAse II & 0.78 & 0.003 & 0.68 & 0.18 & 0.95 & 0.01 & - & & - & \\
\hline \multirow{2}{*}{ Day 14} & DNAse I & -0.08 & 0.83 & - & & 0.35 & 0.48 & - & & - & \\
\hline & DNAse II & 0.22 & 0.54 & - & & 0.36 & 0.47 & - & & - & \\
\hline
\end{tabular}

In patients of the "Death" group, the correlation between the investigational parameters was proven for Day 1 and Day $9(p<0.05)$.

Day 7 and Day 14, when it was significantly below the levels of all other main observation groups $(\mathrm{p}<0.01)$.

Throughout the observation period, the values of nitric oxide in patients of the "Recovery" group reduced 6.40 times $(\mathrm{IR}=15.63 \%)$, i.e. from $2.56 \pm 0.62 \mu \mathrm{mol} / \mathrm{L}$ to $0.40 \pm 0.00 \mu \mathrm{mol} / \mathrm{L}(\mathrm{p}<0.01)$. Of note, medium NO levels were documented across all groups, with the exception of Day 5 (the difference for that day was significant, $\mathrm{p}<0.05$ for the values in all groups, including the control group).

Therefore, as a conclusion, an increase in nitric oxide can be seen in patients who subsequently died or remained permanently disabled (a direct strong correlation $[\mathrm{r}=+0.75$, $\mathrm{p}<0.01]$ ), as well as a decrease in nitric oxide over the time of treatment for the groups of patients with moderate disability and patients with recovery (a strong inverse correlation; $\mathrm{r}=-0.77, \mathrm{p}<0.01$ ).

Using Pearson's method, we have performed an analysis of correlations between changes in biochemical indices of blood (nucleic acids, nucleases, lipid peroxidation, L-arginine and middle molecules) with urinary nitric oxide levels during the 30 days of treatment. As a result, a significant mutual dependence was found to exist between $\mathrm{NO}$ and DNAse I and II, which prompted a more detailed analysis.

Assessment of serum activity of alkaline nuclease (DNAse I) and acid nuclease (DNAse II) in healthy subjects has found the following activity levels: DNAse I: $14.81 \pm 0.84$ $\mu \mathrm{U} / \mathrm{mL}$; DNAse II: $13.19 \pm 0.71 \mu \mathrm{U} / \mathrm{mL}$. All patients with severe TBI in the main study group had DNAse levels above normal (depending on their condition and the duration of treatment), namely: DNAse I: a 1.71- to 2.20 -fold increase; DNAse II: a 1.86- to 2.43-fold increase $(\mathrm{p}<0.01)$. Throughout the treatment period, none of the patients with severe TBI had a nuclease value on a par with the control group.

DNAse levels in patients of the "Death" group from observation Day 1 to observation Day 9 were the lowest $(\mathrm{p}<0.05)$ among the levels in all other groups. The prac- tical implication is that the low level of DNAses (below $26 \mu \mathrm{U} / \mathrm{mL}$ ) at the onset of treatment is a potential diagnostic marker of a vitally unfavorable treatment outcome.

The activities of DNAse enzymes in patients of the "Recovery" group have significantly $(\mathrm{p}<0.01)$ changed upwards in course of treatment (IR of DNAse I $=116.82 \%$ and IR of DNAse II $=113.72 \%)$. Compared to other groups, the levels of DNAse I in patients of this group from Day 7 through Day 30 (the last day) were higher $(\mathrm{p}<0.05)$ than the respective values in the rest of the outcome groups, while the values of DNAse II in patients of this group were not specifically different from other groups $(\mathrm{p}>0.05)$. Accordingly, the level of DNAse I above $30.0 \mu \mathrm{U} / \mathrm{mL}$ in patients with severe TBIs from Day 7 of treatment can be a positive prognostic health criterion.

Analysis of the study of correlation between NO levels and DNAse levels in patients of the main group has demonstrated a moderate and strong direct correlation at Day 3, Day 7 and Day 9 of treatment: from $r=+0.43$ to $r=+0.78$, $\mathrm{p}<0.01$ (see Table 1 ).

The most significant mutual dependence between nitric oxide and nucleases was found in patients of the "Severe disability" group: from Day 1 to Day 9, the correlation coefficient was from +0.6 to $+0.9999(\mathrm{p}<0.05)$.

For patients in the "Moderate disability" group, a strong direct correlation was proven for Day 5 and Day $7(p<0.05)$; in patients of the "Recovery" group, this correlation was proven for Day $3(\mathrm{p}<0.001)$.

For better visualization of relationship between the parameters, 3D-images are given (see Fig. 2).

\section{DISCUSSION}

Destruction of nerve cells activates nuclease enzymes (DNAses and RNAses), which are specific enzymes responsible for disintegration and synthesis of nucleic acids, 
leading to further increases in their respective levels in the nerve cells and in the blood of patients [8].

As of today, a number of studies have been conducted, which demonstrate TBI to cause substantial abnormal changes in homeostasis, nucleases, nitric oxide metabolism and cerebral vascular tone in both acute and intermediate period of the condition [8]. The above mentioned changes directly correlate with TBI severity [9].

The NO gas transmitter causes nitrosylation of target proteins and (through post-translational modifications) is able to cause instant effects in target cells and to perform key biological functions. Therefore, detection of $\mathrm{NO}$ (as a small signal gas transmitter) is important due to its involvement in the pathogenesis of a number of human diseases, including that of TBI $[2,10,11]$.

The activity of alkaline and acidic DNAses has also been proven to increase significantly in injuries, especially in the acute period, and to be directly related to the severity of patient's condition $[12,13]$. The levels of DNAses in all our patients with severe TBI were above normal (depending on patient condition and duration of treatment), namely: a 1.71- to 2.20-fold difference for DNAse I and a 1.86- to 2.43-fold difference for DNAse II. A significant difference of nuclease levels from the control group has been demonstrated in all treatment days and in patients of all treatment outcome groups $(\mathrm{p}<0.01)$.

In the remote post-TBI period, the activity of alkaline DNAse I was significantly higher than in control group and the activity of alkaline DNAse II was substantially above control values. The increase in venous serum nuclease activity found in subjects with post-injury syndromes may suggest continuous reparative processes of neuronal regeneration of the brain as a response to increased neuronal death caused by the damaging factors. With ongoing recovery, the activity of nucleases returns to normal level, allowing the use of this criterion for a more precise diagnosis, choice of optimal treatment regimen and prognosis of the course of traumatic brain injury.

The practical implication is that the low level of DNAses (below $26 \mu \mathrm{U} / \mathrm{mL}$ ) at the onset of treatment is a potential diagnostic marker of a vitally unfavorable treatment outcome. The higher DNAse levels persisting at $27-32 \mu \mathrm{U} / \mathrm{mL}$ during the first five days of treatment may be a criterion of further adverse health outcomes. The level of DNAse I above $30.0 \mu \mathrm{U} / \mathrm{mL}$ in patients presenting with a severe TBI from Day 7 of treatment can be a positive prognostic criterion.

The prospects of further research will include the assessment of significance of these biomarkers in patients with polytrauma.

\section{CONCLUSIONS}

1. In patients with severe TBIs, significant changes were observed in parameters of blood and urine, namely urinary levels of nitric oxide and DNAse I/DNAse II enzymes were higher than normal.

2. The levels of nitric oxide were found to be significantly increased in the patients who subsequently died or became permanently disabled and were found to decrease with time of treatment in the groups of patients with moderate disability and with recovery.
3. The levels of DNAse I and DNAse II in patients of the "Death" group from Day 1 to Day 9 of observations were the lowest $(\mathrm{p}<0.05)$ compared to the levels in all other groups and the levels of DNAse I in patients of the "Recovery' group from Day 7 and through the last Day 30 were higher $(\mathrm{p}<0.05)$ than the respective parameters in the rest of the outcome groups.

4. The levels of DNAses significantly $(\mathrm{p}<0.05)$ correlated with nitric oxide levels on Day 3, Day 7 and Day 9 of treatment.

5. The findings of this work can be used when making a diagnosis/selecting an optimal treatment schedule and predicting the sequelae of traumatic brain injury in a patient, which may cumulatively minimize the impact of the injury.

\section{REFERENCES}

1. Maas A, Marmarou A, Murray G, et al. Prognosis and clinical trial design in traumatic brain injury: the IMPACT study. J. Neurotrauma 2007;24:232-8.

2. Wang R. Shared signaling pathways among gasotransmitters, PNAS 2012;109(23):8801-2.

3. Agarwal A, Bolisetty S. Adaptive responses to tissue injury: role of heme oxygenase-1. Trans. Am. Clin. Climatol. Assoc. 2013;124:111-122.

4. Saliy Z.V. Clinical and laboratory correlations in patients with sequelae of traumatic brain injury. ScienceRise. Medical Science 2015;8(3):58-64. URL: http: //nbuv.gov.ua/UJRN/texc_2015_8(3)_12.

5. Wilson NM, Gurney ME, Dietrich WD, Atkins CM. Traumatic brain injury. PLOS ONE 2017;12(5). e0178013. doi: 10.1371/journal.pone.0178013.

6. Ondruschka B, Schuch S, Pohlers D, Franke H, Dreßler J. Acute phase response after fatal traumatic brain injury. Int J Legal Med 2018 Jan;6. doi: 10.1007/s00414-017-1768-2.

7. Maksymets T, Karpyshyn N, Gutor T, Sklyarova H, Sklyarov E. Influence of risk factors on insulin resistance in patients with overweight and obesity. Wiadomosci lekarskie 2018;71(3 pt 1):558-560. https://www. ncbi.nlm.nih.gov/pubmed/29783224.

8. Lee JY, Lee CY, Kim HR, Lee CH, Kim HW, Kim JH. A Role of Serum-Based Neuronal and Glial Markers as Potential Predictors for Distinguishing Severity and Related Outcomes in Traumatic Brain Injury. J Korean Neurosurg Soc. 2015 Aug;58(2):93-100. doi:10.3340/jkns.2015.58.2.93. PMCID: PMC4564754.

9. Cruse D, Norton L, Gofton T, Young GB, Owen AM. Positive prognostication from median-nerve somatosensory evoked cortical potentials. Neurocrit Care 2014 0ct;21(2):238-44. doi: 10.1007/s12028-014-9982-y.

10. Ostapchenko L.I., Synelnyk T.B., Kompanets I.V. Biological membranes and the fundamentals of intracellular signaling. Theoretical aspects: A Textbook Kyiv: VPTs “Kyiv University" 2016:639.

11. García-Mata C, Lamattina L. Gasotransmitters are emerging as new guard cell signaling molecules and regulators of leaf gas exchange. Plant Sci. 2013;201-202:66-73.

12. Zaruts'kyi Ya.L., Denysenko V.M., Tkachenko A.Ye. The specific features of diagnosis in combined cranioabdominal trauma. Collection of Scientific Works of Fellows of P.L. Shupyk National Medical Academy for Postgraduate Education 2015;24(1):52-7.

13. Vokálová L, Lauková L, Čonka J, Melišková V, Borbélyová V, Bábíčková J, et al. Deoxyribonuclease partially ameliorates thioacetamide-induced hepatorenal injury. American Journal of Physiology-Gastrointestinal and Liver Physiology 2017;312(5):457-463. https://doi.org/10.1152/ ajpgi.00446.2016 


\section{Authors' contributions:}

According to the order of the Authorship.

\section{ORCID numbers:}

Oleh Kobyletskyi - 0000-0002-8399-6186

Andrii Netliukh - 0000-0002-6499-1718

Nataliya Matolinets - 0000-0001-6656-3621

Andrii Kulmatytskyi - 0000-0003-3486-1143

Oksana Kovalska - 0000-0001-5242-601X

Dzvenislava Moskviak-Lesniak - 0000-0001-8238-5933

Taras Gutor - 0000-0002-3754-578X

\section{Conflict of interest:}

The Authors declare no conflict of interest.

\section{CORRESPONDING AUTHOR}

\section{Nataliya Matolinets}

Department of Anesthesiology and Intensive Care, Lviv National Medical University named after Danylo Halitsky, 69a, Pekarskaya str., Lviv, 79010, Ukraine tel: +380677741348

e-mail:nmatolinets@gmail.com

Received: 03.07.2019

Accepted: 27.09.2019 


\title{
REHABILITATION OF PATIENTS WITH BOUNDED EDENTULOUS SPACES BY NON-REMOVABLE DENTURE STRUCTURES SUPPORTED BY DENTAL IMPLANTS IN CONDITIONS OF INSUFFICIENT BONE MINERAL DENSITY
}

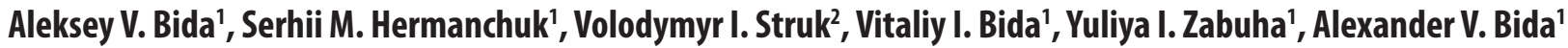 \\ 'SHUPYK NATIONAL MEDICAL ACADEMY OF POSTGRADUATE EDUCATION, KYIV, UKRAINE \\ 2PUBLIC MEDICAL ESTABLISHMENT “MUNICIPAL STOMATOLOGICAL POLYCLINIC", CHERNIVTSI, UKRAINE
}

\begin{abstract}
Introduction: The state of dental implantation is characterized by high efficiency and a significant spectrum of possibilities when replacing dentition defects. At the same time, prevention of complications of dental implantation associated with the loss of bone tissue around dental implants is of great importance are gaining. It leads to a reduction of both the durability and the period of use of orthopaedic structures supported by dental implants.

The aim of the study was to increase the effectiveness of orthopaedic treatment of patients with bounded edentulous spaces with the help of non-removable denture structures supported by dental implants.

Materials and methods: 49 patients aged 30 to 44 years with bounded edentulous space in the upper jaw were examined using clinical (examination, palpation, percussion) and special (computed tomography, resonance-frequency analysis of implant stability) diagnostic methods. Patients were placed 68 dental implants. After 6 months of the osseointegration period, all patients were divided into two groups according to the choice of loading protocol by permanent orthopaedic structures.

Results: Six months after the implants were placed, bone loss was observed in patients from both study groups at the level of $0.823 \pm 0.029 \mathrm{~mm}$ and $0.612 \pm 0.022 \mathrm{~mm}$. The greatest changes regarding the stability of dental implants were noted in patients of both groups in a year. Thus, in group I, where patients had metal ceramic crowns, 6 months after implantation a statistically significant loss of bone tissue $(1.297 \pm 0.049 \mathrm{~mm})$ was noted. The maximum value reached $1.8 \mathrm{~mm}$. And in group II, where orthopaedic treatment was performed by gradually increasing the occlusal load on the dental implant, a statistically significant $(p<0.05)$ increase in the investigated index $(0.651 \pm 0.038)$ was not observed.

Conclusions: The gradual load on the dental implant, in conditions of insufficient bone mineral density, helps to maintain a constant amount of bone around it and prolong the life of the orthopedic structure in general.
\end{abstract}

KEY WORDS: replacement of dentition defects, dental implants, bone mineral density, bone loss

Wiad Lek 2019, 72, 10, 1900-1903

\section{INTRODUCTION}

Despite the development and implementation of modern preventive measures into practice, there is a tendency towards an increase in dental morbidity, which requires orthopaedic interventions. In recent years, there has been a tendency to an increase in the number of people of different age groups who require replacement of defects in dentition $[1,2,3]$.

According to epidemiological studies, due to the complications of caries, first molars are primarily removed; the prevalence of their loss is significant in all age groups of the population. Among etiological factors of tooth loss, diseases of periodontal tissues constitute the lion's share. A significant prevalence of partial absence of teeth leads to a high need for dental prosthetics $[2,3]$.

Over the last 20 years, dental implantology has occupied a significant place in practical dentistry. At present, the state of dental implantation is characterized by high efficiency and a considerable range of possibilities when replacing defects in dentition. $[4,5,6]$.

According to the literature, thanks to the successful development of structures, the improvement of the technology of manufacturing materials and methods of surface treatment, the level of successful osseointegration of placed dental implants reaches $90-98 \%[6,7]$.

At the same time, prevention of complications of dental implantation associated with loss of bone tissue around dental implants is of great importance, as it leads to reduction of both the durability and the period of use of orthopaedic structures supported by dental implants.

\section{THE AIM}

Improvement of the effectiveness of orthopaedic treatment of patients with bounded edentulous spaces with the help of non-removable denture structures supported by dental implants. 


\section{MATERIALS AND METHODS}

To achieve the aim and to solve the set tasks, 59 patients aged 30 to 44 years with bounded edentulous spaces in the upper jaw (which was present from 1 to 2 years) were examined with the help of clinical and special research methods. All studies were conducted in accordance with the Council of Europe Convention On the Protection of Human Rights and Human Dignity in Connection with the Application of Biological and Medical Achievements: the Convention on Human Rights and Biomedicine (ETS No. 164)" of 04.04.1997, and the Helsinki Declaration of the World Medical Association (2008). Each patient signed an informed consent to participate in the study.

When forming a randomly selected representative sample, patients were included in the study group taking into account the following criteria:

- bounded edentulous spaces in the lateral parts of the dentition;

- the duration of the defect formation from 1 to 2 years;

- absence of generalized periodontitis;

- sufficient amount of bone tissue $(12-15 \mathrm{~mm})$ and the absence of indications for bone augmentation;

- bone mineral density 350-850 Hounsfield units, respectively D3 according to C.Misch classification;

- absence of bad habits (smoking);

- the possibility of further follow-up of the patient;

- the implant stability coefficient according to Isq Osstell at the level of 50-55 units 6 months after the first surgical stage. 78 dental implants $10 \mathrm{~mm}$ long and $4.2 \mathrm{~mm}$ in diameter were placed in patients. The installed implants were of the same company, made of pure titanium Grade 4 type, had conical structure with a rounded tip, and also had a microstructured shoulder with a switch platform. The surface of the implant was processed using the SLA technique. After 6 months of the period of osseointegration, all patients were divided into two groups according to the choice of loading protocol by permanent orthopaedic structures. Patients of group I included 28 people ( 35 dental implants). 35 single zirconium dioxide crowns were made for group I two weeks after the placement of healing screw. Occlusal correlations were adjusted so that the tooth-implant contact occurred only after a strong closure of the dentition. Contacts in the area of the tooth implant were polished on an occlusive paper of 200 microns. 31 patients (43 dental implants) were referred to patients in group II. Patients of this group were offered and performed prosthetics according to the following protocol: the healing screw was placed for a period of 1 month. After 1 month an abutment with a temporary plastic crown was placed outside the occlusion, then a temporary crown for occlusal load was made for 1 month, and at the final stage permanent crown on the basis of zirconium dioxide with occlusal ratios as in patients of the first clinical group was fixed.

Computer tomography was performed on the Planmeca $3 \mathrm{D}$ device to determine the density and volume of bone tissue both along the entire length of the dental implant and in the region of the alveolar crest, since it is known that the greatest stress in the bone during the transformation of the occlusal load occurs precisely in this area. When planning a dental implantation, image of the entire jaw was taken, and local tomographic images $50 \times 55 \mathrm{~mm}$ in size were used for further research. Bone loss was measured from the platform level from the proximal side of the implant. In the upper jaw, the distance from the apex of the alveolar crest of the toothless area of the dentition on the border with the dental implant to the edge of the lower border of the maxillary sinus was measured. To determine the level of bone tissue resorption in dynamics, the distance between the level of the dental implant platform and the level of the alveolar crest was measured. It was also compared with the previous measurements to the level of the lower border of the maxillary sinus.

In addition to traditional clinical studies, an objective study was conducted to determine the level of implant stability, since it is the implant stability that may indicate the density and structure of reimplantation tissues.

To determine the degree of primary implant stability, as well as the degree of osseointegration, the Isq Osstell device was used [8].

The method of frequency resonance analysis of implant stability was proposed by N. Meredith in 1997. In clinical practice, the Osstell mentor device manufactured by Integration Diagnostics (Sweden) is used. The device consists of a block with a computer analyser, an emitter-receiver of an electromagnetic field and a magnetized Smartpeg pin, which is connected to the implant or the abutment. The pin is excited by a magnetic pulse from a measuring probe on a hand tool. The method is based on the registration of resonant electromagnetic vibrations of the implant and the surrounding bone under the action of the electromagnetic field through the magnetized pin. The resonance frequency is a measure of the stability of the implant fixation, according to the degree of its osseointegration, and is calculated on the basis of the signal-response. The results are shown on the machine's display as an ISQ - Implant Stability Quotient in the range from 1 to 100 units. The higher the value of this coefficient is, the greater the stability of the fixation is.

The research was carried out immediately after the placement of dental implants and after 6 and 12 months.

The quality of bone tissue in all examined patients was evaluated according to the classification of U.Likholm G. Zarb [9], which provides 4 classes (types) of bone quality (D1-D4). According to this classification, the quality of bone tissue was considered by the percentage correlation of the cortical and spongy substances of the jaws.

\section{RESULTS AND DISCUSSION}

The results of the frequency-resonance evaluation of the stability of dental implants are presented in Table I.

As can be seen from Table I, when analysing the quotient of implant stability, according to the Osstell ISQ device, when implants were placed in patients of Groups I and II (56,360 \pm 0,454 units, $58,579 \pm 0,598$ units, respectively, $p>0,05$ ), there was no statistically significant difference in the indices. This 
Table I. The results of the frequency-resonance analysis of the stability of dental implants in patients of the $1^{\text {st }}$ and $2^{\text {nd }}$ observation groups. (ISQ, unit).

\begin{tabular}{|c|c|c|c|c|c|}
\hline \multirow[b]{2}{*}{$\begin{array}{c}\text { Group No. } \\
\text { (number of placed } \\
\text { dental implants) }\end{array}$} & \multicolumn{5}{|c|}{ Study Period } \\
\hline & $\begin{array}{l}\text { Immediately } \\
\text { after } \\
\text { the placement }\end{array}$ & 6 months & $\begin{array}{c}\text { Statistical } \\
\text { Significance } \\
\text { (p) }\end{array}$ & 12 months & $\begin{array}{c}\text { Statistical } \\
\text { Significance } \\
\text { (p) }\end{array}$ \\
\hline I (35) & $56,360 \pm 0,454$ & $55,967 \pm 0,561$ & $\mathrm{p}<0,05$ & $53,600 \pm 0,606$ & $p>0,05$ \\
\hline II (43) & $58,579 \pm 0,598$ & $61,158 \pm 0,432$ & $\mathrm{p}<0,05$ & $63,158 \pm 0,574$ & $\mathrm{p}<0,05$ \\
\hline $\begin{array}{l}\text { Statistical } \\
\text { significance } \\
\text { between the } \\
\text { groups }(p)\end{array}$ & $p>0,05$ & $p>0,05$ & & $\mathrm{p}<0,05$ & \\
\hline
\end{tabular}

Table II. Loss of bone tissue in patients of the $1^{\text {st }}$ and $2^{\text {nd }}$ clinical groups $(\mathrm{mm})$.

\begin{tabular}{ccccc}
\hline $\begin{array}{c}\text { Group No. } \\
\text { (number of placed } \\
\text { dental implants) }\end{array}$ & $\mathbf{6}$ months & $\begin{array}{c}\text { Statistical Significance } \\
\mathbf{( p )}\end{array}$ & $\mathbf{1 2}$ months & $\begin{array}{c}\text { Statistical Significance } \\
\text { ( })\end{array}$ \\
\cline { 2 - 5 } I (35) & $0.823 \pm 0.029$ & $\mathrm{p}>0,05$ & $\mathrm{p}<0,05$ \\
\hline II (43) & $0,612 \pm 0,022$ & $\mathrm{p}>0,05$ & $\mathrm{p}>0,05$ \\
\hline $\begin{array}{c}\text { Statistical significance } \\
\text { between the groups }(\mathrm{p})\end{array}$ & $\mathrm{p}<0,05$ & & $\mathrm{p}<0,05$ & \\
\hline
\end{tabular}

is explained by the same requirements for patient selection and the identical method of implant placement. As a rule, during the first month after the implant is placed, there is a decrease in the stability of the bone implant joint. Then, in the second and third months after the operation, the increase in the stability of the implant takes place, which confirms the presence of remodeling of the bone tissue around the implant. Since this was not the aim of our study, we did not take measurements after 1 and 3 months in all patients. Six months after the implant was placed, a slight increase in the implant stability quotient was observed. The greatest changes regarding the stability of dental implants were noted in patients of both groups in a year. So in group I, where full metal ceramic crowns were made for patients 6 months after the implants were placed, a statistically insignificant decrease in the implants stability quotient was observed, and in group II where the orthopaedic treatment was performed by gradually increasing the occlusal load on the dental implant, we found a statistically significant $(p<0,05)$ increase of the investigated index up to $63,158 \pm 0,574$ units.

In order to determine the dynamics of bone resorption in the area of the implant neck, bone loss was estimated in the first year after its placement.

In general, according to researchers, during the first year, the loss of bone tissue should not exceed $1.5 \mathrm{~mm}$, and in the future - no more than $0.2 \mathrm{~mm}$ each next year $[4,5,6,7,8,9]$.

The dynamics of bone resorption in the area of the implant neck was evaluated according to computed tomography immediately after the placement of dental implants, and then 6 and 12 months after the implantation.

The analysis of the results of the conducted studies showed that the level of bone tissue around osseointegrated dental implants differs, first of all, depending on the protocol of orthopaedic loading.
The results of determining the amount of bone loss in patients of the $1^{\text {st }}$ and $2^{\text {nd }}$ clinical groups are presented in Table II.

The analysis of the results of the conducted studies indicates significant differences in the level of bone tissue around osteointegrated dental implants depending on the protocol of orthopaedic load $(p<0,05)$. Six months after the implants were placed, bone loss was observed in patients from both study groups at the level of $0.823 \pm 0.029 \mathrm{~mm}$ and $0.612 \pm 0.022 \mathrm{~mm}$. The greatest changes regarding the stability of dental implants were noted in patients of both groups in a year. Thus, in group I, where patients had metal ceramic crowns, 6 months after implantation a statistically significant loss of bone tissue ( 1.297 $\pm 0.049 \mathrm{~mm}$ ) was noted. The maximum value reached 1.8 $\mathrm{mm}$. While in group II, where orthopaedic treatment was performed by gradually increasing the occlusal load on the dental implant, a statistically significant $(p<0.05)$ increase in the investigated index $(0.651 \pm 0.038)$ was not reported.

\section{CONCLUSIONS}

Based on the results of the study, it can be concluded that there is a correlation between the term of the beginning of the load and the degree of loss of the peri-implant bone tissue under the conditions of its insufficient density.

The gradual load on the dental implant, in conditions of insufficient bone mineral density, contributes to maintaining a constant amount of bone around it and prolonging the life of the orthopedic structure in general/. This is evidenced by a significant difference in the bone loss in the studied area of the alveolar process in patients of groups I and II - 1.297 $\pm 0.049 \mathrm{~mm}$ versus $0.651 \pm 0.038(\mathrm{p}<0.05) 12$ months after the placement of dental implants and the stability of the indicators in patients of group II in more remote periods. 


\section{REFERENCES}

1.Bida VI, Bida OV, Zabuha Yul. Derzhavne upravlinnia reformuvanniam okhorony zdorov'ia. Rozvytok derzhavnoho rehuliuvannia stomatolohichnoi sluzhby v Ukraini [Public administration of health care reform. Development of state regulation of dental services in Ukraine]. Kyiv: Synopsy; 2011. $116 \mathrm{~s}$.

2. Bida VI, Pavlenko MO, Bida OV. Mostopodibni konstruktsii zubnykh proteziv [Bridges of dentures]. Lviv: HalDent, 2007. $84 \mathrm{~s}$.

3. Bida VI, Klochan SM. Zamishchennia defektiv zumnykh riadiv suchasnymy konstruktsiiamy znimnykh proteziv [Replacement of defects in dimming rows by modern constructs of removable dentures]. Lviv: HalDent; 2009. $152 \mathrm{~s}$.

4. Kucz PV. Ekspery’mental'no-klinichna ocinka faktoriv, yaki vply`vayut’ na stabil' nist' zubny 'x proteziv, shho opy 'rayut sya na implantaty' [avtoreferat] [Experimental Clinical Assessment of Factors, impacted on the stability of dental prostheses, rely on implantation [author's abstract]]. Ky' yiv: NMU imeni 0.0. Bogomol' cya; 2004. 19 s.

5. Malanchuk VA, Mammadov EA. Neposredstvennaia dentalnaia implantatciia: nauchno-uchebnoe izdanie dlia studentov i vrachei [Immediate dental implantation: scientific and educational publication for students and doctors]. Kiev: Meditcina; 2008. $155 \mathrm{~s}$.

6. Timofeev AA. Khirurgicheskie metody dentalnoi implantatcii [Surgical methods of dental implantation]. Monografiia. Kiev: 000 «Chervona Ruta - Turs); 2007. 128s.

7. Mish KE. Ortopedicheskoe lechenie s oporoi na dentalnye implantaty [Orthopedic treatment based on dental implants]. Moskva: Rid Elsiver; 2010.616s.

8. Sennerby L, Meredith N. Resonance frequency analysis: measuring implant stability andosseointegration. Compendium of Continuous Education in Dentistry. 1998; 19: 493-8.

9. Lekholm U, Zarb G. Patient selection and preparation. En: Brenemark P.I., Zarb G., Albrektsson T., eds. Tissue-integrated protheses. Osseointegration in clinical dentistry. - Chicago: Quintessence; 1985.P 199-209.
Topic of the research: "Modern methods of rehabilitation patients with dental disease using prosthesis constructions». Beginning 02.2017 Finishing 12.2021. National Medical Academy named after P.L. Shupik Institute of Dentistry, Health Ministry of Ukraine universal decimal classification 616.314 .

\section{Authors' contributions:}

According to the order of the Authorship.

\section{ORCID numbers:}

Aleksey V. Bida - 0000-0003-1764-9669

Serhii M. Hermanchuk - 0000-0002-9927-564X

Volodymyr I. Struk - 0000-0002-1127-1485

Vitaliy I. Bida - 0000-0002-1786-2032

Yuliya I. Zabuha - 0000-0001-6800-6861

Alexander V. Bida-0000-0002-6038-6545

\section{Conflict of interest:}

The Authors declare no conflict of interest.

\section{CORRESPONDING AUTHOR}

Serhii M. Hermanchuk

Chekhov street 24, apartment 21, 08200 Irpen, Kyiv region, Ukraine tel: +380506059241

e-mail:shermanchuk@ukr.net

Received: 17.04 .2019

Accepted: 24.09 .2019 


\title{
LOCAL IMMUNITY STATUS OF OROPHARYNX IN PATIENTS WITH SCLEROMA
}

\author{
Vasyl V. Kishchuk ${ }^{1,2}$, Oleksandr D. Bondarchuk ${ }^{1,2}$, Andriy V. Kostyuchenko ${ }^{1}$, Nataliya V. Tytarenko ${ }^{1,2}$, \\ Ihor V. Dmitrenko ${ }^{1,2}$, Andriy I. Bartsihovskyiy' ${ }^{1}$ Kateryna A. Lobko ${ }^{1}$ \\ ${ }^{1}$ VINNYTSIA NATIONAL PIROGOV MEMORIAL MEDICAL UNIVERSITY, VINNYTSIA, UKRAINE \\ 2PIROGOV REGIONAL CLINICAL HOSPITAL, VINNYTSIA, UKRAINE
}

\begin{abstract}
Introduction: Scleroma is a rare chronic granulomatous disease of the upper respiratory tract caused by Klebsiella pneumoniae subsp. rhinoscleromatis. To date its pathogenesis is as yet little understood. At the same time, scleroma is associated with a number of immune system disturbances.

The aim: To study local immunity status of oropharynx in patients with scleroma, and to compare its parameters in various clinical forms of the disease.

Materials and methods: 20 apparently healthy subjects and 92 patients with scleroma (33 males, 59 females) underwent clinical immunologic evaluation. There were 31 patients with dominating infiltrative form of scleroma, 30 - with dominating atrophic form, 31 - with dominating scarring form. Concentration of secretory and monomeric immunoglobulin $\mathrm{A}$, immunoglobulin $\mathrm{G}$, $a$-interferon, interleukin $1 \beta$ in oropharyngeal secretion was determined by enzyme immunoassay.

Results: Patients with scleroma were found to have altered local immunity of oropharyngeal secretion. There was a strong tendency for decreased concentration of secretory immunoglobulin A - 1.3-2.0 times, and decreased immunoglobulin $\mathrm{G}$ level $-1.5-2.3$ times $(\mathrm{p}<0.05)$ as compared to the values in healthy subjects. Specific features of local immunity in oropharyngeal secretion in various forms of scleromatous inflammatory process in upper respiratory tract were found: the most significant decrease of $a$-interferon concentration in atrophic and scarring forms of the disease, and the largest increase of anti-inflammatory interleukin $1 \beta$ and immune complex concentration in infiltrative form of scleroma.

Conclusions: The study revealed deficiency of local immunity factors in oropharynx, being indicative of immunopathogenetic role of diagnosed disturbances in development and persistence of chronic inflammation in scleroma, and emphasizing the necessity of immunocorrection in complex therapy of the disease.
\end{abstract}

KEY WORDS: scleroma, local immunity of oropharynx

Wiad Lek 2019, 72, 10, 1904-1908

\section{INTRODUCTION}

Scleroma is a diagnostic and therapeutic challenge for clinicians due to its chronic course, need for prolonged treatment and relapses. It is characterized by a slowly progressive, specific (granulomatous) inflammation of the respiratory tract. According to the results of several studies, its pathogenesis is influenced by altered immune response because of cellular immunity disturbances $[1,2,3]$. Hence, there is an urgent need for the development of methods of targeted action on the immune status of patients with this pathology.

Disturbances in cellular immunity are of particular significance in scleroma development, as phagocytic reactions are unable to destroy pathogens (incomplete phagocytosis) resulting in persistence of $\mathrm{K}$. rhinoscleromatis, accumulations of lymphoid cells and macrophages (granuloma). Sometimes this leads to nonspecific stimulation of macrophages causing increased resistance to other infections. Several studies have shown that scleroma may result from abnormal macrophage function [4]. Actually, Mikulicz cells are known to have specific features of their ultrastructure as well as enzyme histochemical properties of macrophages. Hence, it has been suggested that Mikulicz cells fail to develop into epithelioid cells, thereby inducing bacterial proliferation [4]. However, monocytes of patients infected with K. rhinoscleromatis demonstrate normal phagocytosis [5]. Thus, the probability of specific deficiency of destructive processes of $\mathrm{K}$. rhinoscleromatis within macrophages cannot be excluded. Mutations affecting the genes, which encode the components of nicotinamide-adenine-dinucleotide-phosphate oxidase complex, proved to cause susceptibility to K. pneumoniae infection in mice [6].

M. Fusconi et al. (2018) hypothesized scleroma to be a type of immunodeficiency state with qualitative reduction in intervention of lymphocytes hyporeactive to K. rhinoscleromatis [7]. Decreased activity of CD4 T cells may result in insufficient activation of macrophages, which can be implicated in survival of Klebsiella spp. within the cells. The hypothesis on decreased CD4 activity, subsequently leading to Mikulicz cell formation, was confirmed in patients with HIV [8].

Evaluation of local immunity status of oropharynx appears to be of particular importance in patients with scleroma because of the necessity to administer proper therapy 
Table 1. Immunoglobulin concentration in oropharyngeal secretion of control subjects and patients with various forms of scleroma ( $\mathrm{M} \pm \sigma$ )

\begin{tabular}{ccccc}
\hline Groups & $\mathbf{n}$ & $\mathbf{s l g A}, \mathbf{g} / \mathbf{l}$ & $\mathbf{l g} \mathbf{G}, \mathbf{g} / \mathbf{l}$ & $\mathbf{~ m l g ~ A , ~ g / l ~}$ \\
\hline Control group & 20 & $0.58 \pm 0.2$ & $0.06 \pm 0.05$ & $0.07 \pm 0.06$ \\
\hline Scleroma, infiltrative form & 31 & $0.4 \pm 0.1^{*}$ & $0.29 \pm 0.15^{*}$ & $0.18 \pm 0.14^{*}$ \\
\hline Scleroma, atrophic form & 30 & $0.35 \pm 0.32^{*}$ & $0.17 \pm 0.08^{* *}$ & $0.17 \pm 0.08^{*}$ \\
\hline Scleroma, scarring form & 31 & $0.3 \pm 0.18^{*}$ & $0.24 \pm 0.22^{*}$ & $0.24 \pm 0.22^{*}$ \\
\hline
\end{tabular}

Notes:

1. Arithmetical mean values of parameters studied $(M)$ and standard deviations $(\sigma)$ are presented in the table;

2. * - statistically significant difference $(p<0.05)$ compared to values in the control group;

3. \# - statistically significant difference $(p<0.05)$ compared to values in the group of patients with dominating infiltrative form of scleroma.

and immune system correction. At the same time, the role of such immune regulatory factors as immunoglobulins of various classes, pro-and anti-inflammatory cytokines, regulatory peptides and other humoral immunity factors in genesis of the disease has rarely been addressed in the literature devoted to scleroma, and to date it is not clearly understood. This paper presents novel data on local immunity status of oropharynx in patients with various clinical forms of scleroma when compared to apparently healthy subjects.

\section{THE AIM}

To study local immunity status of oropharynx in patients with scleroma, and to compare its parameters between the groups with various clinical forms of the disease.

\section{MATERIALS AND METHODS}

92 patients with scleroma (33 males, 59 females) aged 23-79 years (mean age $(\mathrm{M} \pm \sigma)-53.4 \pm 14.52$ years) underwent clinical immunologic evaluation. The study was performed in compliance with the provisions of Declaration of Helsinki at Scleroma Center of Pirogov Regional Clinical Hospital, Vinnytsia.

Local immunity of oropharynx was studied in the following groups: 1) the control group - apparently healthy subjects $(n=20) ; 2)$ patients with dominating infiltrative form $(n=31)$; patients with dominating atrophic form $(n=30)$; patients with dominating scarring form $(n=31)$.

Sampling of oropharyngeal secretion was performed on the day of admission on an empty stomach before rinsing the oral cavity or brushing teeth and gums. After centrifugation of the whole oropharyngeal secretion in supernatant fluid the following local immunity parameters were determined by enzyme immunoassay:

- concentration of secretory and monomeric forms of A immunoglobulins, immunoglobulin $\mathrm{G}$ (chemical reagents Xema-Medica, Russian Federation);

- cytokine content - $\alpha$-interferon, interleukin $1 \beta$ (chemical reagents LLC Tsitokin, Russian Federation);

- level of immune complexes (precipitation method using $3.37 \%$ polyethylene glycol) [9].

Statistical processing of data was performed in statistical package "SPSS 23" (SPSS Inc.) using parametric and non-parametric methods of data evaluation.

\section{RESULTS}

Significantly decreased content of secretory immunoglobulin ( $\operatorname{Ig~A}$ ) and significantly increased content of monomeric immunoglobulin (mIg A) and immunoglobulin G (IgG) in oropharyngeal secretion was found in all forms of scleroma (Table 1).

In healthy subjects median sIg A content in oropharyngeal secretion was $0.5 \mathrm{~g} / \mathrm{l}$, interquartile interval $\mathrm{P}_{25}-\mathrm{P}_{75}$ ranged from 0.5 to $0.7 \mathrm{~g} / \mathrm{l}$. The most significant decrease in sIg A content was documented in atrophic and scarring forms, and less significant decrease - in infiltrative form of the disease. Thus, in infiltrative form of scleroma, sIg A content was 1.3 times less than the control value, $\mathrm{p}=$ 0.001 (the median concentration was $0.4 \mathrm{~g} / \mathrm{l}$, and $\mathrm{P}_{25}-\mathrm{P}_{75}$ range - $0.3-0.5 \mathrm{~g} / \mathrm{l})$. In patients with atrophic and scarring forms of scleroma, the content of this immunoglobulin was 2 times lower than in the controls, $\mathrm{p}<0.001$ (median concentrations were 0.25 and $0.23 \mathrm{~g} / \mathrm{l}$, and $\mathrm{P}_{25}-\mathrm{P}_{75}$ range - 0.2-0.35 and 0.15-0.4 g/l, respectively). No statistically significant difference in sIg A content in atrophic and scarring forms of scleromatous respiratory tract lesion was found.

In control subjects, median contents of Ig $\mathrm{G}$ and $\mathrm{mIg} \mathrm{A}$ in oropharyngeal secretion were 0.1 and $0.07 \mathrm{~g} / \mathrm{l}$, and $\mathrm{P}_{25}-\mathrm{P}_{75}$ range - 0-0.1 and 0.02-0.1 g/l, respectively. Depending on the form of scleroma, specific lesion of the respiratory tract was accompanied by various extent of increase in the content of those immunoglobulins in oropharyngeal secretion. The greatest increase in Ig G level ( 2.3 times, $p=0.001$ ) was observed in infiltrative form of disease (median $-0.23 \mathrm{~g} / \mathrm{l}$, and $\left.\mathrm{P}_{25}-\mathrm{P}_{75}-0.2-0.5 \mathrm{~g} / \mathrm{l}\right)$, and less significant increase - in atrophic (1.8 times, $\mathrm{p}<0.001)$ and scarring $(1.5$ times, $\mathrm{p}<0.001)$ forms of scleroma (median Ig G content - 0.18 and $0.15 \mathrm{~g} / \mathrm{l}, \mathrm{P}_{25}-\mathrm{P}_{75}$ - 0.1-0.2 and 0.15-0.4 g/l, respectively) (See Table 1).

Oropharyngeal secretion showed similar changes in mIg A content in various forms of scleroma (Table 1). In patients with infiltrative and atrophic forms of disease $\mathrm{mIg}$ A level was 2.4 times higher than in the control group, $\mathrm{p}<$ 0.001 (median content -0.18 and $0.17 \mathrm{~g} / \mathrm{l}, \mathrm{P}_{25}-\mathrm{P}_{75}-0.1-0.25$ and 0.1-0.2 g/l, respectively), and it was 2.9 times higher in those with scarring form, $\mathrm{p}=0.002$ (median concentration - $0.2 \mathrm{~g} / \mathrm{l}$, and $\left.\mathrm{P}_{25}-\mathrm{P}_{75}-0.15-0.4 \mathrm{~g} / \mathrm{l}\right)$. No statistically significant difference between monomeric immunoglobulin content in atrophic and scarring forms of scleromatous respiratory tract lesion was found. 
Thus, significant decrease in the content of secretory immunoglobulin (sIg A) and significantly increased content of monomeric immunoglobulin (mIg A) and immunoglobulin $\mathrm{G}$ ( $\mathrm{IgG}$ ) was found in the patients with various forms of scleroma. Such changes in immunoglobulin content are consistent with the studies of local immunity factors in other infectious and inflammatory diseases of the upper respiratory tract.

Concentration of interleukin $1 \beta$ (IL-1 $\beta$ ) - one of the key factors in regulation of inflammatory reaction and induction of immune response - was assessed in oropharyngeal secretion as well (Fig.1). In the control group its content appeared to be $\mathrm{Me}-21.5 \mathrm{pg} / \mathrm{ml}, \mathrm{P}_{25}-\mathrm{P}_{75}-12.0-24.0$. In all forms of scleromatous lesions, oppositely directed alterations in interleukin $1 \beta$ concentration were revealed in oropharyngeal secretion. In infiltrative form its level was $\mathrm{Me}-54.0 \mathrm{pg} / \mathrm{ml}, \mathrm{P}_{25}-\mathrm{P}_{75}-28.0-62.0$, i.e. 2.5 times higher than in the control group $(\mathrm{p}<0.001)$. High IL- $1 \beta$ concentration in infiltrative form of scleroma can suggest that on this stage of disease exudative reactions as well as activation of helper lymphocytes Th1 и Th17, leading to activation of specific humoral immune response, are most pronounced, and this can be confirmed by the measurement of immune complex level in oropharyngeal secretion (Fig. 1).

In atrophic form of scleroma, IL- $1 \beta$ level in oropharyngeal secretion was found to be 1.7 times lower than in the control group, $\mathrm{p}<0.001$ (median concentration - $13.0 \mathrm{pg} /$ $\mathrm{ml}, \mathrm{P}_{25}-\mathrm{P}_{75}-10.0-16.0 \mathrm{pg} / \mathrm{ml}$ ), while in dominating scarring form no significant changes in its level was observed. The data received corroborate the suggestion that forms of scleroma represent various stages of the disease. IL- $1 \beta$ level in oropharyngeal secretion proved to be significantly higher in infiltrative form as compared to that in the other forms of scleroma $(\mathrm{p}<0.05)$ (Fig. 1).

Study of $\alpha$-interferon concentration in oropharyngeal secretion showed its level to be $\mathrm{Me}-13.5 \mathrm{pg} / \mathrm{ml}, \mathrm{P}_{25}-\mathrm{P}_{75}$ 10.0-20.0 in the control group. Specific respiratory tract lesion occurring in scleroma was accompanied by decreased a-interferon level, most evident in atrophic and scarring forms and less significant in infiltrative form. In atrophic and scarring forms, $\alpha$-interferon content was 2.25 (2.0-3.0) and $2.75(2.0-4.5) \mathrm{pg} / \mathrm{ml}$, respectively, being 6 and 4.9 times lower as compared to the control ( $\mathrm{p}<0.001)$, while in infiltrative form its content was $11.0(10.0-18.0) \mathrm{pg} / \mathrm{ml}$ being 1.2 times lower as compared to the control. $\alpha$-interferon content was significantly higher in dominating infiltrative form as compared to that in other forms of scleroma. No statistically significant differences in $\alpha$-interferon level were found between atrophic and scarring forms of the disease (Fig.2).

Inflammatory process activity was evaluated by the content of immune complexes in oropharyngeal secretion (Fig.3). The level of immune complexes in normal individuals is known to range from 0 to $23 \mathrm{ODU}$ (median $-9.0 \mathrm{ODU}, \mathrm{P}_{25}-\mathrm{P}_{75}-0-12.0$ ODU). Patients with scleroma showed significant continuous increase in the content of immune complexes, being most evident in dominating infiltrative form (4.3 times, $\mathrm{p}<0.001)$ (median - 38.5 ODU; $\mathrm{P}_{25}-\mathrm{P}_{75}-37.0-42.0$ ODU). Atrophic and scarring forms of the disease were associated with less significant increase in immune complexes content. Increased level of immune complexes in oropharyngeal secretion in infiltrative form of scleroma were due to intensive processes of pathogen elimination by antibodies of various classes, entering the focus of inflammation from different sources including blood vessels. In atrophic scleroma the content of immune complexes exceeded the control values 1.2 times $(\mathrm{p}>0.05)$ (median - 10.75 ODU, $\mathrm{P}_{25}-\mathrm{P}_{75}-10.0-12.0$ ODU). Scarring form of scleroma was associated with 1.7 time increase $(\mathrm{p}<$ 0.001 ) in the content of immune complexes as compared to the controls (median - 15.25 ODU, $\mathrm{P}_{25}-\mathrm{P}_{75}-12.0-20.0 \mathrm{ODU}$ ). The content of immune complexes was significantly higher in dominating infiltrative form as compared to other forms of scleroma $(\mathrm{p}<0.05)$.

\section{DISCUSSION}

Scleroma is a chronic granulomatous infectious disease that affects the nose and other parts of the respiratory tract down to the trachea [10]. A delay in the diagnosis can lead to complications such as physical deformity, upper airway obstruction and, rarely, sepsis $[11,12]$. The disease has classic histopathologic features consisting of Mikulicz cells, Russell bodies, and gram-negative bacilli. In many cases, the causative agent is identified as Klebsiella rhinoscleromatis [13].

The exact pathogenesis in which Klebsiella spp result in Mikulicz cell formation and eventual rhinoscleroma is unclear. Klebsiella rhinoscleromatis, like K pneumoniae, is characterized by a mucopolysaccharide capsule that contributes to inhibition of phagocytosis, thus facilitating intracellular survival $[12,14]$. Clearly, capsule polysaccharide plays an important role in the interplay between $\mathrm{K}$. pneumoniae and the innate immune system [12].

There are many immune system abnormalities found in patients affected by scleroma [7]. According to the first hypothesis, Klebsiella rhinoscleromatis could induce an alteration of the immune system, thus allowing the evolution of the infection into a chronic form. The second is that the immune system, already altered by other unknown mechanisms, allows KR attacking the body.

It has been postulated that cellular immunity is impaired with a decreased CD4 to CD8 ratio but with humoral immunity remains intact. Lessened activity by $\mathrm{CD} 4 \mathrm{~T}$ cells may result in improper activation of macrophages, further promoting intracellular survival of Klebsiella. Cytokines are key mediators of immune responses and the anti-inflammatory cytokine IL-10 has been shown to be highly produced after K. rhinoscleromatis infection and to play a crucial role in the establishment of a proper environment leading to Mikulicz cells maturation [12].

At the same time, the role of such immune regulatory factors as immunoglobulins of various classes, pro-and anti-inflammatory cytokines, regulatory peptides and other humoral immunity factors in genesis of the disease has rarely been addressed in the literature devoted to scleroma, and to date it is not clearly understood. This paper presents novel data on local immunity status of oropharynx 

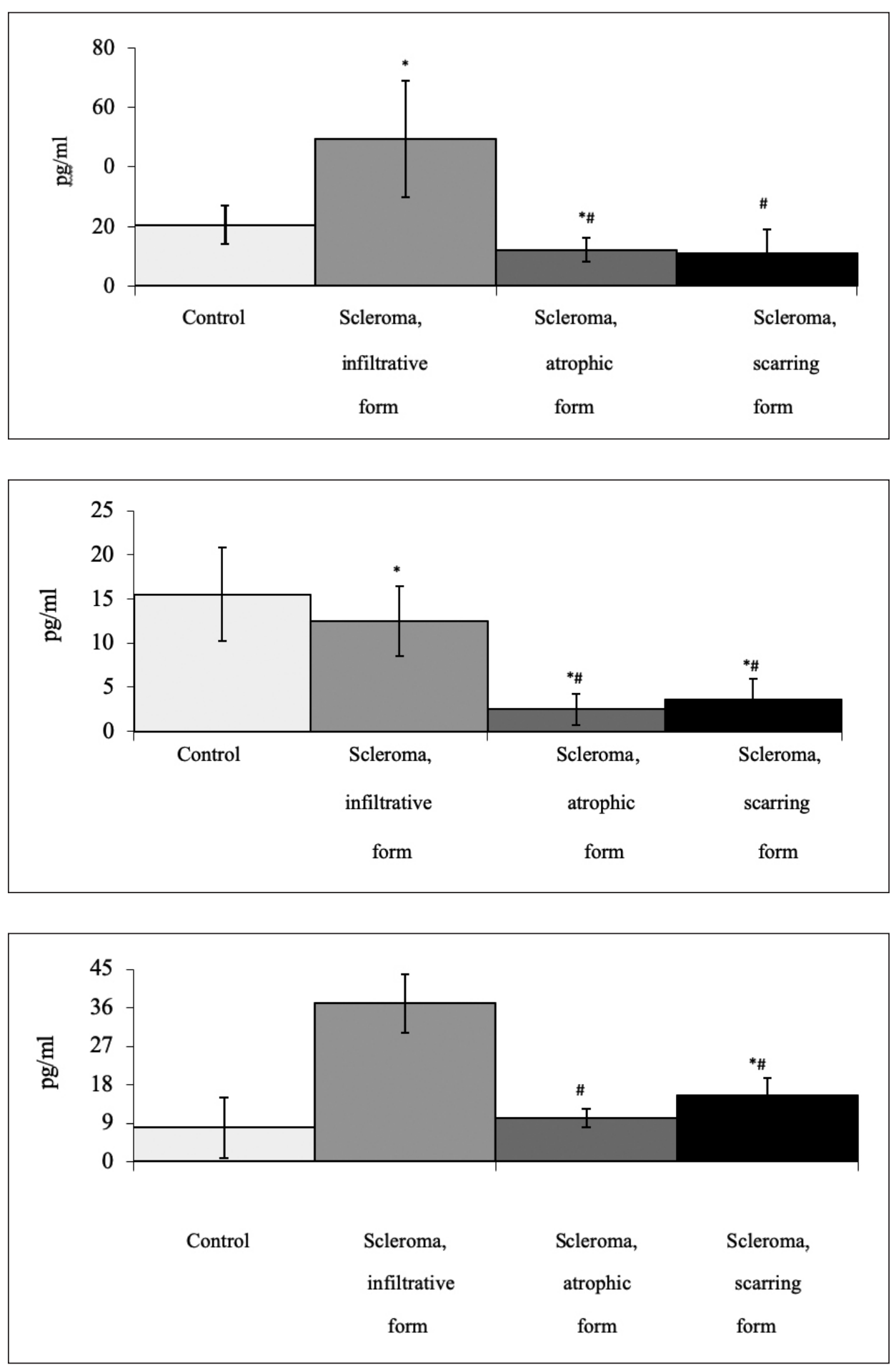

Fig. 1. Interleukin $1 \beta$ concentration in oropharyngeal secretion of control subjects and patients with various forms of scleroma $(M \pm \sigma)$

Notes: ${ }^{*}$ - statistically significant difference $(p<0.05)$ as compared to the control group; \#- statistically significant difference $(p<0.05)$ as compared to the patients with atrophic form of scleroma.

Fig. 2. Concentration of a-interferon in oropharyngeal secretion of control subjects and patients with various forms of scleroma $(M \pm \sigma)$

Notes: ${ }^{*}$ - statistically significant difference $(p<0.05)$ as compared to the control group; \# - statistically significant difference $(p<0.05)$ as compared to the patients with atrophic form.

Fig. 3. Concentration of immune complexes in oropharyngeal secretion of control subjects and patients with various forms of scleroma $(M \pm \sigma)$

Notes: * - statistically significant difference $(p<0.05)$ as compared to the control group; \#- statistically significant difference $(p<0.05)$ as compared to the patients with atrophic form of scleroma. in patients with various clinical forms of scleroma when compared to apparently healthy subjects.

The study demonstrated scleromatous lesion of the upper respiratory tract to be associated with deficiency of local immunity in oropharynx (decreased concentration of secretory immunoglobulin A and immunoglobulin G). The data obtained are indicative of immunopathogenetic role of the diagnosed disturbances in development and persistence of chronic inflammation in scleroma, emphasizing the necessity of immunocorrection in complex therapy of the disease.
Concentration of $\alpha$-interferon was decreased in scarring and atrophic forms of scleroma, while the content of anti-inflammatory iterleukin- $1 \beta$ and immune complexes were the highest in infiltrative form - these findings are likely to be used as additional criteria for verification of disease form in scleroma.

\section{CONCLUSIONS}

1. In patients with scleroma, deficiency of local immunity in oropharynx was found: concentration of secretory im- 
munoglobulin A and immunoglobulin $\mathrm{G}$ demonstrated strong tendency to decrease - 1.3-2.0 and 1.5-2.3 times, respectively, $(\mathrm{p}<0.05)$ as compared to healthy subjects.

2. Specific features of local immunity in oropharengeal secretion were detected in various forms of scleromatous inflammatory process in upper respiratory tract: the greatest decrease of $\alpha$-interferon concentration in atrophic and scarring forms, and the highest concentration of anti-inflammatory iterleukin- $1 \beta$ and immune complexes in infiltrative form of the disease.

\section{REFERENCES}

1.Gaafar HA, Bassiouny M, El Mofty M, Badour NM, Nour YA. Experimental intravenous inoculation of Klebsiella rhinoscleromatis bacilli in albino rats: a histopathological andbacteriological study. Acta Otolaryngol. 2000;120(2):279-85.

2. Malkud S, Mahajan P. Rhinoscleroma: An Unusual Presentation. Indian Dermatol Online J. 2018;9(3):191-3.

3. Mukara BK, Munyarugamba P, Dazert S, Lohler J. Rhinoscleroma: a case series report and review of the literature. Eur Arch Otorhinolaryngol. 2014;:271(7):1851-6.

4. Canalis RF, Zamboni L. An interpretation of the structural changes responsible for the chronicity of rhinoscleroma. Laryngoscope. 2001;111:1020-6.

5. de Pontual L, Ovetchkine P, Rodriguez D, Grant A, Puel A, Bustamante J, et al. Rhinoscleroma: a French national retrospective study of epidemiological and clinical features. Clin Infect Dis. 2008;47(11):1396-402.

6. Nathan C, Shiloh MU. Reactive oxygen and nitrogen intermediates in the relationship between mammalian hosts and microbial pathogens. Proc Natl Acad Sci U S A 2000;97:8841-8.

7. Fusconi M, Greco A, Cattaneo CG, Ciofalo A, Ralli M, de Vincentiis M. Social geography of Rhinoscleroma and qualitatively and quantitatively abnormal cell-mediated immunity. Infect Genet Evol. 2018;62:17-9.

8. Paul C, Pialoux G, Dupont B, Fleury J, Gonzalez-Canali G, Eliaszewicz M, et al. Infection due to Klebsiella rhinoscleromatis in two patients infected with human immunodeficiency virus. Clin Infect Dis. 1993;16:441-2.
9. Kaidashev I.P. Methods of clinical and experimental research in medicine [Metody klinichnykh ta eksperymentalnykh doslidzhen v medytsyni]. Poltava: Polymet; 2003, p. 319.

10. Cataño JC, Gallego S. Rhinoschleroma. Am JTrop Med Hyg. 2015;92(1):3.

11. Castanedo Cazares JP, Martinez Rosales KI. Images in Clinical Medicine. Rhinoscleroma. N Engl J Med. 2015;372(25):e33.

12. Corelli B, Almeida AS, Sonego F, Castiglia V, Fevre C, Brisse S, et al. Rhinoscleroma pathogenesis: The type K3 capsule of Klebsiella rhinoscleromatis is a virulence factor not involved in Mikulicz cells formation. PLoS Negl Trop Dis. 2018;12(1): e0006201.

13. Umphress B, Raparia K. Rhinoscleroma Arch Pathol Lab Med. 2018;142(12):1533-6.

14. Kallel S, Ghorbel AM. Rhinoscleroma: a rare chronic infection of the nasal cavities. Pan Afr Med J. 2018;31:247.

The article is a fragment of planned scientific-research work of Chair of ENT diseases of Vinnytsia National Pirogov Memorial Medical University on the subject: "Modern aspects of early diagnosis and treatment of chronic nonspecific inflammatory diseases of upper airways, ear, scleroma and traumas of ENT organs in time of peace and war" \#0115U007096 in state registration, years 2015-2019.

\section{Authors' contributions:}

According to the order of the Authorship.

\section{ORCID numbers:}

Vasyl V. Kishchuk - 0000-0002-3390-2401

Oleksandr D. Bondarchuk - 0000-0002-7636-9694

Andriy V. Kostyuchenko - 0000-0001-8930-0795

Nataliya V. Tytarenko - 0000-0003-0192-1613

Ihor V. Dmitrenko - 0000-0002-1357-2847

Andriy I. Bartsihovskyiy - 0000-0002-5809-2978

Kateryna A. Lobko - 0000-0002-0045-2352

\section{Conflict of interest:}

The Authors declare no conflict of interest.

\author{
CORRESPONDING AUTHOR \\ Ihor V. Dmitrenko \\ Vinnytsia National Pirogov Memorial Medical University \\ Pyrogov str., 56, Vinnytsia 21018, Ukraine \\ tel: +380675919233 \\ e-mail: igordmitrenko72@gmail.com
}

Received: 11.04 .2019

Accepted: 20.09.2019 
PRACA ORYGINALNA

ORIGINAL ARTICLE

\title{
THE EFFECT OF INTRACELLULAR “DEPOT” HELICOBACTER PYLORI INFECTION ON THE QUALITY OF ERADICATION WITH MONOTHERAPHY OF PATIENTS WITH CHRONIC NON-ATROPHIC GASTRITIS BY THE BISMUTH COLLOIDAL SUBCITRATE
}

\author{
Anatoly A. Avramenko \\ PETRO MOHYLA BLACK SEA NATIONAL UNIVERSITY, MYKOLAIV, UKRAINE
}

\begin{abstract}
Introduction: Noted that monotherapy by the bismuth colloidal subcitrate in the treatment of chronic HP- infection is effective only in $14-40 \%$ of cases, but all the reasons that reduce its effectiveness, are not fully explored.

The aim: To determine the effectiveness of monotherapy by the bismuth colloidal subcitrate among patients with chronic non-atrophic gastritis with or without intracellular "Depot" of HP-infection.

Materials and methods: The 36 patients took comprehensive examination: step-by-step pH-metry, esophagogastroduodenoscopy, helicobacter infection test (HP) (helicobacter urease test and microscopic examination of stained smears), histological investigations of the gastric stump mucous, stool test, HELIC - test, the level of natural killers (CD-16). Control studies were performed 1 months after 1-month monotherapy by the bismuth colloidal subcitrate and included a stool test and HELIK- test.

Results: Helicobacter infection was detected in $100 \%$ of cases. When using two methods: comparing the results of urease test and smears, prints, and the level of natural killer CD-16 intracellular "depot" HP was detected in 29 (80.6\%) patients. While control research in 1 month it was found that monotherapy was effective only among 7 (19.4\%) patients whose primary integrated survey did not reveal intracellular "Depot" HP- infection.

Conclusions: The bismuth colloidal subcitrate is not effective in the presence of intracellular "depot" HP. The definition of "depot" should be carried out by two methods: comparing the results of urease test and smears- prints, and the level of natural killers (CD-16).
\end{abstract}

KEY WORDS: chronic non-atrophic gastritis, intracellular "Depot", bismuth colloidal subcitrate

Wiad Lek 2019, 72, 10, 1909-1911

\section{INTRODUCTION}

Discovery of Helicobacter pylori (HP) in the year 1983 by Australian scientists B. Marshall and J. R. Warren has become a new landmark in understanding the etiology of such diseases as chronic gastritis type B (chronic non-atrophic gastritis), peptic ulcer disease, stomach cancer and MALT-lymphoma [1]. Regarding this the views on the form the data treatment of pathologies began to form that caused the creation in 1993 year the 1-st Maastricht consensus which defines the schema of the treatment of chronic Helicobacter pylori infection. Further consensus was reconsidered now only once and now exist the 5-th Maastricht consensus, which was adopted in the year 2015 (Florence). This consensus noted the effectiveness of quadra therapy, which, in addition to Proton pump inhibitors and their two antibiotics, includes drug of bismuth - bismuth colloidal subcitrate $[2,3,4,5,6,7,8,9,10,11]$. Noted that monotherapy by the bismuth colloidal subcitrate in the treatment of chronic HP- infection is effective only in $14-40 \%$ of cases [5], but all the reasons that reduce its effectiveness have not been fully studied, including the ability of HP infection to penetrate into the parietal cell and form intracellular "depot" under the influence of prolonged stress and the use of proton pump inhibitors [12].

\section{THE AIM}

To determine the effectiveness of monotherapy by the bismuth colloidal subcitrate among patients with chronic non-atrophic gastritis with or without intracellular "Depot" of HP- infection.

\section{MATERIALS AND METHODS}

In the period from January 2016 till January 2017 on the basis of the clinical division of the problem lab on chronic Helicobacter pylori infection of the Petro Mohyla Black Sea National University was initially examined and treated in an integrated manner with the subsequent quality control of eradication 36 patients with chronic non-atrophic gastritis. The age of patients ranged from 23 to 51 year (the meddle age was $30.6 \pm 1.27$ y.); males was 21 (58.3\%), female-15 (41.7\%).

Primary comprehensive survey included: step-by-step intragastric $\mathrm{pH}-\mathrm{Metry}$ based on methodology by Chernobrovii V.N esophagogastroduodenoscopy(EGDS) by generally accepted method, double HP testing: test for ureaz activity and microscoping stained by Giemsa smears, material for which was taken during endoscopy from 4 topographical zones: from the middle third of the gastric antrum and body of stomach on the big and small curvature with our created methodology, which 
Table I. Degree of semination of gastric mucosa with HP infection on topographical zones of patients with chronic non-atophic gastritis while primary survey

\begin{tabular}{cc} 
Topographic zones of the stomach & $\begin{array}{c}\text { Degree of semination of gastric mucosa with } \\
\text { HP infection on zones ( + ) / (M } \pm \mathbf{M})\end{array}$ \\
\hline Antral section & a) $2,13 \pm 0,28 ;$ b) $2,16 \pm 0,28$ \\
\hline Body of stomach & a) $2,14 \pm 0,28 ;$ b) $2,45 \pm 0,28$
\end{tabular}

Note: $n$-the number of studies: a) large curvature, b) small curvature.

Table II. Results of stool-test and HELIK-test before and after treatment among patients with chronic non-atrophic gastritis

\begin{tabular}{ccccc}
\hline & \multicolumn{3}{c}{ Positive result of test } \\
\cline { 2 - 5 } Name of the test & Before treatment & \multicolumn{2}{c}{ After treatment } \\
\cline { 2 - 5 } & Amount of tests & $\%$ & Amount of tests & 29 \\
\hline Stool-test & 36 & 100 & 29 & 80,6 \\
\hline Helik-test & 36 & 100 & 29,6 \\
\hline
\end{tabular}

allows to define both the presence of intracellular "Depot" HP infection and also histological studies of the gastric mucosa, the material for which is taken from the same zone, using a generally accepted method taking into account recent classification $[13,14]$. In addition, all the patients additionally was made the stool test in our test modification [15] and HELIK-test in our test modification [16], as well as determined the presence of intracellular "Depot" of HP infection on thelevel of natural killers (CD-16) [17]. Control studies were performed 1 months after the end of monotherapy by the bismuth colloidal subcitrate, which lasted 1 month, and included a stool test and HELIK test.

The study was conducted in accordance with the basic bioethical provisions of the Helsinki Declaration of the World Medical Association on the ethical principles of scientific 549 medical research involving human (2013) and the order of the Ministry of Health of Ukraine No. 690 dated September 23, 2009, which was confirmed by the findings of the meeting of the Ethical Commission of Petro Mohyla Black Sea National University, Nikolaev

No. 3 dated March 12, 2019.

Primary sequence survey: first patients conducted pH-metry and then EGDS with biopsy material for testing in HP and histological studies of the stomach mucosa. The study was conducted in the morning on an empty stomach, in 12-14 hours after the last meal. The data obtained were processed statistically using Student t-test with the computation of averages $(\mathrm{m})$ and perhaps the likelihood of deviations $(\mathrm{m})$. The changes were considered to be statistically significant at $\mathrm{p}<0.05$. Statistical calculations were performed using Excel tables for Microsoft Office.

\section{RESULTS AND DISCUSSION}

When carrying out the $\mathrm{pH}$ measuring all acidity levels have been identified, except hyperacidity and anacidity: hyperacidity is moderate - 5(13.9\%), normacidity-15 (41.7\%), moderate huperacidity-10 (27.8\%), distinct hyperacidity $-6(16.6 \%)$.

While conducting EGDS active Ulcerative process was not identified in the stomach and in duodenum, but $3(8.3 \%)$ patients had manifestations of ulcers duodenal bulb in the past as scar deformity of varying degrees of severity. When analyzing data of histological investigations of all patients in $100 \%$ of cases have confirmed the existence of chronic non-atrophic gastritis in both active and inactive stages of varying degrees of severity.
When testing on HP Helicobacter infection was detected in $100 \%$ of cases when the degree for semination from $(++)$ to $(+++)$. Data on the extent of the gastric mucosa for semination of HP infection on topographical zones of the stomach patients with chronic non-atrophic gastritis are reflected in table I.

During comparative analysis of data on the medium degree of semination with HP infection on gastric mucosa topographical zones reliable differences were found $(p>0.05)$.

While conducting comparative characteristics urease test and data according to microscoping of stained smears to determine the presence of bacteria in the stomach lining cells intracellular "Depot" HP-infections were found only in the body of the stomach mucosa of 19 (52.7\%) patients: $7(19.4 \%)$ only in the body of the stomach mucosa of large curvature 8 (22.2\%) only in the body of the stomach mucosa on small curvature, $4(11.1 \%)$ in the membrane of the body of the stomach and small and large curvature.

When defining the intracellular "Depot" of HP infection on the level of natural killers (CD-16) the presence of bacteria in the cells were confirmed in $100 \%$ of patients' cases in whom they have identified in the first methodology, as well as $10(27.8 \%)$ patients have. The mean value of the absolute levels of natural killer cells in the blood of the surveyed totaled $754 \pm 3.34$ cells $/ \mu \mathrm{l}$ (with norm-70-552 cells/ $\mu \mathrm{l}$ ).

Data on primary survey before treatment and secondary survey after treatment with the help of a stool-test and HELIK-test are shown in table II.

During the analysis of obtained data, it was found that the negative were stool test and HELIK test after treatment had only 7 (19.4\%) patients whose initial examination did not reveal intracellular "Depot" of HP infection by any of the methods.

These results are understandable from the point of view of impact characteristics of the bismuth colloidal subcitrate on $\mathrm{HP}$ infection. The bismuth colloidal subcitrate is a surface antiseptic and affects on all forms of Helicobacter pylori infection when it is on the surface of the gastric mucosa. Although there is evidence that the particles of the bismuth colloidal subcitrate are captured by the epithelium of the stomach mucosa $[4,5]$, the process apparently poorly expressed, therefore, in the presence of intracellular "Depot" HP infection needs to be the bismuth colloidal subcitrate combined with two antibiotics that penetrate deep into the stomach mucosa [18]. 


\section{CONCLUSIONS}

1. The bismuth colloidal subcitrate is not effective in the presence of intracellular "depot" HP.

2. The definition of "depot" should be carried out by two methods: comparing the results of urease test and smears- prints, and the level of natural killers (CD-16).

\section{REFERENCES}

1. Isakov VA, Domaradskij IV, eds. Helikobakterioz [Helicobacteriosis]. M.: ID Medpraktika-M, 2003. 412s. (Ru).

2. Malfertheiner $P$, Megraud F, $0^{\prime}$ Morain $C A$ et al. Management of Helicobacter pylori infection - the Maastricht V / Florence Consensus Report. Gut. 2017; 66(1): 6-30.

3. Nikiforova YaV, Tolstova TN, Cherelyuk NI. Osnovnye polozheniya Soglasitelnoj konferencii po diagnostike i lecheniyu Helicobacter pylori - MaastrihtV (2015) [The main provisions of the consensus conference on diagnosis and treatment Helicobacter pylori - MaastrichtV (2015)]. Suchasna gastroenterologiya. 2016; 6(92): 119 - 133. (Ru).

4. Fadeenko GD, Nikiforova YaV. Vliyanie kolloidnogo subcitrata vismuta na etiopatogenez hronicheskogo gastrita: novyj vitok izucheniya davnej problemy [Influence of bismuth colloidal sub-citrate on the etiopathogenesis of chronic gastritis: a new round of studying a long-standing problem]. Suchasna gastroenterologiya. 2015; 6 (86): 74-81. (Ru).

5. Harchenko NV, Tkach SM, eds. Gastroenterologiya v voprosah i otvetah [Gastroenterology in questions and answers]. K: 000 «Doktor-MediaGrupp», 2016.36 s. (Ru).

6. Chey WD, Leontiadis GI, Howden CW et al. ACG Clinical Guideline: Treatment of Helicobacter pylori Infection. Am J Gastroenterol. 2017; 112(2): 212-239.

7. Fallone $\mathrm{CA}$, Chiba N, van Zanten SV et al. The Toronto consensus for the treatment of Helicobacter pylori infection in adults. Gastroenterology. 2016; 151(1):51-69.

8. Graham D, Laine L. Toronto H. pylori Consensus Recommendations in Context. Gastroenterology. 2016; 151(1): 9-12.

9. Moayyedi P, Lacy BE, Andrews CN et al. American College of Gastroenterology and Canadian Association of Gastroenterology guidelines on the management of dyspepsia. Am J Gastroenterol. 2017; 112: 988-1013.

10. Stanghellini V, Chan F, Hasler WL et al. Gastroduodenal disorders. Gastroenterology. 2016; 150: 1380-1392.

11. Sugano K, Tack J, Kuipers EJ et al. Kyoto global consensus report on Helicobacter pylori gastritis. Gut. 2015; 64: 1353-67.

12. Avramenko AA, Shuhtina IN. Chastota vyyavleniya vnutrikletochnyh «depo» helikobakternoj infekcii u bolnyh hronicheskim helikobakteriozom pri ih planovom testirovanii (rezultaty 529-ti issledovanij)[ The frequency of detection of intracellular "depot" of Helicobacter pylori infection in patients with chronic Helicobacter pylori during their routine testing (results of 529 studies)]. Zagalna patologiya ta patologichna fiziologiya. 2012; 3: 124 - 127. (Ru).

13. Avramenko AA. Dostovernost stul-testa pri testirovanii bolnykh khronicheskim khelikobakteriozom pri nalichii aktivnykh i neaktivnykh form khelikobakternoy infektsii na slizistoy obolochke zheludka [Reliability of stool test when testing patients with chronic Helicobacter pylori in the presence of active and inactive forms of Helicobacter pylori infection on the gastric mucosa]. Suchasna gastroyenterologíya. 2014; 3 (77): 22-6. (Ru).
14. KímakovichVY, NikishaevVI, eds. Yendoskopiya travnogo kanalu. Norma, patologiya, suchasni klasifikatsiyi [Endoscopy of the digestive canal. Norm, pathology, modern classifications]. Lviv: Vidavnitstvo Meditsina Svítu, 2008. 208 s., il. 4. (UA).

15. Patent № 112840 Ukraine, MPK G01N 33/48 (2006.01) Sposib testuvannya gelikobakternoyi infekciyi u hvorih na hronichnij gelikobakteriozza dopomogoyu viporozhnennya-testu za Avramenkom AO [Method for testing of helicobacter infection in patients with chronic glycobacteriosis by means of a test-freeing test for Avramenko A0] / AO Avramenko. - u 2016 08013; Zayavl. 19.07.2016; Opubl.26.12.2016.; Byul. № 24. -3 s. (UA).

16. Patent № 128945 Ukraine, MPK G01N 33/497(2006.01), A61B 5/091(2006.01) Sposib testuvannya gelikobakternoyi infekciyi u hvorih na hronichnij gelikobakterioz za dopomogoyu HELIK-testu [Method for testing helicobacter infection in patients with chronic helicobacteriosis using the HELIC -test]/ AO Avramenko, OA Avramenko. - u 201805050; Zayavl. 07.05.2018; Opubl. 10.10.2018; Byul. № 19. - 3 s. (UA).

17. Patent № 96920 Ukraine, MPK (2015.01) A61B 1/00 Sposib testuvannya vnutrishnoklitinnih «depo» gelikobakternoyi infekciyi u hvorih na hronichnij gelikobakterioz za Avramenkom A0 [Method for testing of intracellular «depot» of glycobacteric infection in patients with chronic helicobacteriosis for Avramenko A0] /A0 Avramenko. - u 2014 09563; Zayavl. 01.09.2014; Opubl.25.02.2015.; Byul. № 4. - 3 s. (UA).

18. Patent № 95231 Ukraine, MPK (2014.01) A61K 31/00, A61K 35/00 Sposib likuvannya proyaviv hronichnogo gelikobakteriozu hronichnogo gastritu tipu B i virazkovoyi hvorobi za Avramenkom A0 [Method of treatment of manifestations of chronic helicobacteriosis - chronic gastritis type B and peptic ulcer disease for Avramenko A0] / AO Avramenko - u 2014 07938; Zayavl. 14.07.2014; Opubl.10.12.2014; Byul. № $23-5$ s. (UA).

The work is a fragment of research work «Development of information and communication technologies in the system of medical examinations of seamen", the state registration number 0109 U008375.

\section{ORCID numbers:}

Anatoly A. Avramenko-0000-0002-9652-089X

\section{Conflict of interest:}

The Authors declare no conflict of interest.

\author{
CORRESPONDING AUTHOR \\ Anatoly A. Avramenko \\ 118 Chkalova street, apartment 4, Mykolaiv 54003, Ukraine \\ tel: +380976371807 \\ e-mail: aaahelic@gmail.com
}

Received: 25.04.2019

Accepted: 17.09.2019 


\title{
THE CONDITION OF SKELETAL SYSTEM IN PUPILS WITH HEARING IMPAIRMENT
}

\author{
Vera D. Kuroiedova, Yuliya K. Sokolohorska-Nykina, Oleksandr S. Proskurin, Yuriy V. Yukrovskyi \\ UKRAINIAN MEDICAL STOMATOLOGICAL ACADEMY, POLTAVA, UKRAINE
}

\begin{abstract}
Introduction: Pathogenic link of dentofacial abnormalities with posture disturbance and vertebra deformation causes interest in researchers, because the problem of the disorder of skeletal system has an important role. Orthodontic correction of dentofacial abnormalities without treatment of skeletal apparatus is incorrect and it leads to the large number of relapses and complications and also including temporo-mandibular joint.

The aim of the research was to study correlation between injuries of hard tissues of teeth, posture disorders, bite abnormalities (malocclusion) in schoolchildren with hearing disorders.

Materials and methods: The condition of hard tissues of teeth, muscoskeletal system, dentofacial system in pupils with hearing impairment was done and evaluated. The age of examined is 6-19 years old, bite formation: $1^{\text {st }}$ - presents the period of mixed bite (6-13 years old), $2^{\text {nd }}$ - presents the period of permanent bite (14-19 years old).

Results and conclusions: During dental examination it was detected that 58 pupils with hearing disorders $(81,8 \%)$ have carious lesions of the teeth, the level of caries intensity contains 3,36. The condition of skeletal system was investigated in 56 pupils ( 36 boys and 20 girls). Disturbances of skeletal system in schoolchildren with hearing disorders presented $94,74 \% ; 5,26 \%$ of pupils were almost healthy. The condition of the bite was examined in 58 pupils ( 32 boys and 26 girls). Different types of disorders of dentofacial apparatus were detected in $100 \%$ of pupils with hearing disorders. The most widespread pathology of bite was Angle's bite (the first class) $68,97 \%$, the second class - in $27,58 \%$, the third class - 3,45\%. Orthognathic bite among pupils with hearing disorders was not observed. In 31,15\% of pupils during temporo-mandibular joint, deviation of mandible is observed.
\end{abstract}

KEY WORDS: children with hearing impairment, decay, dentofacial pathologies, disorder of skeletal system

Wiad Lek 2019, 72, 10, 1912-1916

\section{INTRODUCTION}

Orthodontic treatment of schoolchildren is complicated due to the complex injury of morphological, functional and aesthetic component of dentofacial area based on age absence.

The number of dentofacial abnormalities has a tendency to increase in many countries of the world and contains $85-90 \%[1]$.

Pathogenic link of dentofacial abnormalities with posture disturbance and vertebra deformation causes interest in researchers $[2,3,4,5]$, because the problem of the disorder of skeletal system has an important role [6]. Epidemiological researches of native and foreign scientists prove that scoliosis takes one of the first places among diseases of skeletal apparatus [7].

The posture is the usual position of the human body in space at rest and in motion. During the correct posture, a man easily and loosely holds his head and body straight, his shoulders slightly lowered and laid back on one level, the abdomen is tightened, the knees are straightened, the chest is somewhat forward [6].

The number of general somatic diseases in children occurs when acid-alkali balance in biological tissues and liquids of an organism is impaired and subtypes of connective tissue pathology are bone and cartilaginous tissues
[8]. So, the abnormality of skeletal system is a scoliosis of different level of severity or scoliotic posture is a consequence of the disorder of bone and cartilaginous tissue of vertebra in infancy [9].

Feet of person present «foundation» of person's organism, so one of the causes of vertebra arcuation in saggital and frontal areas include the disorder of amortizing peculiarities due to decrease of spring possibilities. The increased exertion that occurs when the leg is placed, goes up, reaching to the head. That is why the deformation of the feet and scoliosis is seen as a provocation of the systemic bone injury of the body as a whole, which negatively affects the appearance of the person and the state of bite [10].

Different morphological and functional disorders of feet and other disorders are the cause of posture disorder. Among such disorders one can name platypodia, talipes valgus, talipes varus can be the reason of posture disorder $[11,12]$.

Asymmetry of biomechanics of vertebra causes changes of kinematic chain and leads to the occurrence of scoliotic vertebra deformations [13].

Orthodontic correction of dentofacial abnormalities without treatment of skeletal apparatus is incorrect and it leads to the large number of relapses and complications and also including temporo-mandibular joint [14]. 


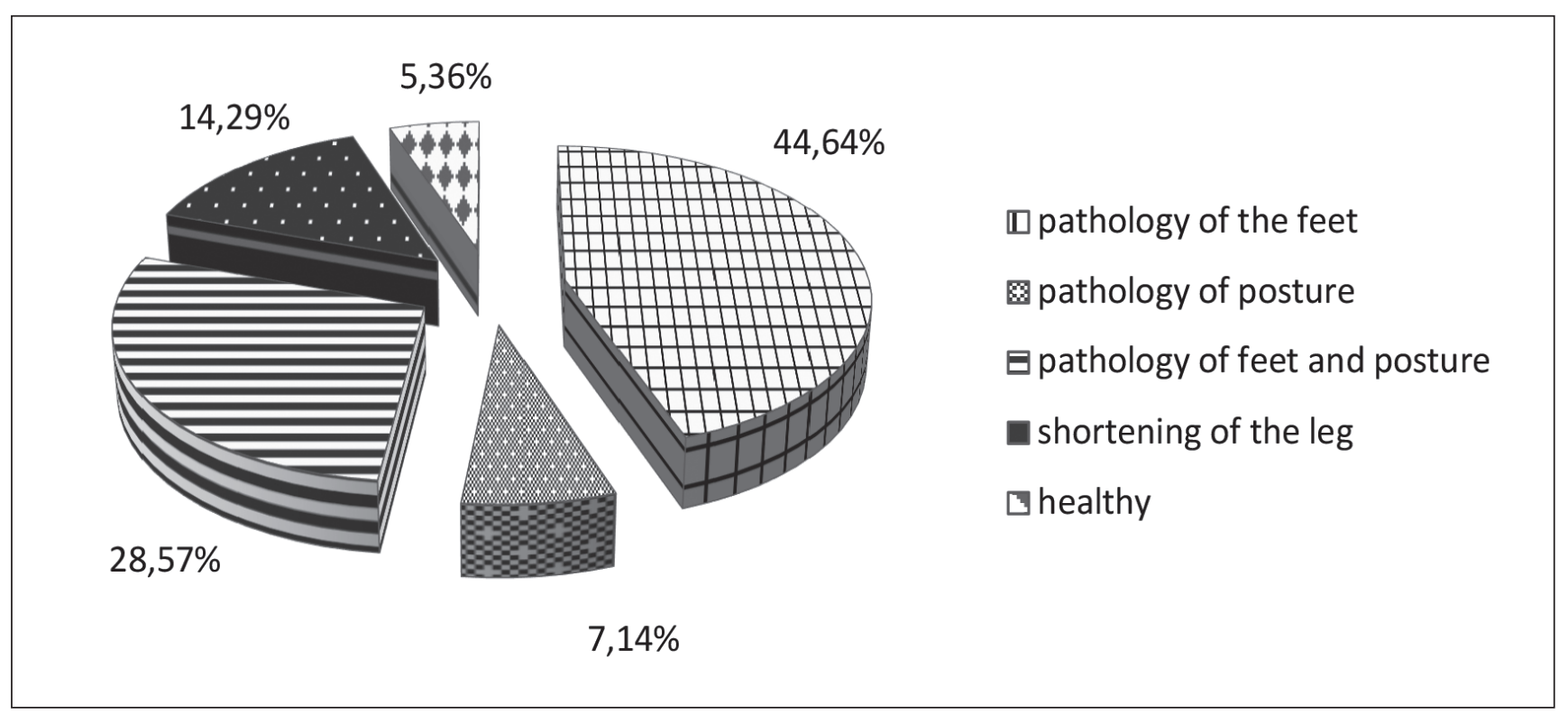

Fig. 1. The condition of skeletal apparatus in pupils with hearing disorders.

Data of etiological pathogenesis of dentofacial abnormalities in children with hearing disorders were not observed.

\section{THE AIM}

The aim of the research was to study correlation between injuries of hard tissues of teeth, posture disorders, bite abnormalities (malocclusion) in schoolchildren with hearing disorders.

\section{MATERIALS AND METHODS}

Child's dentist, orthodontist, orthopedist provided complex clinical treatment of 58 pupils with hearing disorders, who study in Poltava boarding school of I-III degrees. Peculiarities of communicative skills were considered. Communication with schoolchildren of junior age was done by teachers who use sign language.

All children were divided into two groups: $1^{\text {st }}$ - presents the period of mixed bite $-8-13$ years old and $2^{\text {nd }}$ - presents the period of permanent bite - 14-19 years old. Results of the research were evaluated based on nosological types of diseases.

A dentist determined the presence of decay, filling, removed teeth.

The condition of the musculoskeletal system was determined by the orthopedist visually and manually-instrumentally according to the generally accepted method with devices: hardware-software anthropometric complex and feetscope (podoscope). The condition of vertebra, that is, posture (presence or absence of distortion), recorded deformations of the feet (platypodia, talipes valgus, talipes varus, talipes), emphasized the length of the lower extremities was evaluated. Each examined pupil was given a record in case history and reccomendations.

Orthodontist provided clinical evaluation of orthodontic status, determined correlation of jaws in three areas, de- fined pathologies of dental arches, position of some teeth, evaluated symmetry, paid attention to the condition and character of attachment of frenulum of upper and lower lips, tongue, defined peculiarities of the depth of vestibule of the mouth. Much attention was paid to the condition of temporo-mandibular joint. Palpation of temporo-mandibular joint was done, localization of articular heads during open and closed mouth was determined. Character of lateral displacement of mandible was evaluated; amplitude of displacement of mandible was fixed (the presence of deviation or deflexion).

All received data were registered in the card of orthodontic examination.

\section{RESULTS}

Based on results of dental examination caries intensity and prevalence of decay in schoolchildren with hearing disorders was determined and $81,8 \%$ of caries intensity contains 3,36 , that corresponds to average indices in Ukraine.

The evaluation of skeletal apparatus was done in 56 schoolchildren with hearing disorders. The first group contained (the period of mixed bite) 29 pupils (51,79\%), the second group included (the period of permanent bite) 27 pupils (48,28\%). Only 5,26\% of examined pupils were almost healthy and in $94,74 \%$ of cases disorders of skeletal apparatus were registered (Fig. 1).

Different morphological and functional disorders of the foot were diagnosed. The given abnormality occurred both independently and with vertebra deformation.

Almost in half of examined pupils with hearing disorders and in 44,64\% such abnormalities of feet were determined. Talipes valgus (M21.0) contained 23,21\% and acquired platypodia ( M21.4 ) included 21,43\%. The given pathology occurred in schoolchildren of the first group.

In $7,14 \%$ of schoolchildren with hearing disorders pathology of skeletal apparatus was diagnosed (anterior 


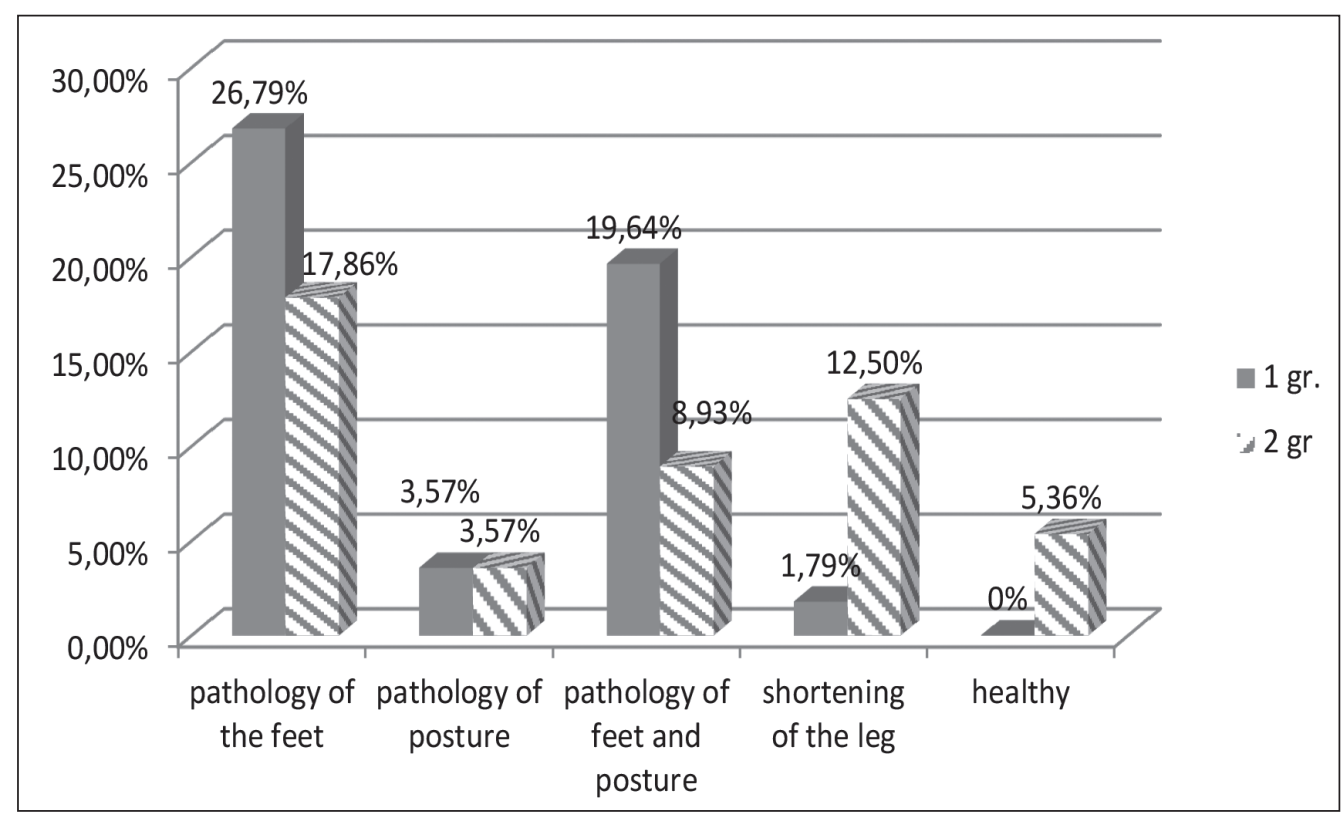

Fig 2. The abnormality of skeletal apparatus in children with hearing disorders (age groups).
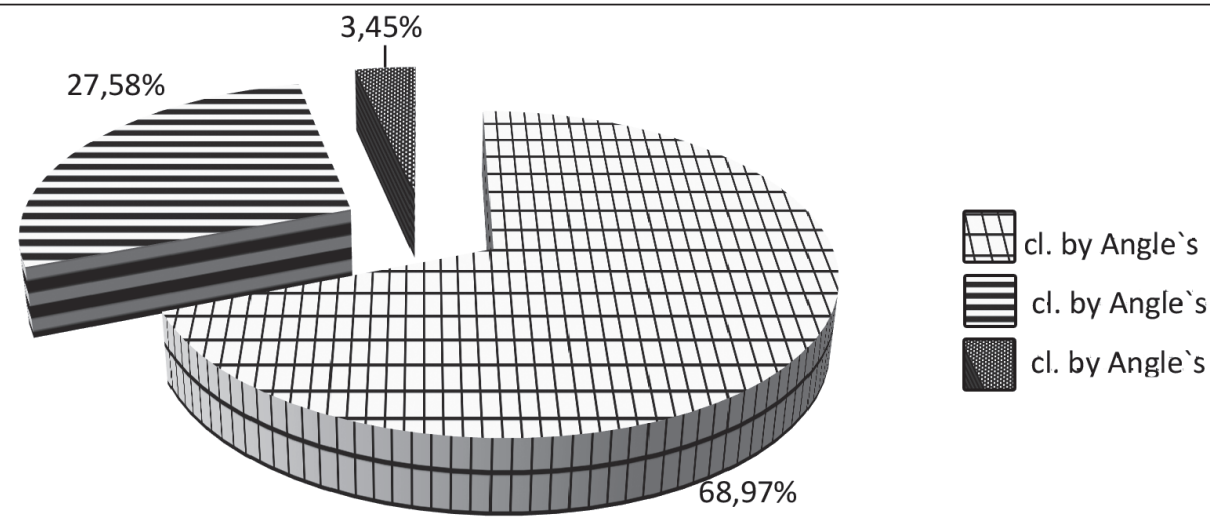

Fig 3. The condition of bite in schoolchildren with hearing disorder.

curvature, backward curvature, scoliosis) with similar frequency in children of both age groups - the first one contained $(3,57 \%)$ and the second one included $(3,57 \%)$, and it defines the absence of self-regulation of this pathology.

In $28,57 \%$ of examined pupils vertebra deformation was combined with feet disorders.

Unilateral shortening of the lower limb was diagnosed in $14,29 \%$ of pupils. If in children of the first group the length of legs was in $1,79 \%$, and with age $\left(2^{\text {nd }}\right)$ the number of asymmetries increased in 7 times - 12,5\%, and it is direct consequence of untimely visit to orthopedist and the absence of hospitalization. Shortening of the left leg occurs more often (Fig. 2).

All examined hearing-impaired schoolchildren who suffered from foot pathology, special covering and physical therapy was recommended. Spinal assistant (jacket) was used for posture correction.

Abnormalities of dentofacial system were detected in 100 of examined schoolchildren. Orthognathic occlusion was not observed in any pupil in both age groups. The division of malocclusion was done based on Angle's classification (1889). The most widespread pathology of examined schoolchildren is the pathology of bite of the first class of Angle's classification, so the abnormality of positioning of teeth which occurred, in $68,97 \%$, the second one presented in $27,58 \%$, abnormality of the third class presented in 3,45\% (Fig.3).

The first group of schoolchildren (6-13 years) in mixed bite occurs the pathology of the first class of Angle's classification and occurred in 41,38\% of schoolchildren with similar frequency of gender sign $-20,69 \%$. The second class of mixed bite (the first group) occurred in 10,34\% of schoolchildren. Both the first class and the second class of Angle's classifications were not determined. The third class of classification was determined and it was defined in 3,45\%.

In schoolchildren in permanent bite ( $2^{\text {nd }}$ group) pathology of the first class contained $27,59 \%$, bite abnormalities of the second class was determined in 17,24\%. Bite disturbance both 


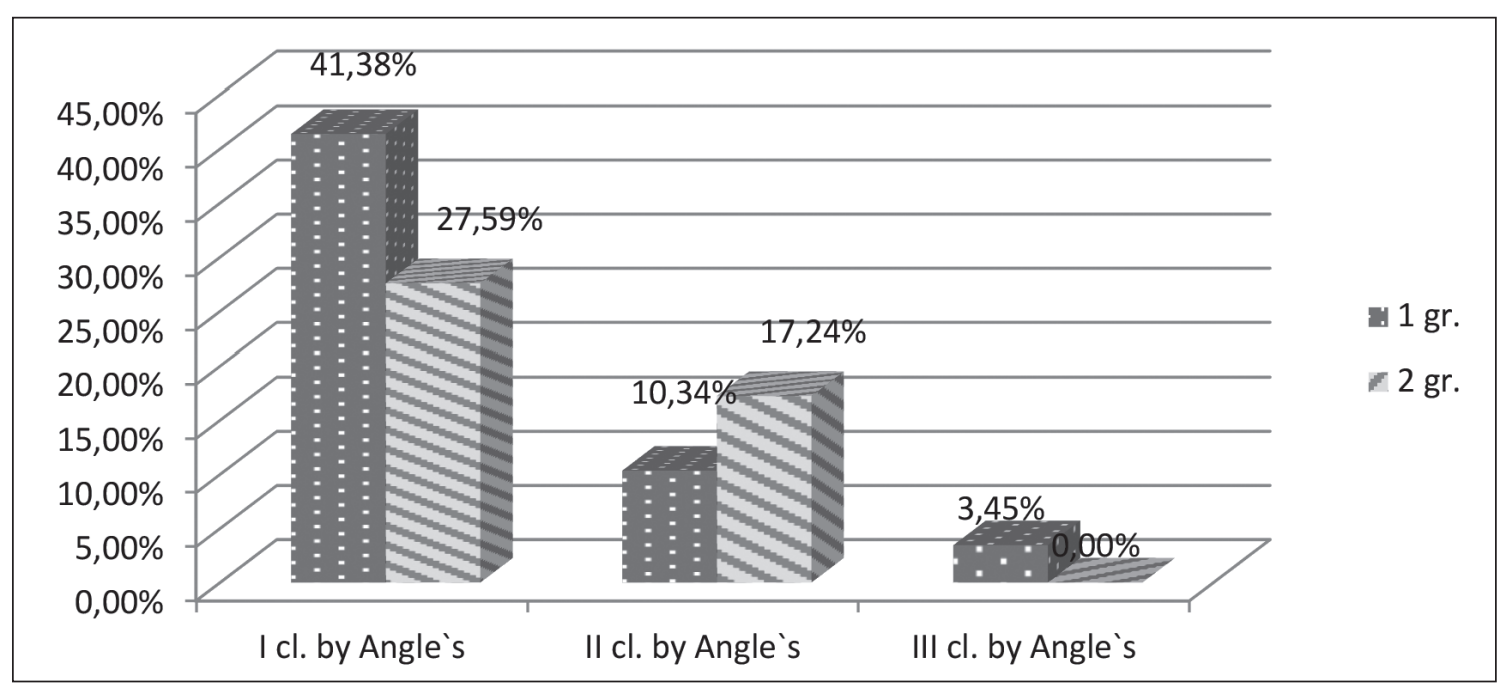

Fig. 4. Bite malocclusion in pupils with hearing disorders.

in the first class and in the second class occurred in 1,5 times more often in girls. The pathology of the third class in examined schoolchildren of 14-19 years old was not occurred (Fig.4).

If the pathology of $1^{\text {st }}$ class by Angle's classification with age tends to be slightly self-regulating (Fig. 4), distal bite in children with age ( 2 g.) increases by $6.9 \%$, which underlines the well-known postulate: prognation has almost no tendency to self-regulation, and, on the contrary, this complicated morphological and functional side pathology only complicates as the child grows up and requires more complex orthodontic intervention.

Much attention is paid to functions of the oral cavity during orthodontic examination. Swallowing and respiration is checked in children (36,36\%) and type of swallowing was determined. Oral type of respiration was found in $27,3 \%$.

The vestibule of the mouth, was determined in the third part of schoolchildren with hearing disorders $(31,82 \%)$ frenulum of upper and lower lips was detected in $38,64 \%$, and in $41 \%$ examined frenulum of tongue was occurred.

In the fifth part of pupils deviation of mandible was observed $(20,5 \%)$ and in the second group in $4,55 \%$ of schoolchildren crepitus was observed.

\section{CONCLUSIONS}

Data of complex dental, orthodontic and orthopedic examination of schoolchildren with hearing impairment determine total morbidity of osteoarticular system and also $81,8 \%$ of schoolchildren suffer from carious damages and the level of intensity of caries contains 3,36, all children are prone to dentofacial abnormalities (100\%), disorders of skeletal system in $94,64 \%$ and it determines the link and direct dependence of morphological and functional status of skeletal system and dentofacial area.

Abnormality of feet $(26,79 \%)$ and combined abnormality of feet and vertebra $(19,64 \%)$ and it leads to unilateral shortening of lower limb $(12,5 \%)$ in pupils with mixed bite.
The development and realization of preventive orthodontic measures in children with hearing disorders should be complex with different specialists (dentists, orthodontists, orthopedists and others), and it will allow decreasing the negative influence of caries risk factors, dentofacial abnormalities and reduction of their spread and severity of orthodontic pathology.

Only complex investigation, complex treatment and prevention of diseases of hard tissues of teeth, skeletal system and dentofacial abnormalities in children with hearing disorders allow reducing the problems of skeletal system of children with peculiar needs.

\section{REFERENCES}

1. Kuroedova V, Makarova A. Rasprostranennost zubocheliustnыkh anomalyi u vzroslykh y dolia asymmetrychnykh form sredy nykh. Myr medytsyny i byolohyy. 2012; 4:031-5.

2. Belous $A$, Nesterenko 0 . Analyz morfofunktsyonalnoho statusa detei 12-17 let s transverzalnymy anomalyiamy prykusa, ymeiushchykh v anamneze narushenyia osanky. 2015; 43: 70-72.

3. Silvestrini-Biavati A. etal.Clinical association between teeth malocclusions, wrong posture and ocular convergence disorders: an epidemiological investigation on primary school children. BMC pediatrics. 2013; 13(1):12.

4. Michelotti A. et al. Dental occlusion and posture: an overview. Progress in orthodontics. 2011; T. 12( 1):53-58.

5. Beliakov S. et al. Yzuchenye vzaymosviazy narushenyi opornodvyhatelnoho apparata s patolohyiamy prykusa u detei. Stomatolohyia dlia vsekh. 2016; 4:53-5.

6. Kuroiedova V. Miohimnastyka i masazh v ortodontii. In: Chykor T, Siryk V, Vyzhenko Ye..Poltava; 2015, p.46-54.

7. SerdiukV.Ydyopatycheskyi skolyoz, mekhanyzmы eho razvytyia. Visnyk ortopedii, travmatolohii ta protezuvannia. 2010;3:19-26.

8. Melnychuk D.0. Pakhomova V.O, Biloklytska H.F. Pryntsypove obgruntuvannia ta rozrobka zasobiv i metodiv intehralnoi profilaktyky i bazysnoi terapii rozpovsiudzhenykh khronichnykh zakhvoriuvan liudyny ta tvaryn. Dosiahnennia biolohii ta medytsyny. 2004;2(4):78 - 84.

9. Rudenko M, Bondarenko V, Konovalov M et al. Osoblyvosti stanu zuboshchelepnoi systemy u shkoliariv iz patolohiieiu oporno-rukhovoho aparatu. Odeskyi medychnyi zhurnal. 2001;1(63):S.27 - 30. 
10. Mandrykov V, Arystakesian V, Mytsulyna M. Ynnovatsyonnye podkhody v profylaktyke y korrektsyy narushenyi oporno-dvyhatelnoho apparata: Uchebnoe posobye. Volhohrad: VolHMU. 2013, p. 15-205.

11. Bychuk $Y$, Aleshyna A, Bychuk A, Analyz byomekhanycheskykh kharakterystyk stopy detei starsheho doshkolnoho vozrasta. Vestnyk Chernyhovskoho hosudarstvennoho pedahohycheskoho unyversyteta ymeny T.H.Shevchenka. Pedahohycheskye nauky. Fyzycheskoe vospytanye y sport. 2010;81:129-132.

12. Aloshyna A, Bychuk 0, Prychyny ta naslidky ploskostoposti u ditei doshkilnoho viku. Molodizhnyi naukovyi visnyk: Fizychne vykhovannia i sport : zb. nauk. pr. Volyn. nats. un-t im. Lesi Ukrainky. Lutsk. 2007, p.37-40.

13. Smahliuk L, Colovei K. Otsinka vzaiemozviazku mizh patolohiieiu okliuzii ta stabilnistiu polozhennia tila liudyny u prostori. Visnyk problem biolohii i medytsyny. 2014; 2.2 (108):148-151.

14. Perova E. Profylaktyka y lechenye zubocheliustnykh anomalyi y deformatsyi u detei s narushenyiamy oporno-dvyhatelnoho apparata: [avtoreferat]. Omsk; 2000, p. 3-25.

\section{Authors' contributions:}

According to the order of the Authorship.

\section{ORCID numbers:}

Vera D. Kuroiedova - 0000-0002-3832-1032

Yuliya K. Sokolohorska-Nykina - 0000-0003-2910-4500

\section{Conflict of interest:}

The Authors declare no conflict of interest.

\section{CORRESPONDING AUTHOR Yuliya K. Sokolohorska-Nykina \\ Ukrainian Medical Stomatological Academy \\ 23 Shevchenko Str., Poltava 36011 Ukraine \\ e-mail: sokolog.yuliya83@gmail.com}

Received: 21.04 .2019

Accepted: 27.08.2019 


\title{
THE POSSIBILITIES OF PREDICTION THE CORONARY HEART DISEASE COURSE AFTER COMMUNITY ACQUIRED PNEUMONIA
}

\author{
Natalia S. Mykhailovska, Tamila 0. Kulynych, Hanna V. Grytsai, Oksana 0. Lisova, Olga I. Riznyk \\ ZAPORIZHZHIA STATE MEDICAL UNIVERSITY, ZAPORIZHZHIA, UKRAINE
}

\begin{abstract}
Introduction: Nowadays there are standard models of risk stratification in coronary heart disease (CHD) patients which include traditional risk factors, but don't account the previous history of acute inflammatory diseases, the degree of biological markers activation, autonomic disorders, structural and functional myocardium changes, etc. The aim: The purpose of the study is to determine the predictors of adverse cardiovascular events and to design the prognostic model of the clinical course in CHD patients with a history of community acquired pneumonia (CAP).

Materials and methods: $60 \mathrm{CHD}$ patients with the history of CAP were examined. All fatal and non-fatal cardiovascular events during one year after the enrolment of patients into the study were evaluated. All patients were exposed to echodoplercardioscopy, their heart rate variability and levels of neopterin, PAPPA and NT-proBNP were studied.

Results: During 1 year of observation, 15 (25\%) patients reached the end points. The patients with adverse cardiovascular events demostrated more significant changes in heart's linear-volume indicators, hypersympathicotonia and increased concentrations of biomarkers $(p<0.05)$. Within the framework of mathematical simulation the discriminant equation was proposed to stratify the CHD patients into a high-risk group of adverse cardiovascular events during one year after CAP (sensitivity - 85.71\%; specificity - 94.73\%). Conclusions: The major predictors of adverse cardiovascular events in patients with CHD and a history of CAP to be considered are the following: increased end-diastolic and end-systolic index of left ventricle, elevated stress index in the passive period, as well as the increased level of neopterin, PAPP-A and NT-proBNP.
\end{abstract}

KEY WORDS: coronary heart disease, community-acquired pneumonia, prognosis

Wiad Lek 2019, 72, 10, 1917-1923

\section{INTRODUCTION}

Coronary heart disease (CHD) is a leading cardiovascular disease [1]: in Europe its prevalence rate is about 38\% and about $19,5 \%$ in the structure of general mortality $[2,3]$. The onset of CHD is strongly affected by some comorbid non-specific diseases of the respiratory system, the community acquired pneumonia (CAP), in particular, one of the most common infectious diseases in the world [4]. Nowadays it is well known, that CAP is followed with the increased rate of recurrent admissions due to the exacerbation of CHD in the course of 30 days of the observation and by $60 \%$ risen risk of a short-term [5-7]. The majority of researches is related to the in-hospital period of treatment $[8,9]$, but the impact of CAP in the long-term forecast for the CHD patients still remains unclear. The cardiovascular complications' mechanisms in this cohort of patients require a further clarification.

Today researchers continue to study universal biomarkers with an independent prognostic value in patients with stable coronary artery disease. Thus, numerous studies have placed the emphasis firmly on markers of inflammation, endothelial dysfunction and instability of the atherosclerotic plaque: high-sensitive $\mathrm{C}$-reactive protein (hsCRP), neopterin, matrix metalloproteinases, including plasma protein A (PAPP-A), etc. Independent associations with the progression of atherosclerosis and the development of acute coronary syndrome have been proven [10]. However, their predictive role in the occurrence of complications in CHD patients with a history of CAP has not been determined.

Nowadays there are standard models of risk stratification in patients with CHD, which include risk factors such as smoking, dyslipidaemia, arterial hypertension, and diabetes mellitus. However, these scales do not account the previous history of acute inflammatory diseases, the activation of biological markers, the degree of autonomic support of cardiac activity, structural and functional changes in the heart, etc. [11]. Therefore, the mathematical models of the CHD course in regard with the aforesaid factors will allow to sort out the patients with the high risk of adverse cardiovascular events after CAP and make a prompt correction of these violations.

Thus, summarising of data provided confirms the urgency of the issue of cardiovascular complications predictors' determination in CHD patients with the history of CAP.

\section{THE AIM}

The purpose of the study is to determine the predictors of adverse cardiovascular events and to design the prognostic model of the clinical course of CHD in patients with a history of CAP.

\section{MATERIALS AND METHODS}

A prospective, open-label trial involved 60 patients with CHD and a history of CAP, including 34 (56.67\%) men 
and $26(43.33 \%)$ women. The average age was 71.5 (64.75, 74.25) years old. The CHD and the functional class of a stable angina were diagnosed on the basis of the up-to-date national standards.

Inclusion criteria: the documented stable CHD, signs of CAP according to clinical and radiological examination and the signed informed consent for participation in the study.

Exclusion criteria: any acute or chronic inflammation of another localization, history of myocardial infarction or unstable angina within 28 days prior to the hospitalization, heart failure of II B-III stage before the introduction of the patient into the research, the decompensation of somatic pathology, cancer and other systemic diseases, mental disorders, alcohol abuse and drug addiction.

The study design is approved by the Bioethics Committee of Zaporizhzhia state medical university and meets the ethical requirements of ICH/GCP, the Helsinki Declaration (1964), The European Convention on Human Rights and biomedicine, and the Ukrainian legislation.

During the first 3 days in the hospital the comprehensive clinical examination of patient was carried out considering patients' complaints, medical history, physical examination, laboratory studies and diagnostic imaging modalities according to the up-to-date research standards. The assessment of hsCRP in the serum was performed with the standard sets of reagents (Biomerica, USA); neopterin - by IBL International (Germany); PAPP-A - by DRG Diagnostics (Germany); NT-pro-brain natriuretic peptide (NT-proBNP) - by the immune-enzyme method (Biomedica, Austria) according to the kit's instruction added to the immune-enzyme analyser «SIRIO S» (Italy). The echocardiography was carried out with an ultrasound diagnostic scanner "SONOACE" 8000SE (Medison, Korea) and daily ECG monitoring by the Holter method - with the help of the "Cardiosens K" device ("HAI-MEDICA", Ukraine), according to the current recommendations.

Clinical endpoints were evaluated in one year after the enrolment of patients into the study. All fatal and non-fatal atherothrombotic events, rhythm and conduction disorders, decompensated heart failure, and hospitalization due to some of the above mentioned reasons were considered as clinical endpoints.

Statistical data processing was conducted using the "Statistica 13.0" software package (Statsoft Inc, USA, JPZ8041382130ARCN10-J). The hypothesis about the normalcy of distribution of the indexes studied was checked using the Shapiro-Wilk criterion. Quantitative characteristics are represented as Me (Q25; Q75) (median, 25 and 75 percentiles), as all indexes belonged to the distribution different from the normal one. The significance of the differences was estimated with the Mann-Whitney U-test for independent samples. Intergroup differences in qualitative characteristics were evaluated with Pearson's $\chi^{2}$ criterion (for a small sample - with the Yeats correction). A discriminant analysis with the definition of canonical coefficients and the design of a discriminant function was performed to identify independent predictors of cumulative endpoints and the design of a predictive model. Differences were considered to be significant in the case of $\mathrm{p}<0.05$.

\section{RESULTS}

During 1 year of observation, endpoints were reached by the $15(25,00 \%)$ patients in the main group, of whom 14 (23.33\%) were re-admitted to the hospital (because of acute coronary syndrome $-10 \%$, decompensated heart failure $8 \%$, of arrhythmic failure $-7 \%)$ and $1(1.66 \%)$ patient died.

For further study's purposes, the patients were randomized into 2 groups: patients with endpoints (group 1) $(\mathrm{n}=15)$ and those without re-admissions or complications during 1 year (group 2) $(n=45)$. Clinical characteristics of both groups are presented in Table I.

The patients of both groups were of similar gender, age, risk factors and comorbid pathology. The reliable relationships between the risk of pneumonia (by PSI/PORT scale) and the rate of cardiovascular events $\left(\chi^{2}=1.0666 ; \mathrm{df}=1\right.$; $\mathrm{p}>0.05$ ) were not revealed.

The analysis of echocardiography revealed that patients with further adverse cardiovascular events demonstrated the trend towards the increase in linear-volumetric cardiac indexes such as left (LA), right (RA) atriums and right ventricle (RV), left ventricle end-diastolic dimension, left ventricle end-diastolic volume and a significant increase of end-diastolic and end- systolic indexes of left ventricle (EDI-LV and ESI-LV) $(\mathrm{p}<0.05)$, if compared to the patients without complications (Figure1). There were no significant differences in systolic and diastolic functions between two studied groups.

The analysis of HRV (Table II) represents decreased total heart rate variability in active and passive periods in patients of group 1: the reliable decrease in TP by $28.14 \%$ in active (day time) and $4,43 \%$ in passive periods (night time), a decrease in SDNN by $16.99 \%$ and the triangular index by $25.99 \%(\mathrm{p}<0.05)$ in active period and the tendency to a decrease in these indexes in passive periods, if compared to the patients of the 2 group.

The analysis of spectral indexes of HRV shows a significant decrease in LF (by 26.06\%; $\mathrm{p}<0.05)$ and HF (50.04\%; $\mathrm{p}<0.05)$ and a rise of stress index $\left(\mathrm{SI}_{\mathrm{d}}\right)$ by $8.06 \%(\mathrm{p}<0.05)$ during the day time in patients with further cardiovascular complications, which could be explained by the weak control of the autonomic nervous system during the active period. During the passive period, according to the analysis of spectral indexes of HRV, the patients of group 1, if compared to the second group patients, had a significant decrease in the parasympathetic nervous system' tone. The reliable reduction in HF by $43.84 \%$, an increase in LF and $\mathrm{SI}_{n}$ by $17.70 \%$ and $41.18 \%$ respectively and an increased index of centralization testify the prevalence of the sympathetic regulation during the night period.

Thus, those patients who had reached the cumulative endpoints, had a higher total duration of tachycardia with a higher tone of the sympathetic nervous system and a lower total HRV.

Changes in biomarkers rates in patients with $\mathrm{CHD}$ and a history of CAP, depending on the clinical outcomes, are given in Table III. 
Table I. Clinical characteristics of groups of patients with IHD and a history of CAP according to clinical outcomes during 1 year of observation

\begin{tabular}{ccc}
\hline Indexes, unit of measurement & Group $\mathbf{1}(\mathbf{n}=\mathbf{1 5})$ & Group 2 (n= 45) \\
\hline Age, years & $66(62 ; 74)$ & $72(66 ; 75)$ \\
\hline Men & $5(33.33 \%)$ & $27(60.00 \%)$ \\
\hline Women & $10(66.67 \%)$ & $38(40.00 \%)$ \\
\hline Arterial hypertension & $12(80.00 \%)$ & $9(20.85 \%)$ \\
\hline Type 2 diabetes mellitus & $1(6.67 \%)$ & $16(35.56 \%)$ \\
\hline Obesity & $5(33.33 \%)$ & $11(24.44 \%)$ \\
\hline Tobacco smoking & $1(6.67 \%)$ & $26.81(25.27 ; 31.85)$ \\
\hline BMI, kg/m ${ }^{2}$ & $28.00(26.61 ; 31.04)$ & $71.50(64.00 ; 83.50)$
\end{tabular}

Note 1. Data is given as Me (Q25; $\mathrm{Q75})$ or absolute number of cases and their specific gravity (\%).

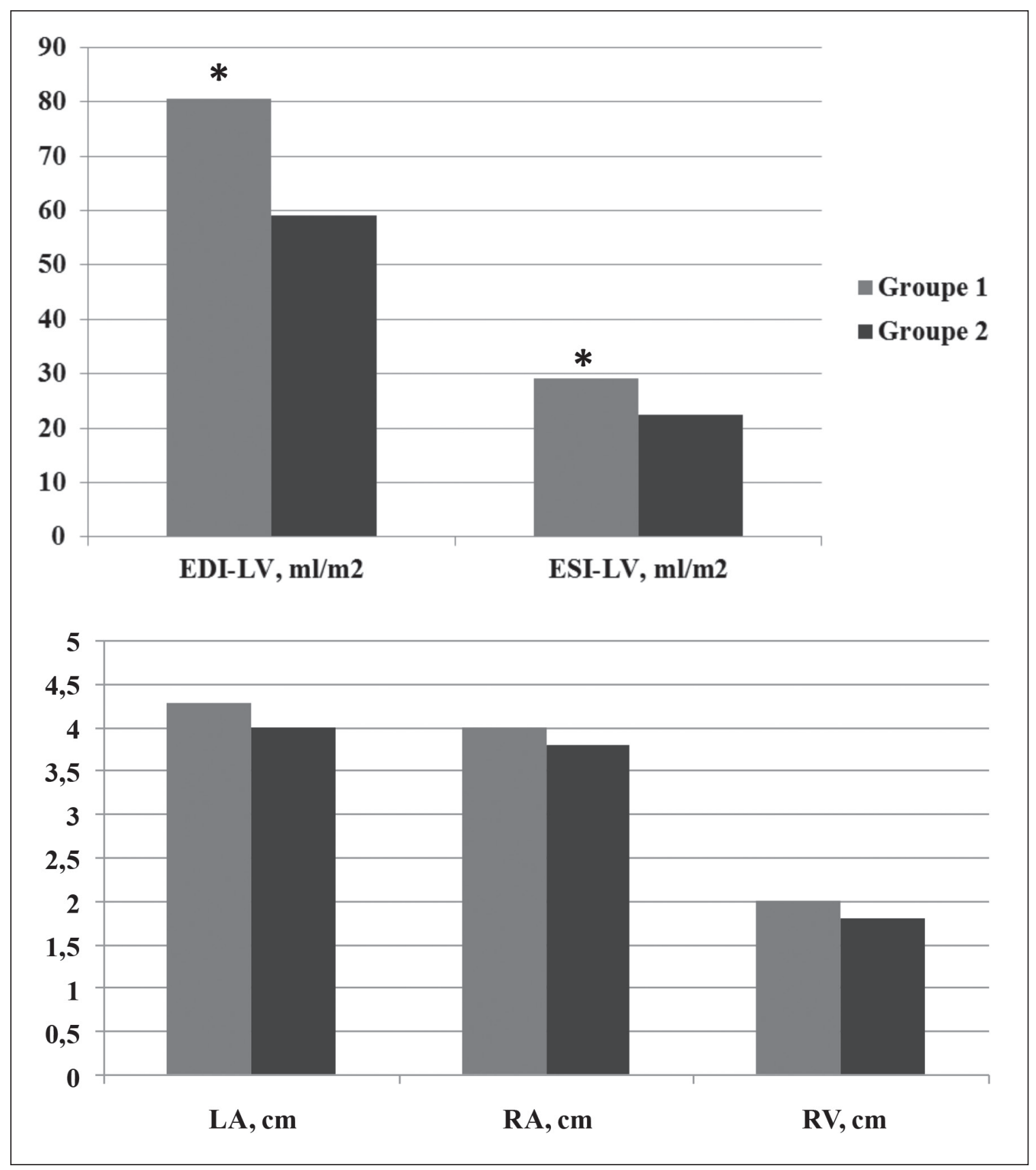

Picture 1. Structural parameters of heart in patients with CHD and CAP

Note: * - the probability of indexes difference $(p<0.05)$ 
Natalia S. Mykhailovska et al.

Table II. Changes in the HRV spectral indices in patients with IHD and background CAP according to the results of daily Holter ECG monitoring, Me (Q25; Q75)

\begin{tabular}{|c|c|c|}
\hline Indexes, unit of measurement & Group $1(n=15)$ & Group $2(n=45)$ \\
\hline \multicolumn{3}{|c|}{ Active period } \\
\hline SDNNi, MS & $35.70(24.40,55.10) *$ & $42.60(32.75 ; 52.10)$ \\
\hline rMSSD, MS & $13.00(12.00 ; 23.00)$ & $20.00(11.00 ; 40.50)$ \\
\hline pNN50, \% & $1.10(0.30 ; 6.00)$ & $2.00(0.30 ; 10.40)$ \\
\hline $\mathrm{TP}, \mathrm{Ms}^{2}$ & $1246.00(523.00 ; 3023.00)^{*}$ & $1734.00(1058.50 ; 2640.50)$ \\
\hline LF, MS & $139.00(62.00 ; 335.00) *$ & $188.00(133.50 ; 368.00)$ \\
\hline LFn, n.o. & $68.50(50.20,79.50)$ & $74.80(64.75 ; 77.75)$ \\
\hline $\mathrm{HF}, \mathrm{ms}$ & $62.00(36.00 ; 71.00) *$ & $125.00(40.00 ; 214.50)$ \\
\hline HFn, n.o. & $31.50(20.50 ; 49.80)$ & $26.50(23.13,35.28)$ \\
\hline LF/HF & $2.20(1.00,3.90)$ & $3.20(1.80,3.60)$ \\
\hline IC & $10.10(4.20 ; 19.20)$ & $10.30(6.10 ; 17.10)$ \\
\hline SI & $67.00(60.00 ; 102.00) *$ & $62.00(30.50 ; 73.50)$ \\
\hline \multicolumn{3}{|c|}{ Passive period } \\
\hline SDNNi, MS & $43.30(27.60 ; 46.10)$ & $43.40(30.90 ; 52.15)$ \\
\hline rMSSD, MS & $22.00(13.00 ; 23.00) *$ & $25.00(17.00 ; 36.50)$ \\
\hline pNN50, \% & $3.10(0.70 ; 3.50)$ & $4.00(0.80 ; 7.05)$ \\
\hline $\mathrm{TP}, \mathrm{Ms}^{2}$ & $1724.00(711.00 ; 2114.00) *$ & $1804.00(834.25 ; 2391.50)$ \\
\hline LF, MS & $358.00(74.00 ; 363.00) *$ & $346.00(133.50 ; 625.50)$ \\
\hline LFn, n.o. & $73.80(62.00 ; 75.60)$ & $62.70(47.40 ; 77.85)$ \\
\hline HF, MS & $82.00(54.00 ; 129.00) *$ & $146.00(88.50 ; 420.00)$ \\
\hline HFn, n.o. & $26.20(24.40 ; 38.00)$ & $32.80(21.85 ; 49.25)$ \\
\hline $\mathrm{LF} / \mathrm{HF}$ & $2.80(1.60 ; 3.10)$ & $3.50(1.70 ; 3.60)$ \\
\hline IC & $9.50(7.10,15.70)$ & $6.70(3.30 ; 12.80)$ \\
\hline SI & $72.00(37.00 ; 97.00) *$ & $51.00(29.00 ; 70.50)$ \\
\hline
\end{tabular}

Note. ${ }^{*}$ - the significance indexes between subsets $(p<0.05)$.

The patients in both groups were similar in the level of the hsCRP, while the levels of neopterin and PAPP-A were reliably higher in patients of group 1 by $39.53 \%$ and $41.18 \%$ respectively $(p<0.05)$. In patients of the main group with further adverse cardiovascular events the serum NT-proBNP concentration was also significantly higher by $84.6 \%$ $(\mathrm{p}<0.05)$ and exceeded significantly this rate in patients of group 2, although at the beginning of the study these groups were comparable by the stage of heart failure $\left(\chi^{2}=\right.$ $0.024 ; \mathrm{df}=1 ; \mathrm{p}>0.05)$.

Thus, the CHD patients with a history of CAP had the increased levels of hsCRP, neopterin, PAPP-A and NT-proB$\mathrm{NP}$, which could be associated with the unfavourable course of the disease at a longer observation. Therefore, a discriminant analysis during which the procedure of stepby-step variables inclusion, aimed at the selection of the most informative indexes was conducted to identify independent predictors of cumulative endpoints' achievement and to create a prognostic model of the CHD course with a history of CAP. These clinical and laboratory, instrumental features were evaluated via Wilks' Lambda values.

According to the data obtained, the highest discriminatory ability in the prediction of the risk of undesirable cardiovascular events during 1 year of observations was demonstrated by the following indexes: the rates of neopterin, PAPP-A, NT-proBNP, the sizes of LA, EDI-LV, ESI-LV and SI during the day and night periods, and overall variability of the autonomic nervous system during the night period. The results of the discriminant analysis of Fisher's forecast for unfavourable cardiovascular events in CHD patients a history of CAP are listed in Table IV.

Further the task-oriented analysis for the above-mentioned variables with the highest discriminant ability to predict the rate of cardiovascular events within 1 year in patients with CHD with a history of CAP was carried out. During the model analysis, the SI index in the daytime was excluded, and this did not significantly decrease the quality and rationality of the forecast model (Wilks' Lambda value was $0.173 ; \mathrm{F}=15.125 ; \mathrm{p}<0.001)$.

Next, the canonical coefficients for variables were calculated. The following discriminant equation obtained for patients with CHD with a history of CAP looks the following way:

$0.046 \times[$ ESI-LV $]-0.040 \times\left[\right.$ EDI-LV] $-0.009 \times\left[\mathrm{SI}_{\mathrm{n}}\right]$ $-0.047 \times$ [neopterin] $-5.798 \times[$ PAPP-A] $-0.012 \times$ $[\mathrm{NT}$-pro BNP $]+5.22613=0$ 
Table III. Biomarkers in patients with IHD with a history of CAP, Me (Q25; Q75)

\begin{tabular}{ccc}
\hline Indexes, unit of measurement & Group $\mathbf{1}(\mathbf{n}=\mathbf{1 5})$ & Group 2 (n= 45) \\
\hline hsCRP, $\mathrm{mg} / \mathrm{l}$ & $8.00(4.00 ; 9.00)$ & $8.00(4.00 ; 9.50)$ \\
\hline Neopterin, $\mathrm{mmol} / \mathrm{l}$ & $16.13(10.87 ; 30.60)^{*}$ & $0.34(0.28,0.52)$ \\
\hline PAPP-A, $\mu \mathrm{g} / \mathrm{ml}$ & $0.48(0.33 ; 0.56){ }^{*}$ & $34.94(14.34 ; 73.28)$ \\
\hline NT-proBNP, $\mathrm{pmol} / \mathrm{l}$ & $64.5(51.44 ; 150.85)^{*}$ & \\
\hline
\end{tabular}

Note. ${ }^{*}$ - the significance indexes between subsets $(p<0.05)$

Table IV. The results of the Fischer's discriminant analysis for the prediction of unfavourable cardiovascular events in patients with IHD with a history of CAP

\begin{tabular}{ccccc}
\hline Indexes & Wilks' Lambda & Partial value of Wilks' Lambda & F-value & The significance \\
\hline Neopterin & 0.519 & 0.769 & 5.981 & 0.024 \\
\hline PAPPA & 0.560 & 0.714 & 8.029 & 0.010 \\
\hline NT-proBNP & 0.907 & 0.695 & 8.759 & 0.008 \\
\hline EDI-LV & 0.995 & 0.765 & 8.317 & 0.008 \\
\hline ESI-LV & 0.940 & 0.809 & 6.359 & 0.018 \\
\hline SI $_{d}$ & 0.756 & 0.717 & 6.725 & 0.019 \\
\hline $\mathrm{TP}_{\mathrm{n}}$ & 0.628 & 0.797 & 4.580 & 0.046 \\
\hline $\mathrm{SI}_{\mathrm{n}}$ & 0.996 & 0.735 & 7.556 & 0.012 \\
\hline
\end{tabular}

The interpretation of the results was carried out via the arithmetic calculation of the value of function: after the patients were examined (echocardiography, daily ECG monitoring by Holter method and a determination of biomarkers) the above mentioned indexes were used to calculate the discriminant function value. The patient is sorted out to a high-risk group with further unfavourable cardiovascular events if the result is less than zero (negative). If the result is positive (i.e., the function value is above zero) the patient is included into the low risk group of cardiovascular complications. This model verification results revealed the $85.71 \%$ sensitivity and $94.73 \%$ specificity of this method, with the general informative value about $90.22 \%$.

\section{DISCUSSION}

The data obtained as to the adverse effects of the CAP on the course of CHD conform to the results of other studies $[7,12,13$.$] . So, T.W. Perry et al. (2011) established the$ high risk of cardiovascular events development (myocardial infarction, unstable angina, stroke) within 90 days of pneumonia outset [7]. In P. Mandal et al. study (2010) , cerebro- and cardiovascular events were observed in $16.5 \%$ of patients with CAP, they were more likely registered in the presence of pre-existing cardiovascular disease [12]. In a study by F. S. Biteker et al. (2016) the decreased systolic function of the left ventricle in CAP patients, correlated with changes in NT-proBNP, severity of pneumonia and associated with unfavorable course of disease was found out [14]. Authors suppose that the following mechanisms of the adverse effects of CAP on the state of the cardiovascular system may be provoked by the following mechanisms: the development and progression of systolic and diastolic myocardium dysfunction; changes in hemostasis, manifested by the increased activity of coagulation factors, increased aggregation properties of platelets and inhibition of fibrinolysis; endothelial dysfunction due to a violation of the synthesis of nitric oxide and activation of systemic inflammation; the imbalance of autonomic regulation of cardiac activity and hypersympathicotonia leading to a biomechanical stress and damage to atherosclerotic plaques [15-17]. These processes can also contribute to hypovolemia, increased metabolic needs of the myocardium under the reduced oxygenation, changes in peripheral vascular resistance [18]. Besides, the lowering blood flow through the stenosed coronary artery and vasoconstriction can lead to the compression of the atheromatous nucleus and cause its intravascular rupture and subsequent erosion of the tire and, consequently, result in the development of acute coronary syndrome and myocardial infarction [7, 19-22]. Therefore, a discriminant equation was proposed by us: it takes into account several principal factors involved in the pathogenetic mechanism of cardiovascular complications' development in patients with CHD after CAP: changes in cardioghemodynamics, autonomic regulations of the heart, activation of markers of systemic inflammation (neopterin), plaque's instability (PAPP-A), cardiac insufficiency and myocardial dysfunction (NT-proBNP), which allows to stratify patients into a high-risk group and prescribe the treatment promptly to prevent cardiovascular complications.

\section{CONCLUSIONS}

1. CAP in patients with CHD is associated with an increased number of cardiovascular complications (arrhythmic disorders, heart failure decompensation, atherothrombotic events), which are cumulatively recorded in $25 \%$ of patients. 
2. For those CHD patients after CAP, who got the cumulative endpoint, if compared to the patients without cardiovascular events, an increase in linear-volume indicators of the heart, vegetative imbalance with the predominance of hypersympathicotonia against the background of more significant changes in the concentration of markers of systemic inflammation, endothelial dysfunction, instability of atheroma and heart failure are peculiar.

3. According to the results of the discriminant analysis, the major predictors of adverse cardiovascular events in CHD patients with a history of CAP are the following: increased EDI-LV and ESI-LV, elevated SI in the passive period, as well as the increased level of neopterin, PAPP-A and NT-proBNP.

4. The designed discriminant equation allows the stratification of patients with CHD and a history of CAP into a high-risk group of adverse cardiovascular events within one year with a high sensitivity $(85.71 \%)$ and specificity $(94.73 \%)$.

\section{REFERENCES}

1. Grasgruber P., Sebera M., Hrazdira E. et al. Food consumption and the actual statistics of cardiovascular diseases: an epidemiological comparison of 42 European countries. Food \& nutrition res. 2016;60(1):31694.

2. Townsend N.,Wilson L., Bhatnagar P. et al. Cardiovascular disease in Europe: epidemiological update 2016. Eur Heart J. 2016;37(42):3232-3245

3. Wilkins E., Wilson L., Wickramasinghe K. et al. European Cardiovascular Disease Statistics 2017 edition. Brussels: European Heart Network. $192 \mathrm{p}$.

4. Welte T., Pletz M. Pneumonia and the risk of cardiovascular death. Time to change our strategy. Am J Respir CritCare Med. 2017;196(5):541-543.

5. Corrales-Medina V. F., Musher D. M., Wells G. A. et al. Cardiac complications in patients with community-acquired pneumonia. Incidents, timing, risk factors, and association with short-term mortality. Circulation. 2012;125:773-781.

6. Rae N., Finch S., Chalmers J. D. Cardiovascular disease as a complication of community-acquired pneumonia. Curr Opin Pulm Med. 2016;22(3):212218.

7. Perry T.W., Pugh M. Jo V, Waterer G. W. et al. Incidence of cardiovascular events following hospital admission for pneumonia. Am J Med. 2011;124(3):244-251.

8. Ostrovskii M. M., Varunkiv 0. I. Osoblyvosti metabolismu oksydu azotu u khvoryh z negospitalnoiu pnevmonieiu na tli ishemichnoi khvoroby sertsia v zalezhnosti vid verifikatsii Chlamydophila pneumonia [The features of metabolism of nitric oxide in patients with communityacquaired pneumonia on the background of coronary heart disease, depending on the Chalimidophila pneumonia identification]. UkrainianPulmonologyJournal. 2010;3:27-29.

9. Syvolap V. V., Kurilets L. 0., Lukashenko L. A. Immunologichni zminy u khvoryh na posalikarnianu pnevmoniiu iz suputnioiu IHS pid vplyvom symvastatinu [The immunological changes in community-acquired pneumonia patients with coronary heart disease under simvastatin influence]. ZaporizhzhiaMedicalJournal. 2016;2:31-35.

10. Ragino Yu. I., Cherniavskiy A. M., Polonskaya Ya. V. Vospalitelnodestruktivnyie biomarkery nestabilnosti ateroskleroticheskih bliashek: issledovania sosudistoy stenki i krovi [Inflammatory-destructive biomarkers of atherosclerotic plaque instability: studies of the vascular wall and blood]. Kardiologia. 2012;5:37-41.
11. Komarov A. L., Shakhmatova 0. 0., lliushchenko T. A. et al. Factory, opredeliaiushchie prognoz u bolnykh so stabilnoy formoy ishemicheskoy bolezni serdtsa (po rezultatam piatiletnego prospektivnogo nabliudenia) [Factors determining the prognosis of patients with a stable form of coronary heart disease (based on the results of a five-year prospective observation)]. Kardiologia. 2012;1:4-14.

12. Mandal P., Chalmers J. D., Choudhury G. et al. Vascular complications are associated with poor outcome in community-acquired pneumonia. QJM: Int J Med. 2011;104:489-495.

13. Mykhailovska N., Kulynych T. The influence of community-acquired pneumonia on the clinical course of coronary heart disease: the results of retrospective analysis. ScienceRise. Medical Science. 2017;11(19):52-56.

14. Biteker F. S., Basaran 0., Dogan V. et al. TAPSE: a novel prognostic marker in community-acquired pneumonia. Eur Heart J. 2016;37:259.

15. Corrales-Medina V.F., Musher D. M., Shachkina S. et al. Acute pneumonia and the cardiovascular system. Lancet. 2013. 381(9865):496-505.

16. Feldman C., Anderson R. Prevalence, pathogenesis, therapy, and prevention of cardiovascular events in patients with communityacquired pneumonia. Pneumonia. 2016;8(1):11-14.

17. Mykhailovska N. S., Kulynych T. 0., Grytsay H. V. Klinichnyy perebig, neyrohumoralni ta hemodynamichni zminy u khvorykh na stabilnu stenokardiiu napruzhennia na tli nehospitalnoi pnevmonii [Clinical course, neurohumoral and hemodynamic changes in patients with stable angina pectoris and community-acquired pneumonia]. Patologia. 2014;2(31):55-59.

18. Feldman C., Anderson, R. Community-acquired pneumonia: pathogenesis of acute cardiac events and potential adjunctive therapies. Chest. 2015;148(2):523-532.

19. Musher D. M., Rueda A. M., Kaka A. S. et al. The association between pneumococcal pneumonia and acute cardiac events. Clin Infect Dis. 2009;15:158-165.

20. Ramirez J., Aliberti S., Mirsaeidi M. et al. Acute myocardial infarction in hospitalized patients with community-acquired pneumonia Clin Infect Dis. 2008;47:182-187.

21. Viasus D., Garcia-Vidal C., Manresa F. et al. Risk stratification and prognosis of acute cardiac events in hospitalized adults with communityacquired pneumonia. J Infect. 2013;66(1):26-33.

22. Griffin A., Wiemken T., Amold F. Risk factors for cardiovascular events in hospitalized patients with community-acquired pneumonia. Int J Infect Dis 2013;17:1125-1129.

The research was carried out within the scientific research work plan of the Department of General Practice - Family Medicine and Internal Diseases of the Zaporizhzhzhia State Medical University on the topic: "Clinical and pathogenetic, prognostic and treatment and diagnostic aspects of cardiovascular pathology with different comorbid states" (State registration number 0118U007138).

\section{Authors' contributions:}

According to the order of the Authorship.

\section{ORCID numbers:}

Natalia S. Mykhailovska - 0000-0001-6781-9406

Tamila O. Kulynych - 0000-0001-9453-8749

Hanna V. Grytsai - 0000-0001-5646-8794

Oksana O. Lisova - 0000-0002-3894-6913

Olga I. Riznyk -0000-0002-2658-2120 


\section{Conflict of interest:}

The Authors declare no conflict of interest.

\section{CORRESPONDING AUTHOR}

Natalia S. Mykhailovska

Department of General Practice - Family Medicine and

Internal Diseases Zaporizhzhia State Medical University

69035 Maiakovskyi avenue 26, Zaporizhzhia, Ukraine

tel: +380978275803

e-mail: natalizgmu@gmail.com

Received: 17.03 .2019

Accepted: 27.08 .2019 


\title{
ASSESSMENT OF ENDOTHELIAL FUNCTION IN PATIENTS WITH INITIAL MANIFESTATIONS OF CHRONIC CEREBRAL ISCHEMIA
}

\author{
Maryna A. Trishchynska, Maryna V. Globa, Vasyl V. Orzheshkovskyi, Yuriy V. Voronenko, Yurij I. Holovchenko, \\ Olena V. Tkachenko, Vasyl M. Mykhalchuk \\ SHUPYK NATIONAL MEDICAL ACADEMY OF POSTGRADUATE EDUCATION, KYIV, UKRAINE
}

\begin{abstract}
Introduction: Over the last decade, the number of patients with cerebrovascular diseases in Ukraine has grown by 1.5 times. This negative trend is based on the significant increase of vascular risk factors - arterial hypertension, dyslipidemia, sedentary lifestyle, excessive weight/obesity, diabetes mellitus, tobacco smoking, etc. - prevalence among the population of the country, their early development and combination of several vascular risk factors, which makes prevention of cerebrovascular diseases at their early stages a priority.

The aim: Study of endothelial vasomotor function in patients with initial symptoms of chronic cerebral ischemia.

Materials and methods: The study included 260 patients of the main group (mean age 50.6 \pm 70.9 ) with initial manifestations of $\mathrm{CCl}$ and 30 persons of similar age of the control group. All the patients underwent a clinical neurological examination, MRI of the brain, ultrasonography with the establishment of flow-mediated endotelium-dependent dilatation (FMD) index based on the results of brachial artery compression test, as well as laboratory tests of endothelin-1 and nitrite levels. The patients were subdivided into 3 groups based on their MRI of the brain data: without structural changes of the brain (group 1), with initial vascular structural changes (group 2), with initial structural changes and mild cerebral atrophy (group 3).

Results: Reliable differences of FMD index were established in the groups with different degrees of structural brain damage, and in comparison with the control group ( $<<0.001$ ). Considerable downward trend of FMD index with increase of the number of existing vascular risk factors (VRF) was identified ( $p<0.05$ ). An associative link with the presence of arterial hypertension $(\mathrm{AH})$, its degree and FMD index $(\mathrm{p}<0.05$ ) was established. It was shown that a thickened intima-media complex (IMC) of common carotid arteries $>0.9$ $\mathrm{mm}$ had a significantly lower predetermination to FMD $(p=0,001)$. Statistically significant lower FMD indices were registered in persons with endothelial vasomotor function disorder according to the biochemical markers: with endothelin level increase and nitrite level decrease $(p<0.001)$.

Conclusions: An associative link with the presence of endothelial dysfunction according to FMD index were established with different degrees of structural brain damage, with the presence of $\mathrm{AH}$, with IMC of common carotid arteries $>0.9 \mathrm{~mm}$, with endothelial vasomotor function disorder according to the biochemical markers: with endothelin level increase and nitrite level decrease.
\end{abstract}

KEY WORDS: initial manifestations of chronic cerebral ischemia, flow-mediated dilatation, endothelial dysfunction, endothelin-1, nitrite

Wiad Lek 2019, 72, 10, 1924-1929

\section{INTRODUCTION}

Over the last decade, the number of patients with cerebrovascular diseases (CVD) in Ukraine has grown by 1.5 times [1]. This negative trend is based on the significant increase of vascular risk factors (VRF) - arterial hypertension (AH), dyslipidemia, sedentary lifestyle, excessive weight/obesity, diabetes mellitus, tobacco smoking, etc. - prevalence among the population of the country, their early development and combination of several VRF, which makes prevention of CVD at their early stages a priority [2]. The vascular system disorders of target organs are latent (take a long time to develop) and are clinically manifested by potentially fatal and disabling vascular events [3].

The permanent influence of VRF suppresses the protection mechanisms of the vascular endothelium, which threatens the functional and structural integrity of the vascular system. There is significant evidence of endothelial dysfunction (ED) involvement in initiation and progression of atheroclerosis and its complications. ED is known to be a systemic syndrome involving several vascular pools, including the cerebral one [4].

ED is considered to be primarily caused by the loss of balance between the vasodilatory and vasoconstrictive factors, and later manifests itself as pro-inflammatory, pro-oxidant, proliferative, pro-coagulative and pro-adhesive changes [4]. That is why, it is the endothelial vasomotor function disorder that can have the highest prognostic value as it can be diagnosed at the earliest stages of vascular disruption to a blood vessel.

It is known that the functional and structural integrity of endothelium makes it possible to assess the degree of VRF influence and the risk of a vascular disease development in the corresponding vascular pool. There are no established standards either of ED diagnosis, or its treatment. The most frequently used methods of endothelial function assessment are as follows: flow-mediated endothelium-de- 
pendent dilatation (FMD), plethysmography, angiography and determination of the concentrations of factors which are synthetized in endothelium, e.g. endothelin 1, nitrite (as NO metabolite), circulating endothelial cells and their fragments, assessment of NOS (NO-synthase) and antigenic structure of endothelium, etc. [5]. Notwithstanding a large amount of recent clinical and experimental studies, features of clinical, neurovisual and hemodynamic initial manifestations of the chronic cerebral ischemia (CCI) not fully understood, as well as mechanisms for the disorder of vasomotor endothelial functions [6].

\section{THE AIM}

Study of vasomotor endothelial function in patients with initial symptoms of chronic cerebral ischemia (CCI).

\section{MATERIALS AND METHODS}

The study included 290 patients $(70.7 \%$ (205/290) women and $29.3 \%(85 / 290)$ men) aged 39 to 65 years. All the patients underwent a clinical, neurological examination, MRI of the brain, ultrasonography, laboratory tests, which were carried out in the hospital N9 in Kyiv in 2012-2016.

The main group consisted of 206 patients (mean age $50.6 \pm 70.9$ ) with initial manifestations of CCI. One or more VRF were found in all patients - $\mathrm{AH}$, dyslipidemia, excessive weight/obesity (body mass index $25-29 \mathrm{~kg} / \mathrm{m}^{2}$ ), diabetes mellitus, positive history of acute vascular events in first-degree relatives up to 55 years of age for men and 65 for women - these factors were defined as eligibility criteria in the main group.

The study did not include patients with history of stroke or myocardial infarction, AH of the $3^{\text {rd }}$ degree or $\mathrm{III}^{\mathrm{rd}}$ stage, persons with severe somatic pathology, oncological pathology, with mental illness.

30 persons, mean age $50.4 \pm 6.6$ without VRF and clinical signs of CCI made up the control group.

Based on the MRI data, our study included persons without structural changes of the brain, as well as patients with initial vascular structural changes. Separate foci (gaps), no more than 3-5, up to $5 \mathrm{~mm}$ in diameter, not affecting the basal ganglia; local leukoaraiosis around the lateral ventricles and mild cerebral atrophy were allowable.

Ultrasonography examination included ultrasound (US) duplex scanning of the main neck and brain vessels, was performed according to standard methods using the device "Sonoline G-50" (Siemens, Germany) [7].

In order to determine the functional condition of endothelium, all patients had a flow-mediated endothelium-dependent dilatation (FMD) index assessment based on the results of brachial artery compression test using the US examination. The state of the vasomotor function of the endothelium was evaluated with the help of FMD index increase of the brachial artery diameter (as \%) during the reactive hyperemia test (Celermajer D. S. (1992)). Brachial artery diameter was measured using a 7-10 MHz US sensor; then the blood flow in brachial artery was blocked for 5 minutes using a compression cuff. After quick decompression the change in diameter was recorded in response to an increase in blood flow. Artery reaction to ischemia due to cuff compression leads to normal NO-synthase (eNOS) activation and to release of nitric oxide (NO). An increase in brachial artery diameter is more than $10 \%$ while maintaining vasomotor function of the endothelium. Vascular reaction is considered pathological in cases when the increase in diameter is less than $10 \%$, or in cases of paradoxical vasoconstriction [8].

The patients were subdivided into 3 groups based on their clinical and neuroimaging findings. Persons with VRF and clinical manifestations of CCI without structural changes of the brain entered the $1^{\text {st }}$ group $(n=134)$. Patients with initial vascular structural changes based on their MRI of the brain data were assigned to the $2^{\text {nd }}$ group ( $\left.n=94\right)$. Structural changes in the $2^{\text {nd }}$ group were characterized by the presence of isolated foci, no more than 3 , in the white matter of cerebral hemispheres up to $5 \mathrm{~mm}$ in diameter, delated perivascular spaces (criblures) up to $3 \mathrm{~mm}$ in diameter, local leukoaraiosis, lack of signs of cerebral atrophy. Patients with above-mentioned structural changes and mild cortical and/or internal cerebral atrophy formed the $3^{\text {rd }}$ group $(\mathrm{n}=32)$ [9].

Endothelin-1 (ET-1) levels were studied in 126 patients of the clinical groups and in 20 persons of the control group by enzime immunoassay using Labline- 100 enzime immunoassay analyzer (WestMedica, Austria), using Endothelin-1 ELISA (EIA-3420) reagents, DRG Instruments Inc., USA. The sensitivity of the method was $0,06 \mathrm{ng} / \mathrm{ml}$.

Nitrite levels were measured in 201 patients of the clinical groups by photometric method, using Griess reagent (Sigma-Alorich); Sph-46 spectrophotometer (Russia) with green filter and $520 \mathrm{~nm}$ optical density was also used. The content of nitrite ions was established using the calibration graph. Reference values for nitrite levels in healthy individuals of the appropriate age and gender were based on blood serum samples analysis in 20 persons of the control group.

Statistical data processing was performed using the program SPSS 20.0. Nonparametric statistics methods were used. The Mann-Whitney U-test was used to compare quantitative indicators in two independent groups. The Kruskel-Wallis ANOVA was used to compare persons in more than two independent groups. The significance level of differences was $\mathrm{p}<0.05$, or $\mathrm{p}<0.017$ in pairwise comparison of three groups, $\mathrm{p}<0.013$ when pairwise comparing four groups.

\section{RESULTS}

Clinical signs of initial manifestations of CCI in patients showed headache complains, dizziness, general fatigue, absent-mindedness, wabbliness when walking without focal neurological symptomatics.

Patients in clinical groups had lower FMD rates according to the results of the compression test of the brachial artery in comparison with the control group. Significant differences from the control group in terms of Kruskel-Wallis 
Table 1. Brachial artery FMD indices in the examined cohorts

\begin{tabular}{|c|c|c|c|}
\hline \multirow{2}{*}{ Groups } & \multicolumn{2}{|c|}{ Brachial artery diameter } & \multirow{2}{*}{ FMD index (\%) } \\
\hline & Baseline & After compression & \\
\hline $\begin{array}{l}\text { Control } \\
(n=30)\end{array}$ & $\begin{array}{c}3.5 \\
(3.4-3.7) \\
\end{array}$ & $\begin{array}{c}4.2 @_{*} \\
(4.0-4.5)\end{array}$ & $\begin{array}{l}17.4 \wedge{ }_{*} \&_{*} @_{*} \\
(14.6-19.6)\end{array}$ \\
\hline $\begin{array}{l}\text { Group } 1 \\
(n=134)\end{array}$ & $\begin{array}{c}3.4^{*} \\
(3.1-4.0)\end{array}$ & $\begin{array}{c}4.0 \\
(3.4-4.4)\end{array}$ & $\begin{array}{c}13.8^{*} \\
(10.0-17.6)\end{array}$ \\
\hline $\begin{array}{l}\text { Group } 2 \\
(n=94)\end{array}$ & $\begin{array}{c}3.7 \\
(3.1-4.0)\end{array}$ & $\begin{array}{c}4.0^{* *} \\
(3.4-4.4)\end{array}$ & $\begin{array}{c}9.7^{* * *} \\
(7.3-12.1)\end{array}$ \\
\hline $\begin{array}{c}\text { Group } 3 \\
(n=32)\end{array}$ & $\begin{array}{c}3.3 \\
(3.0-3.4)\end{array}$ & $\begin{array}{c}3.6 \# \\
(3.3-4.2)\end{array}$ & $\begin{array}{c}7.3 \#_{*} \\
(5.8-9.4)\end{array}$ \\
\hline
\end{tabular}

Notes: materiality level value $p<0.05\left(_{*}-p<0.013\right)$ for Mann-Whitney U-test for the relevant indicator:

* - comparing patients of groups 1 та 2;

\# - comparing patients of groups 1 та 3 ;

** - comparing patients of groups 2 та 3 ;

$\wedge$ - comparing patients of group 1 and control group;

\&- comparing patients of group 2 and control group;

@ - comparing patients of group 3 and control group.

Table 2. FMD indices in patients with a different numbers of VRF

\begin{tabular}{ccl}
\hline VRF & Quantity (n) & FMD index (\%) \\
\hline 0 & 30 & $17.4(14.6-19.6)$ \\
\hline 1 & 91 & $12.0(9.8-17.1)^{*}$ \\
\hline 2 & 93 & $10.0(7.3-12.9)^{*}$ \\
\hline 3 & 58 & $9.7(7.7-11.1)^{*}$ \\
\hline 4 & 16 & $9.4(7.4-10.0)^{*}$ \\
\hline 5 & 2 & $7.4(6.7-8.1)^{*}$
\end{tabular}

Notes: ${ }^{*}$ — materiality level value for Mann-Whitney U-test $p=0.01$ when comparing indicators vertically with patients without VRF.

index $\left(\mathrm{p}=0,01 \cdot 10^{-4}\right)$ : FMD index in control group was $\mathrm{Me}$ $\left(\mathrm{Q}_{1}-\mathrm{Q}_{3}\right): 17.4 \%(14.6-19.6 \%)$, in patients of the $1^{\text {st }}$ group $13.8 \%(10.0-17.6 \%)$, remaining within the normal range, while in patients of the $2^{\text {nd }}$ group $-9.7 \%(7.3-12.1 \%)$, in $3^{\text {rd }}$ group $-7.3 \%(5.8-9.4 \%)$. So, 17 (53.1\%) patients of the $3^{\text {rd }}$ group had reduced FMD indices.

Analysis of FMD indices allowed us to distinguish a group of patients with diffuse ED. It was found that the presence of ED according to the compression test results was reliably associated with degree of structural damage to the brain in initial CCI, namely, $\mathrm{X}_{(2)}^{2}=81.66$; Cramer's $\mathrm{V}=0.517(\mathrm{p}<0.001)$. The FMD indices in the groups were distributed according to the degree of structural changes to the brain are presented in the table 1 .

At the same time a statistically significant association was discovered between signs of ED and the presence of small foci of vascular character in the white matter of cerebral hemispheres $\left(\mathrm{X}^{2}=47.0\right.$; Cramer's $\left.\mathrm{V}=0.393, \mathrm{p}<0.001\right)$, with relative risk of small vascular foci being 2.7 times higher (CI 2.0-3.7) in persons with diffuse ED. A weak association was established between the presence of leukoaraiosis and diffuse $\mathrm{ED}\left(\mathrm{X}^{2}=26.8\right.$; Cramer's V $\left.=0.296, \mathrm{p}<0.001\right)$. The relative risk of the occurrence of leukoaraiosis alongside ED according to the compression test results was 2.2 times higher (CI 1.7-2.8).
The presence of mild cerebral atrophy was significantly associated with diffuse $\mathrm{ED}\left(\mathrm{X}^{2}=44.3\right.$; Cramer's $\mathrm{V}=0.381$, $\mathrm{p}<0.001$ ), and relative risk of the development of cerebral atrophy due to ED was 2.6 times higher (CI 2.0-3.3). The presence of changes in vascular origin on MRI in patients with initial signs of CCI was also significantly associated with diffuse ED with strong density bond $\left(\mathrm{X}^{2}=59.7\right.$; Cramer's $V=0.442, p<0.001)$. The risk of MRI changes due to $\mathrm{ED}$ according to the compression test results was 3.4 times higher (CI 2.4-4.8).

Comparison of brachial artery compression test results with the number of VRF in patients established moderate correlation between the number of VRF and the FMD indices $(r=-0.373, p<0.001)$. The patients with a different number of VRF were statistically significantly different in terms of FMD (by Kruskel-Wallis test $\mathrm{X}_{(6)}=46.4 ; \mathrm{p}=0.03 \cdot 10^{-}$ $\left.{ }^{3}\right)$. Data on the distribution of the FMD index depending on the number of VRF represented in table 2.

One of the most common VRF in patients with initial signs of CCI was AH.

The data analysis revealed a low density association between the presence of $\mathrm{AH}$ and signs of $\mathrm{ED}$ according to the compression test results $\left(\mathrm{X}_{(1)}^{2}=13.7\right.$; Cramer's $\mathrm{V}=0.212$, $\mathrm{p}<0.001)$. Statistical processing of data on FMD index dis- 
Table 3. FMD indices depending on changes in biochemical markers

\begin{tabular}{|c|c|c|c|c|c|}
\hline \multirow{2}{*}{ Vasomotor function of endothelium } & \multicolumn{2}{|c|}{ Unchanged } & \multicolumn{2}{|c|}{ With changes } & \multirow{2}{*}{$\mathbf{p}$} \\
\hline & Me & $Q_{1}-Q_{3}$ & Me & $Q_{1}-Q_{3}$ & \\
\hline ET-1 level & \multicolumn{2}{|c|}{ Within normal limits $(n=84)$} & & $\begin{array}{l}\text { ased } \\
\text { 42) }\end{array}$ & \multirow[t]{2}{*}{$<0.001$} \\
\hline FMD index (\%) & 14.3 & $10.0-19.6$ & 10.0 & $9.1-14.3$ & \\
\hline Nitrite level & \multicolumn{2}{|c|}{$\begin{array}{l}\text { Within normal limits } \\
\qquad(n=118)\end{array}$} & \multicolumn{2}{|c|}{$\begin{array}{l}\text { Outside the norm } \\
\qquad(\mathrm{n}=83)\end{array}$} & \multirow{2}{*}{$<0.001$} \\
\hline FMD index (\%) & 16.1 & $10.0-20.0$ & 10.0 & $8.6-12.5$ & \\
\hline
\end{tabular}

tribution in patients without $\mathrm{AH}(57$ / 21.9\%) and with $\mathrm{AH}$ (171/65.8\%) showed a statistically significant difference between cohorts of patients in ability to FMD, namely Me $\left(\mathrm{Q}_{1}-\mathrm{Q}^{3}\right): 13.3 \%(10.0$ - $17.9 \%)$ та $10.0 \%(7.5-12.5 \%)$, $\mathrm{p}<0.05$ for the Mann-Whitney U-test. Office systolic blood pressure was moderately inversely correlated with FMD indicator $(\mathrm{r}=-0.306)$.

Besides, it was discovered that patients with $2^{\text {nd }}$ degree AH (66 / 38.5\%) had a statistically significant lower FMD rates $-\mathrm{Me}\left(\mathrm{Q}_{1}-\mathrm{Q}_{3}\right): 9.7 \%(6.7-12.0 \%)$ in comparison with $1^{\text {st }}$ degree hypertension patients $(105 / 61.4 \%)-10.0 \%$ $(8.6-13.3 \%), p<0.05$ for the Mann-Whitney U-test [8].

A significant marker of subclinical arterial damage is the thickening of the intima-media complex (IMC) in common carotid artery $>0.9 \mathrm{~mm}$, its disorganization. It was established that in persons with IMC $\leq 0,9 \mathrm{~mm}(162 / 62.3 \%)$ the FMD index median $(\mathrm{Me})$ was $11.8 \%(9.4-17.2 \%)$. In patients with IMC $>0.9 \mathrm{~mm}$ (98/37.7\%) FMD index was lower $-9.8 \%(7.3-11.9 \%)$. Wherein the patients in groups were statistically significant different for this FMD index for the Mann-Whitney U-test $\left(\mathrm{p}=0.004 \cdot 10^{-2}\right)$.

It was found that the thickening of the IMC moderately associated with diffuse ED according to the compression test results $\left(\mathrm{X}^{2}=10.1\right.$; Cramer'V $\left.=0.239, \mathrm{p}=0.001\right)$, wherein the relative risk of diffuse ED in patients with thickened IMC was 1.8 times higher (CI 1.3-2.6).

Assessment of biochemical parameters of vasomotor function of endothelium showed statistically significant differences between the groups of patients, which confirms the participation of this factors in the pathogenesis of the initial manifestations of CCI [10]. So, signs of vasomotor endothelial dysfunction revealed by biochemical markers were found in 91 patients. In 83 / 201 / 41.3\% patients endothelial dysfunction was due to a deviation in the nitrite level. The levels of this index $\left(\mathrm{Me}\left(\mathrm{Q}_{1}-\mathrm{Q}_{3}\right)\right.$, micromole/l) significantly differed in clinical and control groups: 5.24 $(4.79-6.77)$ in the $1^{\text {st }}$ group, $3.57(2.41-4.16)$ in the $2^{\text {nd }}, 2.28$ $(1.82-4.16)$ in the $3^{\text {rd }}$ and $4.61(4.18-5.02)$ in the control group, materiality level value $\mathrm{p}<0.0125$ for Mann-Whitney U-test. An increase in endothelin-1 (ET-1) levels occurred in $42 / 126 / 33.3 \%$ patients in the $2^{\text {nd }}$ and $3^{\text {rd }}$ groups, with a significant difference in indices relative to control ( $\mathrm{Me}$ $\left.\left(\mathrm{Q}_{1}-\mathrm{Q}_{3}\right), \mathrm{ng} / \mathrm{ml}\right): 0.478(0.311-1.38)$ in the $2^{\text {nd }}$ group, 2.02 $(0.566-2.46)$ in the $3^{\text {rd }}$ group and $0.211(0.176-0.258)$ in control group, materiality level value $\mathrm{p}<0.0125$ for
Mann-Whitney U-test. There were no significant differences in ET- 1 levels in the $1^{\text {st }}$ group $(0.222(0.163-0.395)$ $\mathrm{ng} / \mathrm{ml}$ ) in comparison with the control group.

Relationship between oppositely directed vasomotor factors of endothelium (ET-1 and nitrite) showed significant inversely correlated density $(r=-0.865, p=0.03 \cdot 10$ ${ }^{3}$ ), and the connection significantly decreased with the onset of structural brain damage in the presence of VRF $\left(r=-0.368, p=0.012 \cdot 10^{-2}\right)$. This indicated the importance of an imbalance between vasomotor endothelial factors with progression of CCI.

The level of biochemical markers of vasomotor endothelial function had a statistically significant association of moderate strength with FMD indices: ET-1 level inversely correlated with FMD index $\left(r=-0.345, p=0.02 \cdot 10^{-4}\right)$; nitrite level directly correlated with FMD index on Spearman coefficient $\left(\mathrm{r}=0.319, \mathrm{p}=0.008 \cdot 10^{-2}\right)$.

The presence of ED according to the compression test results was poorly associated with increased ET-1 levels $\left(\mathrm{X}^{2}=6.2\right.$; Cramer's $\left.\mathrm{V}=0.222, \mathrm{p}=0.013\right)$, the relative risk of the development of diffuse ED amid rising ET-1 level was 1.5 times higher (DI 1.1-2.0). The presence of diffuse ED was poorly associated with deviation of the nitrite level $\left(\mathrm{X}^{2}=6.5\right.$; Cramer's $\left.\mathrm{V}=0.18, \mathrm{p}=0.011\right)$ and the relative risk of the coexistence of these changes increased 1.2 times (DI 1.1-1.5).

Given the possibility of deviations of the nitrite level both above and below the normative values, a relationship was found between nitrite level deviation and ED according to the compression test results, a moderate strength relationship was identified $\left(\mathrm{X}_{(2)}^{2}=20.3\right.$; Cramer's $\mathrm{V}=0.319$, $\mathrm{p}<0.001$ ).

Taking into consideration the poors relationship between FMD indices and biochemical markers of vasomotor endothelial function, analysis of the FMD index depending on the presence or absence of vasomotor dysfunction was performed (table 3).

The data presented in the table 3 indicated that FMD indices according to the brachial artery compression test results were statistically significantly lower in persons with ET-1 and nitrite levels deviations.

\section{DISCUSSION}

Overall, patients in clinical groups had lower FMD indices according to the compression test for reactive hyperemia 
in the brachial artery in comparison with the control group [11].

It was found out that the presence of common ED according to the compression test results was significantly associated with the degree of structural damage to the brain in initial manifestations of CCI $\left(\mathrm{X}_{(2)}^{2}=81.66, \mathrm{p}<0,001\right)$. The relative risk of MRI changes due to diffuse ED was 3.4 times higher (CI 2.4-4.8) [12].

Persons with thickened IMC $>0.9 \mathrm{~mm}$ had signs of diffuse ED according to the compression test results. It was found out that the thickening of the IMC was moderately associated with common $\mathrm{ED}\left(\mathrm{X}^{2}=10.1\right.$; Cramer's $\mathrm{V}=0.239$, $\mathrm{p}=0.001)[11,13]$.

A study of biochemical markers of of vasomotor function of endothelium has established that nitrite level in patients of the $1^{\text {st }}$ group was significantly higher in comparison to persons in control group and groups 2 and 3. While ET-1 levels progressively increased in clinical groups, the control group and group 1 without structural brain damage were an exception for the ET-1 index, which confirms the value of this marker for the formation of clinically significant structural brain damage. At the same time, patients with structural brain damage (groups 2 and 3) did not differ in nitrite levels; $\mathrm{NO}$ concentration was important at the early stages of CCI.

The correlation between ET-1 and nitrite was inverse and had a significant density $\left(\mathrm{r}=-0.865, \mathrm{p}=0.03 \cdot 10^{-3}\right)$, the connection density significantly decreased as brain damage appeared alongside vascular risk factors $(\mathrm{r}=-0,368$, $\left.\mathrm{p}=0,012 \cdot 10^{-2}\right)$. This indicates the significance of imbalance between vasomotor factors in endothelium with CCI progression. In other words, as ET-1 levels increased and nitrite levels decreased, a downward trend in FMD index was observed [10].

The dynamism of the synthesis of biologically active substances in the endothelium in healthy persons and in pathological conditions was observed earlier, however, it requires further study $[14,15]$.

Further research may be directed at finding other factors affecting the endothelial function in patients with initial manifestations of CCI and determination of their prognostic significance for clinical progression of CCI.

\section{CONCLUSIONS}

1. Study results confirm that diffuse ED has a part in the development of the initial manifestations of CCI.

2. According to the brachial artery compression test, the presence of diffuse ED is significantly associated with the degree of structural damage to the brain.

3. It has been found out that combinations of VRF contribute to the occurrence of diffuse ED thus promoting a greater probability of vascular events. The tendency to the decrease of FMD indices due to the increased number of simultaneously existing VRF was determined.

4. FMD indices were significantly lower in patients with grade $2 \mathrm{AH}$ in comparison to those with $\mathrm{AH} 1$ and without hypertension $(\mathrm{p}<0.05)$.

5. The presence of diffuse ED was associated with structural changes in the carotid arteries.
6. FMD indices were significantly lower in persons with impaired vascular function of the endothelium according to biochemical markers when the levels of ET- 1 or nitrite were deviant from a norm, drawing close to ED borderline.

\section{REFERENCES}

1. Filipets 0.0. , Pashkovsky V. M. Stroke Burden in Ukraine: Analysis of the Official Stroke Statistics and Overview of PopulationBased Epidemiological Studies. J Clin Exp Pathol, . 2014; 13 (3): 189-193.

2. Piepoli M. F., Hoes A. W., Albus C. et al. European Guidelines on cardiovascular disease prevention in clinical practice. Eur. Heart J. 2016; 37: 2315-81.

3. Nelson M. R. Doust J. A. Primary prevention of cardiovascular disease: new guidelines, technologies and therapies. Med. J. 2013; 198 (11): 606-10.

4. Poggesi A, Pasi M, Pescini F et al. Circulating biologic markers of endothelial dysfunction in cerebral small vessel disease: A review. J. Cereb. Blood Flow Metab. 2016; 36 (1): 72-94.

5. Choi H. A. Lee M. J., Chung C.S. Cerebral endothelial dysfunction inreversible cerebral vasoconstrictionsyndrome: a case-control study. The Journal of Headache and Pain. 2017; 18(1): 29.

6. Matsuzawa Y., Sugiyama S., Sumida H. et al. Peripheral endothelial function and cardiovascular events in high-risk patients. J. Am. Heart Assoc. 2013; 2 (6):e000426.

7. Globa M.V. KalashnikovV.I., Lins'ka G.V. Propozitsiï schodo standartizatsiï ul'trazvukovogo doslidzhennya sudin shiï ta golovi. [Ultrasonography of blood vessels of the head and neck: proposals for standardization]. J. Ukraine neurosurgical. 2017; 1 (77): 40-45.

8. Trishchynska M. A. Potokozalezhna vazodilyatatslya u zhinok z pochatkovimi proyavami hronichnoyi ishemiyi mozku [Flowmediated dilation in women with initial manifestations of cerebral ischemia]. Zdorove zhenschinyi. 2016; 2 (108): 56-59. (In Ukrainian)

9. Arablinskiy A. V., Makotrova T. A., Trusova N. A. et al. Neyrovizualizatsionnyie markeryi tserebralnoy mikroangiopatii po dannyim magnitno-rezonansnoy tomografi. [Neuroimaging markers of cerebral microangiopathy according to magnetic resonance imaging]. Rossiyskiy elektronnyiy zhurnal luchevoy diagnostiki. 2014;4(1):24-33. (In Russian)

10. Trishchynska M. A. Stan sudinoruhovoyi funktsiyi endoteliyu v patcientiv z tserebrovaskulyarnoyu patologieyu riznogo stupenya tyazhkosti [State of vasomotor endothelial function in patients with cerebrovascular pathology different severity]. Ukrayinskiy nevrologlchniy zhurnal. 2015; 3: 26-29. (In Ukrainian)

11. SanchetiS. Shah P., Phalgune D.S. Correlation of endothelial dysfunction measured by flow-mediated vasodilatation to severity of coronary artery disease. Indian Heart J. 2018; 70(5): 622-26.

12. Konukoglu D., Uzun H. Endothelial Dysfunction and Hypertension. Adv Exp Med Biol. 2017; 956: 511-40.

13. Ghosh A., Gao L., Thakur A. et al. Role of free fatty acids in endothelial dysfunction. J Biomed Sci. 2017; 24(1): 50.

14. Durand M. J., Gutterman D. D. Diversity in Mechanisms of EndotheliumDependent Vasodilation in Health and Disease. Microcirculation. 2013; 20(3): 239-47.

15. A. Vilar-Bergua, L. Riba-Llena, C. Nafria, A. et al. Blood and CSF biomarkers in brain subcortical ischemic vascular disease: Involved pathways and clinical applicability J. Cereb. Blood Flow Metab. 2016; 36(1): 55-71. 
The research was performed in accordance with the research plan of Department of Neurology №1 in P. L. Shupyk National Medical Academy of Postgraduate Education, Kiev, Ukraine, research work by state registration number 0111 U008888 (without funding)

\section{Authors' contributions:}

According to the order of the Authorship.

\section{ORCID numbers:}

Maryna A. Trishchynska - 0000-0002-1022-0635

Maryna V. Globa - 0000-0001-5112-5143

Vasyl V. Orzheshkovskyi - 0000-0002-9033-0753

Yuriy V. Voronenko - 0000-0003-4945-1817

Yurij I. Holovchenko - 0000-0003-0152-1759

Olena V. Tkachenko - 0000-0001-5486-4996

Vasyl M. Mykhalchuk - 0000-0002-5398-4758

\section{Conflict of interest:}

The Authors declare no conflict of interest.

\section{CORRESPONDING AUTHOR}

\section{Vasyl M. Mykhalchuk}

Department of Healthcare Management of

Shupyk National Medical Academy of Postgraduate Education 9 Dorohozhytska Str., Kyiv, 04112, Ukraine

e-mail: shepit@ukr.net

Received: 05.07.2019

Accepted: 30.09 .2019 


\title{
PECULIARITIES OF THE PROCESS OF PSYCHOLOGICAL ADAPTATION OF FOREIGN STUDENTS OF UKRAINIAN HIGHER EDUCATION INSTITUTIONS OF MEDICAL PROFILE, ROLE OF EMOTIONAL INTELLIGENCE IN THE SOCIALIZATION PROCESS
}

\author{
Larysa Katrushova', Svitlana Yalanska' ${ }^{1}$, Lesia Rudenko², Oleksandr Katrushov ${ }^{3}$ \\ 'POLTAVA V.G. KOROLENKO NATIONAL PEDAGOGICAL UNIVERSITY, POLTAVA, UKRAINE \\ ${ }^{2}$ ALUNA PUBLISHING, KONSTANCIN-JEŻIORNA, POLAND \\ 3UKRAINIAN MEDICAL STOMATOLOGICAL ACADEMY, POLTAVA, UKRAINE
}

\begin{abstract}
Introduction: The dynamics of increasing rates of interstate educational migration of student youth exacerbates the problems of psychological adaptation and socialization of foreign students in the context of the recipient country's society.

The aim is to study the peculiarities of emotional intelligence changes in the process of social adaptation of foreign students of Ukrainian higher educational institutions of medical profile in the conditions of educational migration.

Materials and methods: There were formed the observational groups of foreign students, natives from different countries, varying in linguistic affiliation and religion. In the research the Hall Emotional Intelligence Test (EQ test) was used, which gave an opportunity to evaluate the dynamics of emotional intelligence development in the process of learning and social adaptation in relation to the first and last courses at a medical higher education institution.

Results: As a result of the conducted researches it is possible to notice a marked increase of the level of emotional intelligence in the process of education and socialization of different ethnic groups of foreign students in Ukraine. At initial values in the first year of study (within 30,0-38 points), which is treated as "low" level, after the end of the sixth course of study this indicator increased to values of 59-72 points, which falls within the limits of values of "average", and even "high" in English speaking educational groups (Ghana, Nigeria, Sudan). The obtained data have a statistical probability $(p<0.05)$. It is especially important to emphasize the growth of more than 2 times the components of emotional intelligence on the scales "empathy" and "management of other people, emotions" which are crucial for the successful fulfillment of their professional duties as a doctor. At these scales, the indicators reached the "high" level at statistical probability $(p<0.05)$. First-year students from Arab countries had the lowest baseline on the scale of "managing of one's emotions" $(5.9+0.4)$, which led to a sufficiently large number of manifestations of deviant behavior, but by the end of the sixth course, this indicator increased to values $10.0+0.9(\mathrm{p}<0.05)$. Accordingly, the deviance of behavioral responses has decreased significantly.

Conclusions: In our view, it is expedient to deepen the theoretical analysis of the social-psychological portrait of migrant students with the aim of their effective psychological and pedagogical support in the process of adaptation and assistance while building a professional perspective on the basis of effective development of emotional intelligence.
\end{abstract}

KEY WORDS: foreign students, psychological adaptation, socialization, educational migration, emotional intelligence

Wiad Lek 2019, 72, 10, 1930-1934

\section{INTRODUCTION}

Recently, interest to the problem of migration in general, and interstate educational migration of young people as one of the vectors of migration, in particular, has become the focus of psychological science. Educational migration is mainly called temporary resettlement, which lasts from several months to several years and is aimed at studying outside the administrative-territorial unit of permanent residence [1].

\section{ANALYSIS OF RECENT RESEARCH AND PUBLICATIONS}

The global socio-economic systemic changes in the world and the increasing tempos of interstate educational migration of young people exacerbate the importance of the problem of social adaptation of broad contingents of student youth in the new conditions of a "foreign" society. One of the key issues is deviant behavior caused by the conflict of moral and ethical norms and rules of the country of residence of migrant students and the new society. This necessitates a more in-depth study of the causes and forms of deviant behavior, the search for more effective measures of preventive, corrective, rehabilitation and other nature $[2,3]$. This is especially concerns the medical faculties students, as obtaining the profession of doctor is considered to be the most difficult educational process in the world. This necessitates a more in-depth study of disadaptation problems, since effective professional training of a future doctor cannot be conducted without a high degree of student assimilation into the learning process. 
The need for acquaintance and research of this problematic situation with a wide range of specialists — psychologists, lawyers, educators, social workers, doctors, law enforcement officers and others, grows objectively. In order to solve the consultative and corrective practical problems effectively a specialist psychologist and teacher need systematic knowledge about social behavior disorders that lead to personality deformation, serious consequences in interpersonal relationships and social disadaptation in society [4].

\section{THE AIM}

The aim of the research was to study the peculiarities of emotional intelligence changes in the process of social adaptation of foreign students of Ukrainian higher edu- cation institutions of medical profile in the conditions of educational migration.

\section{MATERIALS AND METHODS}

We conducted a research of possible predicted behavioral reactions of a person, depending on the degree of development of emotional intelligence in the social adaptation of foreign students in the process of study at the Ukrainian higher education institutions, with the help of screening psychological testing. Since psychological tests require a profound knowledge of the language in order to understand the nuances of the test questions asked, it is not necessary to count on reliable answers when testing first-year students with Ukrainian or Russian-language tests. This

Table 1. The largest ethnic groups of foreign students are presented with the citizens of the following countries (2010 - 2017)

\begin{tabular}{|c|c|c|}
\hline \multicolumn{3}{|c|}{ Countries of the Arab world (Maghreb and Mashriq) } \\
\hline Country of permanent residence & Amount of students & Language \\
\hline Egypt & $32-43$ & Arabic \\
\hline Eritrea & $2-8$ & Arabic \\
\hline Yemen & $8-11$ & Arabic \\
\hline Israel & $34-42$ & Hebrew, Arabic \\
\hline Iraq & $43-49$ & Arabic \\
\hline Jordan & $96-123$ & Arabic \\
\hline Kuwait & $14-18$ & Arabic \\
\hline Lebanon & $9-16$ & Arabic \\
\hline Libya & $8-13$ & Arabic \\
\hline Morocco & $77-84$ & Arabic \\
\hline Palestine & $21-30$ & Arabic \\
\hline Syria & $8-11$ & Arabic \\
\hline Tunisia & $18-24$ & Arabic \\
\hline \multicolumn{3}{|c|}{ CIS countries and post. Soviet space } \\
\hline Azerbaijan & $33-38$ & Azerbaijani \\
\hline Russian Federation & $21-25$ & Russian \\
\hline Tajikistan & $9-13$ & Tajik \\
\hline Turkmenistan & $97-112$ & Turkmen \\
\hline Uzbekistan & $62-73$ & Uzbek \\
\hline \multicolumn{3}{|c|}{ Countries of the African continent not members of the Arab League } \\
\hline Ghana & $17-23$ & English \\
\hline Nigeria & $19-27$ & English \\
\hline Cameroon & $2-6$ & English, French \\
\hline Sudan & $29-34$ & Arabic, English \\
\hline Uganda & 3- 7 & English, Swahili \\
\hline \multicolumn{3}{|c|}{ Asian countries } \\
\hline India & $33-42$ & $\begin{array}{c}\text { English, Hindi and others (26 } \\
\text { languages). }\end{array}$ \\
\hline Iran & $9-14$ & Persian (Farsi) \\
\hline Pakistan & $3-7$ & Urdu, English \\
\hline China & $1-5$ & Chinese \\
\hline
\end{tabular}


was demonstrated by our previous studies, when identical tests in Ukrainian or Russian languages (depending on the profile of the preparatory department) and in the firstyear student's native language gave incomparable results. We thank the UMSA (Ukrainian Medical Stomatological Academy) foreign clinical ordinators as native speakers, for their help in translating psychological tests into the languages of major ethnic groups of students studying at the Academy. Applicable psychological tests were selected and adapted into Russian, English and native languages of the ethnic groups - Arabic, Azerbaijani, Uzbek, Turkmen to identify and predict possible reactions of the person for changing social environment, as well as to form observation groups. In the research the Hall Emotional Intelligence Test (EQ test) was used, which gave an opportunity to evaluate the emotional intelligence dynamics in the process of learning and social adaptation.

\section{RESULTS AND DISCUSSION}

The complicated socio-political conditions caused by military actions in eastern Ukraine do not contribute to the development of large-scale educational migration of students from other countries to get higher education in Ukrainian higher education institutions. It is very likely that this statement is true for medical higher education institutions. The statistics of the movement of foreign students studying at the Ukrainian Medical Stomatological Academy shows that in 2011 their total number was 822 persons, in 2014 - 645, and in 2017 - 571. The decrease in the number of foreign students was due to reducing enrollment to the first year of study. However, educational migration is a prolonged process that covers many years, so significant quantitative fluctuations at the time of observation are displayed mainly by first-course students. The contingent of foreign students studying at the Ukrainian Medical Stomatology Academy fluctuated quantitatively according to the data of the dean's office for work with foreign students during the years of analysis (2010 - 2017) from 571 persons to 784 persons, and included citizens from more than 40 countries.

Also, during the observation period citizens of Belarus, Great Britain, Georgia, Denmark, the Netherlands, Germany, Poland, the USA, Sweden were studying at the Academy. But the number of contingents from each country did not reach 5 people every year, so we did not include them into our studies, especially since these students are usually descendants of Ukrainian emigrants, and they do not observe any particular problems with social adaptation in Ukraine. The above statement also applies to students, which are Israel citizens.

As can be seen from Table 1, the largest group of foreign students was made up of persons whose mother tongue is Arabic (about 450 students, natives of 13 countries), followed by Turkmen (about 100), English (almost 90), Uzbek (about 70), Azerbaijani (about 35). The prevailing religions are Islam, Christianity, Hinduism.
Despite the decrease in educational migration tempos, the problems of social adaptation of migrant students in Ukrainian society do not lose their relevance and urgency.

From the point of view of pedagogy and psychology, education acts as a result of learning and upbringing $[5,6]$. Education is regarded as "a process of formation of consciousness, and upbringing appeals mainly to the subconscious" [7]. Moreover, both categories do not exist separately from each other: there is always a share of upbringing in learning, and in upbringing there is a share of learning. Migrants moving to another country form new attitudes, habits in accordance with the new social environment, which is a manifestation of self-upbringing. And their learning consists in acquiring certain knowledge, including outlook, moral and ethical, legal, aesthetic and others. Communication is regarded as "interaction between a certain number of people, which is connected with the transfer of information", and learning is defined as "any improvement in behavior, awareness, knowledge, understanding, attitudes, values, abilities" [8]. It is important to note that during the educational period, there is an expansion of communication channels for receiving information, and the level of emotional intelligence increases. All of this contributes to the acceleration of social adaptation and manifests the positive changes in behavioral reactions.

Since deviant behavior is a form of personal behavior, all the basic properties of human behavior are inherent to it. In psychology the term behavior is used to determine the type and level of human activity. Modern understanding of behavior goes beyond the reactions to an external stimulus. In addition to external human activity (movement, activity, actions, expressions, vegetative reactions), there are also internal components in behavior: motivation and purposefulness, cognitive processing, emotional reactions, self-regulation processes. Behavior is a process of interaction of a person with the social environment, mediated by individual characteristics and internal activity of the person, which is expressed in the form of external actions and deeds. Human behavior is social (formed and implemented in society) and connected with to language regulation. In general, the behavior of a person reflects the process of its socialization - integration into society. Socialization, in turn, implies adaptation to the social environment, taking into account individual peculiarities. The following variants of social adaptation can be distinguished [9]:

- radical adaptation - self-realization through the person's changes of the existing social world;

- hyperadaptation - self-realization through the influence of a person on social life indirectly through over-achievement;

- harmonious adaptation - the self-realization of a person in society is mediated through the orientation to social demands;

- conformist adaptation - adaptation through the suppression of individuality, blocking self-realization;

- deviant adaptation - self-realization indirectly through going beyond the existing social requirements (norms); - social and psychological disadaptation - a state of 
Table 2. Dynamics of students emotional intelligence development in the process of obtaining higher medical education according to the Hall test

\begin{tabular}{|c|c|c|c|c|c|c|}
\hline \multirow[t]{2}{*}{ Scales } & \multicolumn{2}{|c|}{$\begin{array}{c}\text { Arab countries (Arabic } \\
\text { language, faith-Islam - Islam) }\end{array}$} & \multicolumn{2}{|c|}{$\begin{array}{l}\text { Turkmenistan (Turkmen } \\
\text { language, Islam - Religion) }\end{array}$} & \multicolumn{2}{|c|}{$\begin{array}{l}\text { Ghana, Nigeria, Sudan (English, } \\
\text { Religion - Christianity, Islam) }\end{array}$} \\
\hline & I course & 6 course & 1 course & 6 course & 1 course & 6 course \\
\hline Emotional awareness & $\begin{array}{r}7,0 \\
\pm 0,9 \\
\end{array}$ & $\begin{array}{r}12,0 \\
\pm 1,4 \\
\end{array}$ & $\begin{array}{r}7,0 \\
\pm 0,8 \\
\end{array}$ & $\begin{array}{r}13,0 \\
\pm 2,2 \\
\end{array}$ & $\begin{array}{r}6,0 \\
\pm 0,7 \\
\end{array}$ & $\begin{array}{r}14,0 \\
\pm 1,9 \\
\end{array}$ \\
\hline Manage your emotions & $\begin{array}{r}5,9 \\
+0,4 \\
\end{array}$ & $\begin{array}{r}10,0 \\
\pm 0,9 \\
\end{array}$ & $\begin{array}{r}8,0 \\
\pm 1,1 \\
\end{array}$ & $\begin{array}{r}12,0 \\
\pm 1,4 \\
\end{array}$ & $\begin{array}{r}11,0 \\
\pm 0,9 \\
\end{array}$ & $\begin{array}{r}14,0 \\
\pm 1,8 \\
\end{array}$ \\
\hline Self-motivation & $\begin{array}{r}6,0 \\
\pm 0,5 \\
\end{array}$ & $\begin{array}{r}11,0 \\
\pm 1,3 \\
\end{array}$ & $\begin{array}{r}7,0 \\
\pm 0,9 \\
\end{array}$ & $\begin{array}{r}12,0 \\
\pm 1,7 \\
\end{array}$ & $\begin{array}{r}10,0 \\
\pm 1,1 \\
\end{array}$ & $\begin{array}{r}15,0 \\
\pm 1,5 \\
\end{array}$ \\
\hline Empathy & $\begin{array}{r}8,0 \\
\pm 1,0 \\
\end{array}$ & $\begin{array}{r}14,0 \\
\pm 1,6 \\
\end{array}$ & $\begin{array}{r}8,0 \\
\pm 1,1 \\
\end{array}$ & $\begin{array}{r}16,0 \\
\pm 1,4 \\
\end{array}$ & $\begin{array}{r}12,0 \\
\pm 1,6 \\
\end{array}$ & $\begin{array}{r}15,0 \\
\pm 1,3 \\
\end{array}$ \\
\hline $\begin{array}{l}\text { Managing the emotions of } \\
\text { other people }\end{array}$ & $\begin{array}{r}4,0 \\
+0,5 \\
\end{array}$ & $\begin{array}{r}13,0 \\
\pm 1,1 \\
\end{array}$ & $\begin{array}{r}6,0 \\
+0,4 \\
\end{array}$ & $\begin{array}{r}11,0 \\
+0,9\end{array}$ & $\begin{array}{r}9,0 \\
\pm 0,7 \\
\end{array}$ & $\begin{array}{r}14,0 \\
\pm 1,5 \\
\end{array}$ \\
\hline $\begin{array}{l}\text { Integrative level of } \\
\text { emotional intelligence }\end{array}$ & $\begin{array}{r}30,0 \\
\pm 4,3\end{array}$ & $\begin{array}{r}59,0 \\
\pm 6,1\end{array}$ & $\begin{array}{r}36,0 \\
\pm 4,1\end{array}$ & $\begin{array}{r}64,0 \\
\pm 8,2\end{array}$ & $\begin{array}{r}38,0 \\
\pm 5,4\end{array}$ & $\begin{array}{r}72,0 \\
\pm 9,3\end{array}$ \\
\hline
\end{tabular}

blocking the processes of self-realization and adaptation. In any variant of socialization the behavior of a specific person can be described using the general characteristics of behavior:

- motivation - an internal conscious willingness to act, guided by the needs and goals of the person;

- adequacy - consistency with the specific situation;

- adaptability - correspondence to the leading requirements of the social environment, namely, to moral and ethical;

- authenticity - the correspondence of the individual's behavior, its naturalness for the person;

- productivity - realization of conscious goals.

Equally important are the following features of behavior of a person, such as:

- level of activity (energy and initiative);

- emotional expressiveness (strength and nature of manifesting affect);

- dynamic (tempo);

- stability (constancy of manifestations at different times and in different situations);

- awareness (understanding of one's behavior);

- spontaneity (self-control);

- flexibility (behavior changes in response to environmental changes).

All the considered characteristics of the concept of "behavior" extend to such its variety as the "deviant behavior" of a person, which is often found among foreign students at the initial stage of adaptation to the conditions of stay and study in a new society. Data of the development of emotional intelligence and its dynamics of foreign students of different ethnic groups for I - 6 courses of study are presented in table 2 .

When analyzing the data presented in Table 2, it is possible to see a marked increase in the level of emotional intelligence in the process of education and socialization of different ethnic groups of foreign students in Ukraine. At the initial values in the first year of study (within 30.038 points), which is treated as "low" level, after the end of the sixth course of study this indicator increased to the values of 59-72 points, which falls within the limit values of "medium" and even "high" levels in English speaking educational groups (Ghana, Nigeria, Sudan). The obtained data have a statistical probability $(\mathrm{p}<0.05)$. It is especially important to emphasize the growth of more than 2 times the components of emotional intelligence on the scales "empathy" and "management of other people emotions" which are crucial for the successful fulfillment of their professional duties as a doctor. At these scales, the indicators reached the "high" level at statistical probability ( $\mathrm{p}$ $<0.05$ ). The lowest baseline on the scale of "managing their emotions" $(5.9+0.4)$ had first-year students from Arab countries, which led to a sufficiently large number of manifestations of deviant behavior, but by the end of the sixth year this indicator increased to values $10.0+0.9(\mathrm{p}<0.05)$. Accordingly, the deviance of behavioral responses has decreased significantly.

Based on the above, we can outline the main vectors that contribute to the psychological adaptation and adequate socialization of foreign students in the conditions of Ukrainian society during educational migration due to the dynamics of the development of emotional intelligence.

1. Personally-motivational attitude to the higher educational institutions and study: the willingness (or unwillingness) to take educational tasks, to fulfill the lecturer's assignments, in other words - to study.

- According to this vector of student socialization, the efforts of the higher educational institutions administration and the teaching staff are minimized, as the motivation and personal student's desire to willingness are decisive.

2. Acceptance of the educational task: understanding of the tasks set by the lecturer; willingness to fulfill them; desire of success or the desire to avoid the failure.

- Overcoming the language barrier is extremely important in this point, as learning is impossible without a thorough understanding of the information provided. This is especially important for the medical student, because the process of information assimilation is followed by its 
comprehension, associative synthesis of the answer to the task (conducting the differential diagnosis, preparation of treatment plan, medical prognosis of consequences, etc.).

3. The idea of the content of the educational activity and ways of its implementation: the level of elemental knowledge and skills formed before the start of training.

- Existence of basic level of knowledge is a necessary component of learning success. There are problems for foreign students in this perspective, as general secondary education programs in the countries of residence are different from the Ukrainian ones.

4. Information field: provides the perception, processing and storage of different information in the learning process.

- The information field for the medical student is very extensive and forms gradually in the process of education - from theoretical disciplines to clinical ones, which contributes to the accumulation of information and the widening of the outlook.

5. Activity management: planning, controlling and evaluating one's own activities, as well as receptivity to learning.

- The concept of "activity management" contains the self-management, based on a sufficiently high level of IQ (innate intelligence that practically does not change with age and education), and EQ (emotional intelligence, which is formed in the process of life and learning).

\section{CONCLUSION}

In our view, it is expedient to deepen the theoretical analysis of the social-psychological portrait of migrant students with the aim of their effective psychological and pedagogical support in the process of adaptation and assistance while building a professional perspective on the basis of effective development of emotional intelligence.

\section{REFERENCES}

1. Rovenchak 0 . Viznachennya ta klasifikaciï migracij: nablizhennya do operacijnih ponyat'. Politichnij menedzhment. 2006; 2 (17): 127-139.
2. Bazhenov V.G. Determinaciya prestupnogo povedeniya nesovershennoletnih v usloviyah sovremennogo rossijskogo obschestva (kriminologicheskij analiz). SPb. 2002:187.

3. Klejberg Yu.A. Social'nye normy i otkloneniya. Kemerovo. 2001; 234.

4. Kondrashenko V.T. Obschaya psihoterapiya. M., 2004: 346.

5. KudryavcevV. N. Zakon, postupok, otvetstvennost'. M.: Nauka. 1987: 448.

6. Krys'koV.G. Psihologiyaipedagogika:kurslekcij.M.:Izd-vo Omega-L.2006:124.

7. Ananko L. Migracijni riziki osvitn'ogo procesu v Ukraïni. Efektivnist' derzhavnogo upravlinnya: zb. nauk. pr. 2011;4: 33-38.

8. Nacional'nij osvitnij glosarij: vischa osvita / avt.-uklad. : I. I. Babin, Ya.Ya. Bolyubash, A. A. Garmash j in.; za red. D.V. Tabachnika iV. G. Kremenya. - K. : TOV «Vidavnichij dim «Pleyadi», 2011: 100.

9. Zmanovskaya E.V. Psihologiya deviantnogo povedeniya: strukturnodinamicheskij podhod: avtoref. dis. na soiskanie nauchn. stepeni dokt. psihol. nauk. Sankt-Peterburg, 2006: 28.

Initiative applied research work: "Scientific substantiation of psychohygienic support of social adaptation of foreign students in medical higher education institutions of Ukraine" State regastration No. 0115U007174 deadline 2015-2019 years.

\section{Authors' contributions:}

According to the order of the Authorship.

\section{Conflict of interest:}

The Authors declare no conflict of interest.

\section{CORRESPONDING AUTHOR Oleksandr Katrushov \\ Ukrainian Medical Stomatological Academy \\ Shevchenka Str., 23, 36011 Poltava, Ukraine \\ e-mail: Katrushov.Poltava@rambler.ru \\ e-mail: Katrushov.Poltava@gmail.com}

Received: 11.07.2019

Accepted:26.09.2019 


\title{
PREVENTION OF MAIN DENTAL DISEASES IN CHILDREN USING HERBAL TEA «DENTESVITA»
}

\author{
Anatoliy M. Potapchuk, Volodymyr S. Melnyk, Liudmyla F. Horzov, Vasyl' M. Almashi \\ UZHHOROD NATIONAL UNIVERSITY, UZHHOROD, UKRAINE
}

\begin{abstract}
Introduction: Transcarpathian region refers to the climate-geographic zone with a low level of fluoride and iodine in the environment and as shown by the epidemiological survey «very high» according to WHO criteria for the level of intensity of main dental diseases. With the purpose of directing the implementation of the state policy in the field of health care and for the prevention of dental diseases, the industrial release of a functional food product - «DentesVita» enriched with iodine and fluorine - has been adjusted. The aim: Was to study the effectiveness of the use of functional food product - DentesVita for the prevention of dental caries in children.

Materials and methods: A comprehensive dental examination of 180 children of 12 years of age has been carried out: 60 of them in each of the climatic and geographical zones of Transcarpathia: plain, foothills and mountains. The intensity of caries according to the DMF index, increase of intensity was determined. A simplified hygiene index $(\mathrm{OHI}-\mathrm{S})$ was used to assess the hygienic state of the oral cavity. Carried out research on the mineralization potential of saliva.

Results: The growth of caries in children of the main group of the plain zone was 1.8 times smaller, and in the foothills and mountains 1.6 times smaller than the similar rates of control group children $(\mathrm{p}<0.05)$. The caries prophylactic effect at that was among schoolchildren in the plain zone: $43.48 \%$, foothill - $38.66 \%$, and mountainous - $23.53 \%$. Conclusions: These studies confirm the effectiveness of using «DentesVita» for the prevention of dental caries in children living in conditions of biogeochemical deficiency of fluorine and iodine on the basis of caries intensity growth indexes, hygienic indexes of the oral cavity and mineralizing ability of oral liquid.
\end{abstract}

KEY WORDS: iodine deficiency and fluoride, dental caries, hygiene, prevalence, herbal tea

Wiad Lek 2019, 72, 10, 1935-1938

\section{INTRODUCTION}

The level of dental health in children is closely linked to an increase in the relative weight of the risk factors for the formation and progression of diseases of hard and soft tissues of the oral cavity, which is reflected in the structure of the main dental diseases [1]. In particular, in Ukraine the prevalence of dental caries in 6-year-old children is $87.9 \%$ with a lesion intensity of 4.6 ; in 12 -year-olds $-72,3 \%$ at intensity $-2,75$. The frequency of detection of chronic catarrhal gingivitis $(\mathrm{CCH})$ among children and adolescents is on average 70 $80 \%$, and in some regions reaches $95-98 \%$. Orthodontic anomalies are registered in more than $60 \%$ of those surveyed aged 7-18 years [2,3]. As in most countries of the world, Ukraine has a tendency to increase these indicators [4].

Transcarpathia refers to the climate-geographic zone with a low level of fluoride and iodine in the environment, and as shown by epidemiological surveys «very high» according to WHO criteria, the level of intensity of major dental diseases associated with a deficit in the daily intake of iodine and fluorine $[1,5,6]$.

In order to direct the implementation of state policy in the field of health care and prevention of dental diseases in Transcarpathia, has been adjusted the industrial release of a functional food product - a herbal tea «Dentsvita» enriched with iodine and fluorine.

This functional food product is a mixture of herbal materials: Surrexit coxis $-30 \%$, Chamaemelon flores $-10 \%$,
Lucus Veronicae medicamento relinquit - 20\%, Rosae medicamento pelyustrb - 10\%, Caeditur et tilia flores aucuparia $-10 \%$, Urtica crescet myrtus $-20 \%$, kalium iodide $-0,0093 \%$, kalium fluoride $-0,165 \%$, which creates optimal dietetic conditions for the general strengthening of the body and the prevention of major dental diseases - caries teeth, diseases of periodontal tissues and iodine deficiency diseases. In one glass of herbal tea, the following percentages of daily consumption are required: iodine - $92 \%$ for children 3-6 years old, $85 \%$ for children $7-12$ years old, and $55 \%$ for children from 12 years of age and adults; Fluoride - 75\% - for children 3-6 years, 50\% for children 7-12 years old, and $33 \%$ - for children from 12 years and adults. For territories with optimal levels of fluoride in the environment and food, we recommend general health-improving herbal tea "DentesVita " (iodinated), since iodine has a direct impact on the functions of all organs and systems of the body and dental health. General health-improving herbal tea "DentesVita" are useful for children of different age groups, adults and pregnant women living in territories with natural ecologically deficient iodine and fluoride in the environment, in particular the territories of the Carpathian Euroregion (Hungary, Slovakia, Romania, Poland) and Ukraine.

Herbal teas "DentesVita" are not medicines. This patented development of the department of postgraduate dentistry of UzhNU is registered in the state standard of Ukraine TU U 
15.8-35347011 - 001: 2011 and TI to them with the positive conclusion of the sanitary and epidemiological examination of the Ministry of Health of Ukraine in the number 05.03.0206 / 51955 dated May 20, 2011 certificate quality, bar code EAN Association of the Chamber of Commerce «JEESI Ukraine» No. 17048-2 dated July 13, 2011 [7].

\section{THE AIM}

The purpose was to study the effectiveness of the use of a functional food product - a general health-improving herbal tea "DentesVita" for the prevention of dental caries in children living in conditions of biogeochemical deficiency of fluorine and iodine on the basis of indicators of growth of caries intensity, hygienic indexes of the oral cavity and mineralizing ability of oral fluid.

\section{MATERIALS AND METHODS}

In order to evaluate the effectiveness of using the functional food product - general health-improving herbal tea «DentesVita», a comprehensive dental examination of 180 children of 12 years of age was carried out: 60 of them in each of the climatic and geographical zones of Transcarpathia: plain, foothills and mountains. The number of main and control groups was 30 children in each of the climatic-geographical zones. For the endogenous prevention of dental caries the «DentesVita» herbal tea was used for 30 days, twice a year (in autumn and spring) for 2 years. The assessment of clinical efficacy was carried out 6, 12, 18 and 24 months from the beginning of the study. A comprehensive dental examination of children was conducted in accordance with WHO recommendations [8].

The intensity of caries according to the DFM index, intensity increase in percent was determined. A simplified hygiene index was used to assess the oral hygiene state (OHI-S Green J.C., Vermillion J.K., 1964). Investigation of the mineralizing potential of saliva (Leus P. A., 1976), Sayfulin H. M. (1992)). The statistical processing of the results was carried out in Microsoft Excel 2010.

\section{RESULTS AND DISCUSSION}

According to the results of the study, in the children of the main group living in the plain zone after 12 months of application of the "DentesVita", the growth of the caries of the teeth was $0.45 \pm 0.11$ caries tooth, and in the control group - $0.59 \pm$ 0,09 teeth $(p>0.05)$. The reduction of dental caries at this stage was $13.79 \% .24$ months after the start of the study, the growth of caries in the main group of children was $0.91 \pm 0.08$ and was significantly lower $(\mathrm{p}<0.01)$ for a similar index of children in the control group $1.61 \pm 0.08$. The caries prophylactic effect (CPE) in the children of the main group was $43.48 \%$. In children of the main and control groups in the foothills zone, the importance of the DFM index before the start of preventive measures was at approximately the same levels and amounted to $4.62 \pm 0.03$ and $4.65 \pm 0.04$ tooth, respectively.

Already after 6 months, the use of the "DentesVita» in children of the main group DFM index was $21.43 \%$, and the growth of caries of teeth was equal to $0.14 \pm 0.03$ caries tooth. In the control group of children, the growth of caries of teeth at this stage of the study was $0.2 \pm 0.04$ caries tooth. The maximum CPE in the main group of children in the foothills was observed after 2 years of application of the proposed algorithm and was $38.66 \%$; the index of growth of the caries of permanent teeth in schoolchildren of this group was $1.19 \pm 0.06$ caries tooth.

In the control group, 24 months after the start of the study, the growth rate of the caries was $1.94 \pm 0.09$ caries tooth and was significantly higher than in the children of the main group $(p<0.001)$. In children of the main group of the mountain zone, the growth of caries of teeth in 12 months was $0.39 \pm 0.12$ caries tooth, the value of the similar index of children in the control group was $0.51 \pm 0.14(\mathrm{p}>0.05)$. CPE in children of the main group at the same time was $23.53 \%$.

After 24 months of observation, the growth of caries of teeth in children of the main group was $0.99 \pm 0.13$ caries tooth, which is 1.6 times less than the value of the similar indicator in children of the control group $(1.6 \pm 0.14)$ $(p<0,01)$. Throughout the entire period of the use of the herbal tea «DentesVita», the reduction of caries in children of the main group gradually increased reaching its maximum after 24 months, at the same time making 36.88\%. Thus, the CPE achieved in children of major groups, which in various climatic-geographical zones ranged from 36.88 to $43.48 \%$, which may indicate its effectiveness.

The dynamics of the effect of herbal tea on the oral hygiene status of children was traced using the OHI-S index. The values of hygiene indices in children of the main and control groups living in the plain zone prior to the application of preventive measures were treated as unsatisfactory and amounted to $1.79 \pm 0.12$ and $1.77 \pm 0.13$ points, respectively (Table 1). After 12 months of application of herbal tea in the main group of children hygiene index decreased 1.4 times from baseline $(p<0,05)$ and amounted to $1,32 \pm$ 0,15 points, which corresponded to a satisfactory level of hygiene. In the control group children, the OHI-S index in the given time period was higher than in the children of the main group and averaged $1.67 \pm 0.13$ points, however, this difference was unreliable $(p>0.05)$. The values of the indexes of oral hygiene in the children of the main group after 18 and 24 months of observations showed a dynamism to increase and comprised $1.42 \pm 0.17$ and $1.6 \pm 0.14$ points, respectively, but did not reach the level prior to the start of the survey. In the control group children in the 24-month period, the OHI-S exceeded 1.2 times the initial data of $2.04 \pm 0.14$ points and was interpreted as high.

In the group of children in the foothills, which was used herbal tea in 12 months of follow-up, the state of oral hygiene was characterized as satisfactory with the value of the OHI-S index of $1.35 \pm 0.19$ balls, whereas in the control group children, for the specified time, the value of this index was $1,65 \pm 0.11$ points, which corresponded to poor oral hygiene.

After 24 months, in the children of the main group, the hygienic index tended to grow and was $1.72 \pm 0.15$ points, however, it did not reach the level before the introduction 
Table I. Dynamics of the indicator OHI-S in children as a result of preventive measures (points).

\begin{tabular}{ccccccc}
\hline \multirow{2}{*}{ Terms of examination } & \multicolumn{2}{c}{ Plain area } & \multicolumn{2}{c}{ Foothills zone } & \multicolumn{2}{c}{ Mountain zone } \\
\cline { 2 - 7 } & MG & CG & MG & CG & MG & CG \\
\hline Before preventive measures & $1,79 \pm 0,12$ & $1,77 \pm 0,13$ & $1,84 \pm 0,14$ & $1,82 \pm 0,16$ & $2,41 \pm 0,11$ & $2,42 \pm 0,17$ \\
\hline After 6 months & $1,38 \pm 0,12$ & $1,54 \pm 0,14$ & $1,32 \pm 0,16$ & $1,59 \pm 0,17$ & $1,43 \pm 0,12$ & $1,51 \pm 0,12$ \\
\hline After 12 months & $1,32 \pm 0,15$ & $1,67 \pm 0,13$ & $1,35 \pm 0,19$ & $1,65 \pm 0,11$ & $1,59 \pm 0,13$ & $2,04 \pm 0,11$ \\
\hline After 18 months & $1,42 \pm 0,17$ & $1,72 \pm 0,15$ & $1,49 \pm 0,15$ & $1,84 \pm 0,16$ & $1,77 \pm 0,16$ & $2,31 \pm 0,15$ \\
\hline After 24 months & $1,6 \pm 0,14$ & $2,04 \pm 0,14$ & $1,72 \pm 0,15$ & $2,03 \pm 0,19$ & $2,13 \pm 0,13$ & $2,57 \pm 0,18$ \\
\hline
\end{tabular}

Note: MG - main group, CG - control group; the reliability of the difference between the indicators of the children of the main and control groups before and after the preventive measures - $(p \leq 0,05)$.

Table II. Dynamics of indicators of mineralizing potential of saliva of children under the influence of preventive measures.

\begin{tabular}{ccccc}
\hline \multirow{2}{*}{ Climatogeographic zones } & \multicolumn{2}{c}{ Main group } & \multicolumn{2}{c}{ Control group } \\
\cline { 2 - 5 } & $\begin{array}{c}\text { Prior to taking } \\
\text { preventive measures }\end{array}$ & $\begin{array}{c}\text { After carrying out } \\
\text { preventive measures }\end{array}$ & $\begin{array}{c}\text { Prior to taking } \\
\text { preventive measures }\end{array}$ & $\begin{array}{c}\text { After carrying out } \\
\text { preventive measures }\end{array}$ \\
\hline Plain & $2,56 \pm 0,15$ & $3,63 \pm 0,17$ & $2,58 \pm 0,15$ & $2,38 \pm 0,16$ \\
\hline Foothills & $2,58 \pm 0,16$ & $3,52 \pm 0,15$ & $2,56 \pm 0,16$ & $2,22 \pm 0,13$ \\
\hline Mountainous & $2,29 \pm 0,15$ & $3,43 \pm 0,17$ & $2,28 \pm 0,15$ & $2,11 \pm 0,14$ \\
\hline Average value & $2,47 \pm 0,09$ & $3,53 \pm 0,1$ & $2,47 \pm 0,09$ & $2,24 \pm 0,08$ \\
\hline
\end{tabular}

Note: the reliability of the difference between the indicators of the children of the main and control groups before and after the preventive measures - $(p \leq 0,05)$.

of the herbal tea at $1.84 \pm 0.14$ points. In the control group children, after 2 years, the OHI-S index was $2.03 \pm 0.19$ points, which exceeded the baseline $-1.82 \pm 0.16$ points, indicating a deterioration in the hygienic state of the oral cavity. It should be noted that there was no significant difference between the indexes of hygienic indices in children of control and experimental groups of the foothill zone at any stage of the observation ( $p>0.05)$. The hygienic state of the oral cavity in children of the main group of the mountain zone in the interval from 6 to 12 months was interpreted as satisfactory with the value of OHI-S indicators from $1.43 \pm 0.17$ to 1.59 \pm 0.13 points, which was significantly lower in comparison with a baseline of $2.41 \pm 0.11$ points $(\mathrm{p}<0.05)$. After 2 years of observation, the oral hygienelevel in children in this group worsened and amounted to $2.13 \pm 0.13$ points, however, not reaching the initial degree. In the control group, 6 months after the start of the study, the index of hygiene was $1.51 \pm$ 0.12 points, which corresponded to its average level, after 12 months, the OHI-S increased by 1.4 times, correspondingly, to $2.04 \pm 0,11$ points and was evaluated as an unsatisfactory state of oral hygiene. After 2 years, the value of the hygienic index in children increased to $2.57 \pm 0.18$ points and exceeded its initial level of $2.42 \pm 0.17$ points, indicating a deterioration of the hygienic state of the oral cavity ( $p>0.05$ ).

The effectiveness of the proposed functional food product - "DentesVita" is also evidenced by the positive dynamics of the mineralizing ability of saliva in children of the main groups of all climatological and geographical zones. Before the study in children of experimental groups were dominated crystals of 2 type, the proportion of which was in the plain zone of $56.67 \pm 5.25 \%$, foothill -51.11 $\pm 5.3 \%$ and mountainous $-52.22 \pm 5.3 \%$. After 2 years of application of therapeutic and prophylactic measures in children of the main groups, there was a significant increase compared with the initial level of increase in the number of type I crystals in the plain zone at 2.8 times from $(16.66 \pm 3.95) \%$ to $(46.67 \pm 5,29) \%$, in the foothills -2.1 times from $(21.11 \pm 4.33) \%$ to $(43.33 \pm 5.25) \%$ and in the mountains - 3.7 times from $(12.22 \pm 3,47) \%$ to $(45.56 \pm 5.28) \%$, which indicates an improvement in the mineralizing function of the oral liquid $(\mathrm{p}<0.001)$. Along with this, there was a statistically significant decrease in the proportion of crystals of type III, the percentage of which in schoolchildren in the plain zone was $13.33 \pm 3.6 \%$, in the foothills $-15.56 \pm 3.84 \%$, and in the mountains - 17.78 $\pm 4,05 \%(\mathrm{p}<0.05)$. In children of all control groups after 24 months of study, there was a decrease in the mineralization capacity of mixed saliva, which was manifested by a 1.4-fold decrease in the number of I-type crystals and a 1.3 -fold increase in the number of samples of mixed saliva with type III compared to baseline ( $p>0.05)$.

Indicators of mineralization potential of saliva (MPS) in children of the main groups to the preventive measures were interpreted as satisfactory and equal to $2.56 \pm 0.15$ points in the plain zone, in the foothills $-2.58 \pm 0.16$ points and in the mountains $-2.29 \pm 0.15$ (Table 2). After 2 years of application of the proposed «DentesVita» among the children of these groups, it was found that in comparison with the initial level of growth of the MPS in children of plain and foothill zones in 1.4 times, mountainous - in 1.5 times, which corresponded to its high level $(\mathrm{p}<0.05)$.

In children of the control groups of all climatic and geographical zones after 24 months of study observed a tendency to decrease the MPS in the plain zone was $2.38 \pm 0.16$ points, in the foothills -2.22 \pm 0.13 points, in the mountains $-2,11 \pm 0.14$ points. The obtained results testify to the positive influence of «DentesVita», which was manifested in increasing the mineralizing potential of oral liquid 
in children of major groups by an average of $30 \%$ in relation to the baseline ( $\mathrm{p}$ <.05). Green J. C., Vermillion J. K., 1964).

Caries of teeth are still a social problem in many countries around the world [4]. Through epidemiological studies conducted in index groups among children and adults, it is possible to monitor progress and take appropriate measures. The research conducted by Rodakovsky and co-authors shows similar results of high values of caries intensity among 12-year-old children of the Podlask region (Poland), which corresponds to the results of this study [9].

The results obtained by us coincide with the data of similar studies conducted in Georgia on the correlation between environmental risk factors and the emergence of caries in young people [10].

Data on the prevalence and intensity of dental caries show their combination with a high incidence of poor oral hygiene, as evidenced by studies in recent years, including Kaminsky A. and collaborators in this direction [11].

\section{CONCLUSIONS}

As a result of the two-year application of the proposed herbal tea «DentesVita», the growth of caries in children of the main group of the plain zone was 1.8 times smaller, and in the foothills and mountains 1.6 times smaller than the similar rates of control group children $(\mathrm{p}<0.05)$.

At the same time, CPE of children in the plain zone was $43.48 \%$, in the foothills $-38.66 \%$ and $23.53 \%$ of the mountains. Positive influence of preventive actions is also observed in improving the level of hygiene of the oral cavity of children after 24 months of its introduction. This is evidenced by a 1.3 times lower value of OHI-S in persons of the main group of the plain zone $(\mathrm{p}<0.05)$ and by 1.2 times the lower OHI-S values in the persons of the main groups of foothills and mountainous areas in relation to the indicators of the hygienic index in children of control groups $(p<0.05)$. The prophylactic effectiveness of the proposed complex is confirmed by statistically significant increases in the mineralizing potential of oral liquid in children of major groups by 1.5 times in the plains and 1.6 times in the foothills and mountainous areas as compared to the MPS of the control group children $(\mathrm{p}<0.05)$.

\section{REFERENCES}

1.Horzov I.P., Potapchuk A.M. Ekolohichni aspekty kariiesu zubiv ta khvorob parodontu [Environmental aspects of caries of teeth and periodontal diseases]. Hoverla.1998; 225.

2. Smoliar N. I., Musii-Sementsiv Kh. H. Chastota urazhennia riznykh hrup molochnykh zubiv u ditei doshkilnoho viku shcho meshkaiut v silskii mistsevosti [The frequency of defeat of various groups of milk teeth in preschool children living in rural areas]. Visnyk stomatolohii. 2013;. 2: 84-87.

3. Pynda M. Ya. Epidemiolohichni doslidzhennia stanu tverdykh tkanyn zubiv u ditei doshkilnoho viku mista Ternopolia [Epidemiological studies of hard dental tissues in preschool children in Ternopil] Aktualni pytannia pediatrii, akusherstva ta hinekolohii. 2014; 2: 77-80.

4. Ahmedbeyli RM. Caries prevention with fluoridated and iodinated salt in school-aged children living in areas with fluoride and iodine deficiency. Stomatologiia (Mosk). 2017;96(5):66-68. doi: 10.17116/stomat201796566-68.
5. Yvanov V. S., Denha 0.V., Shnaider S.A. Pokazately zabolevaemosty karyesom zubov u detei raznykh stran myra za 1990 - 2010 hody. (chast 2: Evropa, Severnaia y Yuzhnaia Ameryka, Okeanyia) [Indicators of the incidence of tooth decay in children from different countries of the world for 1990-2010. (part 2: Europe, North and South America, Oceania)]. Innovatsii v stomatolohii 2015; 1:76-82.

6. Melnyk V. S., Horzov L. F., Sabov A.V.Epidemiolohiia stomatolohichnykh zakhvoriuvan sered dytiachoho naselennia Zakarpattia.[Epidemiology of dental diseases among the children of the Transcarpathians] Aktualni problemy suchasnoi medytsyny. 2016; 16, 3(55): 20-22.

7. Potapchuk A.M., Politun A.M., Fabri Z.I., Shnitser R.I,, Chobo Hehedush, Baloh Y.S., Odainyk I.V. Endohenna profilaktyka osnovnykh stomatolohichnykh zakhvoriuvan z vykorystanniam funktsionalnykh kharchovykh produktiv «Dentesvita» [Endogenous prophylaxis of basic dental diseases using functional food products «Dentosvit»] Klinichna stomatolohiia 2011;3:36-41.

8. World Health Organization. Oral Health Surveys: Basic Methods. 4th. Geneva, Switzerland: World Health Organization; 1997.

9. Rodakowska E, Wilczyńska-Borawska M, Bagińska J, Stokowska E. Epidemiological analysis of dental caries in 12-year-old children residing in urban and rural settings in the Podlaskie region of north-eastern Poland. Ann Agric Environ Med 2013;20(2):325-8.

10. Shishniashvili TE, Margvelashvili VV, Suladze NN, Kobakhidze KA Correlation between the ecological risk factors and significant index of caries in young children. Georgian Med News 2012;(206):30-3.

11. Kamińska A, Szalewski L, Batkowska J, Wallner J, Wallner E, Szabelska A, Borowicz J. The dependence of dental caries on oral hygiene habits in preschool children from urban and rural areas in Poland. Ann Agric Environ Med 2016; 23;23(4):660-65.

This work is a fragment of the research work of pediatric dentistry department Uzhhorod National University "Prevention, diagnosis, treatment of basic dental diseases in children of Transcarpathia", state registration number $0116 U 003555$.

\section{Authors' contributions:}

According to the order of the Authorship.

\section{ORCID numbers:}

Anatoliy M. Potapchuk - 0000-0001-9857-1407

Volodymyr S. Melnyk - 0000-0001-6256-5355

Liudmyla F. Horzov - 0000-0001-5299-3401

Vasyl' M. Almashi - 0000-0002-2943-4844

\section{Conflict of interest:}

The Authors declare no conflict of interest.

\section{CORRESPONDING AUTHOR}

\section{Liudmila Horzov}

Uzhhorod National University

Dovzhenka Str., 18/3, 88000, Uzhhorod, Ukraine

tel: +380507626129

e-mail: liudmyla.horzov@uzhnu.edu.ua

Received: 20.04.2019

Accepted: 16.09 .2019 
PRACA ORYGINALNA

ORIGINAL ARTICLE

\title{
FEATURES OF ESTIMATION OF MUSCLE TONE AND FUNCTIONAL STATE OF SPINAL MOTOR NEURONS IN PATIENTS WITH POST-STROKE SPASTICITY ON A BACKGROUND OF A PHARMACOLOGICAL CORRECTION
}

\author{
Anzhelika V. Payenok', Olga G. Morozova², Oleksandr S. Payenok³ ${ }^{3}$ Irina M. Mitelman' ${ }^{1}$, Oleg Yu. Bilianskyi ${ }^{4}$ \\ 'DANYLO HALYTSKYI LVIV NATIONAL MEDICAL UNIVERSITY, LVIV, UKRAINE \\ 2KHARKIV MEDICAL AKADEMY OF POSTGRADUATE EDUCATION, KHARKIV, UKRAINE \\ 'LVIV STATE UNIVERSITY OF PHYSICAL CULTURE, LVIV, UKRAINE \\ ¿UKRAINIAN CATHOLIC UNIVERSITY, LVIV, UKRAINE
}

\begin{abstract}
Intorduction: Recent scientific research has shown that post-stroke spasticity occurs in 20-30\% of cases. Very often spasticity impairs and gives discomfort for a person who has it. In that case it should be managed and relieved.

The aim: To conduct standardization of determination of degrees of spasticity by means of foregoing scales and methodologies with further comparison of their sensitiveness and objectivity of the obtained data.

Materials and methods: 24 patients with post-stroke spasticity were treated during 14 days using the same centrally acting anti-spastic drug (oral tolperisone hydrochloride). The average duration of spasticity was 25 months (minimum 20 months and maximum 36 months). 24 patients were rated on the Modified Ashworth Scale and of those patients: 1 was rated stage "1", 5 - stage " $1+$ ", 7 - stage "2", 7 - stage " 3 " and 3 patients were rated stage " 4 ". Assessment of muscle tone for each patient was performed daily during morning round. At our study we have used the Modified Ashworth Scale, the Modified Tardieu Scale, Functional Independence Measure, Visual Analog Scale for Pain and some parameters from ENMG study (Hoffmann's reflex and F/M max measured for ulnar nerve at the side of paresis).

The results were statistically analyzed through Microsoft Excel 2010 using Student's method and Spearman's rank correlation coefficient. P value less that 0,05 was considered as a significant level.

Results: According to collected statistics we can advise for control of treatment of post-stroke spasticity using ENMG parameters and Visual Analog Scale for Pain during first 7 days of treatment, using of Modified Ashworth Scale and Tardieu Scale is more appropriate starting on 7th day of taking anti-spastic medications. Unfortunately, according to gathered statistics there is no correlation between Modified Ashworth Scale and parameters of ENMG.

Conclusion: For the estimation of efficiency of post-stroke spasticity treatment in the first 7 days of the therapy more informative are electroneuromyographic parameters and Visual Analog Scale. Muscle tone assessment scales (Modified Ashworth Scale and Modified Tardieu Scale) for the monitoring of dynamic changes of efficiency of the treatment can be recommended beginning from the seventh day of the therapy.
\end{abstract}

KEY WORDS: post-stroke spasticity, assessment of spasticity, electroneuromyographic assessment of spasticity

Wiad Lek 2019, 72, 10, 1939-1941

\section{INTRODUCTION}

Prevalence of spasticity that is related to the stroke has not been studied enough. About 80 percent of all patients that suffered a cerebral stroke, develop insufficiency of contralateralextremities, in another words hemiparesis. And recent scientific researches specify the frequency of post-stroke spasticity within the limits of 20-30 percent. The damage to fibres of the pyramid and extrapyramid neuronal pathways assists to the development of the upper motor neuron syndrome that includes the presence of positive and negative signs. Negative signs include those, that are characteristic for a person at the terms of normal condition, but as a result of damage a specific area of brain was lost, in another words it is muscular force and movement. Under positive signs are meant those, that in a normal condition are not present but arising up as a result of damage of certain cerebral structures, in another words its spasticity and anomalous positions of extremities [2,3].

Spasticity can be useful, as, for example, in the case when synergicity of muscles extensors helps to maintain a bodyweight on weak extremities [5]. Also post-stroke spasticity helps to keep the volume of muscles and postpone the development of osteoporosis [1]. When spasticity inflicts discomfort to the patient at implementation of everyday activity, then a task is to remove it or even to facilitate the degree of its expression. For such purpose the whole row of the recommended pharmaciological facilities are used, 
Table 1. Dynamic changes of the degree of post-stroke spasticity measured during the period of examination using different methods of estimation

\begin{tabular}{|c|c|c|c|c|c|c|c|c|c|c|c|c|c|c|c|}
\hline \multirow{2}{*}{\multicolumn{2}{|c|}{$\begin{array}{l}\text { Method of estimation of } \\
\text { spasticity }\end{array}$}} & \multicolumn{14}{|c|}{ Value on the indicated day of examination } \\
\hline & & 1 & 2 & 3 & 4 & 5 & 6 & 7 & 8 & 9 & 10 & 11 & 12 & 13 & 14 \\
\hline \multirow{3}{*}{ 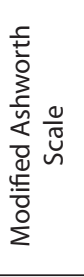 } & Average & $\begin{array}{c}4,2 \\
\pm 0,2\end{array}$ & $\begin{array}{c}4,2 \\
\pm 0,2\end{array}$ & $\begin{array}{c}4,2 \\
\pm 0,2\end{array}$ & $\begin{array}{c}4,0 \\
\pm 0,3\end{array}$ & $\begin{array}{c}4,0 \\
\pm 0,3\end{array}$ & $\begin{array}{c}3,7 \\
\pm 0,3\end{array}$ & $\begin{array}{c}3,2 \\
\pm 0,3\end{array}$ & $\begin{array}{c}3,1 \\
\pm 0,2\end{array}$ & $\begin{array}{c}3,0 \\
\pm 0,2\end{array}$ & $\begin{array}{c}3,0 \\
\pm 0,2\end{array}$ & $\begin{array}{c}2,9 \\
\pm 0,2\end{array}$ & $\begin{array}{c}2,7 \\
\pm 0,2\end{array}$ & $\begin{array}{c}2,6 \\
\pm 0,2\end{array}$ & $\begin{array}{c}2,5 \\
\pm 0,2\end{array}$ \\
\hline & $\begin{array}{c}\% \text { in comparison with } \\
\text { the } 1^{\text {st }} \text { day }\end{array}$ & - & 0 & 0 & $-4,0$ & $-5,0$ & $-11,0$ & $-23,0$ & $-25,0$ & $-27,0$ & $-29,0$ & $-31,0$ & $-36,0$ & $-37,0$ & $-40,0$ \\
\hline & $\begin{array}{c}\text { Significant } \\
\text { difference in comparison } \\
\text { with the } 1^{\text {st }} \text { day }\end{array}$ & - & $>0,05$ & $>0,05$ & $>0,05$ & $>0,05$ & $>0,05$ & $<0,05$ & $<0,05$ & $<0,05$ & $<0,05$ & $<0,05$ & $<0,05$ & $<0,05$ & $<0,05$ \\
\hline \multirow{3}{*}{ 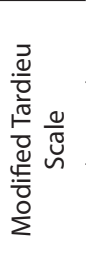 } & Average & $\begin{array}{c}2,3 \\
\pm 0,2 \\
\end{array}$ & $\begin{array}{c}2,3 \\
\pm 0,2 \\
\end{array}$ & $\begin{array}{c}2,3 \\
\pm 0,2 \\
\end{array}$ & $\begin{array}{c}2,3 \\
\pm 0,2 \\
\end{array}$ & $\begin{array}{c}2,1 \\
\pm 0,2 \\
\end{array}$ & $\begin{array}{r}1,9 \\
\pm 0,2 \\
\end{array}$ & $\begin{array}{r}1,4 \\
\pm 0,2 \\
\end{array}$ & $\begin{array}{c}1,2 \\
\pm 0,2 \\
\end{array}$ & $\begin{array}{c}1,1 \\
\pm 0,2 \\
\end{array}$ & $\begin{array}{r}1,0 \\
\pm 0,2 \\
\end{array}$ & $\begin{array}{r}1,0 \\
\pm 0,2 \\
\end{array}$ & $\begin{array}{r}1,0 \\
\pm 0,2 \\
\end{array}$ & $\begin{array}{c}1,0 \\
\pm 0,2 \\
\end{array}$ & $\begin{array}{r}0,9 \\
\pm 0,2 \\
\end{array}$ \\
\hline & $\begin{array}{l}\% \text { in comparison to the } \\
1^{\text {st }} \text { day }\end{array}$ & - & 0 & 0 & 0 & $-5,6$ & $-14,8$ & $-37,0$ & $-46,3$ & $-51,9$ & $-53,7$ & $-57,4$ & $-57,4$ & $-57,4$ & $-59,3$ \\
\hline & $\begin{array}{l}\text { Significant } \\
\text { difference in comparison } \\
\text { with the } 1^{\text {st }} \text { day }\end{array}$ & - & $>0,05$ & $>0,05$ & $>0,05$ & $>0,05$ & $>0,05$ & $<0,05$ & $<0,05$ & $<0,05$ & $<0,05$ & $<0,05$ & $<0,05$ & $<0,05$ & $<0,05$ \\
\hline \multirow{3}{*}{ 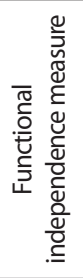 } & Average & $\begin{array}{l}54,7 \\
\pm 3,5\end{array}$ & $\begin{array}{r}57,0 \\
\pm 3,9 \\
\end{array}$ & $\begin{array}{r}60,4 \\
\pm 3,8\end{array}$ & $\begin{array}{r}62,6 \\
\pm 3,5\end{array}$ & $\begin{array}{r}63,0 \\
\pm 3,6 \\
\end{array}$ & $\begin{array}{r}63,1 \\
\pm 3,5\end{array}$ & $\begin{array}{c}63,3 \pm \\
3,5\end{array}$ & $\begin{array}{r}63,4 \\
\pm 3,5 \\
\end{array}$ & $\begin{array}{r}63,6 \\
\pm 3,4 \\
\end{array}$ & $\begin{array}{r}63,9 \\
\pm 3,4\end{array}$ & $\begin{array}{r}63,9 \\
\pm 3,4 \\
\end{array}$ & $\begin{array}{c}64,0 \pm \\
3,4\end{array}$ & $\begin{array}{c}64,0 \pm \\
3,4\end{array}$ & $\begin{array}{r}63,9 \\
\pm 3,4\end{array}$ \\
\hline & $\begin{array}{c}\% \text { in comparison with } \\
\text { the } 1^{\text {st }} \text { day }\end{array}$ & - & 4,1 & 10,4 & 14,4 & 15,2 & 15,4 & 15,7 & 15,8 & 16,2 & 16,8 & 16,8 & 17,0 & 16,9 & 16,8 \\
\hline & $\begin{array}{c}\text { Significant } \\
\text { difference in comparison } \\
\text { with the } 1^{\text {st }} \text { day }\end{array}$ & - & $>0,05$ & $>0,05$ & $>0,05$ & $>0,05$ & $>0,05$ & $>0,05$ & $>0,05$ & $>0,05$ & $>0,05$ & $>0,05$ & $>0,05$ & $>0,05$ & $>0,05$ \\
\hline \multirow{3}{*}{$\begin{array}{l}\frac{0}{\sqrt{0}} \\
\sim \\
0 \\
\frac{0}{\pi} \\
\frac{0}{5} \\
\frac{\pi}{5} \\
\frac{3}{5}\end{array}$} & Average & $\begin{array}{l}59,8 \\
\pm 3,7 \\
\end{array}$ & $\begin{array}{r}62,9 \\
\pm 3,5 \\
\end{array}$ & $\begin{array}{l}68,1 \\
\pm 3,3 \\
\end{array}$ & $\begin{array}{l}72,3 \\
\pm 3,2 \\
\end{array}$ & $\begin{array}{l}73,5 \\
\pm 3,4 \\
\end{array}$ & $\begin{array}{r}73,8 \\
\pm 3,3 \\
\end{array}$ & $\begin{array}{r}75,2 \\
\pm 3,2 \\
\end{array}$ & $\begin{array}{r}75,4 \\
\pm 3,2 \\
\end{array}$ & $\begin{array}{r}75,8 \\
\pm 3,3 \\
\end{array}$ & $\begin{array}{r}75,8 \\
\pm 3,3 \\
\end{array}$ & $\begin{array}{l}75,8 \\
\pm 3,3\end{array}$ & $\begin{array}{l}75,8 \\
\pm 3,3 \\
\end{array}$ & $\begin{array}{l}76,0 \\
\pm 3,2 \\
\end{array}$ & $\begin{array}{l}76,5 \\
\pm 3,1 \\
\end{array}$ \\
\hline & $\begin{array}{c}\% \text { in comparison with } \\
\text { the } 1^{\text {st }} \text { day }\end{array}$ & - & 5,2 & 13,9 & 20,9 & 23,0 & 23,3 & 25,8 & 26,1 & 26,8 & 26,8 & 26,8 & 26,8 & 27,2 & 27,9 \\
\hline & $\begin{array}{c}\text { Significant } \\
\text { difference in comparison } \\
\text { with the } 1^{\text {st }} \text { day }\end{array}$ & - & $>0,05$ & $>0,05$ & $<0,05$ & $<0,05$ & $<0,05$ & $<0,05$ & $<0,05$ & $<0,05$ & $<0,05$ & $<0,05$ & $<0,05$ & $<0,05$ & $<0,05$ \\
\hline \multirow{3}{*}{ 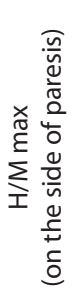 } & Average & $\begin{array}{l}47,7 \\
\pm 2,8\end{array}$ & $\begin{array}{l}42,4 \\
\pm 2,9\end{array}$ & $\begin{array}{l}38,2 \\
\pm 2,6\end{array}$ & $\begin{array}{l}36,7 \\
\pm 2,6\end{array}$ & $\begin{array}{l}36,8 \\
\pm 2,6\end{array}$ & $\begin{array}{l}36,8 \\
\pm 2,6\end{array}$ & $\begin{array}{l}36,5 \\
\pm 2,6\end{array}$ & $\begin{array}{l}36,6 \\
\pm 2,6\end{array}$ & $\begin{array}{l}36,5 \\
\pm 2,6\end{array}$ & $\begin{array}{l}36,5 \\
\pm 2,6\end{array}$ & $\begin{array}{l}36,4 \\
\pm 2,6\end{array}$ & $\begin{array}{l}36,5 \\
\pm 2,6\end{array}$ & $\begin{array}{l}36,5 \\
\pm 2,6\end{array}$ & $\begin{array}{l}36,5 \\
\pm 2,6\end{array}$ \\
\hline & $\begin{array}{l}\% \text { in comparison with } \\
\text { the } 1^{\text {st }} \text { day }\end{array}$ & - & $-11,1$ & $-20,0$ & $-23,1$ & $-23,0$ & $-22,9$ & $-23,5$ & $-23,4$ & $-23,4$ & $-23,5$ & $-23,6$ & $-23,5$ & $-23,5$ & $-23,2$ \\
\hline & $\begin{array}{l}\text { Significant } \\
\text { difference in comparison } \\
\text { to the 1st day }\end{array}$ & - & $>0,05$ & $<0,05$ & $<0,05$ & $<0,05$ & $<0,05$ & $<0,05$ & $<0,05$ & $<0,05$ & $<0,05$ & $<0,05$ & $<0,05$ & $<0,05$ & $<0,05$ \\
\hline \multirow{3}{*}{ 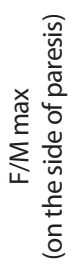 } & Average & $\begin{array}{r}16,0 \\
\pm 1,4\end{array}$ & $\begin{array}{l}12,0 \\
\pm 1,1\end{array}$ & $\begin{array}{l}10,4 \\
\pm 0,0\end{array}$ & $\begin{array}{l}10,2 \\
\pm 0,9\end{array}$ & $\begin{array}{l}10,2 \\
\pm 0,9\end{array}$ & $\begin{array}{l}10,1 \\
\pm 0,9\end{array}$ & $\begin{array}{l}10,2 \\
\pm 0,9\end{array}$ & $\begin{array}{l}10,2 \\
\pm 0,9\end{array}$ & $\begin{array}{c}9,9 \\
\pm 0,9\end{array}$ & $\begin{array}{l}10,0 \\
\pm 0,9\end{array}$ & $\begin{array}{c}9,8 \\
\pm 0,8\end{array}$ & $\begin{array}{c}9,7 \\
\pm 0,8\end{array}$ & $\begin{array}{c}9,8 \\
\pm 0,8\end{array}$ & $\begin{array}{r}9,8 \\
\pm 0,8\end{array}$ \\
\hline & $\begin{array}{c}\% \text { in comparison with } \\
\text { the } 1^{\text {st }} \text { day }\end{array}$ & - & $-25,3$ & $-34,8$ & $-36,2$ & $-36,5$ & $-36,9$ & $-36,5$ & $-36,1$ & $-37,9$ & $-37,3$ & $-39,0$ & $-39,2$ & $-38,8$ & $-39,0$ \\
\hline & $\begin{array}{c}\text { Significant } \\
\text { difference in comparison } \\
\text { with the } 1^{\text {st }} \text { day }\end{array}$ & - & $<0,05$ & $<0,05$ & $<0,05$ & $<0,05$ & $<0,05$ & $<0,05$ & $<0,05$ & $<0,05$ & $<0,05$ & $<0,05$ & $<0,05$ & $<0,05$ & $<0,05$ \\
\hline
\end{tabular}

and for the estimation of their efficiency there are a lot of modern scales and instrumental methods.

In our clinical practice for estimation of muscle tone the most widespread are used the following: the modified Ashworth Scale as well as the Tardieu Scale, and for the estimation of quality of life we use Functional independence measure and Visual Analog Scale of Pain, besides we use some electroneuromyografic parameters for the estimation of dynamic functional changes of spinal motor neurons of the patients with spastic muscle hypertone.

\section{THE AIM}

To conduct standardization of determination of degrees of spasticity by means of foregoing scales and methodologies with further comparison of their sensitiveness and objectivity of the obtained data.

\section{MATERIALS AND METHODS}

At the $1^{\text {st }}$ and $2^{\text {nd }}$ neurological departments of the Lviv City Municipal Communal Emergency Hospital a study of treatment of patients with post-stroke spasticity has been 
conducted by means of the same antispastic drug of central action (tolperisone hydrochloride) during a course of 14 days. The total amount of participants of the study was 24 persons ( 8 women and 16 men), an average age $57 \pm 5$ years, an average presence of post-stroke hemitype spasticity was 25 months (the minimum duration 20 months and the maximal 36 months). A muscle tone has been evaluated according to a modified Ashworth Scale: 1 patient was with the " 1 st" degree of spasticity, 5 patients with the " 2 nd" degree of spasticity, 7 patients with the " 3 rd" degree, 7 people with the " 4 th" degree and 3 patients with the " 5 th" degree of post-stroke spasticity. Electroneuromyographic study was conducted with the use of 4 channel computer electroneuromyograph ("Neurosoft", Russia) after standard methodologies for determination of the ulnar nerve $\mathrm{F}$ wave and parameters of Hoffman reflex, that were measured on the both extremities and the measurements from the paretic side were statistically evaluated. All patients have been examined at the beginning of the therapy and then every day during a morning round.

Statistical evaluation of the results was conducted with the help of Microsoft Excel 2010 using Student's t-parameter and Spearman rank correlation. The results were considered statistically reliable at $\mathrm{p}<0,05$.

\section{RESULTS AND DISCUSSION}

At the end of the study we came to a conclusion that the most sensitive by means of determination of dynamic changes of functional state of patients with muscle spasticity are electroneuromyographic parametrs. In a comparison with the first day we already got statistically significant reduction on the third day of therapy for Hoffman reflex and on the second day for the ulnar nerve F-wave. During the estimation of the results obtained with Visual Analog Scale of Pain we have got significant differences on the fourth day of their treatment in comparison with the first day. Scales for determination of spastic muscle tone showed some dynamic changes as well, however a statistically significant difference was determined on the seventh day of examination. By using Functional independence measure we have seen some positive dynamic changes by means of increasing a total score for each patient, however statistically significant difference in comparison with the first day have not been noticed (Table 1).

With the aim to reveal the correlation between the Modified Ashworth Scale and electroneuromyographic parameter (H/M max) we used Spearman rank correlation. The maximal calculated coefficient of correlation was got on the $12^{\text {th }}$ day of the therapy, and it was a negative weak correlation $(-0,34)$. However this coefficient was not statistically significant, that allows to draw a conclusion about the absence of reliable correlation between the Modified Ashworth Scale and parameters of Hoffman reflex.

\section{CONCLUSIONS}

For the estimation of efficiency of post-stroke spasticity treatment in the first 7 days of the therapy more informative are electroneuromyographic parameters and Visual Analog Scale. Muscle tone assessment scales (Modified Ashworth Scale and Modified Tardieu Scale) for the monitoring of dynamic changes of efficiency of the treatment can be recommended beginning from the seventh day of the therapy. Unfortunately, the absence of statistically significant correlation between the dynamic changes of electroneuromyographic parameters $(\mathrm{H} /$ Mmax) and score obtained with Modified Ashworth Scale does not give an opportunity to establish fixed interval of electroneuromyographic parameters for every degree of spasticity measured with the Modified Ashworth Scale. Also as a result of a conducted study it is possible to draw a conclusion, that among all estimated methods of spasticity the assessment electroneuromyographic parameters are the most sensitive to the changes during pharmacological reduction of spasticity.

\section{REFERENCES}

1. Kunkel CF, Scremin AM, Eisenberg B, et al. Effect of "standing" on spasticity, contracture, and osteoporosis in paralyzed males. Arch Phys Med Rehabil. 2003 Jan;74(1):73-8.

2. Malhotra S, Pandyan AD, Day CR, et al. Spasticity, an impairment that is poorly defined and poorly measured. Clin Rehabil 2009; 23:651-8.

3. Pinelli P., Di Lorenzo G. Electromyographic assessment of spasticity. Ital J Neurol Sci. 2009 Apr;10(2):137-44.

4. Sommerfeld DK., Gripenstedt U., Welmer AK., Spasticity after stroke: an overview of prevalence, test instruments, and treatments. Am J Phys Med Rehabil. 2012; 91 (9): 814-20.

5. Yelnik AP, Simon 0, Parrate B, et al. How to clinically assess and treat muscle overactivity in spastic paresis. Journal of Rehabilitation Medicine 2010;42:801-807

\section{Authors' contributions: \\ According to the order of the Authorship.}

\section{ORCID numbers:}

Angelika V. Payenok - 0000-0003-0531-751X

Olga G. Morozova - 0000-0002-3088624X

Oleksandr S. Payenok - 0000-0002-8517-7424

Oleg Y. Bilianskyi - 0000-0001-9700-9586

\section{Conflict of interest:}

The Authors declare no conflict of interest.

\author{
CORRESPONDING AUTHOR \\ Olga G. Morozova \\ Department of Reflexology \\ Kharkiv Medical Academy of Postgraduate Education \\ 58 Amosova Street, Kharkiv 61176, Ukraine \\ tel: $+380(50) 6693665$ \\ e-mail:morozova.olga.0201@gmail.com
}

Received: 05.04.2019

Accepted: 25.09.2019 


\title{
THE PECULIARITIES OF IMMUNOLOGICAL INDICATORS IN HIV-INFECTED PERSONS WITH TUBERCULOSIS
}

\author{
Vasyl D. Moskaliuk, Tetiana R. Kolotylo, Khrystyna I. Pudiak, Ivanna V. Rudan, Oksana I. Goliar, Iryna V. Balanyk \\ HSEI BUKOVININAN STATE MEDICAL UNIVERSITY, CHERNIVTSI, UKRAINE
}

\begin{abstract}
Introduction: Epidemics of such dangerous diseases as HIV infection and tuberculosis continue to develop annually. Tuberculosis has become the main cause of mortality in AIDS patients. Both diseases have a negative effect on the state of the immune system, affecting the cells of the lymphatic system.

The aim of the work is to carry out a comparative comprehensive immunological examination of HIV-infected and immunocompetent patients with active tuberculosis.

Materials and methods: It was carried out a comprehensive immunological examination of 231 patients, in particular 155 HIV-infected patients with active TB and 76 cases with TB only. The HIV / TB group was divided into 3 subgroups depending on the time of TB attachment to HIV infection.

It was compared with CD4 + T-lymphocytes, CD8 + T-lymphocytes, CD4 + / CD8 +, levels of interleukin-4 (IF-4), interferon- $($ (IFN- $\gamma$ ), tumor necrosis factor-a (TNF- $a$ ) and results delayed-type hypersensitivity reactions (TGS) with tuberculin for groups with a combined HIV / TB infection and TB-mono-infected patients.

Results: The difference between CD4 + T-lymphocytes, CD4 + / CD8 + with associated HIV / TB infection, and also in the 1st and 3rd HIV / TB subgroups, as compared to those with TB monoinfection, was shown to be significantly more pronounced CD4 + T lymphocytes and a higher index of CD4 + / CD8 + in patients with TB monoinfection.

Conclusions: CD4 + T-lymphocyte ratios, CD4 + / CD8 + ratios are significantly lower with associated HIV / TB infection in comparison with patients with TB monoinfection. The level of CD4 + T-lymphocytes is significantly lower in infiltrative, fibrous-cavernous and extra pulmonary (peripheral and central lymph nodes) TB, which is combined with HIV infection compared to TB monoinfection.
\end{abstract}

KEY WORDS: HIV infection, tuberculosis, CD4 + T-lymphocytes, CD8 + T-lymphocytes

Wiad Lek 2019, 72, 10, 1942-1946

\section{INTRODUCTION}

As you know, the relationship between tuberculosis and HIV infection at the cellular level is very complicated and insufficiently studied. Reducing the number of CD4 + T-lymphocytes in HIV infection significantly increases susceptibility to tuberculosis infection or reactivation of primary latent tuberculosis infection. The severity of clinical manifestations of tuberculosis, including the development of severe extra pulmonary and disseminated forms, correlates with a decrease in the level of CD4 + T-lymphocytes in peripheral blood [1].

A serious problem is the annual increase of the number of patients with tuberculosis in the stage of clinical exposure to HIV $(72.5 \%)$ and a high proportion of overdue and destructive forms of tuberculosis (31.3\%) in newly diagnosed patients with HIV / TB infection.

\section{THE AIM}

The aim of the work is to carry out a comparative comprehensive immunological examination of HIV-infected and immunocompetent patients with active tuberculosis.

\section{MATERIALS AND METHODS}

There were 231 people - 184 (79.7\%) men and 47 (20.3\%) women at the age of 23 to 60 years under observation. The average age was $(38.8 \pm 1.2)$ years.

All patients were subjected to a comprehensive laboratory examination and divided into such groups.

I. Non-HIV-infected (immunocompetent) people with active first-time TB - 76 patients (TB group).

II. HIV-infected with active for the first time detected tuberculosis - 155 patients (HIV / TB group). Within the HIV / TB group, 3 subgroups were identified depending on the time of TB attachment to HIV infection:

$1^{\text {st }}$ subgroup - HIV-infected, in which TB was detected at different stages of HIV infection (primary illness) - 72 patients;

$2^{\text {nd }}$ subgroup - persons in whom for several years before the registered HIV infection and the time of hypothetical infection (according to the epidemiological history) TB was diagnosed, that is, the primary disease was TB - 26 people;

The third subgroup - HIV-infected, in which the disease was recorded at about one time and it was impossible to find out which ailment was the primary one - 57 people. 
We compared CD4 + T-lymphocyte, CD8 + T-lymphocytes, CD $4+/$ CD8 +, IL-4, IFN- $\gamma$, TNF- $\alpha$ and the results of the reaction of TBGT with tuberculin for groups with combined HIV / TB and TB patients, monoinfection. The immune status was studied in a group of HIV / TB patients within 3-6 months since the diagnosis of associated infection.

Statistical processing of the obtained results of research was carried out with the help of the software complex Windows, Word and Excel; STATISTICA 6.0 using the method of variation statistics with validity determination using Student's criterion, and with the number of observations less than 20, the non-parametric Wilcoxon method for independent aggregates was used, or the dispersion analysis of Kraskele-Wallis. U-Mann-Whitney Criteria were used to compare two independent groups. The differences were considered statistically significant at $\mathrm{P}<0.05$. Spearmen rank method was used for correlation analysis [2].

\section{RESULTS AND DISCUSSION}

The average number of CD4 + Tlymphocytes was significantly lower in the HIV / TB group $(389.1 \pm 24.5) \mathrm{kl} / \mathrm{mm}^{3}$ than in patients with TB alone $(542.2 \pm 27.4) \mathrm{kl} / \mathrm{mm}^{3}(\mathrm{P}<0.001)$. But the level of CD8 + T-lymphocytes in the groups with combined and monoinfection did not differ - $(464.8 \pm 25.6) \mathrm{kl} / \mathrm{mm}^{3}$ and $(426.9 \pm 24.9) \mathrm{kl} / \mathrm{mm}^{3}$, respectively.

Comparing the indicators of CD4 + T-lymphocytes in patients with primary TB with a combined infection in three subgroups, depending on the time of TB attachment, it can be noted that the patterns typical for the whole HIV / TB group are traced to all three subgroups as compared to monoinfection $(\mathrm{P}<0,05-0.01$, Table 1$)$.

The spontaneous production of IL-4 was higher - (7.1 \pm $1.0 \mathrm{pg} / \mathrm{ml} / \mathrm{106}$ ) in the HIV / TB group compared to TB monoinfection - $(3.2 \pm 0.6) \mathrm{pg} / \mathrm{ml} / 106(\mathrm{P}<0.05)$ with the caseogenesis pneumonia, while the spontaneous production of IFN $-\gamma$ also exceeded the corresponding indicator in patients with $\mathrm{TB}$ alone $-(90.7 \pm 32.6) \mathrm{pg} / \mathrm{ml} / 106 \mathrm{vs}$. $(7.3 \pm 1.1) \mathrm{kp} / \mathrm{ml} / 106(\mathrm{P}<0.001)$. HHV was kept at a moderate level $-(92450 \pm 22890) \mathrm{kp} / \mathrm{ml}$.
When comparing the indicators of CD8 + T-lymphocytes in patients with primary $\mathrm{TB}$ with a combined infection in three subgroups, depending on the time of TB attachment, it can be noted that the smallest number of cells appeared in the $1^{\text {st }}$ subgroup - $(378.5 \pm 18.2) \mathrm{kl} / \mathrm{mm}^{3}$, and the largest in the $2^{\text {nd }}-(526,7 \pm 32,6) \mathrm{kl} / \mathrm{mm}^{3}$ subgroup of HIV-infected people. However, in general, the average number of CD8 + T-lymphocytes in patients with mono-TB and associated infections did not differ.

The CD $4+/$ CD8 + index in patients with associated infections, as well as in each of the three subgroups, was statistically significantly lower than with TB monoinfection.

The indicators of CD4 + T-lymphocytes for different forms of TB were analyzed. The differences in CD4 + T-lymphocyte levels, CD8 + T-lymphocytes were not detected at focal TB in patients with HIV-infection, in its subgroups, and in patients with TB monoinfection. In infiltrative TB, CD4 + T-lymphocyte indexes are significantly lower in patients with HIV / TB - $(441.6 \pm 36.7) \mathrm{kl} / \mathrm{mm}^{3}$ compared to TB monoinfection - $(619.8 \pm 67.6, \mathrm{P}<0,01)$. The same pattern can be traced to all subgroups of HIV + TB infected $(\mathrm{P}<0.05-0.01$, Table 2).

The significant differences were observed with respect to CD8 + T-lymphocytes in caseogenesis. Thus, this indicator was significantly lower in the patients with TB monoinfection than in the HIV-infected group - $(279.6 \pm 40.3)$ $\mathrm{kl} / \mathrm{mm}^{3}$ vs. $(404.9 \pm 43.6) \mathrm{kl} / \mathrm{mm}^{3}(\mathrm{P}<0.01)$. The same pattern was inherent in the $3^{\text {rd }}$ subgroup of HIV-infected patients as compared to patients with TB monoinfection.

A significantly lower number of CD4 + T lymphocytes was detected in a group of people with fibro-cavernous tuberculosis (FCT) with a combination of HIV infection and TB - (320, 9 $\pm 43,9) \mathrm{kl} / \mathrm{mm}^{3}$ compared with a group of patients with TB alone - $(473.2 \pm 56.0) \mathrm{kl} / \mathrm{mm}^{3}(\mathrm{P}<0.05)$. But the level of CD8 + T-lymphocytes was significantly higher with concomitant HIV infection - $(615.3 \pm 52.6) \mathrm{kl} / \mathrm{mm}^{3}$ compared with patients only with TB - $(236.4 \pm 70.8, \mathrm{P}<0.001)$. The same regularities were true for the $3^{\text {rd }}$ subgroup of HIV-infected people.

The average number of CD8 + T-lymphocytes was significantly higher in patients with associated TB-disseminated

Table 1. Indicators $C D 4+, C D 8+$, index $C D 4+/ C D 8+$ in the groups of patients under investigation

\begin{tabular}{|c|c|c|c|c|c|c|c|c|c|c|}
\hline \multirow{4}{*}{ Indicator } & \multicolumn{8}{|c|}{ HIV/TB } & \multirow{2}{*}{\multicolumn{2}{|c|}{$\begin{array}{c}\text { TB monoinfection, } \\
n=76\end{array}$}} \\
\hline & \multicolumn{2}{|c|}{$1^{\text {st }}$ subgroup, $\mathrm{n}=72$} & \multicolumn{2}{|c|}{$2^{\text {nd }}$ subgroup, $\mathrm{n}=26$} & \multicolumn{2}{|c|}{$3^{\text {rd }}$ subgroup, $n=57$} & \multicolumn{2}{|c|}{ all, $n=155$} & & \\
\hline & \multicolumn{2}{|c|}{1} & \multicolumn{2}{|c|}{2} & \multicolumn{2}{|c|}{3} & \multicolumn{2}{|c|}{4} & \multicolumn{2}{|c|}{5} \\
\hline & $\begin{array}{c}\text { abs. } \\
\text { number }\end{array}$ & $\begin{array}{c}M \% \pm \\
m \%\end{array}$ & $\begin{array}{c}\text { abs. } \\
\text { number }\end{array}$ & $\begin{array}{c}M \% \pm \\
m \%\end{array}$ & $\begin{array}{c}\text { abs. } \\
\text { number }\end{array}$ & $\begin{array}{c}M \% \pm \\
m \%\end{array}$ & $\begin{array}{l}\text { abs. } \\
\text { Number }\end{array}$ & $\begin{array}{l}M \% \pm \\
m \%\end{array}$ & $\begin{array}{c}\text { abs. } \\
\text { number }\end{array}$ & $\begin{array}{c}M \% \pm \\
\mathbf{m} \%\end{array}$ \\
\hline $\mathrm{CD}^{4}+$ & $\begin{array}{l}339,6 \pm \\
23,3^{2,5}\end{array}$ & $\begin{array}{c}19,5 \pm \\
0,7\end{array}$ & $\begin{array}{l}434,2 \pm \\
25,8^{1,5}\end{array}$ & $\begin{array}{c}33,7 \pm \\
0,9\end{array}$ & $\begin{array}{c}393,6 \pm \\
24,3^{5}\end{array}$ & $\begin{array}{c}20,6 \pm \\
0,8\end{array}$ & $\begin{array}{c}389,1 \pm \\
24,5^{5}\end{array}$ & $\begin{array}{c}24,6 \pm \\
0,8\end{array}$ & $\begin{array}{l}542,2 \pm \\
27,4^{1-4}\end{array}$ & $\begin{array}{c}38,0 \pm \\
1,0\end{array}$ \\
\hline $\mathrm{CD}^{8}+$ & $\begin{array}{l}378,5 \pm \\
18,2^{2,3}\end{array}$ & $\begin{array}{c}22,6 \pm \\
0,9\end{array}$ & $\begin{array}{l}526,7 \pm \\
32,6^{1,5}\end{array}$ & $\begin{array}{c}28,5 \pm \\
1,0\end{array}$ & $\begin{array}{c}489,3 \pm \\
26,1^{1}\end{array}$ & $\begin{array}{c}25,4 \pm \\
0,9\end{array}$ & $\begin{array}{c}464,8 \pm \\
25,6\end{array}$ & $\begin{array}{c}25,5 \pm \\
0,9\end{array}$ & $\begin{array}{c}426,9 \pm \\
24,9^{2}\end{array}$ & $\begin{array}{c}24,7 \pm \\
0,7\end{array}$ \\
\hline $\begin{array}{l}\mathrm{CD}^{+} / \\
\mathrm{CD}^{+}\end{array}$ & \multicolumn{2}{|c|}{$0,90 \pm 0,06^{5}$} & \multicolumn{2}{|c|}{$0,82 \pm 0,08^{5}$} & \multicolumn{2}{|c|}{$0,80 \pm 0,07^{5}$} & \multicolumn{2}{|c|}{$0,84 \pm 0,07^{5}$} & \multicolumn{2}{|c|}{$1,27 \pm 0,09^{1-4}$} \\
\hline
\end{tabular}

Note (here and below). The digit in power denotes a subgroup with which the difference is significant $(\mathrm{P}<0,05-0,001)$. 
Table 2. The average quantity $\mathrm{CD} 4+\mathrm{i} C \mathrm{D} 8+$ in the study groups of patients $(\mathrm{kl} / \mathrm{mm} 3)$

\begin{tabular}{|c|c|c|c|c|c|c|c|c|c|c|}
\hline \multirow{4}{*}{ Form of TB } & \multicolumn{8}{|c|}{ HIV/TB } & \multirow{2}{*}{\multicolumn{2}{|c|}{$\begin{array}{c}\text { TB- } \\
\text { monoinfection, } \\
\mathbf{n}=76\end{array}$}} \\
\hline & \multicolumn{2}{|c|}{$\begin{array}{c}1^{\text {st }} \text { subgroup, } \\
n=72\end{array}$} & \multicolumn{2}{|c|}{$\begin{array}{c}2^{\text {nd }} \text { subgroup, } \\
n=26\end{array}$} & \multicolumn{2}{|c|}{$\begin{array}{c}3^{\text {rd }} \text { subgroup, } \\
n=57\end{array}$} & \multicolumn{2}{|c|}{$\begin{array}{c}\text { all, } \\
n=155\end{array}$} & & \\
\hline & \multicolumn{2}{|c|}{1} & \multicolumn{2}{|c|}{2} & \multicolumn{2}{|c|}{3} & \multicolumn{2}{|c|}{4} & \multicolumn{2}{|c|}{5} \\
\hline & $\mathrm{CD}^{+}$ & $\mathrm{CD8}^{+}$ & $\mathrm{CD4}^{+}$ & $\mathrm{CD8}^{+}$ & $\mathrm{CD4}^{+}$ & $\mathrm{CD8}^{+}$ & $\mathrm{CD4}^{+}$ & $\mathrm{CD8}^{+}$ & $\mathrm{CD4}^{+}$ & $\mathrm{CD8}^{+}$ \\
\hline Fulminant & $\begin{array}{c}447,6 \pm \\
54,9\end{array}$ & $\begin{array}{c}471,3 \pm \\
34,8\end{array}$ & $\begin{array}{c}556,4 \pm \\
77,6\end{array}$ & $\begin{array}{c}659,9 \pm \\
89,2\end{array}$ & $\begin{array}{c}439,8 \pm \\
69,1\end{array}$ & $\begin{array}{c}478,5 \pm \\
67,3\end{array}$ & $\begin{array}{c}481,3 \pm \\
67,2\end{array}$ & $\begin{array}{c}536,6 \pm \\
63,8\end{array}$ & $\begin{array}{c}648,3 \pm \\
65,4\end{array}$ & $\begin{array}{c}489,6 \pm \\
67,6\end{array}$ \\
\hline $\mathrm{N}$ & \multicolumn{2}{|c|}{13} & \multicolumn{2}{|c|}{4} & \multicolumn{2}{|c|}{7} & \multicolumn{2}{|c|}{24} & \multicolumn{2}{|c|}{8} \\
\hline Infiltrative & $\begin{array}{c}419,5 \pm \\
52,0^{5} \\
\end{array}$ & $\begin{array}{c}512,5 \pm \\
25,5 \\
\end{array}$ & $\begin{array}{c}444,0 \pm \\
29,5^{5} \\
\end{array}$ & $\begin{array}{c}567,0 \pm \\
43,0 \\
\end{array}$ & $\begin{array}{c}461,4 \pm \\
28,7^{5} \\
\end{array}$ & $\begin{array}{c}573,3 \pm \\
21,6 \\
\end{array}$ & $\begin{array}{c}441,6 \pm \\
36,7^{5} \\
\end{array}$ & $\begin{array}{c}550,9 \pm \\
30,0 \\
\end{array}$ & $\begin{array}{c}619,8 \pm \\
67,6^{1-4} \\
\end{array}$ & $\begin{array}{c}492,9 \pm \\
79,5 \\
\end{array}$ \\
\hline $\mathrm{N}$ & \multicolumn{2}{|c|}{20} & \multicolumn{2}{|c|}{10} & \multicolumn{2}{|c|}{19} & \multicolumn{2}{|c|}{49} & \multicolumn{2}{|c|}{14} \\
\hline Caseous pneumonia & $\begin{array}{c}433,5 \pm \\
36,5\end{array}$ & $\begin{array}{c}340,0 \pm \\
49,5\end{array}$ & $\begin{array}{c}370,3 \pm \\
32,7\end{array}$ & $\begin{array}{c}344,8 \pm \\
36,4\end{array}$ & $\begin{array}{c}492,9 \pm \\
28,3\end{array}$ & $\begin{array}{c}529,8 \pm \\
44,7^{5}\end{array}$ & $\begin{array}{c}432,2 \pm \\
32,5\end{array}$ & $\begin{array}{c}404,9 \pm \\
43,6^{5}\end{array}$ & $\begin{array}{c}411,3 \pm \\
58,5\end{array}$ & $\begin{array}{l}279,6 \pm \\
40,3^{3,4}\end{array}$ \\
\hline $\mathrm{N}$ & \multicolumn{2}{|c|}{6} & \multicolumn{2}{|c|}{3} & \multicolumn{2}{|c|}{9} & \multicolumn{2}{|c|}{18} & \multicolumn{2}{|c|}{6} \\
\hline FCT & 155 & 340 & $\begin{array}{c}560,0 \pm \\
92,0^{3}\end{array}$ & $\begin{array}{c}584,5 \pm \\
70,5^{3}\end{array}$ & $\begin{array}{l}247,8 \pm \\
39,6^{2,5} \\
\end{array}$ & $\begin{array}{l}921,3 \pm \\
87,3^{2,5}\end{array}$ & $\begin{array}{c}320,9 \pm \\
43,9^{5}\end{array}$ & $\begin{array}{c}615,3 \pm \\
52,6^{5}\end{array}$ & $\begin{array}{c}473,2 \pm \\
56,0^{3,4}\end{array}$ & $\begin{array}{l}426,4 \pm \\
70,8^{3,4} \\
\end{array}$ \\
\hline $\mathrm{N}$ & \multicolumn{2}{|c|}{1} & \multicolumn{2}{|c|}{2} & \multicolumn{2}{|c|}{3} & \multicolumn{2}{|c|}{6} & \multicolumn{2}{|c|}{12} \\
\hline Disseminated & $\begin{array}{c}208,3 \pm \\
36,5\end{array}$ & $\begin{array}{c}269,0 \pm \\
38,3^{2}\end{array}$ & $\begin{array}{c}311,5 \pm \\
39,0\end{array}$ & $\begin{array}{l}410,0 \pm \\
26,0^{1,5}\end{array}$ & $\begin{array}{c}243,6 \pm \\
43,9\end{array}$ & $\begin{array}{c}291,7 \pm \\
48,3\end{array}$ & $\begin{array}{c}254,5 \pm \\
39,8\end{array}$ & $\begin{array}{c}323,6 \pm \\
24,8^{5}\end{array}$ & $\begin{array}{c}337,4 \pm \\
41,2\end{array}$ & $\begin{array}{c}222,7 \pm \\
26,8^{4}\end{array}$ \\
\hline $\mathrm{N}$ & & & & & & & & & & \\
\hline Generalized & $\begin{array}{c}145,6 \pm \\
32,6\end{array}$ & $\begin{array}{c}252,3 \pm \\
25,3\end{array}$ & 423 & 403 & $\begin{array}{c}120,0 \pm \\
19,0\end{array}$ & $\begin{array}{c}245,0 \pm \\
20,0\end{array}$ & $\begin{array}{c}229,5 \pm \\
17,2\end{array}$ & $\begin{array}{c}300,1 \pm \\
15,1\end{array}$ & $\begin{array}{c}337,0 \pm \\
80,0\end{array}$ & $\begin{array}{c}208,5 \pm \\
66,5\end{array}$ \\
\hline $\mathrm{N}$ & & & & & & & & & & \\
\hline Extra-pulmonary & $\begin{array}{c}252,8 \pm \\
33,1\end{array}$ & $\begin{array}{c}339,2 \pm \\
35,3\end{array}$ & $\begin{array}{c}218,7 \pm \\
0,0\end{array}$ & $\begin{array}{c}252,0 \pm \\
0,0\end{array}$ & $\begin{array}{c}207,9 \pm \\
42,0\end{array}$ & $\begin{array}{c}356,7 \pm \\
36,9\end{array}$ & $\begin{array}{c}226,5 \pm \\
25,0\end{array}$ & $\begin{array}{c}316,0 \pm \\
24,1\end{array}$ & $\begin{array}{c}360,3 \pm \\
77,2\end{array}$ & $\begin{array}{c}248,2 \pm \\
31,5\end{array}$ \\
\hline $\mathrm{N}$ & & & & & & & & & & \\
\hline Pleurisy & $\begin{array}{c}378,5 \pm \\
22,5\end{array}$ & $\begin{array}{c}511,0 \pm \\
35,0^{3}\end{array}$ & 254 & 263 & $\begin{array}{c}252,0 \pm \\
84,5\end{array}$ & $\begin{array}{c}279,5 \pm \\
76,0^{1}\end{array}$ & $\begin{array}{c}294,8 \pm \\
32,1\end{array}$ & $\begin{array}{c}351,2 \pm \\
37,0\end{array}$ & $\begin{array}{c}541,2 \pm \\
154,2\end{array}$ & $\begin{array}{c}403,6 \pm \\
57,8\end{array}$ \\
\hline $\mathrm{N}$ & & & & & & & & & & \\
\hline Meningitis & $\begin{array}{c}156,3 \pm \\
33,3\end{array}$ & $\begin{array}{c}261,6 \pm \\
34,5\end{array}$ & & & 134,0 & 255,0 & $\begin{array}{c}96,8 \pm \\
11,1 \\
\end{array}$ & $\begin{array}{c}172,2 \pm \\
96,5\end{array}$ & & \\
\hline $\mathrm{N}$ & & & & & & & & & & \\
\hline $\begin{array}{l}\text { Peripheral and central } \\
\text { lymph nodes }\end{array}$ & $\begin{array}{c}223,6 \pm \\
43,4\end{array}$ & $\begin{array}{c}245,0 \pm \\
36,4^{3}\end{array}$ & 402,0 & 493,0 & $\begin{array}{c}237,8 \pm \\
41,6\end{array}$ & $\begin{array}{c}535,7 \pm \\
34,6^{1}\end{array}$ & $\begin{array}{c}287,8 \pm \\
28,3^{5}\end{array}$ & $\begin{array}{c}424,6 \pm \\
23,7\end{array}$ & $\begin{array}{c}539,6 \pm \\
77,4^{4}\end{array}$ & $\begin{array}{c}341,1 \pm \\
36,8\end{array}$ \\
\hline $\mathrm{N}$ & & & & & & & & & & \\
\hline
\end{tabular}

infection compared to the TB monoinfection group (323.6 $\pm 24.8) \mathrm{kl} / \mathrm{mm}^{3}$ against $(222.7 \pm 26.8) \mathrm{kl} / \mathrm{mm}^{3}(\mathrm{P}<0.01)$.

The big attention is drawn to the fact that in the structure of extra pulmonary TB in HIV / TB patients there were no such forms as TB of the urogenital system, bone and ligament. The level of CD4 + T-lymphocytes was significantly below the above indicator only with TB $-(287.8 \pm$ $28.3) \mathrm{kl} / \mathrm{mm}^{3}$ against $(539.6 \pm 77.4) \mathrm{kl} / \mathrm{mm}^{3}(\mathrm{P}<0.001)$ at TB of peripheral and central lymph nodes against the background of HIV infection.

The frequent development of complicated forms of the tuberculosis process, in particular dissemination and generalization in HIV-infected patients at later stages, is fixed by many authors [3-6]. Moreover, the conditions in the HIV-infected organism (progressive decrease of CD4 + T-lymphocytes level and their functional failure) are created, when even a moderate immune deficiency, even the infiltrative tuberculosis process often leads to unfavorable results.

The results of the study of the level of cytokines - serum concentration and spontaneous production of IL-4, IFN- $\gamma$, TNF- $\alpha$ in HIV / TB and TB patients only were analyzed. Simultaneously with the study of the level of cytokines, the burden of HIV in patients with different forms of TB was also determined.

The differences were observed in various forms of TB. Thus, with focal TB, serum IL-4 concentration was higher with combined HIV / TB infection than with TB monoinfection - $(2.8 \pm 1.2) \mathrm{kp} / \mathrm{ml}$ against $(1.5 \pm 0.2) \mathrm{kp} / \mathrm{ml}(\mathrm{P}$ $<0.05)$, and the serum IFN- $\gamma$ concentration was lower $(24.2$ $\pm 8.9) \mathrm{kp} / \mathrm{ml}$ versus $(50.6 \pm 9.4) \mathrm{kp} / \mathrm{ml}(\mathrm{P}<0.05)$. Viral load (VH) of HIV was the lowest - $(33115 \pm 9896 \mathrm{kp} / \mathrm{ml})$. 
Table 3. The level of TNF- $a$ in the patients with HIV / TB and TB

\begin{tabular}{|c|c|c|c|c|}
\hline \multirow{4}{*}{ The form of TB } & \multirow{2}{*}{\multicolumn{2}{|c|}{$\begin{array}{c}\text { HIV/TB } \\
\text { TNF- } a \\
\end{array}$}} & \multicolumn{2}{|c|}{ TB-momoinfection } \\
\hline & & & \multicolumn{2}{|c|}{ TNF- $a$} \\
\hline & $\begin{array}{l}\text { serum, } \\
\text { pc/ml }\end{array}$ & $\begin{array}{c}\text { spontaneous, } \\
\mathrm{pc} / \mathrm{ml} / 1^{\circ} 6\end{array}$ & $\begin{array}{l}\text { serum, } \\
\mathrm{pc} / \mathrm{ml}\end{array}$ & $\begin{array}{c}\text { spontaneous, } \\
\mathrm{pc} / \mathrm{ml} / 1^{\circ} 6\end{array}$ \\
\hline & $1-1$ & $1-2$ & $2-1$ & $2-2$ \\
\hline Fulminant & $22,6 \pm 4,3^{2-1}$ & $209,2 \pm 76,3$ & $5,3 \pm 1,0^{1-1}$ & $60,9 \pm 13,2$ \\
\hline $\mathrm{N}$ & \multicolumn{2}{|c|}{24} & \multicolumn{2}{|c|}{8} \\
\hline Infiltrative & $40,5 \pm 7,7^{2-1}$ & $43,5 \pm 20,2$ & $6,5 \pm 1,3^{1-1}$ & $7,1 \pm 3,4$ \\
\hline $\mathrm{N}$ & \multicolumn{2}{|c|}{49} & \multicolumn{2}{|c|}{14} \\
\hline Caseous pneumonia & $20,2 \pm 4,4$ & $181,0 \pm 62,2^{2-2}$ & $9,9 \pm 2,7$ & $11,3 \pm 1,5^{1-2}$ \\
\hline $\mathrm{N}$ & \multicolumn{2}{|c|}{18} & \multicolumn{2}{|c|}{6} \\
\hline FCT & $46,4 \pm 8,1^{2-1}$ & $47,9 \pm 22,7$ & $4,3 \pm 0,8^{1-1}$ & $4,5 \pm 2,2$ \\
\hline $\mathrm{N}$ & \multicolumn{2}{|c|}{6} & \multicolumn{2}{|c|}{12} \\
\hline Disseminated & $20,8 \pm 6,9$ & $25,1 \pm 10,7$ & $6,6 \pm 1,4$ & $7,8 \pm 1,7$ \\
\hline $\mathrm{N}$ & \multicolumn{2}{|c|}{28} & \multicolumn{2}{|c|}{14} \\
\hline Generalized & $32,7 \pm 6,2^{2-1}$ & $40,6 \pm 19,2$ & $4,1 \pm 0,8^{1-1}$ & $11,3 \pm 7,0$ \\
\hline $\mathrm{N}$ & \multicolumn{2}{|c|}{11} & \multicolumn{2}{|c|}{4} \\
\hline Extra-pulmonary & $23,3 \pm 7,3$ & $31,1 \pm 18,5$ & $9,1 \pm 1,9$ & $9,8 \pm 3,6$ \\
\hline $\mathrm{N}$ & \multicolumn{2}{|c|}{19} & \multicolumn{2}{|c|}{18} \\
\hline Together & $29,5 \pm 6,4^{2-1}$ & $82,6 \pm 32,8^{2-2}$ & $6,5 \pm 1,4^{1-1}$ & $16,1 \pm 4,7^{1-2}$ \\
\hline $\mathrm{N}$ & \multicolumn{2}{|c|}{155} & \multicolumn{2}{|c|}{76} \\
\hline
\end{tabular}

The serum IL- 4 concentration significantly exceeded the indicator for TB monoinfection - $(3.8 \pm 0.7) \mathrm{kp} / \mathrm{ml}$ versus $(1.5 \pm 0.3) \mathrm{kp} / \mathrm{ml}(\mathrm{P}<0,05)$ in infiltrative $\mathrm{TB}$ in a group with a combined infection. At the same time, the viral load was quite high - $(201834 \pm 53984) \mathrm{kp} / \mathrm{ml}$ (high $\mathrm{VN}$ is considered at a level $>100$ thousand $\mathrm{kp} / \mathrm{ml}$ ).

The serum concentration and spontaneous production of TNF- $\alpha$ in TB and HIV / TB groups were investigated. The significant differences were found between the levels of tumor necrosis factor- $\alpha$ in HIV-infected patients and patients with TB alone. Thus, at serous, infiltrative, fibro-cavernous and generalized TB in association with HIV infection, the serum concentration of TNF- $\alpha$ was statistically significantly higher than that for TB monoinfection $(\mathrm{P}<0.05-0.001)$. In the case of caseous pneumonia, the spontaneous production of TNF- $\alpha$ in the HIV / TB group was $(181.0 \pm 62.2) \mathrm{pc} / \mathrm{ml} / 106$, significantly exceeding the study level in patients with TB alone - $(11.3 \pm 1.5) \mathrm{pc}$ / $\mathrm{ml} / 106(\mathrm{P}<0.001$, Table 3$)$.

In general, the serum concentration and spontaneous production of TNF- $\alpha$ was higher in the group of patients with a combined infection $(29.5 \pm 6.4) \mathrm{pc} / \mathrm{ml}$ and $(82.6$ $\pm 32.8) \mathrm{pc} / \mathrm{ml} / 106$ compared with $\mathrm{TB}$ - monoinfection - $(6,5 \pm 1,4) \mathrm{pc} / \mathrm{ml}$ and $(16,1 \pm 4,7) \mathrm{pc} / \mathrm{ml} / 106$ (in both cases $\mathrm{P}<0,001)$.

Thus, with the progression of HIV infection (a decrease in the number of CD $4+$ T-lymphocytes and an increase in viral load of HIV), an increase in serum IFN- $\gamma$ and TNF- $\alpha$ is observed, which is likely to indicate a decrease in the number of anti-inflammatory T-regulatory cells, or about reducing their suppressor activity [7].

\section{CONCLUSIONS}

1. CD4 + T-lymphocyte ratios, CD4 + / CD8 + ratios are significantly lower with associated HIV / TB infection in comparison with patients with TB monoinfection.

2. The level of CD4 + T-lymphocytes is significantly lower than that of TB monoinfection, in infiltrative, fibrous-cavernous and extra pulmonary (peripheral and central lymph nodes) TB, which is combined with HIV infection.

3. An increase in serum IFN- $\gamma$ and TNF- $\alpha$ is observed with the progression of HIV infection (a reduction in the number of CD4 + T-lymphocytes and an increase in the burden of HIV), which is likely to indicate a decrease in the number of anti-inflammatory T-regulatory cells or a decrease their suppressor activity.

4. The signs of the progression of combined HIV / TB infection should be considered as a rapid decrease in the number of $\mathrm{CD} 4+\mathrm{T}$-lymphocytes, the ratio of CD4 + / CD8 +, increased HIV load, increased serum levels of TNF- $\alpha$ and IFN- $\gamma$.

5. It was found that CD4 + T lymphocyte levels were significantly lower in those who died soon in the case of primary or simultaneous diagnosis of HIV infection, compared to patients who had tuberculosis with primary background illness. 


\section{REFERENCES}

1. Sarrazin H, Wilkinson KA, Andersson J et al. Association between tuberculin skin testreactivity, CD4cell subset memory and circulating FoxP3-expressing cells in HIV-infected individuals: J. Infect. Dis. 2009;199 (5):702-710.

2. Lapach SN, Chubenko AV, Babich PN. Statistical methods in medicalbiological research using Excell: Kyiv: MORION, 2000, p.320.

3. Alexandrina TA. The features of the TB epidemic in Ukraine: Tuberculosis, pulmonary diseases, HIV-infection. 2012;2:7-12.

4. Redzwan M, Rashid AliS, Ralph AP et al. Individualized second line antituberculosis therapy for an extensively resistant pulmonary tuberculosis (XDR PTB) in East Malaysia: Med. J. Malaysia. 2015;70 (3):200-204.

5. Sulis G, Centis R, Sotgiu G et al. Recent developments in the diagnosis and management of tuberculosis: NPJ Prim. Care Respir. Med. 2016;26:1-8.

6. Petrenko VI, Protsiuk RG. The problem of tuberculosis in: Tuberculosis, pulmonary diseases, HIV-infection. 2015;2 (21):16-29.

7. Chase AJ, Yang HC, Zhang $\mathrm{H}$ et al. Preservation of FoxP3 + regulatory $T$ cells in the peripheral blood of human immunodeficiency virus type 1-infected elite suppressors con-elating with low CD4 + T-cell activation: JVirol. 2015;82:8307-8315.
The work is performed within the limits of the HSEI Bukovininan state medical university scientific work "Molecular-genetic and clinical-pathogenetic features of the combined the pathology of internal organs, the role of infectious and metabolic factors in its development".

\section{Authors' contributions:}

According to the order of the Authorship.

\section{ORCID numbers:}

Vasyl. D. Moskaliuk - 0000-0002-4104-8153

Tetiana R. Kolotylo - 0000-0002-0821-7904

Khrystyna I. Pudiak - 0000-0002-0157-1433

Ivanna V. Rudan - 0000-0002-4985-5363

Oksana I. Goliar - 0000-0001-9165-4840

Iryna V. Balanyk - 0000-0002-3258-9791

\section{Conflict of interest:}

The Authors declare no conflict of interest.

\section{CORRESPONDING AUTHOR Tetiana Kolotylo}

HSEl Bukovininan state medical university, Chernivtsi, Ukraine tel: +380664669273

e-mail: taniakolotyl015@gmail.com

Received: 19.03 .2019

Accepted: 20.09.2019 
PRACA ORYGINALNA

ORIGINAL ARTICLE

\title{
HEALTH IN THE CIVIC STUDENTS' VALUE SYSTEM: EMPIRICAL ANALYSIS
}

\author{
Halyna 0. Vaskivska', Svitlana P. Palamar², Olha M. Vlasenko³ \\ IINSTITUTE OF PEDAGOGY OF THE NATIONAL ACADEMY OF EDUCATIONAL SCIENCES OF UKRAINE, KYIV, UKRAINE \\ 2BORYS GRINCHENKO KYIV UNIVERSITY, KYIV, UKRAINE \\ ${ }^{3}$ ZHYTOMYR IVAN FRANKO STATE UNIVERSITY, ZHYTOMYR, UKRAINE
}

\begin{abstract}
Introduction: Nowadays one of the priority directions of state education policy in Ukraine is the formation of a healthy lifestyle through education, creation health-preserving educational environment in high educational institutions.

The aim of our work was to give an analytical estimation of the formation of health value as an integral characteristic of a modern Ukrainian student in high educational institutions of Zhytomyr region, to develop a scientifically substantiated system of diagnosing the value of health in the system of civic values of a future specialist in contemporary socio-economic conditions.

Materials and methods: Two students' surveys were carried out in Zhytomyr region of Ukraine, among young people of 15-22 years old. A number of methods were used: observation, comparison, analysis, synthesis, generalization, the study of products of students' activity, tests, etc.

Results: the success of the process of the formation of students ' health value depends on the factors such as educational environment, the culture of health, training of university teachers to cultivate health value in collaboration with society, and using modern forms, methods, and tools in the formation of health value.

Conclusion: Thus, the policy recommendations for high education institutions are: the prevention of drug addiction, smoking, consumption of alcohol, chronic diseases, Internet addiction; the organization and conduction of mass physical culture and recreational activities; the creation an effective health service system in high educational institutions; the providing the system for monitoring both the future specialists' health and health work results in high educational institution.
\end{abstract}

KEY WORDS: health value, civic values, physical activity, healthy lifestyle, valeological culture, health preservation competence

Wiad Lek 2019, 72, 10, 1947-1952

\section{INTRODUCTION}

At the present stage of human development, the health of the nation is regarded as an indicator of civility of the country, reflecting the socio-economic situation of society, and it is the basic criterion for the effectiveness in all areas of human activity and social development.

Modern social and economic conditions are characterized by the accelerated pace of life, increased activity of interpersonal relations, problems of adaptation of an individual in the society, which require a high level of mobilization of all internal processes of a young person, which provide the vital functions of the organism and affect future specialist's health.

There is a major concern of health care of young generation, which constitutes about $35 \%$ of the population of Ukraine. It affects directly the national workforce, economic development of the country, it is also crucial for the health of the future generation and the Ukrainian population as a whole [1]. The sharp deterioration of the health of Ukrainian young people in recent years demands the immediate activation of the state youth policy, especially in the health sector. An increase in the rate of depopulation, a decrease of the quality of life and health of young people, deterioration of conditions of obtaining full education, active departure of citizens aged 21-35 for employment in Western Europe, an increase in the number of drug addicts, growth of delinquency and crime in the youth, environment complicate the process of participation of a young person in the civil life of Ukrainian society.

Health is a normal psychosomatic state of a person, reflecting his physical and mental well-being in order to ensure the full implementation of labour and biological functions [7], which define to a large extent person's lifestyle, the level of his social, economic and labour activity, mobility, his attraction to the contemporary achievements of culture, science, art, engineering and technology, the way of spending leisure and recreation.

\section{THE AIM}

The aim of the research is to give an analytical assessment of the formation of the value of health as an integral characteristic of a modern Ukrainian student in higher education institutions of Zhytomyr region, to develop an evidence-based diagnostic system and the formation of the health value of a future specialist in contemporary socio-economic conditions. 
Table I. General characteristics

\begin{tabular}{ccc}
\hline Gender & & \\
\hline Female & 792 & 67.0 \\
\hline Male & 390 & 32.9 \\
\hline University Level & & 63.4 \\
\hline Junior (I, II, III years of study) & 750 & 36.5 \\
\hline Senior (IV year of study and master's degree) & 432 & 29.2 \\
\hline Major & 350 & 70.8 \\
\hline Health-related & 832 & \\
\hline Living Situation & & 56 \\
\hline On campus & 661 & 44 \\
\hline Live with family & 521 & \\
\hline
\end{tabular}

Source: Survey

Table II. Peculiarities of physical activity

\begin{tabular}{|c|c|c|c|c|c|}
\hline \multirow{2}{*}{ Running } & 171 & 254 & 308 & 258 & 190 \\
\hline & $(14.5 \%)$ & $(21.5 \%)$ & $(26.1 \%)$ & $(21.8 \%)$ & $(16.1 \%)$ \\
\hline \multirow{2}{*}{ Regular walk } & 298 & 487 & 258 & 100 & 39 \\
\hline & $(25.2 \%)$ & $(41.2 \%)$ & $(21.8 \%)$ & $(8.5 \%)$ & $(3.3 \%)$ \\
\hline \multirow{2}{*}{ Swimming } & 35 & 42 & 394 & 580 & 129 \\
\hline & $(3.0 \%)$ & $(3.6 \%)$ & $(33.3 \%)$ & (49.1\%) & $(10.9 \%)$ \\
\hline \multirow{2}{*}{ Fitness } & 154 & 434 & 351 & 146 & 97 \\
\hline & $(13.0 \%)$ & $(36.7 \%)$ & $(29.7 \%)$ & $(12.4 \%)$ & $(8.2 \%)$ \\
\hline \multirow{2}{*}{ Health nutrition } & 290 & 494 & 254 & 107 & 35 \\
\hline & $(24.5 \%)$ & $(41.8 \%)$ & $(21.5 \%)$ & $(9.1 \%)$ & $(3.0 \%)$ \\
\hline \multirow{3}{*}{ The adherence of sleep mode } & 183 & 441 & 286 & 168 & 104 \\
\hline & $(15.5 \%)$ & $(37.3 \%)$ & $(24.2 \%)$ & $(14.2 \%)$ & $(8.8 \%)$ \\
\hline & V Often & Often & Rare & V Rare & Never \\
\hline
\end{tabular}

Source: Survey

To achieve the goal, the scientists of the Zhytomyr Medical Institute and Zhytomyr Ivan Franko State University set the following tasks: to assess students' state of health according to statistics of their morbidity in higher education institutions; to determine the factors influencing the formation of the value of health and healthy lifestyle of students in the educational process during the period of study in higher education institutions in Zhytomyr region.

\section{MATERIALS AND METHODS}

Two independent student surveys were carried out in Zhytomyr region of Ukraine, among young people born between 1997 and 2003. The subjects included in the surveys were 15 to 22 years old. The total sample size of the survey was 1,182 in two educational institutions - Zhytomyr Ivan Franko State University and Zhytomyr Medical Institute. The present analyses include 390 men and 792 women.

Semi-structured questionnaires, interview schedules, focus group discussions and monitoring checklists were used to collect quantitative and qualitative data from respondents.

A number of methods were used in the experiment: pedagogical observation, comparison, analysis, synthesis, generalization, the study of products of student activity, testing, statistical processing of obtained results, etc. Among the survey methods, the most effective in the context of the subject of research were the methods of questioning and conversations, through which information about health-preserving activities, the degree of its focus on improving future professional activities was gathered.

Quantitative data was obtained in SPSS format, while qualitative data was obtained in written format and in audio format. Figures on quantitative data were analyzed using SPSS V.23, while qualitative data was originally placed in MS Word format before being analyzed using NVivo V.11.

Since the data analysis was independent one from another, they were triangulated to minimize deviations. 
Table III. Negative tendencies

\begin{tabular}{|c|c|c|c|c|c|}
\hline \multirow{2}{*}{ Difficulty in doing daily physical activities } & 401 & 243 & 326 & 179 & 32 \\
\hline & $(33.9 \%)$ & $(20.6 \%)$ & $(27.6 \%)$ & $(15.2 \%)$ & $(2.7 \%)$ \\
\hline \multirow{2}{*}{ Feeling very tired every day } & 92 & 379 & 232 & 271 & 204 \\
\hline & $(7.8 \%)$ & $(32.1 \%)$ & $(19.7 \%)$ & $(23.0 \%)$ & $(17.3 \%)$ \\
\hline \multirow{2}{*}{ Increased weight } & 83 & 265 & 263 & 254 & 340 \\
\hline & $(7.0 \%)$ & $(22.4 \%)$ & $(20.3 \%)$ & $(21.5 \%)$ & $(28.8 \%)$ \\
\hline \multirow{2}{*}{ Smoking } & 197 & 354 & 308 & 248 & 74 \\
\hline & $(16.7 \%)$ & (30.0\%) & (26.1\%) & $(20.9 \%)$ & (6.3\%) \\
\hline \multirow{2}{*}{ Consumption of alcohol } & 271 & 260 & 301 & 164 & 185 \\
\hline & $(23.0 \%)$ & $(21.9 \%)$ & $(25.5 \%)$ & $(13.9 \%)$ & $(15.7 \%)$ \\
\hline \multirow{3}{*}{ Psychological atmosphere at home } & 392 & 343 & 146 & 42 & 256 \\
\hline & $(33.2 \%)$ & $(29.1 \%)$ & $(12.4 \%)$ & $(3.6 \%)$ & $(21.7 \%)$ \\
\hline & V Often & Often & Rare & V Rare & Never \\
\hline
\end{tabular}

Source: Survey

Table IV. Screen Time

\begin{tabular}{|c|c|c|c|c|}
\hline \multirow[b]{2}{*}{ Days } & \multicolumn{2}{|c|}{ Games } & \multicolumn{2}{|c|}{ Social networks } \\
\hline & $\mathbf{N}$ & $\%$ & $\mathbf{N}$ & $\%$ \\
\hline \multicolumn{5}{|c|}{ Monday-Friday } \\
\hline$<2$ hours & 772 & 65.5 & 579 & 49.1 \\
\hline 3-5 hours & 234 & 19.7 & 463 & 39.1 \\
\hline$>6$ hours & 176 & 14.8 & 140 & 11.8 \\
\hline \multicolumn{5}{|c|}{ Saturday-Sunday } \\
\hline$<2$ hours & 522 & 44.21 & 498 & 42.1 \\
\hline 3-5 hours & 403 & 34.09 & 485 & 41 \\
\hline$>6$ hours & 257 & 21.7 & 199 & 16.8 \\
\hline
\end{tabular}

\section{RESULTS AND DISCUSSION}

The culture of health of a young person should include the motivation and value attitude of an individual, knowledge, and concept of health, the ability to realize this knowledge in his future professional activities and everyday life, the ability to evaluate himself as a health preserving entity, analysis of learning outcomes, mastering self-assessment methods, self-control and self-correcting lifestyle.

Negative tendencies in the health of young people of Zhytomyr region are noted to a large extent in the process of professional education: an increase in morbidity among students is observed in Zhytomyr region, the range of "student" diseases is expanding; the number of students with disabilities increases. Only $11.5 \%$ of students were certified as healthy.

Obviously, most of the reasons for the deterioration in the dynamics of the formation of a healthy lifestyle among young people are beyond the competence of the education system. However, after analyzing this problem in the scientific literature, we can delegate partially responsibilities to the educators, for example, problems of providing the didactic conditions of a healthy environment for the for- mation of the value of health in educational institutions; the problem of the organization of educational life, which counteracts the limitation of motor activity, overload and stress.

The formation of chronic pathology is often due to the unformed attitude of young people towards their health as to something valuable, low physical activity and competence in healthy lifestyles, the widespread use of asocial forms of behavior $[2 ; 5]$.

Assessment of the healthy lifestyle of the students of Zhytomyr Medical Institute and Zhytomyr Ivan Franko State University was conducted based on the study of various types of physical activity, the attitude of young people (I, II, III, IV years and Master degree) to health (Tab.I).

After analyzing the responses of students during the questionnaire, we received such results: only $10.4 \%$ of the respondents rated their physical activity as high, $41.8 \%$ as the average and $47.8 \%$ as low. Students understand the importance of health in life, but only $29.2 \%$ favor physical exercise (e.g. running, walking, fitness, swimming), while $24.5 \%$ give preference to healthy eating and $15.5 \%$ adhere to correct sleeping and relaxing habits. As for the desire 
and plan of students to engage in physical activity, a certain passivity can be traced. Mostly, among the typical sports for our region, the rates are rather low (Tab.II).

The level of formation of the value of health in the system of civic values of a modern student depends on the psychological characteristics of an individual, the peculiarities of the organism, the specifics of the educational process at different courses (days, weeks), occupation, degree of physical fitness, daily regime, nutrition, and the presence of harmful habits.

During questioning about the factors influencing the healthy lifestyle of students, it was revealed: reluctance to physical activity - $54.5 \%$, chronic fatigue $-39.9 \%$, weight gain - 29.4\%, etc (Tab.III).

According to students, health condition depends heavily on such common factors as harmful habits: alcohol consumption (44.9\%), smoking (36.7\%), which were also assessed by using the self-administered questionnaire, according to which the participants were classified as never smokers, ex-smokers and current smokers $(<5$ or $\geq 10$ cigarettes per day). The participants were categorized into abstainers and alcohol users.

Online addiction is among the negative trends in the development of the value of health of Zhytomyr students. In spite of a rather slow pace of development of information technology in Ukraine compared to other European and world countries, the extent of online addiction has proven to be substantial. In the process of diagnosing the value system of higher education students, cybergaming and cyber-relational addiction (dependence on communication in social networks, forums and chats) was over 50\% (Tab.IV).

Significant influence on the health of future specialists is due to the unfavorable socio-economic conditions of the population in Zhytomyr region (poverty, in 2018 40\% of registered unemployed people in Zhytomyr region had higher education and $29 \%$ had vocational education), ecology of Zhytomyr region (radioactive contamination as a result of the Chernobyl disaster mainly Cs137 and Sr90), hydrosphere pollution as a result of sewage discharges of industrial enterprises and municipal wastewaters, the state of municipal waste landfills - Zhytomyr, Berdychiv, Novograd-Volynsky, Korostyshiv, Malyn); sanitary and hygienic conditions of training and life of future specialists (work and recreation regime, inappropriate nutrition, living conditions, etc.), as well as high level of mental tension.

In the research process conducted in the Zhytomyr Medical Institute and Zhytomyr Ivan Franko State University, scientists and practitioners of medical specialties developed a system of formation of the value of health of students in the educational process of the high educational institution (Fig. I). We offer the following components of the system of formation of the health value of students: the target component is represented by the necessary conditions for effective training of the future specialist, among them: meaningful familiarization with the basics of health preservation; application of acquired knowledge in practical healthcare activities; mastering the methods of diagnosing your own level of health; the motivational component involves personal interest in maintaining health and preventing diseases. The motivational component reveals the positive motivation of an individual, which manifests in a combination of sustainable needs (the desire of self-discovery, the need for security, self-improvement, creative professional longevity, etc.); motives (to be healthy and able to work, to lead a healthy life, to apply methods of health improvement, health-saving technologies, etc.; motivational-value: value attitude to health, positive motivation for health-saving activity. Such urge implies an awareness of the necessity and significance of this type of activity, focus on its application, and recognition of a student as a subject of pedagogical interaction, pedagogical optimism, formed reflexion and empathy, ability to communicate with others through cooperation $[4 ; 6 ; 7]$.

While organizing the process of forming of the value of health of students it is necessary to take into account personal factors - biological (age, physical ability, dexterity), psychological (state of health, self-esteem, self-motivation) and socio-cultural (ethnicity, socio-economic status, education, level of success). The attentive and correct attitude of a student towards himself is important, the desire for self-knowledge, self-improvement, awareness of spare capacity of the body (physical, mental, spiritual), awareness of the value of own health, ethical norms of a healthy lifestyle, ability to overcome difficulties of the objective and subjective nature [8;9], feel the joy of a healthy lifestyle, adapt the body ability to physical activity, endurance, speed, agility, strength, flexibility.

The substantial component of the system of formation of the value of health of students involves the formation of knowledge about the laws of conservation and development of health, physical, mental, social, occupational health, healthy lifestyle, health culture, individual characteristics and potential capabilities of organism in accordance with the biological age, sex, methods of health improvement, health-saving technologies, factors that have a negative impact on the health and livelihoods of humans.

We consider the healthcare-saving environment of a higher education institution as a comprehensive program based on the appropriate social infrastructure of a higher education institution, which includes educational, medical, administrative, managerial and other forms of work to ensure the formation of the value of the health of younger generation in the educational process $[2 ; 9]$. The educational process is the most significant factor in the duration and impact on the student's health [10]. Accordingly, its intensification and the use of new learning technologies leads to problems of adaptation of freshmen students to the educational workload.

The purpose of the healthcare environment in higher education institution is to provide students with a high level of real health by arming them with the necessary knowledge and skills necessary for a healthy lifestyle, involve the student in various activities, both educational and professional, social, creative, physical, recreation and mass sports, which contribute to the formation of health-saving 


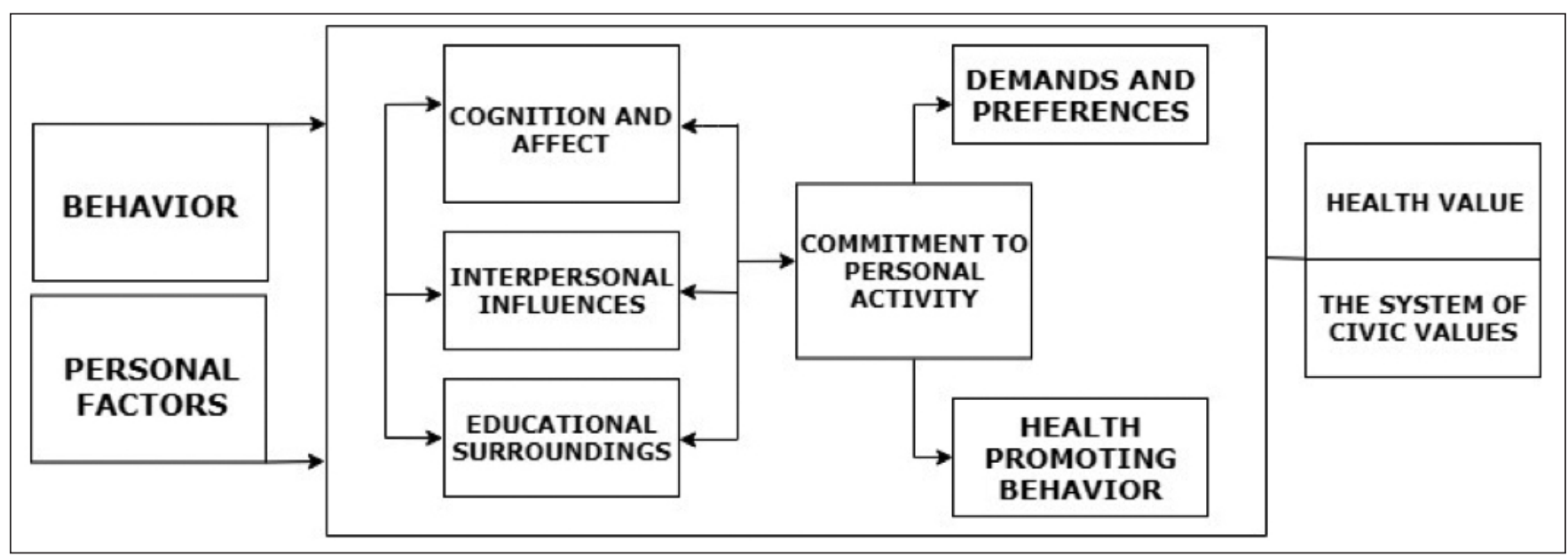

Fig. I. The system of health value formation in high educational institutions

competence. The result of the healthcare environment is the competence of actions in the interest of public health.

The active component of the system of forming the value of health of students involves the formation of health-preservation and commitment to a healthy lifestyle, active participation in physical culture and health activities of higher education institution, the ability to perform diagnostics of the psychophysiological state of body, to form an effective program for the preservation of health; the ability to create a health-saving space; know how to organize preventive measures and healthcare; actualize personal experience of healthcare activities, etc.

The efficient component of the system of forming the value of health of students determines the stability of established positions, a positive attitude to health conservation activity.

\section{CONCLUSIONS}

Preservation and improvement of the health of students is a priority issue of national importance, common task of society, community and higher education institutions because the health of students is a prerequisite for their social value, active longevity, and productive contribution to the life of their families and the Ukrainian nation in general.

Out of the findings of this survey, we made the following policy recommendations:

- Fast track the implementation of the revised national policy on the formation of students' health-saving competence in high educational institutions;

- Prevent of drug addiction, smoking, consumption of alcohol, chronic diseases, Internet addiction;

- Organize and conduct of mass physical culture and recreational activities;

- Create an effective health service system in high educational institutions;

- Equip the material resources of high educational institutions to improve and promote a healthy lifestyle of students;

- Enhance and rationalize staffing in educational insti- tutions in order to facilitate the process of health value formation and prevent negative trends among students

- Provide the system for monitoring both the future specialists' health and health work results in a high educational institution.

\section{REFERENCES}

1. Self-assessment of the population's health and the level of accessibility of certain types of medical care in 2017. Retrieved from: http://www. ukrstat.gov.ua/operativ/operativ2018/gdvdg/Arh_snsz_u.htm (in Ukrainian)

2. Meshko, H. Formation of health-saving educational environment as an aspect of activity of the head of an educational institution. Scientific Bulletin of Uzhgorod National University. 2017:1:157-161. Retrieved from http://nbuv.gov.ua/UJRN/Nvuuped_2017_1_42 (in Ukrainian)

3. Healthy People 2020: Social Determinants of Health, Office of Disease Prevention and Health Promotion, accessed April 25, 2018. Retrieved from https://www.healthypeople.gov/2020/topics-objectives/topic/ social-determinants-of-health

4. McGibbon, E., Etowa, J., \& McPherson, C. Health-care access as a social determinant of health. The Canadian Nurse. 2008;104(7):22-7

5. Mikkonen, J. \& Raphael, D. Social determinants of health:The Canadian facts. Toronto: York University School of Health Policy and Management. 2010. Retrieved from http://www.thecanadianfacts.org/

6. Commission on Social Determinants of Health. Closing the gap in a generation: health equity through action on the social determinants of health: Commission on Social Determinants of Health final report. Geneva:World Health Organization; 2008. Retrieved from https://apps. who.int/iris/bitstream/handle/10665/43943/9789241563703_eng. pdf;;sessionid $=4$ D1066D5F030D6605F658C1BE435476C? sequence $=1$

7. Dahlgren, G. \& Whitehead, M. Policies and strategies to promote social equity in health. Background document to WHO - Strategy paper for Europe, Arbetsrapport 2007:14, Institute for Futures Studies. Retrieved from https://core.ac.uk/download/pdf/6472456.pdf

8. Cadar, D. \& Pikhart, H. \& Mishra, G. \& Stephen, A. The role of lifestyle behaviors on 20-year cognitive decline. J Aging Res. 2012;2012:304014. doi:10.1155/2012/304014

9. Bednarzyk, M. \& Wright, T. \& Bloom, K. Body image and healthy lifestyle behaviors of university students. International Journal of Advanced Nursing Studies. 2013;2.10.14419/ijans.v2i2.1290. 
10. Cox, R. Addressing healthy lifestyle behaviours amongst young people in out-of-home care, 2015. Ph.D.(Psych) thesis, School of Psychology, Deakin University. Retrieved from: http://dro.deakin.edu.au/eserv/ DU:30084733/cox-addressinghealthy-2016a.pdf

\section{Authors' contributions:}

According to the order of the Authorship.
ORCID numbers:

Halyna O. Vaskivska - 0000-0002-8714-8512

Svitlana P. Palamar - 0000 -0001-6123-241X

Olha M. Vlasenko - 0000-0001-7258-2108

\section{Conflict of interest:}

The Authors declare no conflict of interest.

\section{CORRESPONDING AUTHOR}

Svitlana P. Palamar

Borys Grinchenko Kyiv University,

I.Shamo Blvd 18/2 cab. 318, Kyiv, Ukraine

e-mail:svetlana_03@ukr.net

Received: 05.06 .2019

Accepted: 30.09 .2019 


\title{
THE MAIN MISTAKES IN SONOGRAPHIC EXAMINATION OF HIP JOINTS IN INFANTS UNDER ONE YEAR OF AGE
}

\author{
Nataliia 0. Marchenkova, Svitlana S. Riabokon, Mariia 0. Riabokon \\ I. HORBACHEVSKY TERNOPIL NATIONAL MEDICAL UNIVERSITY, TERNOPIL, UKRAINE
}

\begin{abstract}
Introduction: Developmental dysplasia of hip (DDH) remains one of the most common and severe congenital pathologies in infants. The best results of DDH treatment are observed in early-infancy up to 3 months. A sonographic examination was long recognized as a "golden standard" of early diagnosis of hip dysplasia, but some practitioners still do not trust this method through a certain number of pseudo-positive and pseudo-negative diagnoses.

The aim: To carry out the quality analysis of sonographic examination of hip joints in infants under one year of age, to identify the main mistakes during the diagnosis and the causes of their occurrence; determine the dependence of the number of errors on the age of the examined child; suggest a method for assessing the quality of the received sonograms during the survey to reduce the number of false results.

Materials and methods: The sonographic images of the hip joints of 782 infants (1564 sonograms in total) aged 0.1-12 months were analyzed, who had been examined in Ortoclinic on the basis of Ternopil Town Clinical Hospital of Emergency Medical Care from 2016 to 2019. The ultrasound examination was performed according to a standard R. Graf technique.The comprehensive evaluation of each sonogram included the following parameters: a clear visualization of all the anatomical structures of the hip joint, the correctness of mutual spatial arrangement of the joint elements, the correct sonographic marking.

Results and conclusions: 498 low-grade sonograms (31,84\%) were identified, which make impossible to objectively assess the degree of development of the joint. The basic causes of errors were found out - incorrect examination and incorrect estimation of the image. The use of special patterns was suggested, which helps to check the quality of the received image at once during the examination and to adjust it according to the standards.
\end{abstract}

KEY WORDS: hip joint, sonographic examination, errors

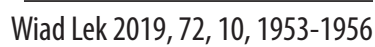

\section{INTRODUCTION}

Among all birth defects and pathological changes of the musculoskeletal system in infants, developmental dysplasia of hip (DDH) remains one of the most common and severe congenital pathologies. The best results of DDH treatment are observed in early-infancy, preferably up to 3 months [1], when excellent and good results reach $97 \%$. The exception is only a group of infants, mainly with a neuro- or myogenic pathology where the formation of hip dysplasia in the process of growth is possible. Untimely detection of this problem in the first months after the birth leads to prolonged conservative or surgical treatment. In $50 \%$ of children with late-diagnosed $\mathrm{DDH}$, hip osteoarthritis [2] and coxarthrosis develops in the future and there is a need for an early endoprosthetics of the hip joint [3]. A sonographic examination was long recognized as a "golden standard" of early diagnosis of hip dysplasia [4], but some practitioners still do not trust this method through a certain number of pseudo-positive (30-40\%) and pseudo-negative (20-25\%) diagnoses [5].

\section{THE AIM}

To carry out the quality analysis of sonographic examination of hip joints in infants under one year of age, to identify the main mistakes during the diagnosis and the causes of their occurrence; determine the dependence of the number of errors on the age of the examined child; suggest a method for assessing the quality of the received sonograms during the survey to reduce the number of false results

\section{MATERIALS AND METHODS}

The sonographic images of the hip joints of 782 infants (1564 sonograms in total) aged 0,1-12 months were analyzed, who had been examined in Ortoclinic on the basis of Ternopil Town Clinical Hospital of Emergency Medical Care from 2016 to 2019. Among them, there were 485 girls and 297 boys with an average age of 5,5 months. The ultrasound examination was performed on the SYMENS 2000 device with a linear $9 \mathrm{~Hz}$ sensor using Pediatric hip software according to a standard R. Graf technique [4]. An infant was put on the side so that the shoulder and pelvic belt were on the same line. The leg was bent in the hip joint at an angle of $30^{\circ}-60^{\circ}$, and was slightly rotated inside. The sensor was located laterally from the zone of a trochanter in a strictly coronal area. A dynamic survey was conducted. The provocative test was performed with bending of a leg up to $90^{\circ}$, maximum reduction and internal rotation with additional thrust in the cranial direction. 
Table I. The most common mistakes of sonograms of hip joints and their causes

\begin{tabular}{|c|c|c|c|c|}
\hline $\begin{array}{l}\text { Group of } \\
\text { mistakes }\end{array}$ & Mistake type & Reason of mistake & $\begin{array}{l}\text { Absolute } \\
\text { number }\end{array}$ & $\%$ \\
\hline \multirow{6}{*}{$\begin{array}{l}\text { Unclear } \\
\text { image }\end{array}$} & «blur», unclear image & motion of the sensor during examination & 62 & 12,45 \\
\hline & thickening of lines of the image & $\begin{array}{l}\text { slight inclination of the sensor relative to } \\
\text { the coronal area }\end{array}$ & 94 & 18,88 \\
\hline & lack of all joint elements & $\begin{array}{l}\text { scanning of acetabulum in its not } \\
\text { maximum diameter }\end{array}$ & 59 & 11,85 \\
\hline & presence of additional joint elements & $\begin{array}{c}\text { the sensor is located more ventrally or } \\
\text { dorsally }\end{array}$ & 47 & 9,44 \\
\hline & $\begin{array}{l}\text { iliac bone is at an angle to the edge of } \\
\text { sonographic picture }\end{array}$ & $\begin{array}{l}\text { deviation from the coronal plane during } \\
\text { joint scan }\end{array}$ & 23 & 4,61 \\
\hline & $\begin{array}{c}\text { iliac bone is parallel to the edge of } \\
\text { sonographic picture, but bent }\end{array}$ & $\begin{array}{l}\text { the sensor is located rear-laterally or front- } \\
\text { laterally }\end{array}$ & 46 & 9,24 \\
\hline \multirow{4}{*}{$\begin{array}{l}\text { Incorrect } \\
\text { image } \\
\text { evaluation }\end{array}$} & $\begin{array}{l}\text { incorrect definition of } \\
\text { the lower limb of the iliac bone }\end{array}$ & $\begin{array}{c}\text { image mistakes; inaccurate sonogram } \\
\text { marking }\end{array}$ & 79 & 15,86 \\
\hline & incorrect definition of bony rim & $\begin{array}{l}\text { inaccurate marking at rounded or round } \\
\text { shape of bony prominence }\end{array}$ & 108 & 21,69 \\
\hline & incorrect definition of the centre of labrum & $\begin{array}{l}\text { centre of labrum confused with the } \\
\text { tendon of rectus femoris or joint capsule }\end{array}$ & 29 & 5,82 \\
\hline & obtained data mismatch of angles $a$ and $\beta$ & $\begin{array}{l}\text { inaccurate construction of the angles a } \\
\text { and } \beta \text { or estimation of the incorrect image }\end{array}$ & 47 & 9,44 \\
\hline
\end{tabular}

The comprehensive evaluation of each sonogram included the following parameters:

A clear visualization of all the anatomical structures of the hip joint - iliac bone, bony rim (concavity-convexity), triradiate cartilage, the bottom of glenoid cavity (the upper edge of the ischia bone), the acetabular labrum, the center of the acetabular labrum, joint capsule, femoral head, ossification center (if present).

The correctness of mutual spatial arrangement of the joint elements and correspondence of the image to the standard scanning area is the position of the iliac bone parallel to the edge of the sonographic picture without the bends of the iliac bone, the clarity of lines, the absence of their thickening, visualization in a similar cartilage (absence of the pubic or ischial bone in the scan plane).

The correct sonographic marking - clear definition of the points of the lower limb of the iliac bone (undersurface of the medial border of the acetabulum where the iliac bone meets the triradiate cartilage), the bony rim of acetabulum, centre of labrum. Accuracy of constructing and measuring angles $\alpha$ and $\beta$.

\section{RESULTS AND DISCUSSION}

All sonograms were divided into 2 large groups - correct sonograms and incorrect sonograms. The group 1 included 1066 $(68,16 \%)$ sonograms made without errors, the group 2 included $498(31,84 \%)$ sonograms with a number of mistakes that could not objectively assess the degree of joint development.

All correct sonograms according to the descriptive and quantitative estimation of the formation of the hip joint by
R. Graf and the Institute of Traumatology and Orthopedics of the Academy of Medical Sciences of Ukraine $[4,1]$ were divided into 5 groups: age norm - 332 children $(31,15 \%)$; delay in development of the hip joint - 310 (29.08\%); dysplasia of the hip joint $-412(38.65 \%)$, subluxation of the hip - 9 (0,84\%); hip dislocation - $3(0,28 \%)$.

498 poor-quality sonograms were of greater interest for us. The analysis of the latter allowed identifying the most typical errors and the reasons for their occurrence. The results are presented in Table 1.

The total number of errors was 594 cases $(119,28 \%)$. In 96 cases $(19,28 \%)$ the sonogram had 2 or more errors.

The cause of poor-quality image in 331 cases $(66,47 \%)$ was incorrect location of the sensor. The largest number of errors in this group is due to the thickening of the image lines - 94 cases $(18,8 \%)$ and "blur", unclear image in 62 cases $(12,45 \%)$. The main reason for such errors was the movement of the sensor during the examination or its slight inclination relative to the coronal area. Other errors in this group in general were the result of a false scan area. - The absence of one or more elements of the joint (iliac bone, bony rim, cartilage, labrum, etc.) was in 59 cases $(11.85 \%)$ - there was a scanning of the acetabulum not in its maximum diameter;

- The presence of additional elements (47 cases - $9.44 \%$ ) - visualization of the pubic bone (the sensor is located more ventrally), visualization of the ischial bone (the sensor is located more dorsally);

- The iliac bone is located at an angle to the edge of the sono- 
Table II. Dependence of the number of errors of sonograms of the hip joints on the age of the examined infants

\begin{tabular}{ccccc}
\hline $\begin{array}{c}\text { Age of an infant, } \\
\text { months }\end{array}$ & Number of infants & Number of sonograms & $\begin{array}{c}\text { Number of low-grade } \\
\text { sonograms }\end{array}$ & $\begin{array}{c}\text { Percentage of low-grade } \\
\text { sonograms, \% }\end{array}$ \\
\hline $0,1-1,0$ & 39 & 78 & 7 & 12 \\
\hline $1,1-2,0$ & 41 & 82 & 17 & 14,63 \\
\hline $2,1-3,0$ & 58 & 116 & 32 & 28,07 \\
\hline $3,1-4,0$ & 57 & 114 & 76 & 34,23 \\
\hline $4,1-5,0$ & 111 & 222 & 32 & 30,60 \\
\hline $5,1-6,0$ & 134 & 268 & 74 & 38,14 \\
\hline $6,1-7,0$ & 97 & 194 & 50 & 34,25 \\
\hline $7,1-8,0$ & 73 & 146 & 43 & 41,35 \\
\hline $8,1-9,0$ & 52 & 104 & 36 & 42,86 \\
\hline $9,1-10,0$ & 42 & 84 & 39 & 43,33 \\
\hline $10,1-11,0$ & 45 & 90 & 30 & 45,45 \\
\hline $11,1-12,0$ & 33 & 66 & 498 & 31,84 \\
\hline $0,1-12,0$ & 782 & 1564 & & \\
\hline
\end{tabular}

graphic picture ( 23 cases $-4,61 \%)$; there was a deviation from the coronal plane during the scanning of the joint;

- The iliac bone is parallel to the edge of the sonographic picture, but curved (46 cases - 9,24\%) (the sensor is located in the front-lateral or rear-lateral position).

Incorrect estimation of the image made 263 cases ( $52.81 \%$ ).

The largest number of errors in this group was when determining the bony rim of acetabulum - 108 sonograms $(21.69 \%)$ and the point of the lower limb of the iliac bone - 79 sonograms $(15,86 \%)$. The identification of these two points is extremely important for the construction of the angles $\alpha$ and $\beta$, since the correct determination of the angles depends on the type of this joint (I, II, or III), whether there is a need for common observation in dynamics or treatment and what type of treatment should be used. Problems with the determination of bony rim occurred in case of its rounded form. In 49 sonograms $(9,84 \%)$, the rounded or round shape was not taken into account, and the bony rim point was determined as a rectangular form of the bony rim, which resulted in the size of the angle $\alpha$ artificially decreasing and infants were unjustifiably assigned treatment. When marking the other 59 sonograms $(11,85 \%)$, the point of the bony rim was determined closer to triradiate cartilage, herewith angle a was artificially increased and the necessary treatment was not prescribed. At the same time, the magnitude of angle $\beta$ was also associated with the precise definition of the bony rim, hence the angle $\beta$ was artificially increased or decreased.

The false definition of the point of the lower limb of the iliac bone was in 79 cases $(15,86 \%)$, which also led to an incorrect determination of the angle $\alpha$. In 37 cases $(7,43 \%)$, errors were related to the "blur" of the image, the thickening of the lines, the absence of triradiate cartilage, the excessive visualization of the ischial bone, in other cases, inaccuracy in the marking of the sonogram.
With the determination of the center of the labrum, the least problems arose (29 cases, which is 5,82 \%). Tendon of rectus femoris or joint capsule were mistakenly considered as an acetabular labrum.

In 47 cases $(9,44 \%)$ the inconsistency of the angles a and $\beta$ was determined. At dimensions of the angle $\alpha$ 60-64 degrees the magnitude of the angle $\beta$ was $65-77$ degrees, and in the dimensions of the angle $\alpha$ 53-60 degrees, the angle $\beta$ is $40-52$ degrees. Such data are impossible due to the usual geometry and spatial structure of the hip joint. The reason is the inaccurate construction of the angles $a$ and $\beta$ or an estimate of the wrong image.

It was interesting for us to analyze the dependence of the number of errors from the age of the examined infant and to identify the percentage of mistakes in each age group. The results are presented in Table II

The smallest number of errors was in the age range up to 3 months, among them the most qualitative X-ray examination were in infants under 1 month. The worse indicators in infants from 7 months and older, among them the worst were in the group of 10-12 months, and not all of them could be fully visualized all structures of the hip joint. As a rule, it is difficult to visualize the bottom of the acetabulum due to the shadow of the ossification center of femoral head and it is quite difficult in plump children. The survey was also complicated by the active behavior of infants of the older age group, when it is quite difficult to obtain a full-fledged image at full compliance with the survey methodology.

To avoid mistakes during the examination, strict observance of the survey method is necessary. To achieve the correct image in the coronal area, a special device or 2 rollers are used for fixing the infant, and to fix the sensor, fasten it in the stand [6]. However, the older the infant is, the more difficult is to keep it on its side, in a stationary position. All our efforts call even more negative reaction and active 
behavior of the small patient. At the same time, a number of practitioners cite data on the high efficiency of sonographic examinations without similar fixing devices [7].

We believe that in order to avoid mistakes during the sonographic examination of the hip joints, it is necessary to constantly compare the images on the screen with the standard one. We propose to use special patterns for this purpose. The pattern is a sheet of dense transparent plastic on the size of the screen with a schematic image of the sonogram of the hip joint (with all its elements) of the same size as the image on the screen. The pattern is fixed on the screen before or after the examination and compares the images by overlaying the pattern and the resulting image. The size of the image on the screen can be adjusted to match the pattern. When you receive an incorrect image, a re-examination is performed.

Patterns are made in accordance with the average-statistical sizes of the size of the hip joints according to the sonograms of infants aged 1, 3, 6, 9 and 12 months with markings for joints of type Ia, Ib, II and III according to R. Graf. We consider inappropriate the marking for joints of type IV because the sonographic picture of such a joint is not difficult.

We conducted a survey of 47 infants (94 sonograms) using these patterns. The average age of infants was 4.5 months. Patterns were used for 3 and 6 months. According to the obtained data, it was found that 15 sonograms belonged to type Ia, 21 - type Ib and 11 - type II according to R. Graf. Errors were not detected when repeated analysis of sonograms.

Probably the use of the proposed method is discursive, but it helps to check the quality of the image immediately at the time of the examination and adjust it according to the standards, which has a positive effect on the results of the survey.

\section{CONCLUSIONS}

1. During a standard sonographic examination of hip joints there is a certain amount of incorrect results (in our case $31,84 \%$ ). The main reasons are incorrectly performed examinations and incorrect assessment of the received image.

2. The greatest number of errors during the sonographic examination of the hip joint occurs in infants aged 7 months and older, among them the maximum is in the group of 10-12 months, which is due to the active behavior of older infants and the processes of ossification of the hip joint elements.

3. The method of sonographic examination of the hip joint requires prerequisites for obtaining a standard image and its correct interpretation.
4. We consider one of the possible ways of solving this issue is an application of patterns, which helps to check the quality of the image obtained immediately during the examination and adjust according to the standards of the survey.

\section{REFERENCES}

1. O. H. Haiko A. Ya. Vovchenko Ya. B. Kutsenok R.V. Luchko A.S.Stetsula Rannia promeneva diahnostyka vrodzhenykh porushen formuvannia kulshovoho suhloba u novonarodzhenykh i ditei do roku [Early radiodiagnosis of congenital disorders of the hip formation in newborns and infants] Herald of orthopedics, traumatology and prosthetics. 2014; 3:38-44 (UA)

2. Jacobsen S, Sonne-Holm S. Hip dysplasia: a significant risk factor for the development of hip osteoarthritis. A cross-sectional survey. Rheumatology (0xford). 2005;44(2):211-218.

3. Scott Yang and Quanjun Cui. Total hip arthroplasty in developmental dysplasia of the hip: Review of anatomy, techniques and outcomes. World J Orthop. 2012 May 18; 3(5): 42-48.

4. R. Graf. Hip Sonography. Diagnosis and Management of Infant Hip Dysplasia Springer-Verlag Berlin Heidelberg 2006

5. Sewell M. D., Rosendahl K., Eastwood D. M. Developmental dysplasia of the hip. BMJ. 2009;339: b4454.

6. Reinhard Graf, Mohammad Mohajer, Florian Plattner. Hip sonography update. Quality-management, catastrophes - tips and tricks. Med Ultrason 2013; 15(4): 299-303

7. Peter K Voitl, Christian Sebelefsky, Sara Hosner, Astrid Woditschka. Ultrasound of the infant hip: Manual fixation is equivalent to Graf's technique regarding image quality - A randomized trial. BMC Pediatrics 19(1) December 2018.

Authors' contributions:

According to the order of the Authorship.

ORCID numbers:

Nataliia O. Marchenkova - 0000-0002-3021-8882

Svitlana S. Riabokon - 0000-0002-4413-0582

Mariia O. Riabokon - 0000-0002-6873-3206

\section{Conflict of interest:}

The Authors declare no conflict of interest.

\section{CORRESPONDING AUTHOR}

\section{Svitlana Ryabokon}

I. Horbachevsky Ternopil National Medical University

Ternopil, Ukraine

e-mail: ryabokonsvitlana@gmail.com

Received: 05.07 .2019

Accepted:30.09.2019 
PRACA ORYGINALNA

ORIGINAL ARTICLE

\title{
CHOICE OF THE TREATMENT METHOD OF THE INFLAMMATORY PROCESS IN THE ALVEOLAR TOOTH SOCKET
}

\author{
Vira M. Helei, Natalia I. Zhero, Nazariy I. Helei, Vladimir V. Kryvanich \\ SHEI «UZHGOROD NATIONAL UNIVERSITY», DENTAL FACULTY, UZHHOROD, UKRAINE
}

\begin{abstract}
Introduction: Alveolitis - is one of the most common complications in surgical dentistry after tooth extraction and their roots, accompanied by symptoms, the leading of which are pain in the alveoli with irradiation and partial or complete decay of the blood clot.

The aim of our research is to study the clinical efficacy of antihomotoxic drugs and colloidal silver in patients with inflammatory processes in the alveolar tooth socket.

Materials and methods: 58 patients with inflammatory process in the alveoli after extraction of teeth or their roots (38 - female, 20 - male), aged 18-60 years, were examined with the help of clinical and microbiological, cytological study. The main group consisted of 38 patients who were prescribed complex drug therapy after diagnosis of alveolitis. 20 patients were referred to the control group where allopathic treatments were used.

Results: The main observation group in $93 \% \pm 0.07 \%$ of patients with serous form alveolitis already on the 2nd day disappear pain, redness, swelling of the soft tissues. Gradually, the function of the mandible and the temperature response were restored. In purulent alveolitis, the function of the jaw was restored on days 3 and 4 . Patients in the control group experienced a slow course of the inflammatory process in the wound, a late decrease in local pain response, swelling and hyperemia of the wound edges. Jaw function recovery averaged $3.4 \pm 0.1$ days longer.

Conclusions: The complex effect of drug and surgical treatment of alveolitis was studied. The combined use of colloidal silver, Traumeel ${ }^{\circledR}$ S, Polymic ${ }^{\circledR}$, makes it possible to eliminate the inflammatory process in the alveoli faster and to reduce the period of active disease up to 2 - 3 days.
\end{abstract}

KEY WORDS: alveolitis, periodontitis, lymphadenitis, blood clot, colloidal silver

Wiad Lek 2019, 72, 10, 1957-1960

\section{INTRODUCTION}

The inflammatory process of the tooth socket (alveolitis) after the removal of teeth and roots is a common complication. Despite the advent of modern available antibacterials and non-steroidal anti-inflammatory drugs, the number of patients is not decreasing. As a result of observations, the frequency of alveolitis in Ukraine and in the world fluctuates in the range of $0.24 \%-28 \%$ and is $25 \%-35 \%$ of the total number of complications that occur in patients after removed teeth and their roots $[1,2,3]$. According to WHO, alveolitis in $35 \%$ of cases is observed after atypical tooth extraction [4]

The cause of alveolitis is a violation of the formation of a blood clot, the patient's failure to follow the doctor's recommendations after surgical extraction of teeth and their roots, sensitization of the body, oral hygiene (the presence of plaque and hard dental deposits), presence of concomitant diseases $[5,6]$. The inflammatory process in the alveolar tooth socket may precede the development of other inflammatory diseases with severe clinical course, such as cell osteomyelitis and lymphadenitis $[7,8,9]$.

In recent years, there has been an increase in scientific research aimed at finding effective therapies and selecting medicines for the treatment of alveolitis $[10,11,12,13]$.

\section{THE AIM}

The aim of our research is to study the clinical efficacy of antihomotoxic drugs and colloidal silver in patients with inflammatory processes in the alveolar tooth socket.

\section{MATERIALS AND METHODS}

In our study, there were 58 patients ( 38 - females, 20 males) between 18 and 60 years of age, who underwent surgery to remove the teeth or roots of the teeth for chronic periodontitis in the acute or remission stage. 30 patients had acute serous alveolitis and 28 patients had acute purulent alveolitis.

The treatment was performed on the basis of "University Dental Clinic” (Uzhgorod) from 2017 to 2019.

For patients, the following research methods were applied:

- general clinical methods - study of dental status of the patients;

- microbiological methods - examination of microbial contamination;

- cytological methods - examination of the phase of wound regeneration.

The main observation group included 38 patients, who after diagnosis of alveolitis were prescribed complex drug 
Vira M. Helei et al.

Table I. Wound planimetry data according to L.N. Popova

\begin{tabular}{cccc}
\hline Time of wound measurement & Observation groups & $\begin{array}{c}\text { Acute serous alveolitis } \\
\text { (mm/day) }\end{array}$ & $\begin{array}{c}\text { Acute purulent alveolitis } \\
\text { (mm/day) }\end{array}$ \\
\hline \multirow{2}{*}{ After 2 days } & Main & $15.2 \pm 0,1$ & $16,4+0,1$ \\
\cline { 2 - 4 } & Control & $15.3+0,1$ & $16,9+0,1$ \\
\hline \multirow{2}{*}{ After 4 days } & Main & $9,2+0,1$ & $10,6+0,2$ \\
\cline { 2 - 4 } & Control & $10,8+0,1$ & $11,7+0,2$ \\
\hline \multirow{2}{*}{ After 6 days } & Main & $4,1+0,2$ & $6,5+0,1$ \\
\cline { 2 - 4 } & Control & $6,3+0,2$ & $8,2+0,1$ \\
\hline
\end{tabular}

Table II. Dynamics of the cytological profile of postoperative wound healing in patients of different groups with alveolitis of the alveolar socket during treatment in percentage ratio

\begin{tabular}{|c|c|c|c|}
\hline $\begin{array}{l}\text { Subgroup } \\
\text { Curation day }\end{array}$ & Cells & Main group (\%) & Control group (\%) \\
\hline \multirow{5}{*}{ Day 2} & Desquamated epitheliocytes & 3,5 & 2,5 \\
\hline & Segmented neutrophil granulocytes & 87,8 & 85,4 \\
\hline & Lymphocytes & 5,7 & 8,9 \\
\hline & Monocytes & 2,1 & 4 \\
\hline & Macrophages & 0,9 & 1,6 \\
\hline \multirow{5}{*}{ Day 4} & Desquamated epitheliocytes & 0 & 0 \\
\hline & Segmented neutrophil granulocytes & 78,2 & 80,6 \\
\hline & Lymphocytes & 8,6 & 11,9 \\
\hline & Monocytes & 2,5 & 1,7 \\
\hline & Macrophages & 10,7 & 5,8 \\
\hline \multirow{7}{*}{ Day 6} & Desquamated epitheliocytes & 0 & 0 \\
\hline & Segmented neutrophil granulocytes & 57 & 68,2 \\
\hline & Lymphocytes & 7 & 12,3 \\
\hline & Monocytes & 1,5 & 1,2 \\
\hline & Macrophages & 6,4 & 7,2 \\
\hline & Fibroblasts & 22 & 9,4 \\
\hline & Active epitheliocytes & 6,1 & 1,7 \\
\hline
\end{tabular}

therapy. 20 patients were included in the control group, where allopathic agents were used.

For patients of both groups the step-by-step surgical complex of treatment of alveolitis was developed:

- food residues and a defective blood clot were removed from the tooth socket under application conduction anesthesia with the help of a curette;

- the socket of the removed tooth was debrided by the applicator, moistened with colloidal silver.

The patients of the main group were offered a drug therapy method for treatment of serous and purulent alveolitis. The patients were prescribed anti-inflammatory and immunomodulatory drug Traumeel $\mathrm{S}$ according to the initiating scheme - 1 tab. every 15 minutes within 2 hours, followed by $1 \mathrm{tab}$. four times a day after $30 \mathrm{~min}$. after meals. Traumeel $\mathrm{S}$ activates the processes of local and general immunity, stimulates cleansing and healing of wounds, reduces swelling and has an analgesic effect (allowed for use by the order of the Ministry of Health of Ukraine No. 86 of March 27, 2006 "On Amendments to the List of Medicines") $[14,15,16,17,18]$.
In the transition of the process to the purulent stage antimicrobial drug Polymic" was introduced to the treatment regimen ( $1 \mathrm{tab}$. twice daily) and resorption tablets Chlorophylliptum ${ }^{\circledast}$ (25 mg every 4-5 hours) $[19,20]$.

The methods of treatment of alveolitis used in the study conformed to the protocols of treatment of the Ministry of Health according to the order No. 507 of 28.12.2002 "On approval of standards of medical care and quality of medical care indicators".

The results of all the studies were recorded in an electronic database built using MS Excel, LibreOfficeCalc and analyzed using tests of parametric and non-parametric statistics, extensive spreadsheet and graphical analysis. It uses computer software STATISTICA (StatSoft, Inc.) version 6 [21].

\section{RESULTS AND DISCUSSION}

The disease began on the $2^{\text {nd }}-3^{\text {rd }}$ day after tooth extraction. Long-lasting pain in the postoperative wound gradually 
progressed and became irritated during the trigeminal nerve, increased during eating. Patients complained of reduced general condition, malaise, fever up to $37.8-38^{\circ} \mathrm{C}$, limited opening of the oral cavity, offensive breath (halitosis). On oral examination, there was no blood clot - "dry socket", filling of the alveolar tooth socket with food residues, swelling of the soft tissues of the vestibule of mouth and cheeks on the transitory fold. The mucous membrane around the tooth socket was hyperemic, swollen, painful on palpation. The alveolitis was accompanied by regional lymphadenitis.

The method of treatment of alveolitis with the use of antihomotoxic drugs had an anti-inflammatory and analgesic effect, which made it possible to improve the general condition of the patient, reduce the manifestations of local inflammatory process, pain in the area of the tooth socket and lymph nodes already on the $2^{\text {nd }}$ day.

In the main observation group $93 \%+0.07 \%$ of patients with serous alveolitis noticed that tenderness, hyperemia, soft tissue oedema, and offensive breath disappeared already on the $2^{\text {nd }}$ day. Gradually, the function of the mandible and the temperature response were restored. In purulent alveolitis, the function of the mandible was restored on $3^{\text {rd }}$ and $4^{\text {th }}$ days.

According to L.N. Popova planimetry of the wound indicated the active course of the phase of wound regeneration $[22,23,24]$. Within three days the overall condition of the body and the temperature response returned to normal. On the $5^{\text {th }}$ and $6^{\text {th }}$ days granulation tissue elements appeared (Table I).

Cytological studies of post-extraction wound healing in patients with alveolitis revealed that the postoperative wound healing processes progressed rapidly and efficiently in patients of the main group - a progressive decrease in neutrophil granulocytes count over 5 days of observation from 87.8 to $57.0 \%$; appearance of colonies of fibroblasts from 0 to $22.0 \%$ and active epitheliocytes $(6.1 \%)$ at the end of observation. In patients of the control group the processes of regeneration were less intense and tended to chronization of inflammation - the number of neutrophilic granulocytes decreased from 83.2 to $68.2 \%$ in 5 days, the number of fibroblasts increased from 0 to $9.4 \%$; the number of active epitheliocytes was $1.7 \%$. The number of lymphocytes increased significantly (up to $12.3 \%$ ), which was not observed in the main group and which can be considered as a sign of chronization of inflammation (Table II).

On microbiological examination of patients with alveolitis, the predominance of aerobic microflora with the prevalence of cultures of staphylococcus (68.4\%) and streptococcus (15.9\%) was found, herewith, in $46.3 \%$ of patients St. aureus was found and in $24.1 \%$ - St. epidermidis, in $8.9 \%$ - Str. Faecalis, and Str. pyogenes in 5.0\%.

In contrast to the main group, 20 patients in the control group experienced a smoldering course of inflammatory process in the wound, a late decrease in local pain reaction, oedema and hyperemia of the wound edges. Jaw function recovery averaged $3.4 \pm 0.1$ days longer. Wound planimetry indicated the slow progress of the tissue regeneration process. Normalization of the overall condition of the body and its temperature response was delayed by an average of $4.8 \pm 0.2$ days compared to the main observation group.

\section{CONCLUSIONS}

The results of the study showed that the use of a designated step-by-step drug and operative therapy of post-extraction alveolitis should include anti-inflammatory, antibacterial, and antiseptic agents.

The application of the proposed scheme at the clinical appointments was effective and allowed to counteract the hyperaergic reactions, oedema, tenderness, temperature response of patients in $100 \%$ of cases and reduce the period of active course of the disease to 2-3 days. The method of treatment of alveolitis cells may be recommended for use in practical surgical dentistry.

\section{REFERENCES}

1. Ramos E. Santamaria, J., Santamaria, G. et al. Do systemic antibiotics prevent dry socket and infection after third molar extraction? A systematic review and meta-analysis. Oral surgery, oral medicine, oral pathology and oral radiology. 2016; 122(4): 403-425.

2. Taberner-Vallverdú M., Sánchez-Garcés M. Á., Gay-Escoda C. Efficacy of different methods used for dry socket prevention and risk factor analysis: A systematic review .Medicina oral, patologia oral y cirugia bucal. 2017; 22(6): 750-758.

3. Blum I. R. Contemporary views on dry socket (alveolar osteitis): a clinical appraisal of standardization, aetiopathogenesis and management: a critical review. International journal of oral and maxillofacial surgery. 2002; 31(3): 309-317.

4. Birn H. Etiology and pathogenesis of fibrinolytic alveolitis ("dry socket"). International journal of oral surgery. 1973; 2(5): 211-263.

5. Hamad S. A., Naif J. S., Abdullah M. A. Effect of diode laser on healing of tooth extraction socket: an experimental study in rabbitsю. Journal of maxillofacial and oral surgery. 2016; 15(3): 308-314.

6. Tasoulas, J., Daskalopoulos, A., Droukas, C. et al. An unusual microscopic pattern of foreign body reaction as a complication of dry socket management. Oral surgery, oral medicine, oral pathology and oral radiology. 2018; 125(5): 118-123. doi: 10.1016/j.0000.2017.08.010

7. Miranzadeh S., Adib-Hajbaghery, M., Soleymanpoor, L.etal. Effect ofadding the herb Achillea millefolium on mouthwash on chemotherapy induced oral mucositis in cancer patients: A double-blind randomized controlled trial. European Journal of Oncology Nursing. 2015; 19 (3): 207-213.

8. Mustafaev M. S. Complex Prophylaxis and Prognosis of Inflammatory Complications after Dental Implantation. Asian Journal of Pharmaceutics (AJP): Free full text articles from Asian J Pharm. 2018; 11(04):975-984.

9. Mamoun J. Dry socket etiology, diagnosis, and clinical treatment techniques. Journal of the Korean Association of Oral and Maxillofacial Surgeons. 2018; 44(2): 52-58.

10. Popovich S.V., Katerenchuk I.P." Traumeel S - bioregulatory approach in the treatment of inflammation". The Moldovan Medical Journal. 2017; 60 (2): 45-48.

11. Rodrigues M. T.V. Experimental alveolitis in rats: microbiological, acute phase response and histometric characterization of delayed alveolar healing. Journal of Applied Oral Science. 2011; 19(3): 260-268.

12. Cardoso C. L. Clinical concepts of dry socket. Journal of Oral and Maxillofacial Surgery. 2010; 68(8): 1922-1932.

13. Martín Reyes 0., Lima Álvarez M., Zulueta Izquierdo M. M. Alveolitis: Literature review and update. Cuban Magazine of Stomatology. 2001; 38(3): 176-180. (In Spanish)

14. Walter Tatch Method of using traumeel in oral surgical procedures. U.S. Patent Application. 2015; №. 14/097,317. p. 18. 
15. Ahmadi-Motamayel F., Goodarzi, M. T., Jamshidi, Z., et al. Evaluation of salivary and serum antioxidant and oxidative stress statuses in patients with chronic periodontitis: a case-control study. Frontiers in physiology. 2017; 8(189): 1-6. doi: 10.3389/fphys.2017.00189

16. Grech, D., Velagala, J., Dembek, D. J., B. et al. Critical Literature Review of the Homeopathic Compound Traumeel for Treatment of Inflammation. Pharmacology \& Pharmacy. 2018; 9(03): 67-83. doi: 10.4236/pp.2018.93006

17. Ben-Arye E., Samuels N. Homeopathy on the crossroads of traditional and integrative medicine in the Middle-East Journal of Medicine and the Person. 2015; 13(1): 65-71.

18. Saliyeva Z.S. Treatment of patients with acute purulent-inflammatory diseases of the soft tissues of the maxillofacial area with the use of drugs Gentaxan and Traumel S. Dissertation of the candidate of medical sciences: 14.01.22. National Medical University. 00 Bogomolets. Kiev: 2003, 22 p. (In Ukrainian)

19. Dmitrieva N.V. Polymyxin in the clinical practice of oncologists. Siberian Oncology Journal. 2018; 17(3): 88-93. (In Russian)

20. Ananieva M. M. The effect of chlorophylliptum solution on the adhesiveness of candida spp. World of Medicine and Biology. 2019; 15(68): 167-170.

21. Lapach S.N., Chubenko A.V., Babich P.N. Statistical methods in biomedical studies using Excel. Experimental studies. Clinical trials. Pharmaceutical market analysis. Kiev: Morion, 2000, 319 p. (In Ukrainian)

22. Popova L. N. How are the boundaries of the newly formed epidermis measured during wound healing: abstract of a dissertation of a candidate of medical sciences. Voronezh: 1942, 22 p. (In Russian)
23. Gerasymchuk P.A., Fira D.B., Pavlyshyn A.V. The use of vacuum therapy at the stages of surgical treatment of diabetic foot syndrome. Clinical Surgery. 2017; 2: 16-18. (In Ukrainian)

24. Lyakhovsky V.I., Loban G.A., Gancho O.V. et al. Dynamics of bacteriological and planimetric indicators of the wound under the action of silver nanoparticles stabilized with 3-hydroxypyridine and polyvinylpyrrolidone. Clinical Surgery. 2016; 4: 67-69. (In Ukrainian)

The work was performed in accordance with the plan of research works of the State Higher Educational Institution "Uzhgorod National University" and is a fragment of the scientific theme of the dental faculty: "Clinical-experimental substantiation of the application of modern dental technologies, expert evaluation of the quality of treatment and prevention of major dental diseases" (state registration No. 0113U003611).

\section{Authors' contributions:}

According to the order of the Authorship.

\section{ORCID numbers:}

Vira M. Helei - 0000-0001-6277-3568

Natalia I. Zhero - 0000-0002-8083-9310

Nazariy I. Helei - 0000-0002-7437-6874

Vladimir V. Kryvanich-0000-0002-0247-9137

\section{Conflict of interest:}

The Authors declare no conflict of interest.

\section{CORRESPONDIG AUTHOR Nazariy I. Helei}

Department of Surgical Dentistry, Maxillofacial Surgery

and Oncostomatology

State Higher Educational Institution «Uzhhorod National University»

Uzhhorod. Ukraine.

tel: +380508267265

e-mail: nazariy.heley@uzhnu.edu.ua

Received: 09.07.2019

Accepted: 30.09.2019 
PRACA ORYGINALNA

ORIGINAL ARTICLE

\title{
THE RESULTS OF THE MICROSCOPIC AND HEMATOLOGICAL STUDIES OF LIQUID BODY MALOLYAKHOVSKY MAMMOTH
}

\author{
Palmira G. Petrova' ${ }^{1}$, Eya E. Egorova', Victoriya E. Egorova ${ }^{2}$, Semen E. Grigor'ev' ${ }^{1}$, Lena R. Turkebaeva' \\ 'NORTH-EASTERN FEDERAL UNIVERSITY NAMED AFTER M.K. AMMOSOV, MEDICAL INSTITUTE, YAKUTSK, RUSSIA \\ 2EDUCATIONAL AND SCIENTIFIC CLINICAL DIAGNOSTIC LABORATORY OF CLINIC OF MI NEFU, YAKUTSK, RUSSIA
}

\begin{abstract}
Introduction: Mammoth trunk excavation of on the island Malyi Lyakhov in the Laptev Sea became a historical discovery for the Republic Sakha (Yakutia) in 2013. According to paleontologists, the age of this find is 43 thousand years. The main features of the Malolyakhovsky mammoth are preservation of the soft tissues and a detection of the dark-brown liquid substance, which was found along the bottom of the mammoth's trunk.

The aim: Firstly, to reveal and study preservation of cell elements of biomaterial received at excavation of 2013. Secondly, to find out and study preservation of cell elements taken from a blood vessel of a front extremity, during preparation of the Malolyakhovsky mammoth trunk which was carried out in March, 2014.

Materials and methods: 1. A dark-brown liquid substance, which flowed out at excavation; 2. biomaterials from a blood vessel taken during preparation of the mammoth's trunk became the materials of this researches. In order to study morphological properties of gained biomaterials, we used the following methods: microscopic smear research, hematological analyses with use of technology of peroxidase cytochemical reaction, a technique of two-dimensional laser light, and cyanide-free hemoglobin estimation.

Results: Under microscopic examination, the cell elements similar to elements of blood of mammals, were found: the monocytes, neutrophils, lymphocytes containing nuclear inclusions. The comparative analysis showed that the cells found in a dark-brown liquid substance received at excavation and in smear of the biomaterial taken from a blood vessel, have the identical morphological structure of cell elements. Studying of primary biomaterial on the hematological analyzer confirmed the maintenance of the same cells (lymphocytes, monocytes and granulocytes), and availability of hemoglobin which value was $22 \mathrm{~g} / \mathrm{l}$.

Conclusions: The unique preservation of the soft tissues, which were found in permafrost, allowed to find and describe morphological properties of cell elements of a fossil animal for the first time.
\end{abstract}

KEY WORDS: cell, phagocytosis, hemoglobin, microscopy, mammoth

Wiad Lek 2019, 72, 10, 1961-1965

\section{INTRODUCTION}

Mammoths, extinct mammals, have always attracted the attention of scientists around the world. In recent years the mammoth body parts discovery and excavation allowed us to think about the possibility of reconstruction of the body of this fossil animal. The discovery of mammoth carcass in 2013 on the Maly Lyakhov island (the Laptev Sea) the Republic of Sakha (Yakutia) Russian Federation became a historical event. According to paleontologists, the age of the findings is 43.5 thousand years. The main feature of Malolyakhovsky mammoth is a unique preservation of soft tissues and the fluid, very similar to blood, that was found in the carcass. In the absence of information about the probability of tissues preservation for such a period our research study is certainly interesting and unique and makes it possible to advance the morphological ancient animal reconstruction.

\section{THE AIM}

Firstly, to reveal and study preservation of cell elements of biomaterial received at excavation of 2013. Secondly, to find out and study preservation of cell elements taken from a blood vessel of a front extremity, during preparation of the Malolyakhovsky mammoth trunk which was carried out in March, 2014.

\section{MATERIALS AND METHODS}

The research study was done on the basis of educational and scientific clinical diagnostic laboratory in the Clinic Medical Institute of the North-Eastern Federal University named after M.K. Ammosov. The material of our research study: dark brown liquid taken out during the time of excavation of Malolyahovsky Mammoth (2013), biomaterials taken out during the dissection of the mammoth carcass (March 2014).

To study the morphological properties of the biomaterials we used the microscopic examination of swabs by the classical Romanovky-Giems [2] staining method for formed elements and we used binocular microscope «Olympus CX31» (10F eye lens FN20i wide field of view, zooming in 40-1000). This method allows us to identify the elements of nuclear cells by affinity to the basic colors, 
in which the acidophile elements are stained in various shades of red, and basophil elements - from purple to blue.

Hematological analysis of biomaterial was performed in an automated analyzer Adviya 2120 (Siemens Healthcare Diagnostics Inc., 2010), which allowed us to detect and differentiate accurately the cellular elements in a wide linearity and range $\left(0.2-400 \times 10^{9} / \mathrm{L}\right)$. In addition to these, we used two-dimensional laser diffusion of light technique, which allowed us to identify each cell and determine its individual properties. To study hemoglobin we used technique of non-cyanide definition [4] .

\section{RESULTS AND DISCUSSION}

During the research study of similar to blood fluid swabs, the main background was gray-pink, the background is a homogeneous mass of destroyed nuclear-free cellular elements, which is similar to the hemolysis in its morphology. Against this background, we found individual cellular elements having morphological picture similar to the description of formed blood cells of large mammals (neutrophils, lymphocytes, and monocytes).

\section{NEUTROPHILS}

The discovered cellular elements had intense color and morphologically were similar to polymorphonuclear leukocyte (neutrophils). Being studied the cells had clear contours, diameter sizes ranged from 5 to 7 micrometers. The cell plasmolemma had more distinct color and thickness. Basophilic cytoplasm was filled with dust-like grains and preserved nucleus. Nuclear inclusions were deep purple color, consisted of 4-6 segments. Some parts of the nucleus were connected by thin constrictions, the nuclear chromatin had inhomogeneous large - lumpy structure (Fig.1).

The microscopic study of the concentration taken from a blood vessel of the forelimb during the mammoth carcass thawing in 2014 showed us cells identical to the initial biomaterial similar to neutrophils (Fig. 2).

The swab background had a completely different staining - smoky-blue, there were numerous clusters of destroyed cellular elements, preserved cells were rare in the field of vision. Simple structures were present (Fig. 3).

Hematologic study showed us that total number of leukocytes was $1.6 \times 109 / \mathrm{L}$. The research study of the peroxidase channel shows that the number of leukocytes - 1.4 x 109/ $\mathrm{L}$. The analyzer differentiated absolute neutrophil number $(0,2 \times 109 / \mathrm{L})$ and the relative neutrophil number was 11.9\%. (Table 1).

\section{LYMPHOCYTES}

Cell structure was similar to lymphocyte structure and had a diameter of 3-4 microns, clear contours, basophilic cytoplasm and the non-segmented nucleus. The structure was also inhomogeniousand large - lumpy, the nucleus had a rounded shape (Fig. 4).
In the microscopic study of the concentration taken from a blood vessel of the forelimb during the mammoth carcass thawing in 2014 we found identical cells, like the cells of a dark brown liquid (Fig. 5).

Hematologic study of the vessel concentrations tested on the analyzer, confirmed the presence of the lymphocytes in the composition, the absolute and relative number of which was $0.8 \times 10^{9} / \mathrm{L}$ and $54.6 \%$, respectively (Table 1 ).

\section{MONOCYTES}

Per field of vision we also found concentrations of larger cells with the diameter of 13-14 micrometers, they had precise contours and irregular shapes. Plasmolemma was thin, cytoplasm - basophilic (smoky-blue) and there were numerous dust-like granules. The nucleus had large, polymorphic form, it was non-segmented. Chromatin was loose and irregular. (Fig. 6).

In the microscopic study of the concentration taken from a forelimb blood vessel during the mammoth carcass thawing in 2014 we found the same cells like monocytes. Swab background was smoky-blue, it had numerous ghosts of destroyed cellular elements (Fig. 7).

Hematological study of the blood vessel concentrations we conducted in analyzer confirmed the presence of monocytes in the fluid composition, the absolute and relative amount of which was $\left(0,2 \times 10^{9} / \mathrm{L}\right)$ and $15.5 \%$, respectively (Table 1 ).

The obtained results of microscopic examination of the initial dark-brown liquid, allowed us to conclude that the liquid cell comprises elements in their morphology similar to mammoth blood elements: monocytes, neutrophils, lymphocytes containing nuclear inclusions. We made a comparative analysis of cells found in the dark brown liquid swab obtained during the excavations of the Mammoth, the swab was taken from the bottom of the trunk and a swab of biological material taken from a blood vessel of the forelimb, during the dissection of the carcass, conducted in March 2014. The analysis showed us the same morphological structure of cell elements in both swabs.

Thus, the microscopic examination of swabs made from dark brown liquid vessel concentrations and the front limbs having the same morphological structure of cellular elements, allow us to conclude that the blood of the fossil animal indeed exists in the composition of dark-brown liquid.

\section{PHAGOCYTOSIS}

The study of swabs, to our surprise, showed us some cellular elements in the various stages of phagocytosis. Neutrophils and monocytes (macrophages, in tissues) are referred to one of the types of professional phagocytes mammals. As is known, one of the initial steps of the phagocytosis is chemotaxis wherein the directed migration of leukocytes [6] take place. On the surface of the object there were the molecule receptors on the surface of phagocytes, so the next step is adhesion. We registered adhesion and activation stages of membrane in the swab. 
Table 1. Malolyahovsky mammoth neutrophil, lymphocytes, monocytes hematological indices obtained during the thawing in 2014.

\begin{tabular}{cc}
\hline Defined parameters & $1,6 \times 109 / л$ \\
\hline WBC - White blood cell count (x10E3 cells / micro-L) & $1,4 \times 109 / л$ \\
\hline WBCP - White blood cell count from the peroxidase method ( x10E3 cells / micro-L) & $0,2 \times 109 / \pi$ \\
\hline NEUT / - Absolute count of neutrophils ( x10E3 / micro-L) & $11,9 \%$ \\
\hline NEUT \% - Percent of neutrophils & $0,8 \times 109 / \pi$ \\
\hline LYMPH \# -Absolute count of lymphocytes ( x10E3 / micro-L) & $54,6 \%$ \\
\hline LYMPH \% -Percent of lymphocytes & $0,2 \times 109 / л$ \\
\hline MONO \# - Absolute count of monocytes ( x10e3 / micro-L) & $15,5 \%$ \\
\hline MONO \% - Percent of monocytes
\end{tabular}

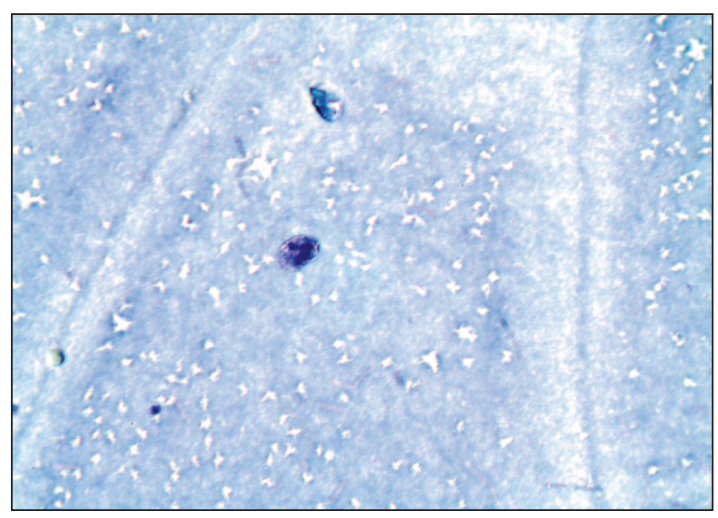

Fig. 1. Malolyahovsky mammoth fluid obtained during the excavations of 2013 (zooming in $10 \times 1000$ ).

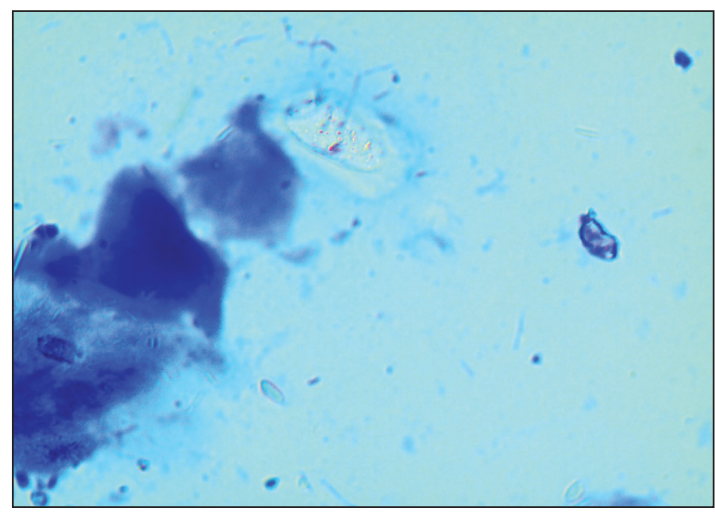

Fig. 3. The concentration of the Malolyahovsky mammoth blood vessel obtained during the mammoth carcass thawing in 2014. (Zooming in $10 \times 1000$ ).

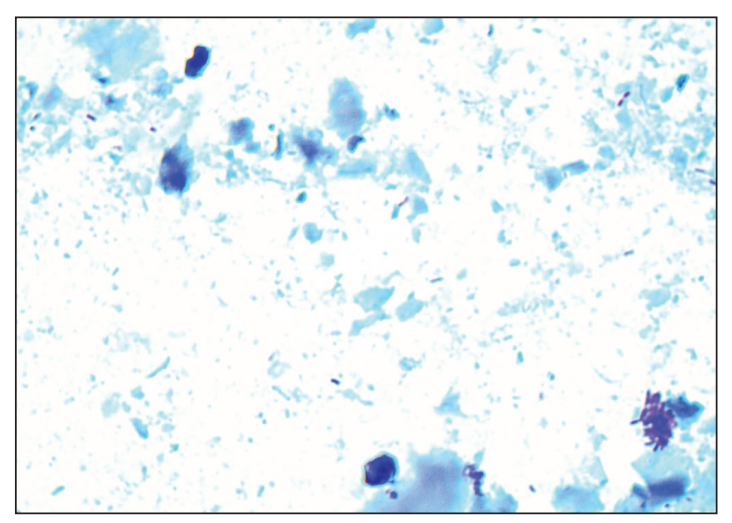

Fig.5. The concentration of the Malolyahovsky mammoth blood vessel obtained during the mammoth carcass thawing in 2014. (zooming in $10 \times 1000$ ).

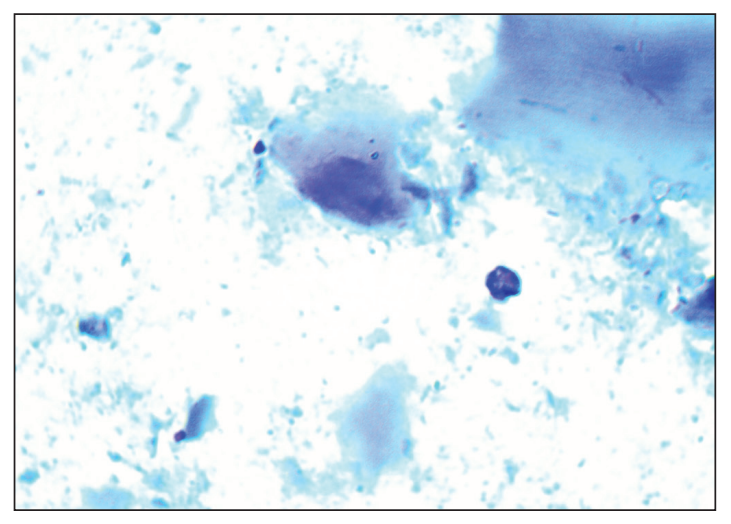

Fig. 2. The concentration of the Malolyahovsky mammoth blood vessel obtained during the mammoth carcass thawing in 2014. (Zooming in $10 \times 1000$ ).

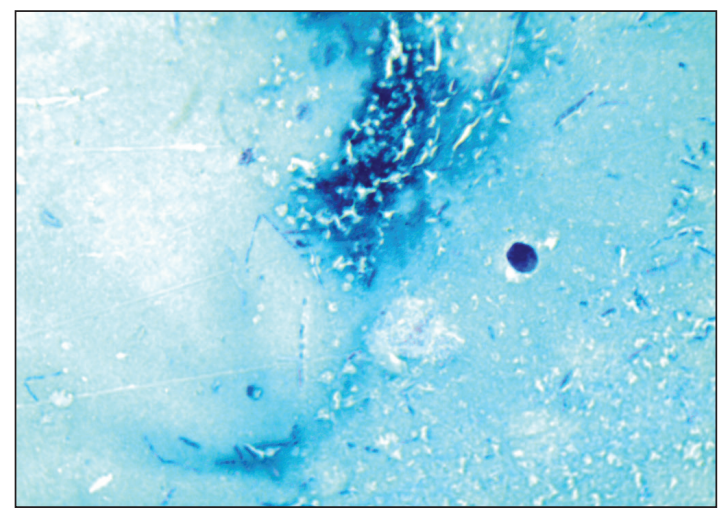

Fig. 4. Malolyahovsky mammoth fluid obtained during the excavations in 2013. (zooming in $10 \times 1000$ ).

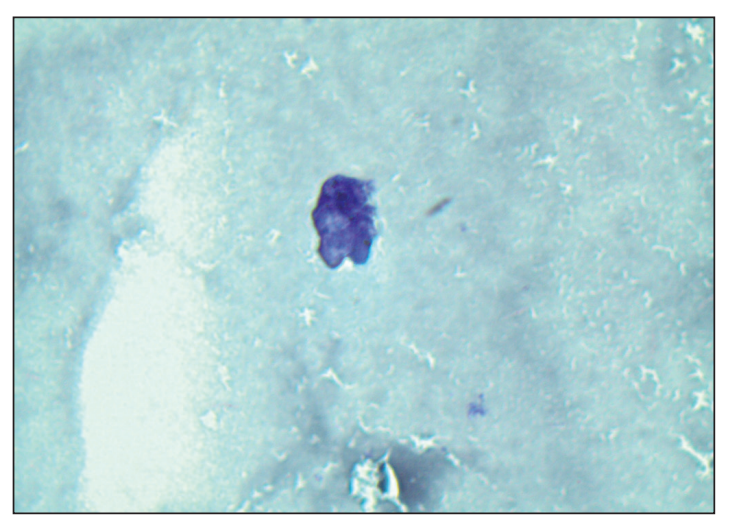

Fig. 6. Malolyahovsky mammoth fluid obtained during the excavations in 2013. (zooming in $10 \times 1000)$. 


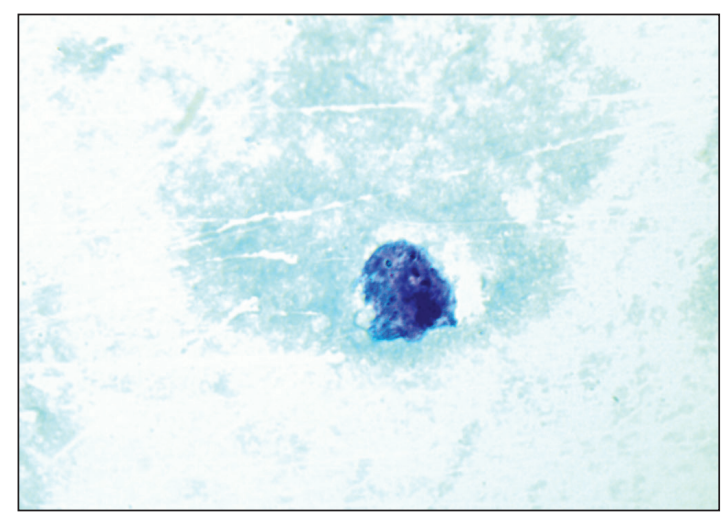

Fig. 7. The concentration of the Malolyahovsky mammoth blood vessel obtained during the mammoth carcass thawing in 2014. (zooming in $10 \times 1000$ ).

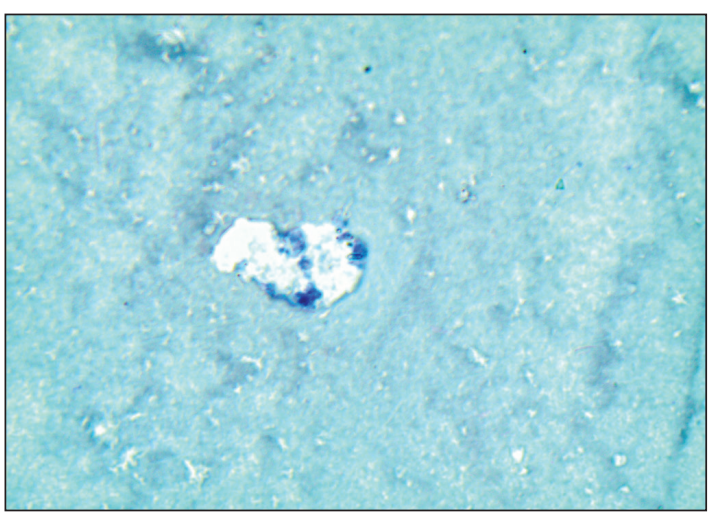

Fig. 9. Malolyahovsky mammoth fluid obtained during the excavations of 2013 (zooming in $10 \times 1000$ ).

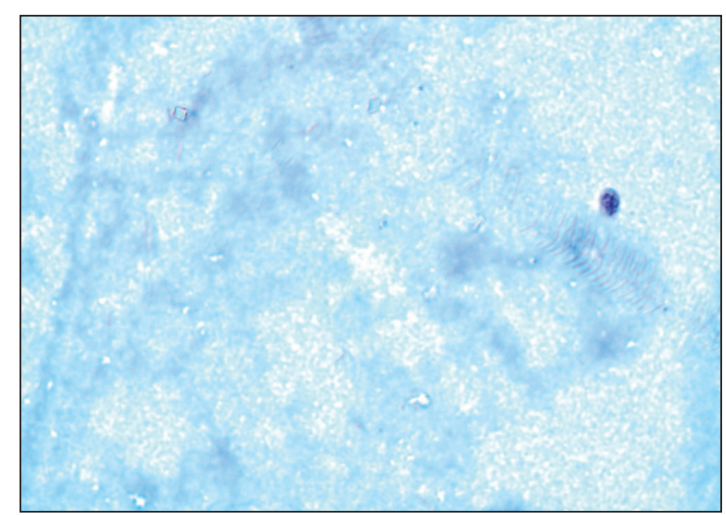

Fig. 11. Picture Malolyahovsky mammoth fluid obtained during the excavations of 2013. (zooming in $10 \times 400$ ).

One of the stages of phagocytosis is a phagosome formation stage. This stage per field of vision registered a single element, which had an irregular shape, and the boundaries of which were preserved, cytoplasm had inhomogeneous structure, nuclear inclusion were eccentrically located (Fig. 8).

Microscopic study of swabs often showed incomplete phagocytosis at the stage of interflowing and destruction (Fig. 9).

One of the final stages of phagocytosis is the release of degradation impurity. This stage was also registered in the swab of the original material. Against the back-

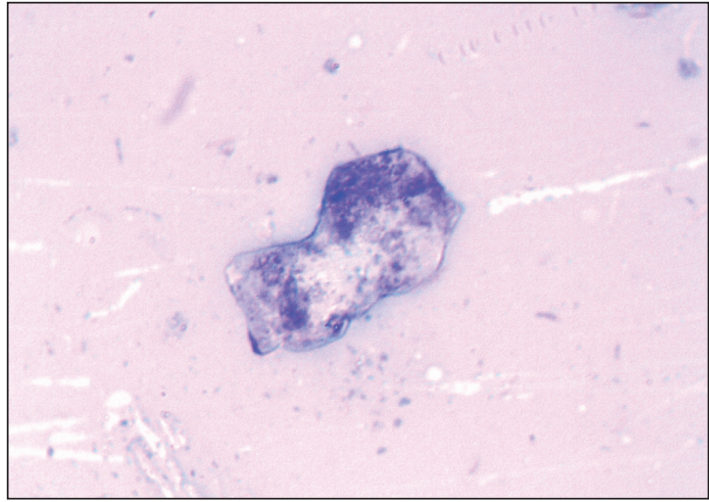

Fig. 8. Malolyahovsky mammoth fluid obtained during the excavations of 2013. (zooming in $10 \times 1000)$.

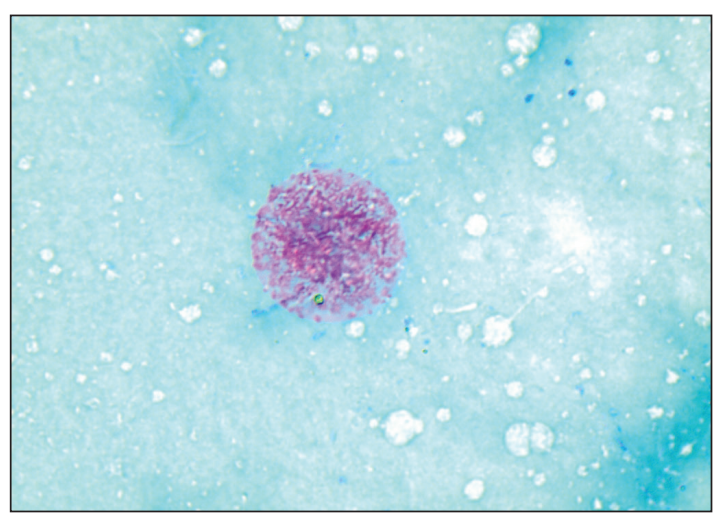

Fig. 10. Malolyahovsky mammoth fluid obtained during the excavations of 2013 (zooming in $10 \times 1000$ ).

ground of hemolysis there were some ghosts of the destroyed cells and an isolated element in the process of release (Fig. 10).

Thus, it should be noted that in a liquid similar to blood taken during the excavations in 2013, some microscopic individual stages of phagocytosis were found out to our surprise.

\section{RED BLOOD ELEMENTS RESEARCH STUDY}

Microscopic examination of swabs of different liquid showed us aspect of hemolysis (Fig. 11). The background swab had blue-smoky staining, visible stroma of destroyed cellular elements called "gousts of red blood cells."

In the context of hemolysis, the destruction of the erythrocyte membrane is accompanied by the release of hemoglobin into the blood plasma. This aspect of hemolysis let us suggest that there had been some quantity of hemoglobin, which was confirmed at the hematology study (Table 2).

Indices of Malolyahovsky mammoth hemoglobin $(22 \mathrm{~g} / \mathrm{l})$ Malashevska mammoth when compared with the literature data G. Kleppel and R. Klepper significantly exceeded the content of hemoglobin in the blood of the living white elephants $(13,72 \mathrm{~g} / \mathrm{l})[5]$.

Thus, we are the first to study and describe the fossil mammoth blood cells, which are related to leucocytes of heamatherm: neutrophils, monocytes, lymphocytes. 
Table 2. Hemoglobin hematological parameters of Malolyahovsky mammoth obtained during thawing in 2014

\begin{tabular}{|c|c|}
\hline Defined parameters & \\
\hline HGB -Hemoglobin ( g/dL) & 22 \\
\hline RBC - Red blood cell count (x10E6 cells / micro-L) & $0,03 \times 10^{9} / ת$ \\
\hline HCT - Hematocrit (\%) & 0,2 \\
\hline MCV -Mean corpuscular volume ( $\mathrm{fL}$ ) & 67,3 \\
\hline MCH -Mean corpuscular hemoglobin (pg) & 862,9 \\
\hline $\mathrm{CH}$-Cellular hemoglobin content (pg) & 15,8 \\
\hline MCHC - Mean corpuscular hemoglobin concentration (g/dL) & 12831 \\
\hline CHCM - Corpuscular hemoglobin concentration mean (g/dl) & 243 г/л \\
\hline$\%$ HYPO & +++ \\
\hline
\end{tabular}

The conducted research, in view of the lack of information in the literature about the probability of tissue preservation for such period, is certainly unique in the morphological reconstruction of the ancient animal.

\section{CONCLUSIONS}

The results of microscopic examination of dark brown liquid, allowed us to conclude that the liquid contains cell elements similar in their morphology to mammalian blood elements: monocytes, neutrophils, lymphocytes, containing nuclear inclusions.

Comparative analysis of cells found out in the swab of dark-brown liquid taken during the Malolyahovsky Mammoth excavation, and a swab of biological material taken from a blood vessel of the forelimb, showed the same morphological structure of cellular elements.

Thus, we are the first to study and describe the fossil mammoth blood cells, which are related to leucocytes of heamatherm: neutrophils, monocytes, lymphocytes.

Study of primary biomaterial in hematological analyzer confirmed the concentration of these cells (lymphocytes, monocytes and granulocytes), as well as the presence of hemoglobin, the value of which was $22 \mathrm{~g} / \mathrm{l}$.

Thus, the initial results of hematological research studies of Malolyahovsky mammoth are unique materials and they require an integrative approach to the interpretation of the results.

\section{REFERENCES}

1. Giemsa G. Eine Vereinfachung und Vervollkommnung meiner Methylenazur-Methylenblau-Eosin-Färbemethode zur Erzielung der Romanowsky-Nochtschen Chromatinfärbung. Centralbl f Bakt etc : magazin. 1904;Bd. 37:308-311.
2. Methodical recommendation: Hematology analyzer. Interpretation of blood test// http://ramld.ru/articles/files/hemanalizator.pdf

3. Lepel G., Kleppel R., Studies of blood elephants. "White elephant", 2007, p.19-23.

4. Vorotnikov A.V. Uspehi boilogicheskoy himii [The success of biological chemistry] Moscow, 000 "Geos", 2011, vol.51, p. 335-400 (in Russian)

5. Semyon E. Grigoriev, Daniel C. Fisher, Theodor Obada et al. A woolly mammoth (Mammuthus primigenius) carcass from Maly Lyakhovsky Island (New Siberian Island, Russian Federation). Quaternary International, 2017; 445: 89-103 https: //doi.org/10.1016/j.quaint.2017.01.007

\section{Authors' contributions:}

According to the order of the Authorship.

\section{ORCID numbers:}

Palmira G. Petrova - 0000-0003-3108-9530

Eya E. Egorova - 0000-0002-1948-0169

Victoriya E. Egorova - 0000-0003-1869-8833

Semen E. Grigor'ev - 0000-0001-9932-6008

Lena R. Turkebaeva - 0000-0001-6945-261X

\section{Conflict of interest:}

The Authors declare no conflict of interest.

\section{CORRESPONDING AUTHOR Palmira G. Petrova \\ Medical Institute, North-Eastern Federal University \\ named after M.K. Ammosov, Yakutsk, Russia \\ e-mail:mira_44@mail.ru}

Received: 03.04.2019

Accepted: 24.09.2019 
PRACA POGLĄDOWA

REVIEW ARTICLE

\title{
PATTERNS OF CARDIOVASCULAR DISEASE IN THE CARPATHIAN REGION
}

\author{
Igor P. Vakaliuk ${ }^{1,2}{ }^{2}$ Roksolana V. Nesterak', Denys A. Volynskyi' ${ }^{1}$, Volodymyr I. Sovtus ${ }^{1}$, Viktor M. Yakimchuk ${ }^{2}$, \\ Andrij I. Volynskyi \\ 'IVANO-FRANKIVSK NATIONAL MEDICAL UNIVERSITY, IVANO-FRANKIVSK, UKRAINE \\ 2IVANO-FRANKIVSK REGIONAL CLINICAL CARDIOLOGY CENTRE, IVANO-FRANKIVSK, UKRAINE
}

\begin{abstract}
Introduction: Cardiovascular diseases remain a problem of the modern medical community. Mortality from cardiovascular disease is at the forefront in the structure of the causes of mortality, so active support for the prevention and treatment of this group of diseases is the most effective measure as it will affect the continuation of life expectancy. The aim: To analyze features and patterns of cardiovascular disease in the Carpathian region.

Materials and methods: The features of the course and treatment of acute coronary syndrome in the period 2014-2018 in the Ivano-Frankivsk region are analyzed. Clinicalanamnestic, geographical, demographic, the effectiveness of patient care, statistical and acute coronary syndrome registry data were studied.

Conclusions: Preventive activities, both primary and secondary, with the promotion of knowledge on the preservation and strengthening of health, are a guarantee of positive progress in overcoming cardiovascular diseases. Creation of rehabilitation centers with a multidisciplinary approach, along with medical and physical interventions of psychological support and training, will contribute to the improvement and prevention of complications of cardiovascular disease. The cooperation of cardiological communities between the regions has a social and medical significance, namely the training of specialists, the exchange of experience, scientific projects with the medical community of Opole Voivodship is one of the directions of increasing the efficiency of treatment of cardiological patients
\end{abstract}

KEY WORDS: acute coronary syndrome, coronary artery bypass grafting, region, rehabilitation, psychology, training

Wiad Lek 2019, 72, 10, 1966-1973

\section{INTRODUCTION}

The relevance of the study of cardiovascular pathology in the Carpathian region is due to the wide prevalence of diseases of the cardiovascular system in both Ukraine and Europe as a whole. Thus, according to WHO, nearly 85.5 million Europeans suffered from cardiovascular disease, namely: peripheral blood vessels (35.7 million), ischemic heart disease (29.4 million), lesions of the pericardium and heart valves (13.3 million ), atrial fibrillation (9.5 million) and strokes (7.5 million) [1].

Analyzing the dynamics of prevalence and mortality in Ukraine of cardiovascular and vascular diseases from 2000 to 2018, we can note their fluctuations - from increase to decrease, both from all diseases and due to diseases of the circulatory system in all regions Ukraine, which leaves the forecast pessimistic.

The Ivano-Frankivsk region occupies an area of 13.9 thousand $\mathrm{km}^{2}$, which is $2.4 \%$ of Ukraine's territory. The geographic feature of the region is the division of relief into three zones: plain, foothill, on which the regional center is located - Ivano-Frankivsk ( $255 \mathrm{~m}$ above sea level), mountains (Carpathian mountains, occupy the southwestern part of the region, here is the highest mountain of Ukraine - Hoverla (2061 m)). The relief elevation rises from northeast to southwest.
The climate of the region is moderately continental, moist, characterized by significant fluctuations in temperature, atmospheric pressure, humidity, wind direction in accordance with the relief zones (Fig.1.) [2].

Population of the region - 1,381.5 thousand, including in plain areas - 369.5 thousand, foothill areas - 708.4 thousand, mountainous areas - 304.7 thousand in administrative division includes 14 districts, and 5 city councils (Fig. 2.).

Main part of the region's population lives in villages $57.1 \%$ (788.2 thousand), the part of urban population is $42.9 \%$ (593.3 thousand).

The uneven density of the population, which goes down from the plains to mountainous regions is one of the unique features of the region. An average population density of the region - 101.4 persons $/ \mathrm{km}^{2}$, the highest density is in plain areas - 115 persons $/ \mathrm{km}^{2}$, the lowest is in the Verkhovinsky district - 24 persons $/ \mathrm{km}^{2}[3]$.

\section{ORGANIZATION OF CARDIOLOGY MEDICAL CARE}

The municipal institution "Ivano-Frankivsk Regional Clinical Cardiology Center" was organized in December 1986, in which activities diagnostic and advisory and organizational-methodical work prevails. 


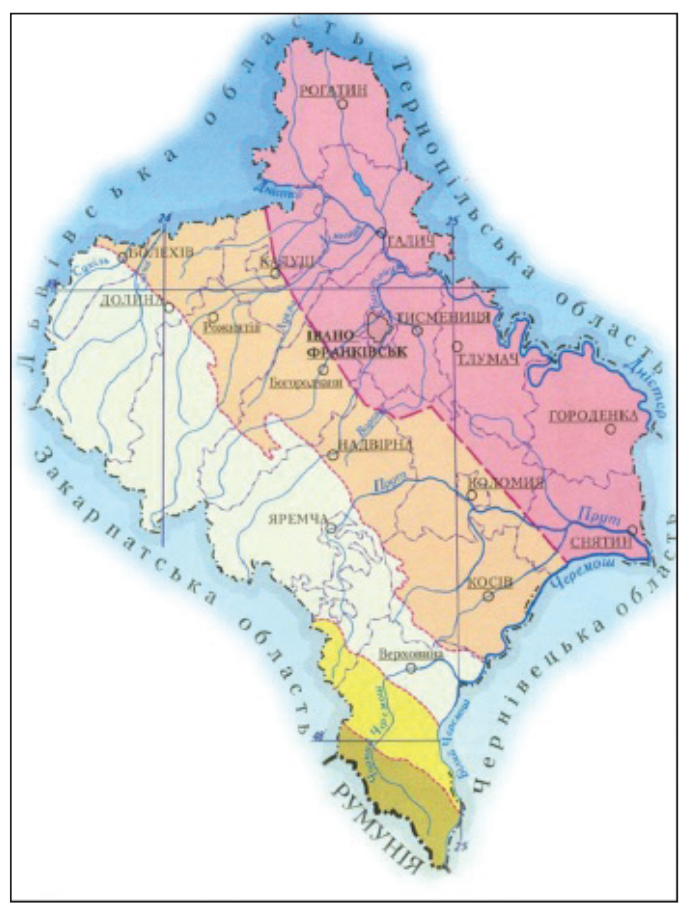

Fig. 1. The climate map of the Ivano-Frankivsk region.

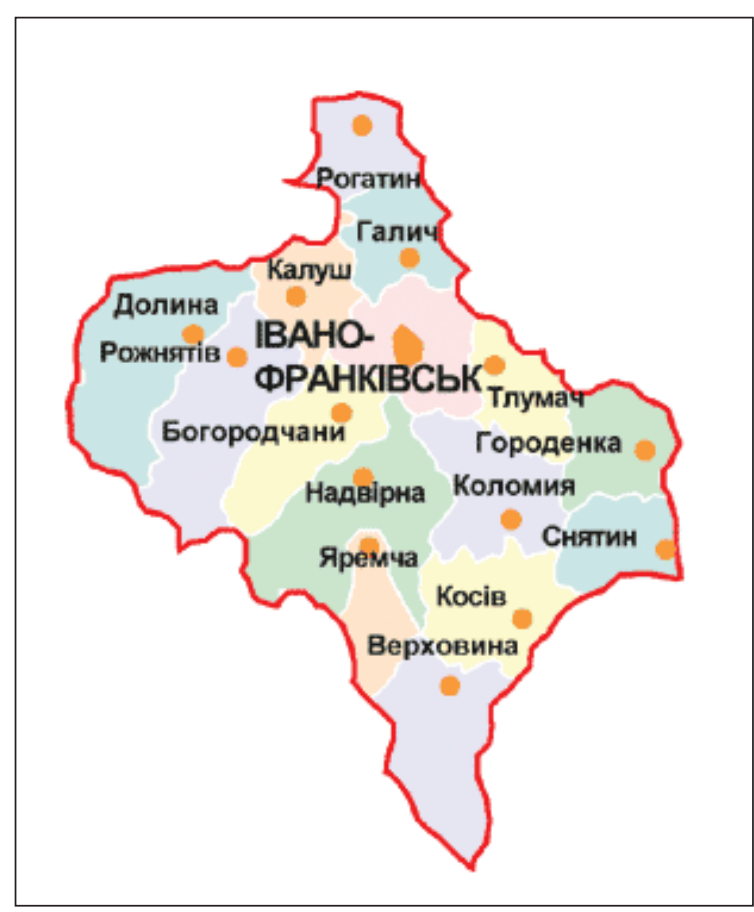

Fig. 2. The administrative map of Ivano-Frankivsk region.
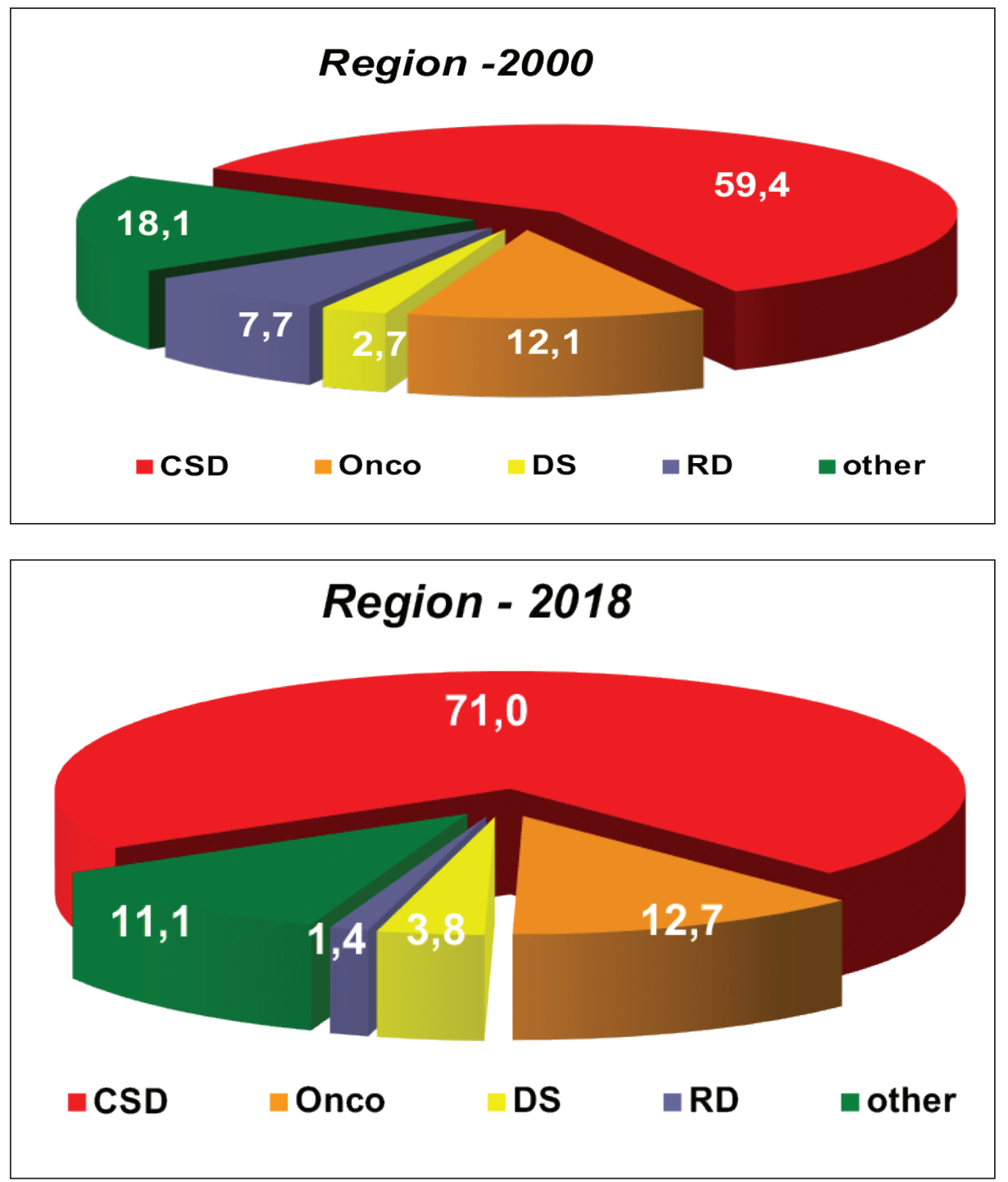

Fig. 3. Health indicators of the IvanoFrankivsk region during 2000.
Fig. 4. Health indicators of the IvanoFrankivsk region during 2018. 

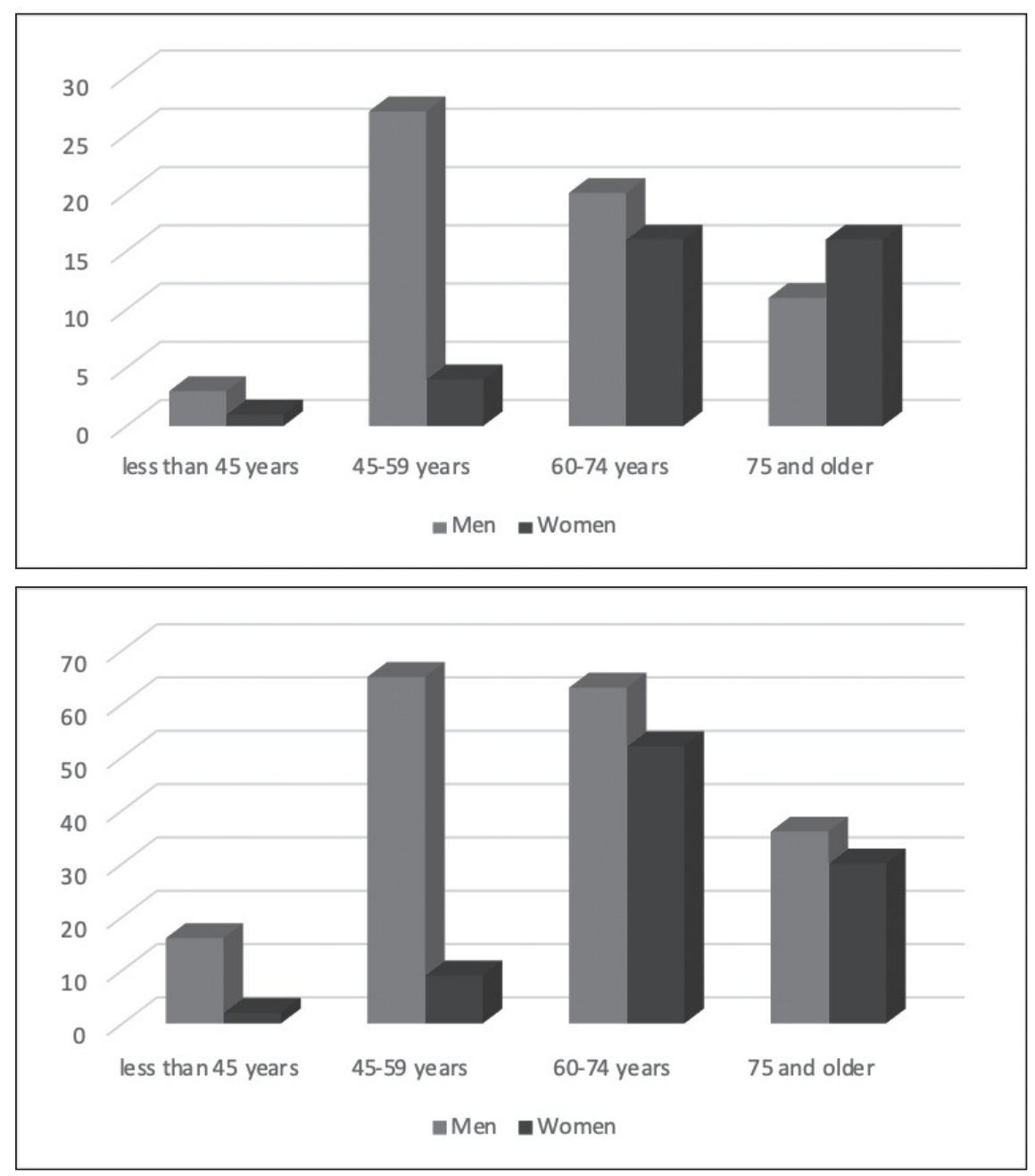

Fig. 5. Distribution of patients with NSTEMI by age and sex.

Fig. 6. Distribution of patients with STEMI by age and sex.

Table I. Distribution of patients with ischemic heart disease, who underwent treatment and rehabilitation in the Ivano-Frankivsk Cardiology Center.

\begin{tabular}{|c|c|c|c|c|c|c|}
\hline \multirow{2}{*}{ Age } & \multicolumn{2}{|c|}{ NSTEMI } & \multicolumn{2}{|c|}{ STEMI } & \multicolumn{2}{|c|}{ Repeated MI } \\
\hline & 2014 & 2018 & 2014 & 2018 & 2014 & 2018 \\
\hline Less than 45 years & $\begin{array}{c}4 \\
(4.8 \%)\end{array}$ & $\begin{array}{c}4 \\
(4.1 \%)\end{array}$ & $\begin{array}{c}20 \\
(9.0 \%)\end{array}$ & $\begin{array}{c}18 \\
(6.5 \%)\end{array}$ & - & - \\
\hline 45-59 years & $\begin{array}{c}24 \\
(28.6 \%) \\
\end{array}$ & $\begin{array}{c}31 \\
(31.6 \%) \\
\end{array}$ & $\begin{array}{c}52 \\
(25.5 \%)\end{array}$ & $\begin{array}{c}74 \\
(26.8 \%)\end{array}$ & $\begin{array}{c}18 \\
(18.9 \%)\end{array}$ & $\begin{array}{c}26 \\
(23.2 \%)\end{array}$ \\
\hline $60-74$ years & $\begin{array}{c}40 \\
(47.6 \%)\end{array}$ & $\begin{array}{c}36 \\
(36.7 \%)\end{array}$ & $\begin{array}{c}86 \\
(42.2 \%)\end{array}$ & $\begin{array}{c}11 \\
(3.9 \%)\end{array}$ & $\begin{array}{c}40 \\
(42.1 \%)\end{array}$ & $\begin{array}{c}49 \\
(43.8 \%)\end{array}$ \\
\hline 75 and older & $\begin{array}{c}16 \\
(19.1 \%)\end{array}$ & $\begin{array}{c}27 \\
(27.5 \%)\end{array}$ & $\begin{array}{c}46 \\
(22.5 \%)\end{array}$ & $\begin{array}{c}69 \\
(25.0 \%)\end{array}$ & $\begin{array}{c}37 \\
(38.9 \%)\end{array}$ & $\begin{array}{c}37 \\
(33.0 \%)\end{array}$ \\
\hline
\end{tabular}

Notes: The absolute number of patients is indicated.

Scientists of the Ivano-Frankivsk National Medical University have developed and maintained a local registry of patients at the stage of rehabilitation after heart attack $[4,5]$.

In 2000-2019 in the regional and central city clinical hospitals, the centers of low-invasive surgery have been organized and are successfully functioning. Coronary angiography, stenting of coronary vessels, the implantation of permanent pacemakers and cava filters are performed. In 2018 angiographic system, ultrasound scanner of the expert class, equipment for laboratory diagnostics were purchased.

The information support and training of cardiologists for the purpose of improving their qualification is carried out by the "Ukrainian Cardiology Magazine", which is published by the National Science Center "M.D.Strazhesko Institute for Cardiology", methodical recommendations, wide participation in scientific congresses, conferences of different levels. Every month, cardiologists study at inter- 

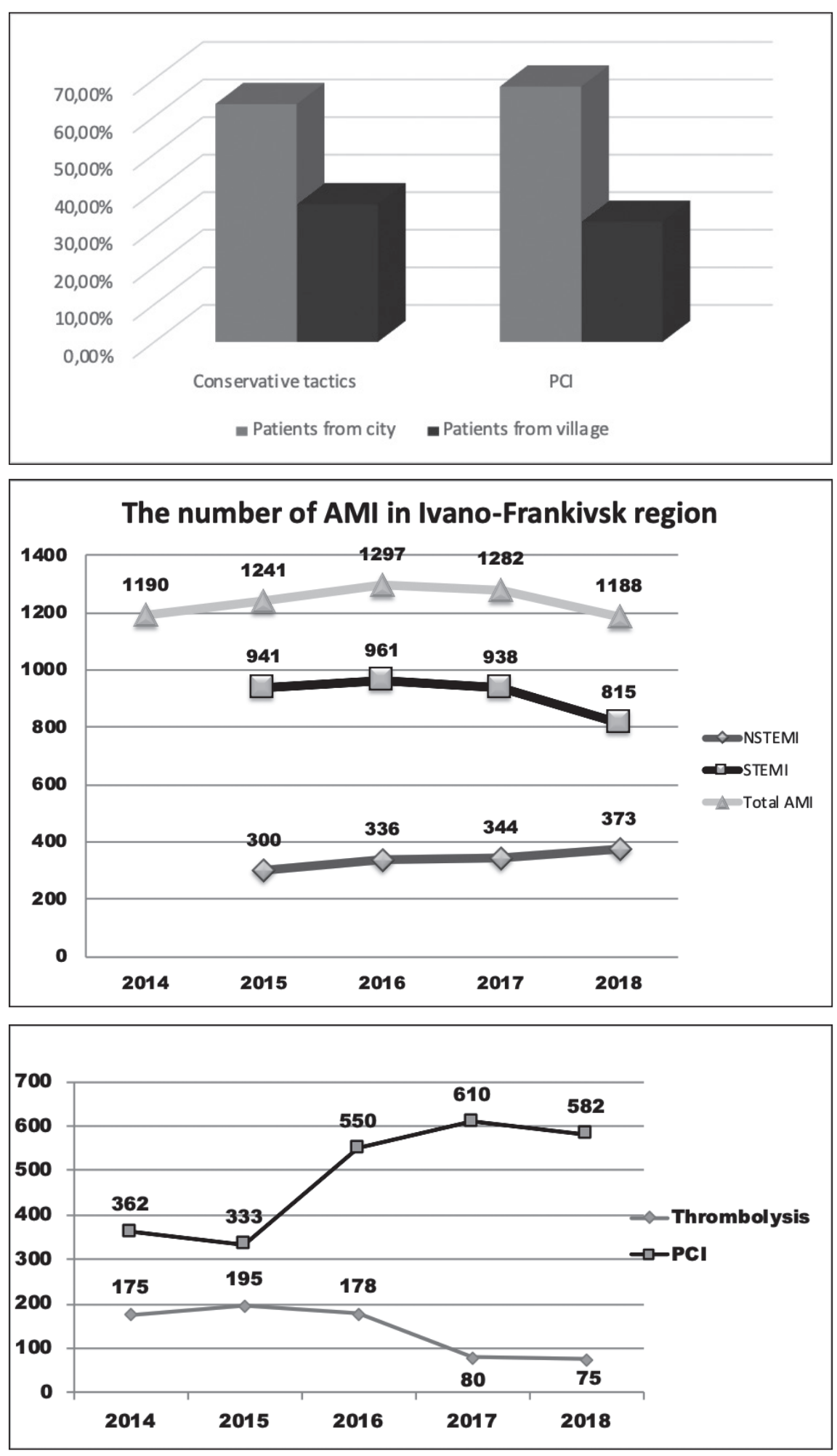

Fig. 7. Distribution of patients with NSTEMI by residence.

Fig. 8. The number of acute myocardial infarction 2014-2018.

Fig. 9. Treatment of AMI 2014-2018 mittent courses involving district cardiologists, advanced training courses by leading scientists from Ukraine and the near abroad.

In accordance with the agreement on cooperation with University Clinical Hospital in Opole and the Ivano-Frankivsk Regional Clinical Cardiology Center, the scientific and practical activity continues, and 110 doctors and scientists have been trained on the basis of clinics in Opole.

\section{THE AIM}

The aim: to analyze features and patterns of cardiovascular disease in the Carpathian region.

\section{MATERIALS AND METHODS}

The features of the course and treatment of acute coronary syndrome in the period 2014-2018 in the Ivano-Frankivsk 

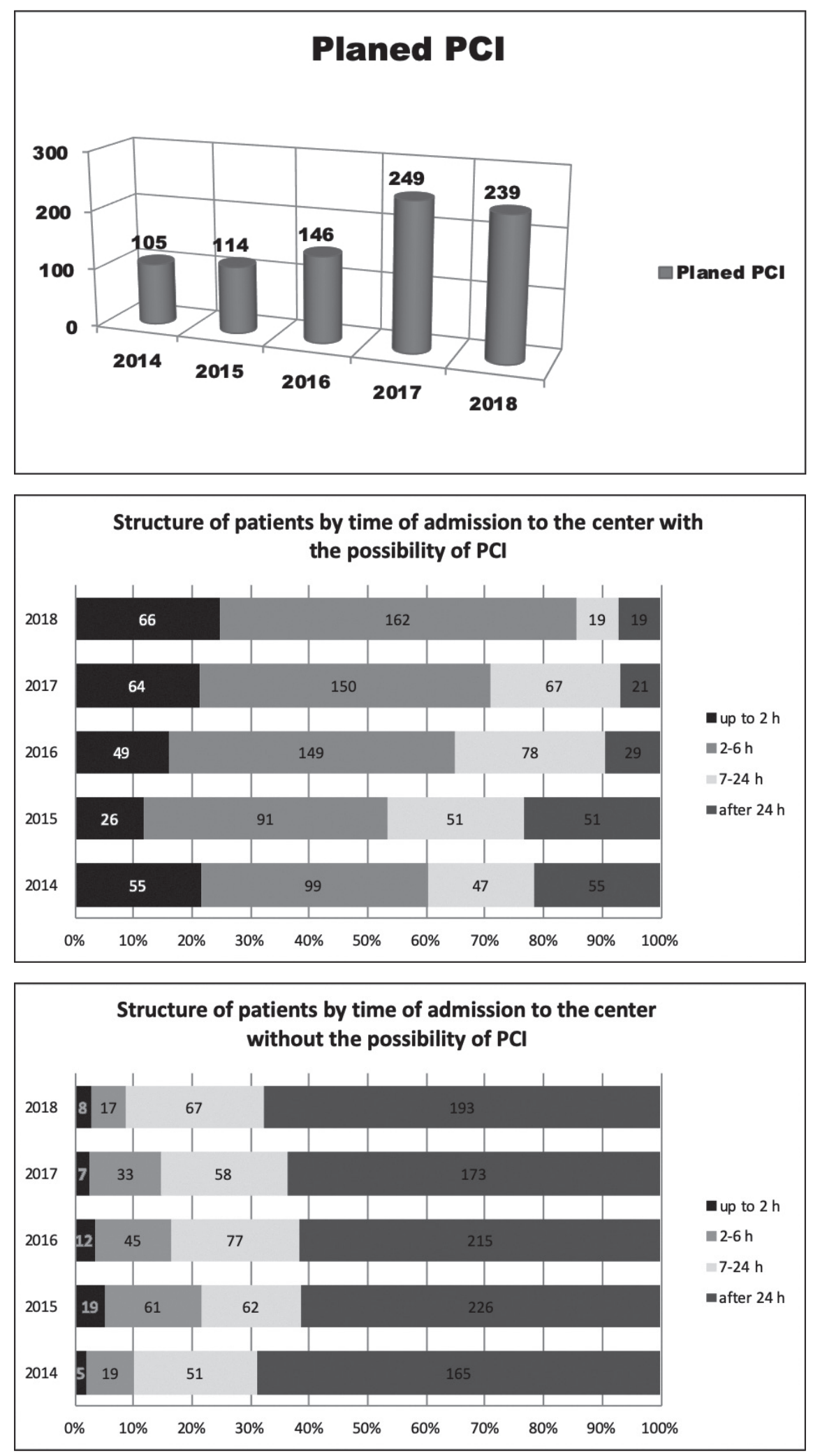

Fig. 10. Planed PCI from 2014-2018

Fig. 11. Structure of patients by time of admission to the center with the possibility of $\mathrm{PCl}$
Fig. 12. Structure of patients by time of admission to the center without the possibility of $\mathrm{PCl}$ region are analyzed. Clinical-anamnestic, geographical, demographic, the effectiveness of patient care, statistical and acute coronary syndrome registry data were studied. The study does not contradict the Declaration of Helsinki and received positive feedback from the ethics committee of the Ivano-Frankivsk National Medical University.

\section{REVIEW AND DISCUSSION}

The analysis of the basic indicators of health of the population in Ivano-Frankivsk region shows that the most important medical-social problem are circulatory system diseases (CSD) due to the increasing prevalence, morbidity, severe consequences of disability (third part of 
Table II. The percentage of patients who have undergone rehabilitation

\begin{tabular}{cccccccccc}
\hline & Total MI & \multicolumn{3}{c}{ Rehabilitation } & \multicolumn{3}{c}{$\%$} \\
\hline 2015 & 2016 & 2017 & 2015 & 2016 & 2017 & 2015 & 2016 & 2017 \\
\hline 1241 & 1292 & 1282 & 412 & 374 & 360 & 33.2 & 28.9 & 28.1 \\
\hline
\end{tabular}
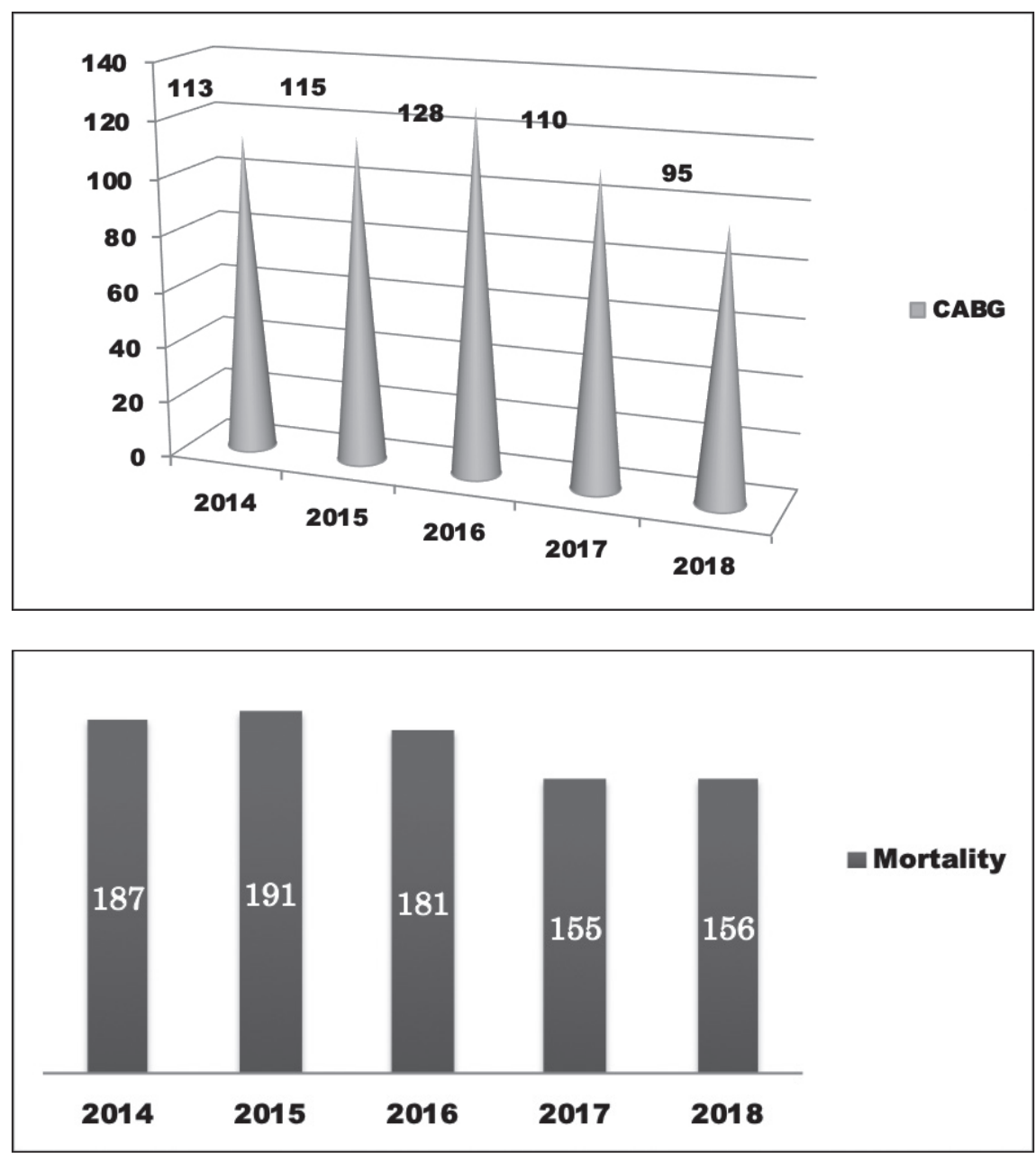

Fig. 13. CABG performed in years 2014-2018 all causes of disability) and high mortality (more than half of all cases of death). These CSD are atherosclerosis, ischemic heart disease (IHD), arterial hypertension (AH) and their complications (heart attack, stroke), which rank first among other.

While analysing health indicators of the population, the primary attention was paid to the structure of total mortality of the population, in which during 2000-2018 growth for diseases of the digestive system $(+40.0 \%)$, cholesterol $(+19.5 \%)$, onco $(+4.9 \%)$ and decrease in respiratory diseases $(-82.0 \%)$ was noted (Fig. 3,4$)$.

As for the distribution of ischemic heart disease patients by age and sex (2018), at the age of 45-59, the main percentage is men $27(27.5 \%)$, women 4 - (4.08\%) with NSTEMI and $65(23.5 \%)$ and $9(3.2 \%)$ at STEMI, respectively; in the age group 60-74, the proportion of women with NSTEMI 16 (16.3\%) and STEMI 52 (16.84\%) versus men is $20(20.4 \%)$ and $16(16.33 \%)$, and at the age above
75 years for NSTEMI women prevail - 16 (16.3\%). This trend was observed in previous years and is comparable to the general data of Ukraine (Table I.).

The distribution of patients with NSTEMI by gender and age is presented in Figure 5, STEMI (Figure 6).

According to the distribution of patients by place of residence the main percentage is the city's residents. In particular, $63.33 \%$ of patients with NSTEMI who were given a conservative treatment were from the city and $36.68 \%$ from the village. In the case of conducting PCI, 68\% and 32\% respectively (Fig. 7). This distribution is same for patients with STEMI

In the region between 2014 and 2018 there is a decrease in cases of myocardial infarction (Fig. 8). So, the highest level was in 2016 - 1297 cases, in 2018 - 1188 cases. No significant fluctuations in percentages are observed for STEMI and NSTEMI cases. STEMI in 2016 was 962 cases $(74.1 \%)$, and in $2018-815$ cases $(68.3 \%)$. NSTEMI in 2016 - 336 cases (25.9\%), and in 2018 - 373 cases $(31.7 \%)$. 
There is an increase in the percentage of patients who have been diagnosed with PCI. So, in 2015, 333 patients with ACS were treated by PCI, in 2018 there were 582 interventions. Due to the geographical features and remoteness of some districts from the only one center in the region where primary $\mathrm{PCI}$ is performed, in part of patients, thrombolytic therapy (TLT) was used. There were 75 TLT in 2018 compared to 175 in 2014.(Fig 9,10.).

Structure of patients by time of admission to the center with the possibility of PCI: 343 patients with ACS in 2018 were admitted to the united center of Ivano-Frankivsk region: up to 2 hours - 66 patients - 21\%, 2-6 years - 162 patients - 51\%, 7-24 hours of patients - 19-6\%, more than 24 hours - 19 patients $-6 \%$ (Fig. 11).

More than $68.0 \%$ of patients were hospitalized after 24 hours without the possibility of providing percutaneous interventions. Such features also have been noted for the past years (Fig. 12.).

\section{REHABILITATION OF CARDIAC PATIENTS}

On the basis of the Ivano-Frankivsk Regional Clinical Cardiology Center there is a rehabilitation department where patients of working age underwent rehabilitation after acute coronary syndrome and cardiac surgery.

In the region there is a need for a rehabilitation institution, where provision of more effective rehabilitation for the entire population of the region. The percentage of rehabilitation is low, for example in $2017-28.1 \%$ of patients (Table II).

The rehabilitation department has a multidisciplinary approach, covering all components of rehabilitation.

Along with medical support, physical rehabilitation is conducted (including morning gymnastics, medical physical exercise, dosed walking, massage, physiotherapy procedures)

Psychological rehabilitation uses suggestive methods (autotraining, music therapy), individual and group counseling, trainings.

One of the methods used in the department is the teaching of patients, for this purpose a school-club "Healthy heart" was created. The purpose of the work is to support patients in the medical and psychological areas; increase of awareness of patients with cardiovascular diseases, psychological component of diseases; improve of rehabilitation of patients; increase patient's attachment to non-drug and medical treatment; form the internal picture of health, work on the internal picture of the disease; form skills and abilities of influence on behavioral risk factors; train self-control skills; provide the first pre-medical care; promote healthy lifestyle, increasing the patient's responsibility for maintaining his health and motivating him to recover; work with families and relatives of patients.

Also, for social awareness, a web-page is created in social networks.

\section{CARDIO-SURGICAL INTERVENTIONS}

In the dynamics from 2014 to 2018, the provision of cardiac surgery is increasing. In the structure of this care there are interventions for infective endocarditis, congenital heart defects, acquired heart defects, implantation of artificial pacemakers, CABG, coronary stenting, cardiac ventriculography.

In 2018881 cardio-surgical interventions were performed against 744 in 2017, including: with infectious endocarditis - 7; with congenital heart defects - 21; with acquired heart defects - 65; CABG - 95; coronary stenting - 506; implantations of artificial pacemakers - 116 (110 implanted, 6 - reimplanted) (Fig.13).

The mortality rate for AMI is somewhat diminished. In particular, in 2014 it was 187 cases, which was $17.0 \%$, and in 2018 , respectively, 156 cases $-14.2 \%$ (Fig.14).

The health of the population of the region is determined by a number of medical and non-medical factors, in particular demography and the region's economy, population composition and the availability of modern medical technologies. The gradual introduction of modern reperfusion technologies can significantly affect the effectiveness of rehabilitation of patients, their disability and quality of life.

One of the important factors that determine the above priorities is the age and gender of the patients. In particular, the highest percentages of patients with coronary artery disease were observed at the age of 45-59 and 60-74 years, during these periods, there appeared both NSTEMI and STEMI. In recent years there has been an increase in the number of patients in the older age category.

The introduction of modern reperfusion technologies gradually changes the ratio of NSTEMI and STEMI. In particular, timely planned treatment for patients with SIHD contributes to a decrease in STEMI, with a slight increase in the number of NSTEMI, although this pattern varies in different regions of the region [6].

Thrombolytic therapy is still an important method of reperfusion therapy in a special regional environment. The amount of thrombolysis is gradually decreasing, which is due to the introduction of PCI on the one hand, and, on the other hand, the creation of conditions for rapid transport to the catheterization laboratory

Growing of the network of reperfusion centers, as well as reforming emergency medical care, helps to increase the quantity, timeliness and efficiency of reperfusions. At the same time, at the regional level, a significant percentage of patients with a limited possibility of PCI and full reperfusion remain.

Despite the use of reperfusion tactics or the impossibility of its implementation, the effectiveness of further restorative treatment of patients is determined by the complex of medical treatment, physical and psychological rehabilitation

It is clear that an effective rehabilitation complex can be carried out in the event of the establishment of appropriate rehabilitation centers and their equipment, using a multidisciplinary approach.

Along with the methods of physical rehabilitation there is a need to introduce a variety of methods of psychological rehabilitation. It is important to effectively study the formation of an optimal internal picture of health $[8,9]$.

Among patients with SIHD, despite organizational and medical measures to prevent acute coronary syndrome and the introduction of PCI, there remains a certain contingent 
of patients whose further healing is possible through the use of CABG. CABG along with other cardiac surgical interventions for heart defects, endocarditis, implantation of artificial rhythm drivers is the way that increases the duration and quality of life of patients.

The comprehensive approach to primary and secondary prevention of coronary artery disease and prevention of complications remains the main priorities of improving cardiology assistance to the population.

Economic and medical ties of different regions have important social and medical importance. In particular, during the past 10 years, a close co-operation between the cardiological community of Ivano-Frankivsk region and the cardiology community of Opole Voivodeship has been established. Training of specialists, their internships, exchange of experience, scientific projects is one of the steps to improve the efficiency of treatment of patients.

\section{CONCLUSIONS}

Due to increasing rates of the prevalence of circulatory system diseases in the area the following points should be adressed:

1. Medical regularities:

- reducing the public's attention to their health

- shortcomings in rehabilitation and medical examination

- request for medical assistance in critical situations

- insufficient number of centers with the possibility of percutaneous interventions

- failure to provide preventive or supportive treatment

- demographic processes, geographic features, a significant decrease in density of population in the direction from the plains to mountainous areas.

2. Mortality from cardiovascular disease is at the forefront in the structure of the causes of mortality, so active support for the prevention and treatment of this group of diseases is the most effective measure as it will affect the continuation of life expectancy.

4. The urgent need is to use and maintain a registry of patients with cardiovascular diseases.

5. Preventive activities, both primary and secondary, with the promotion of knowledge on the preservation and strengthening of health, are a guarantee of positive progress in overcoming cardiovascular diseases.

\section{REFERENCES}

1. Kovalenko VM, Kornatsky VM. State of health of the people of Ukraine and tertiary level medical care. Kiev: F0 Kolomycin 2019. 222 p.

2. Geographical location and natural conditions of the Carpathian region. Ivano-Frankivsk Regional Universal Library I.Franka. [cited 2019 May 10]. Available on: https://lib.if.ua/exhib/1534076504.html

3. Yatsuba VG, etc. Administrative-territorial structure of Ukraine. History and the present. KIEV. 2001:272 pp.

4. Kovalenko VN, Dolzhenko MN, Nesukai EG, Dyachenko Ya. Comparative characteristics of prevention of cardiovascular diseases in Ukraine and Europe according to EUROASPIREVI: hospital line. Arterial hypertension. 2016; 1 (45): 57-61.
5. Chengdu TV, Ratotch YaG, Logoyda VV. Register of acute coronary syndromes in Transcarpathia: first results. Heart and blood vessels. 2017; 2: 38-44.

6. Unified clinical protocol of emergency, primary, secondary, third medical care and medical rehabilitation "Acute coronary syndrome without elevation of segment ST", Order of the Ministry of Health of Ukraine 03.03.2016 № 164

7. Nesterak RV. Evaluation of the internal picture of health in patients with acute coronary syndrome in presenting without ST-segment after percutaneous coronary interventions and in the process of rehabilitation. EUREKA: Health Sciences. 2019;3:9-17

8. Nesterak RV, Gasjyk MB. Pilot investigation of the method of interactive training of patient at the stage of medical rehabilitation and treatment. Deutscher Wissenschaftsherold German Science Herald. 2017;4: 38-41.

9. Nesterak RV. Peculiarities of the Course and Provision of Medical Care to Patients with Acute Coronary Syndrome in the Precarpathian Region. Archive of Clinical Medicine. 2019; 25:1-10.

10. Horbas MI. Ischemicheart disease: epidemiology and statistics. Zdorovya Ukrayiny. 2015 [cited 2015 March 27]. Available on: http://health-ua. com/article/15840-shemchna-hvoroba-sertcya-epdemologya-statistika.

11. Diachuk DD. Yashchenko YuB. Lysenko IYu. The prevalence of circulatory system diseases among the adult population. which is provided with medical aid at the DNU“NPC PKM"DUS. Bulletin of Problems in Biology and Medicine. 2015; 2 (1): 290-294.

12. Klymenko VI. Denysenko IM. Topical issues of organization of medical rehabilitation of cardiological patients in modern conditions. Ukraine. Zdorovya natsiyi. 2010; 2 (14): 79-83.

The present study is a fragment of the research project "Non-alcoholic fatty liver disease: influence on the course of cardiovascular diseases, optimization of treatment» (state registration number No. 0118U004756).

\section{Authors' contributions:}

According to the order of the Authorship.

\section{ORCID numbers:}

Igor P. Vakaliuk - 0000-0002-4430-6816

Roksolana V. Nesterak - 0000-0002-4062-0939

Denys A. Volynskyi - 0000-0003-4849-8197

Volodymyr I. Sovtus - 0000-0001-9488-1707

Viktor M. Yakimchuk - 0000-0002-2669-9150

Andrij I. Volynskyi - 0000-0001-5036-8872

Conflict of interest:

The Authors declare no conflict of interest.

\section{CORRESPONDING AUTHOR \\ Roksolana V. Nesterak \\ Ivano-Frankivsk National Medical University, \\ Ivano-Frankivsk, Ukraine \\ e-mail: roxolana.nesterak@gmail.com}

Received: 03.07.2019

Accepted: 37.09 .2019 
PRACA POGLĄDOWA

REVIEW ARTICLE

\title{
CHANGES IN HEALTH STATUS OF CHILD POPULATION OF UKRAINE AFTER CHERNOBYL CATASTROPHE
}

\author{
Oleksandr P. Volosovets' ${ }^{1}$, Sergii P. Kryvopustov' ${ }^{1}$, Tetiana M. Volosovets' ${ }^{2}$, Oleksandr E. Abaturov ${ }^{3}$, Tetyana 0. Kryuchko ${ }^{4}$ \\ 10.0. BOHOMOLETS NATIONAL MEDICAL UNIVERSITY, KYIV, UKRAINE \\ 2P.L. SHYPUK NATIONAL MEDICAL ACADEMY OF POSTGRADUATE EDUCATION, KYIV, UKRAINE \\ ${ }^{3}$ SI «DNIPROPETROVSK MEDICAL ACADEMY OF HEALTH MINISTRY OF UKRAINE», DNIPRO, UKRAINE \\ ${ }^{4}$ UKRAINIAN MEDICAL STOMATOLOGICAL ACADEMY, POLTAVA, UKRAINE
}

\begin{abstract}
Introduction: The article is concerned with problems of morbidity of children and infant mortality during the latest $30^{\text {th }}$ years after Chernobyl catastrophe. The 30 th anniversary of the Chornobyl disaster is a stage that determines the analysis of its consequences, the assessment of the effects of radiation, the impact of the accident factors on the health of the population of the most affected countries and on global processes.

The aim: to study the condition of child population of regions of Ukraine, which were contaminated by radionuclides in the result of Chernobyl catastrophe.

Materials and methods: statistic assessment and epidemiological analysis were used to analyze materials of the investigations.

Conclusions: Results of comparative analysis demonstrate the stabile increase of morbidity level as residents of regions of TRC. Abnormalities of respiratory system present the first group of the morbidity among children. The morbidity level of blood and blood forming diseases, tumors formation, diseases of endocrine system, digestive disorders, metabolism disorders significantly increases. The level of child population morbidity after Chernobyl catastrophe increases in 3.2 times. Respiratory diseases are involved in the first place in this structure.
\end{abstract}

KEY WORDS: children; morbidity; chernobyl catastrophe; disability

Wiad Lek 2019, 72, 10, 1974-1976

\section{INTRODUCTION}

April 26, 1986 occurred one of the largest ecological and social catastrophe of mankind - disaster on Chernobyl $\mathrm{Nu}-$ clear Power Plant (CNPP) [1,2]. This catastrophe not only caused numerous casualties but also significantly affected the quality of life of the Ukrainian population. Chernobyl catastrophe presents radiological catastrophe, which is characterized by high level of radioactive substances on population, especially on child one, residents of radioactive contaminated territories in Ukraine $[3,4]$.

The radioactively contaminated territories were home to 17.5 million people, including 2.5 million children under the age of 7 years old. In 1986-89, more than 600000 people participated in disaster relief work. The value of the collective effective dose of Ukraine's population is about 50000 man-Sieverts 10 years, except for thyroid doses. Collective dose of thyroid irradiation in twenty-one regions of Ukraine and Kiev - 1306000 man-Gray, of which 607000 man-Gray occur in children and adolescents. The number of healthy people during the period of the latest $30^{\text {th }}$ years decreases. Yu. H. Antipkin (academician of National academy of medical sciences) considered that nowadays problems of health of children, teenagers born from suffered people (participants of Chernobyl catastrophe, evacuated citizens) require great attention $[5,6]$. In the past thirty years, Ukrainian radiobiol- ogy and radiation medicine have strengthened. During this period real assessments of the consequences of the accident were made, conclusions and forecasts for the future.

\section{THE AIM}

The aim of the investigation is to study the condition of child population of regions of Ukraine, which were contaminated by radionuclides in the result of Chernobyl catastrophe.

\section{MATERIALS AND METHODS}

Data of the Center of medical statistics of Ministry of Public Health was used in the given investigation. These data determine the morbidity and infant mortality, and child disability that live in regions of territories of radioecological control (TRC) for the latest 23 years. Methods of statistic assessment and epidemiological analysis were used to analyze materials of the investigations.

\section{REVIEW AND DISCUSSION}

It has been demonstrated, that morbidity and spread of diseases among child population of Ukraine, level of infant 
Table I. Morbidity of residents (children) in regions with TRC and without TRC

\begin{tabular}{|c|c|c|c|c|c|c|c|}
\hline \multirow{2}{*}{ № } & \multirow{2}{*}{ Diseases } & \multicolumn{3}{|c|}{ Child Morbidity (on 1000) } & \multirow{2}{*}{$\begin{array}{c}\% \text { of } \\
\text { excess }\end{array}$} & \multirow{2}{*}{$\begin{array}{l}\text { S.G. in the } \\
\text { structure of } \\
\text { diseases (\%) }\end{array}$} & \multirow{2}{*}{ Degree } \\
\hline & & Ukraine & $\begin{array}{l}\text { Regions } \\
\text { with TRC }\end{array}$ & $\begin{array}{c}\text { Regions } \\
\text { without TRC }\end{array}$ & & & \\
\hline 1 & Respiratory diseases & 903,45 & 992,63 & 867,32 & $+14,45$ & 68,65 & 1 \\
\hline 2 & Skin diseases & 64,76 & 74,43 & 60,84 & $+22,33$ & 4,92 & II \\
\hline 3 & $\begin{array}{c}\text { Diseases of the digestive } \\
\text { system }\end{array}$ & 45,46 & 56,62 & 40,94 & $+38,3$ & 3,45 & IV \\
\hline 4 & Traumas and poisoning & 50,06 & 56,23 & 47,56 & $+18,23$ & 3,83 & III \\
\hline 5 & $\begin{array}{l}\text { Infectious and parasitic } \\
\text { diseases }\end{array}$ & 45,21 & 50,04 & 43,24 & $+15,73$ & 3,43 & V \\
\hline 6 & $\begin{array}{c}\text { Diseases of eye and adnexa } \\
\text { diseases }\end{array}$ & 41,79 & 47,97 & 39,29 & $+22,09$ & 3,17 & VI \\
\hline 7 & $\begin{array}{c}\text { Diseases of ear and mastoid } \\
\text { process }\end{array}$ & 38,09 & 41,91 & 36,54 & $+14,7$ & 2,89 & VII \\
\hline 8 & Musculoskeletal diseases & 26,03 & 30,12 & 24,38 & $+23,54$ & 1,97 & VIII \\
\hline 9 & Urinary diseases & 25,09 & 26,23 & 24,62 & $+6,56$ & 1,91 & IX \\
\hline 10 & Endocrine system diseases & 15,11 & 21,18 & 12,65 & $+67,4$ & 1,15 & $\mathrm{XI}$ \\
\hline 11 & Diseases of nervous system & 17,8 & 20,92 & 16,54 & $+26,5$ & 1,35 & $x$ \\
\hline 12 & $\begin{array}{c}\text { Diseases of blood and blood } \\
\text { forming organs }\end{array}$ & 12,94 & 17,84 & 10,96 & $+62,8$ & 0,98 & XII \\
\hline 13 & Diseases of blood circulation & 7,85 & 9,10 & 7,34 & $+24,03$ & 0,6 & XIII \\
\hline 14 & Congenital abnormalities & 5,63 & 5,35 & 5,74 & $-7,29$ & 0,42 & XIV \\
\hline 15 & Tumors & 3,41 & 4,208 & 3,08 & $+36,6$ & 0,26 & $\mathrm{XVI}$ \\
\hline 16 & $\begin{array}{c}\text { Mental disorders and behavior } \\
\text { disorders }\end{array}$ & 4,04 & 4,18 & 3,98 & $+5,02$ & 0,31 & $X V$ \\
\hline 17 & All diseases & 1316,07 & 1471,93 & 1252,94 & $+17,48$ & 100 & - \\
\hline
\end{tabular}

mortality in the latest decade significantly exceeds central European meaning of these indices, table I.

Considering the level of morbidity it should be noted that it did not exceed the meanings of morbidity in suffered children from unaffected ones during the first years after catastrophe (1987-1992). But, since 1993 the level of morbidity among children, residents in regions with TRC, begins to increase $[3,7,8]$. So, from 1987 to 2016 the level of child's morbidity, living in regions with TRC, increased in 3.2 times - from 455.4 to 1471.93 on 1000 children, and the level of morbidity rate - on $41 \%$ (from 1253.0 to 1777.16 on 1000 children). For the latest 23 years the difference of the morbidity rate among children, who live in regions of TRC and who do not live in such regions increased on $80.3 \%$.

Analyzing the indices of the level of morbidity of children in Ukraine, it should be noted that diseases of respiratory system occur the main group of all diseases. Compared with $90^{\text {th }}$ years, the level of hemopathy, blood forming organs diseases and tumors significantly increases (in 1.9 times), the level of diseases of endocrine system, digestive disorders, metabolism disorders increased in 1.8 times.

For the latest 23 years there is high level of tumors: the growth of such condition contained 169.9\%. Tumors formation and diseases of respiratory system among children continue increasing in all regions of Ukraine and also in regions with TRC, but high level of morbidity of congenital diseases and endocrine system diseases appeared in 1999, diseases of digestive system - 2006. The nearest prognosis of children who live in regions with TRC includes the further growth of morbidity level; especially respiratory diseases and tumors formation are involved in this process. At that time, since 2010 there is retardation of the level of endocrine system diseases, digestive disorders, skin diseases, diseases of blood and blood forming organs, mental disorders, and congenital abnormalities.

The number of children's disability increased in 1.8 times for the latest two decades in Ukraine. Therefore, in 1994, 130154 children with disability were under medical supervision (113.1 on 10000 children), and nowadays the number of children contains 156099 (205 on 10000 children). The highest frequency of children disability occurs in regions with TRC, where an index of disability contains 234.4 on 10000 children. At the same time, 23 years ago levels of children disability in regions with TRC and other regions did not differ from each other and contained 121.6 and 120.4 on 10000 children.

The level of infant mortality contained 7.4 on 1000 born alive in Ukraine in 2016. It contained 3-5\% in EC countries $[8,9]$. According to data of the Center of Medical Statistics of Ministry of Public Health of Ukraine indices of infant mortality in regions with TRC range from $7.9 \%$ to $9.2 \%$. 


\section{CONCLUSIONS}

1. The population of residents in regions with TRC is characterized by high level of general morbidity. The level of child population morbidity after Chernobyl catastrophe increases in 3.2 times.

2. The structure of child's' morbidity living in regions with TRC does not differ from general state. Respiratory diseases are involved in the first place in this structure.

3. Considering identified tendencies, there is prognosis of further increase of respiratory diseases and tumors in children living in TRC.

4. Regions with TRC are characterized by the increase of number of children's disability.

\section{REFERENCES}

1. Bazyka D. et al. Thirty Years of the Chernobyl Disaster: Radiological and Medical Implications: National Report of Ukraine. Kiev: DU “National Scientific Center of Radiation Medicine of the National Academy of Medical Sciences of Ukraine"; 2016: 177.

2. Vozianov 0., Bebeshko V., Bazyka D. Medical consequences of the accident at ChNPP. Kyiv: State Scientific Center"National Scientific Center of Radiation Medicine of the National Academy of Medical Sciences of Ukraine. 2007: 800.

3. Bobylyova 0 . et al. Health indicators and provision of medical care to the victims of the Chernobyl accident in 1998 (part 1). Kiev: NDVP "Tehmedecol".1999: 208.

4. Press release to the 20th anniversary of the Chernobyl disaster. Kiev: Press Center of the Ministry of Health of Ukraine. 25.04.2006. https:// www.google.com.ua. Accessed 26 June 2018.

5. Antypkin Yu. The state of children's health in the conditions of various environmental factors. The Art of Cure. 2005; 2: 1723.
6. Antypkin Yu. Chornobyl catastrophe and state of health of pregnant women and children. Journal of the Academy of Medical Sciences of Ukraine. 2011; 2: 152-155.

7. PivenN.etal.Diseaseofthechild population of themostradioactivecontaminated territories of Ukraine by diseases of the digestive system. Environment \& health. 2014;4:55-59.https://doi.org/.doi: 10.13140/RG2.1.1284.2488.

8. Shafranskyj V. Annual report on the state of health of the population, sanitary and epidemiological situation and activities of the health care system. 2015 year. Kiev: Ministry of Health of Ukraine. 2016; 452.

9. Golubchikov M., Rudenko N. Monitoring of the health status of children 0-17 years inclusive retrospective 2003-2010. Kiev: The handbook of the Ministry of Health of Ukraine. 2010: 48.

Funding from the state budget. Implementation of the initiative-search research work of the Department of Pediatrics No. 2 O.O. Bohomolets National Medical University "Optimization of diagnosis and treatment of allergic diseases in children with comorbid conditions" (2016-2019). Code of state registration 0116 U002416.

\section{Authors' contributions:}

According to the order of the Authorship.

\section{ORCID numbers:}

Oleksandr P. Volosovets - 0000-0001-7246-0768

Tetiana M. Volosovets - 0000-0001-9950-3748

Oleksandr E. Abaturov - 0000-0001-6291-5386

Tetyana O. Kryuchko - 0000-0002-5034-4181

\section{Conflict of interest}

The authors declare that they have no conflict of interest.

\section{CORRESPONDING AUTHOR Oleksandr E. Abaturov}

SI «Dnipropetrovsk Medical Academy of Health Ministry of Ukraine» Street V. Vernadskogo, 9, Dnipro, 49044, Dnipro, Ukraine tel: +380503404438

e-mail: alexandrabaturov56@gmail.com

Received: 05.04 .2019

Accepted: 19.09.2019 
PRACA POGLĄDOWA

REVIEW ARTICLE

\title{
EPIDEMIOLOGICAL SUPPORT FOR HIV / AIDS IN THE ARMED FORCES OF UKRAINE: PROBLEM QUESTIONS AND WAYS FOR DECISION-MAKING
}

\author{
Andriy M. Galushka', Olesya M. Ivanko², Irina V. Ogorodniyshyk², Mikolay Yu. Olym³ , Borys I. Palamar4, \\ Vyacheslav P. Pechyborshch ${ }^{2}$ \\ 'THE CHIEF MILITARY MEDICAL DIRECTORATE, KYIV, UKRAINE \\ 2UKRAINIAN MILITARY MEDICAL ACADEMY, KYIV, UKRAINE \\ ${ }^{3}$ CENTRAL SANITARY AND EPIDEMIOLOGICAL CONTROL, KYIV, UKRAINE \\ 4BOGOMOLETS NATIONAL MEDICAL UNIVERSITY, KYIV, UKRAINE
}

\begin{abstract}
The article assesses of the system of epidemiological surveillance of HIV / AIDS in the Armed Forces of Ukraine. It has been established that now the current system of epidemiological surveillance is imperfect. There is a risk of increasing the incidence of HIV infection in organized military groups. Existing gaps in the epidemiological surveillance system create problems in planning and implementing measures to prevent the emergence and spread of HIV among the military.
\end{abstract}

KEY WORDS: HIV / AIDS, Armed Forces of Ukraine, epidemiological surveillance

\section{INTRODUCTION}

Every year in Ukraine from two to three thousand newly discovered AIDS patients are diagnosed. The HIV / AIDS epidemic in Ukraine is growing, although in recent years there have been some signs of some stabilization $[1,2]$. It is also relevant to establish a valid HIV / AIDS incidence level in the security and defense forces, including the Armed Forces of Ukraine.

The country has mobilized a significant amount of national and foreign donor resources to support the implementation of national anti-infection programs. International support plays an important role in overcoming the epidemic in the country $[3,4,5]$.

Priority measures to overcome the HIV / AIDS epidemic in Ukraine, the state recognize the intensification of HIV / AIDS prevention; provision of treatment for HIV / AIDS patients who need it; respect for the rights of people living with HIV, and the formation of a tolerant attitude towards them in society $[2,6,7]$.

\section{THE AIM}

The purpose of the study - to analyze the effectiveness of HIV / AIDS epidemiological surveillance implemented in the Armed Forces of Ukraine (AF of Ukraine).

\section{MATERIALS AND METHODS}

Methods of investigation - bibliographical, epidemiological, immunochromatographic and statistical.
The epidemiological analysis was carried out on the basis of received daily data on the incidence among the personnel of the Armed Forces of Ukraine with the help of the informational and analytical system for recording infectious, occupational and socially dangerous morbidity of military personnel in the Armed Forces of Ukraine, introduced by the medical service of the Armed Forces of Ukraine. Data on the incidence rate among the civilian population of Ukraine are available on the website of the Center for Public Health. The immunochromatographic method was used for the rapid testing of military personnel of the Armed Forces of Ukraine.

\section{RESULTS AND DISCUSSION}

The incidence of HIV / AIDS in Ukraine has been gradually increasing since 1996.

The reduction period of morbidity (2014-2017) can be called "imaginary", which arose due to the exclusion from statistics of part of the population of Donetsk, Luhansk regions and the Autonomous Republic of Crimea, due to annexation by the Russian Federation of part of the territory of these areas that historically had a high level of morbidity.

The main method of HIV transmission in Ukraine, from 1995 to 2007, was the parenteral, mainly for the injection of narcotic substances.

Since 2007, the proportion of transmission pathways has changed - the proportion of parenteral transmission pathways has become below the sexual level. 


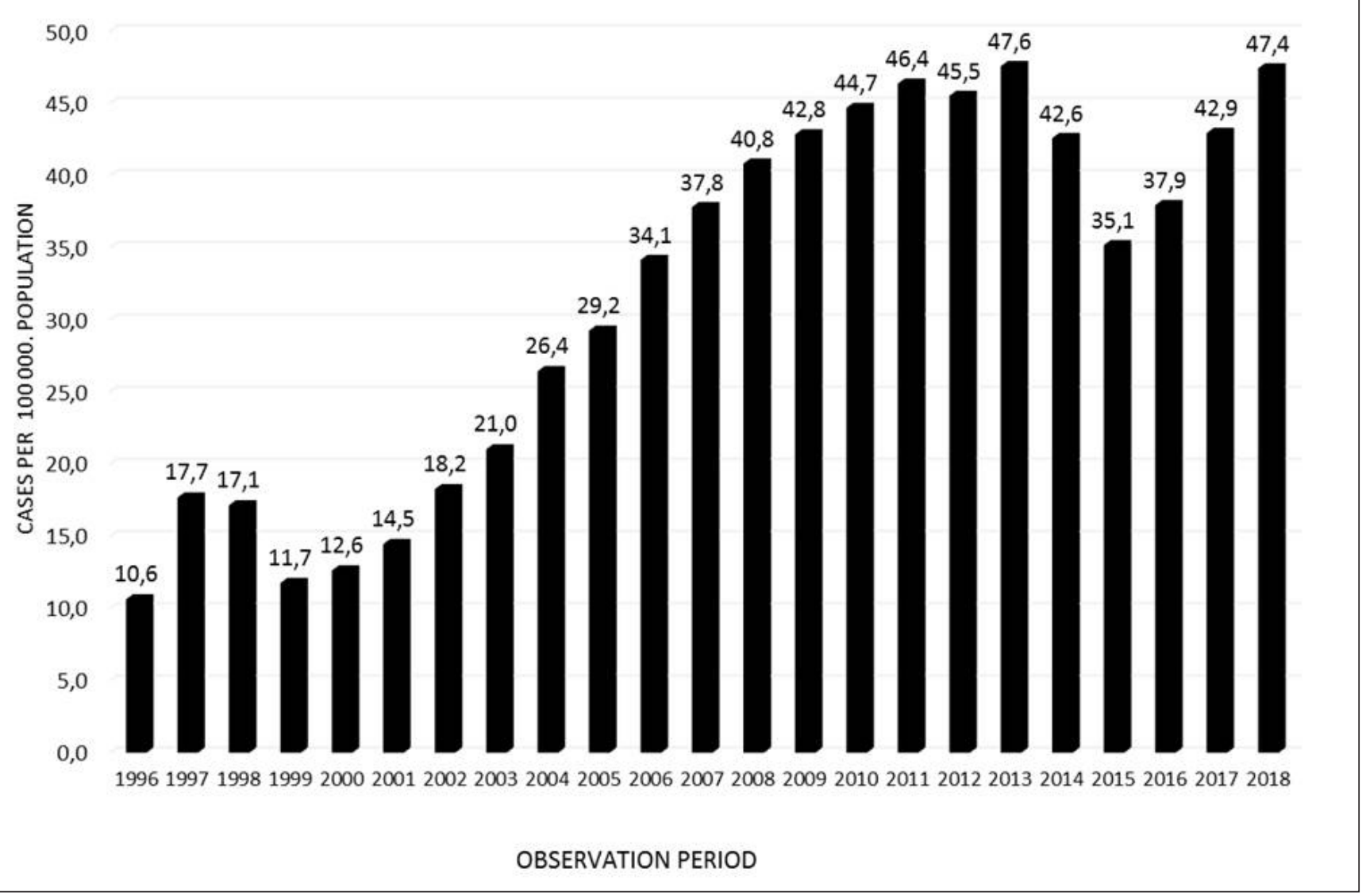

Fig. 1. HIV / AIDS incidence in Ukraine, 1996-2017.

Sexual behavior of HIV-positive persons remains dangerous [2,4]. It is obvious that sexually transmitted infections mainly occur among people of reproductive age, especially among young people.

It should be borne in mind that a significant part of young people are people who are in military service or work in law enforcement agencies, and they also face similar risks. Additional risk factors for servicemen and law enforcement officers include limited access to information and diagnosis, long periods of sexual retention (which may lead to reckless risky behavior), contacts with representatives of vulnerable groups of the population (primarily in law enforcement agencies) [8].

Now, the regulatory framework of the Ministry of Health of Ukraine ( $\mathrm{MoH}$ of Ukraine) requires the approval of methods and procedures for both counseling and testing, incl. the instructions on the organization of work of laboratories for diagnosis of HIV infection, methodical recommendations for the use of rapid tests for testing blood for antibodies to HIV, accounting and reporting documentation, etc.

In order to provide medical care to people with HIV in Ukraine, a network of specialized medical and prophylactic institutions - centers for the prevention and control of
AIDS which carry out dispensary supervision of HIV-infected and AIDS patients - diagnose the stage of the disease and determine the treatment tactics, was established.

Medical Service of the Armed Forces of Ukraine operate in a single system of monitoring, state registration and mutual information. To accomplish these tasks, a multi-level infrastructure has been created, which includes medical units of military institutions; voluntary counseling and testing rooms for HIV/AIDS in National Military Medical Clinical Center, Military Medical Clinical Centers (MMCC); establishments of the Preventive Medicine Service; Research Institute of Military Medical Problems. Information on the detection of the disease among the military personnel of the Armed Forces of Ukraine on HIV / AIDS according to the results of rapid tests is submitted to the Preventive Medicine Service of the Ministry of Defense of Ukraine daily (online). At the same time, it includes long-term studies to confirm the diagnosis at the AIDS Centers that are the basis for further action.

Approximately 15 thousand servicemen are tested annually for HIV/AIDS in the MMCC of the regions. In addition, voluntary counseling and testing (VCT) offices at the MMCC of the regions annually survey and volunteer counseling about 14 thousand servicemen and their fam- 


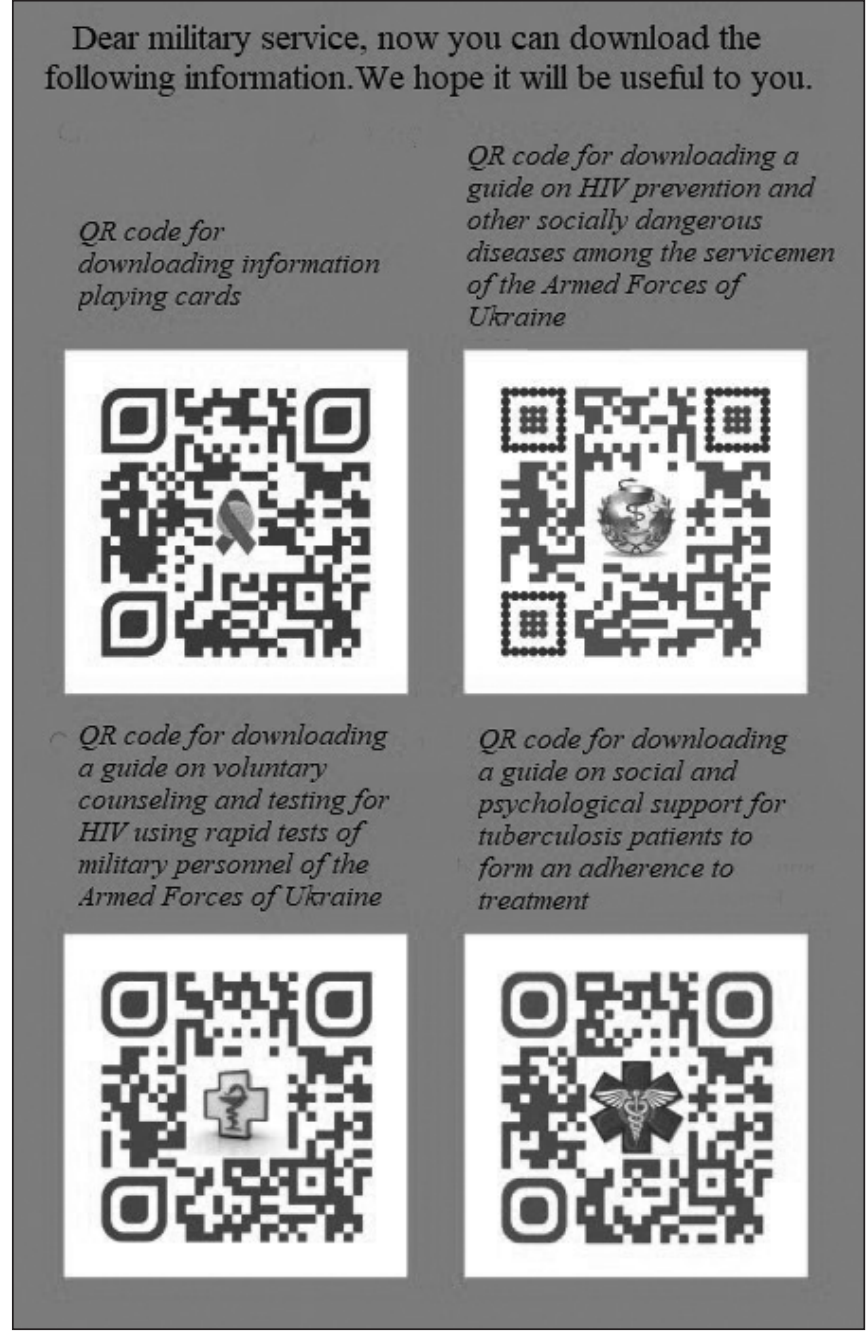

Fig. 2. Unified and personalized QR codes for sanitary and educational work

ily members. All military conscripts and contract service members carry out health and education work on HIV / AIDS prevention.

In order to improve the situation on counteracting HIV infection and other socially dangerous infectious diseases among military personnel of the Armed Forces of Ukraine a number of social prophylactic programs with the participation of charitable organizations $(\mathrm{CO})$ and International Charitable Foundations (ICF) were introduced. The aforementioned members include: ICF "Alliance for Public Health", All-Ukrainian Network of PLWH (People Living with HIV/AIDS), up-to-date name - "100\% LIFE" and International NGO "International Institute of HIV/ AIDS and Tuberculosis".

One of the steps to achieve this goal from 2017 to the middle of 2018 was to improve the quality and effectiveness of testing, counseling and improvement of knowledge of medical personnel at the Ministry of Defense of Ukraine (MD of Ukraine) in the implementation of program interventions using testing and counseling on HIV/AIDS.

So, for the purpose of early diagnosis of HIV/AIDS among the military men, 60000 units of immunohromatic one-stage tests (test-cards) for definition of antibodies to
HIV and 25000 various sanitary-educational typographic materials were provided for the health care institutions of the MD of Ukraine by the NGO "International Institute of HIV/AIDS and Tuberculosis", supported by the project DHAPP PEPFAR.

At the beginning of 2018, 100,000 units of men's contraceptive barrier type (condoms) were provided by the leadership of the ICF "Alliance for Public Health" for the Armed Forces servicemen who perform assigned tasks in the area of the Combined Forces Operation (CFO). In order to increase the commitment of the personnel of the Armed Forces of Ukraine to a healthy lifestyle and for the collective promotion of hygienic knowledge among the personnel of the Armed Forces of Ukraine, it was introduced a number of unified and personalized QR codes for easier access to sanitary and educational work (Figure 2). With the help of a smartphone, servicemen can scan the corresponding QR-code and immediately go to download (in PDF format) methodical recommendations, combat letters, manuals, samples of information gambling cards and other materials.

The main preventive measures implemented by the medical service of the Armed Forces of Ukraine on the prevention and reduction of the HIV/AIDS disease among military personnel are: organization of voluntary HIV counseling and testing with the help of express tests; diagnosis and treatment of sexually transmitted infections (STIs); carrying out testing of youth, which is called in the Armed Forces of Ukraine; a system of redirection to specialized specialists in cases where there is a need for highly specialized medical, legal or other consultations; observance of strict anti-epidemic regime in armed and medical establishments, etc.

At the same time, in collaboration with the international non-governmental organization "International Institute of Problems of HIV/AIDS and Tuberculosis", the Preventive Medicine Service of the Ministry of Defense of Ukraine and the State Institution "Center for Public Health of the Ministry of Health of Ukraine", 4 GeneXpert systems in the health facilities of the Ministry of Defense of Ukraine in 2018 were installed, due to which timely diagnostics of not only HIV/AIDS, but also tuberculosis is possible.

The timely identification of HIV status not only affects behavioral changes, but should be a guarantee of timely treatment. For this purpose, an HIV-positive person, after receiving VCT services, should go to the regional AIDS centers for medical treatment and receive medical assistance, including antiretroviral therapy (ART).

According to the results of the analysis, it was found that the increase in the incidence rate from 1996 to 1998 is related to the implementation of the Law of Ukraine "On donation of blood and its components" 240/95-BP from 23.06.95, according to which blood, its components and preparations and appropriate preservative solutions are subject to mandatory control, including HIV [9].

After a gradual decrease in 1998, the conscription for regular service and the reduction of planned blood donations in the Armed Forces of Ukraine (mainly servicemen in the regular service were donors) and the introduction 


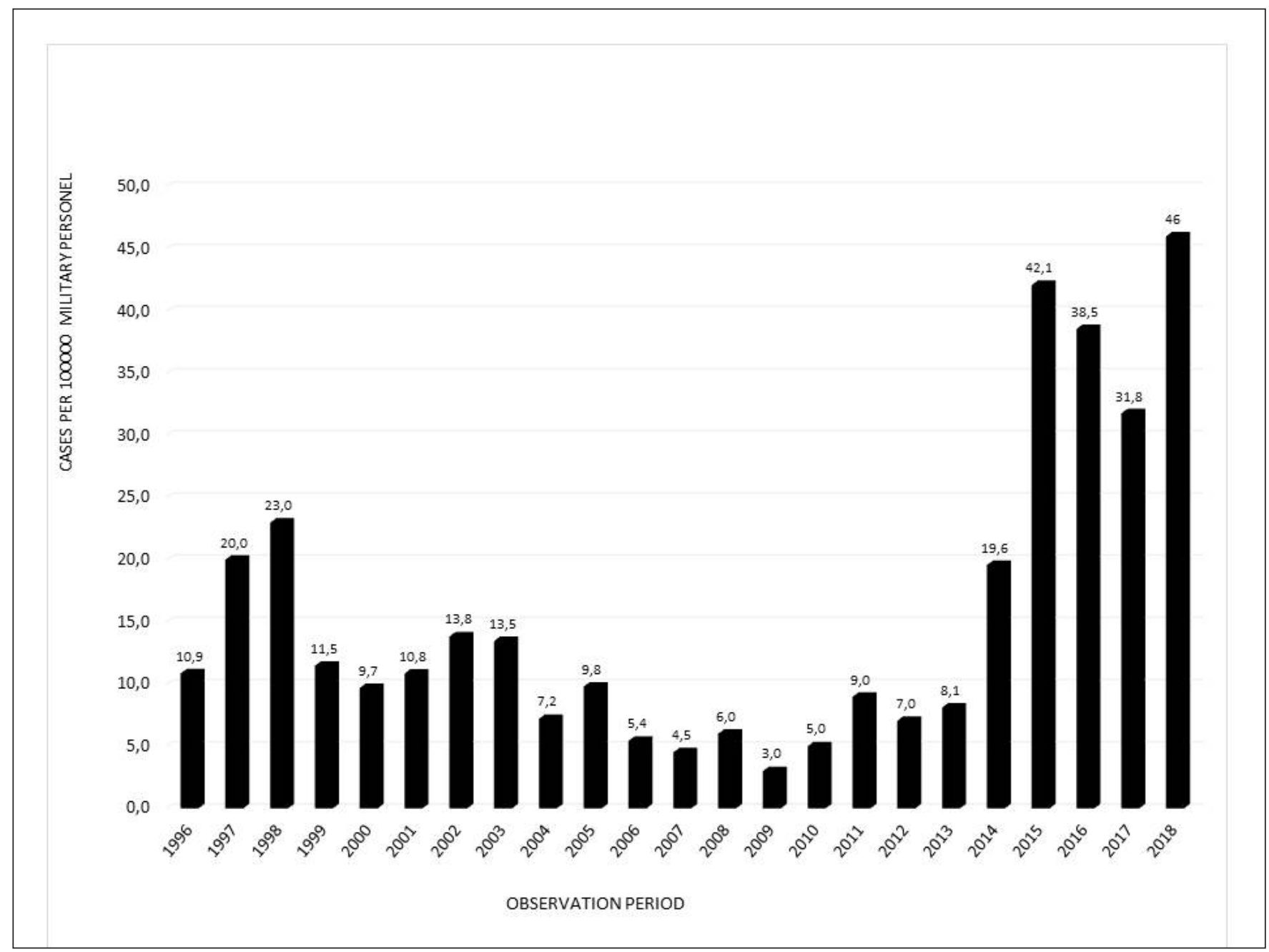

Fig. 3. HIV incidence among servicemen, 1996-2018.

of a "barrier to entry of an infection in the Armed Forces of Ukraine", namely the study of recruits and young adolescents candidates for military service with the help of express tests on the basis of regional military commissariats, the level of general morbidity decreased, and its structural state (morbidity by type of service) has changed (Fig. 3, 4).

In 2008, rapid-fire HIV screening was introduced for recruits, which ensured the identification of infected persons before joining the Armed Forces of Ukraine and HIV-positive persons were not admitted to military service.

The situation has changed dramatically at the beginning of the ATO. In 2014, the mobilization of the population began, with waves of which the Ukrainian Armed Forces received a number of people, which according to the current legislation did not pass HIV testing in the civilian medical institutions and during mobilization in the Armed Forces of Ukraine.

Approximately $50 \%$ of these people signed the contract and remained to serve without passing the test and continuing to affect the level of morbidity, which led to an increase in the incidence of HIV among contract servicemen to 91,59\% (Fig. 4).

The ways of identifying HIV/AIDS in the Armed Forces of Ukraine are as follows: in accordance with the "Regula- tion on Military Medical Examination in the Armed Forces of Ukraine", serological analysis of blood for antibodies to the human immunodeficiency virus (HIV) is carried out at conscripts (pre-conscripts), citizens who wish to study at the Higher Military Institutions (HMI), persons who are enlisted for military service under the contract, reservists, citizens who are recruited for military service for prize-winning officers, soldiers of the Armed Forces of Ukraine in the event of a medical examination [10].

In addition, soldiers of the Armed Forces of Ukraine, after obtaining written consent, conduct voluntary counseling and testing for HIV in accordance with the Order of the Ministry of Health of Ukraine dated August 19, 2005 No. 415 "On Improving Voluntary Counseling and Testing for HIV" [11].

Testing for HIV during mobilization is not carried out.

When HIV/AIDS diagnosis is established, there is the following algorithm for further service (Fig. 5, 6).

According to the Regulations on military medical examination in the Armed Forces of Ukraine, HIV-infected servicemen of temporary service in peacetime are considered unfit for military service and are to be released to the reserve and are limited in time for use in war. Contract 


\section{6 - 1999}

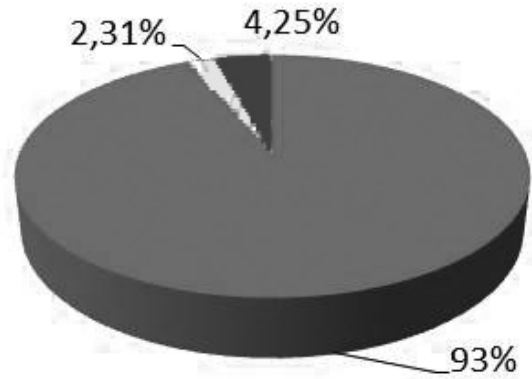

2004 - 2007

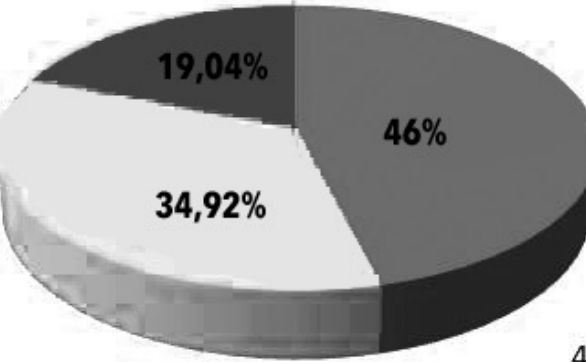

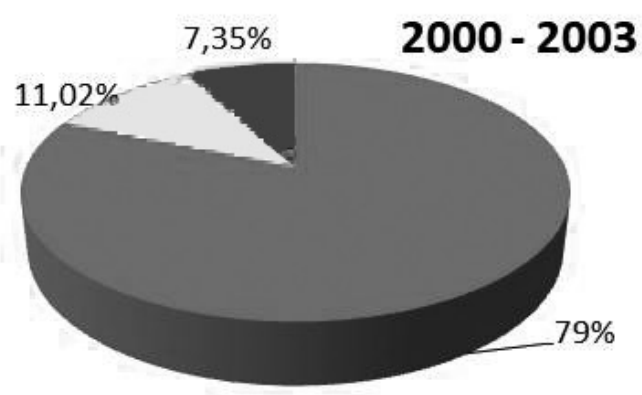

2008 - 2013

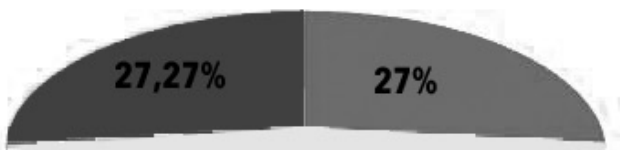

$46,97 \%$

\section{4 - 2017}

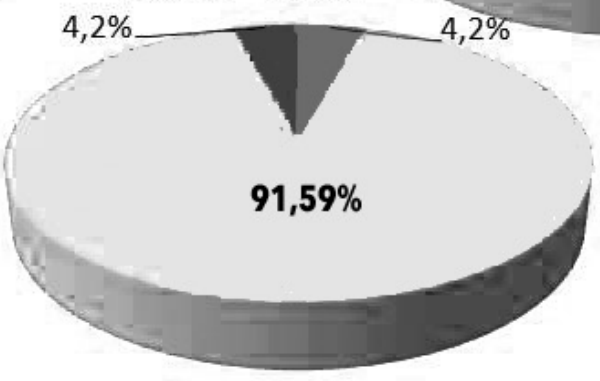

conscripts

14 contract servicemen

officers

Fig. 4. Structure of HIV-infected servicemen of the Armed Forces of Ukraine,\%.

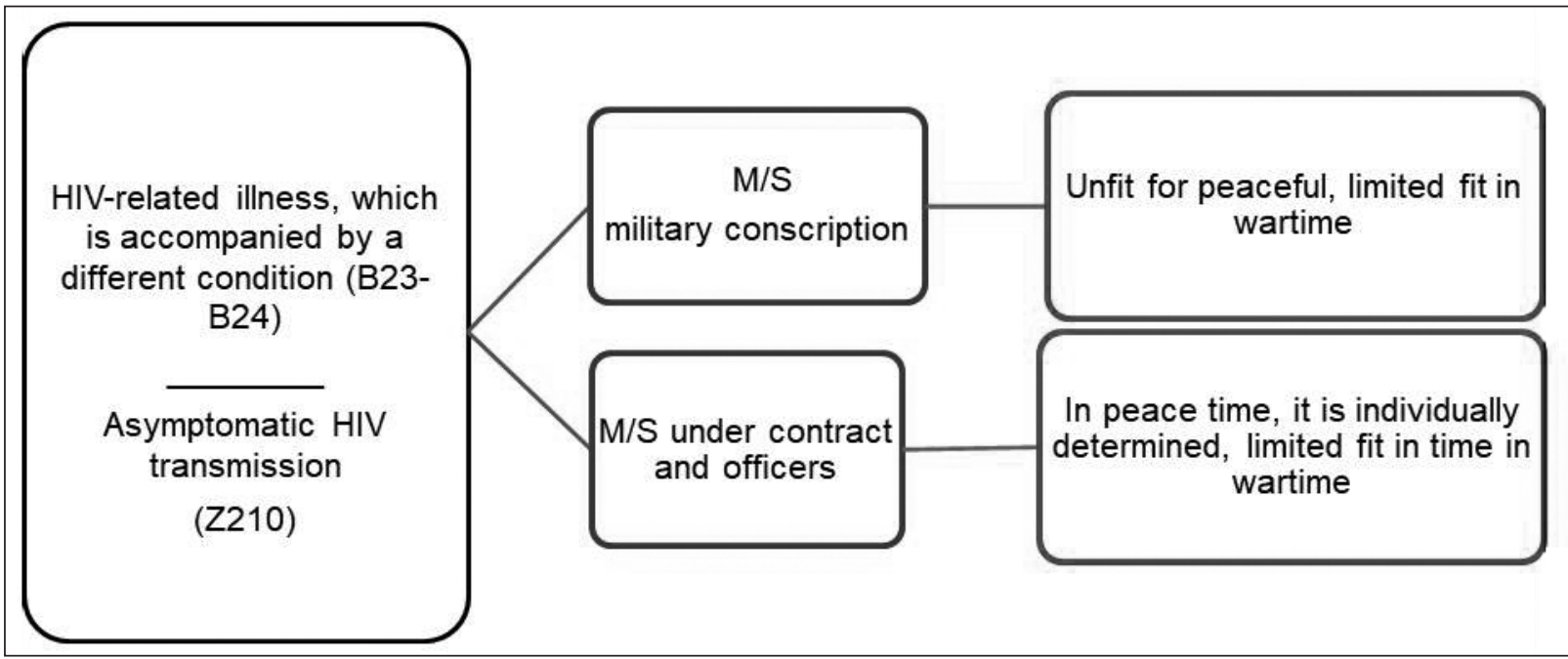

Fig. 5. The algorithm of action for further military service while person has been HIV diagnosed.

servicemen and officers can not be released from military service only on the basis of HIV infection in the asymptomatic stage of the disease. The prospect of passing a further service is solved individually on the conclusion of the Military Medical Commission [10].
In the case of a finding of HIV-positive result in a serviceman of emergency service (with blood donation, serological examination, hospitalization in military medical institutions), data about him are transferred to the territorial centers of AIDS prevention and treatment at the place of residence; the 


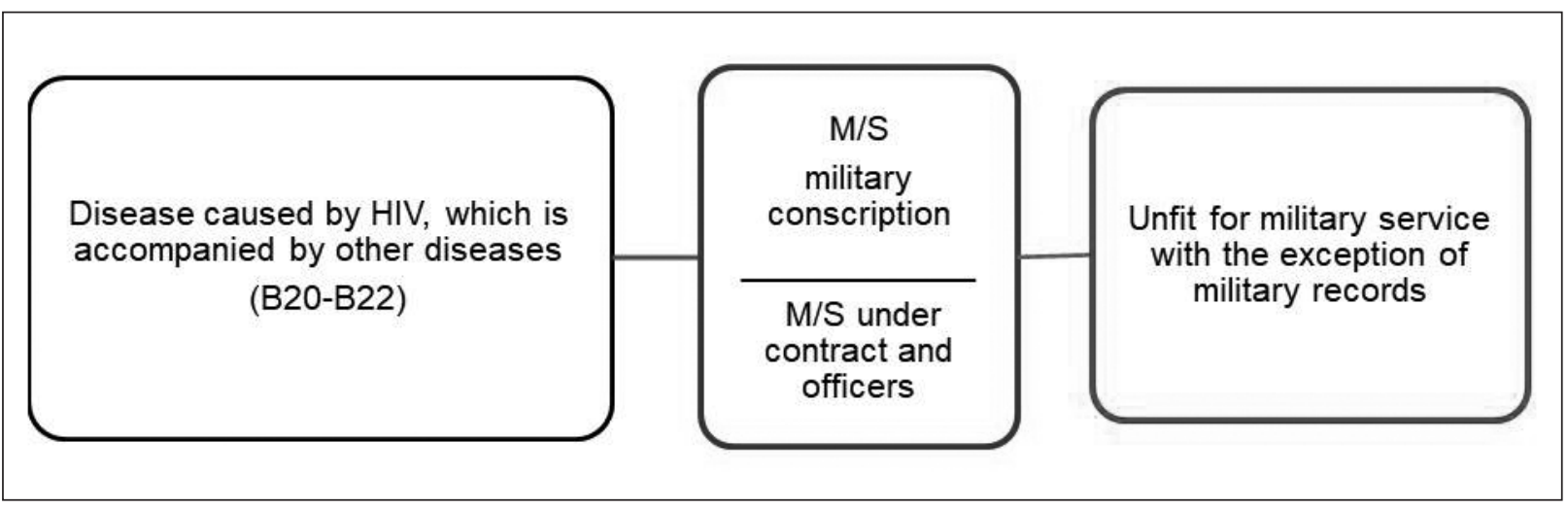

Fig. 6. The algorithm of action for further military service while person has been HIV/AIDS diagnosed

serviceman is sent to the Military Medical Commission for determining eligibility for military service, is deemed unfit under Article 5 of the Schedule of illnesses, conditions and physical defects that determine the degree of fitness for military service and is released from the armed forces of Ukraine. Further treatment is taking place in the health care facilities of the Ministry of Health of Ukraine. In this case, it is difficult to talk about the preservation of medical secrets due to the specifics of military service. The HIV-positive result is known to the command, although Art. 13 of the Law of Ukraine dated 12.12.1991 No. 1972-XII "On the response to the spread of diseases caused by the human immunodeficiency virus (HIV), and the legal and social protection of people living with HIV", stipulates the right of people living with HIV to information and provides protection of information about the positive HIV-status of a person from disclosure to third parties [12].

An analysis of the international experience of the NATO medical service has shown that, for example, mandatory testing in the United States was introduced in 1985, and is now being conducted once every two years, with newly discovered HIV-infected armed forces not being released and undergoing treatment in military hospitals. If the HIV test turned out to be positive when entering military service, this is the reason for the refusal.

In many countries (according to UNAIDS), the military command is under severe pressure to introduce or maintain mandatory HIV testing before the military conscription, before deploying parts abroad, or at certain intervals. At the same time, for a number of reasons, such an approach is being criticized by various civic organizations. The arguments are made that compulsory testing violates human rights and it is impossible to justify special requirements in force that the testing is economically unjustified, that the positive results of the test in people without asymptomatic stage of the disease do not affect their right to work or "suitability for work" etc. Another argument is that voluntary testing programs that are widely supported and fully funded can be, if not more, no less effective than mandatory testing $[13,14]$.

\section{CONCLUSIONS}

1. The system of epidemiological surveillance of HIV in the Armed Forces of Ukraine needs improvement in its adaptation to modern requirements. Existing gaps in the system of epidemiological surveillance create problems in the planning and implementation of measures to prevent the emergence and spread of HIV infection in the Armed Forces of Ukraine.

2. Since the beginning of 2014, the incidence of HIV infection in the Armed Forces of Ukraine has increased due to the entry of HIV-infected mobilized servicemen without proper research.

3. Amendments to the existing legislation through the introduction of annual routine testing in the Armed Forces of Ukraine, which will allow to establish a real level of incidence of HIV infection.

4. It is proposed to introduce a mutual information and integrated reporting system between the $\mathrm{MoH}$ of Ukraine and the medical service of the Armed Forces of Ukraine.

\section{REFERENCES}

1. HIV in Ukraine: Newsletter № 47. Ministry of Health of Ukraine. K.: 2017.

2. HIV infection in Ukraine. Newsletter. № 46. - State Institution “Ukrainian Center for Control over Socially Dangerous Diseases of the Ministry of Health of Ukraine", State Institution "L.V. Gromashevsky Institute of Epidemiology and Infectious Diseases of the National Academy of Medical Sciences of Ukraine". K.: 2016.

3. Luchynska OV. Ways to Improve State-Public Interaction in HIV / AIDS in Ukraine. Investments: Practice and Experience. 2017; 17: 124-131.

4. Strengthening of the adolescent component within the national HIV / AIDS program: advocacy report / ed. O.M. Balakireva; UNICEF, Ukr. inst. soc. research. named after 0. Yaremenko. Kyiv: 2017; 88.

5. Bilak - Lukyanchuk VI, Ratanina OM. Review of International and National HIV / AIDS Laws and Policies. Economics and Law of Health. 2017: 2 (6). p.20-27.

6. Law of Ukraine from December 12, 1991 No. 1972-XII"On Prevention of Acquired Immune Deficiency Syndrome (AIDS) and Social Protection of the Population". Bulletin of the Verkhovna Rada of Ukraine. March 17, 1992 - 1992::11, Article 152.

7. Datsyuk VV. State Policy on Combating HIV / AIDS: Ways to Eliminate Discrimination // NADU Bulletin to the President of Ukraine. 2016:p.121-126.

8. Pogorila NB, Sasko OV, Pashkovich VL. Monitoring the behavior of servicemen as a component of second-generation HIV surveillance . Kyiv: ICF International HIV / AIDS Alliance in Ukraine, 2005. 28 p. 
9. The Law of Ukraine "On Donation of Blood and its Components" from 23.06.95. No. 240/95-VR. Bulletin of the Verkhovna Rada of Ukraine from 06.06.1995 - 1995:: 23, Article 183.

10. Order of the Minister of Defense of Ukraine 14.08.2008 № 402 On Approval of the Regulation on Military Medical Expertise in the Armed Forces of Ukraine, Official Gazette of Ukraine, 01.12.2008 - 2008.: 89, p. 76, Article 2996, Act Code 44979/2008.

11. Ministry of Health of Ukraine Order No. 415 from 19.08.2005 "On Improvement of Voluntary Counseling and Testing for HIV". Official Bulletin of Ukraine of 14.12.2005 - 200: 48, p. 112, Article 3018, Act Code 34422/2005.

12. Law of Ukraine from December 12, 1991: 1972-XII “On combating the spread of diseases caused by the human immunodeficiency virus (HIV) and the legal and social protection of people living with HIV". Verkhovna Rada of Ukraine (BB), 1992:11, Art.

13. AIDS and UNAIDS servicemen. Point of view. UNAIDS Best Practice Examples [Electronic resource] - Access mode: https: //www.unaids. org/sites/default/files/media_asset/militarypv_en_0.pdf.-Title.from the screen. - The language grew.

14. Simperovich SV, Kashchenko RA, Borysova S.L, Stukan LI. On the Problem of Mandatory HIV Testing of Conscripts and Servicemen of the Armed Forces of the Ukrainian Armed Forces. Military Health Issues. 2012:33. p.219-225.

\section{Authors' contributions:}

According to the order of the Authorship.

\section{ORCID numbers:}

Olesya M. Ivanko - 0000-0002-5929-255X

Irina V. Ogorodniyshyk - 0000-0003-1063-1829

Mikolay Yu. Olym - 0000-0001-8772-0032

Borys I. Palamar - 0000-0003-2510-0713

Vyacheslav P. Pechyborshch - 0000-0003-4598-9644

\section{Conflict of interest:}

The Authors declare no conflict of interest.

\section{CORRESPONDING AUTHOR Borys I. Palamar \\ Department of Social Medicine and Public Health, Bogomolets National Medical University 13, Taras Shevchenko Blvd, 01601, Kyiv, Ukraine tel: +380672387654 \\ e-mail:palamar.bi@ukr.net}

Received: 17.04.2019

Accepted: 23.09.2019 
PRACA POGLACDOWA

REVIEW ARTICLE

\title{
SEXUAL PROBLEMS IN THE PATIENTS WITH PSYCHIATRIC DISORDERS
}

\author{
Alicja Piontek, Jakub Szeja, Michał Błachut, Karina Badura-Brzoza \\ DEPARTMENT OF PSYCHIATRY IN TARNOWSKIE GÓRY, SCHOOL OF MEDICINE WITH THE DIVISION OF DENTISTRY IN ZABRZE, \\ MEDICAL UNIVERSITY OF SILESIA IN KATOWICE, TARNOWSKIE GÓRY, POLAND
}

\begin{abstract}
Sexual disorders are very common problems in the psychiatric patients. Many factors induce sexual dysfunction, e.g. the effects of antidepressants and antipsychotics. The article reviews literature on sexual disorders in psychiatric diseases such as schizophrenia, bipolar disorder, depressive, anxiety, obsessive-compulsive disorders and eating disorders. Bipolar disorder significantly affects the quality of life and increases the risk of sexual dysfunction. In the manic phase there is an increase in libido, which is associated with the risky sexual behavior. Depressive disorders are associated with reduced libido and dissatisfaction with sexual activity. Panic disorder and obsessive-compulsive disorder are correlated with less frequent sexual contact. Decreased sexual desire and sexual aversion are strongly associated with anxiety disorders. The prevalence of sexual dysfunction in patients with schizophrenia is high among both those treated and untreated. Women suffering from schizophrenia have anorgasmia, decreased libido, vaginal dryness, vaginism, and dyspareunia. Men suffering from schizophrenia as the main complaints give lowering the drive of difficulty in maintaining an erection, delaying orgasm. In patients with eating disorders, libido decreases as well as sexual activity and the level of sexual satisfaction decreases. Satisfaction with sexual life is an important factor affecting the quality of life. Patients rarely deal with problems in sexual life, so questions about this area of life should not be overlooked during a medical interview.
\end{abstract}

KEY WORDS: sexual dysfunction, mental disorders

Wiad Lek 2019, 72, 10, 1984-1988

\section{INTRODUCTION}

Sexual dysfunction (SD) is defined as a persistent impaired sexual function in any of the stages of the sexual response cycle thought to include desire, arousal, orgasm, and resolution [1].

Sexual disorders are very common problems in patients at psychiatric wards. There are many factors which influence negatively sexual function e.g. the side effects of the drug treatment such as antipsychotics and antidepressants, problems with forming relationships, direct effects of psychosis, abnormalities in the limbic system or hyperprolactinemia[2]. There is also many other somatic comorbities which affects negatively sexual functions such as diabetes, atherosclerosis, cardiac diseases, neurological conditions. Sexual problems are rarely reported by the patients who underestimate sexual dysfunctions. Most of them think that disorder is embarrasing. There are differences in sexual dysfunctions between men and women. Men often have problems in the second phase of the sexual cycle. Erectile dysfunction is highly prevalent. Study by K. Mosaku i D. Ukpong has shown that prevalence of the erectile dysfunctions is $86.5 \%$ of the patients treated in psychiatric ward [3]. Female frequently have difficulties with arousal which signigicantly influence well-being and quality of life. Only one-third of women with SD is looking for help [4]. The article reviews literature examining various aspects of sexual disorders in some of the psychiatric ill- nesses like schizophrenia, bipolar affective disorder, major depressive disorder, obsessive - compulsive disorder and eating disorders.

\section{BIPOLAR AFFECTIVE DISORDER}

There is association between bipolar disorder, quality of life, sexual satisfaction and sexual function[5]. Bipolar disorder is a disease with two phases: in a manic or hypomanic phase there is an elevation in libido, increased sexual thoughts, risk taking sexual behavior, unsuitable relationships. In the research by Kopeykina I. i Kim HJ [6] where sexual dysfunctions, sexual distress, general sexual satisfaction and Qol were investigated in a cohort of a 61 women with bipolar disorder. $25 \%$ had a sexual dysfunction, $50 \%$ of the group was sexually distressed and one-third was unsatisfied with their sexual life. hypersexuality was found in more than $50 \%$ patients in a manic phase and was higher in female patients. While mixed and depressive attacks sexual drive was decrease in a $60 \%$ and $30 \%$ of patients[6]. In the other study by Z. Namli [7] where patients with bipolar disorder were compared with healthy control group it was found that half of the patients group has sexual dysfunctions. It was statistically higher than in the control group. It was no difference between gender in this study.

In the case report by MR Heare et al.[8], gender dysphoria has been described in combination with hypersexuality 
throughout manic episodes. Patients desired to be another gender. This disorder has been temporary and dissapeared after treatment with walproic acid.

The research by Dell'Osso et al.[9] has shown that sexual dysfunctions are related with suicidality. In addition to desire, arousal nad achieving orgasm patients with bipolar disorder have problems o risky sexual behaviors, frequent changing partners compare to unipolar disorder. All of this dysfunctions may increase thoughts of death, suicide plans and attemps.

Depression is related with reduced sexual function and sexual dissatisfaction in the group of patients who take antidepressants but also in the untreated patients.

A Brithish study by D.S. Baldwin et al. [10] of 6669 women shows that depression increase risk of sexual dysfunction. Anhedonia has been specifically connected with low of desire.

There is a bidirectional relation with depression and sexual dysfunction. Patients with depression should be screened for sexual dysfuntion and oppositely. It is important to asess these symptoms before treatment with antidepressant drugs which are associated with development or aggravation of sexual disorders in a substantial proportion od patients [11].Selective serotonin reuptake inhibitors and serotonin-norepinephrine reuptake inhibitors influence sexual function because affect adrenergic and dopamine receptors, elevate level of prolactine and decrease nitrous oxide which is needed for erection[12].

Sexual dysfunctions which are induced by antidepressants are worsening quality of life, self-confidence, temper in the $20 \%$ of patients. Sexual dysfunctions induced by antidepressant treatment are a reason of abandoning therapy by patients.

While $26 \%$ of people without depression have some sexual dysfunction, this number increases to $45 \%$ in the group of patients with untreated depression and $63 \%$ in the patients treated pharmacologically[12].

In a research by Montejo- Gonzales et al.[13] decreased libido was reported in $40,5 \%$ to $57.6 \%$ of patients, delayed orgasm or ejaculation in $45,6 \%$ to $58,8 \%$, anorgasmia or no ejaculation in $30 . \%$ to $48.2 \%$ of patients and impotence in $9,5 \%$ to $34,1 \%$. Sexual dysfuntions was the most associated with paroxetine and least common in the group treated by fluvoxamine. In the patients treated by citalopram 54\% of patients has decreased libido, $36 \%$ had a problem with achieving orgasm. Erectile dysfunction has been found in $37 \%$ of patients. Women have problems with decreased libido, delayed orgasm and anorgasmia.

There is a lot of strategies of treatment sexual dysfunctions induced by antidepressants: waiting and observations of the symptoms, changing the time when patient takes antidepressants, drug holiday (skipping two doses in the weekend) or decreasing the dose. Some studies show improvement during augmention with mirtazapine and bupropion. In the randomized placebo- controlled studies of phosphodiesterase (PDE) inhibitors it was an improvement in antidepressant-induced sexual dysfunctions in both genders [13].

\section{ANXIETY DISORDERS}

A significant co-morbidity of anxiety and sexual problems was presented in the study by Agnes van Minnen and M. Kampan[14]. It was found that panic disorder and obsessive compulsive disorder is correlated with lower frequency of sexual contact. Also, hypoactive sexual desire disorder and a sexual aversion disorder are strongly connected to anxiety disorders. It seems that OCD patients were affected more by sexual problems than panic disorder patients. One of conclusions may be that the female anxiety patients suffer mainly from sexual desire abnormalities. Another sexual response cycle elements such as excitement and orgasm remain unaffected, however this is not applicable to male anxiety patients. Men tend to suffer from either problems with sexual desire, frequency of sexual contact, excitement and orgasm. It is possible that excitement and orgasm disorders of men may be connected with the sexual desire problems of their female partners. Research indicates that disorders in anxiety patients are different for men and women.

In the study by Fiqueira et al [15] patients with panic disorder had more sexual disorders than patients with social phobia $75 \%$ vs $33,3 \%$. The most common disorder was sexual aversion in the patients with panic disorder and premature ejaculation in male patients with social phobia.

A high prevalence of sexual dysfunction has been reported in women with anxiety disorders[16].

Rajkumar and Kumaran [17] described the occurrence of anxiety disorders in 64 men with premature ejaculation and erectile dysfunction. $12.5 \%$ of men also suffered from depressive disorders, $23.4 \%$ were treated for anxiety disorders. The most common syndrome was a generalized anxiety disorder.

\section{SCHIZOPHRENIA}

The prevalence of sexual dysfunction in schizophrenic patients is high, both treated and untreated and amounts to $30-60 \%$ of women and $45-80 \%$ in men [18]. However, Chojnowski et al.[19] in their review inform that only about $10 \%$ of patients spontaneously report sexual dysfunctions.

The most characteristic for people with schizophrenia are loss and decrease of sexual desire, sexual deviations and erectile and ejaculation dysfuctions. Case reports of patients with schizophrenia suggest that patients may experience symptoms of sexual nature, erotomanic delusions, delusions related to sexual identity, the sexual act, or pregnancy. In acute psychoses, hypersexuality may be present. It can manifest itself as a pathological masturbation [20,21].

Kokoszka et all [22] performed a research on 56 patients of day-care psychiatric wards suffering from schizophrenia ( 25 women and 31 men). The aim of the study was to assess their subjective feelings about sexual function. Women with schizophrenia reported anorgasmia (76\%), decreased libido (68\%), diminished lubrication (56\%), vaginitis (44\%) and dyspareunia (32\%). Often, in comparison to the healthy population, excessive sexual desire was observed in 32\% of women. Men suffering from 
schizophrenia report reduced libido (71\%), difficulty in maintaining an erection (54.8\%), delayed orgasm (43.3\%). They also reported excessive sexual desire and premature ejaculation, but the results were similar to those in the healthy population $[22,23]$.

Assesing sexual dysfunctions in patients with schizophrenia it should be noted that social functioning and personal relationships play important role, which is often disturbed by symptoms of the disease. In the review, Kasperek-Zimowska [20] emphasizes that sexual contacts of mentally ill women are more frequent than healthy ones, but the contacts are mainly initiated by men, and the satisfaction of these contacts is usually lower. More often, they were also victims of sexual abuse. Ma et all [24] report that women over 50 years more often report sexual dysfunctions and attach less importance to the quality of sex life. While men suffering from schizophrenia have more problems with the maintenance of interpersonal relationships than women, and less likely to initiate contact with them $[20-22,25]$.

Another reason causing sexual dysfunction in patients with schizophrenia is the use of antipsychotics. Adverse symptoms of treatment are one of the main reasons for patients discontinuing drug therapy [22]. Üçok et al.[26] studied sexual dysfunction in people with schizophrenia treated with neuroleptics. Among 827 patients, $52.6 \%$ had sexual dysfunctions, $54.2 \%$ had low-level sexual needs and $41.7 \%$ had problems with orgasm. The study also showed that erectile dysfunction occurred in $48.1 \%$ and ejaculation disorders occurred in $64.2 \%$ of men. However, the lack of menstruation was noticed in $24.9 \%$ of women. Dossenbach [27], in his study on a group of 3,828 patients with schizophrenia, notes that sexual dysfunction occurred sequentially in $71.1 \%$ of patients treated with haloperidol, $67.8 \%$ treated with risperidone, $60.2 \%$ treated with quetiapine and $55.7 \%$ treated with olanzapine. Similar results were obtained in the Kelly and Conley [28] study, sexual dysfunctions in $78 \%$ of patients taking fluphenazine, $50 \%$ in quetiapine, while only $42 \%$ of patients treated with risperidone reported sexual dysfunction. Baggley in his analysis of the effects of neuroleptics on sexual dysfunctions describes that they are most often when using risperidone. Haloperidol and quetiapine have a smaller effect, and the smallest aripiprazole [29].

The literature [30] shows that long-term neruroleptic drug use causes dopamine synthesis disorders, which is the main hormone inhibiting the synthesis of prolactin. It has been noted that the increase in prolactin in men causes a decrease in the level of testosterone in the blood, which indirectly affects the decrease in libido. The physiologically highest level of prolactin is achieved during orgasm. At that moment, the partner's interest is gradually decreased. Similarly, drug-induced hyperprolactinemia may inhibit the sexual desire [31].

A study by the Johnsen et all [31], among men using second generation antipsychotic medications, nearly half of the patients reported a reduction of sexual desire, and nearly $36 \%$ reported erectic and ejaculatory dysfunction.
In this study, the highest prolactin levels were tested in patients using risperidone, followed by olanzapine, ziprasidone, quetiapine, and the lowest after aripiprazole. Nakonezny et al. [32] did not notice any significant influence of quetiapine on sexual disorders [11].

In their review, de Boer et al. [21] showed that orgasm dysfunction in people using antipsychotic drugs is higher in patients using risperidone - $49 \%$ than aripiprazole (from $3 \%$ to $4 \%)$. Patients using clozapine improved the quality of orgasm to patients using classic neuroleptics.

Erectile dysfunction occurs most frequently during treatment with risperidone - 39\%, but aripiprazole occurred in $0-7 \%$ of patients. Diminished vaginal lubrication in women is comparatively frequently reported as erectile dysfunction in men treated with the same antipsychotics.

The reduced ejaculate volume is a problem in $8-58 \%$ of patients treated with neuroleptics. It is more common after risperidone and the most rare is aripiprazole. Ejaculation disorders can also be caused by chlorpromazine and thioridazine. There are studies that show that the effect of drugs on $\alpha$-adrenergic recetors can affect the amount of ejaculate. A similar mechanism may be responsible for priapism, which is described in only a few cases (such cases are noted after the use of haloperidol, clozapine, risperidone, olanzapine, aripiprazole and quiapine) [20] [21][29][33].

Increase weigh and sedation are side effects of treatment that can lead to reduced sexual interest. Extrapyramidal symptoms during treatment may reduce the precision of movement during sexual activity [22].

\section{OBSESSION COMPULSIVE DISORDERS}

There is an increase in the number of people with this pathology of our modern clinical practice of psychiatric disorders, which is associated with lower age in the field of interpersonal, communication and sex [34]. In Ghassemzadeh's work [35] in a group of 56 people diagnosed with OCD, $80.6 \%$ of women and $25 \%$ of men complained about sexual dysfunction. In turn, in a Kendurkar and Kaur review [36] on a group of 50 people with OCD, half of them reported sexual dysfunction (53.6\% women and $45.4 \%$ men).

The biggest problem was orgasm dysfunction and was higher than in the healthy population. Apart from problems with orgasm, men complain about lack of erection (35.5\%), lack of feeling of desire $(45.2 \%)$ and interest (32.2\%). This group of patients often experience sexual abuse [37].

On the other hand, in women in $42.1 \%$ diminished vaginal lubrication occurs, which happens twice as often as in a healthy group. Anorgasmia is more common than in the healthy population. Compared to men, women often complain of reduced partner interest and desire (respectively $57.9 \%$ and $68.4 \%$ ). As a result, they avoid sexual contact more often [38]

In the Aksaraya study [39] comparing sexual dysfunction among women with OCD and GAD, it was found that women with OCD are more sexually neutral and avoid sexual contact and complain about lack of orgasm compared to women with GAD. 


\section{EATING DISORDERS}

Eating disorders at an early age can cause delayed psychosexual development. This results in deficiencies in sexual activity in adulthood $[40,41]$. Excessive starvation causes in the human brain reduction of sexual desire. In patients with eating disorders, the libido decreases as well as the reduction of sexual activity and unsatisfaction are more frequent [42]. In Kluck et al [43], on 167 women with eating disorders, it was found that women who had a problem related to sexual behavior and discomfort experienced during sexual stimulation had an increase in eating disorders [44].

In women suffering from anorexia nervosa, sexual life correlates with their negative attitude to the image of their own body. In a large number of patients, sexual activity is inhibited until optimal weight is restored. Patients suffering from bulimia have self-mutilating sexual behavior. It is connected with a feeling of anger and aversion to one's own body caused by bad perception of it. In these patients, as compared to patients with anorexia, sexual activity is greater. In some studies, there were no differences in sex disorders between bulimia patients and healthy patients. [40, 42, 43]

Sexual dysfunction in patients with binge eating disorders is greater than in patients without these disorders. This is caused by the continuous control of nutrition, impulsiveness and evaluation of their body [45]. Also, depression, which occurs with eating disorders, is responsible for sexual dysfunctions in patients $[40,43]$.

\section{SUMMARY}

To resume, sexuality is an important aspect of quality of life and sexual dysfunctions are common in patients with differerent psychiatric disorders. Sexual impairments are associated with interaction among psychological, sociological and biochemical-pharmacological factors. The inquiries about sexual function should be routinely carried out by clinicians. Patients rarely deal with problems in sexual life, so questions about this area of life should not be overlooked during a medical interview. Due to the significant, often negative impact of pharmacotherapy in psychiatric diseases on sexual function, it is worthwhile to anticipate the patient about possible side effects, and in the event of their occurrence, modify the treatment.

\section{REFERENCES}

1. Hatzimouratidis K. Hatzichristou D. Sexual dysfunctions: classifications and definitions. J Sex Med. 2007;4(1):241-250

2. Olisah V, Sheikh T, Abah E, Mahmud-Ajeigbe A. Sociodemographic and clinical correlates of sexual dysfunction among psychiatric outpatients receiving common psychotropic medications in a Neuropsychiatric Hospital in Northern Nigeria. Niger J Clin Pract 2016;19(6):799-806.

3. Mosaku K, Ukpong D. Erectile dysfunction in a sample of patients attending a psychiatric outpatient department. Inter J Impot Res. 2009;21:235-239.

4. Chokka R, Hankey J. Assessment and management of sexual dysfunction in the context of depression. Ther Adv Psychopharmacol. 2018;8(1):13-23.

5. Sørensen T, Giraldi A, Vinberg M. Sexual distress and quality of life among women with bipolar disorder . International Journal of Bipolar Disorder. 2017:5(1):29.
6. Kopeykina I, Kim HJ, Khatun T, Boland J, Haeri S, Cohen L et al. Hypersexuality and couple relationships in bipolar disorder: A review. J Affect Disord. 2016;195:1-14.

7. Namlı Z, Karakuş G, Tamam L. Assessment of Dyadic Adjustment and Sexual Functions in Patients with Bipolar Disorder. Arch Neuropsychiatry 2018;55(2):171-176.

8. Heare MR, Barsky M, Faziola L. A Case of Mania Presenting with Hypersexual Behavior and Gender Dysphoria that Resolved with Valproic Acid. Ment Illn. 2016;8(2):6546.

9. Dell'Osso L, Carmassi C Carlini M, Rucci P, Torri P, Cesari D et al. Sexual dysfunctions and suicidality in patients with bipolar disorder and unipolar depression. J Sex Med 2009;6(11):3063-3070.

9. Downey J. Driven sexual behavior in bipolar spectrum patients: psychodynamic issues. J Am Acad Psychoanal Dyn Psychiatry: 2011;39:77-92.

10. Baldwin DS, Manson C, Nowak M. Impact of Antidepressant Drugs on Sexual Function and Satisfaction. CNS Drugs 2015;29:905-13

11. Atlantis E, Sullivan T. Bidirectional association between depression and sexual dysfunction: A systematic review and meta-analysis. J Sex Med 2012;9:1497-1507.

12. Francois D, Levin A., Kutscher E, Asemota B. Antidepressant-induced sexual side effects: incidence, assessment, clinical implications, and management. Psychiatr Ann. 2017;47(3):154-160.

13. Montejo-Gonzales, Llorca G, Izquierdo JA, Ledesma A, Bousoño M, Calcedo A et al. SSRI-induced sexual dysfunction: fluoxetine, paroxetine, sertraline, and fluvoxamine in a prospective, multicenter, and descriptive clinical study of 344 patients. J Sex Marital Ther. 1997;23(3):176-194.

14. Minnen $A$, Kampman $M$. The interaction between anxiety and sexual functioning: A controlled study of sexual functioning in women with anxiety disorders. Sex and Relationsh Ther. 2000;15:1, 47-57.

15. Marques C, Hayes K, Possidente E, Marques C. Sexual dysfunction: a neglected complication of panic disorder and social phobia. Arch Sex Behav. 2001;4:369-77

16. Bradford A, Meston C. The impact of anxiety on sexual arousal in women Behav Res Ther .2006;44(8):1067-1077.

17. Rajkumar $R$, Kumaran A. Depression and anxiety in men with sexual dysfunction: a retrospective study. Compr Psychiatry. 2015;60:114-8.

18. Baggaley M. Sexual dysfunction in schizophrenia: focus of recent evidence. Hum Psychopharmacol. 2008;23:201-209.

19. Chojnowski J, Więdłocha M, Mosiołek A. Zaburzenia seksualne u pacjentów ze schizofrenią. Psychiatria 2017;14(1):35-39

20. Kasperek-Zimowska B, Brodniak W. A., Sarol-Kulka A. Zaburzenia seksualne w schizofrenii - przegląd badań. Psychiatr Pol. 2008;42(1):97104

21. de Boer MK, Castelein S, Wiersma D, Schoevers RA, Knegtering H. The facts about sexual (dys)function in schizophrenia: an overview of clinically relevant findings. Schizophr Bull. 2015;41(3):674-686

22. Kokoszka A, Abd El Aal M, Jodko A, Kwiatkowska A. Rozpowszechnienie subiektywnie ocenianych objawów dysfunkcji i zaburzeń seksualnych w schizofrenii. Psychiatr Pol. 2009;43(6):705-718

23. Acuña MJ, Martín JC, Graciani M, Cruces A, Gotor F. A comparative study of the sexual function of institutionalized patients with schizophrenia. J Sex Med. 2010; 7(10):3414-3423

24. Ma MC, Chao JK, Hung JY, Sung SC, Chao IC. Sexual activity, sexual dysfunction, and sexual life quality among psychiatric hospital inpatients with schizophrenia. J Sex Med. 2018;15(3):324-333

25. Laxhman N, Greenberg L, Priebe S. Satisfaction with sex life among patients with schizophrenia. Schizophrenia Research 2017; 190:63-67 
26. Üçok A, Inescu C, Aker T, Erkoc Ş. Sexual dysfunction in patients with schizophrenia on antipsychotic medication. Eur. Psychiatry 2007;22:238-333

27. Dossenbach M, Dyachkova Y, Pirildar S, Anders M, Khalil A, Araszkiewicz A et al. Effects of atypical and typical antipsychotic treatments on sexual function in patients with schizophrenia: 12-month results from the Intercontinental Schizophrenia Outpatient Health Outcomes (IC-SOHO) study. Eur. Psychiatry 2006;21:251-258

28. Kelly DL, Conley RR. A randomized double-blind 12-week study of quetiapine, risperidone or fluphenazine on sexual functioning in people with schizophrenia. Psychoneuroendocrinol. 2006;31:340-346.

29. Shah SK. A comparative study of sexual dysfunction in schizophrenia patients taking aripiprazole versus risperidone. Kathmandu Univ Med J 2013; 11(42):121-125.

30. Konarzewska B, Szulc A, Popławska R, Galińska B, Juchnowicz D. Wpływ poneuroleptycznejhiperprolaktynemiinawystępowaniezaburzeńseksualnych u mężzzyzn chorych na schizofrenię; Psychiatr Pol. 2008;42(1):87-95.

31. Johnsen E, Kroken R, Løberg EM, Kjelby E, Jørgensen HA. Sexual dysfunction and hyperprolactinemia in male psychotic inpatients: a cross-sectional study. Adv Urol. 2011;2011:686924.

32. Nakonezny PA, Byerly MJ, Rush AJ. The relationship between serum prolactin level and sexual functioning among male outpatients with schizophrenia or schizoaffective disorder: a randomized double-blind trial of risperidone vs. quetiapine. J Sex Marital Ther. 2007;33(3):203-216

33. Adam RL, Sidi H, Midin M, Zakaria H, Das S, Mat KC. The Role of Atypical Antipsychotics in Sexuality: Road to Recovery in Schizophrenia. Current Drug Targets 2018;19(12):1402-1411

34. Garasimenko L. Development of sexuality and motivational aspects of sexual behavior in men with obsessive-compulsive disorders. Georgian Med News. 2014;234:85-8.
35. Ghassemzadeh H, Raisi F, Firoozikhojastefar R, Meysamie A, Karamghadiri N, Nasehi AA i wsp. A Study on Sexual Function in Obsessive-Compulsive Disorder (OCD) Patients With and Without Depressive Symptoms. Perspect Psychiatr Care 2017;53(3):208-213

36. Kendurkar A, Kaur B. Major Depressive Disorder, Obsessive-Compulsive Disorder, and Generalized Anxiety Disorder: Do the Sexual Dysfunctions Differ?. Prim Care Companion J Clin Psychiatry 2008;10(4):299-305.

37. Fontenelle LF, de SouzaWF, de Menezes GB, Mendlowicz MV, Miotto RR, Falcão R. i wsp. Sexual function and dysfunction in Brazilian patients with obsessive-compulsive disorder and social anxiety disorder. J Nerv Ment Dis. 2007;195(3):254-257

38. Aksaray G, Yelken B, Kaptanoğlu C, Oflu S, Ozaltin M. Sexuality in women with obsessive compulsive disorder.J Sex Marital Ther. 2001;27(3):273-277

39. Aksaray G, Yelken B, Kaptanoğlu C, Oflu S, Ozaltin M. Sexuality in women with obsessive compulsive disorder. J Sex Marital Ther. 2001;27(3):273-277.

40. Kravvariti V, Gonidakis F. Eating disorders and sexual function. Psychiatriki. 2016;27(2):136-143.

41. Castellini G, Lelli L, Ricca V, Maggi M. Sexuality in eating disorders patients: etiological factors, sexual dysfunction and identity issues. A systematic review. Horm Mol Biol Clin Investig. 2016;25(2):71-90

42. Beerens V, Vermassen A, Vrieze E, Pieters G. Sexuality in eating-disorder patients. Tijdschr Psychiatr. 2014;56(4):268-272.

43. Gonidakis F, Kravvariti V, Varsou E Sexual function of women suffering from anorexia nervosa and bulimia nervosa. J Sex Marital Ther. 2015;41(4):368-378

44. Kluck AS, Garos S, Shaw L. Sexual functioning and disordered eating: A new perspective. Bull Menninger Clin. 2018;82(1):71-91

45. Castellini G, Mannucci E, Mazzei C, Lo Sauro C, Faravelli C, Rotella CM i wsp. Sexual function in obese women with and without binge eating disorder. J Sex Med. 2010;7(12):3969-3978.

\section{ORCID:}

Alicja Piontek

Jakub Szeja

Michat Błachut

Karina Badura-Brzoza

Conflict of interest

Authors declare no conflict of interest

\author{
CORRESPONDING AUTHOR \\ Alicja Piontek \\ Department of Psychiatry \\ Pyskowicka 49 \\ 42-612 Tarnowskie Góry, Poland \\ phone/fax number: +48322854358 \\ e-mail: alicja.paulina.piontek@gmail.com
}

Received: 12.06.2019

Accepted: 21.09 .2019 
PRACA POGLĄDOWA

REVIEW ARTICLE

\title{
PROVIDING THE RIGTH TO HEALTH OF INVOLUNTARILY DISPLACED PERSONS
}

\author{
Vitalii Pashkov', Marianna Liubchenko' ${ }^{2}$, Oleksii Liubchenko ${ }^{3}$ \\ 'DEPARTMENT OF CIVIL, COMMERCIAL AND FINANCIAL LAW, POLTAVA LAW INSTITUTE OF YAROSLAV MUDRIY NATIONAL LAW UNIVERSITY, POLTAVA, UKRAINE \\ 2DEPARTMENT OF THEORETICAL AND LEGAL DISCIPLINES, POLTAVA LAW INSTITUTE OF YAROSLAV MUDRIY NATIONAL LAW UNIVERSITY, POLTAVA, UKRAINE \\ ${ }^{3}$ DEPARTMENT OF CONSTITUTIONAL, ADMINISTRATIVE, ENVIRONMENTAL AND LABOR LAW, POLTAVA LAW INSTITUTE OF YAROSLAV MUDRIY NATIONAL \\ LAW UNIVERSITY, POLTAVA, UKRAINE
}

\begin{abstract}
Introduction: The article deals with the issues of international law concerning defense of the right to health of involuntarily displaced persons. As a result of the study, it has been demonstrated that providing of the right to health is essential as a requirement for countries, which, in turn, stem from consensus on international cooperation and general support for migrants. The latter are undeniably protected in accordance with documents proclaiming human rights, but for the sake of a more detailed explanation of their rights and the substance of the state's obligations towards such persons, the international community has created a solid foundation in the form of specialized refugee documents that further emphasize the need protection of the latter as persons who, as a result of their movement, are vulnerable.

The aim: To elucidate the international mechanisms for the protection of the right to health of involuntarily displaced persons.

Materials and methods: The study used a set of general-philosophical and special-legal methods of scientific research, in particular, dialectical, historical, socio-political, formal-legal and comparative legal methods of scientific research. The historical method of scientific research has been used in the analysis of tendencies of the regulation of the refugee problem from the beginning of the 20th century. The comparative legal method is used in the analysis of the legal regulation of involuntarily displaced persons' rights by international treaties and conventions, rules of national legislation of Ukraine and foreign legislation.

Review: Authors analyze the issue of a migrant's (social, medical etc.) rights under the principle of equality of refugees' and citizens' rights. Reviewing the mechanisms of guarding such rights under treaties it is obvious that these mechanisms have legislative and institutional features. Closer look is taken on the Council of Europe's mechanism for protecting the rights of refugees with its own normative and institutional features.

Conclusions: As a result of the study, it has been demonstrated that migrants' rights, including right to health, stem from consensus on international cooperation and general support for migrants. The latter are undeniably protected in accordance with the documents proclaiming human rights. In order to provide a more detailed explanation of their rights and the nature of the state's obligations towards such persons, the international community has created a solid foundation in the form of specialized refugee documents, which further emphasize the need to protect the latter as persons who, as a result of their displacement, are vulnerable.
\end{abstract}

KEY WORDS: right to health, human rights, migration, refugees, asylum, international law, obligations, highest state bodies decision-making

Wiad Lek 2019, 72, 10, 1989-1994

\section{INTRODUCTION}

Today, the assessment of migration processes in the world is based on a clear understanding that the transboundary movement of people for forced reasons is inevitable in a coherent society. It is clear that strengthening the protection of involuntarily displaced persons, especially providing their right to health, is an important task of the states, but subject to close international cooperation in this sphere. International cooperation to promote the protection of migrants' rights lies both in the interaction in specific cases, and in the active discourse and the development of international law rules.

According to WHO, there are an estimated 60 million refugees or internally displaced persons worldwide. Their displacement circumstances vary greatly, from those temporarily displaced by conflict or natural disaster to those who spend years in camps or urban areas far from home. About two thirds live in "situations of seemingly unending exile".

While becoming a refugee changes many things, it does not change the human right to the highest attainable standard of health and well-being. All people regardless of race, ethnicity, sex, age and country of origin have health needs and specific vulnerabilities - and these are often exacerbated when they are forcibly displaced. For example, as refugees on the move, women and children may have problems accessing even basic services, such as care at the time of delivery, postnatal check-ups for mothers and babies, routine vaccinations and family planning. This leaves them exposed to common illnesses and often unable to plan their families [34].

Principle 19 of the "Guiding Principles on Internal Displacement" of the United Nations prioritizes the care of the displaced persons with disabilities, infectious diseases, and 
women, especially in the field of sexual and reproductive health (SRH) [35]. The World Health Organization (WHO) [36] mentions that the public health should avoid inequities between the displaced population and the host population regarding the health condition and access to HS. It states that health rights should be ensured without discrimination and any obstacles for preventive and curative interventions that reduce excess morbidity and mortality and minimize the consequences both on community health and cohesion should be removed [25].

In a message dedicated to the International Migrants Day on December 18, 2017, UN Secretary-General Antonio Guterres noted that "worldwide, unfortunately, hostility towards migrants is increasing" [30]. On September 19, 2016, the New York Declaration on Refugees and Migrants was adopted [9]. The Declaration contains a list of the commitments undertaken by States to save lives, the protection of the human rights of migrants and the equitable sharing of responsibilities at the global level in addressing various migration-related issues.

The Global Compact for Safe, Orderly and Regular Migration was signed in December 2018 in addition. It contains the most relevant and progressive approaches to migration: human dimension, international cooperation; the principle of recognition of the state's discretion of conducting a national migration policy, while applying all possible instruments in all areas of public administration; the principles of the rule of law and the principle of due diligence in public administration. The treaty is enshrined in the Sustainable Development Agenda of 2030 and is based on the recognition that migration is a "multidimensional reality".

Thereby, a human rights-based approach, clearly defined in the Global Compact, has already shown a steady tendency towards the extension of the general provisions on human rights to displaced persons. Under such circumstances the legislation of some European states appears to be xenophobic. For example, the law adopted in Hungary summer, 2018 provides criminal penalties for the provision of assistance to migrants, the dissemination of information relating to migrants, the provision of advice to migrants and the control of what is happening at the border [31]. Thus, the urgent issues of mutual assistance between the European Union countries in overcoming the difficulties and increasing the control of migration within the framework of the Central-Mediterranean, East and West-Mediterranean routes became key at the meeting of the European Council on June 28, 2018. The European countries' leaders focused on developing concrete efforts: stopping migrant smugglers, supporting Italy on migrant acceptance matters and migration control; on developing a concept for regional landing platforms for people rescued at sea, reviewing and improving EU Asylum Rules [32].

\section{THE AIM}

To elucidate the international mechanisms for the protection of the involuntarily displaced persons' right to health.

\section{MATERIAL AND METHODS}

The study used a set of general-philosophical and special-legal methods of scientific research, in particular, dialectical, historical, socio-political, formal-legal and comparative legal methods of scientific research. The historical method of scientific research has been used in the analysis of tendencies of the refugee problem's regulation since the 20th century. The comparative legal method is used in the analysis of the legal regulation of involuntarily displaced persons' rights in the international treaties and conventions, rules of national legislation of Ukraine and foreign legislation.

\section{REVIEW AND DISCUSSION}

The issue of medical rights of a refugee, which is guarded under Art. 24 of the Convention on the Status of Refugees and establishes the principle of equality of rights of refugees and citizens in matters related to social security due to sickness, disability, etc.

Currently, processes of cross-border movement of persons occur predominantly as "medical tourism" in the western and eastern directions [22]. However, even if migrants arrive in the host country in relatively good health conditions, their health status appears to decline over time. Financial barriers emerged as a fundamental and serious obstacle to healthcare for migrants or ethnic minorities. User fees and dental care represent the two most frequently mentioned barriers [23, p. 78].

The main challenges are the intersectoral, participatory, and integral approach (with emphasis on mental health and sexual and reproductive health), ensured accessibility to health services, the need for a reliable registration and information system of the population displaced by violence and its characteristics, and the addressing of the biopsychosocial problems of the different groups, especially women, persons with disabilities or infectious diseases, adolescents, children, ethnic minorities, older adults and the lesbian, gay, bisexual, transsexual, and intersexual population [25].

Challenges of health services related to the population displaced by violence in Mexico

Challenges of health services related to the population displaced by violence in Mexico

The outlined problems are of great importance for Ukraine. As the analytical study of the Delegation of the International Organization for Migration in Ukraine states, "since the introduction of democratic freedoms, in particular freedom of movement," since 2013, the transboundary mobility of the Ukrainian population has grown rapidly mainly due to crossings of the western border" [27].

Undoubtedly, the annexation of the Crimea and military actions on the East of Ukraine in 2014 - 2015 significantly influenced external involuntary migration. The number of asylum applications filed by Ukrainian citizens in European countries (most notably in Italy, Germany, Spain and Poland) exceeded 22 thousand applications in 2015, which was one third more than in 2014, and more than 20 times in 2013; in 2015 the status of refugee in the countries of 
the European Union in accordance with the Geneva Convention of 1951 was acquired by 415 Ukrainian citizens, an additional form of asylum for humanitarian reasons by 1150 people; in 2015, for different reasons, there were 1 million more of Ukrainian citizens registered in Russia than in 2014 [27].

For Ukraine, significant changes in migration regulation have taken place since the adoption of the new wording of the Law of Ukraine "On the legal status of foreigners and stateless persons", the Law of Ukraine "On refugees and persons requiring additional or temporary protection", the adoption in 2012 of the Law of Ukraine "On the unified state demographic register and documents confirming the citizenship of Ukraine, certify the person or its special status", as well as the Law of Ukraine" On Foreign Labor Migration "in 2015.

It is worth noting that the Association Agreement between Ukraine and the European Union (2014) aims to strengthen dialogue on the basic principles of solidarity, mutual trust, joint responsibility and partnership, and cooperation on migration, asylum and border management, using a system approach and paying attention to legal migration and cooperation in the fight against illegal immigration, human trafficking and effective implementation of the provisions (see Preamble to the Agreement). Aspects of migration policy are contained in various articles of the Agreement such as: Article 16 - Cooperation in the field of migration, asylum and border management (counteraction to illegal migration, study of legal migration, illegal transfer of persons across the state border and human trafficking, as well as the inclusion of problem issues in the field of migration to national strategies for economic and social development of regions from which migrants originate); Article 18 - mobility of workers; Article 19 - movement of persons, increase of citizens mobility and further progress in visa dialogue; etc. [8].

Aforementioned protection of the rights of displaced persons is primarily ensured through the use of universal human rights instruments. It is concerning those provisions that point to the equality of all people and the obligation of states to guarantee the rights of all with no exceptions. Thus, the Universal Declaration of Human Rights of 1948 proclaims that "all men are born free and equal in their dignity and rights" (Article 1), and that "every human being must have all the rights and freedoms proclaimed by this Declaration without any differences"(Article 2). Undoubtedly, the right to health is the most important. Besides, other rights also play significant role, such as stated in Article 14 of the Declaration, that for the first time enshrined the right of every person to seek asylum from persecution in other countries and to use shelter ${ }^{1}$. The International Covenant on Civil and Political Rights, proclaiming the human right to life, liberty, and personal integrity, in Article 12, focuses on guarantees for everyone "who is legally in the territory of any State" within this territory, on the right of "Free movement and freedom of choice of place of residence", as well as the right of everyone to leave any country, including its own. The circumstances which may justify the restriction of these rights are: state security, public order, health or morals of the population or the rights and freedoms of others, if such circumstances are compatible with other rights of this Covenant. Article 13 of this Covenant also prohibits the unjustified deprivation of people right to enter their own country. An alien lawfully in the territory of a State Party to the present Covenant may be expelled therefrom only in pursuance of a decision reached in accordance with law and shall, except where compelling reasons of national security otherwise require, be allowed to submit the reasons against his expulsion and to have his case reviewed by, and be represented for the purpose before, the competent authority or a person or persons especially designated by the competent authority, while respecting all guarantees of human rights in expulsion (right to a fair trial) etc. [1].

While the demands for assistance are reaching all-time highs, the resources available for food, shelter, and health services are failing to keep pace. Added to the traditional programmatic demands facing providers of refugee assistance are new political challenges that have arisen in recent months. A particularly momentous question concerns the provision of aid to internally displaced persons in the face of official governmental disapproval of such intervention in the country's internal affairs [37].

The Convention against Torture and Other Cruel, Inhuman or Degrading Treatment or Punishment of 1984, in its Article 3, states that "no State Party shall send, return or release any person to another State, if there are serious grounds for believing that she may be subjected to torture"; the state must take into account all circumstances relevant to the case, including, where applicable, the existence of a constant practice of brutal and massive human rights violations in that State" [2]. The world community seems to have reached the necessary consensus that recognizing the equal and inalienable rights of all members of the human community is the foundation of freedom, justice and universal peace" [19]. The report of the Special Rapporteur on Torture and Other Cruel, Inhuman or Degrading Treatment or Punishment, issued in early 2018, states that today, approximately 258 million people or about $3 \%$ of the world's population, live outside their place of residence origin or habitual residence and therefore may be called (international) "migrants" regardless of their personal status. Thus, about 10\% (about 25 million people) fled from their country as refugees, and another 40 million people are forcibly displaced to other countries and may well become migrants in

\footnotetext{
${ }^{1}$ Later, in 1967, the Declaration on the Territorial Asylum, adopted by the UN GA Resolution, confirmed the right of persons who had the right to refer to Article 14 of the Universal Declaration of Human Rights, the right to seek asylum and to use asylum, with the exception of those persons where are serious grounds for believing that they have committed a crime against peace, a war crime or an offense against humanity in the context of those international acts that determine the composition of these crimes.
} 
the future. The report states that today's increasingly restrictive and burdensome migration laws, policies and practices have led to an increase in the number of migrants displaced outside formal procedures and, as a result, in corruption, violence and abuse; many states have created mechanisms to prevent the arrival of new people, the criminalization and detention of illegal migrants, the separation of families, inappropriate conditions for admission and medical care, delaying procedures for determining the status, or expulsion in the absence of mechanisms for recognizing such status; many states began to physically prevent the arrival of illegal migrants through the closure of the border, the establishment of fences, walls and other physical barriers, often in cooperation with other states or even non-state actors [33].

The article 22 of The Convention on the Rights of the Child of 1989, establishes the state's responsibility for taking the necessary steps to ensure that a child who wishes to receive refugee status or who is considered a refugee, is adequately protected and given humanitarian assistance in the exercise of his rights; promoting the protection of such child and assisting him in finding parents or other family members of any refugee child for family reunification. In cases where parents or other family members cannot be found, this child is given the same protection as any other child deprived of a family environment" including right to health.

It should be noted that at the beginning of the XX century the international community began to pay attention to the problem of refugees as a matter of responsibility for the protection and assistance to refugees: the League of Nations adopted a number of international agreements for the protection of refugees, as referred to in Article 1 of the Convention relating to the Status of Refugees (1951). Thus, instead of special agreements adopted in connection with specific refugee situations, a document containing the general definition of a refugee was proposed [26]. The meaning of this Convention is as follows: (1) the general definition of the term "refugee" (Article 1) is given; (2) provision of minimum standards for the rights of refugees, non-discrimination in the treatment of refugees, freedom of religion, and the guarantee of social, economic and political rights; (3) securing the ban on the expulsion or forced return of refugees; consolidating the foundations of naturalization and assimilation of refugees. As Laura Thompson, Deputy Director-General of the International Organization for Migration emphasizes, the main element in the concept of "refugee" is persecution and impossibility / unwillingness to take advantage of the protection of their state [21]. The Protocol Relating to the Status of Refugees of 1967 abolishes the geographical and time constraints set out in the original version of the Convention on the Status of Refugees, the scope of which is not limited to States Parties to the Convention.

It should also be reminded that often refugees are under the control of one of the parties of the international armed conflict: in this case they are protected by the rules of international humanitarian law and international refugee law [18]. From the point of view of protecting refugees, the Geneva Convention for the Protection of Civilian Persons in the War of 1949 and the Additional Protocol I to the Geneva Conventions of August 12, 1949, concerning the Protection of Victims of
International Armed Conflict, are important instruments of international humanitarian law. The Convention states that any detaining state should not act hostile to refugees who are not actually protected by any government solely on the basis of their legal affiliation with the State of the adversary (Article 44). The Additional Protocol states that persons who, before the beginning of hostilities, were treated as stateless persons or refugees, are protected under all circumstances and without any discrimination [5].

The explanatory report to the ECHR notes that the system of human rights' protection under the ECHR "may be useful additionally to the existence of a non-judicial preventive mechanism, which tasks include studying the treatment of persons deprived of their liberty, if necessary, strengthening the protection of such persons from torture or inhuman or degrading treatment or punishment" [7]. At the same time, according to Article 17 of the European Convention for the Prevention of Torture and Inhuman or Degrading Treatment or Punishment indicates that it "does not adversely affect the provisions of national law or any international agreement providing for more reliable protection of persons deprived of their liberty"; moreover, nothing in this Convention can be interpreted as limiting or violating the powers of the bodies provided for by the European Convention on Human Rights or as allowing itself to derogate from the obligations assumed by the Parties under the said Convention". For example, according to the results of the inspections of illegal migrants' places of detention, the $\mathrm{CPT}$ formulated three basic rights that detained illegal migrants have been using since the beginning of their detention: (1) the right to have access to a lawyer, (2) the right to have access to a doctor, and (3) the right to be able to inform a relative or a third person of his or her choice of taking into custody [28].

Thus, it is very important for highest state bodies to effectively implement the norms of international law in national legislation through their decision-making.

Despite attempts to legally address the protection of internally displaced persons' rights to health care in Ukraine, according to the OSCE thematic report on access to health care, the situation is ambiguous. In some areas, the provision of medical services to such persons by public health institutions is provided at the appropriate level, while in other areas access to medical care is problematic. Most of the respondents said that they did not need medical assistance yet and therefore they do not know whether there are difficulties in obtaining medical services or not. Hoping to return home soon, internally displaced persons didn't try to figure out how the system works. Several resorts provide medical care, as well as some local doctors and nurses provide them with medical services on a volunteer basis. However, internally displaced persons often need financial support to obtain the necessary medicines or to gain access to specialized medical services. Those who suffer from chronic diseases and take prescribed medications have had difficulty trying to get prescriptions for the necessary medications again. Representatives of civil society, for their part, partly solve this problem by covering medical expenses and assisting such persons in gaining access to hospital treatment [38]. 
Returning to the system of protection of human rights within the framework of the Convention for the Protection of Human Rights and Fundamental Freedoms, it is important to note the conclusions made by European Court of Human Rights on the consideration of complaints from persons whose rights as migrants have been violated: (1) members of the Council of Europe have to ensure that everyone under their jurisdiction, in particular refugees, has respect of their rights guaranteed by the Convention, in particular Article 2 of the Convention guaranteeing the right to life, and Article 3 prohibiting torture, punishment, inhuman treatment and punishment. Consequently, the Court confirms the principles of non-refoulement, which means that no person can be expelled where he or she is faced with a real risk ("real", "predictable" and "personal") to be treated contrary to Articles 2 and 3 of the Convention [10]; (2) The treatment prohibited by Articles 2 and 3 of the Convention must attain a minimum level of cruelty [11], the assessment of which must be thoroughly investigated by the sending State [12], taking into account that the person may belong to vulnerable groups [13]; (3) the host States are bound by the obligation to create appropriate conditions for the stay of asylum seekers [13].

Researchers empathize that ECHR does not guarantee the right to free medical care [24, p. 1111]. Also, in its Wasilewski v. Poland judgment, (No. 32734/96) Court stated, that the ECHR does not guarantee the right to any particular level of medical care or the right to access treatment [15].

ECHR in its judgment Cyprus v. Turkey (2001) (No. 25781/94) acknowledged that Article $2 \S 1$ obliges States to take appropriate steps to safeguard the lives of those within its jurisdiction; and, as it relates to the present case, a violation of Article 2 may occur when an individual's life is put at risk through the denial of health care which a State has undertaken to make available to the population generally [14].

Though ECHR does not guarantee the right on health protection, it can be argued that it (the right) is one of the aspects of "moral and physical integrity" that may be covered by art. 8, guaranteeing the right to respect for private life, especially regarding mental health, as it seems from Case of Bensaid v. the United Kingdom ECHR judgment (2001) [16].

However, under certain circumstances, it is possible to refer to the responsibility of a member state provided for by the ECHR, if it is proved that the authorities of this state put the life of a certain person at risk as a result of actions or inaction, as a result of which the person is not provided with medical care provided to the rest [17].

\section{CONCLUSIONS}

Thus, the arsenal of international measures of protecting the migrants' human rights is quite broad. It is discovered that the international documents on the human rights of refugees are mostly agreements that have no binding force. However, their value lies not only in the proclaiming the inviolability of human rights, including those of involuntarily displaced persons, but also in providing of the right to health, which expresses the duty of states in protecting and safeguarding the rights of refugees, and, therefore, specific obligations in this field. It is also important that these international instruments provide minimum standards for ensuring the rights of migrants and the proper conditions for their stay within other states' territories; these documents are a groundbreaking reference point for developing national approaches in this scope. However, it should be recognized that the fulfillment of these commitments largely depends on the formal aspects and internal procedures for the implementation of these standards - ratification, implementation, etc., as well as the will of the states themselves, embodied in specific policies and practices.

\section{REFERENCES}

1. International Covenant on Civil and Political Rights, adopted by the United Nations General Assembly with resolution 2200A (XXI) on 16 December 1966.

2. The Convention against Torture and Other Cruel, Inhuman or Degrading Treatment or Punishment, 1984. URL: https://www.ohchr.org/en/ professionalinterest/pages/cat.aspx

3. The 1951 Refugee Convention, United Nations. URL: http://www.unhcr. org/3b66c2aa10

4. Convention (IV) relative to the Protection of Civilian Persons in Time of War. Geneva, 12 August 1949. URL: https://ihl-databases. icrc.org/ihl/385ec082b509e76c41256739003e636d/6756482d$86146898 c 125641$ e004aa3c5

5. Protocol Additional to the Geneva Conventions of 12 August 1949, and relating to the Protection of Victims of International Armed Conflicts (Protocol I), 8 June 1977. URL: https://ihl-databases.icrc.org/ihl/ INTRO/470

6. Convention Governing the Specific Aspects of Refugee Problems in Africa, 1969. URL: http://www.unhcr.org/about-us/background/45dc1a682/ oau-convention-governing-specific-aspects-refugee-problems-africaadopted.html

7. Evropeyska konventsiya pro zapobigannya katuvannyam chi nelyudskomu abo takomu, scho prinizhuye gidnist, povodzhennyu chi pokarannyu/Tekst Konventsiyi ta poyasnyuvalna dopovid. URL: https:// rm.coe.int/16806dbaca

8. Ugoda pro asotsiatsiyu mizh Ukrayinoyu, z odnieyi storoni, ta Evropeyskim Soyuzom, Evropeyskimi spivtovaristvom $z$ atomnoyi energiyi i yihnimi derzhavami-chlenami, z inshoyi storoni. URL:http:// www.kmu.gov.ua/kmu/docs/EA/00_Ukraine-EU_Association _ Agreement_(body).pdf

9. UN General Assembly Resolution, adopted on 9 September 2016. URL: https://undocs.org/ru/A/RES/70/302

10. Case of Sufi and Elmi v. United Kingdom (Application nos. 8319/07 and 11449/07), Judgment of European Court of Human Rights 28 November, 2011. URL: https://hudoc.echr.coe.int/app/conversion/ pdf $/$ library $=E$ CHR\&id $=001-105434 \&$ filename $=001-105434$.pdf.

11. Case of Soering v. United Kingdom (Application no. 14038/88), Judgment of European Court of Human Rights, 7 July, 1989. URL: https:// www.google.com.ua/url? $\mathrm{s} a=t \& r c t=j \& q=\& e s r c=s \&$ source $=$ web\&c $\mathrm{d}=3 \&$ ved=2ahUKEwiLwv68roDeAhXGCywKHbaABqMQFjACegQICBAC\&url=http\%3A\%2F\%2Fwww.asylumlawdatabase.eu\%2Fsites $\% 2 F w w w . a s y l u m l a w d a t a b a s e . e u \% 2 F f i l e s \% 2 F a l d f i l e s \% 2 F-$ CASE\%25200F\%2520SOERING\%2520v.\%2520THE\%2520UNITED\%2520KINGD0M_0.doc\&usg=A0vVaw3J1fLVb4rmE58bGulcR2vB

12. Case of Ireland v. the United Kingdom (Application no. 5310/71), Judgment of European Court of Human Rights, 18 January 1978. URL: http://hudoc.echr.coe.int/rus?i=001-57506 
13. Case of M.S.S. v. Belgium and Greece (Application no. 30696/09), Judgment of European Court of Human Rights [GC], 21 January 2011. URL: http://www.asylumlawdatabase.eu/en/content/ecthr-mss-vbelgium-and-greece-gc-application-no-3069609

14. Case of Cyprus v. Turkey (Application no. 25781/94), Judgment of European Court of Human Rights [GC], 10 May 2001. URL: https://www. asylumlawdatabase.eu/en/content/ecthr-cyprus-v-turkey-applicationno-2578194-10-may-2001

15. Case of Wasilewski v. Poland (Application No. 32734/96) ), Judgment of European Court of Human Rights, URL: https://hudoc.echr.coe.int/ eng\#\{\%22itemid\%22:[\%22001-4875\%22]\}

16. Case of Bensaid v. the United Kingdom (Application no. 44599/98), Judgment of European Court of Human Rights, URL: https://hudoc. echr.coe.int/eng\#\{\%22itemid\%22:[\%22001-59206\%22]\}

17. Case of Powell v. the United Kingdom (Application no. 45305/99), Judgment of European Court of Human Rights, URL: http://hudoc.echr. coe.int/eng?i=001-5215

18. Gnatovskiy M. M. Mizhnarodne gumanitarne pravo. Dovidnik dlya zhurnalistiv / M.M. Gnatovskiy, T. R. Korotkiy, N. V. Hendel. 2-ge vid., dopovn. Odesa: Feniks, 2015. - $92 \mathrm{~s}$.

19. Zakonodavstvo Ukrayini proti katuvan ta inshih zhorstokih, nelyudskih abo takih, scho prinizhuyut gidnist, vidiv povodzhennya i pokarannya. Naukovo-praktichniy komentar. Havronyuk M. I., Gatselyuk V. 0. Kiyiv: VAITE, 2014. - $320 \mathrm{~s}$.

20. Prava bezhentsev: uchebnoe posobie: sost. S. Karnes, F. Elberts i dr. Assotsiatsiya obucheniya pravam cheloveka, 2002. Perevod na russkiy yazyik: Tsentr po pravam cheloveka Universiteta Minnesotyi, 2003.

21. Fraser J. Towards the Benefit of All: Protecting Migrants' Rights in a Globalised World: An Interview with Deputy Director General Ambassador Laura Thompson; International Organization for Migration. Utrecht Journal of International and European Law. 2012;22/75:65-76.

22. Vitaliy M. Pashkov, Andrii A. Harkusha. Rehabilitation tourism as the Part of Medical Tourism. Acta Balneologica. 2018;1 (151):48-53.

23. Vitaliy M. Pashkov, Andrii A. Olefir. Problem of Patient Discrimination in Sphere of Health Protection. Socrates. 2018;1 (10):76 - 93.

24. Vasyl Tatsiy, Nataliya Gutorova, Vitalii Pashkov. Legal aspect of cancer deseases prophylactics: patients rights context. Wiad. Lek. 2017;6(I):1108 - 1113.

25. María Beatriz Duarte-Gómez, Silvia Magali Cuadra-Hernández, Myriam Ruiz-Rodríguez, Armando Arredondo, and Jesús David Cortés-Gil. Challenges of health services related to the population displaced by violence in Mexico. URL: https://www.ncbi.nlm.nih.gov/pmc/articles/ PMC6063640/

26. Handbook on Procedures and Criteria for Determining Refugee Status under the 1951 Convention and the 1967 Protocol relating to the Status of Refugees, HCR/IP/4/Eng/REV.1 / Reedited, Geneva, 1992 (UNHCR 1979). URL: http://hrlibrary.umn.edu/instree/refugeehandbook.pdf

27. Migratsiya v Ukrayini: fakti i tsifri. Mizhnarodna organizatsiya z migratsiyi. Predstavnitstvo v Ukrayini / up. 0. Malinovska. URL: http:// iom.org.ua/sites/default/files/ff_ukr_21_10_press.pdf

28. Utrimannya migrantiv pid vartoyu. Informatsiyniy byuleten. KZK, 2017. URL: https://www.google.com.ua/url?sa =t\&rct=j\&q=\&es$\mathrm{rc}=\mathrm{s} \&$ source $=$ web\& $c d=2 \& v e d=2$ ahUKEwiJoLHrj__dAhVDISwKHQ2IAE0QFjABegQICRAC\&url=http\%3A\%2F\%2Fwww.vasu.gov. ua\%2Fuserfiles\%2Ffile\%2FListy\%2FCPT-factsheet-2017_UKR. doc\&usg=AOvVaw0CygUpsYHJBPk9VCn-Nw3W

29. MKS vidkriv poperednye rozsliduvannya schodo zlochiniv proti rohindzha/DW. URL: https://www.dw.com/uk/golovna/s-9874
30. Mizhnarodniy zahist migrantiv/ Ukrayinske pravo. URL: http:// ukrainepravo.com/international_law/public_international_law/ pkzrauserym-iashyfkh-tuav-pkguarkhkv/

31. Verhovnyiy komissar 00N nazval pozorom novyiy zapret Vengrii na podderzhku migrantov i bezhentsev. URL: https://news.un.org/ru/ story/2018/06/1332882

32. European Council, 28-29/06/2018 / European Council, Council of the European Union. URL:https://www.consilium.europa.eu/en/meetings/ european-council/2018/06/28-29/

33. 32. Report of the Special Rapporteur on torture and other cruel, inhuman or degrading treatment or punishment / Human Rights Council, Thirty-seventh session (26 February-23 March 2018): Promotion and protection of all human rights, civil, political, economic, social and cultural rights, including the right to development. URL:

34. https://www.ohchr.org/EN/.../A_HRC_37_50_EN.docx

35. WHO. Promoting health through the life-course. The right to health for everyone, no matter where people live or travel. URL: https://www.who. int/life-course/news/commentaries/world-refugee-day/en/

36. Organización de las Naciones Unidas. Comisión de Derechos Humanos. Principios rectores de los desplazamientos internos. Ginebra, Suiza: ACNUR; 1998. E/CN.4/1998/53/Add.2.URL: https://www.icrc.org/spa/ resources/documents/misc/5tdmhb.htm.

37. Organización Mundial de la Salud. Consejo Ejecutivo 122. Salud de los migrantes: informe de la Secretaría. Ginebra: 0MS; 2008. [cited $2016 \mathrm{Jul}$ 7]. URL: http://apps.who.int/iris/bitstream/10665/26222/1/A61_12sp.pdf.

38. The Health of Refugees and Displaced Persons: A Public Health Priority. URL: https://www.apha.org/policies-and-advocacy/public-healthpolicy-statements/policy-database/2014/07/29/10/34/the-healthof-refugees-and-displaced-persons-a-public-health-priority

39. OSCE. Thematic report. Internally Displaced Persons in Ukraine. August 12, 2014. URL: https://www.osce.org/ru/ukrainesmm/246196?download=true

\section{Authors' contributions:}

According to the order of the Authorship.

\section{ORCID:}

Vitalii Pashkov - 0000-0001-9489-7768

Marianna Liubchenko - 0000-0001-7090-2403

Oleksii Liubchenko - 0000-0002-8068-5665

\section{Conflict of interest:}

The Authors declare no conflict of interest.

\section{CORRESPONDING AUTHOR Vitalii Pashkov \\ Poltava Law Institute of Yaroslav the Wise National Law University 6 Monastyrska str., 36000, Poltava, Ukraine \\ e-mail: v.pashkov26.06@ukr.net}

Received: 12.07.2019

Accepted: 30.09.2019 
PRACA POGLĄDOWA

REVIEW ARTICLE

\title{
DIAGNOSTYKA POSTACI SPORADYCZNEJ CHOROBY CREUTZFELDTA-JAKOBA - PRZEGLĄD PIŚMIENNICTWA DIAGNOSTICS OF SPORADIC CREUTZFELDT-JAKOB DISEASE - LITERATURE REVIEW
}

\author{
Wojciech Maciej Ciepierski ${ }^{1}$, Monika Adamczyk-Sowa ${ }^{2}$, Tomasz Męcik Kronenberg ${ }^{3}$, Krzysztof Wierzbicki ${ }^{4}$ \\ 'KOŁO NAUKOWE PRZY KATEDRZE I ZAKŁADZIE PATOMORFOLOGII, WYDZIAŁ LEKARSKI Z ODDZIAŁEM LEKARSKO DENTYSTYCZNYM W ZABRZU, ŚLASKI \\ UNIWERSYTET MEDYCZNY W KATOWICACH, ZABRZE, POLSKA \\ 2KATEDRA I KLINIKA NEUROLOGII, SPSK NR 1 IM. PROF. S. SZYSZKO, ŚLASKI UNIWERSYTET MEDYCZNY W KATOWICACH, ZABRZZ, POLSKA \\ ${ }^{3}$ KATEDRA I ZAKŁAD PATOMORFOLOGII SPSK NR 1 IM. PROF. S. SZYSZKO, ŚLASKI UNIWERSYTET MEDYCZNY W KATOWICACH, ZABRZE, POLSKA \\ 4KATEDRA I KLINIKA NEUROLOGII, SPSK NR 1 IM. PROF. S. SZYSZKO, SLA SKI UNIWERSYTET MEDYCZNY W KATOWICACH, ZABRZE, POLSKA
}

\begin{abstract}
STRESZCZENIE
Sporadyczna odmiana choroby Creutzfeldta-Jakoba (sCJD) jest najczęściej występującą chorobą należącą do grupy encefalopatii gąbczastych wywołanych białkowy czynnik zakaźny - priony. Pomimo braku znanych lekarstw umożliwiających wyleczenie czy choćby spowolnienie postępu choroby, jej prawidłowa diagnostyka jest niezwykle istotna, z uwagi na dużą grupę chorób które mogą naśladować jej przebieg, a dla których istnieje opracowane leczenie przyczynowe/objawowe. Głównym problemem który uniemożliwia rozpoznanie różnicowe, jest brak powszechnie dostępnej i nieinwazyjnej procedury przyżyciowego stwierdzenia obecności patologicznego białka PrPsc $w$ układzie nerwowym pacjenta. Dodatkowo obowiązujące w chwili obecnej kryteria WHO są przestarzałe i wymagają aktualizacji, z uwagi na pojawienie się nowych metod diagnostycznych od czasu ich publikacji. Celem niniejszej pracy jest zebranie najnowszych trendów w diagnostyce sporadycznej odmiany choroby Creutzfeldta-Jakoba, zwrócenie uwagi na potrzebę przeprowadzenia uważnej diagnostyki różnicowej u pacjentów z podejrzeniem sporadycznej odmiany Creutzfeldta-Jakoba, oraz weryfikacji obecnie obowiązujących kryteriów jej rozpoznania i ich uaktualnienia.
\end{abstract}

SŁOWA KLUCZOWE: diagnostyka, choroba Creutzfeldta-Jakoba, płyn mózgowo-rdzeniowy, rezonans magnetyczny, pozytonowa tomografia emisyjna

\begin{abstract}
Sporadic Creutzfeldt-Jakob disease (SCJD) is the most common spongiform encephalopathy caused by protein infectious agents called prions. Despite the lack of known treatment which would cure or at least slow down the progression of the disease, its proper diagnosis is extremely important, because of the large group of diseases that may imitate its course and for which a causal / symptomatic treatment has already been developed. The main problem that prevents the differential diagnosis is the lack of a commonly available and non-invasive procedure for antemortem finding the pathological PrPSc protein in a patient's nervous system. In addition, the current WHO criteria are outdated and need to be updated due to the emergence of new diagnostic methods since their publication. The aim of this study is to collect the latest trends in the diagnosis of sporadic Creutzfeldt-Jakob disease, to draw attention to the need for careful differential diagnosis in patients with suspected sporadic Creutzfeldt-Jakob disease, and to verify the current criteria for its diagnosis and update.
\end{abstract}

KEY WORDS: diagnostics, creutzfeldt-jakob disease, cerebrospinal fluid, magnetic resonance imaging, positron-emission tomography

Wiad Lek 2019, 72, 10, 1995-2004

\section{WSTĘP I RYS HISTORYCZNY}

Choroba Creutzfeldta-Jakoba (CJD - Creutzfeldt-Jakob Diseas,) należy do grupy encefalopatii gąbczastych. Czynnikiem zakaźnym są nieprawidłowo pofałdowane białka, zwane prionami (proteinacious infectious particle - zakaźne cząsteczki białek) [1]. Spośród czterech podtypów CJD, najczęstszym (blisko 85\% wszystkich zdiagnozowanych przypadków) jest postać sporadyczna [2] (sCJD - sporadic Creutzfeldt-Jakob disease), która jest przedmiotem niniejszej pracy.
W 1921 roku niemiecki neuropatolog Alfons Maria Jakob, opublikował trzy prace, w których opisał występujące u ludzi nietypowe zmiany, obejmujące postępującą demencję, zaburzenia funkcji motorycznych, a następnie śmierć, maksymalnie w ciągu roku od wystąpienia pierwszych objawów. Rok wcześniej Hans Gerhard Creutzfeldt, pochodzący z Wrocławia neurolog opisał przypadek choroby, która w opinii Jakoba, opisywała tę samą patologię, co on sam, co w konsekwencji doprowadziło do powstania nowej jednostki chorobowej nazwanej na część odkrywców chorobą 
Tabela 1. Kryteria rozpoznania sCJD wg WHO.

\begin{tabular}{|c|c|c|}
\hline Rozpoznanie pewne & Rozpoznanie prawdopodobne & Rozpoznanie możliwe \\
\hline $\begin{array}{l}\text { Białko PrPsc odporne } \\
\text { na proteazę lub włókna } \\
\text { związane z białkiem } \\
\text { scrapie wykryte metodą } \\
\text { immunohistochemiczną, } \\
\text { lub western blot i/lub } \\
\text { potwierdzenie w badaniu } \\
\text { neuropatologicznym przy } \\
\text { użyciu standardowych technik }\end{array}$ & $\begin{array}{c}\text { Szybko postępująca demencja oraz przynajmniej } 2 \text { z } 4 \\
\text { poniższych objawów: } \\
\text { 1. Mutyzm akinetyczny } \\
\text { 2. Mioklonie } \\
\text { 3. Objawy wzrokowe lub móżdżkowe } \\
\text { 4. Objawy piramidowe lub pozapiramidowe } \\
\text { Oraz } \\
\text { Typowy obraz EEG w trakcie trwania choroby i/lub } \\
\text { dodatni wynik badania PMR w kierunku białka 14-3-3 } \\
\text { ponadto czas trwania choroby nie może przekraczać } 2 \\
\text { lat, a standardowa diagnostyka nie powinna sugerować } \\
\text { innego rozpoznania }\end{array}$ & $\begin{array}{c}\text { Szybko postępująca demencja oraz } \\
\text { przynajmniej } 2 \text { z } 4 \text { poniższych objawów: } \\
\text { 1. Mutyzm akinetyczny } \\
\text { 2. Mioklonie } \\
\text { 3. Objawy wzrokowe lub móżdżkowe } \\
\text { 4. Objawy piramidowe lub } \\
\text { pozapiramidowe } \\
\text { Oraz }\end{array}$ \\
\hline
\end{tabular}

Tabela 2. Kryteria rozpoznania sCJD wg NCDJRSU i CDC

\begin{tabular}{|c|c|c|}
\hline Rozpoznanie pewne & Rozpoznanie prawdopodobne & Rozpoznanie możliwe \\
\hline $\begin{array}{c}\text { Białko PrPsc odporne } \\
\text { na proteazęlub włókna } \\
\text { związane z białkiem } \\
\text { scrapie wykryte metodą } \\
\text { immunohistochemiczną, } \\
\text { lub western blot i/lub } \\
\text { potwierdzenie w badaniu } \\
\text { neuropatologicznym przy } \\
\text { użyciu standardowych technik }\end{array}$ & $\begin{array}{c}\text { Objawy neuropsychiatryczne + dodatni wynik badania } \\
\text { RT-QulC i płynie mózgowo rdzeniowym lub innych } \\
\text { tkankach } \\
\text { Szybko postępująca demencja oraz przynajmniej } 2 \text { z } 4 \\
\text { poniższych objawów: } \\
\text { 1. Mutyzm akinetyczny } \\
\text { 2. Mioklonie } \\
\text { 3. Objawy wzrokowe lub móżdżkowe } \\
\text { 4. Objawy piramidowe lub pozapiramidowe } \\
\text { Oraz } \\
\text { Typowy obraz EEG w trakcie trwania choroby i/lub } \\
\text { dodatni wynik badania PMR w kierunku białka 14-3-3, } \\
\text { ponadto czas trwania choroby nie może przekraczać } 2 \\
\text { lat, a standardowa diagnostyka nie powinna sugerować } \\
\text { innego rozpoznania } \\
\text { Jądra ogoniastego/skorupy lub z przynajmniej dwóch } \\
\text { regionów korowych (skroniowy, ciemieniowy, potyliczny) } \\
\text { w projekcji DWI lub FLAIR }\end{array}$ & $\begin{array}{c}\text { Szybko postępująca demencja oraz } \\
\text { przynajmniej } 2 \text { z } 4 \text { poniższych objawów: } \\
\text { 1. Mutyzm akinetyczny } \\
\text { 2. Mioklonie } \\
\text { 3. Objawy wzrokowe lub móżdżkowe } \\
\text { 4. Objawy piramidowe lub } \\
\text { pozapiramidowe } \\
\text { Oraz } \\
\text { Brak zmian w EEG lub zmiany } \\
\text { nietypowe i czas trwania choroby nie } \\
\text { może przekraczać } 2 \text { lat } \\
\text { Brak dodatniego któregokolwiek } \\
\text { z testów zawartych w kolumnach } \\
\text { „prawdopodobne i pewne” decyduje } \\
\text { o zaklasyfikowaniu rozpoznania jako } \\
\text { „możliwe”. }\end{array}$ \\
\hline
\end{tabular}

Creutzfeldta-Jakoba [3]. Jej etiopatogeneza nie była znana aż do 1982, kiedy amerykański biochemik Stanley B. Prusiner zaproponował termin „priony”, oraz opisał hipotetyczny mechanizm powstawania zmian w mózgu, na zupełnie nowym podłożu, za co w 1997 roku został uhonorowany nagrodą Nobla w dziedzinie fizjologii i medycyny [1].

Osobną jednostkę nozologiczną stanowi wariant choroby Creuztfeldta-Jakoba (vCJD), będący przepasażowaniem encefalopatii gąbczastej bydła (BSE - bovine spongiform encephalopathy) na ludzi [4]. Inna postać choroby - jatrogenna (iCJD - iatrogenic Creuztfeldt-Jakob disease), wywoływana jest przez przeszczep materiału biologicznego zainfekowanego prionami (opona twarda, rogówka, hormon wzrostu, opisano także przypadki przeniesienia $w$ trakcie transfuzji) [5]. Oprócz postaci sporadycznej, jatrogennej i wariantu
CJD, istnieje także postać rodzinna (fCJD - familial Creuztfeldt-Jakob disease), dziedziczona w sposób autosomalny dominujący [6, 7], należąca do tej samej grupy, co zespół Gerstmanna-Sträusslera-Scheinkera (GSS) oraz śmiertelna bezsenność rodzinna (FFI - fatal familial insomnia) [7].

\section{METODOLOGIA}

Przegląd piśmennictwa odbywał się poprzez wyszukiwarkę PubMed $\mathrm{z}$ wykorzystaniem zdalnego dostępu zapewnianego przez Śląski Uniwersytet Medyczny według następującego schematu:

- Wpisanie frazy „Creutzfeldt-Jakob disease” w wyszukiwarkę z zaznaczeniem opcji wyszukiwania po haśle $\mathrm{MeSH}$ 
- Następnie poprzez opcję Search Builder z wykorzystaniem wyrażenia: ( „Creutzfeldt-Jakob Syndrome/analysis”[Mesh] OR „Creutzfeldt-Jakob Syndrome/cerebrospinal fluid”[Mesh] OR „Creutzfeldt-Jakob Syndrome/ diagnosis”[Mesh] OR „Creutzfeldt-Jakob Syndrome/ diagnostic imaging”[Mesh] OR „Creutzfeldt-Jakob Syndrome/epidemiology”[Mesh] OR „Creutzfeldt-Jakob Syndrome/genetics”[Mesh] OR „Creutzfeldt-Jakob Syndrome/physiopathology”[Mesh] ) wyszukanie artykułów związanych z pracą

- Odnaleziono 3754 artykuły. Wprowadzono następujące filtry:

- Typ artykułu: artykuł w czasopiśmie naukowym

- Data publikacji : Ostatnie 10 lat

- Gatunek : człowiek

- Języki : Angielski/Polski

- Dostępność tekstu: pełny tekst dostępny za darmo

- Dokonano ewaluacji 318 uzyskanych wyników za pośrednictwem tytułu i streszczenia w celu wybrania możliwych do wykorzystania w dalszej części pracy

- Po dokonaniu ewaluacji uzyskano 47 prac

Podobny schemat zastosowano dla bazy danych Polskiej Bibliografii Lekarskiej oraz Embase uzyskując finalnie kolejne 31 prac. Pozostałe elementy bibliografii zostały uzyskane po ich wyszukaniu w pracach znalezionych według powyższego schematu, a także za pośrednictwem wyszukiwania przez Google Scholar po haśle „Creutzfeldt-Jakob disease history” oraz „Creutzfeldt-Jakob epidemiology”.

\section{CHARAKTERYSTYKA PRPC ORAZ PRPSC}

Białko prionowe (prion protein, $\mathrm{PrP}$ ), występujekonstytutywnie u większość ssaków, głównie w neuronach (także limfocytach) [14] zachowując przy tym duży konserwatyzm [8, 9, 12]. Kodowane jest u ludzi przez gen PRNP zlokalizowany na krótkim ramieniu 20 chromosomu, w regionie 1 prążku 3 (locus 20p13), który zawiera 2 eksony (niektóre ssaki posiadają 3), z czego drugi niemal w całości zawiera fragment kodujący białko $[3,10,11]$. Produktem translacji powyższego genu jest 253 aminokwasowe białko ulegający następnie obróbce potranslacyjnej, w wyniku której aminokwasy 1-22 od N-końcowej strony ulegają odszczepieniu, a aminokwasy 231-253 od strony C-końcowej, zostają zastąpione glikozylofosfatydyloinozytolową kotwicą, umiejscawiającą je po zewnętrznej stronie błony komórkowej neuronów $[3,9,12,13,19,20]$. Struktura drugorzędowa różni się w obu typach białka. Forma komórkowa zawiera 3 a-helisy i $2 \beta$-harmonijki, w przypadku formy patologicznej dokładna budowa jest niepewna w związku z brakiem dostatecznie oczyszczonych i niezagregowanych próbek, wiadomo jednak, że zawiera więcej struktur $\beta$-harmonijek (około $40 \%$, przy $3 \%$ w postaci komórkowej), ponadto cechuje się obniżoną rozpuszczalnością w wodzie i częściową odpornością na działanie proteinazy $\mathrm{K}$ $[15,16,18]$. Domena N końcowa PrP zawiera 4 oktapeptydy, które posiadają zdolność do wiązania dwuwartościowych jonów wykazując szczególne powinowactwo do $\mathrm{Cu}^{2+}[17,19]$.

Mechanizm leżący u podstaw przekształcenia formy komórkowej w patologiczną do dnia dzisiejszego jest przedmiotem sporu. Dwie najszerzej rozpowszechnione teorie, obejmują template assistance model oraz nucleation polimerizaton model. Pierwsza hipoteza zakłada termodynamiczny „zakaz” uniemożliwiający spontaniczną konwersję formy komórkowej (bardziej stabilnej, energetycznie uprzywilejowanej) do patogennej (formy energetycznie niedozwolonej, niewystępującej naturalnie). Aby doszło do agregacji białka prionowego, musi nastąpić etap konwersji, w którą zaangażowany jest wariant patogenny białka (powstający w wyniku mutacji lub pochodzenia egzogennego), służący jako matryca dla białka prawidłowo pofałdowanego. Dodatkowo postuluje się istnienie nieznanego czynnika „białka X” (choć nieudowodniono, że to białko), który proces katalizuje $[14,20]$. Połączenie pomiędzy dwoma białkami tworzy najpierw dimer $\operatorname{PrP}^{\mathrm{C}}-\mathrm{PrP}^{\mathrm{Sc}}$, a następnie dimer $\mathrm{PrP}^{\mathrm{Sc}}$ - PrP $\mathrm{P}^{\mathrm{Sc}}$. Przyłączenia kolejnych dimerów powodują powstawanie coraz dłuższych agregatów $\mathrm{PrP}^{\mathrm{Sc}}$, a następnie, w związku z niestabilnością rosnącej struktury, jego fragmentację i zwiększenie tempa rozprzestrzeniania się choroby, w związku rosnącą liczbą fragmentów, zdolnych do infekowania kolejnych cząstek $\operatorname{PrP}^{\mathrm{C}}[14,20]$.

Druga hipoteza - nucleation polimerization model zakłada istnienie w warunkach fizjologicznych obu form, jako termodynamicznie dopuszczalnych, jednakże aby mogła nastąpić przemiana $\operatorname{PrP}^{\mathrm{C}} \mathrm{w} \mathrm{PrP}^{\mathrm{Sc}}$ niezbędna jest jednostka konwersji, która powstaje po połączeniu kilku monomerów $\mathrm{PrP}^{\mathrm{Sc}}$. Etap ten stanowi czynnik ograniczający szybkość całego procesu i nazywany jest lag phase. Utworzony oligomer umożliwia konwersję $\mathrm{PrP}^{\mathrm{C}}$ do $\mathrm{PrP}^{\mathrm{Sc}}$. Jak zostało wspomniane wcześniej w hipotezie tej obie formy istnieją w równowadze termodynamicznej. Tworzenie się agregatów prowadzi do uprzywilejowania formy patogennej i ułatwia konwersję w nią. Po osiągnięciu odpowiedniej wielkości agregaty służą jako czynniki konwertujące białko komórkowe do formy patologicznej. Podobnie jak w przypadku pierwszej hipotezy, także i tutaj po osiągnięciu odpowiedniego rozmiaru agregaty rozpadają się na mniejsze, zwiększając tempo infekcji kolejnych cząsteczek prawidłowego białka $[14,20,21]$.

\section{KLASYFIKACJA CHORÓB PRIONOWYCH}

Choroby prionowe dzieli się w najbardziej podstawowym podziale na sporadyczne, do których należy sCJD, sFI - sporadic fatal insomnia oraz opisana niedawno prionopatia ze zmienną wrażliwością na proteazę (VPSP - variable protease-sensitive prionopathy). Drugą grupę stanowią postacie rodzinne-GSS, FFI, fCJD, a ostatnią nabyte, do których oprócz iCJD oraz vCJD należy także niewspomniane wcześniej kuru, które występuje endemicznie wśród ludu Fore zamieszkującego Papuę Nową Gwinee w związku z kanibalistycznymi zwyczajami, (za badania nad Kuru Charleton Gajdusek otrzymał w 1976 roku nagrodę Nobla) [22, 23, 27, 34].

Podstawowym podziałem w odniesieniu do postaci sporadycznej choroby Creutzfeldta-Jakoba jest podział oparty o analizę molekularną w żelu poliakrylamidowym deglikozylowanego produktu trawienia białka $\mathrm{PrP}^{\mathrm{Sc}}$ proteazą $\mathrm{K}$ (na którą to białko jest częściowo odporne), a także o polimorfizm kodonu 129 w genie PRNP, w którym to kodowanym aminokwasem może być Walina (V) albo Metionina (M). Typ 1 charakteryzuje się powstawaniem $\mathrm{w}$ procesie trawienia proteinazoodporną do- 


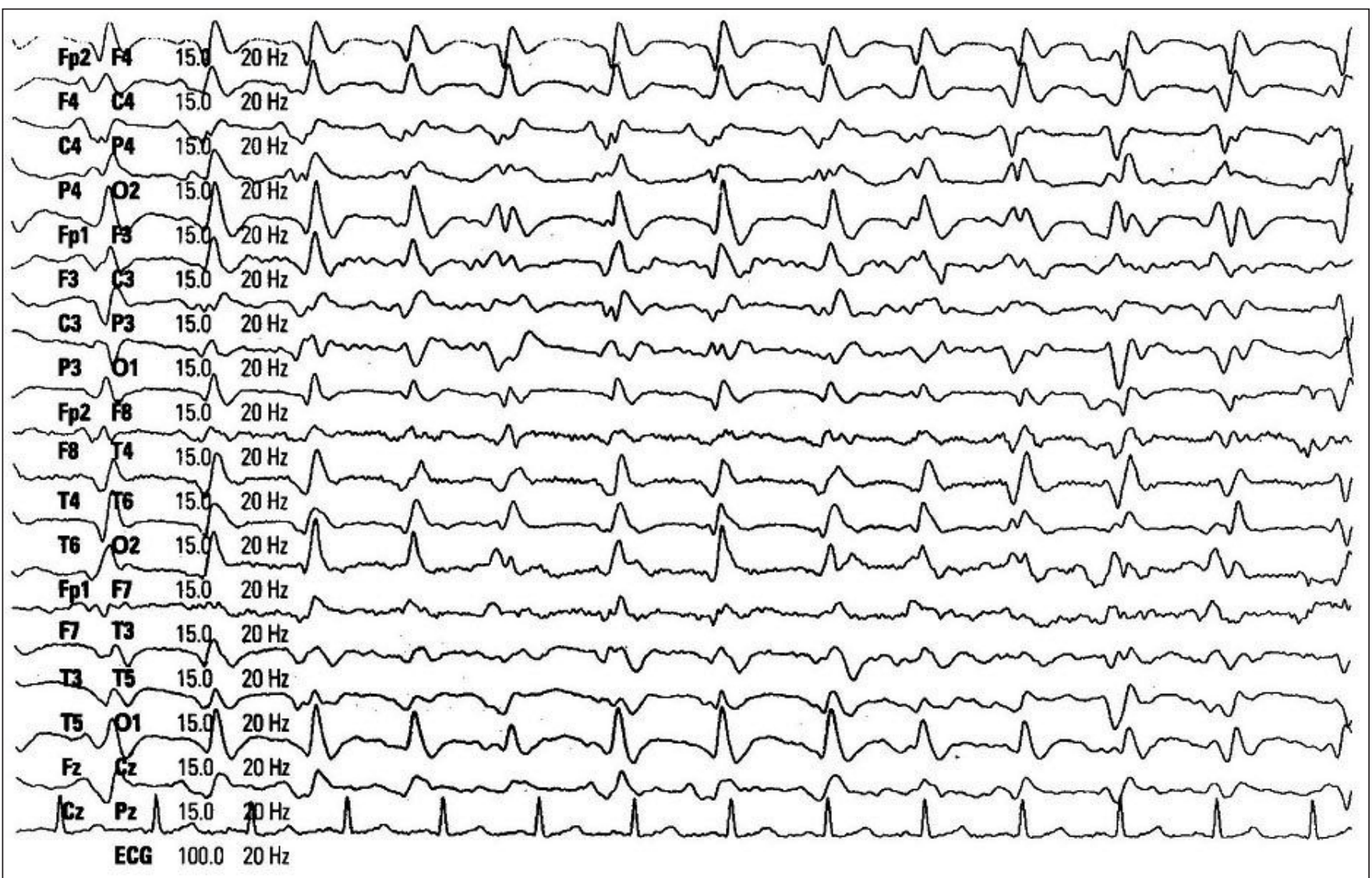

Ryc. 1. PSWC w przebiegu sCJD - charakterystyczne periodyczne zespoły fal wolnych i ostrych w zapisie EEG. Wykres otrzymano dzięki uprzejmości prof. Piotra Pawła Liberskiego z Zakładu Patologii Molekularnej i Neuropatologii Łódzkiego Uniwersytetu Medycznego

meną (PK-resistant) o masie $21 \mathrm{kDa}$, oraz punkcie przerwania trawienia przy 82 aminokwasie, natomiast typ 2 związany jest z PK-odpornym fragmentem o masie $19 \mathrm{kDa}$, którego punkt odcięcia znajduje się przy 97 aminokwasie. W odniesieniu do kryteriów molekularnych oraz polimorfizmu kodonu 129 proponuje się następujący podział: MM1/MV1 (typ miokloniczny ze ślepotą korową - zespołem Heidenhaina, klasyfikowany łącznie z uwagi na identyczną charakterystykę kliniczną), VV1, z synaptyczną akumulacją $\operatorname{PrP}^{\mathrm{sc}}$, MV2 z obecnymi blaszkami kuru i z nadzwyczajnie długim przebiegiem sięgającym ponad dwóch lat, VV2 ataktyczny (zespół Betty Brownell), oraz występujący w dwóch postaciach typ MM2 - MM2T (thalamic - wzgórzowa, identyczna pod względem klinicznym z FFI), oraz MM2C (cortical - korowa) [23-27]. Wyróżniamy także postacie mieszanie, które zarówno pod względem neuropatologicznym jak i klinicznym stanowią połączenie więcej niż jednej odmiany: MM1/MV1 + 2C, MV2K + 2C, MM2T + 2C oraz VV2 + 1. Istnieje tam dodatnia korelacja między ilością $\mathrm{PrP}^{\mathrm{Sc}}$ danego typu w konkretnych obszarach mózgu, a objawami klinicznymi występujacymi $\mathrm{w}$ niemieszanym procesie chorobowym [23-24].

\section{EPIDEMIOLOGIA SCJD}

Sporadyczna postać choroby Creutzfeldta-Jakoba stanowi około 85-90\% wszystkich przypadków CJD [28], występując ze średnią częstością na poziomie 1 do 1,5 na 1000000 osób w populacji, przy czym wraz z wiekiem odsetek ten rośnie i powyżej 50. roku życia wynosi około 3,4 na $1000000[29,30]$. W Polsce częstość występowania kształtuje się na poziomie 0,25-0,5 na 1000000 osób, jednakże w związku z brakiem odpowiedniego monitoringu i pozyskiwania danych epidemiologicznych, można domniemywać niedodiagnozowanie $[27,40]$.

\section{DIAGNOSTYKA SCJD}

Obecny złoty standard diagnostyki sCJD obejmuje rozpoznanie pewne, prawdopodobne i możliwe, w oparciu o kryteria sformułowane przez WHO w 1998 (Tab. 1) [31]. Upływ czasu udowodnił konieczność uzupełnienia powyższych metod diagnostycznych o kolejne, odkryte w międzyczasie. Największym wyzwaniem pozostaje bowiem brak możliwości nieinwazyjnego potwierdzenia diagnozy sCJD przyżyciowo. Wydaje się, iż kluczową kwestią w potrzebie aktualizacji poniższych kryteriów jest diagnostyka różnicowa sCJD obejmująca jednostki nozologiczne w których istnieje możliwość poprawy stanu klinicznego pacjenta. Powyższe wnioski potwierdzają rozszerzone standardy diagnostyczne zalecane przez CDC oraz NCJDSRU uwzględniające m.in opisane niżej markery, takie jak: białko tau, stosowanie metody RT-QuIC do wykrycia przyżyciowo $\mathrm{PrP}^{\mathrm{Sc}}$ oraz użycie diagnostyki obrazowej pod postacią MRI, w sekwencji FLAIR lub DWI (Tab. 2) [32, 33]. 


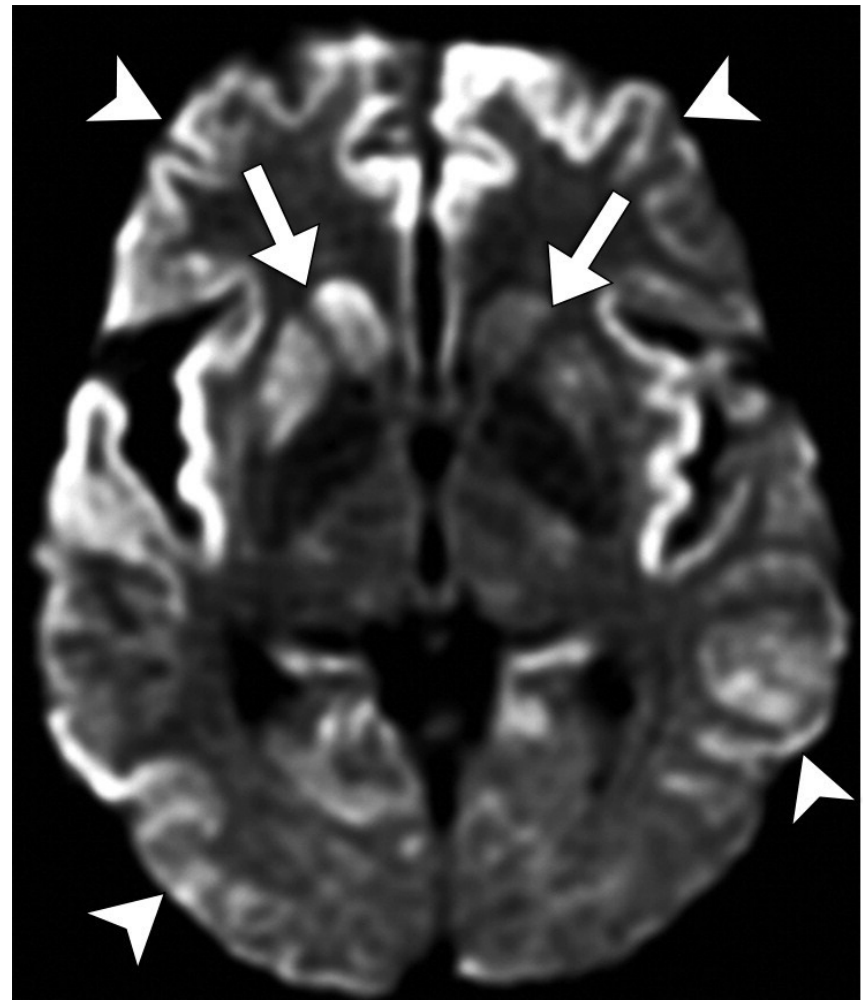

Ryc. 2. Asymetryczne hiperintensywne obszary obejmujące jądra podstawne (strzałki) i korę mózgu (groty strzałek) w projekcji MRI DWI. Cardoso Fragoso D, Lio da Mota Gonçalves Filho A, Torres Pacheco F, et al. Imaging of Creutzfeldt-Jakob disease: Imaging patterns and their differential diagnosis. RadioGraphics2017;37:234-257. Illustrations received thanks to courtesy and permission of the RadioGraphics Journal

\section{BADANIE PRZEDMIOTOWE I DIAGNOSTYKA RÓŻNICOWA}

Szybko postępująca demencja (RPD - rapidly progressive dementia) jest pierwszym jawnym klinicznie objawem sCJD, który jednak nie jest dla niej patognomomiczny, a co za tym idzie wymaga diagnostyki różnicowej. Obejmuje ona m.in inne choroby neurodegeneracyjne, jak: choroba Alzheimera, zwyrodnienie korowo-podstawne, postępujące porażenie nadjądrowe, otępienie $z$ ciałami Lewy'ego, a także przyczyny naczyniowe, jatrogenne, autoimmunologiczne, nowotworowe, metaboliczne oraz infekcyjne $[35,36]$.

$\mathrm{Z}$ uwagi na dużą odmienność fenotypową odmian sCJD, badanie neurologiczne oraz starannie zebrany wywiad z reguły nie wystarczają by określić, nawet w przybliżeniu, z którym typem choroby lekarz ma do czynienia w gabinecie. Objawy są ponadto często niejednoznacznei w zalezności od stadium choroby często wspólne dla wszystkich typów. Określenie, z którym fenotypem mamy do czynienia jest istotne dla komfortu psychicznego pacjenta $\mathrm{w}$ związku $\mathrm{z}$ bardzo istotnie różniącym się średnim czasem przeżycia (rozpiętość waha się od 3 miesięcy do ponad 2 lat) $[23,24]$.W poniższych podpunktach zebrano najważniejsze z klinicznego punktu widzenia konstelacje objawów przedmiotowych i podmiotowych w zależności od typu choroby:

1. Typ MM1/MV1 (klasyfikowane łącznie z uwagi na kliniczną nierozróżnialność) stanowi od 40 do $70 \%$ wszystkich przypadków sCJD [23, 24,26]. Początek

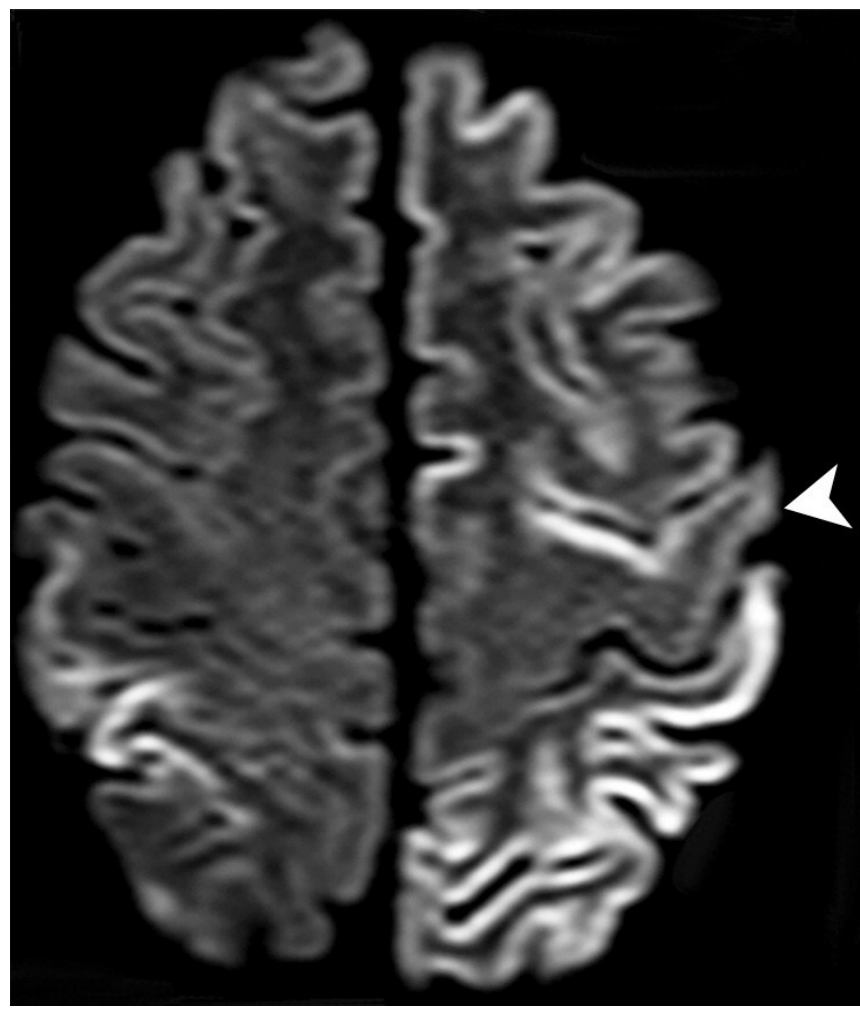

Ryc. 3. Asymetryczne hiperinstywne obszary z wyłączeniem obszaru bruzdy rolanda (grot strzałki) w projekcji MRI DWI Cardoso Fragoso D, Lio da Mota Gonçalves Filho A, Torres Pacheco F, et al. Imaging of Creutzfeldt-Jakob disease: Imaging patterns and their differential diagnosis. RadioGraphics2017;37:234-257. Illustrations received thanks to courtesy and permission of the RadioGraphics Journal

nagły, w okolicach 65.-70. roku życia, z dominującymi na początku zaburzeniami funkcji poznawczych $(70 \%$ przypadków), do których wraz z przebiegiem choroby dołączają objawy ruchowe wsród których wyróżnić należy przede wszystkim ataksję. Przebieg szybki, mediana czasu przeżycia to 4 miesiące $[23,24,34,37]$.

2. Typ VV2 stanowi 15\% diagnozowanych sCJD odznacza się występowaniem ataksji w niemalże każdym przypadku. Zaburzenia poznawcze dotyczą $1 / 3$ pacjentów, brak jest natomiast objawów korowych (afazja, apraksja). Wraz z postępem choroby dochodzi do poszerzenia spektrum objawów o mioklonie (mimo to $\mathrm{w} 1 / 3$ przypadków nieobecne) i objawy piramidowe oraz postępującą demencję. Średni wiek zachorowania to 60 lat, natomiast mediana przeżycia około 6 miesięcy $[23,24,26,2734,39]$

3. Typ MV2 odpowiada za około $8-10 \%$ przypadków i charakteryzuje się stosunkowo długą medianą przeżycia (około 16 miesięcy) przy średnim wieku zapadania na chorobę wynoszącym między 60 a 65 lat. Typowe dla choroby są występujące od początku ataksja i postępujące otępienie. [23, 26, 34].

4. Typ MM2T jest fenotypowo identyczny z FFI i charakteryzuje się bezsennością, trudnością z utrzymaniem snu, żywymi marzeniami sennymi i licznymi zaburzeniami piramidowymi oraz zaburzeniami mowy i wzroku. 
Zawsze obecne są mioklonie spontaniczne, ale także indukowane. Mediana przeżycia relatywnie długa, przekraczająca 15 miesięcy $[24,26]$.

5. Typ MM2-C i MV2 stanowią bardzo nieliczny odsetek diagnozowanych przypadków, w granicach $1 \%$. Cechują się długim czasem przeżycia sięgającym 20 miesięcy, oraz bardzo niespecyficznym przebiegiem choroby z dominującym w obrazie klicznym postępujacym otepieniem, przy jednoczesnym braku, lub rzadkim występowaniu objawów piramidowych, wzrokowych czy móżdżkowych nawet na dość zaawansowanych etapach choroby $[24,26]$.

6. Typ VV1 jest bardzo rzadki, stanowi mniej niż 1\% wszystkich diagnozowanych przypadków sCJD. Najbardziej charakterystyczną cechą jest zdecydowanie najwcześniejszy sposród wszystkich typów początek choroby - około 40. roku życia. Mediana przeżycia to 15 miesięcy, a objawy obejmują przede wszystkim otępienie typu czołowo-skroniowego. Typowo brak jest ataksji i mioklonii $[23,24,26]$.

7. Mieszany typ MM1/MV1 $+2 \mathrm{C}$ charakteryzuje się podobieństwem do MM1/MV1 co prowadzi do niedoszacowania jego występowalności. Charakterystyczna jest tu odwrotnie proporcjonalna zależność między liczbą $\mathrm{PrP}^{\mathrm{Sc}}$ typu 1 a medianą przeżycia, oraz liczbą $\mathrm{PrP}^{\mathrm{Sc}}$ typu 2 a występowaniem objawów móżdżkowych [24].

8. Typ MV2K $+2 \mathrm{C}$ oraz MM2T $+2 \mathrm{C}$ stanowią typy wydzielone na podstawie badań neuropatologicznych, bowiem tylko na ich gruncie możliwe jest takowe rozróżnienie. W aspekcie objawów klinicznych są to różnice niemożliwe do dostrzeżenia, a co za tym idzie nie są w stanie poprawić efektywności procesu diagnostycznego [24].

9. Typ VV2 + 1 odznacza się przede wszystkim występowaniem ataksji oraz zaburzeń poznawczych. W ujęciu klinicznym jest to typ podobny do VV2 [24, 26].

Powyższe informacje potwierdzają heterogenność symptomatologii sCJD, równocześnie podkreślając szczególną wagę badań molekularnych, jako jedynych mogących w definitywny sposób rozstrzygnąć o przynależności konkretnego przypadku do danego typu molekularnego sCJD.

Mając na uwadze powyższe informacje, należy także pamiętać o kilku przydatnych obostrzeniach, pozwalających ukierunkować diagnostykę w prawidłową stronę:

- w odniesieniu do 3 najpopularniejszych typów sCJD mogących stanowić nawet $>90 \%$ wszystkich przypadków, mioklonie będące jednym $\mathrm{z}$ kryteriów diagnostycznych sCJD wg WHO istotnie występują niemalże zawsze, na każdym etapie choroby, wykazując tendencję do nasilenia wraz z progresją choroby [34,37];

- objawy oczne stanowią niecharakterystyczny objaw i nie powinny wskazywać sCJD jako przyczyny zgłoszenia się pacjenta do lekarza, tym niemniej mogą one stanowić składową obrazu klinicznego, choć raczej w zaawansowanym stadium głównie w typie MM1/MV1 [34];

- afazja nie jest objawem charakterystycznym, występuje rzadko (w granicach $10 \%$ przypadków, niektóre prace pokazują dane do 30\% [38]) i jako taka powinna kierować badającego w stronę innych chorób, choć nie może ona wykluczyć rozpoznania sCJD [27, 34];
- Ataksja jest typowym objawem (ponad 90\% występowania) w początkowym stadium choroby we wszystkich typach za wyjątkiem MM1/MV1 [26,27,34,39].

\section{EEG}

ZastosowanieEEG w diagnostyce SCJD nadal pozostaje złotym standardem, w związku $\mathrm{z}$ występowaniem $\mathrm{w}$ zapisie chorych charakterystycznych, periodycznie występujących zespołów fal ostrych i wolnych (PSWC - periodic sharp wave complexes) (Ryc. 1). Pomimo tego, brak PSWC w żadnym razie nie może stanowić podstawy do zaprzestania diagnostyki w kierunku sCJD, bowiem w nawet najpowszechniej występującym typie (MM1/MV1) odsetek wyników dodatnich, wynosi, w zależności od źródła od 65 do 80\% [26, 34, 37, 41]. We wszystkich pozostałych typach sCJD PSWC właściwie nie występują, bądź znajdujemy je w marginalnej liczbie przypadków. Diagnostyka zatem musi być uzupełniona o badania o wyższej czułości. Warto pamiętać, że stosowanie benzodiazepin w leczeniu drgawek w przebiegu sCJD może prowadzić do osłabienia wzorca PSWC i w konsekwencji - fałszywie ujemnego wyniku EEG [55].

\section{BADANIE PŁYNU MÓZGOWO-RDZENIOWEGO (PMR)}

Biomarkery choroby Creutzfeldta-Jakoba badane podczas analizy płynu mózgowo rdzeniowego mogą służyć jako wartościowe narzędzie diagnostyczne tylko wówczas, kiedy analizowane są łącznie z metodami obrazowymi [5] oraz przy uwzględnieniu typu choroby. Jest tak dlatego, że polimorfizm kodonu 129 wpływa na wartość predykcyjną badań. Na chwilę obecną dostępne i szeroko stosowane markery sCJD obecne w PMR to białko 14-3-3, białko MAP- $\tau$ oraz białko S-100, oraz ich kombinacje [26].

Białko 14-3-3, a właściwie grupa białek, istotnych w procesie transdukcji sygnału i apoptozie, a przy tym wykazująca szczególną ekspresję w komórkach nerwowych [59], pojawia się w PMR w momencie masywnego uszkodzenia neuronów. Warto jednak pamiętać, że dzieje się tak nie tylko w przebiegu CJD, bowiem wirusowe zapalenie mózgu, guzy OUN oraz przerzuty nowotworowe do OUN oraz szybko postępująca choroba Alzheimera i otępiennie z ciałami Lewy'ego także mogą dawać dodatni wynik testu $[5,34,42]$. Cechą charakterystyczną badania białka 14-3-3 w PMR jest jego jakościowy charakter, jako testu western blot, co determinuje ograniczenie zastosowania tegoż markera. Te trudności mogą niebawem stać się nieaktualne w związku z rozwojem badań nad testami ELISA służącymi do oceny ilościowej białka P 14-3-3 w PMR. Badanie to jest obarczone jednak pewnymi wadami, jak np wrażliwość na fałszywie pozytywne wyniki w chorobach zapalnych, lub z powodu kontaminacji próbki PMR krwią $[57,65]$. Także brak danych dotyczących wartości odcięcia dla P 14-3-3 w teście ELISA nie pozwala na rutynowe stosowanie go w diagnostyce. W związku z faktem, że P 14-3-3 nie jest patognomomiczne dla sCJD, może być interpretowane jedynie w kombinacji z cechami klinicznymi i wynikami innych badań. Czułość badania P 143-3 waha się od 72 do 97\% natomiast specyficzność - od 52 do 95\% [5,41-54]. Stanowisko NCJDSRU z 2010 roku klasyfikuje 
oznaczenie P 14-3-3 jako badanie o najwyższej czułości spośród analizowanych (zwłaszcza w późnych etapach choroby), tj. na poziomie $86 \%$ oraz ze swoistością niższą niż białko tau (odpowiednio: 74\% i 84\%) [61].

Stosowane często wspólnie $\mathrm{z}$ białkiem 14-3-3 w diagnostyce sCJD białko $\tau$, jest powszechnie używanym markerem, którego zastosowanie nie ogranicza się jedynie do encefalopatii gąbczastych, bowiem jego podwyższone poziomy, jako markera uszkodzenia neuronów, obserwuje się także w chorobie Alzheimera oraz zwyrodnieniu czołowo-skroniowym [26]. Badania pokazują jednak, że choć fałszywie dodatnie wyniki są możliwe, to zastosowanie odpowiedniej wartości granicznej (na poziomie około $>1200-1500$ pg/ml) $[26,54,56,57]$ dla białka t-tau (total tau) oraz stosunku p-tau (ufosforylowane białko tau, phosphorylated tau protein) do t-tau mogą wyraźnie zwiększyć specyficzność i czułość tej metody. Połączenie oznaczania poziomu białka 14-3-3 wraz z tau gwarantuje wysoką czułość i specyficzność z dodatnią wartością predykcyjną na poziomie 91\% [41], ponadto takakombinacja badań może pomóc $\mathrm{w}$ różnicowaniu sCJD z chorobami spoza grupy encefalopatii gąbczastych, zwłaszcza z $\mathrm{AD}[57,59]$. Pomimo roli jaką białko 14-3-3 pełni w diagnostyce sCJD, będąc elementem złotego standardu WHO, istnieją doniesienia, że powyższa pozycja powinna ulec uzupełnieniu lub też zmianie, w obliczu równie dobrych, lub niekiedy lepszych parametrów statystycznych izolowanego oznaczenia białka t-tau, niż 14-3-3, zwłaszcza w przypadkach o mniej jednoznacznym przebiegu [42, 57]. Powyższa ocena stoi w sprzeczności z konstatacją NCJDSRU zawartą w badaniu przeglądowym z 2010 roku, iż izolowane oznaczenie białka tau, chociaż cechujące się największą swoistością spośród standardowo oznaczanych w sCJD markerów, nie może wyprzeć $\mathrm{P}$ 14-3-3 z procesu diagnostycznego, chociaż powinno zdecydowanie być $\mathrm{w}$ nim uwzględnione [61].

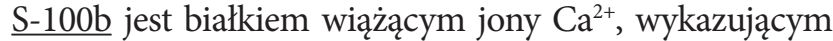
największą ekspresję $\mathrm{w}$ astrocytach otaczających naczynia krwionośne w obrębie mózgowia [60]. Podobnie jak powyższe dwa markery, także i ten nie jest patognomomiczny dla $\mathrm{sCJD}$ - jego podwyższony poziom występuje m.in w $\mathrm{AD}$, tym niemniej jego wartość jako markera stosowanego łącznie $\mathrm{z} P$ 14-3-3, czy też w kombinacji z t-tau oferuje wyższy poziom czułości i specyficzności, z dodatnią wartością predykcyjną $\mathrm{w}$ kombinacji t-tau + S-100b na poziomie PPV $=95 \%[61$, 62]. Dodatkowym atutem tego markera jest możliwość jego oznaczenia w surowicy, zwracając jednak uwagę na fakt, że wtedy czułość wynosi $83 \%$ a specyficzność $74 \%$, przy odpowiednio 82\% i 95\% w mierzeniu S-100b w CSF [62].

$\mathrm{W}$ praktyce klinicznej wykorzystując markery biochemiczne w diagnostyce sCJD warto pamiętać o kilku istotnych aspektach:

1. Nie jest w sposób jednoznaczny i niepodlegający żadnej wątpliwości stwierdzone, że łączne stosowanie wszystkich powyższych markerów w różnych kombinacjach zawsze jest przydatne $\mathrm{w}$ diagnostyce różnicowej sCJD $\mathrm{z}$ innymi jednostkami chorobowymi, tym niemniej wiele prac wskazuje na to, że takie zestawienia mogą przynieść istotne korzyści w procesie diagnostycznym $[30,42,57,61,63]$.

2. Zasadnym wydaje się pytanie, czy rola białka 14-3-3 jako podstawowego $\mathrm{w}$ diagnostyce laboratoryjnej sCJD nie powinna ulec uzupełnieniu o t-tau oraz stosunek $\mathrm{p}$-tau/ttau, a ponadto białko S-100b jako czynniki wyraźnie poprawiające prawidłowy odsetek diagnoz sCJD [30, 61]

3. Wśród nieklasycznych postaci sCJD, o przebiegu fenotypowo odmiennym od MM1 i MV1, z dłuższym czasem przeżycia, wyniki badań laboratoryjnch mogą się różnić. W praktyce klinicznej należy zatem pamiętać, że polimorfizm kodonu 129 oraz typ białka $\mathrm{PrP}^{\mathrm{Sc}}$ mogą wpływać na proces diagnostyczny, dlatego ujemne wyniki badań PMR nie mogą decydować o wykluczeniu sCJD jako potencjalnej przyczyny objawów chorego $[42,64]$.

4. Kontaminacja próbki PMR krwią może prowadzić do wyniku fałszywie dodatniego w odniesieniu do oznaczania P 14-3-3 [34].

5. Markery takie jak S-100b czy białko tau przyjmują wartość wprost proporcjonalną do skali uszkodzenia neuronów, a więc mogą służyć za czynnik rokowniczy [57].

\section{BADANIA OBRAZOWE}

Skuteczność badań obrazowych w diagnostyce sCJD jest dobrze udokumentowana, czego wyrazem jest m.in obecność MRI DWI oraz MRI FLAIR w standardzie diagnostycznym sugerowanym przez CDC oraz NCJDRSU. Poza standardem, ale $\mathrm{z}$ potwierdzoną $\mathrm{w}$ licznych badaniach skutecznością, znajduje się obrazowanie za pomocą metody PET z zastosowanie ${ }^{18} \mathrm{~F}$-fluorodeoksyglukozy.

Typowy obraz MRI w sCJD obejmuje hiperintensywne obszary w obrębie głowy jądra ogoniastego i/lub skorupy oraz w co najmniej dwóch obszarach korowych (ciemieniowy, skroniowy, potyliczny) w obrazowaniu dyfuzji (DWI) lub sekwencji tłumienia sygnału wolnego płynu (FLAIR) (Ryc. 2-3) $[32,33]$. Specyficzność MRI w diagnostyce sCJD wynosi $83 \%$, przy czułości wynoszącej 81\% [66]. Dodatkowo zastosowanie parametrycznych map ADC (apparent diffusion coefficient) w obrazowaniu DWI pozwala na osiągnięcie czułości w granicach $93 \%$ a swoistości bliskiej 100\% [67]. Zaletą stosowania badania DWI jest krótki czas trwania (1-3 min) [68], który jest istotny u pacjentów z pełnoobjawowym sCJD, w związku częstym występowaniem w obrazie klinicznym mioklonii czy drgawek, które utrudniałyby wykonanie standardowego MRI w projekcji T1 i T2. Diagnostyka różnicowa obejmuje ciężką encefalopatię z niedotlenienia niedokrwiennego, hipoglikemię, hiperamonemia, choroby infekcyjne oraz przede wszystkim wariant choroby Creutzfeldta-Jakoba, który jest, pomimo wspólnego nazewnictwa osobną jednostką chorobową o innym przebiegu i charakterystycznych objawach [69].

Coraz częściej wykorzystywanym badaniem diagnostycznym jest pozytonowa tomografia emisyjna (PET) z wykorzystaniem głównie ${ }^{18} \mathrm{~F}$-fluorodeoksyglukozy (FDG). W obrazie FDG-PET dominują ogniska hipometaboliczne, choć ich związek z obrazem w DWI/FLAIR i badaniem neuropatologicznym bywa niejasny. Część badań wskazuje na zależność pomiędzy hiperintensywnością korową w obrazie MRI-DWI a hipometabolizmem tychże miejsc w FDG-PET, zwracając jednak uwagę, że zależność ta nie występuje w kontekście jąder podstawy 
[70-72]. Mimo to, FDG-PET może zapewnić diagnostyczną korzyść w przypadkach nietypowych, gdzie obraz MRI nie jest spójny z objawami klinicznymi, wyniki badań PMR niejednoznaczne, a w EEG nie występują PSWC [71].

\section{RT-QUIC}

Podstawowy problem z diagnostyką CJD polegający na braku badania umożliwiającego przyżyciową diagnostykę, w której ponad wszelką wątpliwość wykaże się obecność $\mathrm{PrP}^{\mathrm{Sc}}$ właściwie wykluczał podstawienie definitywnego rozpoznania. Wśród kryteriów WHO/CDC/NCJDRSU dotyczących rozpoznania pewnego, jest wprawdzie biopsja mózgu, ale pomimo tego istnieją silne dowody na to, że jej skuteczność jest zaskakująco niska, zmiana diagnozy mało prawdopodobna. Ponadto jej stosowanie, jako inwazyjnej metody diagnostycznej jest kontrowersyjne, w obliczu braku skutecznej terapii sCJD oraz licznych powikłań pobiopsyjnych $[41,73]$.

Opisana w 2008 roku [74] metoda RT-QuIC (Real Time Quaking Induced Conversion) polega na cyklicznej amplifikacji białka $\mathrm{PrP}^{\mathrm{Sc}} \mathrm{w}$ badanej próbce (np. PMR) w obecności substratu w postaci $\operatorname{PrP}^{\mathrm{C}}$, przy użyciu wytrząsania. Pierwotnie uzyskaną próbkę analizowano w technice western blot, która jednak jest metodą jakościową, więc nie pozwalała na określenie ilości patologicznego białka [40]. Stosuje się zatem roztwór badanego preparatu wraz z detergentem którym jest laurynosiarczan sodu, w obecności barwnika fluorescencyjnego tioflawiny $\mathrm{T}$ (ThT) [75]. Z klinicznego punktu widzenia istotne jest, by próbka przesłana do badania nie była zanieczyszczona krwia podczas pobierania PMR, bowiem może to prowadzić do fałszywie ujemnych wyników $[76,77]$. Powyższy problem związany z kontaminacją próbki można rozwiązać poprzez zastosowanie materiału pobranego $\mathrm{z}$ błony śluzowej nosa. Istnieją dowody, że takie badanie daje lepszą czułość (od 95 do 98,5\%], niż analogiczne przeprowadzone na PMR [78, 79]. Niewątpliwą zaletu RT-QuIC jest fakt ukierunkowania go na czynnik etiologiczny, wspólny dla wszystkich chorób prionowych - białko $\mathrm{PrP}^{\mathrm{sc}}$. Wobec powyższego swoistość testu ocenia się na bliską 100\%, a czułość w zależności od źródła od 80 do 96\% [80-84]. Powyższe wyniki badań zostały uwzględnione poprzez włączenie RT-QuIC do kryteriów diagnostycznych CDC i NCJDRSU prawdopodobnej sCJD.

\section{DYSKUSJA}

Sporadyczna postać choroby Creutzfelda-Jakoba należy do chorób występujących na świecie rzadko, w związku z utrzymującą się stale zapadalnością na poziomie 1 zachorowania na 1000000 osób. Pomimo to dla klinicystów stanowi diagnostyczne wyzwanie w związku $\mathrm{z}$ bardzo zróżnicowanym obrazem klinicznym oraz brakiem opcji diagnostycznych umożliwiających definitywne, przyżyciowe potwierdzenie choroby pomimo, iż ostatnie lata przyniosły zdecydowany rozwój nowych metod, jak np RT-QuIC. Niewątpliwie kryteria diagnostyczne WHO wymagają aktualizacji, m.in w związku z faktem, że powstały ponad 20 lat temu [41]. W tym momencie bardziej zasadnym wydaje się korzystanie z kryteriów NCJDRSU i CDC, które zawierają w sobie te zawarte w WHO, ponadto uzupełniają je nowszymi rozwiązaniami diagnostycznymi. Szybka progresja choroby od momentu wystąpienia pierwszych objawów do śmierci, brak skutecznej metody leczenia przyczynowego oraz bardzo ograniczone możliwości leczenia objawowego powodują, że obecnie diagnostyka sCJD jest nakierowana na lepsze poznanie choroby i dostarczenie niezbędnych danych do przyszłych badań oraz wykluczenie chorób w przebiegu podobnych do sCJD. Należą do nich przede wszystkim inne zespoły otępienne, jak: $\mathrm{AD}$, otępienie $\mathrm{z}$ ciałami Lewy'ego oraz otępienie czołowo-skroniowe, a także przyczyny nowotworowe, infekcyjne i autoimmunologiczne. Pomimo niewątpliwie niełatwej diagnostyki sCJD, dane mówiące o blisko $2 / 3$ nieprawidłowo zinterpretowanych przez radiologów zdjęć MRI DWI pokazujących charakterystyczne dla sCJD zmiany wskazują na potrzebe edukacji na ten temat. Ponadto fakt, że blisko 1/3 wszystkich zmarlych, skierowanych na badanie autopsyjne do ośrodka badań nad prionami (US National Prion Disease Pathology Surveillance Center) miało diagnozę inną, niż CJD, a wśród wszystkich skierowanych niecałe $10 \%$ miało wyleczalne choroby OUN jest alarmujący [85].

\section{PIŚMIENNICTWO}

1. Prusiner SB. Novel proteinaceous infectious particles cause scrapie. Science. 1982;216(4542):136-44.

2. Ladogana A, Puopolo M, Croes EA, et al. Mortality from CreutzfeldtJakob disease and related disorders in Europe, Australia and Canada. Neurology. 2005;64:1586-1591.

3. Liberski PP, Bartosiewicz J. Choroby wywołane przez priony i choroba szalonych krów. Med Praktyczna. 2001;1:119-120.

4. Ironside J. Creutzfeldt-Jakob disease. Brain Pathol. 1996;6:379-388.

5. M Makowska. Choroba Creutzfeldta-Jakoba - wspókczesne metody diagnostyki. Aktualn Neurol. 2013;13(3):195-200.

6. Katscher F. It's Jakob's disease, not Creutzfeldt's. Nature. 1998;393:11.

7. Mastrianni JA. The Genetics of prion diseases. Genetics in Medicine. 2010;12:187-195.

8. Wulf MA, Senatore A, Aguzzi A. The biological function of the cellular prion protein: an update. BMC Biol. 2017;15(1):34. doi:10.1186/s12915017-0375-5.

9. Rafael Linden, Vilma R. Martins, Marco A. M. Prado et al. Physiology of the Prion Protein. Physiol Rev. 2008; 88: 673-728. doi:10.1152/ physrev.00007.2007.

10. http://www.omim.org/entry/176640?search=prnp $\% 20$ gene\&highlight=gene\%20prnp

11. Choi SH, Kim IC, Kim DS, et al.Comparative genomic organization of the human and bovine PRNP locus. Genomics. 2006;87(5):598-607. https:// doi.org/10.1016/j.ygeno.2005.12.012.

12. Wopfner F, Weidenhöfer G, Schneider R, et al. Analysis of 27 mammalian and 9 avian PrPs reveals high conservation of flexible regions of the prion protein 11. Journal of Molecular Biology. 1999; 289 (5): 1163-1178. https://doi.org/10.1006/jmbi.1999.2831.

13. Pastore A, Zagari A. A structural overview of the vertebrate prion proteins. Prion. 2007;1(3):185-97.

14. Aguzzi A , Polymenidou M. Mammalian Prion Biology One Century of Evolving Concepts. Cell 2004;116:313-327.

15. Kupfer L, Hinrichs W, Groschup MH. Prion protein misfolding. Curr Mol Med. 2009:9(7):826-35. 
16. Baldwin MA, Pan KM, Nguyen J. Spectroscopic characterization of conformational differences between PrPC and PrPSc: an alpha-helix to beta-sheet transition. PhilosTrans R Soc Lond B Biol Sci. 1994;343:435-441.

17. Eric G.B. Evans, GL Millhauser. Chapter Two - Copper- and ZincPromoted Interdomain Structure in the Prion Protein: A Mechanism for Autoinhibition of the Neurotoxic N-Terminus. Prog Mol Biol Transl. 2017:150:35-56.

18. Smirnovas V, Baron GS, Offerdahl DK, et al. Structural organization of brain-derived mammalian prions examined by hydrogen-deuterium exchange. Nat Struct Mol Biol. 2011;18(4):504-6.

19. GuestWC. Template-directed protein misfolding in neurodegenerative disease. University of British Columbia. 2012; doi : http://dx.doi. org/10.14288/1.0072694.

20. Abid K, Soto C. The intriguing prion disorders. Cell Mol Life Sci. 2006;63(19-20):2342-51.

21. Harper JD, Lansbury PT Jr. Models of amyloid seeding in Alzheimer's disease and scrapie: mechanistic truths and physiological consequences of the time-dependent solubility of amyloid proteins. Annu Rev Biochem. 1997; 66:385-407.

22. Prusiner SB, DeArmond SJ. Prion diseases and neurodegeneration. Annu Rev Neurosci. 1994; 17: 311-39.

23. Gambetti P, Kong Q, Zou W et al. Sporadic and familial CJD: classification and characterization. Br Med Bull. 2003;66:213-39.

24. Parchi P, Strammiello R, Giese A et al. Phenotypic variability of sporadic human prion disease and its molecular basis: past, present, and future. Acta Neuropathol. 2011; 121: 91-112.

25. Cali I, Castellani R, Yuan J. Classification of sporadic CreutzfeldtJakob disease revisited. Brain. 2006;129(9):2266-2277. https://doi. org/10.1093/brain/awl224.

26. Kozubski W, Liberski PP. Choroba Creutzfeldta-Jakoba i inne choroby wywoływane przez priony. In: Kozubski W, Liberski PP, Barcikowska M (eds). Neurologia podręcznik dla studentów medycyny. Warszawa: Wydawnictwo Lekarskie PZWL; 2019, 458-467.

27. Paweł P. Liberski. Pasażowalne encefalopatie gąbczaste albo choroby wywołane przez priony - podsumowanie 2007. Aktualn Neurol. 2007;7(3):158-187.

28. https://web.archive.org/web/20090506212244/http://www.cdc.gov/ ncidod/dvrd/cjd/index.htm

29. https://www.cdc.gov/prions/cjd/occurrence-transmission. html?CDC_AA_refVal=https $\% 3$ A \% 2F\%2Fw w w. cdc. gov\%2Fprions\%2Fcjd\%2Foccurance-transmisison.html

30. Lee, J, Hyeon JW, Kim SY et al. Review: Laboratory diagnosis and surveillance of Creutzfeldt-Jakob disease. J MedVirol. 2015;87:175-186. doi:10.1002/jmv.24004.

31. https://www.who.int/csr/resources/publications/bse/WHO_EMC_ ZDI_98_9/en/[data uzyskania dostępu: 5.03.2019]

32. https://www.cdc.gov/prions/cjd/diagnostic-criteria.html [data uzyskania dostępu: 5.03.2019]

33. https://www.cjd.ed.ac.uk/sites/default/files/NCJDRSU\%20 surveillance\%20protocol-april\%202017\%20rev2.pdf

34. Puoti G, Bizzi A, Forloni G et al. Sporadic human prion diseases: molecular insights and diagnosis. Lancet Neurol. 2012;11(7):618-28. doi: 10.1016/ S1474-4422(12)70063-7.

35. https://memory.ucsf.edu/cjd-differential-diagnosis [Data uzyskania dostępu: 10.03.2019]

36. Anuja P, Venugopalan V, Darakhshan N, et al. Rapidly progressive dementia: An eight year (2008-2016) retrospective study. PLOS One. 2018;13(1):e0189832. doi:10.1371/journal.pone.0189832.
37. Iwasaki Y. Creutzfeldt-Jakob disease. Neuropathology. 2017;37:174188. doi: 10.1111/neup. 12355.

38. El Tawil S, Chohan G, Mackenzie J. Isolated language impairment as the primary presentation of sporadic Creutzfeldt Jakob Disease. Acta Neurol Scand. 2017;135:316-323.

39. Baiardi S, Magherini A, Capellari S et al. Towards an early clinical diagnosis of sporadic (JD VV2 (ataxic type). J Neurol Neurosurg Psychiatry. 2017;88:764-772.

40. Ewa Golańska, Paweł P. Liberski. Wykrywanie białka prionu w płynach ustrojowych - nowe perspektywy w diagnostyce choroby CreutzfeldtaJakoba. Aktual Neuro. 2013; 13 (3): 208-216

41. Manix M, Kalakoti P, Henry M, et al. Creutzfeldt-Jakob disease: updated diagnostic criteria, treatment algorithm, and the utility of brain biopsy. Neurosurgical Focus F0. 2019;39(5).

42. Lattanzio F, Abu-Rumeileh S, Franceschini A, et al. Prion-specific and surrogate CSF biomarkers in Creutzfeldt-Jakob disease: diagnostic accuracy in relation to molecular subtypes and analysis of neuropathological correlates of $p$-tau and $A \beta 42$ levels. Acta Neuropathol. 2017;133(4):559-578.

43. Poggiolini I, Saverioni D, Parchi P. Prion protein misfolding, strains, and neurotoxicity: an update from studies on mammalian prions. Int J Cell Biol. 2013;2013:1-24. https://doi.org/10.1155/2013/910314.

44. Bahl JM, Heegaard NH, Falkenhorst G et al. The diagnostic efficiency of biomarkers in sporadic Creutzfeldt-Jakob disease compared to Alzheimer's disease. Neurobiol Aging. 2009; 30(11):1834-1841.

45. Baldeiras IE, Ribeiro MH, Pacheco Petal. Diagnostic value ofCSF protein profile in a Portuguese population ofsCD patients.J Neurol.2009;256(9):1540-1550.

46. Collins S, Boyd A, Fletcher A, et al. Creutzfeldt-Jakob disease: diagnostic utility of 14-3-3 protein immunodetection in cerebrospinal fluid. J Clin Neurosci 2000;7(3):203-208.

47. Coulthart MB, Jansen GH, Olsen E et al. Diagnostic accuracy of cerebrospinal fluid protein markers for sporadic Creutzfeldt-Jakob disease in Canada: a 6-year prospective study. BMC. 2011;11:133.

48. Forner SA, Takada LT, Bettcher BM et al. Comparing CSF biomarkers and brain MRI in the diagnosis of sporadic Creutzfeldt-Jakob disease. Neurol Clin Pract. 2015; 5(2):116-125.

49. Green AJ, Ramljak S, MullerWE et al. 14-3-3 in the cerebrospinal fluid of patients with variant and sporadic Creutzfeldt-Jakob disease measured using capture assay able to detect low levels of 14-3-3 protein. Neurosci Lett. 2002; 324(1):57-60.

50. Matsui Y, Satoh K, Miyazaki T et al. High sensitivity of an ELISA kit for detection of the gamma-isoform of 14-3-3 proteins: usefulness in laboratory diagnosis of human prion disease. BMC. 2011; Neurol 11:120.

51. McGuire LI, Peden AH, Orrú CD et al. RT-QulC analysis of cerebrospinal fluid in sporadic Creutzfeldt-Jakob disease. Ann Neurol. 2012;72(2):278-285.

52. Pennington C, Chohan G, Mackenzie J et al. The role of cerebrospinal fluid proteins as early diagnostic markers for sporadic Creutzfeldt-Jakob disease. Neurosci Lett. 2009; 455(1):56-59.

53. Sanchez-Juan P, Green A, Ladogana A et al. CSF tests in the differential diagnosis of Creutzfeldt-Jakob disease. Neurology. 2006;67(4):637-643.

54. Koscova S, Zakova Slivarichova D, Tomeckova I et al. Cerebrospinal Fluid Biomarkers in the Diagnosis of Creutzfeldt-Jakob Disease in Slovak Patients: over 10-Year Period Review. Mol neurobiology. 2017;54(8):5919-5927. doi: 10.1007/s12035-016-0128-4.

55. Marquetand J, Knake S, Strzelczyk A et al. Periodic EEG patterns in sporadic Creutzfeld-Jakob-Disease can be benzodiazepine-responsive and be difficult to distinguish from non-convulsive status epilepticus Seizure. Seizure. 2017; 53:47-50. 
56. Skillbäck T, Rosén C, Asztely F et al. Diagnostic Performance of Cerebrospinal Fluid Total Tau and Phosphorylated Tau in Creutzfeldt-Jakob Disease: Results From the Swedish Mortality Registry. JAMA Neurol. 2014;71(4):476-483. doi:10.1001/jamaneurol.2013.6455.

57. Llorens F, Karch A, Golanska E et al. Cerebrospinal Fluid Biomarker-Based Diagnosis of Sporadic Creutzfeldt-Jakob Disease: A Validation Study for Previously Established Cutoffs. Dement Geriatr Cogn Disord. 2017;43:71-80. doi: 10.1159/000454802.

58. PeckeuL, Delasnerie-LauprètreN, Brandel JPetal. Accuracy of diagnosis criteria in patients with suspected diagnosis of sporadic Creutzfeldt-Jakob disease and detection of 14-3-3 protein, France, 1992 to 2009. Euro Surveill. 2017;22(41). doi: 10.2807/1560-7917.ES.2017.22.41.16-00715.

59. Dorey A, Tholance Y, Vighetto A et al. Association of Cerebrospinal Fluid Prion Protein Levels and the Distinction Between Alzheimer Disease and Creutzfeldt-Jakob Disease. JAMA Neurol. 2015;72(3):267-275. doi:10.1001/ jamaneurol.2014.4068.

60. Wang DD, Bordey A. The astrocyte odyssey. Prog Neurobiol. 2008;86(4):342367. doi:10.1016/j.pneurobio.2008.09.015.

61. Chohan G, PenningtonC, Mackenzie JM, etalThe role of cerebrospinal fluid 143-3 and other proteins in the diagnosis of sporadic Creutzfeldt-Jakob disease in the UK: a 10-year review Journal of Neurology, Neurosurgery \& Psychiatry 2010;81:1243-1248.

62. Steinacker, P Weidehaas, K Cepek, et al. Influence of the blood-SF-barrier function on S100B in neurodegenerative diseases. Acta Neurol Scand. 2013; 128:249-256.

63. Hamlin C, Puoti G, Berri S et al. A comparison of tau and 14-3-3 protein in the diagnosis of Creutzfeldt-Jakob disease. Neurology. 2012;79(6):547-552. doi:10.1212/WNL.0b013e318263565f.

64. Golańska E, Liberski PP. Białko 14-3-3 w diagnostyce sporadycznej choroby Creutzfeldta-Jakoba. Aktualn Neurol. 2011;11(1):38-43.

65. Humpel C, Benke T. Cerebrospinal Fluid Levels of 14-3-3 Gamma: What Does It Tell Us About Sporadic Creutzfeldt-Jakob Disease? Pharmacology. 2017;100:243-245. doi: 10.1159/000479115.

66. Zerr I, Kallenberg K, Summers DM et al. Updated clinical diagnostic criteria for sporadic Creutzfeldt-Jakob disease [published correction appears in Brain. 2012;135(Pt4):1335]. Brain.2009;132(Pt 10):2659-2668. doi:10.1093/brain/ awp191.

67. RudgeP,HyareH,Green A, etal. Imaging andCSFanalyses effectively distinguish CID from its mimics. J Neurol Neurosurg Psychiatry. 2018;89:461-466.

68. Chilla GS, Tan CH, Xu C et al. Diffusion weighted magnetic resonance imaging and its recent trend-a survey. Quant Imaging Med Surg. 2015;5(3):407-422. doi:10.3978/j.issn.2223-4292.2015.03.01.

69. DC Fragoso, AL Gonçalves Filho, FT Pacheco et al. Imaging of Creutzfeldt-Jakob Disease: Imaging Patterns and Their Differential Diagnosis. RadioGraphics. 2017;37(1):234-257.

70. Mente KP, O'Donnell JK, Jones SE et al. Fluorodeoxyglucose Positron Emission Tomography (FDG-PET) Correlation of Histopathology and MRI in Prion Disease. Alzheimer Dis Assoc Disord. 2017;31(1):1-7. doi:10.1097/ WAD.000000000000018878.

71. RenardD, Castelnovo G,CollombierLetal.FDG-PET in Creutzfeldt-Jakob disease: Analysis of clinical-PET correlation. Prion. 2017;11(6):440-453.doi:10.1080/19 336896.2017.1387348.

72. KimEJ,ChoSS, Jeong BHetal.Glucosemetabolismin sporadicCreutzfeldt-Jakob disease: astatistical parametricmapping analysis of (18) F-FDG PET. Eur JNeurol. 2011;19(3):488-493. doi:10.1111/j.1468-1331.2011.03570.x.

73. Harrison XB, Zou Y, Lee AM et al. Diagnostic Value and Safety of Brain Biopsy in Patients With Cryptogenic Neurological Disease: A Systematic Review and Meta-analysis of 831 Cases. Neurosurgery. 2015;77(2): 283-295.
74. Atarashi R, Wilham JM, Christensen L et al. Simplified ultrasensitive prion detection by recombinant PrP conversion with shaking. Nat. Methods. 2008;5:211-212.

75. Atarashi R, Satoh K, Sano K et al. Ultrasensitive human prion detection in cerebrospinal fluid by real-time quaking-induced conversion. Nat Med. 2011;17:175-178 https://doi.org/10.1038/nm.2294.

76. Green AJE. RT-QulC: a new test for sporadic CJD. Practical Neurology. 2019;19:49-55.

77. Kang HE, Mo Y, Abd Rahim R. Prion Diagnosis: Application of Real-Time Quaking-Induced Conversion. Biomed Res Int. 2017;2017:5413936. https://doi.org/10.1155/2017/5413936.

78. Orrú CD, Bongianni M, Tonoli $G$ et al. A test for Creutzfeldt-Jakob disease using nasal brushings [published correction appears in N Engl J Med. 2014;371(19):1852]. N Engl J Med. 2014;371(6):519-529. doi:10.1056/ NEJMoa1315200.

79. Behaeghe 0, Mangelschots $E$, De Vil B et al. Acta Neurol Belg. 2018;118:395. https://doi.org/10.1007/s13760-018-0995-8.

80. Cheng K, Vendramelli R, Sloan A et al. Endpoint Quaking-Induced Conversion: a Sensitive, Specific, and High-Throughput Method for Antemortem Diagnosis of Creutzfeldt-Jacob Disease. J Clin Microbiol. 2016;54(7):1751-1754. doi:10.1128/JCM.00542-16.

81. Cramm M, Schmitz M, Karch A et al. Stability and reproducibility underscore utility of RT-QulC for diagnosis of Creutzfeldt-Jakob disease. Mol Neurobiol. 2016; 53(3):1896-1904.

82. McGuire LI, Peden AH, Orrú CD et al. RT-QulC analysis of cerebrospinal fluid in sporadic Creutzfeldt-Jakob disease. Ann Neurol. 2012;72(2):278-285.

83. Bongianni M, Orru C, Groveman BR et al. Diagnosis of human prion disease using real-time quaking-induced conversion testing of olfactory mucosa and cerebrospinal fluid samples. JAMA neurology. 2017; 74(2):155-162.

84. Groveman BR, Orrú CD, Hughson AG et al. Extended and direct evaluation of RT-QulC assays for Creutzfeldt-Jakob disease diagnosis. Ann Clin Transl Neurol. 2017; 4(2):139-144.

85. Paterson RW, Torres-Chae CC, Kuo AL et al. Differential diagnosis of Jakob-Creutzfeldt disease. Arch Neurol. 2012;69(12):1578-1582. doi:10.1001/2013.jamaneurol.79.

\section{ORCID:}

Tomasz Męcik-Kronenberg - 0000-0002-0618-8265

Monika Adamczyk-Sowa - 0000-0002-6894-9891

Krzysztof Wierzbicki - 0000-0001-5019-581X

Konflikt interesów

Autorzy deklarują brak konfliktu interesów.

\section{AUTOR KORESPONDUJĄCY Wojciech Ciepierski}

ul. Częstochowska 9/4 Gliwice 44-100

tel. +48507149825

e-mail:wojciech.ciepierski@med.sum.edu.pl

Nadesłano:

Zaakceptowano: 
PRACA POGLĄDOWA

REVIEW ARTICLE

\title{
PERIPHERAL NERVE GAP MANAGEMENT: ROCK-PAPER-SCISSORS
}

\author{
Liudmyla Sokurenko ${ }^{1}$, Sergiy Omelchuk' ${ }^{1}$, Serhii Herashchenko², Olena Deltsova ${ }^{2}$, Yuri Chaikovsky ${ }^{1}$ \\ 'BOGOMOLETS NATIONAL MEDICAL UNIVERSITY, KYIV, UKRAINE \\ 2FRANKIVSK NATIONAL MEDICAL UNIVERSITY, IVANO-FRANKIVSK, UKRAINE
}

\begin{abstract}
Peripheral nerves injury is one of the topical medical, social and economic problems. One of the crucial factors of surgical treatment of nerve trunks injuries ensuring their successful regeneration is the precise and tight connection of the proximal and distal stumps. To fulfill this goal a whole wealth of suturing and adhesive materials, laser and high-frequency electric welding techniques were suggested.

Currently microsurgical autoneurografting, which is considered the gold standard, is preferred in repairing nerve trunks defects. However, although effective, this surgical intervention has certain limitations, including the injury at the site of donor nerve harvesting with subsequent hypo- or anesthesia, scarring of the donor site, instances of formation of the painful neuroma of the central stump of the cutaneous nerve, lack of grafting material in the case of significant defect of the injured nerve or during reoperation, mismatch between the bundle structure of the damaged nerve trunk and the grafted segments of the cutaneous nerve. This situation stimulates the search for alternatives to autoneurografting.
\end{abstract}

KEY WORDS: peripheral nerve injury, nerve defect, autoneurografting, alloneurografting, stem cells

Wiad Lek 2019, 72, 10, 2005-2009

\section{INTRODUCTION}

Peripheral nerves injury is one of the topical medical, social and economic problems, since oftentimes they lead to disability of people of both reproductive and productive age [1]. One of the crucial factors of surgical treatment of nerve trunks injuries ensuring their successful regeneration is the precise and tight connection of the proximal and distal stumps. To fulfill this goal a whole wealth of suturing and adhesive materials, laser and high-frequency electric welding techniques were suggested [2-4].

\section{AUTONEUROGRAFTING}

Peripheral nerve injuries treatment seems quite challenging in those cases when the defect is located between the central and the peripheral nerve stumps and neurografting should be done. Currently microsurgical autoneurografting, which is considered the gold standard [5] is given preference to in repairing nerve trunks defects [6], However, although effective, this surgical intervention has certain limitations, including for instance, the injury at the site of donor nerve harvesting with subsequent hypo- or anesthesia, scarring of the donor site, instances when the painful neuroma develops at the central stump of the cutaneous nerve, lack of grafting material in the case of significant defect of the injured nerve or during reoperation, mismatch between the bundle structure of the damaged nerve trunk and the grafted segments of the cutaneous nerve $[7,8]$. This situation stimulates the search for alternatives to autoneurografting, one of which alloneurografting has been around for quite a long time, and the second one - the use of stem cells (SCs) is quite recent.

\section{ALLONEUROGRAFTING}

Alloneurografting is considered as an alternative to autografting, since it has a number of advantages. For instance, there are no limitations in the amount of grafting material, it is possible to select a nerve-donor segment matching the damaged nerve trunk in caliber and bundle structure, and no additional traumas to the cutaneous nerves are caused. The main disadvantage of alloneurografting is the immunological conflict between the recipient and the donor nerve $[9,10]$. In the $80^{\text {th }}$ of the past century a method of peripheral nerves grafting by cryopreserved allograft was created, studied in the experiment [11] and found its use in the clinical setting [12]. Cryopreservation was shown to decrease immunogenicity of the nerve tissues $[13,14]$. Experimental study of neurografting with cryopreserved allografts continued $[15,16]$ and the method was successfully used in clinical practice [17-18]. Theoretically cryopreservation made it possible to create a bank of allografts and by thorough matching of donors and recipients by the major histocompatibility complex to avoid rejection reaction. However this way seemed to be too costly and the development has gone along the path of using fresh allografts and immune suppression [19, 20]. 
As immune suppressants cyclosporin A[21], tacrolimus (FK506) [14], and rapamicyn[22] were used. It was shown that short-term immunosuppression had not created longterm tolerance [23], but was sufficient for the recipient's neurolemmocytes to migrate to the graft and replace the similar donor cells [24].

Short-term immunosuppression in the clinical setting [25-28] ensured positive outcomes of alloneurografting in patients with peripheral nerves and brachial plexus injuries. Immune suppressing therapy during allografting of the nerve trunks was further developed in the form of the so-called "co-stimulatory blockade". In work[29] allograft of the tibial nerve of mice was made, followed by a three-day administration of a monoclonal antibody to the anti-CD-40-ligand, thereby blocking the CD-40/CD40L co-stimulatory pathway. 60 days after grafting stable immunological tolerance [decreased levels of gamma-interferon, IL -4 and IL-2] was observed, which correlated with functional restoration of the $m$. extensor hallucis.

Under the conditions of sciatic nerve allografting in mice [30] immunosuppression was achieved by blocking the co-stimulatory pathways LFA-1/ICAM, CD-40/CD-40L and CD28/B7 [administration of the anti-lymphocytic antigen-1 [anti-LFA], anti- CD40-ligand [anti-CD40L] and cytotoxic T-lymphocyte immunoglobulin antigen-4 [anti- CTLA4Ig], which resulted in successful regeneration of axons.

In the study [31], blockade of co-stimulatory pathways CD-40/CD-40L, CD28/B7 and ICOS/ICOSL also led to the improved outcomes of sciatic nerve allografting in mice.

Taking into account that besides the blockade of four co-stimulatory pathways studied in alloneurografting, we currently know six more [32], it should be recognized that this strategy is quite promising and in the near future may be applied in the clinical setting.

Achieving better outcomes of alloneurografting depends both on the refining of microsurgical methods, and on implementation of molecular biology advancements into clinical practice [33]. In the study addressing the problems and achievements of alloneurografting [34], it is rightly noted that current developments in the field of neurobiology open prospects for the development of nerve allografting, which in future may surpass autoneurografting by its efficacy.

\section{USE OF STEM CELLS}

The history of using cell technologies to solve the problem of nerve trunks regeneration started with the grafting of Shwann cells (SchCs) into a nerve defect. SchCs are cells which dedifferentiate after nerve injury, transforming in fact into the unipotent stem cells [34-37]. Autologous neurolemmocytes had been cultivated in vitro, and their grafting into the conduit improved both morphological and electrophysiological indicators of the reparative process [38]. In recent years, the possibility of more efficient use of neurolemmocytes grafting has been demonstrated through the use of genetically modified cells. The authors used Schwann cells with neurotrophin-3[39], FGF-2[40], GDNF overexpression [41].
Nevertheless, the use of autologous neurolemmocytes to treat acute nerve damage may be complicated by the fact that a few weeks of cultivation may be required to obtain a sufficient amount of cells. From this perspective the idea of grafting allogenic Schwann cells looks attractive. They can be harvested in sufficient quantities, preserved in tissue banks and subjected to immunological screening for compatibility with the recipient, as is the case with organ transplantation. Such an attempt was made in the experiment, however the process of cell rejection "was way too fast" and regeneration of the nerve fibers did not substantially change compared with control [42]. Thus Schwann cells grafting, although developed in the experiment, have not found broad clinical application. And the next step was the search for stem cells [SCs] from different sources to be used as grafts of damaged peripheral nerves.

Walsh [43] found that stem cells grafting may be quite promising, useful and can enhance treatments of nerve injuries. In 2015 the World Journal of Stem Cells published a comprehensive review of the use of SC to stimulate peripheral nerves regeneration [44]. Detailed information about various sources of SCs, such as embryonal SCs, fetal SCs, neural SCs, bone marrow derived stem cells (BDMSCs), adipose tissue derived stem cells (ATDSCs), dermal SCs, hair follicle SCs (HFSCs), dental pulp SCs (DPSCs) and induced pluripotent SCs (iPSCs) was provided. The author concluded that ATDSCs represent the most promising source for grafting into the damaged nerve defect. Although alternative sources like BDMSCs, fetal SCs, HFSCs and DPSCs have large potential, their use is limited at present.

Moreover, the impact of olfactory ensheathing SCs (OESCs) and SCs from peripheral blood was also studied. Olfactory epithelium cells may be considered as a promising source for grafting into the damaged structures of CNS and PNS [45]. Grafting of Olfactory SCs into the damaged peripheral nerve revealed improved regeneration, which was confirmed by methods of morphometry [46] and electrical physiology [47]. Moreover, immunohistochemistry has proved that OESC exhibit features of the Schwann cells and myelinize the regenerating axons. After transplantation of Olfactory SCs, Schwann cells and their mixture it was found that in the latter case axon regeneration was most effective [46]. The authors believe that this is due to the stimulating impact of Olfactory SCs on Schwann cells.

Study of the spinal cord neurons reaction to nerve cutting revealed that use of OESC and even fragments of olfactory epithelium had greatly prevented neuronal death [48].

Mononuclears of human peripheral blood contain almost 0,04\% CD133+ cells. Administration of these cells into the silicon conduit placed between the central and the peripheral stumps of the rat's sciatic nerve has significantly improved outcomes of its regeneration, which was confirmed by methods of electrophysiology and morphometry. It was also found that the grafted cells had differentiated into the Schwann cells and expressed S100 protein [49].

Another promising direction in the $\mathrm{SC}$ use for repairing nerve trunks defects is their use in conduits or scaffolds in accordance with the basic concepts of neuroengineering: 1) making in the laboratory setting active complexes for 
Table 1. Strengths and limitations of neurografting methods

\begin{tabular}{|c|c|c|c|c|c|c|c|}
\hline Grafting material & $\begin{array}{l}\text { Injury at } \\
\text { the site of } \\
\text { harvesting }\end{array}$ & $\begin{array}{l}\text { Scarcity } \\
\text { of } \\
\text { grafting } \\
\text { material }\end{array}$ & $\begin{array}{l}\text { Mismatch } \\
\text { of the } \\
\text { bundle } \\
\text { structure }\end{array}$ & $\begin{array}{l}\text { Mismatch } \\
\text { of the } \\
\text { caliber }\end{array}$ & $\begin{array}{l}\text { Immunological } \\
\text { conflict and } \\
\text { the need for } \\
\text { immunosuppression }\end{array}$ & $\begin{array}{l}\text { Lengthy } \\
\text { cultivation }\end{array}$ & $\begin{array}{c}\text { Potential } \\
\text { oncotransformation }\end{array}$ \\
\hline Autografting & + & + & + & + & - & - & - \\
\hline Allografting & - & - & - & - & + & - & - \\
\hline Embryonal SCs & - & - & + & - & - & + & + \\
\hline Fetal SCs & - & - & + & - & - & + & - \\
\hline Neural SCs & + & - & + & - & - & + & - \\
\hline BDMSCs & + & - & - & & - & + & - \\
\hline ADSCs & + & - & + & - & - & + & - \\
\hline HFSCs & + & - & + & - & - & + & - \\
\hline DPSCs & - & - & + & - & - & + & - \\
\hline iPSCs & - & - & + & - & - & + & + \\
\hline
\end{tabular}

creating microenvironment corresponding to that in the nerve trunk; 2) seeding the conduits with these complexes, which are extremely important for the regeneration of nerve fibers and which are absent in the nonneural grafts [50]. Conduits have the form of small tubes of different diameters filled with biologically active substances, cells, micro- and nanofibers in various combinations.

Historically these tubes made of different materials for repairing nerve defects have been tested for over 100 years since the late $19^{\text {th }}$ century. For this purpose very different biological and non-biological materials have been tried.

Unfortunately, the analysis of experimental and clinical material led to the conclusion that this method should not be overestimated. The success of this type of operations was observed only in cases of repairing small defects in the thin nerves. However, the emergence of new materials and techniques has revived interest in the use of conduits, and the last $4-5$ years were marked by a real boom in the development of this trend [51].

The first conduits created according to the neuro engineering concept were segments of veins or biodegradable synthetic tubes enriched with growth factors and SchCs [52-55]. In Udina [56] study it was shown that regenerating axons have successfully crossed the $6-\mathrm{cm}$ defect of the peroneal nerve in rabbits. The ideal conduit should be biocompatible, biodegradable, soft and flexible, its cover should be semi-permeable, prevent fibrosis and ingrowth of connective tissue into the lumen, ensure directed growth of axons, meet the technical requirements for further manufacturing, sterilization, long term storage and surgical use [57]. In [58] silk conduits with gold nanoparticles seeded with SchCs culture were used for this purpose. Successful regeneration of the rat sciatic nerve was observed after simulation of $10 \mathrm{~mm}$ defect.

Conduits are increasingly used in clinical practice [59]. Use of neuroengineering approaches is promising [60] and in future is sure to give positive functional results along with the autoneurografts [61].
Over the last 3-4 years study of the SCs impact on peripheral nerve regeneration has continued. Thus the impact of BDMSCs [62, 63], HFSCs [64], DPSCs [65,66], cordal [67] and peripheral [68] blood has been studied. So, cell technologies are promising and can ensure improved results of nerve injury treatment. However, the number of works where cell technologies are used for the damaged nerve in clinical setting is still relatively small. Apparently, this is due to the lack of long-term results of SC transplantation and the caution regarding their possible oncotransformation or autoimmune process. Therefore, more profound fundamental studies in this area are needed.

So, each of the discussed methods has its strengths and limitations (Table 1). The current situation resembles the well- known game, which gave the title of this review. And although autoneurografting is currently the "gold standard", each of the other two methods has its own advantages and in the near future may receive the "platinum" status.

\section{CONCLUSION}

In concluding this review, it should be stated that the use of alloneurografts and conduits seeded with SCs in experiments on animals allowed to obtain positive results comparable to those of autoneurografting. In clinical practice autoneurografting remains the gold standard, however not free from limitations as discussed above. Alternative methods (alloneurografting, conduits) are successfully used for small defects of the thin nerves. Further development of immunosupression methods, reduction of immunogenicity of alloneurografts, and bioengineering will allow to create a method for bridging nerve trunks defects free from the limitations of autoneurografting and equal to it in efficacy.

\section{ABBREVIATIONS}

ATDSCs - adipose tissue derived stem cells

BDMSCs - bone marrow-derived mesenchymal stem cells 
DPSCs -- dental pulp stem cells

HFSCs - hair follicle stem cells

iPSCs - induced pluripotent stem cells

OESCs - olfactory ensheathing stem cells

SchCs- Schwann cells

SCs - stem cells

\section{REFERENCES}

1. Bekelis K, Missios S., Spinner RJ. Falls and peripheral nerve injuries: an age-dependent relationship. J Neurosurg. 2015; 123: 1223-1229.

2. Dahlin LB. Techniques of peripheral nerve repair. Scand J Surg. 2008; 97 (4): 310-316.

3. Menovsky T, Beek JF. Laser, fibrin glue, or suture repair of peripheral nerves: a comparative functional, histological, and morphometric study in the rat sciatic nerve. J Neurosurg. 2001; 95 (4): 694-699.

4. Korsak A, Likhodiievskyi V, Sokurenko L, Chaikovsky Y. New Method of Injured Nerve Repair. J Neurol Surg A Cent Eur Neurosurg. J Neurol Surg A. 2018; 79:291-295.

5. Tzou CH, Aszmann OC, Frey M. Bridging peripheral nerve defects using a single-fascicle nerve graft. Plast Reconstr Surg. 2011; 128 (4): 861-869

6. Dvali L, Mackinnon S. The role of microsurgery in nerve repair and nerve grafting. Hand Clin. 2007; 23: 73-81.

7. Al-Zer H, Kalbouneh H. Dental pulp stem cells-derived Schwann cells for peripheral nerve injury regeneration. Neural Regen Res. 2015; 10 (12): 1945-1946.

8. Li HF, Wang YR,Huo HP, Wang YX, Tang J. Neuroprotective effects of ultrasound-guided nerve growth factor injections after sciatic nerve injury. Neural Regen Res. 2012; 10(11): 1846-1855.

9. Berger A, Lassner F. Peripheral nerve allografts: Survey of present state in an experimental model of the rat. Microsurger. 1994; 15: 773-777.

10. Evans P, Midha R, Mackinnon S. The peripheral nerve allograft: A comprehensive review of regeneration and neuroimmunology. Prog in Neurobiol. 1904; 43: 187-233.

11. Chaikovskii luB, Zurnadzhi luN. Ultrastructure of a sciatic nerve allograft preserved at an ultralow temperature. Arkh Anat Histol Embryol. 1988; 95: 17-21

12. Chaikovskii luB, Galich SP, latsenko VP, DriukNF. Alloplasty of nerves using cryopreserved grafts subjected to total epineurectomy (experimentalclinica1 study) Zh Vopr Neirokhir Im N. N. Burdenko. 1987; 3: 45-49.

13. Atchabahian A, Mackinnon SE, Hunter DA. Cold preservation of nerve grafts decreases expression of ICAM-1 and class II MHC antigens. J Reconstr Microsurg 1999; 15 Suppl 4: 307-311.

14. Grand AG, Myckatyn TM, Mackinnon SE, Hunter DA, Grand AG. Axonal regeneration after cold preservation of nerve allografts and immunosuppression with tacrolimus in mice.J. Neurosurg 2002;96:924-932.

15. Ray WZ, Kale SS, Kasukurthi R, Papp EM, Johnson PJ, Santosa KB, Yan $Y$, Hunter DA, Mackinnon SE, Tung TH. Effect of cold nerve allograft preservation on antigen presentation and rejection J Neurosurg. 2011; 114 (1): 256-262.

16. Evans P, Mackinnon S, Midha R. Regeneration across cold preserved peripheral nerve allografts. Microsurgery. 1999; 19: 115-127.

17. Mackinnon S., Doolabh V, Christine B. Clinical outcome following nerve allograft transplantation. Plast Reconstr Surg. 2001; 107: 1419-1429.

18. Jabłecki J, Pielka S. Clinical applications of peripheral nerve allotransplantation. Present medical experience and review of the literature Neurol Neurochir Pol. 2004; 38: 137-142.

19. Siemionow M, Sonmez E. Nerve allograft transplantation: a review J. Reconstr. Microsurg. 2007; 23(8): 511-520.
20. Muramatsu K. Immunosuppressive effect of 15-deoxyspergualin applied to peripheral nerve allotransplantation in the rat. Exp Neurol. 1995; 132:82-90.

21. Midha R, Mackinnon S, Evans P. Comparison of regeneration across nerve allografts with temporary or continuous Cyclosporin $A$ immunosuppression. J Neurosurg. 1993; 78: 90-100.

22. Myckatyn T, Ellis R, Grand A. The effects of rapamycin in murine peripheral nerve isografts and autografts. Plast Reconstr Surg. 2001; 109: 2405-2417.

23. Brenner M. Anti-CD40 ligand monoclonal antibody induces a permissive state, but not tolerance, for murine peripheral nerve allografts Exp Neurol. 2014; 186: 59-69.

24. WhitlockE, Myckatyn T, Tong A. Dynamic quantification of host Schwann cell migration into peripheral nerve allografts Exp. Neurol. 2010; 225: 310-319.

25. Gunn S, Cosetti M, \& Roland J. (). Processed allograft: novel use in facial nerve repair after resection of a rare facial nerve paraganglioma. Laryngoscope. 2010; 120: S206.

26. Elkwood A, Holland N, Arbes S. Nerve allograft transplantation for functional restoration of the upper extremity: case series. J Spin Cord Med. 2011; 34: 1-7.

27. Stefanescu 0, Jecan R, Badoiu S. Peripheral nerve allograft, a reconstructive solution: outcomes and benefits Chirurgia. 2012; 107: 438-441.

28. Badoiu S., Lascar I, Enescu D. Peripheral nerve allografting - why and how? Chirurgia. 2014; 109: 584-589.

29. Brown D, Bishop D, Wood S. Short-Term Anti-CD40 Ligand Costimulatory Blockade Induces Tolerance to Peripheral Nerve Allografts, Resulting in Improved Skeletal Muscle Function. Plast Reconstr Surg. 2006; 117: 2250-2258.

30. Kvist M, Lemplesis V, Kanje M. Immunomodulation by costimulation blockade inhibits rejection of nerve allografts. J Periph Nerv Syst. 2007; 12: 83-90.

31. Tai CY, Weber R, Mackinnon S, Tung TH. Multiple costimulatory blockade in the peripheral nerve allograft. Neurol Res. 2010; 32: 332-336.

32. Kinnear G, Jones N, Wood K. Costimulation blockade: Current perspectives and implications for therapy Transplantation 2013; 95 : 527-535.

33. Siemionow M, Bozkurt M, Kulahci Y. Current status of composite tissue allotransplantation. Handchir Mikrochir Plast Chir. 2007; 39 (3): 145-155.

34. Battiston B, Geuna S, Ferrero M. Nerve repair by means of tubulization: Literature review and personal clinical experience comparing biological and synthetic conduits for sensory nerve repair. Microsurg. 2005; 25: 258-267.

35. Hadlock T, Sundback C, Hunter D. A. A polymer foam conduit seeded with Schwann cells promotes guided peripheral nerve regeneration. Tissue En. 2000; 6: 119-127.

36. Hood B, Levene HB, Levi AD. Transplantation of autologois Schwann cells for the repair of segmental peripheral nerve defects. Neurosurg Focus. 2009; 26: 1-5.

37. Radtke C, Akiyama Y, Lankford KL. Integration of engrafted Schwann cells into injured peripheral nerve: axonal association and nodal formation on regenerated axons. Neurosci Lett. 2005; 387: 85-89.

38. Tohill M., Mann DJ, Mantovani C. Green fluorescent protein is a stable morphological marker for Schwann cell transplants in bioengineered nerve conduits. Tissue Eng. 2004; 10: 1359-1367.

39. Pattingill LN, Minter RL, Shepherd RK. Schwann cells genetically modified to express neurotrophins promote spiral ganglion neuron survival in vitro. Neuroscience. 2008; 152: 821-828. 
40. Haastert K, Lipokatic E, Fischer M. Differentially promoted peripheral nerve regeneration by grafted Schwann cells over-expressing different FGF-2 isoforms. Neurobiol Dis. 2006; 21: 138-153.

41. Li Q, Ping P, Jiang H. Nerve conduit filled with GDNF gene-modified Schwann cells enhances regeneration of the peripheral nerve. Microsurgery. 2006; 26: 116-121.

42. Mosahebi A. Fuller P, Wiberg M. Effect of allogeneic Schwann cell transplantation on peripheral nerve regeneration. Exp Neurol. 2002; 173: 213-223.

43. Walsh S, Midha R. Practical considerations concerning the use of stem cells for peripheral nerve repair. Neurosurg Focus. 2009. 26: 2-6.

44. Fairbairn NG, Meppelink AM, Ng-Glazier J, Randolph MA, Winograd JM. Augmenting peripheral nerve regeneration using stem cells: A review of current opinion. World J Stem Cells. 2015; 7 (1): 11-26.

45. Radtke C. Aizer AA, Agulian SK. Transplantation of olfactory ensheathing cells enhances peripheral nerve regeneration after microsurgical nerve repair. Brain Res. 2009; 1254: 10-17.

46. You H, Wei L, Liu Y. Olfactory ensheathing cells enhance Schwann cellmediated anatomical and functional repair after sciatic nerve injury in adult rats. Exp Neurol. 2011; 229: 158-167.

47. Guerout N, Duclos C, Drouot L. Transplantation of olfactory ensheathing cells promotes axonal regeneration and functional racovery of peripheral nerve lesion in rats. Muscle Nerve. 2011; 43: 543-551.

48. MurrellW, Feron F, Wetzing A. Multipotent stem cells from adult olfactory mucosa. Dev Dyn. 2000; 233: 496-515.

49. Kijima $Y$, Ishikawa $M$, Sunagawa T. Regeneration of peripheral nerve after transplantation of CD133+ cells derived from human peripheral blood. J Neurosurg. 2009; 110: 758- 767.

50. Lin M, Manzano G, Gupta R. Nerve allografts and conduits in peripheral nerve repair. Hand Clin 2013; 29: 331-348.

51. Terenghi $G$, Wiberg $M, J$. Kingham P. Use of stem cells for improving nerve regeneration. Int Rev Nuerobiol. 2009; 87: 393-403.

52. Pu L, Syed S, Reid M. Effects of nerve growth factor on nerve regeneration through a vein graft across a gap. Plast. Reconstr. Surg. 1999; 104: 1379-1385.

53. Bryan D, Holway A, Wang K. Influence of glial growth factor and Schwann cells in a bioresorbable guidance channel on peripheral nerve regeneration. Tissue Eng. 2000; 6: 129-138.

54. Rodríguez FJ, Verdú E, Ceballos D, Navarro X. Nerve guides seeded with autologous schwann cells improve nerve regeneration. Exp Neurol. 2000; 161 (2): 571-584.

55. Strauch B, Rodriguez DM, DiazJ,Yu HL,Kaplan G, Weinstein DE. Autologous Schwann cells drive regeneration through a $6-\mathrm{cm}$ autogenous venous nerve conduit. J Reconstr Microsurg. 2001; 17 (8): 589-595.

56. Udina E, Rodríguez FJ, Verdú E, Espejo M, Gold BG, Navarro X. FK506 enhances regeneration of axons across long peripheral nerve gaps repaired with collagen guides seeded with allogeneic Schwann cells. Glia. 2014; 47 (2): 120-129.

57. GuX, Ding F, Williams D. Neural tissue engineering options for peripheral nerve regeneration Biomaterials. 2014; 35: 6143-6156.

58. Das S, Sharma M, Saharia D. In vivo studies of silk based gold nanocomposite conduits for functional peripheral nerve regeneration. Biomaterials. 2015; 2: 66-75.

59. Gaudin R, Knipfer C, Henningsen A. Approaches to peripheral nerve repair: generations of biomaterial conduits yielding to replacing autologouys nerve grsfts in craniomaxillofacial surgery. BioMed Res Int. 2016; 16: 1-18.

60. Zhu W, $O^{\prime}$ Brien C, $0^{\prime}$ Brien J. 3D nano/microfabrication techniques and nanobiomaterialsforneural tissue regeneration. 2014; Nanomedicine.9:859-875.
61. Muheremu $A, A 0 Q$. Past, present and future of nerve conduits in the treatment of peripheral nerve injury. BioMed Res Int. 2015; 15: 1-6.

62. Seo N, Lee SH, Ju KW, Woo J, Kim B, Kim S, Jahng JW, Lee JH () Lowfrequency pulsed electromagnetic field pretreated bone marrowderived mesenchymal stem cells promote the regeneration of crushinjured rat mental nerve. Neural Regen Res. 2018; 13 (1): 145-153.

63. Fernandes M,ValenteSG,Sabongi RG, Gomes Dos Santos JB, LeiteVM, Ulrich $H$, Nery AA, da Silva Fernandes MJ. Bone marrow-derived mesenchymal stem cells versus adipose-derived mesenchymal stem cells for peripheral nerve regeneration. Neural Regen Res. 2018; 13 (1):100-104.

64. Yamazaki A, Obara K, Tohgi N, Shirai K, Mii S, Hamada Y, Arakawa N, Aki R, Hoffman RM, Amoh Y. Implanted hair-follicle-associated pluripotent (HAP) stem cells encapsulated in polyvinylidene fluoride membrane cylinders promote effective recovery of peripheral nerve injury. Cell Cycle. 2017; 16 (20): 1927-1932.

65. HeiWH, Kim S, Park JC, Seo YK, Kim SM, Jahng JW, Lee JH. Schwann-like cells differentiated from human dental pulp stem cells combined with a pulsed electromagnetic field can improve peripheral nerve regeneration. Bioelectromagnetics. 2016;37(3):163-174.

66. Ullah I, Park JM, Kang YH, Byun JH, Kim DG, Kim JH, Kang DH, Rho GJ, Park BW. Transplantation of Human Dental Pulp-Derived Stem Cells or Differentiated Neuronal Cells from Human Dental Pulp-Derived Stem Cells Identically Enhances Regeneration of the Injured Peripheral Nerve. Stem Cells Dev. 2017; 26 (17): 1247-1257.

67. Hei WH, Almansoori AA, Sung MA, Ju KW, Seo N, Lee SH, Kim BJ, Kim SM, Jahng JW, He H, Lee JH. Adenovirus vector-mediated ex vivo gene transfer of brain-derived neurotrophic factor (BDNF) to human umbilical cord blood-derived mesenchymal stem cells(UCB-MSCS) promotescrushinjured rat sciatic nerve regeneration. Neurosci Lett. 2017; 643:111-120.

68. Farzamfar S, Naseri-Nosar M, Ghanavatinejad A, Vaez A, Zarnani AH, Salehi M. Sciatic nerve regeneration by transplantation of menstrual blood-derived stem cells. Mol Biol Rep. 2017; 44 (5): 407-412

\section{Authors' contributions: \\ According to the order of the Authorship.}

\section{ORCID numbers:}

Liudmyla Sokurenko - 0000-0002-6870-2290

Sergiy Omelchuk - 0000-0003-3678-4241

Serhii Herashchenko - 0000-0003-0958-4885

Olena Deltsova - 0000-0002-5430-8823

Yuri Chaikovsky - 0000-0002-8821-8930

\section{Conflict of interest:}

The Authors declare no conflict of interest.

\section{CORRESPONDING AUTHOR Yuri Chaikovsky}

Bogomolets National Medical University

Shevchenko blvd 13, 01601 Kiev, Ukraine

tel: +380444544988

e-mail: yuri.chaikovsky@nmu.ua

Received: 16.03 .2019

Accepted: 24.09.2019 
PRACA POGLĄDOWA

REVIEW ARTICLE

\title{
MONITOROWANIE AKTYWNOŚCI ANCA-ZALEŻNYCH UKŁADOWYCH ZAPALEŃ NACZYŃ: WYBRANE SKALE ORAZ PARAMETRY LABORATORYJNE
}

\section{MONITORING THE ACTIVITY OF ANCA-ASSOCIATED VASCULITIS: SOME QUESTIONNAIRES AND LABORATORY PARAMETERS}

\author{
Dorota Suszek', Maria Majdan' ${ }^{1}$, Karolina Widłak², Joanna Radulska², Klaudia Sowa ${ }^{2}$, Ewa Stryjecka², Aleksandra \\ Szuster², Justyna Tyburek², Daria Zalewska ${ }^{2}$ \\ 'KATEDRA I KLINIKA REUMATOLOGIII I UKŁADOWYCH CHORÓB TKANKI ŁACZNEJ, UNIWERSYTET MEDYCZNY, LUBLIN, POLSKA \\ ${ }^{2}$ KOŁO REUMATOLOGICZNE PRZY KATEDRZE I KLINICE REUMATOLOGII I UKŁADOWYCH CHORÓB TKANKI ŁĄCZNEJ, UNIWERSYTET MEDYCZNY, LUBLIN, POLSKA
}

\begin{abstract}
STRESZCZENIE
Układowe zapalenia naczyń to grupa chorób, w przebiegu których występuje zajęcie różnych narządów. Zapalenie małych naczyń może przebiegaćz obecnością przeciwciał przeciwko antygenom cytoplazmy neutrofilów (ANCA - anti-neutophil cytoplasmic antibodies) i wymaga przewlekłego, często agresywnego, leczenia immunosupresyjnego. Leczenie to powinno być dostosowane do aktywności choroby. Ocenę aktywności ANCA-zależnych układowych zapaleń naczyń (AAV) przeprowadza się w oparciu o różne kwestionariusze aktywności choroby, które uwzględniają objawy kliniczne choroby i odchylenia w badaniach laboratoryjnych. Najbardziej przydatnym kwestionariuszem jest skala BVAS wersja 3 (Birmingham Vasculitis Activity Score). W każdym przypadku należy zróżnicować, czy dany objaw AAV jest wynikiem aktywności choroby, czy nieodwracalnego uszkodzenia. Przeciwciała ANCA są u niektórych chorych predyktorem złego rokowania. Wykorzystanie tych przeciwciał w monitorowaniu aktywności AAV ma mniejsze znaczenie.
\end{abstract}

SŁOWA KLUCZOWE: zapalenie naczyń, aktywność choroby, ANCA, skale

\begin{abstract}
Systemic vasculitis is a group of diseases manifested by symptoms from many organs. ANCA-associated vasculitis (AAV) require chronic and often aggressive immunosuppressive treatment. This treatment should be adapted to the disease activity. Assessment of AAV is based on various disease activity questionnaires which contain clinical symptoms of the disease and lab results. The most useful questionnaire is BVAS version 3 (Birmingham Vasculitis Activity Score). In every patients, distinction between activity of AAV and irreversible damage is needed. ANCA antibodies are a predictor of poor prognosis in some patients. Using of these antibodies in monitoring of AAV activity has got minor importance.
\end{abstract}

KEY WORDS: vasculitis, disease activity, ANCA, scales

Wiad Lek 2019, 72, 10, 2010-2016

\section{WSTĘP}

Układowe zapalenia naczyń (UZN) to heterogenna grupa chorób, która manifestuje się objawami zajęcia różnych narządów oraz odchyleniami w badaniach laboratoryjnych.

Ocenę aktywności UZN przeprowadza się w oparciu o badanie fizykalne, parametry laboratoryjne i badania obrazowe. Ocena aktywności jest istotna w podjęciu decyzji o rozpoczęciu lub intensyfikacji leczenia immunosupresyjnego. Bardzo ważne jest rozróżnienie, czy dany objaw UZN jest konsekwencją aktywnej choroby, czy dokonanych uszkodzeń. W podjęciu decyzji o leczeniu powinno uwzględniać się nie tylko aktywność kliniczną choroby, ale również uszkodzenia narządów, czynniki rokownicze. Ocena jakości życia przez chorego jest dopełnieniem oceny klinicznej.

\section{KLASYFIKACJA UKŁADOWYCH ZAPALEŃ NACZYŃ}

Obecnie obowiązuje klasyfikacja i nazewnictwo UZN oparte na konsensusie opracowanym w trakcie konferencji w Chapel Hill w 2012r. [1]:

1. Zapalenia naczyń małych (SVV - small vessel vasculitis) obejmują tętnice śródmiąższowe, tętniczki, żyłki, włośniczki i dzielą się na:

a. zapalenia naczyń związane z przeciwciałami przeciwko antygenom cytoplazmy neutrofilów (ANCA):

- ziarniniakowatość z zapaleniem naczyń (GPA - granulomatosis with polyangiitis),

- mikroskopowe zapalenie naczyń (MPA)

- eozynofilowa ziarniniakowatość z zapaleniem naczyń (EGPA - eosinophilic granulomatosis with polyangiitis), 
b. zapalenia małych naczyń związane z kompleksami immunologicznymi:

- choroba związana z przeciwciałami przeciwko błonie podstawnej (anty-GBM),

- zapalenie naczyń związane z krioglobulinemią,

- zapalenie naczyń związane z przeciwciałami IgA (IgA vasculitis - choroba Schönleina i Henocha),

- pokrzywkowe zapalenie naczyń z hipokomplementemią (zapalenie naczyń związane $\mathrm{z}$ anty-C1q);

2. Zapalenia naczyń średnich (MVV - medium vessel vasculitis) zajmują głównie naczynia trzewne, tzn. tętnice krezkowe, wieńcowe, nerkowe:

- guzkowe zapalenie tętnic (PAN),

- choroba Kawasakiego;

3. Zapalenia naczyń dużych (LVV - large vessel vasculitis) zajmuje aortę i jej największe odgałęzienia:

- zapalenie tętnic Takayasu,

- olbrzymiokomórkowe zapalenie tętnic;

4. Zapalenia naczyń różnych (VVV - variable vessel vasculitis) - małych, średnich i dużych:

- zapalenie naczyń w chorobie Behçeta,

- zapalenie naczyń w chorobie Cogana;

5. Zapalenie naczyń jednego narządu (SOV - single-organ vasculitis):

- leukocytoklastyczne zapalenie naczyń skóry,

- zapalenie tętnic skóry,

- pierwotne zapalenie naczyń ośrodkowego układu nerwowego,

- izolowane zapalenie aorty;

6. Zapalenie naczyń w chorobie układowej:

- toczniowe zapalenie naczyń,

- reumatoidalne zapalenie naczyń,

- sarkoidalne zapalenie naczyń;

7. Zapalenie naczyń o prawdopodobnej etiologii:

- zapalenie naczyń z krioglobulinemią związane z zakażeniem $\mathrm{HCV}$,

- zapalenie naczyń związane z zakażeniem HBV,

- kiłowe zapalenie aorty,

- zapalenie naczyń z odkładaniem kompleksów immuno-

logicznych związane z lekami,

- zapalenie naczyń z ANCA związane z lekami,

- zapalenie naczyń związane z nowotworem.

\section{KLINICZNE MANIFESTACJE ANCA-ZALEŻNYCH UKŁADOWYCH ZAPALEŃ NACZYŃ}

ANCA-zależne UZN (AAV) są martwiczymi zapaleniami naczyń z obecnością skąpych nacieków immunologicznych. Występują w każdym wieku, równie często u kobiet i mężczyzn. Rozpoznanie AAV stawiane jest na podstawie obrazu klinicznego, obecności przeciwciał ANCA, badania histopatologicznego. Pierwszymi objawami UZN mogą być objawy ogólne: gorączka, utrata masy ciała, ogólne złe samopoczucie. U większości chorych występują objawy ze strony układu ruchu: mialgia, artralgia, zapalenie stawów [2]. Chorzy z GPA mają często objawy ze strony górnych dróg oddechowych (zapalenie zatok, nosa, krtani), skóry (macalna plamica) oraz zapalenia oczu, ucha środkowego. $U$ wszystkich chorych z AAV mogą występować objawy neurologiczne, najczęściej wieloogniskowa mononeuropatia, polineuropatia, udary, krwotoki śródmózgowe [3]. Zajęcie nerek przebiega głównie z zajęciem naczyń kłębuszka nerkowego i manifestuje się krwinkomoczem, białkomoczem, upośledzeniem filtracji kłębuszkowej [4]. U części pacjentów pierwszym objawem AAV są krwotoki z pęcherzyków płucnych [5].

\section{WYBRANE SKALE/KWESTIONARIUSZE OCENY CHOREGO NA AAV}

Powstało wiele narzędzi, które całościowo badają chorego na UZN. Narzędzia te służą do oceny 4 domen: aktywności choroby, uszkodzenia narządów, rokowania, jakości życia. Poniżej przedstawiono wybrane skale/kwestionariusze służące do oceny poszczególnych domen (Tab I) [6].

\section{OCENA AKTYWNOŚCI CHOROBY}

Jedną z pierwszych skal do oceny aktywności stosowanych w GPA był wskaźnik Groningen oparty na cechach klinicznych i laboratoryjnych choroby. Uwzględniał on tylko objawy, które pojawiły się w okresie ostatnich 12 tygodni. Wśród tych objawów były również wyniki badań histopatologicznych, co sprawiło, że wskaźnik ten stał się niepraktycznym narzędziem do monitorowania aktywności GPA [7].

Kolejny wskaźnik możliwy do zastosowania we wszystkich postaciach AAV był wskaźnik VAI (Vasculitis Activity Index). Był on podzielony na 3 sekcje $(\mathrm{A}, \mathrm{B}, \mathrm{C})$. W sekcji A i B oceniano objawy nowe/pogorszenie w okresie ostatnich 4 tygodni ze strony 9 układów w postaci wartości liczbowej (od 0 do 4 punktów). W sekcji C liczono punkty za objawy ogólne, gorączkę i wartości OB [8].

Najczęściej używaną skalą do oceny aktywności AAV jest skala BVAS (Birmingham Vasculitis Activity Score). Pierwsza wersja tej skali została opracowana w 1994 roku - BVAS original. Zawierała ona objawy pogrupowane w 9 układów (objawy ogólne; skórne; błony śluzowe/oczy; uszy, nos, gardło; klatka piersiowa; sercowo-naczyniowe; brzuszne; nerkowe i neurologiczne). Każdemu objawowi została przypisana odpowiednia wartość punktowa. Maksymalnie można było uzyskać 63 punkty. Zaznaczano tylko te objawy, które wystąpiły w okresie ostatnich 4 tygodni [9]. Od 1994 r. skala BVAS była kilkukrotnie modyfikowana (wersja 2 i 3 ) i walidowana w konkretnych postaciach UZN, np. BVAS/Wegener w GPA czy PVAS w zapaleniach małych naczyń u dzieci. Obecnie najczęściej stosuje się BVAS wersję 3 (BVASv3) [6] (Tab. II). Skala ta zawiera listę 66 objawów, odpowiednio zdefiniowanych, które zawarto w 9 modułach. Każdemu objawowi przyporządkowana jest określona wartość punktowa w zależności od klinicznej „rangi”, na przykład krwinkomocz ma wartość 6, bóle mięśniowe - 1, a zapalenie osierdzia - 3 punkty. Ponadto każdej grupie objawów (np. ze strony układu nerwowego 
Tabela I. Wybrane metody oceny chorych na zapalenie małych i średnich naczyń [6].

\begin{tabular}{lc}
\hline \multicolumn{1}{c}{ Domeny } & \multicolumn{1}{c}{ Zapalenie małych i średnich naczyń } \\
\hline \multicolumn{1}{c}{ Aktywność choroby } & skale BVAS (BVAS original, wersja 2 i 3; BVAS/WG), wskaźnik DEI, PVAS, PGA, VAI \\
\hline Uszkodzenie narządów & AVID, CDA, PVDI, SNVDI, VDI \\
\hline \multicolumn{1}{c}{ Rokowanie } & FFS, JVAS, VDI \\
\hline \multicolumn{1}{c}{ Jakość życia } & PROMIS, SF-36, HADS, HAQ, EQ-5D, CFS, RAPID3 \\
BVAS - Birmingham Vasculitis Activity Score; & VDI - Vasculitis Damage Index; \\
WG - Wegener Granulomatosis, & FFS - Original and Revised Five - factor score; \\
DEI - Disease Extent Index; & JVAS - Japanese Vasculitis Activity Score; \\
PVAS - Paediatric Vasculitis Activity Score; & PROMIS - Patient-Reported Outcomes Measurement Information System; \\
PGA - Physician's global assessment; & SF-36- Short Form 36; \\
VAI - Vasculitis Activity Index; & HADS - Hospital Anxiety and Depression Scale; \\
AVID-ANCA - associated Vasculitis Index of Damage; & HAQ - Health Assessment Questionnaire; \\
CDA - Combined damage assessment; & EQ-5D - EuroQol-5 Dimension; \\
PVDI - Paediatric Vasculitis Damage Index; & CFS - Chalder Fatigue Scale; \\
SNVDI - Systemic Necrotising Vasculitis Damage Index; & RAPID3 - Routine Assessment of Patient Index Data 3
\end{tabular}

czy sercowo-naczyniowego) odpowiada określona maksymalna liczba punktów oznaczana znakiem „+" [10]. Wartości punktowe są wyższe, gdy dany objaw jest zaznaczony jako nowy/pogorszenie, niż jeśli jest to objaw przetrwały. Wybieramy objawy które można przypisać aktywnemu zapaleniu naczyń. Jeśli nie ma żadnych nieprawidłowości, wybieramy opcję „brak” dla danej grupy objawów. Przy pierwszej ocenie chorego zaznaczmy dany objaw jako nowy lub pogorszenie, bez względu na to jak długo ten objaw trwał [11]. Przy każdej kolejnej ocenie aktywności choroby należy uwzględnić czas, w którym dany objaw się pojawił (ocenić jego „przetrwałość). Objawy, które wystąpiły po raz pierwszy lub uległy zaostrzeniu w okresie ostatnich 4 tygodni powinny być zaznaczone jako nowe/ pogorszenie. Objaw będzie zaznaczony automatycznie jako nowy/pogorszenie, jeśli jest to jeden z objawów, który zgodnie $\mathrm{z}$ definicją ma charakter nagły (nagła utrata wzroku, znaczny wzrost stężenia kreatyniny w surowicy). Za dobrą odpowiedź na leczenie uważa się brak objawów nowych/ pogorszenia po okresie leczenia lub zmniejszenie BVAS od pierwszej oceny o co najmniej 50\%. Zaostrzenie lub nawrót choroby definiuje się jako wzrost BVAS lub pojawienie się bądź pogorszenie co najmniej jednego "dużego" objawu. Zaznaczając dany objaw w skali BVASv3, należy rozważyć inną niż aktywność choroby jego przyczynę. To różni BVASv3 od innych skal aktywności, w których zaznaczone objawy choroby mogły być wynikiem nie tylko aktywności UZN, ale również konsekwencją trwałego uszkodzenia, infekcji czy toksyczności stosowanych leków $[6,11]$. Tylko objawy nowe/pogorszenie wymagają intensyfikacji leczenia immunosupresyjnego. Jeżeli dany objaw jest obecny powyżej $>4$ tygodni, ale trwa nie dłużej niż 3 miesiące, to zaznaczamy go jako przetrwały. Obecność objawów przetrwałych należy zaznaczyć w prawym górnym rogu kwestionariusza BVASv3. Zwykle nie wymagają one zmiany leczenia. Objawy przetrwałe nie są jednoznaczne z objawami uszkodzenia. Jako uszkodzenie definiuje się objawy trwające powyżej 3 miesięcy. Te objawy powinny być oceniane w kwestionariuszu uszkodzeń narządów VDI (Vasculitis Damage Index), a nie w BVAS. W skali BVASv3 pacjent może uzyskać maksymalnie 63 punkty (maksymalnie 33 punkty za objawy przetrwałe).

Nieco odmienną jest skala BVAS/Wegener stosowana tylko u chorych z GPA. Skoncentrowano się w tej skali na objawach charakterystycznych dla GPA, rzadsze objawy AAV zostały pominięte. Objawy nowe/przetrwałe o dużym znaczeniu klinicznym („objawy większe”) otrzymują 3 punkty, o małym znaczeniu („objawy mniejsze”) - 1 punkt. BVAS/WG zostało uzupełnione wizualną skalą analogowa (VAS) ocenianą przez lekarza oraz możliwością przypisania pacjenta do określonych stanów klinicznych: postać ciężka choroby (co najmniej 1 „objaw większy” - nowy / pogorszenie), postać ograniczona choroby (co najmniej 1 „objaw mniejszy" - nowy /pogorszenie), przetrwałej choroby (obecny co najmniej 1 objaw przetrwały, brak objawów nowych/pogorszenia), remisji (brak cech aktywności choroby, bez objawów przetrwałych i nowych/pogorszenia). Takie przyporządkowanie aktywności choroby pozwala na wyznaczenie odpowiednich kierunków leczenia $[10,12]$. BVAS zastąpiło wiele innych narzędzi służących od oceny aktywności choroby, między innymi badań obrazowych i badania histopatologicznego.

Wskaźnik rozszerzania choroby (DEI - Disease Extent Index) ocenia liczbę zajętych narządów i uzupełnia BVAS. Przeanalizowanie dwóch tych skal pokazuje, czy wysoki BVAS jest związany $\mathrm{z}$ ciężką manifestacją choroby w jednym układzie/narządzie, czy jest spowodowany chorobą wielonarządową $[9,12]$.

\section{OCENA USZKODZEŃ}

Uszkodzeniem definiuje się zmiany przewlekłe lub zbliznowacenia wywołane UZN lub związane ze stosowanym leczeniem czy obecnością chorób towarzyszących. Uszkodzenie ma charakter nieodwracalny i nie rokuje poprawy po zastosowanym leczeniu immunosupresyjnym. 
Tabela II. Skala BVAS (Birmingham Vasculitis Activity Score) - wersja 3 [6].

\begin{tabular}{|c|c|}
\hline Zaznacz "tak" jeśli wszystkie objawy są przetrwałe & tak/nie \\
\hline Czy to jest pierwsza ocena chorego? & tak / nie \\
\hline brak objawów aktywna choroba & brak objawów aktywna choroba \\
\hline $\begin{array}{c}\text { 1.Objawy ogólne } \\
\text { Bóle mięśni } \\
\text { Bóle stawów/zapalenie stawów } \\
\text { Gorączka } \geq 38^{\circ} \mathrm{C} \\
\text { Utrata masy ciała } \geq 2 \mathrm{~kg}\end{array}$ & $\begin{array}{l}\text { 6.Objawy ze strony układu } \\
\text { sercowo-naczyniowego } \\
\text { Zaburzenia rytmu } \\
\text { Zmiany zastawkowe serca } \\
\text { Zapalenie osierdzia } \\
\frac{\text { Bóle stenokardialne }}{\text {.Kardiomiopatia }} \\
\text { •Zastoinowa niewydolność serca } \\
\end{array}$ \\
\hline $\begin{array}{l}\text { 2.Objawy skórne } \\
\text { Zawały } \\
\text { Plamica } \\
\text { Owrzodzenia } \\
\text { •Zgorzel } \\
\text { Inne zmiany skórne }\end{array}$ & $\begin{array}{c}\text { 7.Objawy brzuszne } \\
\text { Zapalenie otrzewnej } \\
\text { Krwawienie z przewodu pokarmowego } \\
\text { •Niedokrwienny ból brzucha }\end{array}$ \\
\hline $\begin{array}{c}\text { 3.Objawy ze strony błon śluzowych/oczu } \\
\text { Owrzodzenia jamy ustnej } \\
\text { Owrzodzenia narządów płciowych } \\
\text { Zapalenia przydatków } \\
\text { Znaczący wytrzeszcz } \\
\text { Zapalenie twardówki/nadtwardówki } \\
\text { Zapalenie spojówek/brzegu powiek/rogówki } \\
\text { Zaburzenia ostrości widzenia } \\
\text { Nagła utrata wzroku } \\
\text { Zapalenie błony naczyniowej } \\
\text {.Zmiany w siatkówce (zapalenie/zakrzepica/wysięk/krwotoki) }\end{array}$ & $\begin{array}{c}\text { 8.Nerki } \\
\text { Nadciśnienie tętnicze } \\
\text { Białkomocz }>1+ \\
\text { •Krwinkomocz } \geq 10 \text { erytrocytów wpw } \\
\text { Stężenie kreatyniny } 125-249 \mu / l \\
\text { Stężenie kreatyniny } 250-499 \mu / l \\
\text { Stęż̇enie kreatyniny } \geq 500 \mu / l \\
\text { •Wzrost stężenia kreatyniny }>30 \% \text { lub } \\
\text { spadek klirensu kreatyniny }>25 \% \\
\text { *tylko liczone przy pierwszej ocenie }\end{array}$ \\
\hline $\begin{array}{l}\text { 4.Nos, uszy, jama ustna } \\
\text { Krwista wydzielina z nosa/strupy/owrzodzenia/ziarnina } \\
\text { Zajęcie zatok przynosowych } \\
\text { Zwężenie podgłośniowe krtani } \\
\text { Przewodzeniowa utrata słuchu } \\
\text { •Odbiorcza utrata słuchu }\end{array}$ & $\begin{array}{c}\text { 9.Układ nerwowy } \\
\text { Bóle głowy } \\
\text { Zapalenie opon mózgowo-rdzeniowych } \\
\text { Organiczne zaburzenia świadomości } \\
\text { Padaczka } \\
\frac{\text {-Incydent naczyniowo-mózgowy }}{\text {-Uszkodzenia rdzenia kręgowego }} \\
\text { Porażenie nerwu czaszkowego } \\
\text { Czuciowa obwodowa neuropatia } \\
\text {-Wieloogniskowa mononeuropatia }\end{array}$ \\
\hline $\begin{array}{c}\text { 5.Klatka piersiowa } \\
\text { Świszczący oddech } \\
\text { Guzki lub jamy } \\
\text { Wysięk w opłucnej/zapalenie opłucnej } \\
\text { Nacieki zapalne } \\
\text { Zmiany wewnątrzoskrzelowe } \\
\text { •Masywne krwioplucie/krwawienie śródpęcherzykowe } \\
\text {.Niewydolność oddechowa }\end{array}$ & 10.Inne objawy \\
\hline
\end{tabular}

- objawy duże

Najczęstszą skalą do oceny uszkodzeń jest skala VDI (Tab. III). Każdy objaw utrzymujący się powyżej 3 miesięcy jest traktowany jako trwały (uszkodzenie).

\section{OCENA ROKOWANIA}

Do oceny rokowania można wykorzystać wskaźniki lub skale: FFS (Five Factor Scores), JVAS (Japanese Vasculitis Activity Score) czy VDI (Vasculitis Damage Index). Wskaźnik FFS był oceniany u chorych na PAN, MPA, EGPA (nie był walidowany dla GPA). Uwzględnia 5 zmiennych: dysfunkcję nerek, białkomocz, zajęcie serca, przewodu pokarmowego i CUN [10]. Zrewidowana wersja FFS jest wykorzystywana do oceny rokowania u chorych na GPA. Czynnikiem złej prognozy jest wiek powyżej 65 r.ż., a czynnikiem dobrego rokowania zajęcie górnych dróg oddechowych. Skala VDI silnie koreluje z ryzykiem śmierci. Wartość VDI $\geq 5$ dotyczy $1 / 3$ pacjentów z AAV i wiąże się z ryzykiem śmierci u $12,4 \%$ chorych po 2 latach 
Tabela III. Wskaźnik uszkodzenia narządów VDI (Vasculitis Damage Index) [6].

\begin{tabular}{|c|c|}
\hline $\begin{array}{c}\text { Objawy } \\
\text { nieobecne / obecne }\end{array}$ & nieobecne / obecne \\
\hline $\begin{array}{c}\text { 1. Objawy mięśniowo-szkieletowe } \\
\text { Nieobecne } \\
\text { Znaczące zaniki mięśniowe lub osłabienie } \\
\text { Zniekształcające/nadżerkowe zapalenie stawów } \\
\text { Osteoporoza/złamanie kompresyjne } \\
\text { Martwica aseptyczna } \\
\text { Zapalenie szpiku kostnego }\end{array}$ & $\begin{array}{c}\text { 7. Choroby naczyń obwodowych } \\
\text { Nieobecne } \\
\text { Brak tętna na jednej kończynie } \\
\text { Drugi epizod braku tętna na jednej kończynie } \\
\text { Zwężenie dużego naczynia } \\
\text { Chromanie >3 miesięcy } \\
\text { Niewielka utrata tkanki } \\
\text { Utrata znacznej części tkanki } \\
\text { Kolejna utrata znacznej części tkanki } \\
\text { Powikłana zakrzepica żylna }\end{array}$ \\
\hline $\begin{array}{c}\text { 2. Objawy skórne/błon śluzowych } \\
\text { Nieobecne } \\
\text { Łysienie } \\
\text { Skórne owrzodzenia } \\
\text { Owrzodzenia w jamie ustnej }\end{array}$ & $\begin{array}{c}\text { 8.Objawy żołądkowo-jelitowe } \\
\text { Nieobecne } \\
\text { Zawał/resekcja jelita } \\
\text { Niewydolność krezki/zapalenie trzustki } \\
\text { Przewlekłe zapalenie otrzewnej } \\
\text { Zwężenie przełyku/operacja przełyku }\end{array}$ \\
\hline $\begin{array}{c}\text { 3. Objawy ze strony dróg oddechowych } \\
\text { Nieobecne } \\
\text { Utrata słuchu } \\
\text { Blokada nosa/przewlekłe krwawienie/zestrupienie } \\
\text { Zapadnięcie przegrody nosa/perforacja przegrody nosa } \\
\text { Przewlekłe zapalenie zatok/zmiany radiologiczne } \\
\text { Zwężenie podgłośniowe krtani }\end{array}$ & $\begin{array}{c}\text { 9.Nerki } \\
\text { Nieobecne } \\
\text { GFR } \leq 50 \% \\
\text { Białkomocz } \geq 0,5 \mathrm{~g} / \text { dobę } \\
\text { Schyłkowa niewydolność nerek }\end{array}$ \\
\hline $\begin{array}{c}\text { 4. Objawy oczne } \\
\text { Nieobecne } \\
\text { Zaćma } \\
\text { Zmiany siatkówkowe } \\
\text { Zanik nerwu wzrokowego } \\
\text { Upośledzenie widzenia/podwójne widzenie } \\
\text { Ślepota w jednym oku } \\
\text { Ślepota w drugim oku } \\
\text { Destrukcja ściany oczodołu }\end{array}$ & $\begin{array}{l}\text { 10. Objawy neuropsychiatryczne } \\
\text { Nieobecne } \\
\text { Organiczne zaburzenia świadomości } \\
\text { Duże psychozy } \\
\text { Drgawki } \\
\text { Incydent naczyniowo-mózgowy } \\
\text { Drugi incydent naczyniowo-mózgowy } \\
\text { Uszkodzenie nerwu czaszkowego } \\
\text { Obwodowa neuropatia } \\
\text { Poprzeczne zapalenie rdzenia }\end{array}$ \\
\hline $\begin{array}{c}\text { 5. Objawy płucne } \\
\text { Nieobecne } \\
\text { Nadciśnienie płucne } \\
\text { Włóknienie płuc } \\
\text { Zawał płucny } \\
\text { Przewlekła astma } \\
\text { Przewlekłe trudności z oddychaniem } \\
\text { Przewlekła niewydolność oddechowa }\end{array}$ & $\begin{array}{c}\text { 11.Inne objawy } \\
\text { Nieobecne } \\
\text { Niewydolność gonad } \\
\text { Niewydolność szpiku kostnego } \\
\text { Cukrzyca } \\
\text { Chemiczne zapalenie pęcherza moczowego } \\
\text { Choroba nowotworowa } \\
\text { Inne }\end{array}$ \\
\hline $\begin{array}{c}\text { 6. Objawy ze strony układu } \\
\text { sercowo-naczyniowego } \\
\text { Nieobecne } \\
\text { Choroba wieńcowa/angioplastyka } \\
\text { Zawał serca } \\
\text { Kolejny zawał serca } \\
\text { Kardiomiopatia } \\
\text { Zmiany zastawkowe serca } \\
\text { Ciśnienie rozkurczowe } \geq 95 \text { lub stosowanie leków hipotensyjnych }\end{array}$ & \\
\hline
\end{tabular}

trwania choroby. Skala BVAS jest również skalą rokowniczą - wyższy BVAS łączy się zwiększą śmiertelnością i ryzykiem nawrotów [6]. Według badań przeprowadzonych przez Solans-Laque i Li skala BVAS i wskaźnik FFS okazały się najlepsze do oceny aktywności i rokowania u chorych z AAV $[9,13]$.

\section{OCENA JAKOŚCI ŻYCIA}

U większości chorych z przewlekłą chorobą zapalną jakość życia jest obniżona. Najczęściej do oceny jakości życia wykorzystuje się kwestionariusz SF-36. Co raz więcej mówi się o skali AAV-PRO (ANCA-associated vasculitis patient-re- 
ported outcomes), która składa się z 29 objawów/problemów pogrupowanych w 6 grup: objawy narządowo-swoiste, objawy ogólne, działania niepożądane leczenia, problemy związane z codziennym funkcjonowaniem chorego [14].

\section{ZNACZENIE BADAŃ LABORATORYJNYCH W MONITOROWANIU AKTYWNOŚCI AAV}

Testy laboratoryjne są często wykorzystywane do oceny aktywności AAV. Wskaźniki stanu zapalnego (OB., CRP) są czułymi, ale mało swoistymi markerami laboratoryjnymi i nie pozwalają zróżnicować pomiędzy zaostrzeniem AAV, infekcją czy chorobą nowotworową [15]. Według Kalsh i wsp. tylko CRP wysokiej czułości może być przydatne do oceny aktywności AAV [16]. Również często obecna eozynofilia w EGPA nie koreluje z aktywnością tej postaci zapalenia naczyń [17]. Pewne znaczenie w ocenie aktywności AAV mają składowe dopełniacza, szczególnie składowa C5a. Gou i wsp. wykazali wyższe stężenie C3a, C5a i properdyny u chorych $z$ aktywnym zapaleniem naczyń [18]. Niski poziom składowych C3 dopełniacza na początku choroby wiąże się z gorszym rokowaniem i przeżyciem nerkowym [19]. U 30-50\% chorych z AAV obecny jest czynnik reumatoidalny (RF). Wykazano, że obecność RF jest czynnikiem złego rokowania, a miano RF może korelować z aktywnością choroby. U chorych z obecnym RF stwierdzono wyższe OB, CRP i BVAS. Nie wykazano korelacji pomiędzy wartością RF a mianem ANCA [20]. Przeciwciała anty-CCP występują tylko u nielicznych chorych na AAV. Anty-CCP mogą być przydatnym markerem do różnicowania pomiędzy seropozytywnym RZS a zapaleniem naczyń z obecnością RF [21]. U chorych na RZS i objawami zapalenia naczyń miana anty-CCP są wyższe niż u chorych bez tych objawów [22]. Przeciwciała ANCA są szeroko stosowane w diagnostyce AAV, ale tylko $\mathrm{w}$ niektórych przypadkach mogą być przydatne do oceny aktywności AAV. W 2017 r. przedstawiono rekomendacje dotyczące diagnostyki laboratoryjnej przeciwciał ANCA. Wśród testów diagnostycznych jako pierwszy zaleca się wysokiej jakości test immunoasay. W przypadku wyniku negatywnego i silnego podejrzenia AAV należy użyć innego testu immunoassay lub testu immunofluorescencyjnego. Wynik negatywny nie wyklucza rozpoznania AAV [23]. Użycie przeciwciał ANCA do monitorowania aktywności choroby i podjęcia decyzji o leczeniu jest kontrowersyjne. Największą przydatność mają te przeciwciała w przewidywaniu zaostrzeń nerkowych. Obserwowano również zwiększenie miana ANCA u chorych z nawrotem choroby po leczeniu rytuksymabem. Nie obserwowano takiej zależności po leczeniu cyklofosfamidem czy azatiopryną [24]. Według zaleceń EULAR decyzja o podjęciu leczenia chorego na AAV powinna być podjęta w oparciu o aktywność kliniczną choroby, a nie miano ANCA [25]. Zachęcające są wyniki badań Monacha i wsp., które wykazały przydatność oznaczeń CXCL13, metyloproteinazy 3 (MMP-3) i tkankowego inhibitora metaloproteinazy 1 (TIMP-1) w monitorowaniu aktywności AAV. Markery te okazały się bardziej swoiste niż OB. i CRP. Duże nadzieje w ocenie aktywności UZN i ocenie ryzyka nawrotów wiąże się z oceną stężenia w moczu che- motaktycznej dla monocytów ludzkiej proteiny 1 (MCP-1) $[26,27]$. Coraz więcej danych w piśmiennictwie podkreśla znaczenie wskaźnika neutrofilowo-limfocytowego (NRL) w monitorowaniu aktywności wielu chorób autoimmunologicznych. Ahn i wsp. wykazali istotną korelację NRL $\mathrm{z}$ aktywnością AAV mierzoną skalą BVAS oraz ryzykiem nawrotów UZN [28].

Cały czas istnieje potrzeba poszukiwania takich biomarkerów, które pozwolą na ocenę aktywności AAV, rozróżnienie pomiędzy zaostrzeniem AAV a inną przyczyną stanu zapalnego, będą pomocne w przewidywaniu ryzyka nawrotów choroby i odpowiedzi na leczenie.

\section{PODSUMOWANIE}

Aktywność AAV odzwierciedla stopień stanu zapalnego i uzasadnia potrzebę intensyfikacji leczenia. Uszkodzenie jest konsekwencją zapalenia i nie odpowiada na leczenie. Skale BVAS i VDI są kluczowe do oceny aktywności i uszkodzenia. Obie skale charakteryzują się dużą czułością i przewagą nad innymi narzędziami służącymi do oceny aktywności/uszkodzenia AAV. Przeciwciała ANCA są u niektórych chorych predyktorem złego rokowania. Znaczenie tych przeciwciał w monitorowaniu aktywności AAV ma mniejsze znaczenie.

\section{PIŚMIENNICTWO}

1. Jennette JC, Falk RJ, Bacon PA et al. 2012 revised International Chapel Hill Consensus Conference Nomenclature of Vasculitides. Arthritis Rheum. 2013;65(1):1-11.

2. Jeleniewicz R, Suszek D, Majdan M. Objawy ze strony narządu ruchu w grupie chorych na ziarniniakowatość zzapaleniem naczyń. Wiad Lek. 2018;71:17-20.

3. Zheng Y, Zhang Y, Cai M et al. Central Nervous System Involvement in ANCA-Associated Vasculitis: What Neurologists Need to Know. Front Neurol. 2018; 9: 1166.

4. Haubitz M. Renal manifestation in ANCA-associated vasculitis. Dtsch Med Wochenschr. 2018;143(2):79-88.

5. Okazaki T, Shinagawa S, Mikage H. Vasculitis syndrome - diagnosis and therapy. J Gen Fam Med. 2017;18(2):72-78.

6. Ponte C, Águeda AF, Luqmani RA. Clinical features and structured clinical evaluation of vasculitis. Best Pract Res Clin Rheumatol. 2018; 32(1):31-51.

7. Kellenberg CG: Criteria for disease activity in Wegener's granulomatosis: a requirement for longitudinal clinical studies. APMISSuppl. 1990; 19;37-39.

8. Whiting-O'Keefe QE. Validity of a vasculitis activity index for systemic necrotizing vasculitis. Arthritis Rheum. 1999;42(11):2365-2371.

9. Li S, Zhang Q, Zhou H. Comparison of disease activities and extent measurements for anti-neutrophil cytoplasmic autoantibodyassociated vasculitis. Journal of Peking University (Health Sciences). 2018;50(6):1022-1026.

10. Madej M. Ocena aktywności zapalenia naczyń. Przegl Reumatol. 2008; $3 / 4(21-22), 9$.

11. in:https://rheuma.charite.de/fileadmin/user_upload/microsites/ ohne_AZ/m_cc13/rheuma/Templates/BVAS_v3.0.pdf

12. Flossmann 0, de Groot PK, Jayne D et al. Development of comprehensive disease assessment in systemic vasculitis. Ann Rheum Dis. 2007;66(3):283-292. 
13. Solans-Laqué R, Rodriguez-Carballeira $M$, Rios-Blanco JJ. Comparison of the birmingham vasculitis activity score and the five factors score to assess survival in anca-associated vasculitis. Arthritis Care Res (Hoboken). 2019, 29.

14. Robson JC, Dawson J, Doll H et al. Validation of the ANCA-associated vasculitis patient-reported outcomes (AAV-PRO) questionnaire. Ann Rheum Dis. 2018;77(8):1157-1164.

15. Csernok E, Bossuyt X. Investigations in systemic vasculitis. The role of the laboratory. Best Pract Res Clin Rheumatol. 2018;32(1):52-62.

16. Kälsch Al, Csernok E, Münch D. Use of highly sensitive C-reactive protein for follow-up ofWegener's granulomatosis. JRheumatol. 2010;37(11):2319-2325.

17. Grayson PC, Monach PA, Pagnoux C. Value of commonly measured laboratory tests as biomarkers of disease activity and predictors of relapse in eosinophilic granulomatosis with polyangiitis. Rheumatology (0xford). 2015;54(8):1351-1359.

18. Gou SJ, Yuan J, Chen $M$ et al. Circulating complement activation in patients with anti-neutrophil cytoplasmic antibody-associated vasculitis. Kidney Int. 2013;83(1):129-137.

19. Crnogorac M, Horvatic I, Kacinari P et al. Serum C3 complement levels in ANCA associated vasculitis at diagnosis is a predictor of patient and renal outcome. J Nephrol. 2018; 31:257-262.

20. WatanabeS, Gono T, Nishina Ket al. Rheumatoid factor is correlated with disease activity and inflammatory markers in antineutrophil cytoplasmic antibody-associated vasculitis. BMC Immunol. 2017;18:53.

21. Tervaert JW, Damoiseaux J, Boomsma MM et al. Absence of anti-cyclic citrullinated peptide antibodies in antineutrophil cytoplasmic antibodyassociated vasculitis. Arthritis Rheum. 2002;46(3):849-850.

22. Regent $A$, LofekS,DibHetal. Identification oftargetantigens of anti-endothelial antibodies in patients with anti-neutrophil cytoplasmic antibody-associated vasculitides: a proteomic approach. Clin Immunol. 2014;153:123-135.

23. Bossuyt X, Cohen Tervaert JW, Arimura Y et al.: Revised 2017 international consensus on testing of ANCA in small vessel vasculitis. Nat Rev Rheumatol 2017;13:683-692.

24. Fussner LA, Hummel AM, Schroeder DR et al. Factors determining the clinical utility of serial measurements of antineutrophil cytoplasmic antibodies targeting proteinase 3. Arthritis Rheumato. 2016;68:1700-1710.
25. Mukhtyar C, Guillevin L, Cid MC et al. EULAR recommendations for the management of primary small and medium vessel vasculitis. Ann Rheum Dis. 2009;68:310-317.

26. Monach PA, Warner RL, Tomasson $\mathrm{G}$ et al. Serum proteins reflecting inflammation, injury and repair as biomarkers of disease activity in ANCA-associated vasculitis. Ann Rheum Dis. 2013;72:1342-1350.

27. Tam F, George A, Sanders JS et al. Urinary monocyte chemoattractant protein-1 (MCP-1) is a marker of active renal vasculitis. Nephrol Dial Transplantation. 2019 (11):2761-2768.

28. Ahn SS, Jung SM, Song JJ et al. Neutrophil to lymphocyte ratio at diagnosis can estimate vasculitis activity and poor prognosis in patients with ANCA-associated vasculitis: a retrospective study. BMC Nephrol. 2018;19(1):187.

\section{ORCID:}

Dorota Suszek - 0000-0001-8131-6709

Maria Majdan - 0000-0002-4345-1675

\section{Konflikt interesów}

Autorzy deklaruja brak konfliktu interesów.

\section{AUTOR KORESPONDUJĄCY Dorota Suszek}

Katedra i Klinika Reumatologii i Układowych Chorób Tkanki Łącznej

ul. Jaczewskiego 8, 20-954 Lublin

tel.: 81-7244790; 605920107

email: suszekdorota@wp.pl

Nadesłano: 05.09.2019

Zaakceptowano: 07.10.2019 
PRACA POGLĄDOWA

REVIEW ARTICLE

\title{
THE IMPACT OF AGRICULTURAL PRODUCTION FACTORS ON CHILDREN'S HEALTH
}

\author{
Sergiy 0. Chertov' ${ }^{1}$ Olena M. Batyhina' ${ }^{2}$, Andrii 0. Harkusha ${ }^{3}$ \\ 'DEPARTMENT OF SURGICAL AND PROPAEDEUTIC DENTISTRY, ZAPORIZHZHIA STATE UNIVERSITY, ZAPORIZHZHIA, UKRAINE \\ 2DEPARTMENT OF CONSTITUTIONAL, ADMINISTRATIVE, ENVIRONMENTAL AND LABOUR LAW, POLTAVA LAW INSTITUTE OF YAROSLAV MUDRYI \\ NATIONAL LAW UNIVERSITY, POLTAVA, UKRAINE \\ 3DEPARTMENT OF CIVIL, COMMERCIAL AND ENVIRONMENTAL LAW, POLTAVA LAW INSTITUTE OF YAROSLAV MUDRYI NATIONAL LAW UNIVERSITY, \\ POLTAVA, UKRAINE
}

\begin{abstract}
Introduction: According to the decisions of the European Court of Human Rights and the regulations of the World Health Organization, the right to health and the right to life are interconnected. However, the right to life may be a starting point in the context of the right to health. The issue of ensuring the right to life and health protection of certain sections of society, in particular, children working in agriculture, is on the agenda.

The aim: To analyze the provisions of international law and scientific literature on the effects of workplace factors on the health of children working in agriculture and to examine the existing limitations of such effects.

Materials and methods: International acts, data of international organizations and conclusions of scientists have been examined and used in the study. The study also summarizes information from scientific journals and monographs from a medical and legal point of view with scientific methods. The article is based on dialectical, comparative, analytic, synthetic and comprehensive research methods.

Conclusions: In the context of preserving the right to health and the right to life, children are the most vulnerable categories of agricultural workers. Working conditions and workplace safety in agriculture for minors have to be properly organized. The level of traumatization, occupational morbidity and above all, the standard of health of child labourers in agriculture depend on the level of proper organization of occupational safety. In many countries, the state of the working environment and safety for child labourers in agriculture and, accordingly, the standard of their health remain unsatisfactory.
\end{abstract}

KEY WORDS: agriculture, human health, child labour, working conditions

Wiad Lek 2019, 72, 10, 2017-2023

\section{INTRODUCTION}

It is scientifically proven that agriculture is one of the most insalubrious work sectors at any age $[1,2,3,4,5]$, but this area is most dangerous for children because of their physical and mental development. For historical reasons, a large number of minors are employed in the agricultural sector. The latest global estimates indicate that 152 million children - 64 million girls and 88 million boys - are in child labour globally, accounting for almost one in 10 of all children worldwide [6]. For instance, according to statistics in the field of agriculture, $46 \%$ of all employed children work in urban areas of Malawi and 75\% - in rural areas [7].

Child labour is most commonly used in Africa, South and West Asia. Important factors for involving minors in this area are low labour quality requirements, considerable use of manual labour, almost complete lack of control over manpower utilization, tolerant public attitudes to the work of minors in agriculture, etc. Very often, labour relations involving children are not formalized, and as a result, children remain socially disadvantaged due to the adequate working environment and labour safety. It is well known that agri- cultural production is one of the most traumatic industries and, despite this, the working conditions here are often not appropriate for this category of workers. Many child labourers are injured, killed and have occupational health problems due to the inappropriate working environment.

Children working in agriculture in such countries as Nigeria, Bangladesh, India, Pakistan, Liberia, Somalia, Ethiopia, Chad often use heavy equipment and sharp tools, are exposed to pesticides or other harmful chemicals, can be bitten by harmful insects, work for a long time and in extreme weather conditions; their health is also endangered when they work in farm animal production. That is to say, all these factors, together with the improper labour management, can cause significant harm to the children's health, which is unacceptable and should be clearly regulated by law.

\section{THE AIM}

Aim: to analyze the provisions of international law and scientific literature on the effects of workplace factors on the 
health of children working in agriculture and to examine the existing limitations of such effects.

\section{MATERIALS AND METHODS}

International acts, data of international organizations and conclusions of scientists have been examined and used in the study. The study also summarizes information from scientific journals and monographs from a medical and legal point of view with scientific methods. The article is based on dialectical, comparative, analytic, synthetic and comprehensive research methods.

\section{REVIEW AND DISCUSSION}

The United Nations General Assembly (UNGA) has unanimously adopted a resolution declaring 2021 as the International Year for the Elimination of Child Labour, and has asked the International Labour Organization to take the lead in its implementation. The resolution highlights the member States' commitments "to take immediate and effective measures to eradicate forced labour, end modern slavery and human trafficking and secure the prohibition and elimination of the worst forms of child labour, including recruitment and use of child soldiers, and by 2025 end child labour in all its forms" [8].

In many countries child labour is mainly an agricultural issue. Worldwide 60 percent of all child labourers in the age group 5-17 years work in agriculture, including farming, fishing, aquaculture, forestry, and livestock. This amounts to over 98 million girls and boys. The majority $(67.5 \%)$ of child labourers are unpaid family members. In agriculture this percentage is higher, and is combined with very early entry into work, sometimes between 5 and 7 years of age. Agriculture is one of the three most dangerous sectors in terms of work-related fatalities, non-fatal accidents and occupational diseases. About 59 percent of all children in hazardous work aged 5-17 are in agriculture [9].

It should be emphasized that irrespective of age, agriculture, along with mining and construction, is one of the three most hazardous sectors in terms of fatalities, accidents, and ill health [10].

In many rural areas, children work for their survival and to meet the family's need for cash, food, shelter and clothing. But the factors leading to child labour may be many and intertwined [11].

Poverty is the main cause of child labour in agriculture, together with limited access to quality education, inadequate agricultural technology and access to adult labour, high hazards and risks, and traditional attitudes towards children's participation in agricultural activities. Especially in the context of family farming, small-scale fisheries and livestock husbandry, some participation of children in non-hazardous activities can be positive as it contributes to the inter-generational transfer of skills and children's food security. It is important to distinguish between light duties that do no harm to the child and child labour, which is work that interferes with compulsory schooling and damages health and personal development, based on hours and conditions of work, child's age, activities performed and hazards involved [9].

Food and Agriculture Organization of the United Nations child labour is work that harms, abuses and exploits a child or deprives a child of fully participating in education. It refers to working children below the national minimum employment age, or children under 18 doing hazardous work [12]. It is important to distinguish between economic activities that do no harm to the child, and child labour [12].

We embrace the idea that helping out in farming related activities is not always child labour. Tasks, that do not interfere with a child's education and leisure time, are age-appropriate and safe "can be a normal part of growing up in a rural environment." Through non-hazardous activities, parents often teach their children important skills which can build self-esteem and increase family food security [13].

In other words, it is necessary to separate two different concepts, child labour and child assistance to their parents in the field of agriculture. However, regardless of the difference in essence and meaning of these concepts, it is important to keep the working conditions at the proper level to protect children's health.

According to the World Health Organization's definition of "child health", it is complete physical, mental, and social wellbeing of a child and not merely the absence of disease or infirmity. Healthy development of the child is of basic importance; the ability to live harmoniously in a changing total environment is essential to such development [14].

Children are particularly at risk as their bodies and minds are still developing, and they are more vulnerable to hazards such as pesticides, which are quite often used in agricultural activities. The negative health consequences of their work can last into adulthood [12].

While some children work directly with pesticides, mixing and applying them, other children are indirectly exposed to the hazards of toxic pesticides, for example when working in the fields, weeding or harvesting, or through contaminated water. Such exposure can seriously harm their health and development. Children are more vulnerable than adults because of their smaller size and low body weight, their weight/skin-surface ratio, their need to drink and eat more often that adults and the way they breathe (twice air intake than an adult).

Additionally, children's ability to successfully detoxify and excrete toxins is lower than adults' because their organs are still developing. Finally, children have a lower capacity to assess risks and often cannot read warning labels [12].

Child laborers are often exposed to high levels of organic dust. This generally occurs while harvesting crops or preparing feed for farm animals. Breathing organic dust can result in allergic respiratory diseases, such as occupational asthma and hypersensitivity pneumonia (alveolitis) [10].

Moreover, children working in the livestock sector are at risk of disrupted physical, mental, moral and social development. It is widely thought that working closely with livestock carries inherent risks of health problems caused 
by working long hours in extreme weather conditions, poor sanitation and hygiene, using chemical products (e.g. disinfectants to treat animals) and inhaling (livestock) dust. In addition, there are direct risks of injury when handling animals. Risks include being bitten (also by wild animals) $[15$, p. 7$]$. In addition to the negative physical effects on health, child labour in livestock raising carries a significant risk of psychological disorders in the case of slaughtering, cutting, processing, cleaning of animals. Children who work in livestock raising can see dying, bloodied, tortured animals, which, of course, negatively affects their mental and moral development. Therefore, it is considered unquestionable that there is a high likelihood of deterioration of children's health and psychological condition as a result of child labour in livestock raising.

Skin problems are common. Many of the crops children work with are abrasive, prickly, or contain skin irritants that can provoke allergies, rashes, blistering, etc.

Exposure to loud noise can harm hearing. Continuous exposure to high levels of noise in the workplace such as that from machinery can result in permanent hearing problems and damage in later life [10].

Children also have higher energy and fluid requirements and are more susceptible to dehydration. The physical strain and repetitive movements associated with many agricultural tasks can deform bones and injure ligaments and muscles, especially in the back, causing life-long disabilities [16].

In many countries, children can operate or use powerful machinery and equipment, such as grain screw conveyors, baling machines, liquid manure carts and other large agricultural machinery; they may be also dragged into or injured by such machinery. Furthermore, according to the ILO statistics, half of all fatal accidents occur in agriculture [17].

Child labourers use dangerous cutting tools. These include machetes, knives, scythes, sickles, etc. used to cut crops, hay, weeds, and brushwood. Cuts are frequent, and even more serious injuries can be sustained, such as amputations [10].

Much agricultural work is physically demanding and strenuous. It can involve long periods of standing, stooping, bending, making repetitive and forceful movements in awkward body positions (see cutting tools, below), and carrying heavy or awkward loads (baskets, bundles of crops, water containers, etc.), often over long distances. These types of activities can harm children's musculoskeletal development and may result in permanent disability. Children must often work in extreme temperatures. They may work in the hot sun or in cold, wet conditions without suitable clothing or protective equipment [18]. Children risk falling and injuries from falling objects. They may fall off ladders or even out of trees while picking high-growing fruit. They may also be injured by fruit pods falling from trees [10, p.367].

Exceeding of the permissible working time established by national labour law is a rather common violation concerning children. It can have a significant impact on their health.
Hours of work tend to be extremely long during planting and harvesting. During these high-activity periods, work in the fields can last from dawn to dusk, excluding the transport time to and from the fields. The intensity of the work offers little chance for rest breaks, and the length of the working day offers insufficient time for recuperation or leisure [10, p.367].

Consequently, children working in the agricultural sector face a significant number of physical, chemical, mechanical, biological, moral, ergonomic risks of inadequate occupational health and psychosocial dangers, as well as long working hours and poor working conditions.

All of these threats that children working in the agricultural sector are exposed to have to be overcome due to adequate labour management, well-established legislation and a properly organized public health system. At the same time, in rural areas, health care is often less complex than in urban areas. There are also fewer primary health care clinics in rural areas, which, of course, has a negative impact on addressing potential health problems for children working in agriculture.

The need to improve working conditions for children in the agricultural sector is proven by statistics. According to a recent report by the US government, more than half of work-related deaths among children in the US occur in agriculture, according to a new US government report published this week [19]. For instance, between 2003 and 2016, 237 children died while working in agriculture in the US. Many of these children's injuries and deaths may have been avoided with better work place protections [20].

To prevent diseases and eliminate existing health problems for minors, the employer has to ensure that adolescents working for him undergo preliminary and subsequent periodic medical examinations.

Most national legislations also contain important and necessary provisions aimed at respect of the rights of child labourers requiring a minor's parents, adoptive parents and guardians, as well as government agencies and officials charged with overseeing and controlling compliance with labour law, to initiate termination of employment contract with the minor, including a fixed-term one, when its continuation threatens the health of the minor or violates his legitimate interests.

At the international legal level, namely, in Art. 32 of the Convention on the Rights of the Child of 20 November 1989 , it is defined that 1 . States Parties recognize the right of the child to be protected from economic exploitation and from performing any work that is likely to be hazardous or to interfere with the child's education, or to be harmful to the child's health or physical, mental, spiritual, moral or social development. 2. States Parties shall take legislative, administrative, social and educational measures to ensure the implementation of the present article. To this end, and having regard to the relevant provisions of other international instruments, States Parties shall in particular: (a) Provide for a minimum age or minimum ages for admission to employment; (b) Provide for appropriate regulation of the hours and conditions of employment; (c) Provide 
for appropriate penalties or other sanctions to ensure the effective enforcement of the present article [21].

All these requirements, of course, also apply to the agricultural sector. At the level of national law, states establish rules and requirements similar to those of the Convention. The Preamble to the Minimum Age Convention, 1973 (No. 138) stipulates that noting the terms of the Minimum Age (Agriculture) Convention, 1921 and considering that the time has come to establish a general instrument on the subject, which would gradually replace the existing ones applicable to limited economic sectors, with a view to achieving the total abolition of child labour, andhaving determined that these proposals shall take the form of an international Convention.

According to Art. 1 of the Minimum Age Convention, each Member, for which this Convention is in force, undertakes to pursue a national policy designed to ensure the effective abolition of child labour and to raise progressively the minimum age for admission to employment or work to a level consistent with the fullest physical and mental development of young persons. Under Part 3 of Art. 2 of the above Convention, the minimum age specified in pursuance of paragraph 1 of this Article shall not be less than the age of completion of compulsory schooling and, in any case, shall not be less than 15 years. Notwithstanding the provisions of paragraph 3 of this Article, a Member whose economy and educational facility are insufficiently developed may, after consultation with the organizations of employers and workers concerned, where such exist, initially specify a minimum age of 14 years.

Art. 7 of the Minimum Age Convention warrants that national laws or regulations may permit the employment or work of persons 13 to 15 years of age on light work which is - (a) not likely to be harmful to their health or development; and (b) not such as to prejudice their attendance at school, their participation in vocational orientation or training programmes approved by the competent authority or their capacity to benefit from the instruction received.

Furthermore, the provisions of Art. 10 of the Minimum Age Convention are important since, under them, this Convention revises the Minimum Age (Agriculture) Convention, 1921, which means that all requirements of the minimum age legislation for workers, regardless of their field of activity, are properly harmonized.

Given the existence of international regulations, the minimum age requirement for employment is the first and foremost requirement enshrined in the legislation of many countries. In most countries, the minimum age of employment is 16 years. For instance, under Ukrainian law, namely, Art. 188 of the Labour Code of Ukraine, it is also 16 years old. As an exception, with the consent of a parent or a surrogate parent, persons who have attained the age of fifteen years may be employed. For the preparation of young people for productive labour, it is allowed to recruit students of high schools, vocational and secondary specialized educational institutions to perform light labour which does not harm their health and does not disturb the learning process, during non-study time upon reaching the age of fourteen.
The following example of age restrictions for labour in agriculture can be found in US law. Minors age 16 and above may work at any time in jobs not declared hazardous by the Secretary of Labor (U.S.). Minors ages 14 and 15 may work outside school hours in jobs not declared hazardous by the Secretary of Labour Minors ages 12 and 13 may work in jobs not declared hazardous outside school hours either with written parental consent or on the same farm where their parents are employed. Minors ages 9 through 11 may pick berries and beans outside school hours if the child has the written consent of his/her parents or guardians and only if the farm has used less than 500 mandays of labour in all calendar quarters of the preceding year or the produce is sold within the state and the produce is not transported outside the state in any form [22].

The FLSA child labour provisions are designed to protect the educational opportunities of youth and prohibit their employment in jobs and under conditions detrimental to their health or safety. Night work is prohibited for minors under 16 unless other age indicated. Moreover, numerous occupations have been declared hazardous in 11 categories of employment for minors including, among others, operating tractors of over 20 PTO horsepower; operating or assisting to operate corn pickers, grain combines, hay movers, potato diggers, trenchers or earthmoving equipment, or power-driven circular, hand or chain saws; working in a yard, pen or stall occupied by a stud animal or a sow with suckling pigs; working inside a silo or manure pit; handling or applying certain agricultural chemicals; and handling or using a blasting agent such as dynamite or black powder [23].

In some states of the USA, for example, in Alaska, the legislation sets specific hours when minors are forbidden to work (from $9 \mathrm{pm}$ to $5 \mathrm{am}$ ). In other states, for example, in New Mexico, it is from 9 pm to 7 am, to 14 years.

Moreover, some states of the USA set a different minimum age of employment compared to federal law. Thus, in accordance with the laws of the state of Washington, minimum age of employment is 18 years; hand-harvesting or cult. berries, bulbs, cucumbers and spinach is allowed for minors aged from 14, 12 years during non-school week. The state of Washington has also established the most stringent rules regarding the number of days off for minors working in dairy, livestock, hay and irrigation, namely, one day off every two weeks, under 18 years [23].

Agricultural employment is exempted from or is not listed among the covered sectors in the child labor laws of 17 states. Laws generally exclude minors employed by parents on family farms [23].

Turning back to the general international instruments concerning appropriate working environment in agriculture, we need to mention the Occupational Safety and Health Convention 1981 (No. 155) which defines that the term health, in relation to work, indicates not merely the absence of disease or infirmity; it also includes the physical and mental elements affecting health which are directly related to safety and hygiene at work.

The Promotional Framework for Occupational Safety and Health Convention, 2006 (No. 187) also establishes 
general principles for the organization of proper working conditions, including in the field of agriculture. Its preamble recognizes the global magnitude of occupational injuries, diseases and deaths, and the need for further action to reduce them.

The Occupational Safety and Health Recommendation 1981 (No. 164) is also worth mentioning as it stipulates that to the greatest extent possible, the provisions of the Occupational Safety and Health Convention, 1981, here in after referred to as the Convention, and of this Recommendation should be applied to all branches of economic activity and to all categories of workers. The term health, in relation to work, indicates not merely the absence of disease or infirmity; it also includes the physical and mental elements affecting health which are directly related to safety and hygiene at work.

Moreover, the Chemicals Convention, 1990 (No. 170) applies to all branches of economic activities in which chemicals are used. It is well known that the agricultural sector is quite active in using chemicals to control pests, to improve plant growth and for other purposes.

In addition to the international instruments that prescribe general provisions for implementation of activities, including those in agriculture, by all workers regardless of age and other characteristics, there is a convention regarding child labour. We mean the International Labour Organization Convention on Prohibition and Immediate Action on the Worst Forms of Child Labour, 1999 (No. 182) which was adopted considering the effective elimination of the worst forms of child labour requires immediate and comprehensive action, taking into account the importance of free basic education and the need to remove the children concerned from all such work and to provide for their rehabilitation and social integration while addressing the needs of their families. Art. 2 of the above Convention stipulates that for the purposes of this Convention, the term child shall apply to all persons under the age of 18 . Art. 3 also defines the term the worst forms of child labour which also comprises work which, by its nature or the circumstances in which it is carried out, is likely to harm the health, safety or morals of children.

In the context of international instruments relating to child labour, one cannot but mention the International Programme on the Elimination of Child Labour (IPEC) which was created in 1992 with the overall goal of the progressive elimination of child labour, which was to be achieved through strengthening the capacity of countries to deal with the problem and promoting a worldwide movement to combat child labour. IPEC currently has operations in 88 countries. It is the largest programme of its kind globally and the biggest single operational programme of the ILO [24].

As for the international instruments that directly regulate the implementation of agricultural activities, there is the Safety and Health in Agriculture Convention, 2001 (No. 184) adopted by General Conference of the International Labour Organization. Under Art. 1 of the Convention, the term agriculture covers agricultural and forestry ac- tivities carried out in agricultural undertakings including crop production, forestry activities, animal husbandry and insect raising, the primary processing of agricultural and animal products by or on behalf of the operator of the undertaking as well as the use and maintenance of machinery, equipment, appliances, tools, and agricultural installations, including any process, storage, operation or transportation in an agricultural undertaking, which are directly related to agricultural production. Furthermore, section IV of the Convention deals with the legal status of young workers and hazardous work. Art. 16 of this section stipulates that the minimum age for assignment to work in agriculture which by its nature or the circumstances in which it is carried out is likely to harm the safety and health of young persons shall not be less than 18 years. The types of employment or work to which paragraph 1 applies shall be determined by national laws and regulations or by the competent authority, after consultation with the representative organizations of employers and workers concerned.

For instance, in the legislation of Ukraine, namely in section 31 of the Decree of the Ministry of Health of Ukraine of March 31, 1994, No. 46, which approves the State Regulation on Labour Protection 0.03-8.07-94 containing the "List of heavy jobs and jobs under harmful and dangerous working conditions where employment of child labourers is prohibited", it is prohibited to employ minors as stable boys engaged in the service of stud horses; rear operators at trailed agricultural machines; cattle-breeders; workers employed at silkworm breeding factories; workers employed on opium poppy plantations; workers servicing wells, manure tanks, cisterns and other containers; workers employed in greenhouses; workers engaged in watering cotton manually; workers engaged in tobacco cleaning, transportation and primary processing; veterinary attendants. In other words, the law of Ukraine defines the most complex types of agricultural activities for which there are restrictions on child labour.

The Decree of the Ministry of Health of Ukraine of March 22, 1996, No. 59, approves the limiting norms for lifting and moving heavy things by minors, according to which it is forbidden to employ minors to do jobs that are solely related to lifting, holding or moving heavy things. Adolescents who do not have medical contraindications, as evidenced by the relevant medical certificate, are allowed to perform work that requires lifting and moving heavy things. Prolonged work on lifting and moving heavy things is not allowed for adolescents under 15 years of age. For instance, an IPEC study of tea estates in Lushoto and Rungwe Districts of Tanzania found that 13-year-olds carried up to $20 \mathrm{~kg}$ of green tea leaves, and 14-year-olds up to $30 \mathrm{~kg}$, from the fields to the weighing stations, often for distances between 1 and $4 \mathrm{~km} \mathrm{[25].}$

The Plantations Convention, 1958 (No. 110) is one more special document governing agricultural activities. For the purpose of this Convention, the term plantation includes any agricultural undertaking regularly employing hired workers which is situated in the tropical or subtropical regions and which is mainly concerned with the cultiva- 
tion or production for commercial purposes of coffee, tea, sugarcane, rubber, bananas, cocoa, coconuts, groundnuts, cotton, tobacco, fibres (sisal, jute and hemp), citrus, palm oil, cinchona or pineapple; it does not include family or small-scale holdings producing for local consumption and not regularly employing hired workers. Art. 39 of the Convention mentions the special legal status of young workers. In particular, it stipulates that where appropriate, provision shall be made, in accordance with the established procedure for the regulation of holidays with pay on plantations, for (a) more favourable treatment for young workers, in cases in which the annual holiday with pay granted to adult workers is not considered adequate for young workers.

The Labour Inspection (Agriculture) Convention, 1969 (No. 129) is also a special legal instrument in the field of agriculture. Art. 4 of the said Convention stipulates that the system of labour inspection in agriculture shall apply to agricultural undertakings in which work employees or apprentices, however they may be remunerated and whatever the type, form or duration of their contract. Art. 6 of the Convention states that the functions of the system of labour inspection in agriculture shall be (a) to secure the enforcement of the legal provisions relating to conditions of work and the protection of workers while engaged in their work, such as provisions relating to hours, wages, weekly rest and holidays, safety, health and welfare, the employment of women, children and young persons, and other connected matters, in so far as such provisions are enforceable by labour inspectors. Similar provisions are also contained in the ILO Labour Inspection (Agriculture) Recommendation, 1969 (No. 133).

Summarizing the above, we understand that at the level of the international community, as well as national laws, a number of measures have been taken to eliminate inappropriate conditions for child labour, as well as to eliminate child labour which does not meet the established age criteria for employment.

\section{CONCLUSIONS}

Children working in agriculture are exposed to many health hazards. Workplace hazards and risks can be more damaging and lasting for children's health than that of adults. Despite the support and policy of preventing and reducing agricultural child labour by the international community, and addressing this issue at national level, the above problem is particularly difficult to solve.

It is necessary to separate two different concepts, child labour and child assistance to their parents in the field of agriculture. However, regardless of the difference in essence and meaning of these concepts, it is important to keep the working conditions at the proper level to protect children's health.

Working conditions and workplace safety in agriculture for minors have to be properly organized. The level of traumatization, occupational morbidity and above all, the standard of health of child labourers in agriculture depend on the level of proper organization of occupational safety.
In many countries, the state of the working environment and occupational safety for child labourers in agriculture and, accordingly, the standard of their health remain unsatisfactory.

Thus, taking into account the legal framework concerning exercising children's right to health and life, it is necessary to develop additional guarantees for ensuring these rights in agriculture and a family business. Moreover, it is necessary to raise a concern of prosecuting parents and employers in case of violation of the fundamental rights of children.

\section{REFERENCES}

1.Vitalii M. Pashkov, Olena M. Batyhina, Maryna V. Trotska. Legal restraints of pesticide effect on human organism and environment under international legislation. Wiad Lek. 2017;2, cz. II: 366-371.

2. Vitalii M. Pashkov, Olena M. Batyhina, Maryna V. Trotska. International legal regulation of impact of occupational injuries and diseases on agricultural workers' health. Wiad Lek. 2017;5: 953-959.

3. Vitalii M. Pashkov, Olena M. Batyhina, Maryna V. Trotska. Concept of waste and its impact on human health. Wiad Lek. 2017; 5:964-970.

4. Vitalii M. Pashkov, Olena M. Batyhina, Liudmyla V. Leiba. Ensuring right to organic food in public health system. Wiad Lek. 2018;1 czll:226-229.

5. Nataliya Gutorova, Olena Batyhina, Maryna Trotska. Legal protection of public health through control over genetically modified food. Wiad Lek. 2018; 2 cz II: 366-370.

6. International labour organization Ending child labour by 2025: A review of policies and programmes. URL: https://www.lo.org/wcmsp5/groups/ public/---ed_norm/---ipec/documents/publication/wcms_653987.pdf.

7. International Labour Organization. National Child Labour Survey. Malawi: 2015 National child labour survey report. URL: https://www. ilo.org/ipec/Informationresources/WCMS_IPEC_PUB_29055/lang--en/ index.htm.

8. International Labour Organization 2021 declared International Year for the Elimination of Child Labour. URL:https://www.ilo.org/global/ about-the-ilo/newsroom/news/WCMS_713925/lang--en/index.htm.

9. International Labour Organization. Child in labour agriculture. URL: https://www.ilo.org/ipec/areas/Agriculture/lang--en/index.htm.

10. Peter Hurst. Health and child labor in agriculture. Food and Nutrition Bulletin, vol. 28, no. 2 (supplement) 2007, The United Nations University. URL: https://journals.sagepub.com/doi/ pdf/10.1177/156482650702825216.

11. International Labour Organization. Child labour in agriculture. Published in October 2015, updated in May 2016. URL: https://www. ilo.org/infostories/en-GB/Stories/Child-Labour/Child-Labour-InAgriculture\#teradicating-child-labour.

12. Food and Agriculture Organization of the United Nations. Reducing child labour in agriculture through good agricultural practices: FAO experiences. FA0, 2012. URL: http://www.fao.org/3/a-av096e.pdf.

13. Hazardous Child Labour in Agriculture ECLT Foundation, 19 March 2019. URL: https://www.eclt.org/en/news-and-insights/hazardous-childlabour-in-agriculture.

14. Constitution of the World Health Organization. URL: https://www.who. int/governance/eb/who_constitution_en.pdf.

15. Children's work in the livestock sector: Herding and beyond. FAO Gender, Equity and Rural Employment Division, Economic and Social Development Department. URL: http://www.fao.org/docrep/017/ i3098e/i3098e.pdf. 
16. Occupational Safety and Health (OSH) and hazardous work of children in agriculture. International labor organization. URL: https://www.ilo. org/ipec/areas/Agriculture/WCMS_172349/lang--en/index.htm.

17. International Labour Conference, 88th session. Safety and health in agriculture, Report (VI) 1. Geneva: International Labour Organization, 2000:3. URL: https://www.ilo.org/public/english/standards/relm/ilc/ ilc88/rep-vi-1.htm

18. International Programme on the Elimination of Child Labour. Tackling hazardous child labour in agriculture: Guidance on policy and practice. Chapter 2. Geneva, International Labour Organization, 2006.URL: https:// www.ilo.org/public/english/standards/relm/ilc/ilc88/rep-vi-1.htm.

19. Working Children. Report to Congressional Requesters. United States Government Accountability Office. GAO Highlights, November, 2018. URL: https://www.gao.gov/assets/700/695209.pdf.

20. Margaret Wurth. Child Workers Die in Agriculture Than in Any Other Industry. New US Government Report Highlights Dangers Caused by Weak Child Labor Laws. Human Rights Watch, December 4, 2018. URL: https://www.hrw.org/news/2018/12/04/more-us-child-workers-dieagriculture-any-other-industry.

21. Convention on the Rights of the Child. URL: https://www.ohchr.org/EN/ Professionallnterest/Pages/CRC.aspx.

22. The Employment of Minors in Agriculture. URL: https://www.oregon. gov/boli/WHD/CLU/pages/w_clu_whminag.aspx.

23. U.S. Department of Labor. State Child Labor Laws Applicable to Agricultural Employment. January 1, 2019. URL: https://www.dol.gov/ whd/state/agriemp2.htm

24. International Labour Organization. About the International Programme on the Elimination of Child Labour (IPEC). URL: https://www.ilo.org/ ipec/programme/lang--en/index.htm.
25. International Programme on the Elimination of Child Labour. Investigating the Worst Forms of Child Labour No. 11. Tanzania, Children Working in Commercial Agriculture-Tea. A Rapid Assessment by M. J.Gonza, P. Moshi. Geneva, International Labour Organization, 2002. 162 p.

\section{Authors' contributions:}

According to the order of the Authorship.

\section{ORCID numbers:}

Sergiy O. Chertov - 0000-0001-9867-1061

Olena M. Batyhina - 0000-0002-7245-9369

Andrii O. Harkusha - 0000-0001-5266-3007

\section{Conflict of interest:}

The Authors declare no conflict of interest.

\author{
CORRESPONDING AUTHOR \\ Andrii 0. Harkusha \\ Poltava Law Institute of Yaroslav the Wise National Law University \\ 6 Monastyrska str., 36000, Poltava, Ukraine \\ e-mail:v.pashkov26.06@ukr.net
}

Received: 08.07.2019

Accepted: 30.09.2019 
PRACA POGLĄDOWA

REVIEW ARTICLE

\title{
GENETYCZNE PODŁOŻE ATYPOWEGO ZESPOŁU HEMOLITYCZNO-MOCZNICOWEGO I JEGO WPŁYW NA PRZEBIEG CHOROBY I EFEKTY LECZENIA
}

\author{
GENETIC BACKGROUND OF ATYPICAL HEMOLYTIC-UREMIC \\ SYNDROME AND ITS INFLUENCE ON THE COURSE OF DISEASE \\ AND THERAPEUTIC EFFECTS
}

\author{
Ewelina Użarowska ${ }^{1,2,3}$, Michał Kościółek' ${ }^{1}$ Anna Wójcicka ${ }^{1,2}$ \\ 'WARSAW GENOMICS, WARSZAWA, POLSKA \\ 2ZAKŁAD MEDYCYNY GENOMOWEJ, WARSZAWSKI UNIWERSYTET MEDYCZNY, WARSZAWA, POLSKA \\ ${ }_{3}^{3}$ STUDIUM MEDYCYNY MOLEKULARNEJ, WARSZAWSKI UNIWERSYTET MEDYCZNY, WARSZAWA, POLSKA
}

\begin{abstract}
STRESZCZENIE
Atypowy zespół hemolityczno-mocznicowy (aHUS) jest chorobą związaną z nadmierną, niekontrolowaną aktywacją drogi alternatywnej układu dopełniacza. Istotne jest jego rozróżnienie od innych chorób należących do grupy mikroangiopatii zakrzepowych. W niniejszej pracy autorzy przedstawiają złożonośći istotność tła genetycznego u pacjentów z aHUS, co ma ułatwić zrozumienie wrodzonego podłoża choroby oraz założeń diagnostyki genetycznej, wymaganej m.in. przy kwalifikacji pacjenta do leczenia ekulizumabem. Dokonano przeglądu literatury i opisano zmiany genetyczne istotne w procesach diagnostyki, leczenia oraz w określaniu rokowania pacjentów z aHUS. Warianty te znajdują się nie tylko w genach kontrolujących układ dopełniacza, ale są także związane z układem krzepnięcia. Opisano wpływ zmian genetycznych na skuteczność terapii ekulizumabem oraz ryzyko nawrotu choroby. Opisano także kryteria niezbędne do rozpoczęcia terapii ekulizumabem i zalecaną diagnostykę genetyczną.
\end{abstract}

SŁOWA KLUCZOWE: aHUS, układ dopełniacza, ekulizumab, mikroangiopatia zakrzepowa, genetyka

\begin{abstract}
Atypical hemolytic-uremic syndrome (aHUS) results from excessive, uncontrolled activation of the alternative pathway of the complement system. It is important to distinguish aHUS from other thrombotic microangiopathies. The aim of this paper is to discuss the complexity and relevance of the genetic background of aHUS patients. The review discusses the genetic variants that are important for diagnosis, treatment and prognosis of patients, which is inevitably important for the qualification of patients for treatment with eculizumab. These variants are not only found in the genes involved in the control of complement system but are also related to the coagulation system. The paper emphasizes the diagnostic difficulties resulting from the extremely diverse genetic background of the patients. It is important to conduct further genetic studies of aHUS patients, also paying attention to genes unrelated to the complement system. The paper contains information on the role of genetic predisposition in tailoring the risk for aHUS and determining its clinical outcome, including qualification for eculizumab therapy.
\end{abstract}

KEY WORDS: aHUS, complement system, eculizumab, thrombotic microangiopathy, genetics

Wiad Lek 2019, 72, 10, 2024-2043

\section{EPIDEMIOLOGIA AHUS}

Zespół hemolityczno-mocznicowy (ZHM, HUS - hemolitic-uremic syndrome) należący do grupy mikroangiopatii zakrzepowych (TMA - trombotic microangiopathy) jest chorobą charakteryzującą się triadą objawów: niedokrwistością hemolityczną wywołaną mechanicznym uszkodzeniem erytrocytów przez mikrozakrzepy, małopłytkowością i dysfunkcją nerek. W Polsce w latach 2014-2018 w populacji pediatrycznej zarejestrowano 177 zachorowań na zespół hemolityczno-mocznicowy, z czego postać atypową (aHUS) zdiagnozowano u 57 osób (32,2\%). Obserwacje pokazują, iż choroba występuje głównie u małych dzieci
(3,7 $\pm 3,6 \mathrm{roku})$ [1]. Należy jednak wyraźnie podkreślić, że aHUS diagnozowany jest u pacjentów w różnym wieku $(\leq 16$ lat $-42 \%$; wiek dorosły - 58\%). Biorąc pod uwagę płeć, brak jest różnic w wieku dziecięcym, natomiast u pacjentów dorosłych wskazuje się na większe ryzyko zachorowania u kobiet [2].

\section{LECZENIE ATYPOWEGO ZESPOŁU HEMOLI- TYCZNO-MOCZNICOWEGO}

W 2009 roku European Pediatric Study Group for HUS opublikowało wytyczne dotyczące leczenia plazmaferezami 
jako postępowanie pierwszego rzutu w aHUS. Miały być one wdrażane w ciągu pierwszych 24 godzin i kontynuowane przez 33 dni, do czasu oceny skuteczności sposobu leczenia [3]. Terapia ta w niektórych przypadkach nie była jednak wystarczająco skuteczna, szczególnie u pacjentów z wariantami ryzyka w składowej I dopełniacza oraz genach spoza tego układu, np. genie $M C P[4,5]$ (opis poszczególnych wariantów genów i ich wpływ zostaną omówione w dalszej części pracy). Pomimo dobrej skuteczności wyrównywania parametrów hematologicznych (częściowa lub całkowita remisja), leczenie plazmaferezami nie zapobiegało rozwinięciu niewydolności nerek w ciągu 3 lat od wystąpienia objawów choroby. Odsetek dalszej progresji do schyłkowej niewydolności nerek wahał się od $6 \% \mathrm{w}$ przypadku pacjentów z mutacjami w $M C P$, przez $23 \%$ w THBD do ponad $53-67 \% \mathrm{w}$ pozostałych przypadkach (CFH, CFI, C3, przeciwciała CFH) [5].

Wymienione powyżej przyczyny wymusiły konieczność poszukiwania skuteczniejszego leczenia. Odpowiedzią na potrzebę zapobieżeniu niekontrolowanej aktywności dopełniacza okazał się ekulizumab. Ekulizumab jest monoklonalnym przeciwciałem anty-C5, które zapobiega tworzeniu kompleksu atakującego błonę (MAC - C5b-9) i jednostki C5a. Ponieważ u pacjentów z aHUS dochodzi do niekontrolowanej aktywacji układu dopełniacza, podawanie ekulizumabu pozwala na hamowanie kaskady procesów, prowadzących do rozwoju choroby [6]. W Polsce pierwsze leczenie tym preparatem wprowadzono w 2017 roku u dwojga dzieci, zaś rok później ekulizumab został włączony do programu lekowego Ministerstwa Zdrowia, zwiększając dostępność terapii dla chorych $[1,7]$. Obecnie w leczeniu aHUS i kwalifikacji dzieci do leczenia ekulizumabem obowiązują wytyczne International Pediatric Nephrology Association (IPNA) opublikowane w 2016 roku [8].

W celu wdrożenia terapii za pomocą ekulizumabu (zarówno w przypadku dorosłych, jak i dzieci) niezbędne jest spełnienie kryteriów włączenia i badań ujętych w ramach programu lekowego. Badania te obejmują m.in. analizę aktywności ADAMTS13, w celu różnicowania aHUS od TTP (zakrzepowej plamicy małopłytkowej), wykrywanie obecności przeciwciał anty-CFH, oznaczenie stężenia białek układu dopełniacza w surowicy. Istotne jest to, że jedną ze składowych badań, koniecznych do kwalifikacji jest wykonanie oznaczeń najczęstszych mutacji genetycznych. Nie zostało natomiast sprecyzowane, jakie geny należy objąć diagnostyką oraz jaką technikę zastosować w celu poszukiwania wariantów patogennych [7].

\section{ALGORYTM POSTĘPOWANIA. W KTÓRYM MOMENCIE WDRAŻAMY DIAGNOSTYKĘ GENETYCZNĄ?}

aHUS jest chorobą rzadką, a wiele istotnych informacji bezpośrednio dotyczących populacji polskiej przynoszą wyniki 5-letniego rejestru zespołu hemolityczno-mocznicowego, który współtworzy 11 Ośrodków Nefrologii Dziecięcej w kraju. W 2018 roku aHUS stanowił 32\% przypadków zespołu hemolityczno-mocznicowego (57 chorych). Objawami towarzyszącymi chorobie były w kolejności od najczęstszego: wymioty, bóle brzucha, biegunka i współwystępowanie infekcji dróg oddechowych. Krew w stolcu, w przeciwieństwie do typowego HUS była zjawiskiem rzadkim (5,2 vs. 50\%). Czas oligurii w przypadku aHUS był dłuższy $(18,5 \pm 24,4$ vs. $9,4 \pm 7,0 \mathrm{dni})$ a eGFR przyjmował podobne wartości (średnia dla całej grupy $24,8 \pm 22,0 \mathrm{ml} / \mathrm{min} / 1,73 \mathrm{~m}^{2}$ ) [1]. Ważne jest to, że objawy te mogą naśladować wiele innych, częstszych chorób, szczególnie z grupy mikroangiopatii zakrzepowych, które należy wykluczyć w pierwszej kolejności [8]. Przydatny algorytm postępowania, zawierający zarówno postępowanie dla osób dorosłych, jak i dzieci zawarty jest w pracy R. Raina [9].

W pierwszej kolejności należy potwierdzić występowanie mikroangiopatii zakrzepowej, do której zalicza się aHUS. Trombocytopenia $<150 \times 10^{9} / \mathrm{L}$ (lub spadek PLT o $25 \%$ ) z objawami hemolizy lub pozytywna biopsja tkankowa i zaburzenia czynności narządów (nerek, OUN, układu pokarmowego, oddechowego) przemawiają za rozpoznaniem. Następnie w zależności od wieku należy poszukiwać najczęstszych przyczyn odpowiedzialnych za TMA $[7,9]$.

W przypadku dzieci są to: HUS wywołany przez toksynę Shiga E. coli (STEC-HUS), przez S. pneumoniae (SP-HUS) i wynikający z zaburzeń metabolizmu witaminy $\mathrm{B}_{12}$. Pozostałe, rzadsze przyczyny to: TTP i postać wtórna HUS, wynikająca np. z chorób autoimmunologicznych, zakażenia wirusem HIV, złośliwego nadciśnienia tętniczego, czy wywołana działaniem leków. Dodatkowo należy wdrożyć postępowanie mające na celu wykrycie mutacji w genie $D G K E$ w przypadkach choroby we wczesnym dzieciństwie $[9,10]$.

Wytyczne IPNA jasno precyzują kolejność wykonywania poszczególnych badań u dzieci. Należy wykluczyć: postać wtórną HUS, SP-HUS, HUS wywołany przez infekcję wirusem grypy A H1N1, TTP, STEC-HUS, a na końcu HUS wynikający z zaburzeń metabolizmu witaminy $\mathrm{B}_{12}[8]$.

U osób dorosłych najczęstszą przyczyną zachorowania są: TTP i postać wtórna HUS, natomiast STEC-HUS, SP-HUS, zespół hemolityczno-mocznicowy wynikający z zaburzeń witaminy $B_{12}$ są rzadszą przyczyną TMA w tej grupie wiekowej.

Po wykluczeniu przedstawionych powyżej przyczyn można wnioskować, że prawdopodobną powodem występowania objawów jest aHUS, co pozwala przystąpić do dalszej diagnostyki, której celem jest potwierdzenie rozpoznania. Składa się na to również diagnostyka genetyczna. Zarówno według wytycznych IPNA, jak i wymogów zawartych w obwieszczeniu MZ leczenie ekulizumabem można wdrożyć $w$ trakcie oczekiwania na wynik badania w kierunku najczęstszych mutacji genetycznych. W przypadku dzieci postępowaniem $\mathrm{z}$ wyboru jest jak najszybsze podanie ekulizumabu, natomiast w przypadku dorosłych w pierwszej kolejności można rozpocząć leczenie za pomocą wymiany osocza $[8,11]$

Rekomendacje IPNA nakładają konieczność wykonania analizy genów $C F H, C F I, M C P, C 3, C F B, T H B D$, a w przypadku wczesnego wystąpienia choroby (przed 1-2 r.ż.), 
również genu $D G K E$. Należy także przeanalizować sekwencje genów kodujących białka związane z czynnikiem $\mathrm{H}(\mathrm{CFHR}) \mathrm{w}$ poszukiwaniu rozległych delecji. Niezbędne jest podkreślenie, iż metodą referencyjną wobec analizy dużych delecji jest MLPA (Multiplex Ligation-dependent Probe Amplification) [9]. Zalecania te potwierdzają eksperci z KDIGO (Kidney Disease: Improving Global Outcomes), wskazując powyższy zestaw badań jako podstawowy w diagnostyce aHUS [12]. Opublikowane w 2018 roku wytyczne belgijskie również zalecają przeprowadzenie diagnostyki tych samych genów w kontekście poszukiwania przyczyn występowania aHUS, w razie potrzeby również genu $D G K E$ $\mathrm{u}$ dorosłych [11]. Badania genetyczne należy przeprowadzić, pomimo obecności przeciwciał anty-CFH, ponieważ ich obecność nie wyklucza mutacji w genach składowych dopełniacza $[8,10]$.

Genetyczne podłoże aHUS jest złożone (wielogenowe), stąd też diagnostyka choroby zawsze wymaga przeanalizowania szerokiego zestawu genów. Predyspozycja do aHUS jest powodowana zmianami genetycznymi, które występują w populacji ogólnej z częstością nawet $10-20 \%$, więc do wystąpienia choroby konieczne jest zadziałanie czynnika sprawczego. Rekomendacje nie zalecają badania bezobjawowych członków rodzin pacjentów z aHUS z mutacją w postaci heterozygotycznej. Wyjątek stanowi sytuacja, $\mathrm{w}$ której planuje się zabieg przeszczepienia nerki od dawcy rodzinnego lub w momencie planowania ciąży u najbliższej rodziny chorego [8]. Zgodnie z rekomendacjami KDIGO, przed kwalifikacją do przeszczepienia nerki należy wykonać dokładną diagnostykę genetyczną w celu znalezienia przyczyny choroby u biorcy. Musi być ona zidentyfikowana, a dawca narządu nie może być nosicielem takiej samej zmiany. Nosicielstwo innych zmian podwyższonego ryzyka aHUS u dawcy nie jest przeciwwskazaniem do transplantacji [12]. Z uwagi na złożoność choroby, interpretacja wyników badań genetycznych pacjentów z aHUS wciąż wymaga udoskonalenia. Wiadomo, w jakich genach poszukiwać uszkodzeń związanych z chorobą, ale dokładna klasyfikacja i kliniczna interpretacja znajdowanych u pacjenta wariantów nie jest prosta. Zazwyczaj za wariant patogenny (chorobotwórczy) uznaje się taką odmianę genu, która nie została do tej pory wykryta w populacji lub jest bardzo rzadka. W ostatnio opublikowanej pracy (Fenqxiao i wsp.) na podstawie analizy genetycznej 400 pacjentów wykazano, że najwłaściwszym przy interpretacji patogeniczności zbadanych wariatów jest uwzględnienie wskaźnika MAF (minor allele frequency) na poziomie $<0,1 \%$ [13]. Równocześnie jednak, haplotypy ryzyka aHUS występują w niektórych populacjach z częstością wyższą, co nie wyklucza ich patogenności.

\section{GENETYKA AHUS}

Piśmiennictwo od wielu lat przedstawia doniesienia o wariantach genetycznych występujących u pacjentów z aHUS. Równocześnie należy podkreślić, że tło choroby jest bardzo złożone, jest bowiem wynikiem współistnienia i współdziałania licznych wariantów (zmian) w genach. Większość chorób rzadkich powstaje jako efekt występowania wa- riantów w populacji ogólnej z częstością poniżej 1 na 1000 osób, co ułatwia identyfikację chorobotwórczych uszkodzeń genetycznych. Dla odmiany, zdecydowana większość przypadków aHUS powodowanych jest nie tylko przez obecność licznych zmian, ale przede wszystkim zmiany są na tyle częste w populacji ogólnej (nawet u 20\% osób), że znacząco utrudnia to ich identyfikację i kliniczną interpretację.

Układ dopełniacza stanowi ważny element odporności wrodzonej. Jego aktywacja oparta jest o kaskadę enzymatyczną. Biorąc pod uwagę czynnik sprawczy, wyróżniamy trzy drogi aktywacji układu dopełniacza: klasyczną, lektynową oraz alternatywną. Atypowy zespół hemolityczno-mocznicowy związany jest $\mathrm{z}$ nadmierną i stałą aktywacją drogi alternatywnej. Kaskada rozpoczyna się spontaniczną hydrolizą białka C3 do $\mathrm{C} 3\left(\mathrm{H}_{2} \mathrm{O}\right)$ (Ryc. 1). Następnie do białka C3 przyłączany jest produkt rozkładu czynnika $\mathrm{B}$ $(\mathrm{Bb})$, tworząc konwertazę $\mathrm{C} 3$ fazy płynnej $\mathrm{C} 3\left(\mathrm{H}_{2} \mathrm{O}\right) \mathrm{Bb}$. Powstawanie konwertazy $\mathrm{C} 3$ kontrolowane jest w procesie dodatniego sprzężenia zwrotnego. Związanie kolejnej cząsteczki C3b do konwertazy C3 skutkuje powstaniem konwertazy C5, która bierze udział w ostatniej fazie alternatywnej drogi układu dopełniacza, czyli formowaniu kompleksu atakującego błonę (MAC). Kompleks ten spełnia istotną rolę w kształtowaniu ochronnych funkcji układu immunologicznego, uszkadzając błonę docelowych komórek [14].

\section{GENY ZWIAZANE Z HAMOWANIEM UKŁADU DOPEŁNIACZA}

\section{$\mathrm{CFH}$}

Czynnik H (complement factor $\mathrm{H}$ ) to główny czynnik regulujący alternatywną drogę aktywacji układu dopełniacza. Białko to zbudowane jest z 20 krótkich fragmentów, nazwanych SCRs (short consensus repeats), charakteryzujących się podobną sekwencją nukleotydową [15]. Jego funkcja jest hamowanie konwertazy $\mathrm{C} 3$. $\mathrm{CFH}$ inaktywuje C3b (wraz z CFI) i konkuruje z CFB w wiązaniu się do $\mathrm{C} 3 \mathrm{~b}$, a miejsca wiązania poszczególnych białek znajdują się $\mathrm{w}$ różnych sekwencjach SCR. To właśnie uszkodzenia genu $C F H$ są jednymi z najczęściej odpowiadających za wrodzoną predyspozycję do aHUS. Mutacje te powodują zmiany funkcjonalności białka (np. niezdolność wiązania do C3b), nie wpływając równocześnie na jego ilość $[5,9]$. Należy podkreślić istotność haplotypu ryzyka w genie $C F H$ (H3) (TGTGT), na który składają się: rs3753394 (C>T); rs800292 (G, allel referencyjny); rs1061170 (wariant patogenny w bazie Clin Var, C>T); rs3753396 (A>G); rs1065489 ( $\mathrm{G}>\mathrm{T})$. Obecność haplotypu ryzyka w genie $\mathrm{CFH}$ związana jest $\mathrm{z}$ występowaniem choroby zarówno w sytuacji, gdy haplotyp znajduje się w 1 allelu genu (układ heterozygotyczny), jak i w układzie homozygotycznym [16].

\section{CFHR1 I CFHR3}

Geny CFHR1 i CFHR3 kodują białka należące do rodziny 5 białek związanych z czynnikiem $\mathrm{H}$ układu dopełniacza 


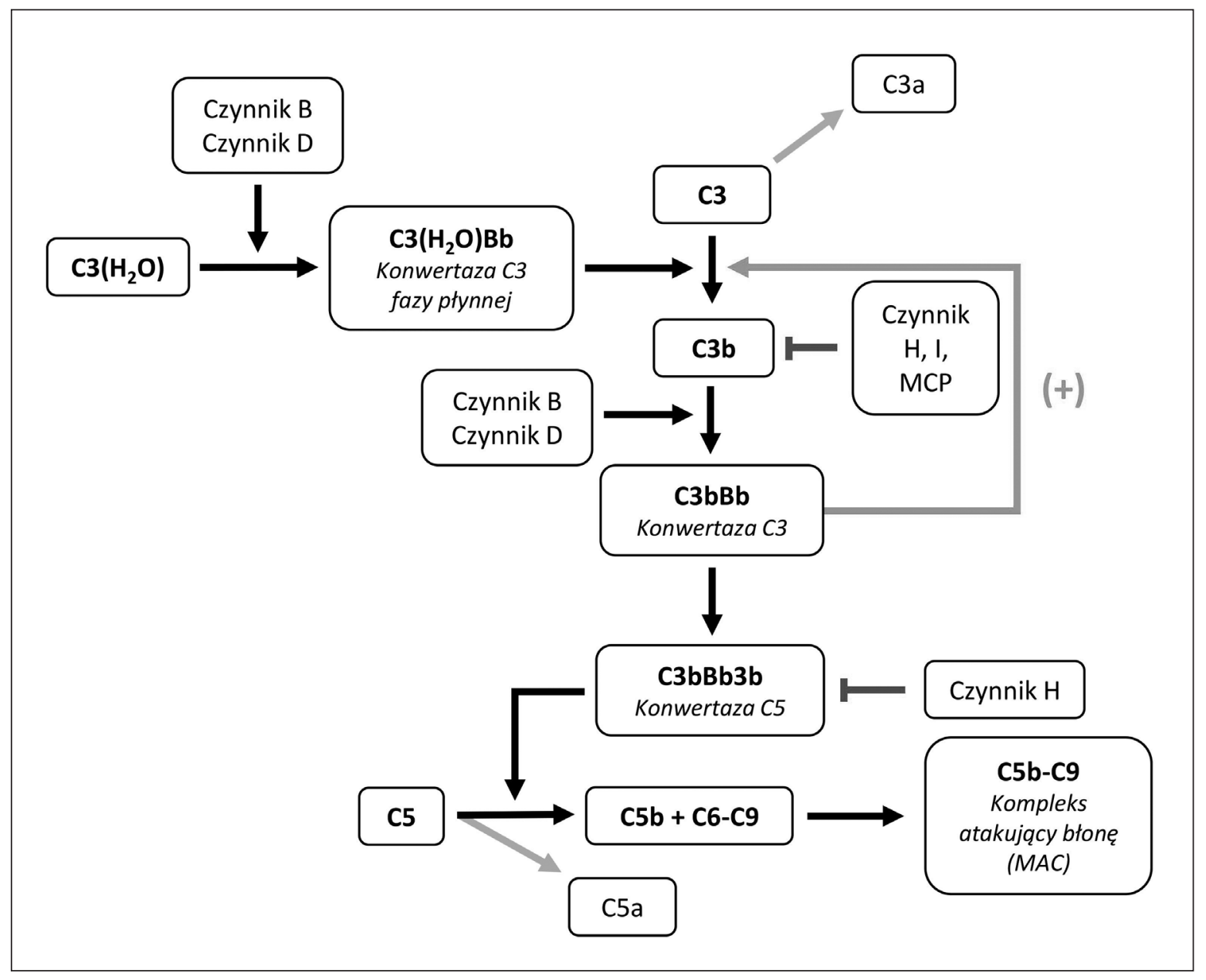

Ryc. 1. Droga alternatywna układu dopełniacza.

Na podstawie: [14].

(complement factor $H$ related proteins). Różne uszkodzenia tych genów powiązano z aHUS: opisano m.in. powstawanie genu hybrydowego, składającego się z SCRs 1-18 genu CFH oraz 4-5 SCRs genu CFHR1, którego produkt nie jest w stanie wiązać się do C3b i tym samym hamować aktywacji dopełniacza [17]. Geny kodujące białka CFHR zlokalizowane są na długim ramieniu chromosomu 1 i są silnie homologiczne (maja podobną sekwencję), co sprawia, że w ich obrębie występuje wysoka częstość zachodzenia procesów homologicznej rekombinacji. Rekombinacje w tym regionie skutkują dużymi delecjami, obejmującymi nawet całe geny CFHR 1 i CFHR3, jak również odpowiadają za tworzenie genów hybrydowych m.in. CFH-CFHR1. Zmiany w obrębie tych genów są ściśle powiązane $\mathrm{z}$ występowaniem przeciwciał anty-CFH. Powstawanie przeciwciał korelowane jest głównie $\mathrm{z}$ delecją CFHR1, ale istotne jest to, że zmiana ta może występować także u osób zdrowych [10].

\section{CFI}

Czynnik I jest proteazą, która rozkłada kompleks C3b i C4b przy wykorzystaniu MCP jako kofaktora na śródbłonku naczyniowym i przy udziale czynnika $\mathrm{H}$ w osoczu. Większość wariantów genu, korelowanych z aHUS, znajduje się w sekwencji kodującej domenę proteazy serynowej. Jej zmniejszona aktywność lub utrata funkcji w wyniku mutacji wpływa na zwiększoną produkcję konwertazy C3 [9]. Mutacje w genie CFI i ich związek z zaburzeniami układu odpornościowego stanowią temat wielu doniesień naukowych. Opisano warianty skutkujące nieprawidłowym wydzielaniem czynnika I lub upośledzeniem jego aktywności $[5,18]$. Publikacja autorstwa S. Nilsson stanowi przegląd kilkunastu prac opisujących warianty w genie CFI [19].

\section{MCP}

Białko MCP (CD46) pełni rolę kofaktora czynnika I w procesie rozkładania białek C3b i C4b na powierzchni śródbłonków. Domena zewnątrzkomórkowa MCP jest odpowiedzialna za wiązanie C3b i to w jej sekwencji jest najwięcej wariantów związanych $z$ aHUS. Mutacje w genie MCP mogą powodować obniżenie aktywności białka (typ II) lub zmniejszenie jego poziomu (typ I). Mutacje mogą być zarówno homo-, jak i heterozygotyczne [9]. 
Tabela 1. Ryzyko śmierci, niewydolności nerek i nawrotu aHUS przed wprowadzeniem leczenia ekulizumabem.

\begin{tabular}{|c|c|c|c|c|}
\hline Gen & $\begin{array}{c}\text { Ryzyko śmierci lub } \\
\text { schyłkowej niewydolności } \\
\text { nerek na początku lub w } \\
1 \text { roku }\end{array}$ & $\begin{array}{l}\text { Ryzyko } \\
\text { nawrotu }\end{array}$ & $\begin{array}{c}\text { Ryzyko śmierci } \\
\text { lub schyłkowej } \\
\text { niewydolności nerek po } \\
\text { 3-5 latach }\end{array}$ & $\begin{array}{c}\text { Ryzyko } \\
\text { nawrotu w } \\
\text { przeszczepionej } \\
\text { nerce }\end{array}$ \\
\hline CFH, geny hybrydowe $C F H-C F H R 1 / 3$ & $50-70 \%$ & $50 \%$ & $75 \%$ & $75-90 \%$ \\
\hline CFI & $50 \%$ & $10-30 \%$ & $50-60 \%$ & $45-80 \%$ \\
\hline Izolowana mutacja $M C P$ & $0-6 \%$ & $70-90 \%$ & $6-38 \%$ & $<20 \%$ \\
\hline$M C P$ z towarzyszącą mutacją $C F H / C F I / C 3$ & $30-40 \%$ & $50 \%$ & $50 \%$ & $50-60 \%$ \\
\hline C3 & $60 \%$ & $50 \%$ & $75 \%$ & $40-70 \%$ \\
\hline$C F B$ & $50 \%$ & $3 / 3$ & $75 \%$ & $100 \%$ \\
\hline$T H B D$ & $50 \%$ & $30 \%$ & $54 \%$ & Nieznane \\
\hline Anty-CFH & $30-40 \%$ & $40-60 \%$ & $35-60 \%$ & $\begin{array}{l}\text { Zależne od } \\
\text { poziomu } \\
\text { przeciwciał }\end{array}$ \\
\hline
\end{tabular}

Na podstawie: [12].

Analizując genetykę aHUS należy podkreślic znaczenie publikacji Esparza-Gordillo, w której opisano między innymi haplotyp ryzyka aHUS zawierający 5 SNP: rs2796267 $(A>G), r s 2796268(A>G), r s 1962149(G>A), r s 859705$ $(\mathrm{G}>\mathrm{A})$, rs7144 $(\mathrm{T}>\mathrm{C})$ [20]. Obecność haplotypu postaci homozygotycznej związane jest ze zwiększonym ryzykiem występowania aHUS [16]. Natomiast posiadanie równocześnie homozygotycznej postaci haplotypów w dwóch genach: $M C P$ i $C F H$ może w pełni uzasadniać występowanie aHUS [6].

\section{GENY ZWIAZZANE Z AKTYWACJĄ UKŁADU DOPEŁNIACZA}

\section{C3}

Białko C3 jest syntezowane głównie w wątrobiei stanowi ważny składnik układu dopełniacza. Warianty genu C3 w Europie wykrywane są u 4-8\% pacjentów z aHUS, w Japonii znacznie częściej - nawet u 31\%, co wskazuje na istotne różnice populacyjne [21]. C3 jest podstawową składową zarówno konwertazy C3 jak i C5; zmiany w kodującym je genie aktywują układ dopełniacza dwojako: mogą zwiększać jego powinowactwo do czynnika B lub też powodować odporność na rozkład jego składowej C3b [9]. W 2008 r. ukazała się publikacja, przedstawiająca analizę mutacji u 26 pacjentów aHUS pod kątem mutacji w C3. W przebiegu badań zidentyfikowano 9 wariantów (w tym 2 powtarzające się u niespokrewnionych osób), które nie występowały u 200 zdrowych ochotników. Obecność części Z wariantów (R570Q, R570W, A1072V, D1093N, Q1139K) skutkowała upośledzeniem wiązania CD46 do C3, co zaburza rozkładanie białka MCP przez CFI, a tym samym skutkuje nadmierną aktywacją alternatywnej drogi układu dopełniacza [22].

\section{CFB}

Białko CFB to proenzym, zawierający miejsce katalityczne dla konwertazy C3. Warianty w kodującym je genie występują $0-4 \%$ pacjentów, zależnie od badanej grupy. [2]. Należy podkreślić istotność wariantów F286L, K323E skutkujących zwiększonym powstawaniem konwertazy C3 [23]. Obecnośc mutacji w CFB wpływa negatywnie na rokowanie pacjentów, zwiększa ryzyko wystąpienia schyłkowej niewydolności nerek oraz wznowy choroby $\mathrm{w}$ przeszczepionym narządzie [24].

\section{GENY NIEZWIAZZANE Z UKŁADEM DOPEŁNIACZA - UKŁAD KRZEPNIĘCIA}

\section{THBD}

Rola trombomoduliny w patogenezie aHUS została po raz pierwszy opisana w 2009 r. Trombomodulina wraz z czynnikiem I i H pośredniczy w inaktywacji C3b oraz zwiększa aktywację karboksypeptydazy B (TAFI), która hamuje C3a i C5a. Warianty opisane dotą w genie THBD zmniejszaja zdolność białka do hamowania drogi alternatywnej układu dopełniacza [25].

\section{$D G K E$}

Mutacje skutkujące zmniejszeniem aktywności kinazy diacyloglirolu $\varepsilon$ powodują indukcję stanu zapalnego oraz zmian prozakrzeprzowych w komórkach śródbłonka, co koreluje z mutacjami w układzie dopełniacza [10]. Pacjenci, u których zidentyfikowano mutacje w DGKE, charakteryzują się wczesnym występowaniem aHUS (w 1. roku życia) oraz wieloma nawrotami choroby do 5. roku życia [26].

\section{PLG}

Gen $P L G$ koduje plazminogen, czyli nieaktywny prekursor plazminy. Piśmiennictwo wskazuje, że większość wariantów, występujących u pacjentów z aHUS, u których nie wykryto zmian w genach układu dopełniacza, dotyczyło 
właśnie układu krzepnięcia, a najczęściej zmiany były w obrębie PLG. Należy zatem zwrócić uwagę na potrzebę poszerzenia diagnostyki aHUS o układ krzepnięcia [27].

\section{PRZECIWCIAŁA ANTY-CFH}

Przeciwciała anty-CFH, poprzez wiązanie się z sekwencjami SCR czynnika $H$, naśladują występowanie mutacji $\mathrm{w}$ tych regionach, upośledzając wiązanie czynnika $\mathrm{H}$ ze składową C3. aHUS z obecnością przeciwciał występuje głównie dzieci (25-50\% w zależności od raportowanych przypadków), rzadziej u dorosłych - średnio u 5-10\% wszystkich pacjentów z aHUS. Wykazano silny związek pomiędzy występowaniem przeciwciał a zmianami w CFHR1 i CFHR3 [10]. W jednej z prac zajmujących się obecnością przeciwciał u pacjentów z aHUS wykazano, że w przypadku homozygotycznej delecji w CFHR1 częstość występowania przeciwciał u pacjentów wynosiła $93 \%$ i towarzyszyła jednoczesnej homozygotycznej delecji CFHR3 w 91\% [28]. Powstawanie przeciwciał i występowanie aHUS jest korelowane z obecnością delecji w obu wymienionych genach, ale warto zaznaczyć, że zmiany te występują także u osób zdrowych (3-6\% zdrowej populacji europejskiej i $20 \%$ afrykańskiej), co bez wątpienia wskazuje, że atypowy zespół hemolityczno-mocznicowy jest chorobą, na którą składa się wiele czynników predysponujących [10].

\section{WARIANTY ISTOTNE W ROKOWANIU PACJENTÓW}

Jak zostało wspomniane, genetyczne podłoże aHUS jest tak złożone, a warianty ryzyka na tyle często występują w populacji ogólnej, że wykonywanie badań przesiewowych w kierunku obciążenia chorobą nie jest zasadne. Istotny jest jednak fakt, że obecność określonych wariantów genetycznych warunkuje kliniczny przebieg choroby (Tab. 1). Wykazano, że pacjenci z mutacjami $M C P$ potrzebują mniej intensywnej kuracji w stosunku do pozostałych grup, ponieważ aż u $88 \%$ pacjentów, u których wykryto mutacje $M C P$, obserwuje się całkowitą remisję choroby. $\mathrm{Z}$ drugiej strony, mutacje $\mathrm{CFH}$ są mocno obciążające - aż 77\% chorych umiera lub rozwija przewlekłą schyłkową chorobę nerek [5]. W populacji francuskiej zaobserwowano także, że istnieje korelacja pomiędzy tłem genetycznym pacjenta a wiekiem, w którym choroba się objawia. Choroba pojawia się wcześniej u osób z mutacjami w $M C P$ w porównaniu do osób z mutacjami w $C F H$, CFI oraz osób, u których nie zidentyfikowano mutacji [2].

Należy wyraźnie podkreślić istotność wariantów w $M C P$ w kształtowaniu efektywności przeszczepiania nerki. Pacjenci, u których aHUS wystąpił jako konsekwencja obecności wariantów w $M C P$ mają dobre rokowania, a ryzyko nawrotu choroby po przeszczepieniu narządu oscyluje na poziomie maksymalnie $25 \%$ [29].

\section{BADANIA POPULACYJNE PACJENTÓW AHUS}

Tegoroczne informacje z polskiego rejestru zespołu hemolityczno-mocznicowego niosą ze sobą istotne dane w kon- tekście genetyki, umożliwiając wstępne zdefiniowanie najczęstszych mutacji występujących w Polsce i to, w jakich genach powinno się poszukiwać wariantów patogennych w pierwszej kolejności.

U dzieci kwalifikowanych do leczenia ekulizumabem (19 osób) w kontekście czynników regulujących układ dopełniacza: $40 \%$ posiadało wariant patogenny w genie CFH, 20\% układ hybrydowy CFHR1/CFHR3, 20\% zmiane w $M C P$ a $8 \%$ miało oznaczalne przeciwciała anty-CFH. W przypadku czynników aktywujących dopełniacz u 20\% badanych wykryto wariant w składowej C3. Warte podkreślenia jest to, że u $4 \%$ badanych mutacji nie znaleziono w genach dopełniacza, lecz w DGKE - związanym z układem krzepnięcia, w tym w jednym przypadku jednocześnie w genie DGKE i CFH. U 4\% dzieci leczenie ekulizumabem wdrożono, pomimo braku wykrycia potencjalnego miejsca mutacji, co wskazuje na fakt, że istnieją jeszcze inne regiony, geny, wymagające podjęcia dalszych badań w celu interpretacji ich znaczenia w rozwoju aHUS w przyszłości. W przypadku 20\% dzieci diagnostyka genetyczna nadal jest w toku, co może wpłynąć na zmianę statystyki w przyszłych latach [1].

Prace zagraniczne, w których analizowano genetyczne podłoże aHUS w różnych populacjach, wskazują na zróżnicowane przyczyny choroby. W pracy Fremeaux-Bacchi opisano wyniki badania przeprowadzonego w grupie 214 francuskich pacjentów z aHUS. Co interesujące, w populacji francuskiej zauważono wyraźną korelację pomiędzy występowaniem mutacji CFH (wykrytą u 59 pacjentów) a rokowaniem pacjentów w populacji dziecięcej; badania w grupie osób dorosłych nie wykazały takiego związku [2]. W roku 2018 ukazała się publikacja analizująca genetyczne podłoże aHUS w grupie 104 pacjentów w Japonii. Badanie wykazało obecność mutacji w genie CFH u 10\% pacjentów, u 31\% w genie C3. Zidentyfikowano wariant C3 p.I1157T, powiązany ze zwiększoną liczbą nawrotów choroby $\mathrm{w}$ porównaniu do pacjentów niosących inne warianty w $C 3$. Co interesujące, w populacji tej różne jest także ryzyko nawrotu choroby warunkowane obecnością wariantów genu $M C P(50 \%)$ oraz $C F H(38 \%)$, co stanowi stosunek całkowicie odmienny od populacji europejskich [21]. Przytoczone powyżej badania wskazują, jak istotne jest prowadzenie badań nad epidemiologią aHUS w konkretnej populacji.

\section{MUTACJE A NIESKUTECZNOŚĆ LECZENIA EKULIZUMABEM}

Działanie ekulizumabu, polegające na blokowaniu aktywacji drogi alternatywnej układu dopełniacza, wpływa hamująco na odpowiedź immunologiczną, w której do ochrony przed patogenami konieczna jest liza komórek przez układ atakujący błonę (MAC). Tym samym konieczne jest zabezpieczenie osób leczonych tym preparatem przed patogenami, realizowane przez szczepienie przeciwko N. meningitidis i profilaktyczną antybiotykoterapię [8]. Jednakże istnieją sytuacje, w których poszczególne mutacje skutkują niewystarczającą odpowiedzią na ekulizumab 
i w tych przypadkach należałoby rozważyć zaprzestanie dalszego leczenia, by nie narażać pacjentów na zwiększone ryzyko infekcji.

U 11 spośród 345 pacjentów japońskiego pochodzenia, leczonych ekulizumabem z powodu nocnej napadowej hemoglobinurii, nie osiągano pożądanego stopnia remisji. Niezmiennie podwyższony poziom LDH w surowicy wskazywał na utrzymującą się hemolizę. Bezpośrednie sekwencjonowanie 41 eksonów genu C5, wykazało obecność pojedynczej mutacji w 1 allelu genu, znajdującej się w eksonie 21 (c.2654G>A) u wszystkich pacjentów, którzy nie odpowiedzieli na leczenie. Obecność mutacji zapobiega łączeniu się czynnika C5 z ekulizumabem, co jest konieczne do powodzenia terapii [30]. Preparat ten może być skuteczny w przypadkach, w których regulacja dopełniacza jest zaburzona poprzez warianty białek odpowiedzialnych za nadmierną jego aktywację, jak i niedostateczne hamowanie. Ekulizumab, z racji łączenia się z bezpośrednio z czynnikiem C5, nie jest skuteczny w momencie, gdy choroba wywołana została mutacjami innych genów niż te kodujące białka dopełniacza. Potwierdzaja to prace dokumentujące niepowodzenia terapii w przypadku mutacji w DGKE [26].

\section{CZY PRZESZCZEPIENIE WĄTROBY UMOŻLIWI WYLECZENIE?}

Przeszczepienie wątroby, która jest bezpośrednio odpowiedzialna za produkcję składowej $C 3$ oraz czynników $\mathrm{H}$ i B, jest nadal rozpatrywanym sposobem leczenia atypowego zespołu hemolityczno-mocznicowego. Jednoczasowe przeszczepienie nerki $\mathrm{z}$ wątrobą wiąże się ze znamiennie wyższym ryzykiem zgonu (wynoszącym średnio 15\%) [31], ale w przypadku powodzenia transplantacji, uniezależnia ono pacjenta od przyjmowania ekulizumabu, który jest lekiem kosztownym dla systemu i obciążającym chorego, ze względu na konieczność przewlekłego leczenia i podwyższonego ryzyka zachorowania na choroby bakteryjne, w których zwalczaniu uczestniczy dopełniacz.

W pracy Saland omówiono 5 operacji przeszczepienia wątroby i nerki u dzieci, które nie zostały wykonane w osłonie plazmaferezy lub ekulizumabu i wszystkie skończyły się niepowodzeniem. Odmiennie, powodzenie operacji po przeprowadzeniu odpowiedniego przygotowania udało się uzyskać w 16 na 20 zabiegów (80\% powodzenia, 3 zgony). Składają się na to: 2 niepowodzenia (na 16 zabiegów), które wystąpiły u chorych z mutacją w $C F H, 1$ niepowodzenie (na 2 operacje) przy obecności delecji/genu hybrydowego CFH/CFHR1, jedna transplantacja w przypadku mutacji C3, która zakończyła się niepowodzeniem (brak podjęcia funkcji nerek, przy prawidłowym podjęciu czynności wątroby) i udana pojedyncza transplantacja u nosiciela mutacji $C F B$ [31].

Jednoczasowa transplantacja lub przeszczepienie wątroby po przeszczepieniu nerki mogą być również rozpatrywane w przypadku nieskutecznej terapii ekulizumabem. W przypadku 5-letniego pacjenta z mutacją czynnika $\mathrm{H}$, u którego po przeszczepieniu nerki terapia ekulizumabem nie zapobiegała epizodom trombocytopenii, przeszczepie- nie wątroby w 8 r.ż. umożliwiło wyrównanie parametrów hematologicznych i poziomu C3b-9, umożliwiając zakończenie terapii ekulizumabem po 3 miesiącach $\mathrm{z}$ dobrym skutkiem [32].

\section{GENETYKA A PROFILAKTYKA NAWROTU AHUS W PRZESZCZEPIONEJ NERCE}

Konieczność wprowadzenia profilaktyki nawrotu zespołu hemolityczno-mocznicowego pod postacią podawania ekulizumabu jest ściśle związana z genotypem chorego. Doświadczenia zgromadzone podczas 71 transplantacji u 57 pacjentów z aHUS pozwoliły podzielić mutacje na poszczególne grupy ryzyka nawrotu, na podstawie których ustalono, czy konieczne jest leczenie podtrzymujące i jak długo powinno być one utrzymywane. Ryzyko nawrotu choroby jest najwyższe podczas pierwszego roku, malejąc gwałtownie w ciągu dwóch lat od przeszczepienia [33].

Belgijskie wytyczne dotyczące leczenia aHUS u pacjentów dorosłych dzielą mutacje na trzy kategorie: niskiego ryzyka nawrotu, w obecności których nie stosuje się profilaktyki ekulizumabem ( $M C P$, przeciwciała anty-CFH, $D G K E)$, pośredniego ryzyka, w którym profilaktyka jest wdrażana na 3 miesiące (brak wykrytej mutacji z/bez wykrytych przeciwciał, występowanie wariantów o nieznanej patogenności, mutacja w CFI) oraz zmiany wysokiego ryzyka nawrotu (warianty $C F H$, rearanżacje w obrębie CFH/CFHR1, C3 i CFB), w których profilaktykę nawrotu stosuje się przez 6 miesięcy [11].

W przypadku dzieci, stanowisko opublikowane w 2016 roku uznaje aktualną wiedzę na temat skutków odstawienia ekulizumabu u biorców nerki za niewystarczającą i zaleca utrzymanie leczenia.

\section{PODSUMOWANIE}

O atypowym zespole hemolityczno-mocznicowym wciąż można powiedzieć, że jest to choroba stawiająca przed lekarzem wiele wyzwań, rozpoczynających się już w momencie diagnozy, której podstawowym celem jest wyodrębnienie cech różnicujących aHUS od typowego HUS. Dla pacjenta, prawidłowa diagnoza to możliwość otrzymania odpowiedniego leczenia. Wiadomo, że tło genetyczne pacjenta ma wpływ na odpowiedź na terapię, rokowanie, na występowanie nawrotów choroby, jednakże dla wielu zidentyfikowanych dotychczas wariantów nie określono związku z przebiegiem choroby. Niezbędna jest zatem szeroka diagnostyka genetyczna pacjentów, która umożliwi opisanie jak najszerszego profilu genetycznego aHUS. Najnowsze piśmiennictwo wskazuje na konieczność analizowania genów związanych nie tylko z układem dopełniacza, ale także z układem krzepnięcia, co niewątpliwie obrazuje poziom skomplikowania choroby. W przypadku choroby o tak złożonym tle genetycznym każdy badany pacjent wnosi nową wiedzę pozwalającą na lepsze diagnozowanie i leczenie osób, które zachorują w przyszłości. 


\section{PIŚMIENNICTWO}

1. Szczepańska M, Adamczyk P, Adamczuk D et al. Zespół hemolitycznomocznicowy w Polsce - podsumowanie 5-lat działania rejestru. Przegl Lek. 2019;76(5):321.

2. Fremeaux-Bacchi V, Fakhouri F, Garnier A et al. Genetics and outcome of atypical hemolytic uremic syndrome: a nationwide French series comparing children and adults. Clin J Am Soc Nephrol. 2013;8(4):554562. doi: $10.2215 / \mathrm{CJN} .04760512$.

3. Ariceta $\mathrm{G}$, Besbas N, Johnson $\mathrm{S}$ et al. Guideline for the investigation and initial therapy of diarrhea-negative hemolytic uremic syndrome. Pediatr Nephrol. 2009;24(4):687-696. doi: 10.1007/s00467-0080964-1.

4. Davin JC, Buter N, Groothoff J et al. Prophylactic plasma exchange in CD46-associated atypical haemolytic uremic syndrome. Pediatr Nephrol. 2009;24(9):1757-1760. doi: 10.1007/s00467-009-1188-8.

5. Noris M, Caprioli J, Bresin E et al. Relative role of genetic complement abnormalities in sporadic and familial aHUS and their impact on clinical phenotype. Clin J Am Soc Nephrol. 2010;5(10):1844-1859. doi: 10.2215/CJN.02210310.

6. Campistol JM, Arias M, Ariceta G et al. An update for atypical haemolytic uraemic syndrome: diagnosis and treatment. A consensus document. Nefrologia. 2015;35(5):421-447. doi: 10.1016/j.nefro.2015.07.005.

7. Ruszkowski J, Heleniak Z, Debska-Slizien A. Atypical hemolytic uremic syndrome: a new drug program and first Polish adult patient treated with eculizumab. Pol Merkur Lekarski. 2018;45(267):119-121.

8. Loirat C, Fakhouri F, Ariceta $G$ et al. An international consensus approach to the management of atypical hemolytic uremic syndrome in children. Pediatr Nephrol. 2016;31(1):15-39. doi: 10.1007/s00467-015-3076-8.

9. Raina R, Krishnappa V, Blaha T et al. Atypical Hemolytic-Uremic Syndrome: An Update on Pathophysiology, Diagnosis, and Treatment. Ther Apher Dial. 2019;23(1):4-21. doi: 10.1111/1744-9987.12763.

10. Noris M, Remuzzi G. Genetics of Immune-Mediated Glomerular Diseases: Focus on Complement. Semin Nephrol. 2017;37(5):447-463. doi: 10.1016/j.semnephrol.2017.05.018.

11. Claes KJ, Massart A, Collard L et al. Belgian consensus statement on the diagnosis and management of patients with atypical hemolytic uremic syndrome. Acta Clin Belg. 2018;73(1):80-89. doi: 10.1080/17843286.2017.1345185.

12. Goodship TH, Cook HT, Fakhouri F et al. Atypical hemolytic uremic syndrome and C3 glomerulopathy: conclusions from a, Kidney Disease: Improving Global Outcomes" (KDIGO) Controversies Conference. Kidney Int. 2017;91(3):539-551. doi: 10.1016/j.kint.2016.10.005.

13. Bu F, Zhang Y, Wang K et al. Genetic Analysis of 400 Patients Refines Understanding and Implicates a New Gene in Atypical Hemolytic Uremic Syndrome. J Am Soc Nephrol. 2018;29(12):2809-2819. doi: 10.1681/ ASN.2018070759.

14. Nester CM, BarbourT, de Cordoba SR et al. Atypical aHUS:State of the art. Mol Immunol. 2015;67(1):31-42. doi: 10.1016/j.molimm.2015.03.246.

15. Goodship TH. Factor $\mathrm{H}$ genotype-phenotype correlations: lessons from aHUS, MPGN II, and AMD. Kidney Int. 2006;70(1):12-13. doi: 10.1038/ sj.ki.5001612.

16. Manenti L, Gnappi E, Vaglio A et al. Atypical haemolytic uraemic syndrome with underlying glomerulopathies. A case series and a review of the literature. Nephrol Dial Transplant. 2013;28(9):2246-2259. doi: $10.1093 / \mathrm{ndt} / \mathrm{gft} 220$.

17. Venables JP, Strain L, Routledge D et al. Atypical haemolytic uraemic syndrome associated with a hybrid complement gene. PLoS Med. 2006;3(10):e431. doi: 10.1371/journal.pmed.0030431.
18. BienaimeF,Dragon-Durey MA, Regnier CHetal. Mutations in components of complement influence the outcome of Factor l-associated atypical hemolytic uremic syndrome. Kidney Int. 2010;77(4):339-349. doi: 10.1038/ki.2009.472.

19. Nilsson SC, Sim RB, Lea SM et al. Complement factor I in health and disease. Mol Immunol. 2011;48(14):1611-1620. doi: 10.1016/j. molimm.2011.04.004.

20. Esparza-Gordillo J, Goicoechea de Jorge E, Buil A et al. Predisposition to atypical hemolytic uremic syndrome involves the concurrence of different susceptibility alleles in the regulators of complement activation gene cluster in 1q32. Hum Mol Genet. 2005;14(5):703-712. doi: 10.1093/hmg/ddi066.

21. Fujisawa M, Kato H, Yoshida $Y$ et al. Clinical characteristics and genetic backgrounds of Japanese patients with atypical hemolytic uremic syndrome. Clin Exp Nephrol.2018;22(5):1088-1099. doi:10.1007/s10157-018-1549-3.

22. Fremeaux-Bacchi V, Miller EC, Liszewski MK et al. Mutations in complement C3 predispose to development of atypical hemolytic uremic syndrome. Blood. 2008;112(13):4948-4952. doi: 10.1182/ blood-2008-01-133702.

23. Vieira-Martins P, El Sissy C, Bordereau P et al. Defining the genetics of thrombotic microangiopathies. Transfus Apher Sci. 2016;54(2):212219. doi: 10.1016/j.transci.2016.04.011.

24. Kavanagh D, Goodship TH, Richards A. Atypical hemolytic uremic syndrome. Semin Nephrol. 2013;33(6):508-530. doi: 10.1016/j. semnephrol.2013.08.003.

25. Delvaeye M, Noris $M$, De Vriese $A$ et al. Thrombomodulin mutations in atypical hemolytic-uremic syndrome. N Engl J Med. 2009;361(4):345357. doi: 10.1056/NEJMoa0810739.

26. Lemaire M, Fremeaux-Bacchi V, Schaefer $F$ et al. Recessive mutations in DGKE cause atypical hemolytic-uremic syndrome. Nat Genet. 2013;45(5):531-536. doi: 10.1038/ng.2590.

27. BuF,Maga T,Meyer NC etal.Comprehensivegenetic analysis of complement and coagulation genes in atypical hemolytic uremic syndrome. J Am Soc Nephrol. 2014;25(1):55-64. doi: 10.1681/ASN.2013050453.

28. Dragon-Durey MA, Sethi SK, Bagga A et al. Clinical features of antifactor $\mathrm{H}$ autoantibody-associated hemolytic uremic syndrome. J Am Soc Nephrol. 2010;21(12):2180-2187. doi: 10.1681/ASN.2010030315.

29. Reuter S, Heitplatz B, Pavenstadt H et al. Successful long-term treatment of TMA with eculizumab in a transplanted patient with atypical hemolytic uremic syndrome due to MCP mutation. Transplantation. 2013;96(10):e74-76. doi: 10.1097/01.TP.0000435705.63428.1f.

30. Nishimura J, Yamamoto M, Hayashi S et al. Genetic variants in $C 5$ and poor response to eculizumab. N Engl J Med. 2014;370(7):632-639. doi: 10.1056/NEJMoa1311084.

31. Saland J. Liver-kidney transplantation to cure atypical HUS: still an option post-eculizumab? Pediatr Nephrol. 2014;29(3):329-332. doi: 10.1007/s00467-013-2722-2.

32. Coppo R, Bonaudo R, Peruzzi RL et al. Liver transplantation for aHUS: still needed in the eculizumab era? Pediatr Nephrol. 2016;31(5):759-768. doi: 10.1007/s00467-015-3278-0.

33. Le Quintrec M, Zuber J, Moulin B et al. Complement genes strongly predict recurrence and graft outcome in adult renal transplant recipients with atypical hemolytic and uremic syndrome. Am J Transplant. 2013;13(3):663-675. doi: 10.1111/ajt.12077.

\section{Podziękowania}

Autorzy pragna serdecznie podziękować prof. dr hab. n. med. Joannie Matuszkiewicz-Rowińskiej (Centralny Szpital 
Kliniczny, UCK WUM), dr hab. n. med. Małgorzacie Pańczyk-Tomaszewskiej, dr Beacie Leszczyńskiej, dr Piotrowi Skrzypczykowi (Dziecięcy Szpital Kliniczny im. Józefa Polikarpa Brudzińskiego, UCK WUM), a w szczególności prof. dr hab.n. med. Marii Szczepańskiej (Samodzielny Publiczny Szpital Kliniczny Nr 1 im. Prof. Stanisława Szyszko, ŚUM) za pomoc okazana podczas pisania niniejszej pracy.

\section{ORCID:}

Ewelina Użarowska - 0000-0002-0443-4733

Michał Kościółek - 0000-0002-4912-4413

Anna Wójcicka - 0000-0001-5803-6397

\section{Źródła finansowania}

Projekt „Comprehensive genetic diagnostics of thrombotic microangiopathies - a genetic test and clinical algorithm to predict risk of renal transplant failure", TEAM TECH 4/2017. Kierownik projektu: dr hab. n. med. Anna Wójcicka oraz Fundacja Rozwoju Diagnostyki i Terapii, ul. Stupecka 11/12, Warszawa.

\section{Konflikt interesów:}

Autorzy sa pracownikami firmy WARSAW GENOMICS.

\author{
AUTOR KORESPONDUJĄCY \\ Ewelina Użarowska \\ Warsaw Genomics \\ ul. Pasteura 5a, 02-093 Warszawa, \\ tel.: 226580180,226580259 \\ e-mail: ewelina.uzarowska@warsawgenomics.pl
}

Nadesłano: 20.05.2019

Zaakceptowano: 04.10.2019 
PRACA POGLĄDOWA

REVIEW ARTICLE

\title{
MODERN DEMOGRAPHIC TRENDS IN UKRAINE AS A GROUND FOR REALIZATION OF PREVENTION STRATEGIES
}

\author{
Tetiana S. Gruzieva, Mykhailo D. Diachuk, Hanna V. Inshakova, Viktoria B. Zamkevych \\ BOGOMOLETS NATIONAL MEDICAL UNIVERSITY, KYIV, UKRAINE \\ STATE INSTITUTION OF SCIENCE «RESEARCH AND PRACTICAL CENTER OF PREVENTIVE AND CLINICAL MEDICINE» STATE ADMINISTRATIVE \\ DEPARTMENT, KYIV, UKRAINE
}

\begin{abstract}
Introduction: The data of the world statistics show that the process of demographic ageing becomes significant in modern conditions, and the number of elderly people annually increases by $3 \%$. Owing to the global tendencies for ageing, the health care and social security systems are facing important challenges to ensure healthy lives and promote the well-being for this segment of population, provide affordable and quality medical care according to needs.

The aim: Establishing modern peculiarities and trends of medical and demographic situation in Ukraine in the context of ageing population in order to substantiate medical and preventive measures

Materials and methods: According to the data of the State Service of Statistics of Ukraine of the Ministry of Public Health for 1990-2017 the tendencies of medical and demographic characteristics of the population of Ukraine have been identified. The national medical and demographic indicators have been compared with the indicators of the countries of WHO European Region according to the data of the European Database "Health for everybody". Using the least squares method, a forecast of the Ukrainian population and its age structure for the period up to 2030 has been made.

Review: A tendency for Ukrainian population decline by $18,1 \%$ over the course of $1990-2017$, which is caused by, along with other reasons, decrease in population birth rate by $25,4 \%$ and increase in mortality by $19,8 \%$, has been identified. A steady tendency for a decline in the proportion of children's population up to the age 14 years inclusive for the twenty-seven-year period from $21,5 \%$ till 15,5\%, and for an increase in the proportion of population aged more than 60 years from 18,3 till $22,9 \%$ has been detected. The share of people over 65 in the age structure of population has increased from $12,0 \%$ till 16,5\%. The analysis of regional indicators confirms that there are unfavorable demographic tendencies in the southeastern, northeastern and central provinces, and more favorable tendencies in the provinces of the West Region of the country. The proportion of children's population up to the age 14 years inclusive was in Ukraine close to the indicator in the countries of European Union and less than the average in WH0 European Region (17,8\%), the proportion of people over 65 - close to European regional indicator (15,5\%) and less than the indicator in the countries of European Union (19,0\%).

A forecast of the population and its age structure up to 2030 has been made, according to which less than 40 million will live in Ukraine, and the proportion of persons over 65 years will reach $19,1 \%$.

Conclusions: The tendencies for Ukrainian population decline and changes in its age structure towards ageing make it necessary to take measures to prevent negative medical and demographic trends and provide conditions for healthy ageing, to increase the affordability and quality of medical care, including for persons of senior age groups, and improve the work of health care facilities on prophylaxis of diseases.
\end{abstract}

KEY WORDS: age structure, death rate, birth rate, ageing, forecast

\section{INTRODUCTION}

The goals in the area of sustainable development for the period up to 2030 , adopted by the world community in 2015 , envisage the formation of a prosperous, inclusive and sustainable world. One of the strategic goals is to ensure healthy lives and promote the well-being for people at all ages [1].

Ukraine, like other countries of the world, has, in accordance with the global goals, developed and approved the national system of sustainable development goals. Among the various components of achieving goal, i.e. ensuring healthy lives and promoting the well-being for people, the priority is given to reducing a premature mortality from non-infectious diseases by one third with the help of prophylaxis and treatment as well as support for mental health und well-being [2].

Actuality of the solution of this problem in Ukraine and other countries is conditioned by considerable levels of prevalence of non-infectious diseases and their risk factors, and negative tendencies for their growth. Among the numerous causes of the unfavorable situation in Ukraine, along with social, economic, environmental, psychological and other determinants, the important role is played by the demographic factor [3-5].

The WHO report on a situation in the area of non-communicable diseases in the world for 2010 states that the epidemic of non-infectious diseases has a global character, and emphasizes its leading causes, namely spontaneous 
urbanization, globalization of an unhealthy lifestyle and demographic ageing [6].

The data of the world statistics show that the process of demographic ageing becomes significant in modern conditions, and the number of elderly people annually increases by $3 \%$. By 2017, the number of residents of the planet aged 60 years and older was 962 millions, or $13 \%$ of the world population. Europe is one of the oldest regions of the world, where $25 \%$ of all people aged 60 and older are concentrated $[7,8]$.

According to the forecasts, the total number of elderly people on the planet will reach approximately 1,4 billion in $2030,2,1$ billion in 2050, and 3,1 billion in 2100. At the same time the number of residents of the planet aged 80 and older will have tripled from 137 million in 2017 to 425 million in 2050 and 909 million in 2100 [9].

Owing to the global tendencies for ageing, the health care and social security systems are facing important challenges to ensure healthy lives and promote the well-being for this segment of population, provide affordable and quality medical care according to needs.

It is known that ageing, along with the formation of a number of problems for the society in the form of the increased demand for emergency medical care, long-term nursing, the burden on the pension system, also opens up numerous opportunities, which may be used to reach the sustainable development goals. In fact, people of elderly age can make a considerable contribution to the life of the society as active members of their families, voluntary helpers and active participants of labor processes. The experts emphasize the responsibility of the societies, communities for the correlation of problems and opportunities related to ageing [10].

Considering it, the WHO has adopted and actively promotes the conception of healthy ageing. The International Community defined the theme of ageing as predominant for the celebration of the World Day of Health in 2012 that was held under the slogan "The health adds life to years». The conception of healthy ageing envisages the creation of conditions that are favorable for people of elderly age and aimed at preservation of health, extension of active life without diseases and disability, with opportunities to carry out the interesting activities and participate in the life of communities. This conception has found its reflection in a number of documents of the WHO, especially in the documents «Health-2020: Principles of Policy and Strategy», «Health-2020: Principles of European Policyin support of actions of the entire state and society in the interests of health and well-being», «Realizing the conceptual vision of the policy "Health-2020": strategy management in the interests of health in XXI century. Realization of tasks planned», etc. [11-13]. The above-mentioned documents emphasize the priority to provide conditions for healthy ageing, investing in health on all stages of life of people, reducing a burden of the underlying diseases, strengthening the systems of public health orientated to needs of people, integration of various medical and non-medical services, strategy management, whole -of- government approach, approach with participation of the entire society, innovation, etc.
An important precondition for solving numerous tasks in the context of promoting healthy ageing and overwhelming non-infectious diseases is the monitoring of demographic processes, their estimation and a forecast for the next future and remote perspective. [10, 14-15].

Taking into account the above-mentioned facts, the research of modern demographic trends in Ukraine is an actual task for the formation of a policy aimed at achieving goals of human development and creation of favorable conditions for people of senior age groups.

\section{THE AIM}

Aim: establishing modern peculiarities and trends of medical and demographic situation in Ukraine in the context of ageing population in order to substantiate medical and preventive measures

\section{MATERIALS AND METHODS}

When carrying out the research, the bibliographic, epidemiologic, medical-statistical and analytical methods have been applied. The analysis of a medical and demographical situation in Ukraine was made in accordance with the data of the State Service of Statistics of Ukraine, the Central Medical Service of the Ministry of Public Health of Ukraine for 1990-2017. The tendencies of average expected lifespan (AEL), mortality and proportion of elderly people in the age structure of population, their peculiarities in the regional aspect and in comparison with the countries in WHO European Region have been researched. The Ukrainian population ageing rate was estimated. Using the least squares method, a forecast of the population and its age structure for the period up to 2030 has been made.

\section{REVIEW AND DISCUSSION}

The analysis of the data of the State Committee of Statistics /Derzhstat/ of Ukraine for 1990-2017 has allowed identifying a steady tendency for decrease in population of Ukraine by 9,3 million or $18,1 \%$ (Fig.1). The depopulation is caused by a number of factors, including increase in death rate, decrease in birth rate, migration processes and occupation of part of territory of the country.

Considering the above-mentioned facts, the changes in the number of population on some administrative territories and a contribution of socioeconomic characteristics to the process of population decline have been researched.

It was established, that the depopulation processes had different tempos on some administrative territories of Ukraine. The single administrative territory with population growth was the city of Kiev, where the number of population has increased by $10,2 \%$ over the course of 1990-2017.

The analysis of death rates of population of Ukraine shows the steady tendencies for increase in mortality from 12,1 per 1000 population in 1990 till 14,5 per 1000 population in 2017 , i.e. by $19,8 \%$. At that the highest mortality 


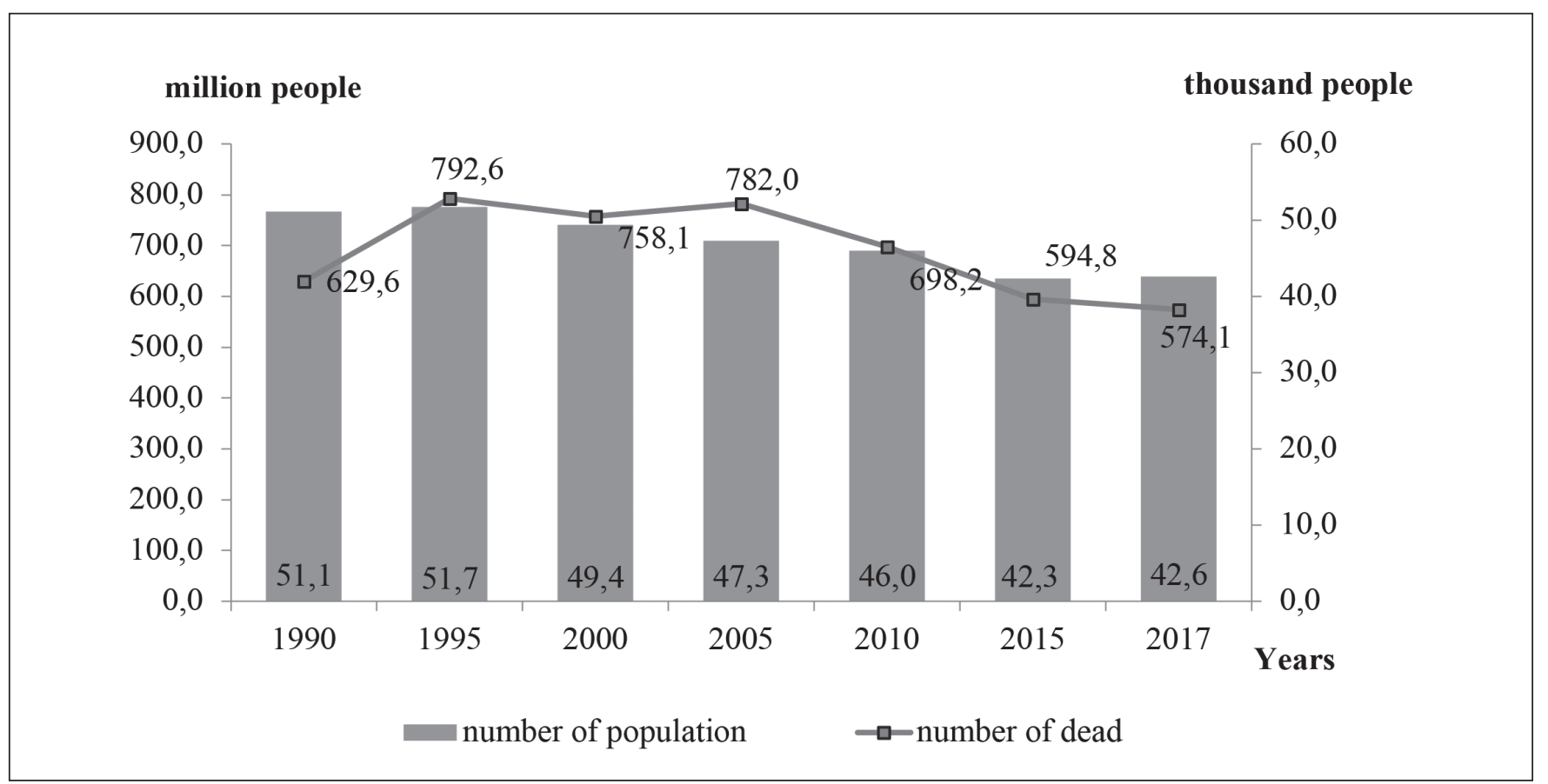

Fig.1. Number of population and cases of death of population of Ukraine in 1990-2017 (absolute data)

levels of population have been observed over the course of 2003-2008, when they exceeded 16,0 per 1000 population. Number of death cases fluctuated in certain years from 574,1 till 792,6 thousand. (Fig.1).

The comparative analysis of death rates in Ukraine and the countries in WHO European Region has shown that the National Death Index for 2015 was $39,0 \%$ above the average in WHO European Region and 36,3\% above the average in the countries of the European Union. The mortality levels, which are lower than those in Ukraine, have been reached in a number of economically developed countries, especially in Ireland $(6,4 \%)$, Norway $(7,8 \%$ ), Switzerland $(8,0 \%)$, France $(8,7 \% 0)$ and others.

Within the country, the regional mortality statistics reflected the regional peculiarities of a population decline. Thus, the highest mortality indices in 2017 have been found in the provinces with the fastest depopulation in the period 1990-2017, where the death rate exceeded 16,0 per 1000 population. The highest mortality indices, which exceeded the initial level by one-third, were detected in the provinces with sufficiently high levels of mortality in 2017.

At the same time, in the majority of the provinces of the West Region, in spite of considerable rate of increase in mortality of population for the seventeen-year period (12,7\%-29,0\%), the mortality levels in 2017 were significantly lower than the average in Ukraine and made up $12,0-12,6$ cases per 1000 population.

Taking into account the important role of human reproduction in the process of formation of the age structure of population, the levels and dynamics of the birth rate in Ukraine in the period 1990-2017 have been analyzed. It was established that the birth rate during the 27-year period had tendency for decrease from 12,6 per 1000 population in 1990 till 9,4 per 1000 population in 2017 , i.e. by $25,4 \%$.
In the context of absolute measurement the number of births has fallen from 657,2 thousand in 1990 till 364,0 thousand in 2017. (Fig. 2).

In the period 1990-2001 a clear trend for decline in birth rates of Ukraine have been observed. The lowest birth rate, that made up 7,7 per 1000 population and was lower than the birth rate of 1990 by 38,9\%, was registered in 2001 . Since 2002 the birth rate has been gradually increasing to maximal level $-11,4$ per 1000 population in 2012 . The increase in number of births in this period made up $48,1 \%$. Afterwards there was a tendency for decline in birth rate till 9,4 per 1000 population in 2017, i.e. decline in birth rate was $17.5 \%$.

By comparison of birth rates in Ukraine and the countries in WHO European Region it was established that the National Index for 2015 was less than the average in the Region by $26,4 \%$ and by $8,0 \%$ - average in the countries of the European Region. The levels of the birth rate higher than the birth rate in Ukraine were in a number of economically developed countries, especially in Great Britain $(12,0 \%)$, Sweden $(11,9 \%)$, Norway $(11,3 \%)$.

The regional peculiarities of the birth rate of population of Ukraine that are expressed in its high levels in the provinces of the West Region and the provinces of the Northern Region have been established. The decline in the birth rates at an extremely fast pace (by $34,9 \%-38,0 \%$ ) was observed both in the provinces with a high birth rate and in the provinces with a low birth rate.

The analysis of indices of natural growth of population of Ukraine in the period 1990-2017 confirms the increase in natural population decline. In 1990 the natural decline was $-4,0$ per 1000 population, in 2017 it reached $-5,1$ per 1000 population. A positive population growth was registered only in the city of Kiev (+1.6 per 1000 population). 


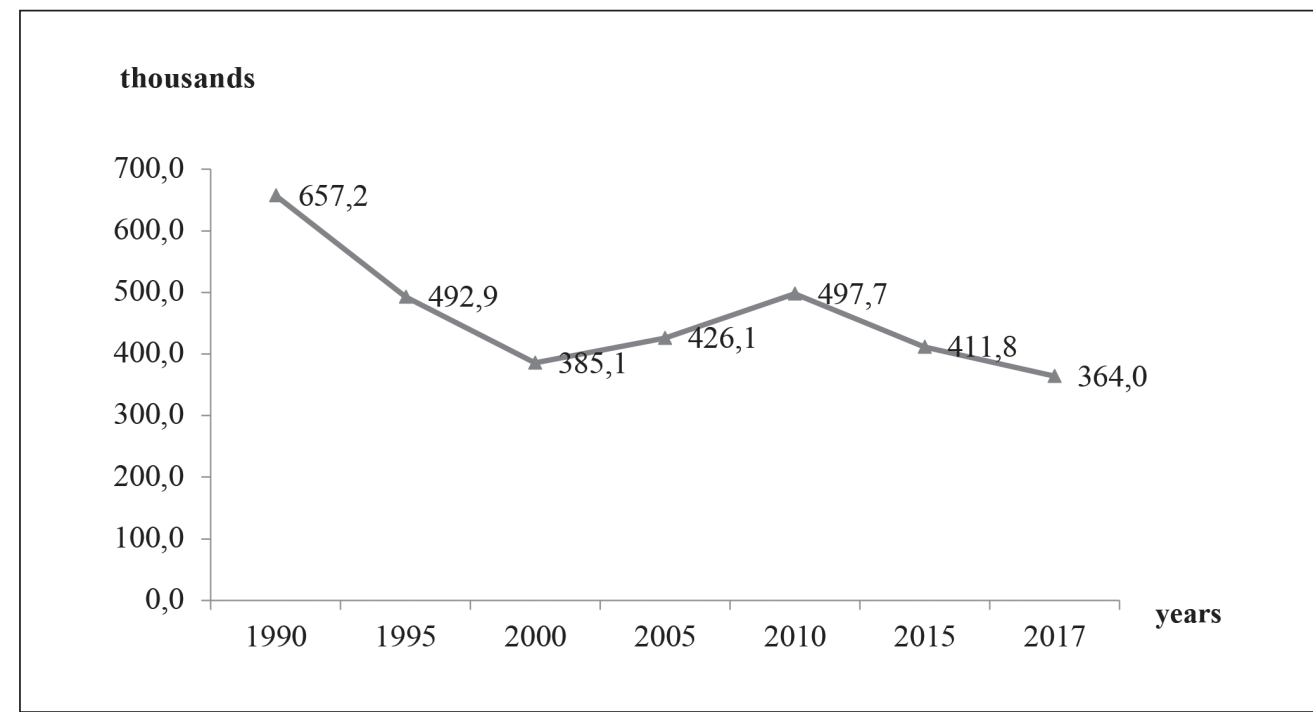

Fig. 2. Birth rate in Ukraine in 19902017 (absolute data).
Relatively low indices of natural population decline were detected in the provinces of the West Region of Ukraine.

Low indices of reproduction of population lead to changes in the age composition of population and increase in the proportion of population of senior age groups.

The analysis of the age structure of population over a period of 1990-2017 detected a steady increase in the proportion of population of senior age groups against the background of decrease in the proportion of children's population. In 1990 the percentage of children at the age 0-14 years in the total population of Ukraine made up 21,5\%. It has fallen till $15,5 \%$ over the twenty-seven-year period.

In WHO European Region the proportion of children's population up to the age 14 years inclusive made up 17,8 \% in 2015, in the countries of the European Union - 15,5\%. According to the data of the European Datebase "Health for Everybody" this indicator in Ukraine made up $15,1 \%$ at this time. In a number of the European economically developed countries the analogous indicator was less than the Ukrainian one, especially in Germany $(13,15)$, Italy $(13,7 \%)$, Bulgaria $(14,0 \%)$, Lithuania (14,6\%), Poland (14,9\%), which confirms the common-European tendency for decline in the proportion of children in the general structure of population.

A rapid ageing of the population of Ukraine is confirmed by increase in the proportion of persons over 60 years of age in the general age structure of population from 18,3\% in 1990 till 22,9\% in 2017 (Fig.3).

The share of persons over 65 years of age made up $16,5 \%$ in 2017, whereas in 1990 it was $12,0 \%$. At that, in some provinces each resident was older than 65 years of age.

The analysis of the European Database «Health for Everybody» detected that the proportion of persons over 65 years of age in the age structure of population in Ukraine in 2015 was close to the European regional indicator (15,5\%) and less than the indicator in the EU countries (19,0\%). So, in Italy $(22,4 \%)$, Germany (21,1\%), Portugal (20,7\%), and Finland (20,3\%) every fifth respondent was older than 65 years of age. Poland had the indicator close to Ukraine (15,6\%).

The process of population ageing and increase in proportion of persons of senior age groups in the age structure is related to decrease in birth rate and increase in life expectancy of population. The analysis of average expected lifespan in Ukraine detected the tendency for decrease in average expected lifespan in Ukraine from 70,4 years in 1990 till 67,1 years in 1996, and in the years that followed - wavelike increase in life expectancy till 72 years in 2017. Difference in average expected lifespan of men and women made up 9,2 years in 1990 and 9,8 years in 2017. With comparison of average expected lifespan in Ukraine und EU countries it was established that the National Indicator for 2015 was $6,8 \%$ less than the average in the Region and $10.4 \%$ less than the average in the EU countries. Indicators of average expected lifespan higher than those in Ukraine were in a number of economically developed countries, especially in Spain ( 83,0 years), Italy ( 82,8 years), Norway ( 82,5 years), Island (82,4 years), Sweden ( 82,2 years), Austria ( 81,9 years), etc.

With the least squares method the forecast of population and the proportion of age groups in the structure of population till 2030 have been determined. It was established that, if the current tendencies for decrease in birth rate and mortality rate continue, the population will decline till 48,4 million of persons till 2030 (Fig.4).

According to the forecast data, the children's population aged up to 17 years inclusive will decrease from 7,6 million in 2017 till 3,7 million in 2030 (Fig.5). At that, the share of children's population makes up $9,6 \%$ in the general age structure of population.

At the same time, the population over the age of 65 is expected to increase from 6,9 in 2017 till 7,4 million in 2030 (Fig. 6).

According to the forecast data, the share of population over the age of 65 in the general age structure of population will make up $17,2 \%$ in 2020 , and $19,1 \%$ in 2030 .

Taking into account the current tendencies for decrease in birth rate and increase in mortality rate of population, the forecast data concerning decrease in children's population till 2030 and increase in contingents of senior age groups in the general structure of population, the issue of improving the socioeconomic, environmental and other determinants of health, enhancing the quality of life and public health protection becomes very actual. For solving the current problems there must be a complex sector-wide approach with the participation of the entire society under the principle «Health in all policies», with 


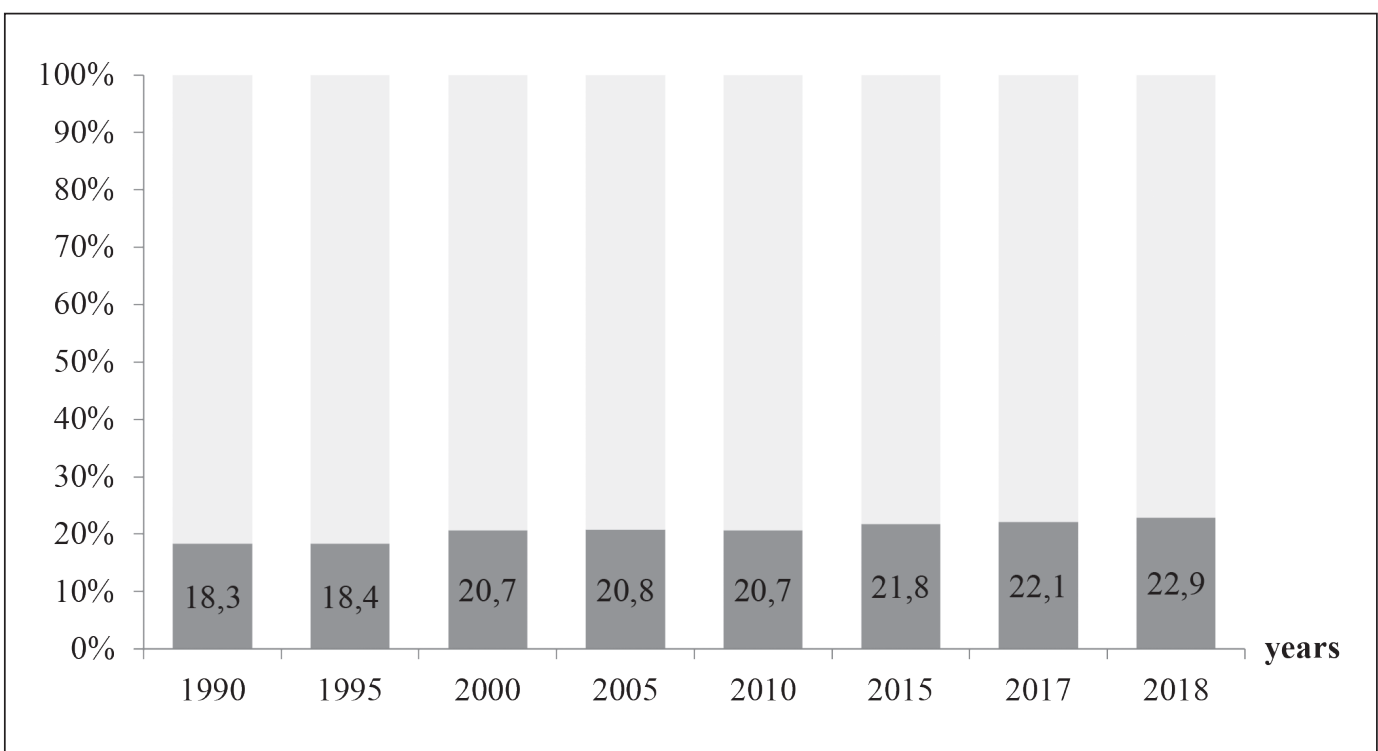

Fig. 3. Proportion of population over 60 years of age in the age structure of population of Ukraine (\%).

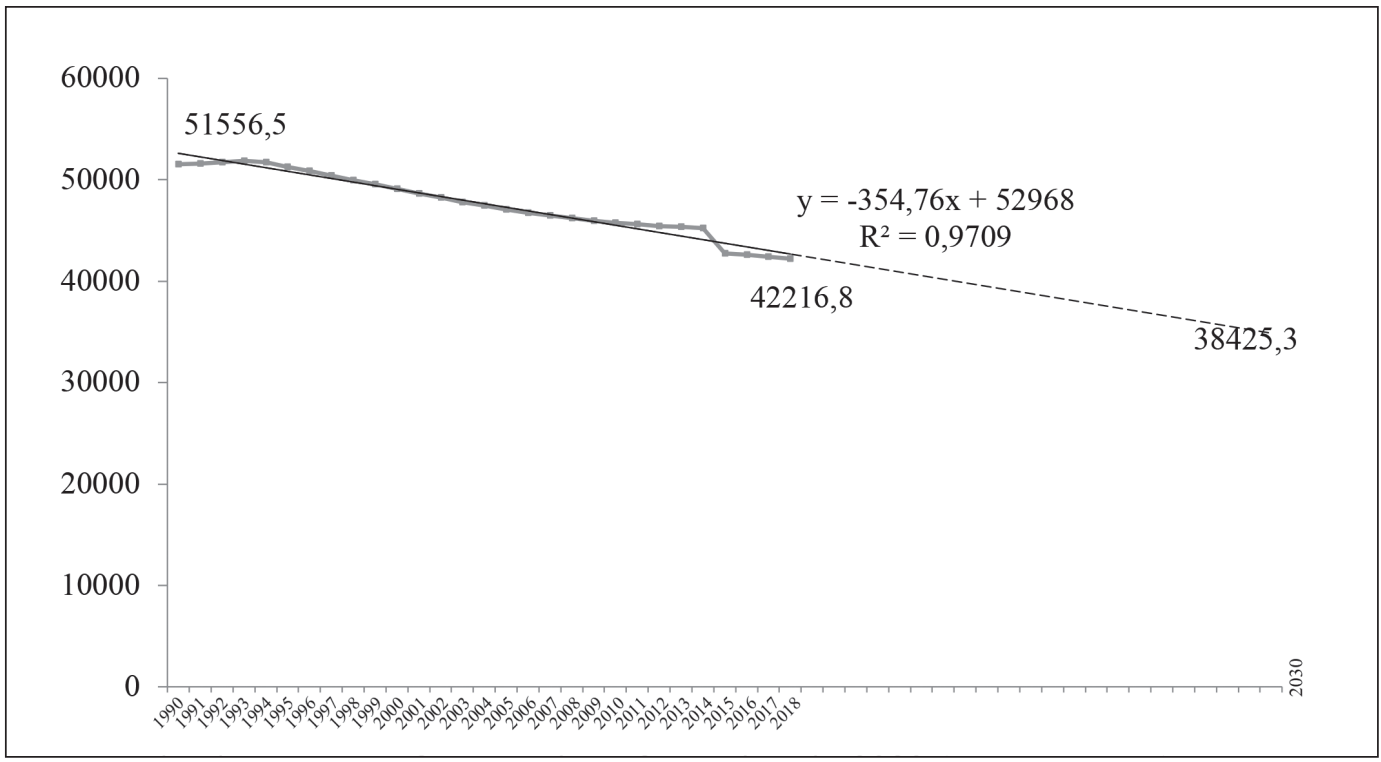

Fig. 4. Forecast of population of Ukraine till 2030 (absolute data)

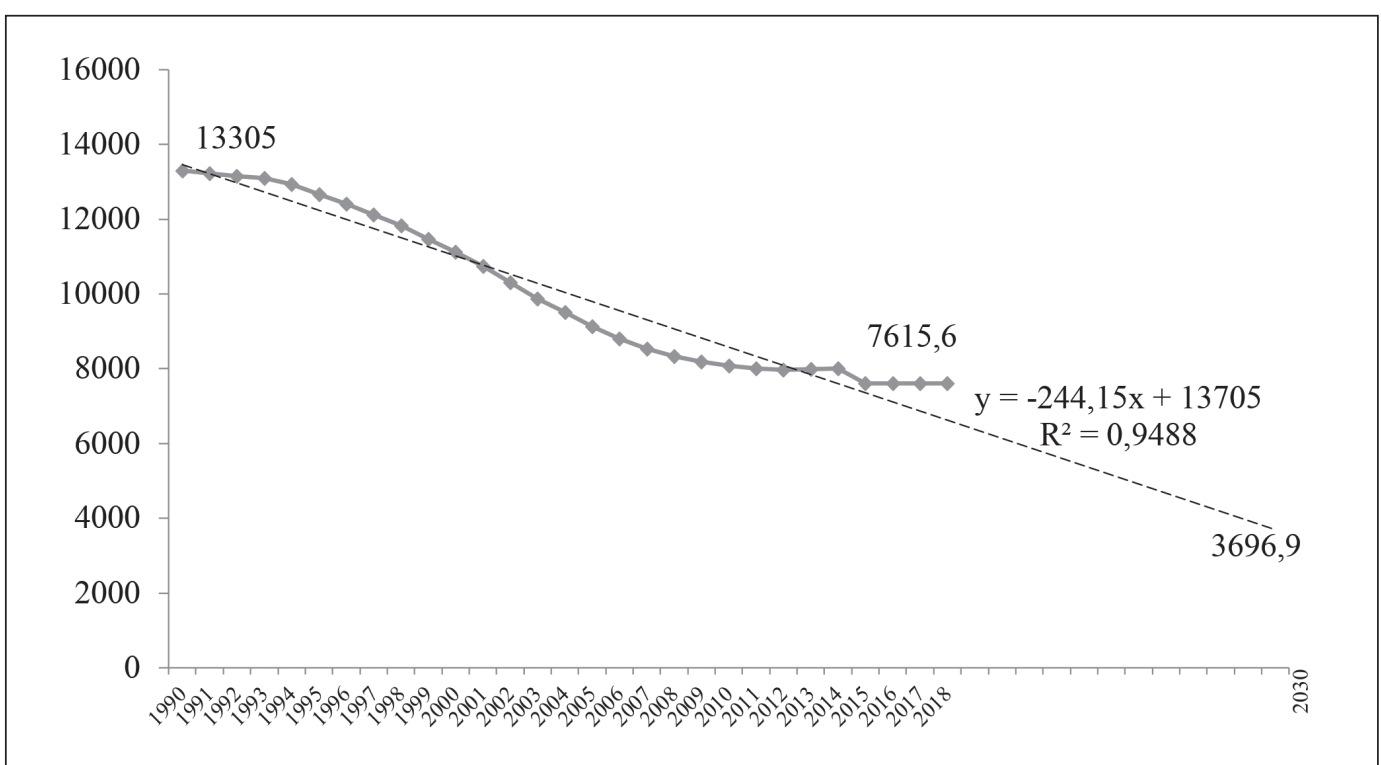

Fig. 5. Forecast of children's population of Ukraine aged up to 17 years inclusive till 2030 (absolute data). 


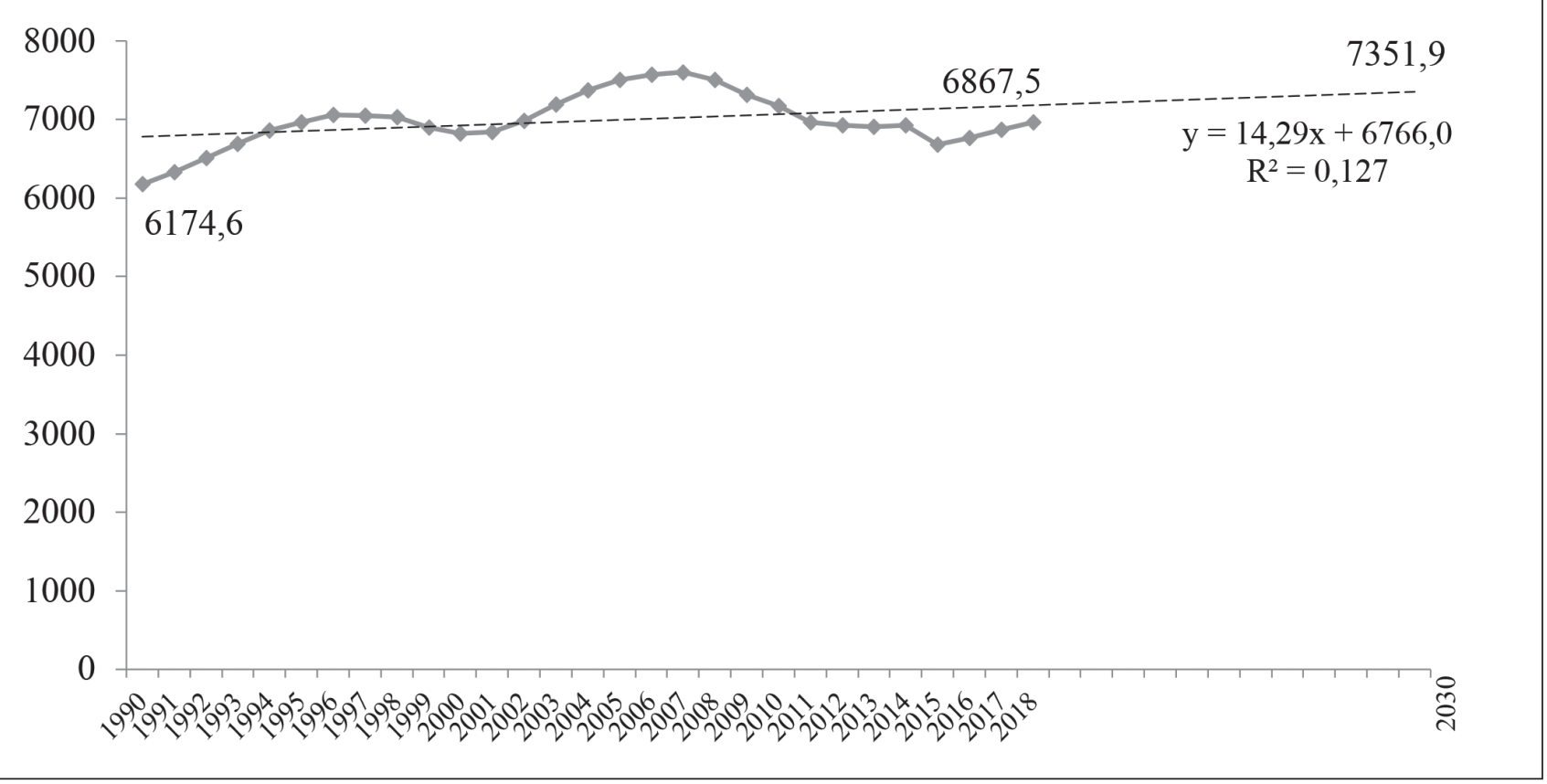

Fig 6. Forecast of population of Ukraine over the age of 65 till 2030 (absolute data).

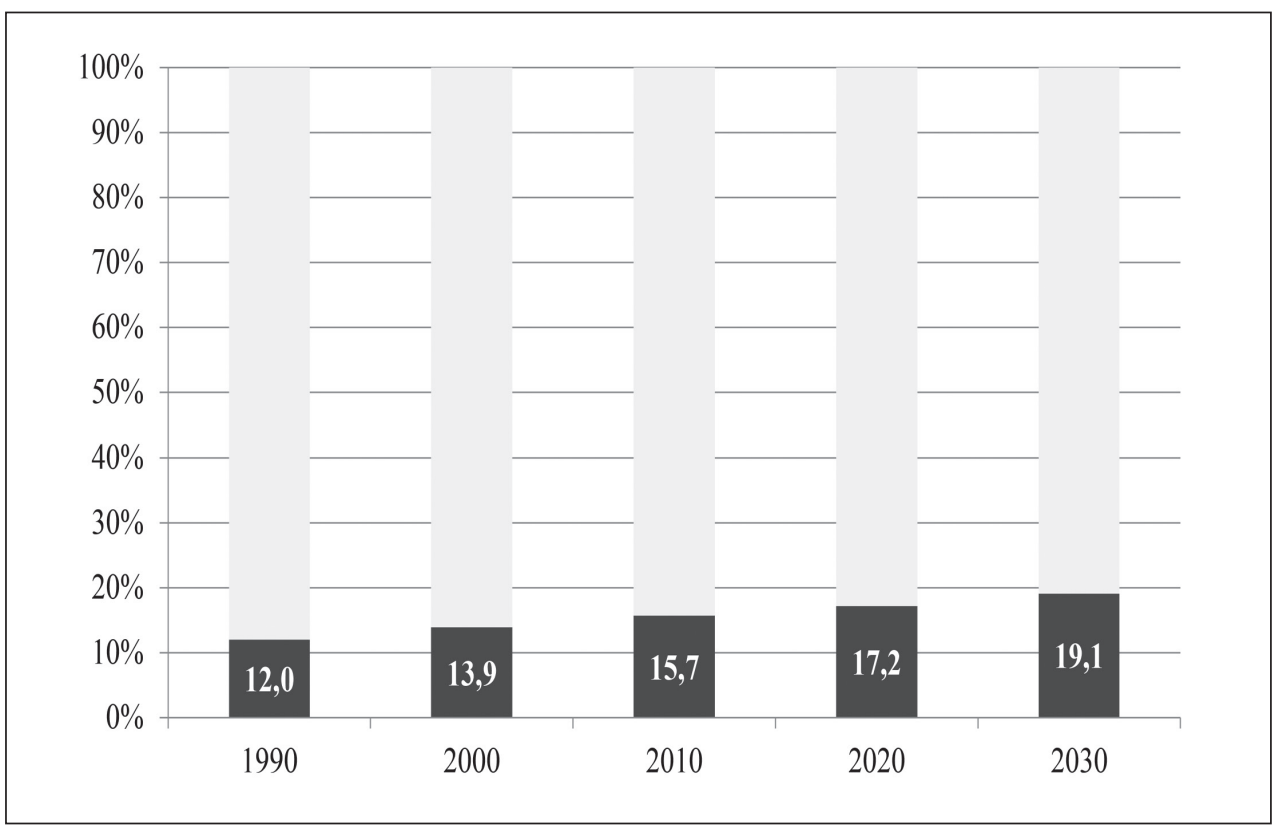

Fig. 7. The proportion of population over the age of 65 in the general age structure of population of Ukraine in the period 1990-2030 (Factual and predicted data, $\%)$.

emphasis on prophylaxis of diseases, their timely detection and quality treatment, from birth and throughout life.

In the context of the identified tendencies, the issue of improvement of medical care and social security of population of elderly age requires a special consideration. It is necessary to change the paradigm of the medical and social assistance that would envisage not only increasing the accessibility and quality of medical assistance for people of senior age groups, development of geriatric and gerontological services, but place the emphasis on the prophylaxis, including a primary, secondary and tertiary prophylaxis. Health care and social security systems are faced with the task to ensure healthy lives und promote the well-being for this segment of population.
An important condition for solving problems is to conduct the prophylactic work with the patients of senior age groups and members of their families so that they could follow a healthy way of life, acquire the self care skills and receive the assistance from their inner circle. Prophylactic recommendations must embrace the issues of healthy nutrition, peculiarities of nutrition of patients with non-infectious diseases, physical activity of patients over the age of 60 with and without age-related pathology, adherence to recommendations and doctor's orders, solution of psychological problems, etc.

In this context, improving the training of medical workers, raising their qualification and acquiring all necessary competencies by them for the work with the patients of senior age groups, including the technologies of prophylactic consulting, 
are important. The substantiation, development and adoption of technologies of prophylactic consulting of persons of senior age groups in the health care facilities will contribute to improving the quality of medical care of this segment of population, preventing many undesirable effects in the elderly, reducing their need for expensive treatment, preserving the potential and ability of elderly people to serve themselves independently, improving the quality of their lives.

\section{CONCLUSIONS}

The medical and demographical situation in Ukraine is characterized by a tendency for population decline that has reached $18,1 \%$ over the course of 1990-2017. The negative tendencies are caused by, along with socioeconomic, environmental and other reasons, decline in birth rate of population by $25,4 \%$, and increase in mortality rate by $19,8 \%$.

A steady tendency for decrease in the proportion of a children's population up to the age 14 years inclusive for the twenty-seven-year period from $21,5 \%$ to $15,5 \%$, and increase in the proportion of people aged more than 60 years in the age structure of population from 18,3 to $22,9 \%$ has been detected. It was established that the proportion of persons aged more than 65 years in the age structure has increased from $12.0 \%$ till $16.5 \%$ over the course of 1990-2017.

The indicator of the proportion of a children's population up to age 14 years inclusive was in Ukraine close to the indicator in the countries of European Union в $(15,5 \%)$ and less that the European middle indicator $(17,8 \%)$, the proportion of persons older than 65 years - close to European regional indicator $(15,5 \%)$ and less than indicator in the countries of European Union (19,0\%).

The analysis of the regional data in Ukraine has shown unfavorable demographic tendencies in southeastern, northeastern and central provinces and more favorable tendencies in provinces of the West region of the country. On all administrative territories there is a population decline, with the exception of the city of Kiev, where the population growth amounts to $10,2 \%$.

A forecast of the number and age structure of population up to 2030 has been made, according to which 38,4 million will live in Ukraine, and the proportion of persons older than 65 years will reach $19,1 \%$.

The tendencies for Ukrainian population decline and changes in its age structure towards ageing make it necessary to take measures to prevent negative medical and demographic trends and provide conditions for healthy aging, increase the affordability and quality of medical care, including for persons of senior age groups, improve the work of health care facilities on prophylaxis of diseases.

\section{REFERENCES}

1. Transforming our world: the 2030 Agenda for Sustainable Development. UN [Internet] 2015. [cited 2019 May 19] 35 p. Available from: https:// sustainable development.un.org/post2015/transformingourworld.

2. Sustainable Development Goals: Ukraine. 2017 National Baseline Report. Kyiv: Ministry of Economic Development and Trade of Ukraine; 2017, $166 \mathrm{p}$.
3. Global status report on noncommunicable diseases 2014 «Attaining the nine global noncommunicable diseases targets; a shared responsibility». Geneva:WH0; 2014, 302 p.

4. Palamar Bl., Gruzieva TS. Criteria of economic effectiveness of preventive measures of chronic non-infectious diseases. Wiad Lek. 2018, tom LXXI, nr 4:897-906.

5. Gruzieva T.S. Neinfektsiini zakhvoriuvannia: masshtaby i tendentsii poshyrenosti, stratehii borotby [Non-communicable diseases: the extent and trends of prevalence, control strategies]. In: Gruzieva T.S., Dyachuk D.D., Zyukov A.L. et al. Annual report on the health status of the population, the sanitary and epidemic situation and the results of the health care system of Ukraine. Kyiv: Ministry of Health of Ukraine; 2016, p. 408-417. (In Ukrainian).

6. Global status report on noncommunicable diseases, 2010. Geneva:WHO; 2011, $176 \mathrm{p}$.

7. World Population Ageing 2017. Highlights. New York: United Nations; 2017, $40 \mathrm{p}$.

8. World Population Prospects. The 2015 Revision. Key Findings and Advance Tables. New York: United Nations; 2015, $59 \mathrm{p}$.

9. World population projected to reach 9.7 billion by 2050 . UN [Internet] 2015. [cited 2019May21].Availablefrom:https://www.un.org/en/development/ desa/news/population/2015-report.html.

10. World report on ageing and health. Geneva: WHO; 2015, $260 \mathrm{p}$.

11. Good health adds life to years: Global brief for World Health Day 2012. A global summary for World Health Day 2012. Geneva:WH0; 2012, 28 p.

12. Health 2020. A European policy framework and strategy for the 21st century. Copenhagen: WHO EURO; 2011, $190 \mathrm{p}$.

13. The European health report 2015. Targets and beyond - Reaching new frontiers in evidence. Copenhagen:WHO EURO; 2015, $150 \mathrm{p}$.

14. Creating age-friendly environments in Europe $A$ tool for local policymakers and planners century. Copenhagen: WHO EURO; 2016, 68 p.

15. Global strategy and action plan on ageing and health. Geneva: WHO; 2017, $46 \mathrm{p}$.

\section{Authors' contributions:}

According to the order of the Authorship.

\section{ORCID numbers:}

Tetiana S. Gruzieva - 0000-0001-9254-7561

Mykhailo D. Diachuk - 0000-0003-0390-4489

Hanna V. Inshakova - 0000-0002-3984-8864

Viktoria B. Zamkevych - 0000-0003-2735-838X

\section{Conflict of interest:}

The Authors declare no conflict of interest.

\section{CORRESPONDING AUTHOR Tetiana S. Gruzieva \\ Bogomolets National Medical University \\ Kyiv, Ukraine \\ e-mail: gruzieva@ukr.net}

Received: 28.06 .2019

Accepted: 26.09 .2019 
PRACA POGLĄDOWA

REVIEW ARTICLE

\title{
MEDICAL AND PSYCHOLOGICAL CONSEQUENCES OF USING ON-SCREEN TECHNOLOGIES OF INFORMATIONAL AND PSYCHOLOGICAL INFLUENCE: ANALYSIS OF THE PROBLEM
}

\author{
Marianna V. Markova', Artur R. Markov ${ }^{1}$, Maya V. Savina ${ }^{2}$, Tsira B. Abdriakhimova ${ }^{3}$, Inna R. Muharovska ${ }^{3}$, \\ Kostiantyn D. Gaponov' ${ }^{1}$ \\ 'KHARKIV MEDICAL ACADEMY OF POSTGRADUATE EDUCATION, KHARKIV, UKRAINE \\ 2V. N. KARAZIN KHARKIV NATIONAL UNIVERSITY, KHARKIV, UKRAINE \\ ${ }^{3}$ BOGOMOLETS NATIONAL MEDICAL UNIVERSITY, KYIV, UKRAINE
}

\begin{abstract}
Introduction: The continuous informatization of modern life dictates the need to identify the consequences of using technologies of informational and psychological influence on the psyche and behavior of the users.

The aim is to analyze the presence of the neurobiological basis of the mechanisms that underlie the pathogenic effect of informational and psychological influence on the state of mental health of the population.

Materials and methods: In the MEDLINE, Index Citation Index Expanded and Social Sciences Citation Index, EMBASE, Cochrane Library databases, content analysis was carried out in three languages on the verification of interconnections between the use of TV and Internet resources and the various characteristics of the mental state of users. Conclusions: The presence and mechanisms of the formation of harmful effects of watching television or using the Internet (social networks), for the state of mental health and psychological well-being of persons of all ages, both children and adults, is proved not only by empirical but also instrumental researches. The way to prevent the negative effects of the use of on-screen technologies of informational and psychological influence is intellectual and physical activity, the capacity for critical reflection of information, the skills of positive thinking, and communication with nature and oneself without any additional means of informational influence.
\end{abstract}

KEY WORDS: informational and psychological influence, television, social networks, medical and psychological consequences

Wiad Lek 2019, 72, 10, 2040-2045

\section{INTRODUCTION}

XXI century - the era of information technology and global integration processes. Information technologies are used in almost all spheres of social life, making society and each particular individual more and more dependent on information [1]. It generates, including the need to determine the presence and vector of the impact of information technologies on the psyche and behavior of their users.

The issue of influence on mass and individual consciousness has always interested mankind: from the founder of the theory of information-psychological war Chinese General and philosopher Sun-Tzi ("Treatise on military art", VI century BC), to G. Lebon ("The Psychology of peoples and masses (crowd psychology)", 1895), V. M. Bekhterev ("Suggestion and its role in public life", 1903) [1] and modern researchers. Sufficient number of specialists learn the basics of the informational-psychological influences (IPI) and manipulative techniques [2], investigate the effect of "mental viruses" [3], others focus on the problem of information-psychological security of the person $[4,5]$, or on attempts to measure the consequences of action / counteraction the negative IPI [6].
Therefore, at the present time, the presence of actions of IPI on the mental state and behavior of users recognized by many scientists of different specialties, however, to date there is no consensus of professionals, particularly in mental health, on the pathogenetic background of this phenomenon. First of all, it concerns the mechanisms of the pathogenic effect of the information-psychological technologies on the mental health of citizens.

\section{THE AIM}

The aim of the work - is to identify and analyze the neurobiological background of the mechanisms that underlying the pathogenic action of the IPI on the state of mental health of the population.

\section{MATERIALS AND METHODS}

Given the fact that on-screen technologies are considered to be one of the strongest among the IPI tools by the degree of destructive action [7], a content analysis of materials on the verification of the interrelationships between the use of 
$\mathrm{TV}$ and Internet resources and the various characteristics of the mental state of users was made. The search was done in three languages (in English, Ukrainian and Russian) in the MEDLINE, Index Citation Index and the Social Sciences Citation Index, EMBASE, Cochrane Library databases located on the leading electronic Internet search engines (Google, Yahoo, Yandex and META).

\section{REVIEW AND DISCUSSION}

As a result of the research, it has been found that there are currently quite a number of studies that examine the various aspects of the relationship between television viewing and the state of health of the individual. Moreover, the largest number of studies is devoted to the study of the influence of television on the development of the psyche and behavior of the child.

Proof of the correlation between the duration of the TV viewing and lower intellectual coefficient (IQ) and school failure appeared in the scientific area in the early 1980s of the XX century [8]. At the same time, it was found that in children, whose viewing of the TV was limited for a short period, improved cognitive abilities [9]. Subsequent studies confirmed the harmful effects of TV viewing in the form of reduced cognitive abilities, including attention [10] and memory [11], deterioration of academic performance of children [12 - 14] and the development of verbal communicative competence [11].

Subsequently, data on the relationship between delayed linguistic development among children before three years and excessive amount of time spent watching television were obtained. It was confirmed that children of school age, who spend two or more hours a day in front of the $\mathrm{TV}$, are more likely to have syndrome of attention deficit hyperactivity disorder, emotional and behavioral problems, and social conflicts with peers $[15,16]$.

In addition to the negative impact on the development of formal intellect IQ, the negative impact of television viewing on the development of the child's emotional intellect EQ was proven, namely, the ability to recognize and manage their own emotions, the ability to understand the parents emotional state and to empathize with other people's intentions and desires, as well as the insolvency to have their own convictions and the inability to recognize the convictions of others. Moreover, the negative effect that was fixed, provided not only direct viewing of TV programs, but also in the presence of the child in the room with the on-set TV running in the background [17].

If the above studies have shown that television viewing may be associated with increasing of emotional and behavioral problems in pre-school or school-age children, then Japanese scientists have invented an identical relationship with children under the age of three. In a prospective study conducted on a sample of children from 18 to 30 months, it was found that hyperactivity - inattention at the age of 30 months was positively associated with exposure on a TV at the age of 18 months (direct correlation), whereas prosocial behavior was negatively related to the hours of television influence at the same age (reverse correlation) [18].

An American research of 2018 shows the link between the peculiarities of using television in early childhood and subsequent social interactions with peers in school or kindergarten. TV viewing conditions were divided into three categories: over-viewing, viewing without parents' supervision, and viewing with adults. The results showed that the risk of social problems with peers in school at a child increases if family members did not participate in viewing interactive television with him in early childhood, or if the kids viewed adult programs. In the end, according to the latest recommendations of the American Academy of Pediatrics, an interactive, interested joint television viewing of parents with babies is a more useful approach than simply restricting the exposure of a TV that the babies are watching [19].

Norwegian scientists, having studied 995 4-year-old children during 2 years, have proven that excessive involvement in watching TV causes insufficient involvement of children in joint activities with their parents, and, in general, negatively affects on the quality of child-parenting relationships, and, in the future - on the ability to build any social relations [20].

Another research by the same authors showed that one of the ways to optimize child-parent, in particular maternal-infant relationship, may be joint games on interactive media devices, such as a tablet. In the example of 22 pairs of mothers and their 2-year-old children, the best indicators of social and emotional development of children and positive-constructive the attitude of mothers towards them are used, provided that they use for joint games the interactive media, in contrast to conventional toys or joint TV viewing [21].

The most widespread discussion was about the results of a study by Japanese scientists who for the first time in history recorded the "structural development of the brain associated with television viewing" and proved the presence of structural changes in the brain in children, depending on the time they spent watching television broadcasts [22]. Researchers from the University of Tohoku examined 276 children (133 boys and 143 girls) under the age of 5 to 18 , who daily watched television from a few minutes to four hours a day. After examining 111 boys and 105 girls after a while, the researchers found that those who viewed more TV channels over longer periods of time experienced more significant changes in their brain structure and, over time, demonstrated a lower level of intellectual development. Scientists have found a correlation between the duration of television viewing and the amount of gray and white matter of the brain - they were able to identify structural changes (thickening) in the front-polar region, the visual part of the cerebral cortex , the hypothalamus, the septum, and the left sensorimotor region, developing depending on the duration of the television viewing.

Thus, for the first time, scientists have been able to detect the effects of watching television on the level of neural systems, and to uncover the mechanisms by which its negative impact on the intellectual abilities of children occurs. The 
ability of the brain to build logical chains and to analyze the information depends on the condition of the frontal cortex, and structural changes in the hypothalamus, septum, and left sensomotor region may correlate with aggression, excessive emotional response, and other behavioral disorders [23]. In addition, the reduction of verbal intelligence in children with structural changes as a result of excessive viewing of television programs was proved [24]. Consequently, this research at the morphological level has finally confirmed that television is directly or indirectly linked to neurocognitive development of children, and its excessive revision causes the formation of neurocognitive deficits, emotional and behavioral disorders.

Taking into account a significant number of high-level evidence, that prove the harm of excessive stay in front of the TV in the United States, for example, was formed movement from informed parents for strict limitation of the time, that was carried out using a TV or even a smartphone for their children [25]. In American society, a new trend formation is now is observed: in general, children from low-income families spend around 8 hours and 7 minutes a day on a TV or smartphone while children from high-paying families - 5 hours and 42 minutes [26].

Despite the fact, that research in which the problems associated with the excessive using of IPI, in particular TV viewing, among adults, are much less studied, but still, there are credible evidence of its negative impact on viewers health.

Thus, Harvard researchers report data, that concerning to an increase of the risk of developing diabetes by $20 \%$, cardiovascular disease by $15 \%$, and premature death by $13 \%$ among those who spend more than two hours each day watching TV [27].

The results of another study, that conducted at the University of Buffalo, show a significantly higher level of stress, anxiety and depression among people who are overly fond of watching TV materials associated with excessive consumption of food and liquor [28].

The results of the study of the dangers of excessive television viewing, published in the Clinical Sleep Medicine magazine in 2017, convincingly demonstrated that high frequency of TV viewing are associated with poor sleep quality, increased fatigue and big number of symptoms of insomnia than among ordinary sample individuals [29].

There are also studies that link the excessive use of television (more than hours per day) with development of diabetes of the second type, or depression. American scientists refer to the results of the study of EEG, which demonstrate that overtime television viewing changes brain electrophysiology activity from beta waves to alpha waves, which provoke the occurrence of the dreamy state and block the use of critical thinking skills [30].

Structural changes in the brain tissue in the form of thickening of the prefrontal cortex, recorded as a result of excessive television viewing, have another paradoxical effect in adults: the research of the neurobiological model of the process of beliefs and doubts, conducted by the members of the American Psychological Association, found, that individuals with prefrontal area lesions are reveal a significantly greater propensity to authoritarianism and religious fundamentalism (due to the breakdown of the process of formation of normative doubts as to the correctly understood cognitive representations) [31].

Besides that scientists identified the area of the brain (in the parietal region of the cerebral cortex) that is activated when a person as a subject of information and psychological influences satisfying the need to be attached to any idea, community, or leader, feels related with something more than himself $[32,33]$.

In addition the negative influence of television viewing, scientists make an attempt to identify the effects of excessive Internet communication, first of all, the use of social networks.

Scientists research of media technology and health research center at the University of Pittsburgh, has even made it possible to propose a new definition - Facebook Depression, the meaning of which is that people who overuse social media may feel that their lives are not corresponds to the idealized life story presented by others in their own profiles, which can become a trigger for the development of depression in them. In the future, a vicious circle is formed: people who become depressed turn to social media with support, but their excessive interaction with its only exacerbates depression [34].

Research by scientists at the University of San Diego, based on the analysis of the results of two nationally-representative teens polls in the United States in grades 8-12 with a total of more than 500,000 people, and also national statistics on suicide deaths in age of 13 to 18 , recorded an increase in cases of depression and suicides among teens during 2010-2015, and proved that teenagers, who spend more time on social media, reported more often about their mental health problems [35].

In addition to the above, the important feature of IPI on individual consciousness is that it, as threats, may not be noticed and not realized by the person himself. Experts say that the dangerous effect of IPI on individual consciousness can lead to two types of interdependent changes [1]. First, it is a change in the psyche, mental health of a person. Since in the case of information influences it is difficult to talk about the limits of norm and pathology, the indicator of change may be the loss of adequacy of reflection of the world in consciousness and own attitude towards the world. We can talk about the deformation of the individual with the simplification of the form of reflection of reality, the coarse reactions and the transition from the need to realize the higher needs (in self-actualization, social recognition) to the lower (physiological, domestic). Secondly, this is a shift in values, attitudes, orientations, outlook of the individual. Such changes determine manifestations of deviant antisocial behavior and constitute a danger already for society and the state.

Consequently, taking into account the identified multi-levelness of the pathological consequences of using on-screen device of IPI on an individual level, we consider that this problem is the sphere of competence of medical 
psychology, because first of all the emotional, cognitive, behavioral and worldview sphere of the individual experience a destructive influence, what leads to an increase in risk of the spread and development among the population of various disorders of the mental sphere [7].

Our own clinical observations also confirm the presence of the negative influence of excessive use of on-screen technologies on the mental health of adults [1]. The purpose of our study was to identify clinical manifestations and psychological mechanisms for the formation of non-adaptive conditions in patients from primary health care with varying degrees of involvement in the use of IPI technologies. Among 393 patients of somatic profile from some district clinics were selected 221 persons with symptoms of psychological maladjustment. The examined persons were divided into two groups according to the expression of passion to the TV viewing (TV), searching news on the Internet or reading periodicals: the main group - 112 patients with signs of psycho-emotional sphere distortion and high involvement to the use of IPI through TV or internet, and the comparison group - 109 patients with symptoms of psychological maladjustment with the low use of TV or online media. The check-up was carried out by using of a social-demographic clinical-psychological and psycho-diagnostic methods, included a clinical interview and psychodiagnostics.

It was found, that the clinical meaning and severity of maladaptive states in primary care network patients vary depending on their involvement in the use of means of onscreen technologies of IPI. Among individuals, who have intense addictive status regarding to seizure of watching $\mathrm{TV}$ and using of Internet, breach of psycho-emotional sphere are expressed at the level of formed or pronounced adaptation. They differ by high levels of psychosocial stress, by syndrome of psycho-emotional stress availability and clinically defined anxiety and depressive symptoms, with an overall prevalence of anxiety psychopathological phenomenon, in which were allocated anxiety-depressive and anxiety-leading dysphoric syndrome. In patients with low levels of involvement in watching TV and using of Internet, violation of psycho-emotional sphere are showed with asthenic-depressive or asthenic-hypochondriacal manifestations, basically of subclinical severity.

Patients who overly involved in watching TV and searching of internet news media have specific individual psychological and behavioral patterns, that lead to the development of their maladaptive states, and should be considered as targets of their psychocorrection. Mosaic combination of personal characteristics forms extrapunitive destructive, disorganizing profile, that determines the presence of maladjustment with the loss of control on cravings, increased anxiety and disorganization of behavior. Low personal resilience causes a lack of sense of personal significance and presence of a sense of loss of control over own lives, and presence of helplessness state and "acquired helplessness". The choice of non-adaptive coping strategies supports and exacerbates psychological maladaptation by distorting the behavioral sphere of the personality. This constellation of personality characteristics leads to the wrong choice of how to reduce basal anxiety and restore the basic sense of security through the addition and identification with some archetypal idea or person, as attempts to be involved in global processes and with aim to create an imaginary false sense of protection, that leads to the formation of negative attitudes and loss of the sense of life, and, by the vicious circle principle, increases disadaptive condition. Patients with low levels of involvement in watching TV and using of Internet are characterized by deformed-intrusive-dysfunctional personality profile, lack of personal viability and the use of relatively adaptive cognitive and emotional strategies in combination with non-adaptive, relatively adaptive and adaptive behavioral copings.

As for the prevention of the medical and psychological consequences of the use of on-screen IPI technologies, scientists in this question are rather unanimous [1]: the main fence of negative consequences is a conscious refusal, or dosed use of them, that should take place against the background of the ability to critically understand the information, intellectual and physical activity of the individual, transferring the focus of attention on close relatives and family interaction, the formation of skills of positive thinking, as well as communication with nature and by oneself without additional means formational influence.

\section{CONCLUSIONS}

1. At present, the fact of the existence of harmful effects of the use of on-screen IPI technologies, namely, watching of the television or using the Internet, on the state of mental health and psychological well-being of a person, is proven.

2. It is established that independent stay near the TV in the early childhood (up to 3 years) causes an increase in manifestations of hyperactivity in the current period and deformation of social interaction with peers and problems in child-parent relationships, in the subsequent life of the child. At the same time, a joint interactive, dosed television viewing of babies with their parents is more useful than the usual limitation of its exposure.

3. A direct correlation between the time spent near TV and the decrease of cognitive abilities, deterioration of academic achievement and increase in manifestations of attention deficit and hyperactivity disorder, emotional and behavioral problems among children of preschool and school age is established. In addition, pathological structural changes in the brain were recorded among children of school age, depending on the time of watching television.

4. Viewing TV more than 2 hours a day in adults is associated with an increased risk of developing 2 nd type diabetes, cardiovascular disease, dyssomnia, depression and stressful state of chronic psycho-emotional stress. TV viewing more than norm in adults causes a pathological transformation of the electrophysiological activity of the brain, which reduces the ability to critical perception of information. 
5. Excessive use of social networks in teens leads to an increase in cases of depression and predisposition to suicidal behavior, and in adults - to the emergence of a new psychopathological phenomenon - "Facebook depression", the course of which is amplified by the vicious circle.

6. An effective way of preventing the negative effects of using IPI screen technologies is intellectual and physical activity, the ability to critically understand the information, the formation of skills of positive thinking, the shift of emphasis on close and family interaction, the formation of communication skills with nature and himself without additional means of information influence.

\section{REFERENCES}

1. Markova M. V., Markov A. R., Agisheva N. K., Martynenko S. A. Y'nformacy onno-psy' xology' cheskaya vojna kak makrosocy'al' nyj stressovyj faktor razvy'ty'ya dezadapty 'vnyx sostoyany `j u grazhdanskogo naseleny' ya: patogenety 'cheskaya model' y' osnovy psy 'xokorrekcy'y' [Information and psychological war as a macrosocial stress-development factor of maladaptive states in civilian population: a pathogenetic model and bases of psychocorrection]. Psychiatry, psychotherapy and clinical psychology. 2017;8(4):534 - 546 .

2. Pocheptsov H. H. Ynformatsyonno-polytycheskye tekhnolohyy [Information and political technologies]. Tsentr. M.2003.

3. Meleshko le., Yakymenko M. Informatsiini virusy v sotsialnykh merezhakh yak zasib informatsiino-psykholohichnoho vplyvu [Information viruses in social networks as a means of information and psychological influence]. Proceedings of the Information, communication, society. Lviv, Ukraine, May, 19-21, 2016.

4. Markov A. R. Informatsiino-psykholohichna bezpeka osobystosti yak aktualna problema suchasnosti [Information psychological security of personality as an actual problem of our time]. Ukrayins'kyy visnyk psykhonevrolohiyi. 2015;23:3(84):142.

5. Panchenko 0. A., Banchuk N. V. Ynformatsyonnaya bezopasnost' lychnosty [Information security of the person]. KYT.Kyiv.2011

6. Pievtsov H.V., Hordiienko A. M., Zalkin S. V. et al. Metodyka otsiniuvannia efektyvnosti vykonannia zakhodiv protydii nehatyvnomu informatsiinopsykholohichnomu vplyvu protyvnyka [Methodology for assessing the effectiveness of measures to counteract the negative informational and psychological impact of the enemy]. Zbirnyk naukovykh prats Kharkivskoho natsionalnoho universytetu Povitrianykh Syl. 2016;1(46):23-28.

7. Markov A. R. Osobly 'vosti psy`xosocial'nogo funkcionuvannya u paciyentiv pervy'nnoyi medy'chnoyi merezhi v zalezhnosti vid zaluchenosti do kory'stuvannya zasobamy' konsciyental' noyi vijny'. [Psychosocial functioning features in primary care patients according to involving by means of consciousness war] Psy 'xologichny j j chasopy`s. 2016;4(2):189-210.

8. Ridley-Johnson R., Chance J.The relation of children's television viewing to school achievement and IQ. J Educ Res.1983:294 - 297.

9. Gadberry $S$. Effect of restricting first grader's TV-viewing on leisure time use, IQ change and cognitive style. J Appl Dev Psychol. 1981;1:45 - 57.

10. Landhuis C.E., Poulton R., Welch D. et al. Does childhood television viewing lead to attention problems in adolescence? Results from prospective longitudinal study. Pediatrics. 2007;120:532 - 537.

11. Zimmerman F.J., Christakis D.A. Children's television viewing and cognitive outcomes: a longitudinal analysis of national data. Arch Pediatr Adolesc Med. 2005;159:619 - 625.
12. Johnson J.G., Cohen P., Kasen S. et al. Extensive television viewing and the development of attention and learning difficulties during adolescence. Arch Pediatr Adolesc Med. 2007;161:480.

13. Johnson J.G., Cohen P., Smailes E.M. et al. Television viewing and aggressive behavior during adolescence and adulthood. Science. 2002;295:2468 - 2471.

14. Christakis D.A., Zimmerman F.J., DiGiuseppe D.L. et al. Early television exposure and subsequent attentional problems in children. Pediatrics. 2004;113:708 - 713.

15. Christy K., Nathanson A.I., Sharp M.L. et al. The Relation Between Television Exposure and Theory of Mind Among Preschoolers. Journal of Communication. 2016.

16. Olson S. Inside The Human Brain: How Watching TV Changes Neural Pathways Versus Reading A Book. https://www.medicaldaily.com/ neural-pathways-watching-tv-human-brain-reading-book-389744 Jun 16, 2016.

17. Nathanson A. I., Aladé F., Sharp M. L. et al. The Relation Between Television Exposure and Executive Function Among Preschoolers. Developmental Psychology. January 2014;50 (5). DOI: 10.1037/ a0035714

18. Cheng Sh., Maeda T., Yoichi S. et al. Early Television Exposure and Children's Behavioral and Social Outcomes at Age 30 Months. Journal of Epidemiology. February 2010;20(2):482-489. D0l: 10.2188/jea. JE20090179

19. Jackson D. B. Does TV viewing during toddlerhood predict social difficulties and conduct problems? Infant and Child Development. January $2018 \mathrm{https}: / /$ doi.org/10.1002/icd.2086

20. Skaug S., Englund K.T., Wichstrom L. Young children's television viewing and the quality of their interactions with parents: a prospective community study. Scandinavian Journal of Psychology. 2018;59:503510.

21. Skaug S., Englund K.T., Saksvik-Lehouillier I. et al. Parent-child interactions during traditional and interactive media settings: A pilot randomized control study. Scand J Psychol. Apr 2018;59(2):135-145. doi: 10.1111/sjop. 12420.

22. Kawashima R., Takeuchi H., Taki Y. et al. The Impact of Television Viewing on Brain Structures: Cross-Sectional and Longitudinal Analyses. Cerebral Cortex. 2016. 2013;25(5):1188-1197. doi:10.1093/cercor/bht315

23. Berns G. S., Blaine K., Preitula M. J. et al. Short- and Long-Term Effects of a Novel on Connectivity in the Brain. Brain Connectivity. 2016.

24. Fernandes $D$. New brain research suggesting TV watching produces bad changes, novels good ones. https://www.scpr.org/blogs/ education/2014/01/16/15611/new-brain-research-suggesting-tvwatching-produces/

25. Bowles N. Silicon Valley Nannies Are Phone Police for Kids. https:// www.nytimes.com/2018/10/26/style/silicon-valley-nannies.html

26. Bowles N. A Dark Consensus About Screens and Kids Begins to Emerge in Silicon Valley. https://www.nytimes.com/2018/10/26/style/phoneschildren-silicon-valley.html

27. Wolfson S. Going TV cold turkey - what is it like to give up the box for a month? https://www.theguardian.com/tv-and-radio/2018/feb/25/ television-binge-watcher-eastenders-give-up-a-month

28. Vaterlaus J. M., Spruance L. A., Frantz K. et al. College student television binge watching: Conceptualization, gratifications, and perceived consequences. The Social Science Journal. October 2018. D0l: 10.1016/j. soscij.2018.10.004

29. Exelmans $L$, Van den Bulck J. Binge viewing, sleep, and the role of presleep arousal. J Clin Sleep Med. 2017;13(8):1001-1008. 
30. Vozza S. How Giving Up TV For A Month Changed My Brain And My Life. https://www.fastcompany.com/3060491/what-happened-tomy-brain-after-a-month-without-watching-tv. 06.06.16

31. Asp E., Ramchandran K., Tranel D. Authoritarianism, religious fundamentalism, and the human prefrontal cortex. Neuropsychology. 2012;26(4):414-421. doi: [10.1037/a0028526]

32. Livni E. Columbia and Yale scientists found the spiritual part of our brains - religion not required. qz.com/1292368/columbia-and-yalescientists-just-found-the-spiritual-part-of-our-brains/ May 30, 2018

33. Dunavin D. Yale Study Shows Your Brain On Religion. http://www.wshu. org/post/yale-study-shows-your-brain-religion\#stream/0 JUN 4, 2018

34. Lewis K. Heavy social media users'trapped in endless cycle of depression' https://www.independent.co.uk/life-style/health-and-families/ health-news/social-media-depression-facebook-twitter-healthyoung-study-a6948401.html

35. Twenge J. M., Joiner T. E., Rogers M. L. et al. (in press). Increases in depressive symptoms, suicide-related outcomes, and suicide rates among U.S. adolescents after 2010 and links to increased new media screen time. Clinical Psychological Science. First Published November 14, 2017. https://doi.org/10.1177/2167702617723376
The research was carried out within the framework of the research work of the Department of Sexology, Medical Psychology, Medical and Psychological Rehabilitation of the Kharkiv Medical Academy of Postgraduate Education of the Ministry of Health of Ukraine on the topic "Medical and Psychological Consequences of Social Stress and Information and Psychological Warfare (macro-, microsocial factors of maladaptation, mechanisms of formation, a system of psychodiagnosis, psychocorrection, psychoprophylaxis)" (state registration number 0117U000371).

\section{Authors' contributions:}

According to the order of the Authorship.

\section{ORCID numbers:}

Marianna V. Markova - 0000-0003-0726-4925

Artur R. Markov - 0000-0002-2164-7159

Maya V. Savina - 0000-0002-1292-7482

Tsira B. Abdriakhimova - 0000-0002-9723-3067

Inna R. Muharovska - 0000-0002-8487-0497

Kostiantyn D. Gaponov - 0000-0002-2835-1027

\section{Conflict of interest:}

The Authors declare no conflict of interest.

\author{
CORRESPONDING AUTHOR \\ Marianna V. Markova \\ Department of Sexology, Medical Psychology, \\ Medical and Psychological Rehabilitation of the \\ Kharkiv Medical Academy of Postgraduate Education \\ Amosova St., 58, 61176 Kharkiv, Ukraine \\ tel: +380506068145 \\ e-mail: mariannochka1807@gmail.com
}

Received: 25.05.2019

Accepted: 30.09.2019 


\title{
CASE REPORT \\ OPIS PRZYPADKU
}

\section{SELECTED PSYCHOLOGICAL ASPECTS OF FUNCTIONING OF A PATIENT AFTER REPEATED MISCARRIAGES - CASE STUDY}

\author{
Martyna Maciejewska', Inga Janik-Fuks' ${ }^{1}$ Patrycja Zielińska' ${ }^{1}$, Agata Mularczyk' ${ }^{1}$, Olimpia Sipak \\ 'DOCTORAL STUDY, DEPARTMENT OF OBSTETRICS AND PREGNANCY PATHOLOGY, POMERANIAN MEDICAL UNIVERSITY IN SZCZECIN, SZCZECIN, POLAND \\ 2DEPARTMENT OF OBSTETRICS AND PREGNANCY PATHOLOGY, POMERANIAN MEDICAL UNIVERSITY IN SZCZECIN, SZCZECIN, POLAND
}

\begin{abstract}
The purpose of our case study was to identify psychological and medical dependencies affecting subsequent pregnancies of women after early pregnancy loss. The patient miscarried three times, gave birth to two children. The case study describes her state of health, emotional reactions and social support in these situations. Based on medical information, psychological interview and questionnaires (STAI, CISS, BHI-R, ISEL) are described factors influencing the patient's coping with such a difficult situation as the loss of pregnancy.
\end{abstract}

KEY WORDS: psychological aspects, coping, repeated miscarriages, case study

Wiad Lek 2019, 72, 10, 2046-2049

\section{INTRODUCTION}

In the moment a woman realizes she is pregnant, changes in the biological, psychological and social sphere begin. This situation aims to protect the developing fetus and change the current lifestyle, preparing for new requirements posed by the body. Although pregnancy is a woman's area of health, not illness, it is such a specific and important state - physically, mentally and emotionally - that it is currently subject to special control and care. Pregnancy can often cause negative reactions: sleep disorders, problems with concentration, as well as negative emotions, anxiety or even depression - especially when problems arise during pregnancy $[1,2]$. A miscarriage is the loss of pregnancy before 22nd week [3]. The specificity of regret after a miscarriage is focused on the imaginations of the expected future and the lost role in opposition to the recollection of past events [4].

The process of coping after experiencing such a loss is described in terms of subsequent stages of mourning [6]. A miscarriage is a traumatic experience, so it is extremely important to provide adequate support to a person who has lost a child $[7,8]$.

\section{THE AIM}

The purpose of our case study was to identify psychological and medical dependencies affecting subsequent pregnancies of women after early pregnancy loss.

\section{CASE STUDY}

\section{MEDICAL INFORMATION}

In 2018, a 39-year-old multipara reported to the Clinic of Pregnancy Pathology SPSK2 of the Pomeranian Medical University (PUM) in Szczecin in the 5th week of the fifth pregnancy for a check-up visit. Due to the eventful obstetric history (two early miscarriages and antiphospholipid syndrome), Clexane 1x $0.4 \mathrm{~g} / 0.4 \mathrm{ml}$ was implemented.

During subsequent visits during the ultrasound examination, fetal heartbeat was not observed, during the 8th week of pregnancy a stillbirth was found. The patient was hospitalized to terminate this pregnancy. From the interview: the first pregnancy ended in the 9 th week due to a stillbirth. The second pregnancy also ended around 9 weeks of pregnancy, due to bleeding from the genital tract, where spontaneous abortion took place. Both pregnancies ended with curettage of the uterine cavity. Two years before the first pregnancy, the patient was diagnosed with hyperthyroidism, Graves' disease, and a partial thyroidectomy was performed due to nodules. She took Euthyrox after the treatment due to the hypothyroidism difficult to compensate. After the second miscarriage, the patient was referred to the Clinic of Pregnancy Pathology SPSK1 PUM in Szczecin, where a whole series of diagnostic tests, both hormonal and immunological, were made, searching for the causes of miscarriages. Decompensated thyroid gland and increased values of cardiolipid IgM antibodies and beta2 glycoprotein 1 were found. In the patient's and her partner's karyotype no abnormalities were observed. The patient was referred to the Rheumatology Outpatient Clinic, where Acard $75 \mathrm{mg}$ was prescribed, which was poorly tolerated in the form of headaches, and which was discontinued after 3 months.

After about a year, the patient became pregnant with her third pregnancy, during which she was under the care of the Clinic of Pregnancy Pathology SPSK1 PUM in Szczecin. From the 5th week of pregnancy, Clexane was implemented at a prophylactic dose of $0.4 \mathrm{~g} / 0.4 \mathrm{ml}$, which was discontinued at 36 th week of pregnancy. In additional 
tests at the beginning of pregnancy, diet-dependent gestational diabetes $\mathrm{G} 1$ was diagnosed, for which reason she was under the care of a diabetologist.

She received Euthyrox at a dose of 75 ug throughout her pregnancy. In the 35 th week of pregnancy edema and hypertension appeared, so she was hospitalized several times. The ultrasound examination revealed suppression of intrauterine fetal growth (IUGR). Dopegyt was implemented at a dose of $3 \times 500 \mathrm{mg}$. At the $37 \mathrm{th}$ week of pregnancy, the patient reported severe headaches accompanied by hypertension up to $180 / 104$. It was decided to terminate the pregnancy by means of Caesarean section, she gave birth to a live daughter, in good condition, with a birthweight of $2300 \mathrm{~g}$. In the first day of puerperium sub-facial hematoma was found, due to which the laparotomy was decided. Next days of puerperium pursued its normal course. On 7th puerperium day, discharged home in good condition.

After about 1.5 years she became pregnant for the 4 th time, from the 5th week of pregnancy she received Clexane $0.4 \mathrm{~g} / 0.4 \mathrm{ml}$ and was under the control of Clinic of Pregnancy Pathology SPSK1 PUM in Szczecin. In the first and second trimesters of pregnancy, she was hospitalized because of initially threatened miscarriage, and then threatened premature labor. In the 39th week of gestation she gave birth by $C$-section to a full-term live son, weight of $4000 \mathrm{~g}$ in good condition. The course of the puerperium without complications.

\section{INFORMATION ABOUT MENTAL FUNCTIONING ON THE BASIS OF THE INTERVIEW}

The patient got married in the age of 27 , she and her husband wanted to have children. The first miscarriage aroused strong negative emotions in both of them. The patient underwent a curettage of the uterine cavity in another city, away from her husband. After the surgery, her parents and sister were visiting her. From that time, she remembers her sister's attitude, describing it: "she was very unhappy when she came to the hospital, as if she had a grudge against me, that I had miscarried in purpose." She judged her husband's attitude as supportive. They had time for themselves, for mourning, the husband would hug her, they were talking about their experiences of miscarriage. During the interview, the patient said: "At the beginning it was very difficult to talk about it. Only with time it came to normal. The worst was perspective that maybe we would not be able to have children at all. That thought was the worst. Helplessness, because one does not know why. Also such anger that often women who do not want to have children, have them, and you cannot and want to. Such a sense of injustice." The second pregnancy was miscarried, the 3rd one she managed to carry to term and delivered a daughter. The childbirth was by caesarean section, which was a difficult experience for the patient - she dreamed about childbirth with the forces of nature. After the birth the patient probably experienced baby blues - frustration during the care and breastfeeding of her daughter, great tiredness, social closeness, weepiness. The patient was not diagnosed for emotional problems by the hospital staff and did not receive psychological support. She describes the first weeks of care for a newborn daughter as very difficult and demanding. As the time passed by, the situation has changed for good with the support of her husband. From the interview with the patient, having children is a great value for her, that is why together with her husband made another attempt to enlarge the family.

he fourth pregnancy was also carried to term. A son was born by another caesarean section. This time the patient was happy with this mode of delivery because it turned out that the childbirth would be difficult. Emotions that appeared with 4th pregnancy were ambivalent: "this time when I was doing a pregnancy test, my hands were shaking, on the one hand positive emotions, on the other - stress, I had such mixed feelings. I was afraid it will end like the two previous pregnancies. There was fear and fright." The patient actively draws here attention to the fact that the pregnancy proceeded emotionally, despite the complications, quite differently than the first one. She emphasizes that it was important that they were already raising an older child - they wanted another child, but there was no despair in this situations. The patient said: "The beginning was also stressful, but later I did not even have time to think about the danger or listen to myself. I just did not have time for this because my daughter was 1.5 years old, I left it itself and I did not think about it. When you already have a child, you take it differently." In 2017, the patient became pregnant for the 5th time. In the 6th week, the ultrasound showed that the fetus had died.

She described emotions from that moment: "It was some resentment, I was sad, my husband too, but it did not last very long. Two weeks after the surgery I returned to work. It is different if you already have children. It is worse if you do not have them at all and you are waiting, then it is harder." Mourning after the last pregnancy lasted much shorter and was less intense than the previous ones. Speaking of miscarriages, the respondent emphasized that support from the husband, parents and mother-in-law was helpful - conversations, sharing and understanding emotions, but also concrete economic support and help in caring for children. In the patient's judgement, the medical staff was positive. However, she mentioned a doctor from another city, whose behavior aroused negative emotions in her. In the situation of miscarriage he suggested that she was not pregnant at all, he referred her to the main doctor: "It was a very unpleasant situation, I was scheduled for an ultrasound in Szczecin, but I did not manage to be there. The doctor said something strange, asked me if I am pregnant at all, because this uterus was so small, and added that if I am treated in Szczecin, I should go there." In addition to this situation, it was emotionally difficult for the patient after finished pregnancy to be in one room with a woman expecting a baby. The patient herself stressed that this was not due to bad will of the staff but to the lack of places in the ward.

\section{INFORMATION ON THE STYLE OF COPING WITH STRESS, LEVEL OF HOPE, ANXIETY LEVEL AS TRAIT AND STATE AND EVALUATION OF SOCIAL SUPPORT}

The patient is characterized by a avoidance coping with stress (CISS results: task-oriented style - sten 5, emotion-oriented style - sten 6 , avoidance oriented - sten 7 , 
involvement in substitute activities - sten 7, search for social contacts - sten 5). This means that in difficult situations causing a strong emotional tension, she looks for various substitute activities (for example watching television, shopping, sleeping) so as not to confront the experienced situation. She may also avoid thinking about the problem and seeking its solution. The patient may not allow emotions lived in a given situation.

She is characterized by a high level of hope (results of BHI-R - 60 points). The higher level of hope, the easier it is for people to come to terms with difficult events, and the world and people are perceived as more friendly. A strong belief in favor and meaningfulness makes it easier to reconcile with new difficult situations that appear in life. This belief allows the subject to adapt to new events with more readiness and confidence. Also more adaptive behaviors in difficult situations are conditioned by a high level of hope. The patient is characterized by an average level of anxiety as a state and high level as a trait (STAI results: $\mathrm{x} 1$ - sten 6, x2 sten 8 ). This means that she may show a greater tendency to perceive objectively non-threatening stimuli as threatening. She can also experience higher anxiety in situations that are extremely threatening. The patient obtained high scores in the assessment of social support. According to her, she experiences instrumental, emotional, financial and self-esteem support (ISEL general score - 40, tangible subscale - 10 , belonging subscale - 10 , self-esteem subscale - 10, appraisal subscale - 10). The social support factor is a very important element affecting the ability to cope better in various difficult situations, such as miscarriage.

\section{DISCUSSION}

The frequency of spontaneous abortions in the first trimester of pregnancy is estimated at 10-24\%. [8] In recent years, the most frequently mentioned psychiatric consequences of early pregnancy loss due to a miscarriage are: depression, anxiety and panic attacks, compulsive disorders, PTSD. [9-11] A woman after a miscarriage experiences, in addition to physical pain, also a number of negative emotions - regret, anger, as well as lower self-esteem or even depressive reactions, mental disorders, and suicidal thoughts. A breakdown of faith in sense of life, a violation of sense of safety and self-control appear. Our case study fits into the above-mentioned symptoms.

During the first miscarriage, the subject experienced sense of meaninglessness of life, a lack of justice, a significant reduction in mood; passed the subsequent stages of mourning. However, the support of the nearest people allowed her to cope with this situation. Also, medical staff plays an important role in the mental support of a woman and her family after a child loss. Professionalism, experience, knowledge and the ability to communicate are necessary in pursuit to achieve goals such as: helping in reconciling with loss, allowing to experience suffering and regret, help in accepting reality and life without a child. [12] The respondent positively assessed the behavior and support of the medical staff she experienced during hospitalization.
Bowles et al. [13] draws attention to the special need for psychological care within a month after miscarriage. The study conducted by Murlikiewicz and Sieroszewski $[9,14]$ showed that the emotion-focused style of coping with stress, highly anxious personality, as well as previous experience of miscarriage, had an impact on the increase in the results of three variables examined (level of depression, anxiety and post-traumatic stress) and may be treated as risk factors for depression and PTSD. The subject is characterized by avoidance style of coping with stress, an average level of anxiety as a state and high level as a trait; with a high level of hope and high scores in the assessment of social support. The description obtained on the basis of the results of the questionnaires shows an incoherent picture - on the one hand her style of coping with stress proved to be favorable, she did not delve into the negative experiences.

She managed better in this difficult situation thanks to the high sense of hope and the support she received from the family and the medical staff. The high level of anxiety as a trait was unfavorable - it is an aspect that could have a negative effect on her emotional functioning after miscarriages. However, the possessed resources allowed for the passage through mourning and reconciliation with the situation, as well as for subsequent attempts to get pregnant. Andersson et al. [15] conducted a similar study - qualitative, individual interviews with pregnant women who had previously experienced a miscarriage. Their conclusion coincides with ours - women in such a situation need a broad support: from a family, friends, medical and psychological staff. However, most often, similarly to our subject, they manage themselves. In the absence of formal support - from doctors and psychologists, they are able to rely only on help of their relatives. Most women waiting for the birth of their children hope that they will be born healthy and on estimated due date. Reproductive failures are perceived as failure to fulfill a parental role. The situation of a pregnancy at risk and change of delivery date is a surprise for a mother and her family, an unpredictable event that one cannot be prepared [16].

\section{CONCLUSIONS}

The interviewee underlined the difference in the course of mourning and coping after a miscarriage - not being a mother, and having children. The first two miscarriages and the first full term pregnancy were extremely difficult for her, while the second pregnancy at risk and the last miscarriage were not so negatively burdened emotionally. The subject pointed out that the main difference was that she was already a mother. In this situation, despite the constant difficulties in maintaining pregnancy, the fact of playing the social role so important for her, was extremely helpful. Perhaps it even allowed the positive end of the fourth pregnancy.

\section{REFERENCES}

1. Pinar SE, Aksoy OD, Daglar G, Yurtsal ZB, Cesur B. Effect of stress management training on depression, stress and coping strategies in pregnant women: a randomised controlled trial. J Psychosomat Obstetr Gynecol. 2018;39(3):203-210. 
2. Lou S, Frumer M, Schluetter MM, Petersen OB, Vogel I, Nielsen CP. Experiences and expectations in the first trimester of pregnancy: a qualitative study. Health Expectat. 2017;20:1320-1329.

3. Bręborowicz G, Paszkowski T. (red.) Medycyna matczyno-płodowa. Położnictwo.Vol. 2nd Warszawa:Wydawnictwo LekarskiePZWL, 2012, 1-9.

4. Brier N. Grief following miscarriage: a comprehensive review of the literature. J Womens Health. 2008;17:451-464.

5. Makara-Studzińska M, Iwanowicz-Palus G. Psychologia w położnictwie i ginekologii. Warszawa: Wydawnictwo Lekarskie PZWL, 2004.

6. Nynas J, Narang P, Kolikonda MK, Lippmann S. Depression and Anxiety Following Early Pregnancy Loss: Recommendations for Primary Care Providers. Prim Care Companion CNS Disord. 2015;17(1).

7. Tavoli Z, Mohammadi M, Tavoli A, Moini A, Effatpanah M, Khedmat L, Montazeri A.Quality of life and psychological distress in women with recurrent miscariagge: a comparative study. Health Quality Life Outcom. 2018;16:150.

8. Bubiak A, Bartnicki J, Knihinicka-MercikZ. Psychologiczne aspekty utraty dziecka w okresie prenatalnym. Piel Zdr Publ. 2014;4 (1):69-78.

9. Murlikiewicz M, Sieroszewski P. Poziom depresji, lęku i objawów zaburzenia po stresie pourazowym w następstwie poronienia samoistnego. Perinatol Neonatol Ginekol. 2013;6 (2):93-98.

10. Boyce PM, Condon JT, Ellwood DA. Pregnancy loss: a major life event affecting emotional health and well-being. Med J Aust. 2002;176(6):250-251.

11. Czarnecka M. Psychological aspects miscarriage. Archiv Perinat Med. 2005;11.
12. Napiórkowska-Orkisz M, Olszewska J. The role of medical personnel in support of mental health of women with a history of miscarriage and their families. Pieleg Pol. 2017;3(65).

13. Bowles SV, Bernard RS, Epperly T et al. Traumatic stress disorders following first-trimester spontaneous abortion. J Fam Pract. 2006;55:969-973.

14. Podolska MZ et al. Personality traits assessed by the NEO Five-Factor Inventory (NEO-FFI) as part of the perinatal depression screening program. Med Sci Monit. 2010;16(9):PH77-PH81.

15. Andersson IM, Nilsson S, Adolfsson A. How women who have experienced one or more miscarriages manage their feelings and emotions when they become pregnant again - a qualitative interview study. Scand J Caring Sci. 2012; 26, 262-270.

16. Guzewicz M. Psychologiczne i społeczne konsekwencje utraty dziecka w wyniku poronienia. Civitas Lex. 2014;1:15-27.

\section{ORCID:}

Martyna Maciejewska - 0000-0002-2017-5196

Inga Janik-Fuks - 0000-0002-4238-0465

Patrycja Zielińska - 0000-0001-7390-8296

Agata Mularczyk - 0000-0002-8273-6737

Olimpia Sipak - 0000-0002-3410-1809

\section{Conflict of interest:}

Authors declare no conflict of interest.

\author{
CORRESPONDING AUTHOR: \\ Olimpia Sipak \\ Department of Obstetrics and Pregnancy Pathology, \\ Pomeranian Medical University in Szczecin, \\ 71-210 Szczecin, 48 Żołnierska St. \\ tel.: +48914800 983, \\ e-mail: olimpiasipak-szmigiel@wp.pl;
}

Received: 17.06 .2019
Accepted: 25.09 .2019 


\title{
CLINICAL-MORPHOLOGICAL FEATURES OF WILMS'TUMOUR: ANALYSIS OF LITERATURE DATA AND A CASE FROM PRACTICE
}

\author{
Victor D. Urzhumov ${ }^{1}$, Nana M. Pasiyeshvili' ${ }^{2}$ Nataliia V. Kapustnyk' ${ }^{2}$, Mykhailo S. Myroshnychenko ${ }^{3}$, \\ Iryna V. Borzenkova ${ }^{4}$, Dmytro V. Molodan ${ }^{3}$, Victor N. Grinevich' \\ ${ }^{1}$ MILITARY MEDICAL CLINICAL CENTRE OF THE NORTHERN REGION, KHARKIV, UKRAINE \\ 2 PUBLIC NONPROFIT ORGANIZATION OF THE KHARKIV DISTRICT COUNCIL "REGIONAL CLINICAL PERINATAL CENTRE», KHARKIV, UKRAINE \\ ${ }^{3}$ KHARKIV NATIONAL MEDICAL UNIVERSITY, KHARKIV, UKRAINE \\ 4 PUBLIC NONPROFIT ORGANIZATION OF THE KHARKIV DISTRICT COUNCIL, "REGIONAL CLINICAL HOSPITAL", KHARKIV, UKRAINE
}

\begin{abstract}
Wilms'tumour, or nephroblastoma, is a malignant tumour, originating from nephrogenic germ cells that copy histology of developing kidneys and often contain cells at different stages of their differentiation. The article analyses clinical-morphological features of Wilms'tumour, which is typical for childhood and seldom occurs in adults. The authors suppose that one of the causes of Wilms'tumour development can be maternal complications, which arise during pregnancy, leading to inhibition of glomerulogenesis and tubulogenesis in the offspring kidneys, an increase the number of foci of primitive (immature) tissue, from which this tumour, as it is known, can originate. The described case from practice of Wilms' tumour is of particular interest because of an untypical age category, when the above pathology was diagnosed, demonstrates necessity of a multidisciplinary approach to its identification and necessitates its inclusion into the differential diagnostic line for the detection of kidneys tumours in adults.
\end{abstract}

KEY WORDS: Wilms'tumour, clinical picture, morphology, case from practice

Wiad Lek 2019, 72, 10, 2050-2055

\section{INTRODUCTION}

Nephroblastoma, or Wilms' tumour, is a malignant tumour, originating from nephrogenic germ cells that copy histology of developing kidneys and often contain cells at different stages of their differentiation [1]. The first description of a nephroblastoma was made in 1872 by D.J. Eberth. In 1879 W. Osler informed about his own 2 observations of a nephroblastoma. In 1899 the German surgeon M. Wilms made the fullest review of the available literature about nephroblastoma and added description of his own 7 clinical observations. His description of the clinical picture of nephroblastoma was so accurate that during subsequent years doctors with an increasing frequency preferred the term «Wilms' tumour» compared with the term «nephroblastoma» [2].

Wilms' tumour affects one in 10,000 children and accounts for $5 \%$ of all childhood cancers. More than $80 \%$ of children are diagnosed with Wilms' tumour under the age of five years, and the median age at diagnosis is 3.5 years [3]. In children, Wilms' tumour is by far the most common ( $85 \%$ of cases), followed by renal cell carcinomas (3-5\%), mesoblastic nephroma (3\%), clear cell sarcoma of the kidney (3-4\%), rhabdoid tumour of the kidney (2\%) and miscellaneous rare tumours (2\%) [4]. Black African children have an increased prevalence of Wilms' tumour compared with whites [5]. The global experience lists isolated cases of Wilms' tumour in adults, they making less than $1 \%$ of all renal tumours. Only 70 new cases of Wilms' tumour in adults are diagnosed in Europe each year [3].

Wilms' tumour develops with the same frequency in boys and girls, equally affecting both kidneys [1].

As it is known, in the kidneys development process the metanephrogenic blastema areas, which form the secretory apparatus of this organ, should disappear completely after 36 weeks of pregnancy, but an insignificant part of the nephrogenic blastema remains functioning at birth in $1 \%$ of babies [6]. Our previous complex morphological studies on autopsy material of the kidneys revealed the above areas in all cases (13 foetuses and 15 newborns at 37-40 weeks of gestation) too [7].

Nephroblastoma is known to develop frequently from preserved embryonal foci of the immature renal tissue. This phenomenon was described in literature as persistence of nephrogenic blastema or nephrogenic rests [8]. It is currently believed that nephrogenic rests give rise to approximately $30-40 \%$ of Wilms tumours, and they are found in up to $99 \%$ of bilateral Wilms' tumours [9, 10]. Nephrogenic rests may be single, multiple or diffuse. Multiple or diffuse nephrogenic rests are also referred to as nephroblastomatosis [11].

Nephroblastomatosis was described at first in 1961, when L. Hou and R. Holman used this term for defining a renal lesion in newborns characterized by an enlargement and 


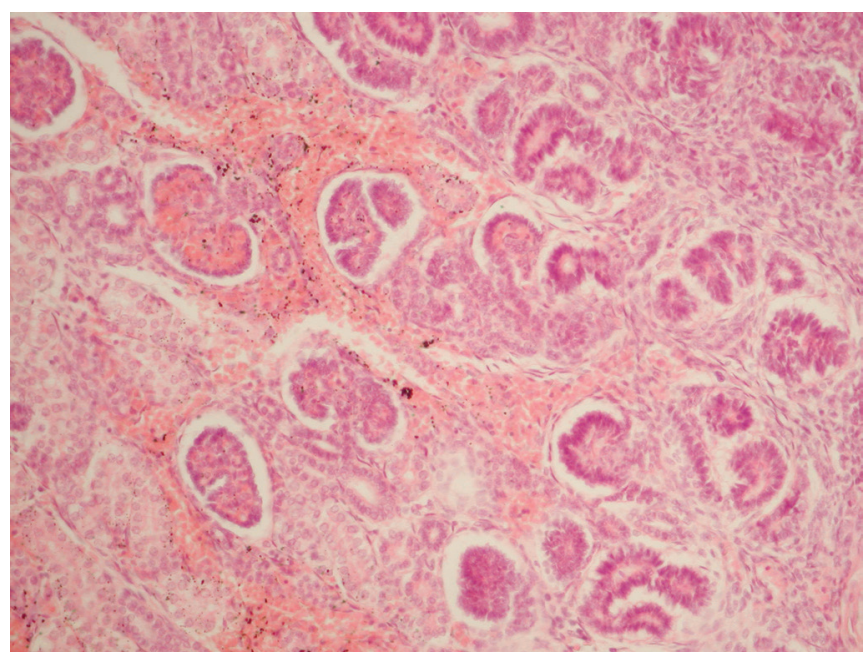

Fig. 1. Foci of the immature tissue in the newborn kidney developing in conditions of maternal iron deficiency anemia. Staining with haematoxylin and eosin, $\times 200$.

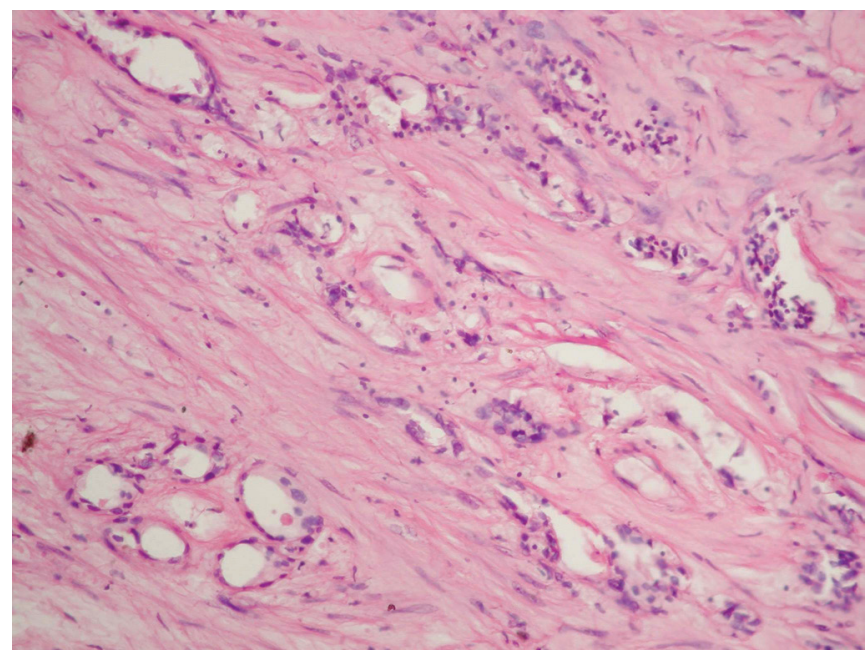

Fig. 3. Prevalence of the mesenchymal component over the epithelial one in the tumour. Focal infiltration of immune cells. Connective tissue disorganization. Staining with haematoxylin and eosin, $\times 200$.

an increased lobulation of the organ. But later the term «nephroblastomatosis» was used for describing multifocal or diffuse nephrogenic rests in one or both kidneys [8].

Morphologically, several variants of nephroblastomatosis are separated: perilobar, intralobar and mixed [12]. In perilobar nephroblastomatosis embryonal nephrogenic rests are localized along the renal cortex periphery; in intralobar nephroblastomatosis they prevail in the renal parenchyma [8]. Nephrogenic rests are classified histologically as dormant, sclerosing, hyperplastic or neoplastic. Dormant and sclerosing rests are usually microscopic and are not considered to have any malignant potential. Hyperplastic and neoplastic rests are grossly visible as small tan nodules surrounded by normal parenchyma [9].

So far the aetiology of Wilms' tumour has not been sufficiently studied [13]. Some scientists believe that maternal diseases and effects of ionizing radiation during the first half of pregnancy belong to causative factors for development of this tumour [13].

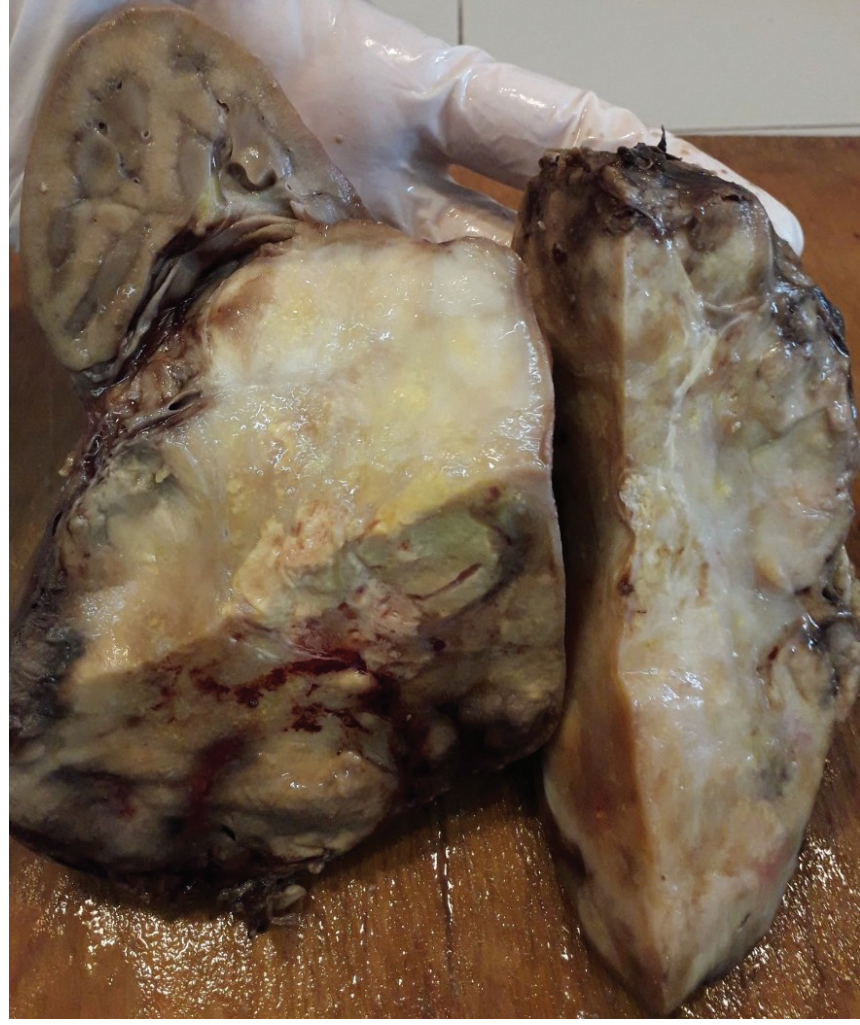

Fig. 2. The kidney with an adjacent tumour.

\section{REVIEW AND DISCUSSION}

Complications that appear in the mother in the course of her pregnancy can be, from our viewpoint, one of the causes for development of Wilms' tumour in the posterity. For example, our study of clinical and experimental material revealed that different degrees of severity of maternal preeclampsia and iron deficiency anaemia $[7,14]$, experimental chronic intrauterine and mixed hypoxias, experimental maternal subacute abdominal infectious-inflammatory process caused by Escherichia coli $[15,16]$ resulted in inhibition of glomerulogenesis and tubulogenesis and an increased number of foci of the immature tissue (fig. 1), thus making the development of Wilms' tumour in such children more probable.

According to data of G.R. Bunin et al., maternal use of hair-colouring products, maternal vaginal infection, parent's tea drinking, a high mean child birth weight and an old maternal age can serve as risk factors for development of Wilms' tumour [17].

A few studies have mentioned some hypothetical risk factors for Wilms' tumor such as occupational, environmental and life style factors [5].

Approximately 5\% of patients with Wilms' tumor have an underlying predisposing genetic syndrome and over 50 such syndromes have been described [3]. It is known that a high risk of development of this tumour is observed in patients with some WT1-associated syndromes (including WAGR and Denys-Drash), Perlman syndrome, mosaic variegated aneuploidy and Fanconi anaemia with biallelic BRCA2 mutation. A moderate risk of nephroblastoma 


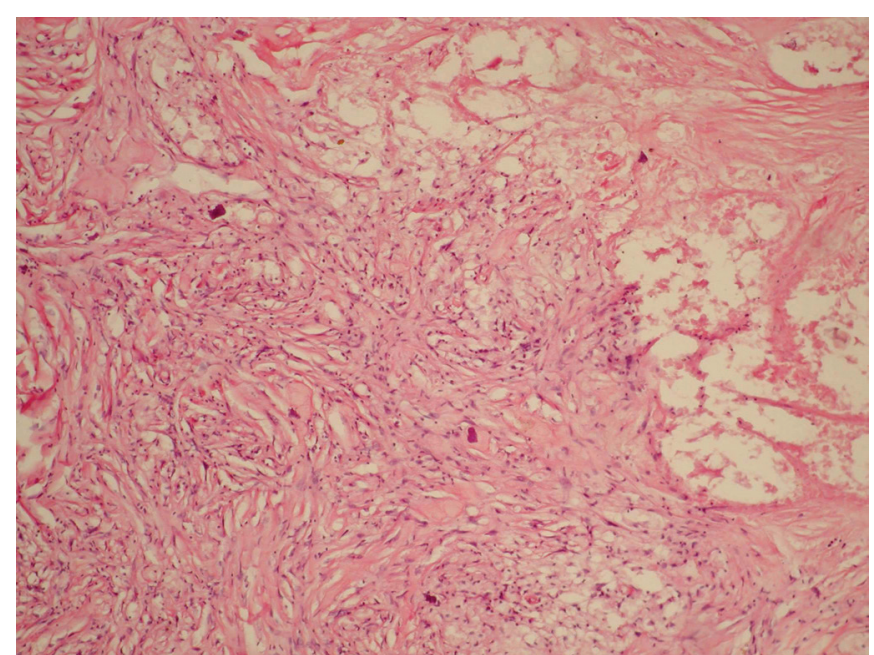

Fig. 4. Myoid, mesenchymoid proper and lipoblastic structures in the mesenchymal component of the tumour. Foci of necrosis and dystrophic calcification. Connective tissue disorganization. Staining with haematoxylin and eosin, $\times 100$.

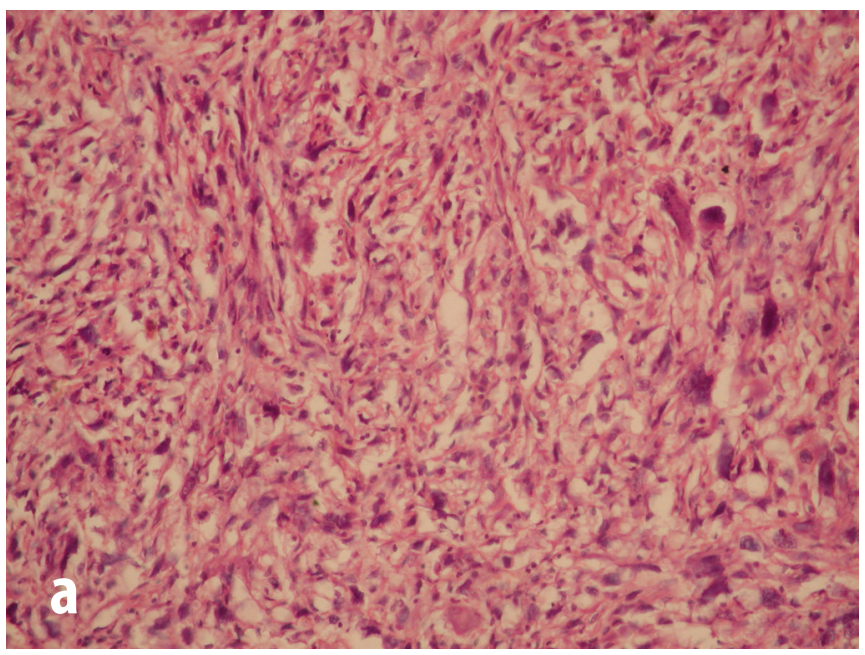

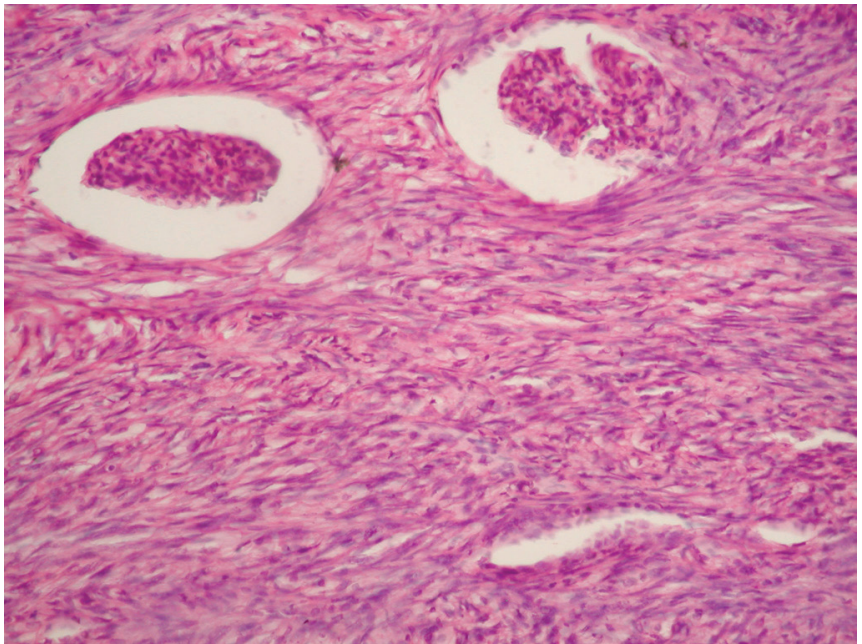

Fig. 5. Wilms' tumour. Glomerular and tubular structures. Staining with haematoxylin and eosin, $\times 200$.

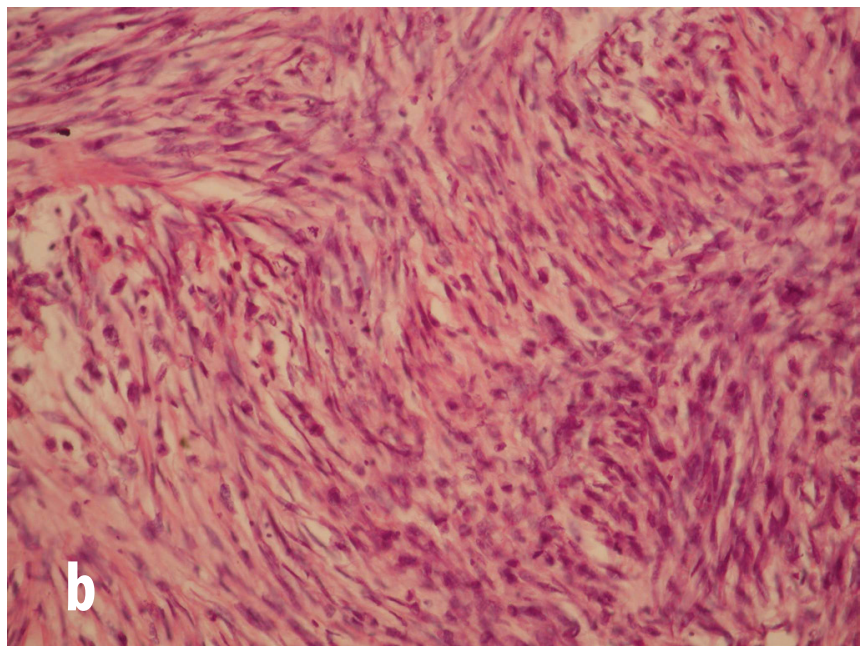

Fig. 6. The undifferentiated type of mesenchymal Wilms' tumour, represented by myosarcoma and fibrosarcoma areas. Staining with haematoxylin and eosin, a), b) $\times 200$.

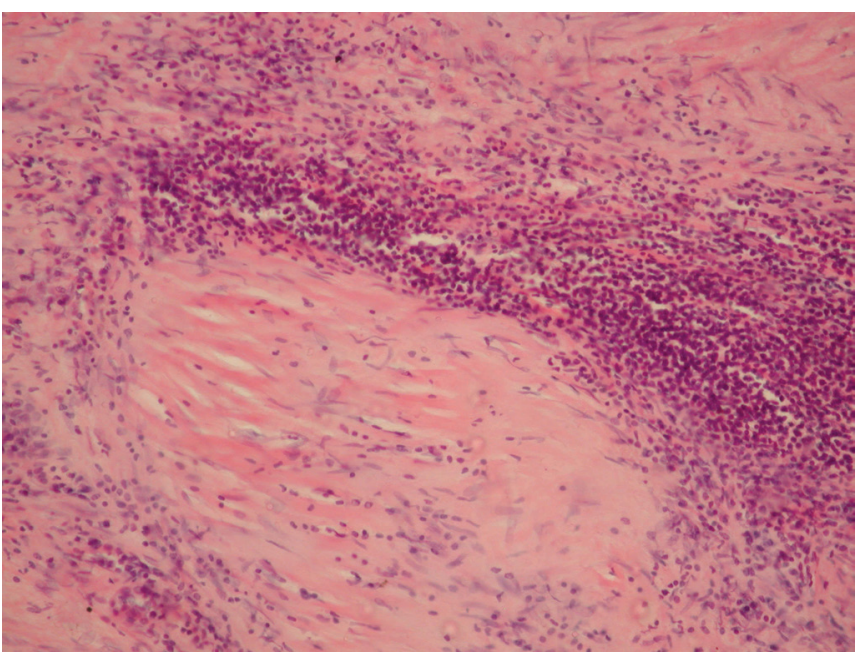

Fig. 7. Disorganization of the connective tissue, immune infiltration in the tumour tissue. Staining with haematoxylin and eosin, $\times 200$. development is found in patients with Fraser and Beckwith-Wiedemann syndromes, which result from disomy of 11p15, and Simpson-Golabi-Behmel syndrome. The group of a low risk for development of the above tumour is made up of cases with isolated hemihypertrophy, Bloom's and Li-Fraumeni syndromes, congenital hyperparathyroidism combined with jaw tumours, Mulibrey nanism and other chromosomal aberrations $[6,10]$.

At the initial stages of the disease any symptoms and signs of Wilms' tumour in children are usually absent or minimal [13]. This tumour is more commonly diagnosed by parents, when they wash or dress their children, palpating a tumour mass in the abdominal cavity or detecting an enlarged or asymmetrical abdomen. Children may suffer from an abdominal pain, haematuria and an acute abdomen. In rarer cases anaemia, hypertension caused by an excessive production of renin and polycytaemia due to production of erythropoietin by the tumour occur in chil- 
dren [1]. As the tumour grows, its clinical manifestations augment. The rates of the tumour enlargement are different. Its slow growth during many months is possible, but more frequently it enlarges rapidly, gradually compressing or pushing away surrounding tissues $[10,13]$. Often the tumour grows through a fibrous capsule of the kidney and encroaches upon the surrounding fat and adrenal gland, grows into the diaphragm, large intestine, spleen, liver, pancreas tail, intestinal mesentery and retroperitoneal lymph nodes [1].

Adult Wilms' tumour is different in many ways when compared with the paediatric one: adults present with local pain and haematuria usually, in contrast to a palpable boggy mass which is a more common presentation in children; adult Wilms' tumour is larger and ill-defined without sharp margins and with areas of necrosis and haemorrhages. Extension into the adjacent retroperitoneum is often present; adult Wilms' tumour has a more aggressive clinical course and a worse prognosis. Metastasis rates for adults and children were respectively $29 \%$ and $10 \%$. The lungs are the commonest sites for a spread of metastases, other sites include the liver, bone, lymph nodes, skin, orbit and the contralateral kidney. Unlike the paediatric population, majority of the adult patients are operated primarily. It is not possible to achieve a safe diagnosis in adults by imaging studies alone [18].

An important part in diagnosing Wilms' tumour in children and adults is played by morphological methods of examination. It is difficult to make the histological diagnosis of nephroblastoma, taking into consideration the various morphological structure of this tumour [19]. Clinicians need a rapid and correct assessment of results of examination of the biopsy material or operated tissues by pathologists in order to choose and carry on adequate diagnostic and treatment measures.

Macroscopically, the tumour looks like a well-defined node, it can achieve a large size and is located under a capsule or near the renal hilum. Consistency of the tumour depends upon maturity of its components. On its sections the tumour varies from whitish-gray to pale brown; it has foci of fresh and old haemorrhages, sometimes with macerations and cysts. Also, the above tumour may contain areas of osseous and cartilaginous tissues as well as foci of calcification [20].

Morphologically, nephroblastoma is a combination of epithelial and mesenchymal elements with different extents of differentiation, thereby making this tumour extremely variable. [2]. The epithelial component is represented by a mesonephral blastema with formation of tubules as well as glomerular and cystic structures with different degrees of differentiation. The mesenchymal component is represented by a connective tissue with structures having different tissue differentiation: myoid (leiomyoblastic and rhabdomyoblastic), mesenchymoid, lipoblastic (of the type of embryonic lipoma and/or hibernoma), chondroblastic as well as osteoblastic and neuroectodermal [2].

Some scientists isolate three components in the structure of Wilms' tumour: blastemic, mesenchymal and epithelial
[10]. In a part of cases Wilms' tumour may not contain all three above components. Proportions of the tumour components may differ, therefore it has 3 variants: typical nephroblastoma, characterized by equal volumes of its epithelial and mesenchymal components; nephroblastoma with prevalence of the epithelial component; nephroblastoma with prevalence of the mesenchymal component. In each of these variants the pathologist should determine the degree of differentiation of the prevailing component [2].

Monoclonal antibodies against Wilms' tumour 1, vimentin, CD 56, CD 57, cytokeratin 22, cytokeratin 18, cytokeratin 8 , epithelial membrane antigen, smooth muscle actin and actin are useful markers for an accurate diagnosis of Wilms' tumour [21].

The prognosis varies. Patients under two years have a more favourable prognosis. The prognosis is unfavorable in cases of the tumour growing outside the limits of the renal capsule, a large size of the tumour, its metastases, anaplasia of the tumour tissue revealed by enlargement of nuclei in cells, their hyperchromia and appearance of patterns of atypical mitoses $[1,2]$.

\section{CLINICAL CASE}

Taking into account that Wilms' tumour occurs in adults infrequently, we would like to give here our analysis of the case from practice with development of the above tumour in a 45-year-old male, who was hospitalized in April of 2019 to the Military Medical Clinical Centre of the Northern Region. Computed tomography of his thoracic and abdominal organs and small pelvis revealed that the middle and lower thirds of the right kidney contained a multinodal cystic-solid formation with the subcapsular spreading and fine areas of calcification. The above formation was intimally adjacent to the lateral inferoposterior segment of the right hepatic lobe and the inferior pudental vein; a spherical formation, $9 \times 8 \mathrm{~mm}$ in size, was visualized in the inferoposterior segment of the right hepatic lobe. The patient underwent laparotomy, removal of his right kidney with the tumour and some part of his ureter. The operated material was sent to the pathology department for morphological examination and pathology identification.

Macroscopic examination determined a slightly reduced kidney with an adjacent tumour, which had the subcapsular localization in the hilum region (fig. 2). The tumour was soft in some places and had dense consistency in others; on sections it was whitish-yellowish and reddish-brownish color.

Microscopic examination revealed structure of Wilms' tumour, characterized by prevalence of its mesenchymal component over the epithelial one (fig. 3), the latter being actually undetectable in some part of visual fields (fig. 4). The epithelial component was characterized by formation of glomerular and tubular structures (figs. 3, 5); the latter ones were both without any lumen and with a wellformed lumen. In some part of visual fields the epithelium produced a secretion into the lumen of ducts, therewith making such structures look like a gland. 
The mesenchymal component revealed an aggregate of myoid (leiomyoblastic and rhabdomyoblastic), mesenchymoid proper and lipoblastic structures (fig. 4) with prevalence of the specific volume of myoid ones.

A.O. Prylutsky et al. note that prevalence of myoid structures in the mesenchymal component of Wilms' tumour demonstrates augmentation of its malignancy, it being caused by a high proliferative activity of muscle elements and their capacity for vascular invasion [19].

In the course of our further analysis of the microslides a few visual fields revealed the differentiated mesenchymal type, where mesenchymal derivates did not have any morphological signs of a malignant growth. But most visual fields demonstrated the undifferentiated type of mesenchymal Wilms' tumour, represented by myosarcoma and fibrosarcoma areas (fig. 6).

Some places of the mesenchymal component of Wilms' tumour contained foci of dystrophic calcification (fig. 4), signs of disorganization of the connective tissue up to the development of extensive necrosis (figs. 3, 4, 7), focal infiltration of immune cells (figs. 3,7 ).

\section{CONCLUSIONS}

The article has analysed clinical-morphological features of Wilms' tumour, which is typical for childhood and rare in adults. One of the causes of Wilms' tumour development can be maternal complications, which arise during pregnancy, leading to inhibition of glomerulogenesis and tubulogenesis in the offspring kidneys, an increase the number of foci of primitive (immature) tissue, from which this tumour, as it is known, can originate. The described case from practice of Wilms' tumour is of particular interest because of an untypical age category, when the above pathology was diagnosed, demonstrates necessity of a multidisciplinary approach to its identification and necessitates its inclusion into the differential diagnostic line for the detection of kidneys tumours in adults.

\section{REFERENCES}

1. Memjanova FN, Jalilov JJ. Opukhol Vylmsa [Wilm's tumour]. The Bulletin of emergency medicine. 2011;1:80-83. (Ru)

2. Zhurilo IP, Grona VN, Litovka VK, Abdullin RF, Latyshov KV, Muzaliov AA. Diagnostyka ta likuvannya nefroblastomy u ditey [Diagnostics and treatment of nephroblastoma in children]. Neoplasm. 2007;1:121125. (Ru)

3. Szychot E, Apps J, Pritchard-Jones K. Wilms' tumor: biology, diagnosis and treatment. Translational pediatrics.2014;3(1):12-24.

4. Vujanić GM, Sandstedt B. The pathology of Wilms' tumour (nephroblastoma): the International Society of Paediatric Oncology approach. Journal of clinical pathology.2010;63(2):102-109.

5. Woldeab WE, Nyongole OV, Frank B. Wilm's tumor: Presentation and outcome at Kilimanjaro Christian Medical Center. The Journal of Medical Research. 2016; 2(4):114-117.

6. Kulyova SA, Imyanitov EN. Opukhol Vylmsa: syndromalnaya y molekulyarnaya dyagnostyka [Wilm's tumor: syndrome-based and molecular diagnostics]. Onkopediatria.2017;4(4):283-289. (Ru)
7. Sorokina IV, Myroshnychenko MS, Kapustnyk NV, Simachova AV, Ivanova AA. Morfometrycheskaya otsenka sostoyanyya pochek plodov y novorozhdennykh, razvyvavshykhsya v uslovyyakh materynskoy zhelezodefytsytnoy anemyy [Morphometrical evaluation of fetuses and newborns kidneys status developing under maternal iron deficiency anemia conditions]. Wiadomości Lekarskie. 2018;LXXI(7):1222-1230. (Ru)

8. Chililova AM, Kachanov DYu, Mitrofanova AM, Konovalov DM, Sukhov MN, Tereshchenko GV, et al. Bylateralnyy dyffuznyy gyperplastycheskyy perylobarnyy nefroblastomatoz: sobstvennoeklynycheskoe nablyudenye [Bilateral diffuse hyperplastic perilobar nephroblastomatosis]. Pediatric hematology/oncology and immunopathology. 2015;14(4):37-43. (Ru)

9. Lowe LH, Isuani BH, Heller RM, Stein SM, Johnson JE, Navarro OM, et al. Pediatric renal masses: Wilms tumor and beyond. RadioGraphics. 2000;20:1585-1603.

10. Huppmann AR. Educational case: Wilms tumor. Academic pathology. 2018:5:1-5.

11. Lonergan GJ, Martinez-Leon MI, Agrons GA, Montemarano H, Suarez ES. Nephrogenic rests, nephroblastomatosis and associated lesions of the kidney. RadioGraphics. 1998;18:947-968.

12. Sharoyev TA, Sokolova IN, Ivanova NM, Rubanskaya MV, Koshechkina NA, Panferova TR. Nefroblastomatoz u detey: obzor lyteratury y sobstvennye materyaly yssledovanyya [Nephroblastomatosis in children: review of literature and the authors'study findings]. Cancer urology. 2009;4:19-24. (Ru)

13. Grigoryev Kl, Boyechenko El. Nefroblastoma u detey [Nephroblastoma in children]. Meditsinskaya sestra. 2013;2:22-29.

14. Sorokina IV, Myroshnychenko MS, Kapustnyk NV, Khramova TO, Dehtiarova OV, DanylchenkoSI.Morfologycheskaya kharakterystykasoedynytelnoytkanypochek donoshennykh plodov y novorozhdennykh ot materey, beremennost kotorykh oslozhnylas preeklampsyey razlychnoy stepeny tyazhesty [Morphological characteristic of kidneys connective tissue of mature fetuses and newborns from mothers, whose pregnancy was complicated by preedlampsia of varying degrees of severity]. Wiadomości Lekarskie. 2018;LXXI(3/1):579-587. (Ru)

15. Sorokina I, Myroshnychenko M, Kapustnyk N. Pathology of the urinary system organs in children population of Ukraine: its past, present and future. Regional Innovations. 2017;4:35-42.

16. Sorokina IV, Myroshnychenko MS, Ivanova MD. Morfologycheskye osobennosty pochek plodov y novorozhdennykh ot materey s podostrym ynfektsyonno-vospalytelnym protsessom v bryushnoy polosty, vyzvannym Escherichia coli (eksperymentalnoe yssledovanye) [Morphological features of kidneys in fetuses and newborns from mothers with subacute infectious-inflammatory process in the abdominal cavity caused by Escherichia coli (experimental study)]. Kidneys. 2018;7(1):18-25. (Ru)

17. Bunin GR, Kramer S, Marrero 0, Meadows AT. Gestational risk factors for Wilms' tumor: results of a case-control study. Cancer research. 1987;47:2972-2977.

18. Varma AV, Malukani $K$, Rihal $P$, Nandedkar SS. Adult Wilms' tumor: a case report with review of literature. Journal of cancer research and therapeutics. 2015;11(4):934-936.

19. Prylutsky A0, Chernyshenko AS, Prylutsky 00. Patomorfologiya neepitelialnogo komponenta pukhlyny Vilmsa (nefroblastomy) [Pathomorphology of nonepithelial component of Wilms tumor (nephroblastoma)]. Morphology. 2007;1(4):120-121. (Ua)

20. Morgoshia TSh, Kokhanenko NYu. Vklad legendarnogo khyrurga y onkologa Maksa Vylmsa (1867-1918) v klynycheskuyu medytsynu (k 150-letyyu so dnya rozhdenyya) [The contribution of the legendary surgeon and oncologist Max Wilms (1867-1918) to clinical medicine (on the 150th anniversary of his birth)]. Russian journal of pediatric hematology and oncology. 2018;5(1):103-105. (Ru) 
21. Vasei M, Moch H, Mousavi A, Kajbafzadeh A. Immunohistochemical profiling of Wilms tumor. Applied immunohistochemistry and molecular morphology. 2008;16(2):128-134.

\section{Authors' contributions:}

According to the order of the Authorship.

\section{ORCID numbers:}

Victor D. Urzhumov - 0000-0002-8648-7758

Nana M. Pasiyeshvili - 0000-0002-8016-4288

Nataliia V. Kapustnyk - 0000-0002-4875-398X

Mykhailo S. Myroshnychenko - 0000-0002-6920-8374

Iryna V. Borzenkova - 0000-0002-0701-5286

Dmytro V. Molodan - 0000-0002-7679-8288

Victor N. Grinevich - 0000-0002-6232-5949

\section{Conflict of interest:}

The Authors declare no conflict of interest.

\section{CORRESPONDING AUTHOR}

Mykhailo S. Myroshnychenko

Kharkiv National Medical University

str. Svetlaya27A, apt. 70, 61129, Kharkiv, Ukraine

tel: +380501699763

e-mail: msmyroshnychenko@ukr.net

Received: 21.04.2019

Accepted: 17.09.2019 
CASE REPORT

OPIS PRZYPADKU

\title{
ROPIEŃ PODNIEBIENIA TWARDEGO I PRZETOKA NOSOWO-PODNIEBIENNA JAKO POWIKŁANIE ZĘBA ZATRZYMANEGO W SZCZĘCE - OPIS PRZYPADKU
}

\section{HARD PALATE ABSCESS AND NASOPALATINE FISTULA AS A RESULT OF IMPACTED TOOTH IN JAW - CASE REPORT}

\author{
Mateusz Jeziorny \\ KATEDRA I KLINIKA OTOLARYNGOLOGII, CHIRURGIII GŁOWY ISZYI UNIWERSYTETU MEDYCZNEGO IM. PIASTÓWŚLĄKICHWEWROCŁAWIU, WROCŁAW, POLSKA
}

\begin{abstract}
STRESZCZENIE
Zęby zatrzymane są jedną z przyczyn zgłaszania się pacjentów do chirurgów szzzękowo-twarzowych lub chirurgów stomatologicznych. Są one często wykrywane przypadkowo podczas diagnostyki innych schorzeń w obrębie nosa, zatok przynosowych lub jamy ustnej. W pracy przedstawiono proces diagnostyki i leczenia rzadkiego przypadku 53-letniej pacjentki, u której doszło do wytworzenia ropnia podniebienia twardego na skutek próchnicy zęba zatrzymanego w szczęce z towarszyszącą torbielą zawiązkową oraz przetoką nosowo-podniebienną.
\end{abstract}

SŁOWA KLUCZOWE: ząb zatrzymany, torbiel, torbiel zawiązkowa, guz torbielowaty, ropień, podniebienie, przetoka nosowo-podniebienna

\begin{abstract}
Impacted teeth are one of causes of patients visits to maxillofacial surgeons or dental surgeons. They are often detected accidentally when diagnosing other diseases in area of the nose, paranasal sinuses or oral cavity. This paper presents the process of diagnostics and treatment of a rare case of a 53-year-old patient, who developed hard palate abscess as a result of caries of impacted tooth accompanied by lateral periodontal cyst and nasopalatine fistula located in jaw.
\end{abstract}

KEY WORDS: impacted tooth, cyst, lateral periodontal cyst, cystic tumor, abscess, palate, nasopalatal fistula

Wiad Lek 2019, 72, 10, 2056-2059

\section{WSTĘP}

Zęby zatrzymane są to w pełni ukształtowane zęby, które nie uległy erupcji (wyrzynaniu) dłużej niż przez dwa lata w stosunku do fizjologicznego czasu wyrżnięcia [1]. Zęby stałe zaczynają się wyrzynać $\mathrm{w}$ wieku około 6 lat, a proces ten powinien zakończyć się około 14. roku życia (pomijając trzecie zęby trzonowe, których okres wyrzynania jest niestały i może sięgnąć nawet 40 roku życia) $[2,3]$. Zwykle do przebicia się do światła jamy ustnej dochodzi, gdy ząb ma uformowane od 1/2 do 3/4 korzenia [4]. Możemy rozróżnić zęby zatrzymane całkowicie lub częściowo - ząb zatrzymany całkowicie otoczony jest kością, natomiast ząb zatrzymany częściowo jest pokryty błoną śluzową lub tylko częściowo przebił się przez dziąsło $[5,6]$. Częstość występowania zębów zatrzymanych jest uwarunkowana etnicznie i waha się między 5.6\% a 38\% [1]. Najczęściej zatrzymaniu ulegają kolejno: górne trzecie zęby trzonowcowe, dolne trzecie zęby trzonowcowe, górne kły $[1,7,8]$.

\section{CEL PRACY}

Celem pracy jest przedstawienie rzadkiego przypadku 53-letniej pacjentki, u której doszło do wytworzenia ropnia podniebienia spowodowanego próchnicą korony zęba zatrzymanego $\mathrm{z}$ towarzyszącą torbielą zawiązkową w szczęce oraz przetoką nosowo-podniebienną.

\section{OPIS PRZYPADKU}

53-letnia pacjentka, aktywna palaczka tytoniu (18 paczkolat w wywiadzie), bez istotnej przeszłości chorobowej, nie lecząca się przewlekle, zgłosiła się ze skierowaniem na Oddział Otolaryngologiczny do Wojewódzkiego Szpitala Specjalistycznego $\mathrm{w}$ Legnicy $\mathrm{z}$ powodu zmiany na podniebieniu twardym. Według relacji pacjentki pojawiła się ona cztery dni wcześniej i od tego czasu powiększała się. Zmiana była bolesna, ponadto pacjentka skarżyła się na ból okolicy ciemieniowej głowy oraz w rzucie oczodołów. Nie gorączkowała. Podawała również utratę wagi w ciągu ostatnich kilku miesięcy, nie była jednak w stanie precyzyjnie jej określić. Podobna zmiana wystąpiła w tym samym miejscu około dwa miesiące wcześniej, towarzyszyły jej podobne objawy - ze zmiany samoistnie ewakuował się wówczas żółto-brązowy płyn a objawy ustąpiły, w związku z czym nie konsultowała tego z lekarzem. 


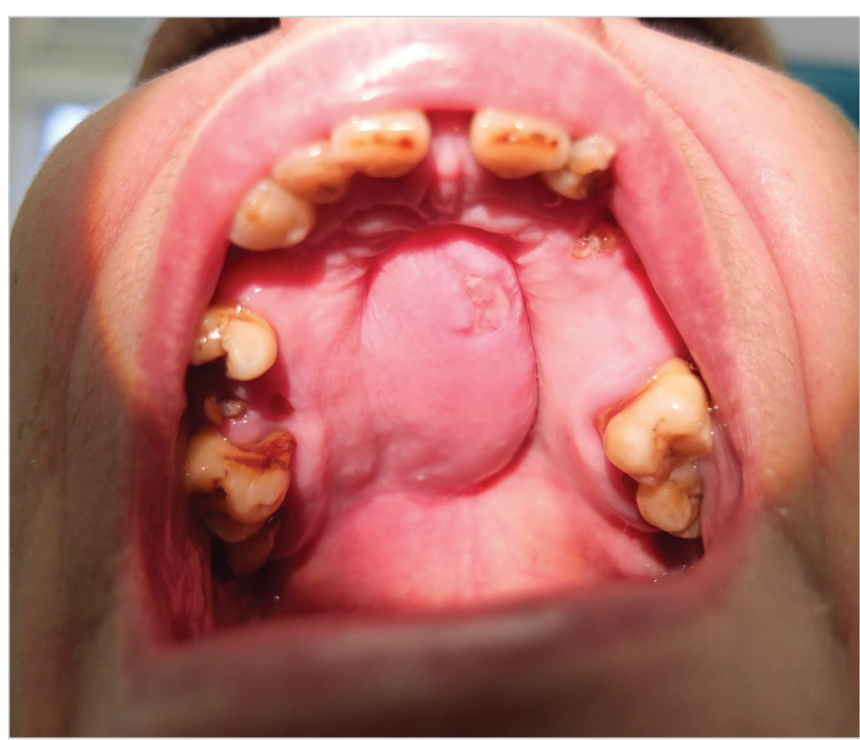

Ryc. 1. Zdjęcie wewnątrzustne.

W badaniu fizykalnym podczas przyjęcia stwierdzono owalną, twardą zmianę obejmującą podniebienie twarde. Uzębienie łuku górnego było niepełne (według numeracji Viohla w jego skład wchodziły zęby $11,12,13,15$, korzeń 16, 17,18,21, pozostałość 22, 27 i 28), w znacznej mierze próchnicze (Ryc. 1). Poza tym w badaniu fizykalnym nie stwierdzono odchyleń w zakresie uszu, nosa oraz gardła. Nie stwierdzono powiększonych węzłów chłonnych w obrębie głowy i szyi. Przy przyjęciu wykonano badania laboratoryjne krwi, w których jedynym odchyleniem od normy był wysoki wynik białka C-reaktywnego - 181.8 [mg/l] (Tab. I). U pacjentki wdrożono dożylną, empiryczną antybiotykoterapię (amoksycylina $\mathrm{z}$ kwasem klawulanowym w dawce 1,2g co 8 godzin oraz metronidazol $w$ dawce $0,5 \mathrm{~g}$ co 8 godzin). W trzeciej dobie hospitalizacji, w związku z brakiem istotnej poprawy, zmianę nakłuto ewakuując treść ropną, a następnie nacięto, poszerzono i przepłukano roztworem wody utlenionej jamę ropnia. Zabieg poszerzenia i przepłukania jamy ropnia powtarzano codziennie. Ze względu na utrzymujący się obfity wyciek ropny pomimo stosowanego leczenia oraz celem wykluczenia zmiany o charakterze nowotworowym w piątej dobie hospitalizacji wykonano badanie TK twarzoczaszki bez i z kontrastem (Ryc. 2-5).

$\mathrm{W}$ badaniu podniebienia twardego opisane zostało rozlane pogrubienie błony śluzowej ze wzmocnieniem kontrastowym wielkości co najmniej 39x16 mm. Pomiędzy błoną śluzową podniebienia a kością podniebienia uwidoczniono komorę powietrzną, która w części przedniej komunikowała się z komorą kostną w kości szczękowej wielkości 18x16 mm. W komorze kostnej kości szczękowej uwidoczniono ząb zatrzymany (ze zmianami próchniczymi w koronie zęba). W części przednio-górnej opisywana komora w kości szczękowej wąskim kanałem łączyła się $\mathrm{z}$ jamą nosową tworząc przetokę nosowo-podniebienną. Całość obrazu odpowiadała zębowi zatrzymanemu (morfologia oraz położenie w przedniej części szczęki według radiologa sugerowały ząb sieczny $\mathrm{z}$ obecną próchnicą
Tabela I. Wynik badań laboratoryjnych krwi

\begin{tabular}{|c|c|}
\hline Wskaźnik & Norma \\
\hline WBC = 8,7 [tys/ul] & 4.0 [tys/ul] - 10.0 [tys/ul] \\
\hline $\mathrm{RBC}=4,2[\mathrm{~m} \ln / \mathrm{ul}]$ & $4.2[\mathrm{mln} / \mathrm{ul}]-6.0[\mathrm{mln} / \mathrm{ul}]$ \\
\hline $\mathrm{HGB}=13,4[\mathrm{~g} / \mathrm{dl}]$ & $14[\mathrm{~g} / \mathrm{dl}]-18[\mathrm{~g} / \mathrm{dl}]$ \\
\hline $\mathrm{HCT}=39,2[\%]$ & $40[\%]-54[\%]$ \\
\hline MCV = 93,8 [fl] & 79 [fl] - 101 [fl] \\
\hline $\mathrm{MCH}=32,1[\mathrm{pg}]$ & 26 [pg] - 35 [pg] \\
\hline $\mathrm{MCHC}=34,2[\mathrm{~g} / \mathrm{dl}]$ & $31[\mathrm{~g} / \mathrm{dl}]-37[\mathrm{~g} / \mathrm{dl}]$ \\
\hline PŁYTKI KRWI = 316,0 [tys/ul] & 130 [tys/ul] - 450 [tys/ul] \\
\hline LYMPH\% = 17,9 [\%] & $12[\%]-50[\%]$ \\
\hline MXD\% = 7,8 [\%] & $0.0[\%]-18.5[\%]$ \\
\hline NEUT\% = 74,3 [\%] & 37 [\%] - 75 [\%] \\
\hline LYMPH =1,6 [tys/ul] & 1.0 [tys/ul] - 3.5 [tys/ul] \\
\hline MXD = 0,6 [tys/ul] & 0.0 [tys/ul] - 2.0 [tys/ul] \\
\hline NEUT = 6,5 [tys/ul] & 2.0 [tys/ul] - 7.5 [tys/ul] \\
\hline $\mathrm{PDW}=11,8[\mathrm{fl}]$ & 9 [fl] - 17 [fl] \\
\hline MPV $=9,9[\mathrm{fl}]$ & 9 [fl] - 17 [fl] \\
\hline CRP ilościowo = 181.8 [mg/l] & $0[\mathrm{mg} / \mathrm{l}]-1[\mathrm{mg} / \mathrm{l}]$ \\
\hline
\end{tabular}

korony - ze względu natomiast na obecność obu zębów siecznych w łuku górnym pacjentki, najprawdopodobniej doszło do zatrzymania kła - ząb 23) z wieloletnią resorpcją okołozębową, a następnie przebiciem do jamy nosowej ku górze i podniebieniu ku dołowi oraz końcowym wytworzeniem ropnia podniebiennego $\mathrm{z}$ rozlanym naciekiem zapalnym. Ze względu na konieczność interwencji chirurgicznej pacjentkę wypisano z Oddziału i skierowano do Kliniki Chirurgii Szczękowo-Twarzowej Uniwersyteckiego Szpitala Klinicznego we Wrocławiu z zaleceniem kontynuacji antybiotykoterapii doustnie do czasu zabiegu. W ósmej dobie od czasu pierwotnego przyjęcia do szpitala wykonano zabieg: usunięto korzeń zęba 23 , a następnie $\mathrm{z}$ cięcia $\mathrm{w}$ przedsionku jamy ustnej okolicy zębów 21-24 odsłonięto i zniesiono korową warstwę kości uwidaczniając ząb dodatkowy wraz z guzem torbielowatym, które usunięto i przesłano do badania histopatologicznego. Pacjentkę wypisano z Kliniki w 2. dobie po zabiegu, w stanie ogólnym i miejscowym dobrym. W rozpoznaniu histopatologicznym stwierdzono torbiel zawiązkową.

\section{OMÓWIENIE}

Przyczyny zatrzymania zębów mogą być różne - miejscowe, ogólnoustrojowe oraz uwarunkowane genetycznie. Najczęstsze są przyczyny miejscowe - przede wszystkim brak miejsca w łuku zębowym spowodowany stłoczeniem zębów, a także między innymi: wcześniejsze ekstrakcje sąsiednich zębów, rozszczep podniebienia lub urazy [4, 9, 10]. Do przyczyn ogólnoustrojowych zaliczyć można zaburzenia hormonalne (m. in. niedoczynność tarczycy lub niedoczynność przysadki), niedobory witaminy A i D, przebytą radioterapię okolicy jamy ustnej $[3,4$, 


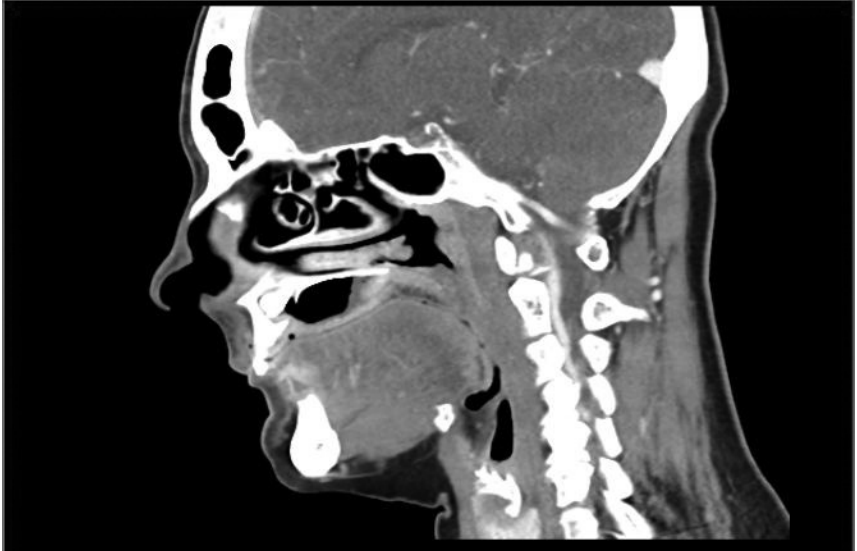

Ryc. 2. Tomografia komputerowa - przekrój strzałkowy.

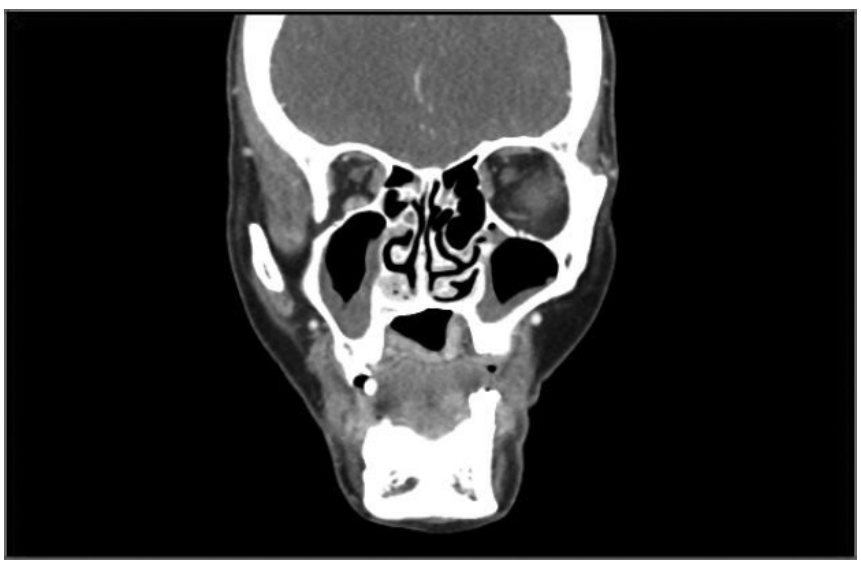

Ryc. 4. Tomografia komputerowa - przekrój czołowy B.

11, 12]. Przyczyn uwarunkowanych genetycznie jest wiele: pierwotne zaburzenia wyrzynania (PFE - primary failure of eruption) związane $\mathrm{z}$ mutacją $\mathrm{w}$ genie PTH1R [13-16], zespół Downa [17], achondroplazja, choroba Albersa-Schönberga, zespół Ellisa-van Crevelda, zespół szkliwno-nerkowy, dysplazja obocjczykowo-czaszkowa [18], amelogenesis imperfecta [19].

W większości przypadków zatrzymanie zęba przebiega dla pacjentów bezobjawowo. Gdy jednak zaistnieje konieczność leczenia, postępowanie obejmuje trzy główne metody: ekstrakcję zatrzymanego zęba, ekstrakcję sąsiadującego zęba lub odsłonięcie i sprowadzenie zatrzymanego zęba w interdyscyplinarnym postępowaniu chirurgiczno-ortodontycznym $[4,6]$. Do najczęstszych patologii powodowanych przez zęby zatrzymane należą ubytki kości przyzębia $(44,4 \%)$, resorpcja sąsiadujących zębów $(33,3 \%)$, torbiele bądź guzy torbielowate $(8,6 \%)$ oraz próchnica sąsiadujących zębów (2,3\%) [1]. Może również dojść do wytworzenia zębiaka (łagodnego guza zębopochodnego) [6].

Wytworzenie przetoki nosowo-podniebiennej może być spowodowane różnymi czynnikami. Rzadko występuje jako powikłanie niezarośniętego przewodu nosowo-podniebiennego [20, 21]. Przetoka tego typu jest również częstym powikłaniem palatoplastyki [22]. Może również wystąpić wskutek nadużywania kokainy [23] lub jako powi-

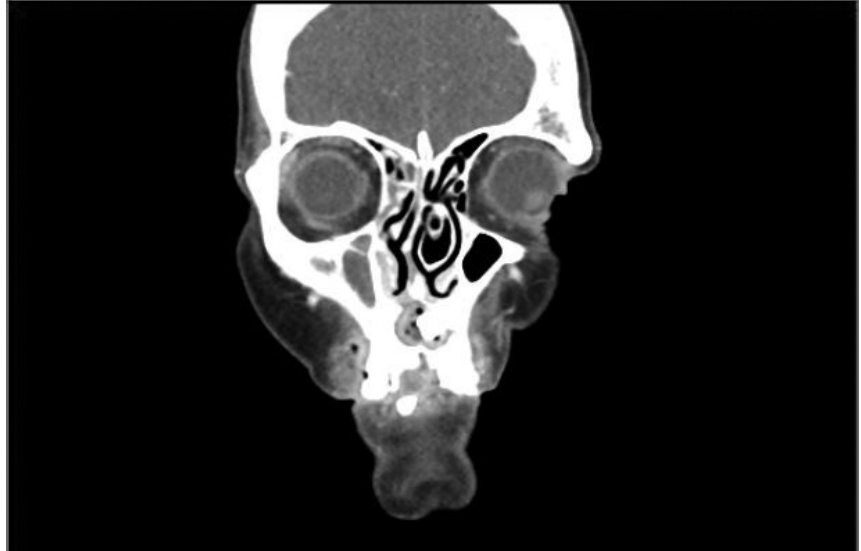

Ryc. 3. Tomografia komputerowa - przekrój czołowy A.

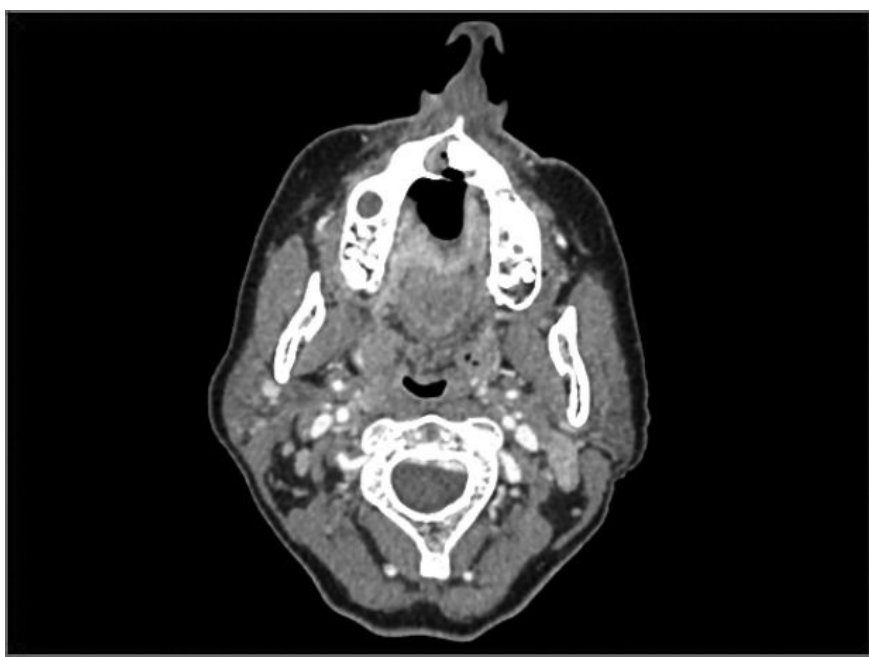

Ryc. 5. Tomografia komputerowa - przekrój poprzeczny.

kłanie miejscowych procesów zapalnych. W opisywanym przypadku najbardziej prawdopodobnym jest wytworzenie przetoki na skutek toczącego się ropnego procesu zapalnego w szczęce.

\section{PODSUMOWANIE}

Przebieg zatrzymania u zęba był u opisywanej pacjentki przez bardzo długi okres życia bezobjawowy. W szczęce pacjentki doszło najprawdopodobniej najpierw do wytworzenia się torbieli zawiązkowej, a następnie ropnego, rozlanego zapalenia na skutek próchnicy korony zatrzymanego zęba. Dodatkowo obecna była przetoka nosowo-podniebienna jako pozostałość przewodu nosowo-podniebiennego lub, co bardziej prawdopodobne - jako następstwo ropnego procesu zapalnego. Przeszukując bazy medyczne Pumbed, Medline i Scopus, autor nie znalazł innego przypadku zęba zatrzymanego z towarzyszącą przetoką tego typu, co czyni z opisywanego przypadku fakt wart odnotowania w literaturze (znaleziono jedynie przypadek wytworzenia przetoki ustno-skórnej, jako powikłanie zatrzymanego trzeciego zęba trzonowcowego w żuchwie) [24]. 


\section{PIŚMENNICTWO}

1. Sarica I, Derindag G, Kurtuldu E, et al. A retrospective study: Do all impacted teeth cause pathology? Niger I Clin Pract. 2019;22:527-533.

2. Szpringer-Nodzak M, Wochna-Sobańska M. Stomatologia wieku rozwojowego.4th edn. Warszawa:Wydawnictwo Lekarskie PZWL, 2006

3. Wright JT, Griffen A, Torchia MM. Anatomy and development of the teeth. Arch Dis Child. 1990;65:386-387.

4. Kaczor-Urbanowicz K, Zadurska M, Czochrowska E. Impacted Teeth: An Interdisciplinary Perspective. Adv Clin Exp Med. 2016;25:575-585.

5. Kryst L. Chirurgia szczękowo-twarzowa. 5th edn. Warszawa: Wydawnictwo Lekarskie PZWL, 2012

6. Diana Karolak JL. Leczenie interdyscyplinarne (chirurgicznoortodontyczne) zębiaka zestawnego związanego z zatrzymanym stałym siekaczem bocznym żuchwy - opis przypadku. Nowa Stomatol. 2018;23:25-31.

7. Chu FCS, Li TKL, Lui VKB et al. Prevalence of impacted teeth and associated pathologies - A radiographic study of the Hong Kong Chinese population. Hong Kong Med. J. 2003;9:158-63.

8. Dachi SF, Howell FV. A survey of 3,874 routine full-mouth radiographs. II. A study of impacted teeth. Oral Surgery, Oral Med. Oral Pathol. 1961;14:1165-1169.

9. Bedoya MM, Park JH. A review of the diagnosis and management of impacted maxillary canines. J Am Dent Assoc. 2009;140:1485-93.

10. Litsas G. A Review of Early Displaced Maxillary Canines: Etiology, Diagnosis and Interceptive Treatment. Open Dent J. 2011;5:39-47.

11. Atreja G, Atreja SH, Jain N et al. Oral manifestations in growth hormone disorders. Indian J Endocrinol Metab. 2012;16:381-3.

12. Gupta R, Goel K, Solanki J et al. Oral manifestations of hypothyroidism: A case report. J Clin Diagnostic Res. 2014;8:20-22.
13. Łyczek J, Antoszewska J. Primary failure of tooth eruption - Etiology, diagnosis and treatment. Dent Med Probl. 2013;50:349-354.

14. Frazier-Bowers SA, Hendricks HM, Wright JT et al. Novel mutations in PTH1R associated with primary failure of eruption and osteoarthritis. J Dent Res. 2014;93:134-139.

15. Hanisch $M$, Hanisch L, Kleinheinz J et al. Primary failure of eruption (PFE): A systematic review. Head Face Med. 2018;14.

16. Marcin Bębenek AJDK. PFE and ankylosis as a cause of disturbances in teeth eruption. Nowa Stomatol. 2013.

17. Moraes MEL, de Moraes LC, de Dotto GN et al. Dental anomalies in patients with down syndrome. Braz Dent J. 2007;18:346-350.

18. Bharti K, Goswami M. Cleidocranial dysplasia: A report of two cases with brief review. Intractable Rare Dis Res. 2016;5:117-120.

19. Hegde $S$. Multiple unerupted teeth with amelogenesis imperfecta in siblings. N Am J Med Sci. 2012;4:235-7.

20. Arx T von, Schaffner M, Bornstein MM. Patent nasopalatine ducts: an update of the literature and a series of new cases. Surg Radiol Anat. 2018;40:165-177.

21. Werder P,Bassetti R, Kuttenberger J.Surgical treatment option of the patent nasopalatine duct: a case report. J Surg Case Reports 2016; 2016: rjw090.

22. Tache A, Mommaerts MY. On the Frequency of Oronasal Fistulation After Primary Cleft Palate Repair. Cleft Palate Craniofac J. 2019;1055665619856243.

23. Silvestre FJ, Perez-Herbera A, Puente-Sandoval A et al. Hard palate perforation in cocaine abusers: a systematic review. Clin Oral Investig. 2010;14:621-8.

24. G S, Kamath AT, Kudva A et al. a Linguoverted Impacted Tooth With Orocutaneous Fistula - a Rare Case Report. Med Pharm Reports 2018;91:479-483.

ORCID:

Mateusz Jeziorny - 0000-0003-3083-1318

Konflikt interesów

Autor deklaruje brak konfliktu interesów

\author{
AUTOR KORESPONDUJĄCY \\ Mateusz Jeziorny \\ ul. Brzozowa 40/9, 52-200 Wysoka, \\ tel. 793665775 , \\ e-mail: mateusz.jeziorny@protonmail.com
}

Nadesłano: 20.08.2019

Zaakceptowano: 05.10.2019 


\title{
PERCUTANEOUS LEFT ATRIAL APPENDAGE CLOSURE IN A PATIENT WITH ATRIAL FIBRILLATION AND OSLER-WEBER-RENDU DISEASE
}

\author{
Urszula Gancarczyk', Piotr Podolec', Tadeusz Przewłocki' , Paweł Prochownik', Monika Komar ${ }^{1}$ \\ KLINIKA CHORÓB SERCA I NACZYŃ, INSTYTUT KARDIOLOGII UJ CM, KRAKOWSKI SZPITAL SPECJALISTYCZNY IM. JANA PAWŁA II, KRAKÓW, POLSKA
}

\begin{abstract}
We present a case report of a 79-year-old woman with permanent atrial fibrillation and 0sler-Weber-Rendu disease who underwent percutaneous closure of left atrial appendage. The patient had a history of small bowel resection due to mesenteric embolism and recurrent episodes of gastrointestinal bleeding, epistaxis and hemarthrosis. Bleeding episodes were exacerbated by anticoagulation therapy causing severe anemia that required repeated red blood cells transfusions. Left atrial appendage occlusion with Watchman $30 \mathrm{~mm}$ LAA Device was successfully performed. In long-term observation no thromboembolic event, epistaxis or severe bleeding have occurred.
\end{abstract}

KEY WORDS: 0sler-Weber-Rendu disease, Hereditary hemorrhagic telangiectasia, atrial fibrillation, left atrial appendage closure

Wiad Lek 2019, 72, 10, 2060-2062

\section{INTRODUCTION}

Atrial fibrillation (AF) is the most common cardiac arrhythmia. Prevalence of AF is 3\% of the general population and still increasing. One of the most important thing about treatment of patients with atrial fibrillation is prevention of thromboembolic complications [1-3]. Anticoagulation therapy by VKA (warfarin, acenocoumarol) or NOAC (apixaban, dabigatran, edoxaban, rivaroxaban) are highly effective however may cause severe bleeding complications especially in patients with coagulation or vascular disorders $[4,5]$. One of the vascular disorders is Osler-Weber-Rendu disease (OWRD) known as hereditary hemorrhagic telangiectasia (HHT) [6].

\section{CASE PRESENTATION}

We present a case report concerning a 79-year-old woman with atrial fibrillation and Osler-Weber-Rendu disease. The syndrome was diagnosed on the basis of clinical Curacao criteria : recurrent severe epistaxis, presence of skin and mucosa lesions (telangiectasias of face, ears, lips, hands, tongue) and positive family history (first-degree relatives with diagnosed OWR disease) (Fig. 1 A-C) [7]. Genetic testing had not been performed. Comorbidities included atherosclerosis, arterial hypertension, type 2 diabetes, chronic heart failure, chronic kidney disease and hypothyroidism. Additionally, the patient had a history of small bowel resection due to mesenteric embolism.

In March 2015 she was hospitalized in the Department of Internal Medicine because of heart failure symptoms. During hospitalization atrial fibrillation was diagnosed for the first time. Due to high thromboembolic risk
(CHA2DS2-VASc score of 9) oral anticoagulant was recommended. After hematologic consultation warfarin was introduced. The patient was also qualified for urgent pacemaker implantation due to sinus sick syndrome. After the procedure oral anticoagulation was sustained.

In July 2015 she was readmitted to the Department of Internal Medicine due to extensive epistaxis. Laboratory tests revealed severe anemia requiring blood transfusions. Because of persistent nosebleeds anterior nasal packing and coagulation was performed. After a few days of observation the patient was discharged in good general condition.

Two weeks later she was hospitalized again for recurrent epistaxis. Laboratory tests showed INR of 7,3 despite proper use of warfarin and moderate anemia. The patient received vitamin $\mathrm{K}$ and cyclonamine along with supplementation of iron, cobalamine and folic acid. Oral anticoagulation was continued. She was referred to cardiology department to be evaluated for percutaneous closure of left atrial appendage (LAA).

Due to high thromboembolic and bleeding risk the patient was qualified for transcatheter LAA occlusion. Before the procedure transesophageal echocardiography (TEE) was done. TEE revealed windsock-shaped LAA with no thrombus inside. Based on the result of imaging examination (TEE) LAA morphology was determined to be suitable for occlusion with Watchman device. LAA closure was performed with three dimensional TEE guidance under general anaesthesia and a Watchman $30 \mathrm{~mm}$ LAA Closure Device was successfully implanted (Fig. 1D). The procedure and recovery were uneventful and after two days the patient was discharged home in good general condition. Dual antiplatelet therapy was prescribed. After 45 days 


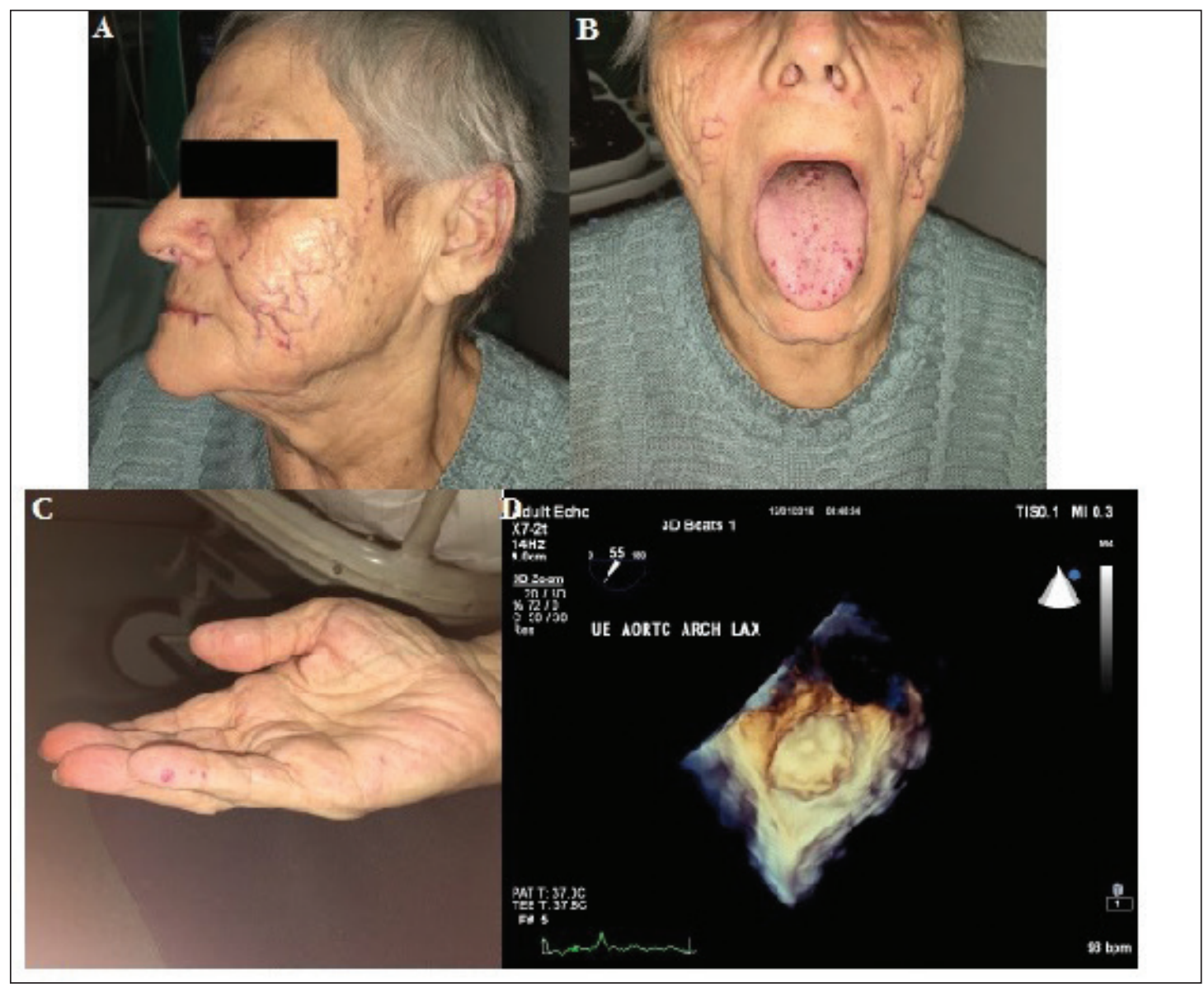

Fig 1: A. Telegiecstasias of face, ears and lips; B. Lesions of face, lips and tongue, C. Telegiecstasias of hand; D. LAA occlusion by Watchman Device $27 \mathrm{~mm}$.

TEE showed proper position of device. In the following 12 months antiplatelet therapy was reduced to low-dose aspirin $(75 \mathrm{mg})$, which was well tolerated. In long-term observetion no thromboembolic event, epistaxis or severe bleeding have occurred.

\section{CONCLUSIONS}

Osler-Weber-Rendu disease (OWRD) also known as hereditary hemorrhagic telangiectasia (HHT) is a rare autosomal dominant vascular dysplasia which causes telangiectases and arteriovenous malformations of skin, mucosa, and internal organs. The prevalence of OWRD in Europe is 1 case per 5000 to 8000 population and has been estimated to range from 1:200 to 1:100000 worldwide. The clinical diagnosis is based on the Curaçao criteria include epistaxis, telangiectases, visceral lesions and family history (a first-degree relative with HHT). Three or four criteria must be present [6-8]. The most common presentation of OWRD are extensive epistaxis which can lead to severe anemia requiring blood transfusion [9-11].

Atrial fibrillation (AF) is the most common arrhythmia with incidence estimated at $3 \%$ of the general population. Thromboembolic events are the most severe complications of this arrhythmia. AF is associated with fivefold higher risk of ischemic stroke [1-3]. Management of AF patients is aimed at prevention of these complications. In order to stratify the individual thromboembolic risk the CHA2DS2-VASc score is used. In patients with high risk of thromboembolism events (a CHA2DS2-VASc score $\geq 2$ ) the anticoagulation therapy is indicated $[12,13]$.

Left atrial appendage (LAA) is the main site of thrombi formation. In patients with non-valvular AF over $90 \%$ of blood cloths originate from LAA $[14,15]$. Non-pharmacological methods of ischemic stroke prevention include surgical exclusion or percutaneous closure of LAA. According to the European Society of Cardiology (ESC) guidelines this procedure may be considered in patients with non-valvular AF, high risk of stroke and contraindications for long-term oral anticoagulation therapy (IIb, level C) $[12,16]$. The randomized trials showed that percutaneous LAA closure and VKA treatment (warfarin), were similarly effective in stroke prevention [17-20].

Patients with AF, high risk of stroke and concomitant vascular disorders like OWRD belong to the group at high risk of bleeding complications. This population is extremely problematic with respect to proper anticoagulation - due to complications up to $50 \%$ of patients discontinue this therapy [21]. The most commonly used oral anticoagulants are vitamin $\mathrm{K}$ antagonist (VKA). Currently there is no data from clinical trials assessing the use of non-vitamin $\mathrm{K}$ oral anticoagulants (NOAC) in patients with HTT. 
At present there are no recommendations regarding treatment of patients with both HHT and AF. There are no specific guidelines that include the best therapeutic strategy in this population.

The case that we present shows a clinical dilemma. Case reports available via Pubmed report considerable reduction of bleeding complications in patients with AF and HHT who underwent percutaneous LAA occlusion $[22,23]$. Further multicenter and randomized clinical trials are required to establish all risks and benefits of LAAC in this group of patients.

\section{REFERENCES}

1. Chugh SS, Havmoeller R, Narayanan K et al. Worldwide epidemiology of atrial fibrillation: a Global Burden of Disease 2010 Study. Circulation 2014;129:837-847.

2. Bjorck S, Palaszewski B, Friberg L et al. Atrial fibrillation, stroke risk, and warfarin therapy revisited: a population-based study. Stroke 2013;44:3103-3108

3. Haim M, Hoshen M, Reges 0 et al. Prospective national study of the prevalence, incidence, management and outcome of a large contemporary cohort of patients with incident non-valvular atrial fibrillation. J Am Heart Assoc 2015;4:e001486.

4. Hart RG, Pearce LA, Aguilar MI. Meta-analysis: antithrombotic therapy to prevent stroke in patients who have nonvalvular atrial fibrillation. Ann Intern Med. 2007;146:857-867.

5. RuffCT,Giugliano RP,Braunwald Eetal.Comparison of the efficacy and safety of new oral anticoagulants with warfarin in patients with atrial fibrillation: a meta-analysis of randomised trials. Lancet 2014;383:955-962.

6. Kritharis A, Al-Samkari H, Kuter DJ. Hereditary hemorrhagic telangiectasia: diagnosis and management from the hematologist's perspective. Haematologica 2018;103(9):1433-1443.

7. Shovlin CL, Guttmacher AE, Buscarini E et al. Diagnostic criteria for hereditary hemorrhagic telangiectasia (Rendu Osler Weber syndrome). Am J Med Genet. 2000;91(1):66-67.

8. Skorek A, Stankiewicz C. The problems in diagnosis and management of Rendu-0sler-Weber disease. Otorynolaryngologia 2010;9(4):155-159

9. Chin CJ, Rotenberg BW, Witterick IJ. Epistaxis in hereditary hemorrhagic telangiectasia: an evidence based review of surgical management. J Otolaryngol Head Neck Surg. 2016;45:3 DOI 10.1186/s40463-016-0116-8

10. Jackson SB, Villano NP, Benhammou JN et al. Gastrointestinal Manifestations of Hereditary Hemorrhagic Telangiectasia (HHT): A Systematic Review of the Literature, Dig Dis Sci. 2017;62(10):2623-2630. doi:10.1007/s10620-017-4719-3

11. Bruzgielewicz A, Brożek-Mądry E, Osuch-Wójcikiewicz E et al. Difficulties in the treatment of epistaxis in Rendu-0sler-Weber disease, Otolaryngologia 2006;5(2):97-102

12. Kirchhof P, Benussi S, Kotecha D et al. 2016 ESC Guidelines for the management of atrial fibrillation developed in collaboration with EACTS. Eur Heart J. 2016;37:2893-2962. doi: 10.1093/eurheartj/ehw210.

13. Nielsen, Peter B. Stroke and thromboembolic event rates in atrial fibrillation according to different guideline treatment thresholds: A nationwide cohort study. 2016. Scientific Reports.6:27410

14. Al-Saady NM, Obel OA, Camm AJ. Left atrial appendage: structure, function, and role in thromboembolism Heart. 1999;82(5):547-555.

15. Onalan 0, Crystal E. Left atrial appendage exclusion for stroke prevention in patients with nonrheumatic atrial fibrillation. Stroke. 2007;38(2 Suppl):624-630, doi: 10.1161/01.STR.0000250166.06949.95, indexed in Pubmed: 17261703.
16. Grygier M. Komu i dlaczego zamykać uszko lewego przedsionka w 2018 roku? Kardiol Inwaz. 2018;13(1):28-32.

17. Reddy VY, Sievert H, Halperin J et al. PROTECT AFSteering Committee and Investigators. Percutaneous left atrial appendage closure vs warfarin for atrial fibrillation: a randomized clinical trial. JAMA 2014;312:1988-1998.

18. Reddy VY, Holmes D, Doshi SK et al. Safety of percutaneous left atrial appendage closure: results from the Watchman Left Atrial Appendage System for Embolic Protection in Patients with AF (PROTECT AF) clinical trial and the Continued Access Registry. Circulation. 2011;123(4):417424, doi: 10.1161/CIRCULATIONAHA.110.976449, indexed in Pubmed: 21242484.

19. Holmes DR Jr, Kar S, Price MJ et al. Prospective Randomized Evaluation of the Watchman Left Atrial Appendage Closure Device in Patients With Atrial Fibrillation Versus Long-Term Warfarin Therapy The PREVAIL Trial, J Am Coll Cardiol. 2014;64(1):1-12.

20. Vivek Y. Reddy VY, Doshi SK, Kar S et al. 5-Year Outcomes After Left Atrial Appendage Closure JACC 2017;70(24):2964-2975. doi: 10.1016/j. jacc.2017.10.021. Devlin HL, Hosman AE, Shovlin CL. Antiplatelet and Anticoagulant Agents in Hereditary Hemorrhagic Telangiectasia. N Engl J Med. 2013;368:876-878.

21. Vorselaars VMM, Velthuis $S$, Swaans MJ et al. Percutaneous left atrial appendage closure-An alternative strategy for anticoagulation in atrial fibrillation and hereditary hemorrhagic telangiectasia? Cardiovasc Diagn Ther 2015;5(1):49-53.

22. Mielczarek M, Gałąska R, Drewla P et al. Left atrial appendage occlusion in a patient with hereditary hemorrhagic telangiectasia and atrial fibrillation - a therapeutic option worth considering. Arch Med Sci Atheroscler Dis. 2017;2(1):e29-e30. doi: 10.5114/amsad.2017.68657. eCollection 2017.

\section{ORCID:}

Urszula Gancarczyk - 0000-0003-2283-3356

Piotr Podolec - 0000-0001-6101-2935

Tadeusz Przewłocki - 0000-0002-9575-7270

Pawet Prochownik - 0000-0002-6957-3590

Monika Komar - 0000-0001-5341-2947

\section{Conflict of interest:}

Authors declare no conflict of interest

\section{CORRESOPONDIG AUTHOR \\ Urszula Gancarczyk}

Oddział Kliniczny Chorób Serca i Naczyń

IK CM UJ, KSS im. Jana Pawła II

ul. Prądnicka 80, 31-202 Kraków

tel: 126142287

e-mail: ula.gancarczyk@gmail.com

Received: 19.07 .2019

Accepted: 18.09 .2019 